\section{$\mathrm{Y}-12$}

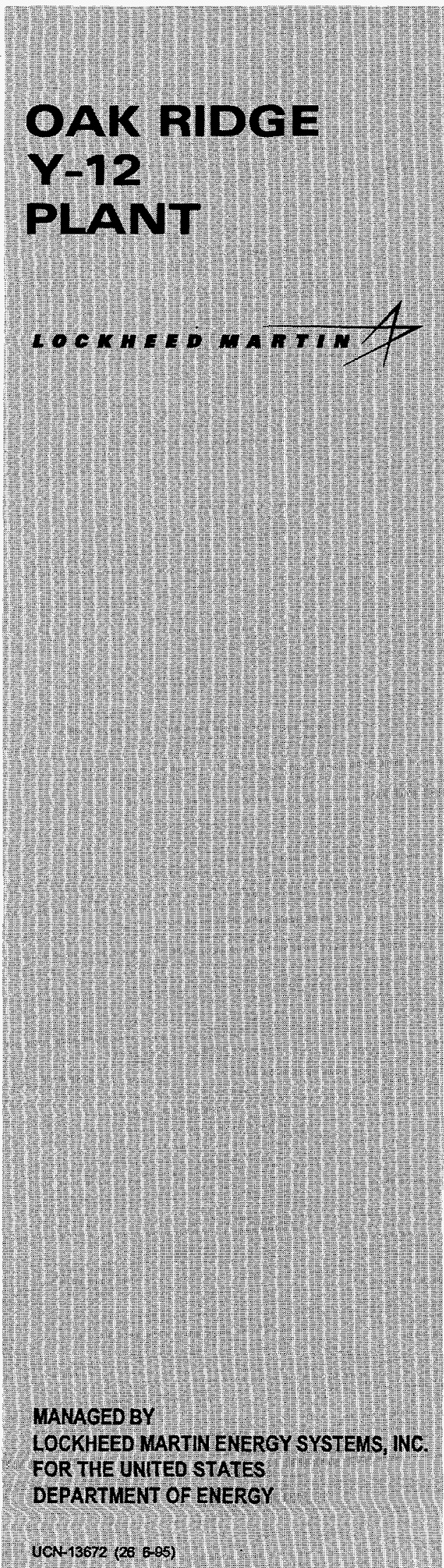

RECEIVEB

AUG 11999

OSTI
CALENDAR YEAR 1996

ANNUAL GROUNDWATER MONITORING REPORT FOR THE

UPPER EAST FORK POPLAR CREEK HYDROGEOLOGIC REGIME

AT THE

U.S. DEPARTMENT OF ENERGY Y-12 PLANT, OAK RIDGE, TENNESSEE

February 1997

\section{MASTER}

Prepared by

AJA TECHNICAL SERVICES, INC.

Under Purchase Order 70Y-KDS15V

for the

Y-12 Surveillance and Maintenance Program, Environmental Restoration Program and the

Water Compliance Department

Environmental Compliance Organization Oak Ridge Y-12 Plant

Managed by

LOCKHEED MARTIN ENERGY SYSTEMS, INC. for the U.S. Department of Energy Under Contract No. DE-AC05-84OR21400 DISTRIBUTION OF THIS DOCUNENT IS UNLIMITED 


\section{DISCLAIMER}

This report was prepared as an account of work sponsored by an agency of the United States Government. Neither the United States Government nor any agency thereof, nor any of their employees, makes any warranty, express or implied, or assumes any legal liability or responsibility for the accuracy, completeness, or usefulness of any information, apparatus, product, or process disclosed, or represents that its use would not infringe privately owned rights. Reference herein to any specific commercial product, process, or service by trade name, trademark, manufacturer, or otherwise, does not necessarily constitute or imply its endorsement, recommendation, or favoring by the United States Government or any agency thereof. The views and opinions of authors expressed herein do not necessarily state or reflect those of the United States Government or any agency thereof. 


\author{
CALENDAR YEAR 1996 \\ ANNUAL GROUNDWATER MONITORING REPORT \\ FOR THE \\ UPPER EAST FORK POPLAR CREEK HYDROGEOLOGIC REGIME \\ AT THE \\ U.S. DEPARTMENT OF ENERGY Y-12 PLANT, \\ OAK RIDGE, TENNESSEE
}

February 1997

Prepared by

AJA TECHNICAL SERVICES, INC.

Under Purchase Order 70Y-KDS15V

for the

Y-12 Surveillance and Maintenance Program, Environmental Restoration Program and the

Water Compliance Department

Environmental Compliance Organization

Oak Ridge Y-12 Plant

Managed by

LOCKHEED MARTIN ENERGY SYSTEMS, INC.

for the U.S. Department of Energy

Under Contract No. DE-AC05-84OR21400 


\section{DISClamitr}

Portions of this document may be illegible in electronic image products. Images are produced from the best available original docomert. 


\section{CONTENTS}

$\underline{\text { Section }} \quad \underline{\text { Page }}$

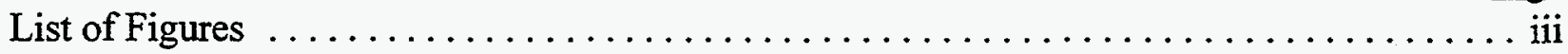

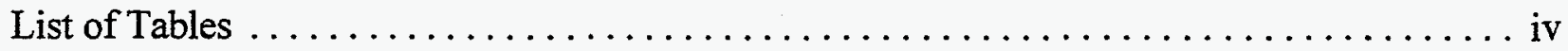

List of Acronyms and Abbreviations $\ldots \ldots \ldots \ldots \ldots \ldots \ldots \ldots \ldots \ldots \ldots \ldots \ldots \ldots$

Certification $\ldots \ldots \ldots \ldots \ldots \ldots \ldots \ldots \ldots \ldots \ldots \ldots \ldots \ldots \ldots \ldots \ldots \ldots \ldots$

1.0 INTRODUCTION $\ldots \ldots \ldots \ldots \ldots \ldots \ldots \ldots \ldots \ldots \ldots \ldots \ldots \ldots \ldots \ldots \ldots \ldots$

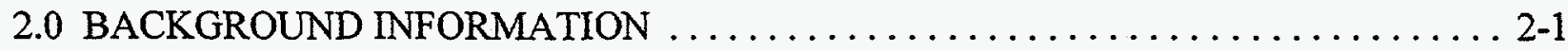

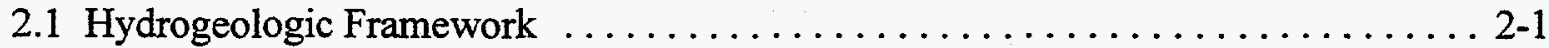

2.1.1 Topography and Bedrock Geology ................ 2-1

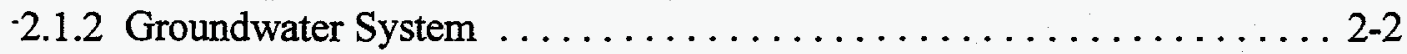

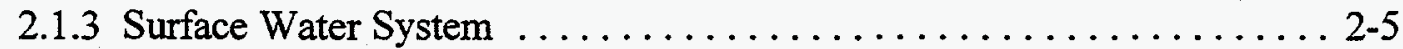

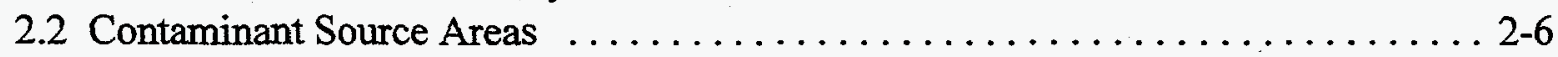

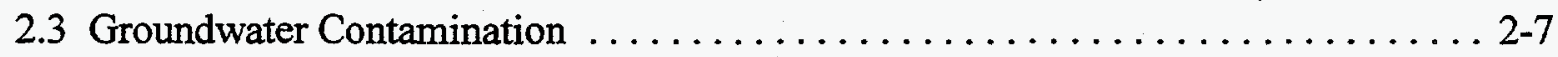

3.0 CY 1996 GROUNDWATER PROTECTION PROGRAM . . . . . . . . . . . . . . 3-1

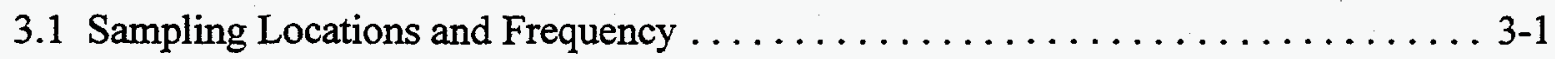

3.1.1 RCRA Post-Closure Corrective Action Monitoring . . . . . . . . . 3-2

3.1.2 RCRA Interim Status Assessment Monitoring . . . . . . . . . . . 3-2

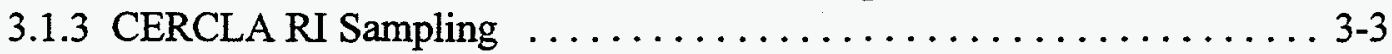

3.1.4 DOE Order 5400.1 Exit Pathway/Perimeter Monitoring . . . . . . . . 3-4

3.1.5 DOE Order 5400.1 Surveillance Monitoring $\ldots \ldots \ldots \ldots \ldots \ldots . . \ldots \ldots$

3.1.6 Best Management Practice Monitoring . . . . . . . . . . . . 3-5

3.2 Sample Collection, Transportation, and Chain-of-Custody Control . . . . . . . 3-6

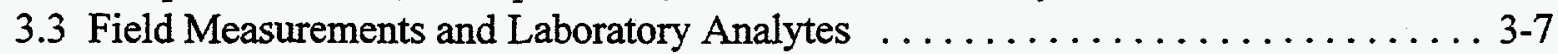

3.4 Quality Assurance/Quality Control Sampling . . . . . . . . . . . . . . . 3-8

3.5 Data Management . . . . . . . . . . . . . . . . . . . . . 3-9

4.0 DATA EVALUATION . . . . . . . . . . . . . . . . . . . . . . 4-1

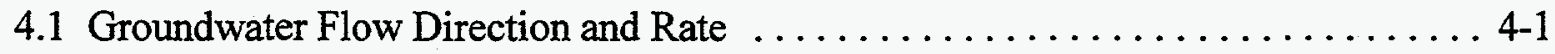

4.2 Point-of-Compliance Concentration Trends $\ldots \ldots \ldots \ldots \ldots \ldots \ldots \ldots \ldots . \ldots \ldots$

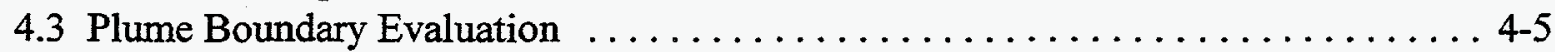

5.0 SUMMARY AND CONCLUSIONS $\ldots \ldots \ldots \ldots \ldots \ldots \ldots \ldots \ldots \ldots \ldots \ldots \ldots$

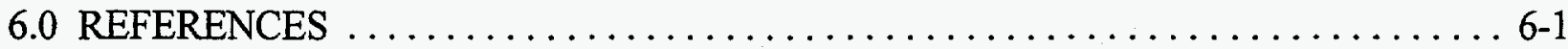




\section{CONTENTS (cont'd)}

\section{APPENDICES:}

A Figures

B Tables

C Monitoring Well Construction Details

D CY 1996 Data for Groundwater and Surface Water Samples

D.1 Field Measurements and Miscellaneous Parameters

D.2 Inorganic Analytes

D.3 Organic Analytes

D.4 Radiochemical Analytes

E CY 1996 Data for Quality Assurance/Quality Control Samples

E.1 Correlation of Groundwater and Surface Water Samples to Associated Blanks

E.2 Trip Blank Data Summary

E.3 Laboratory Blank Data Summary

E.4 Equipment Rinsate Data Summary

E.5 Field Blank Data Summary

F Data Screening Process and DQO Criteria 


\section{List of Figures}

Figure

Page

1 Hydrogeologic Regimes at the $\mathrm{Y}-12$ Plant $\ldots \ldots \ldots \ldots \ldots \ldots \ldots \ldots \ldots \ldots \ldots \ldots$

2 Topography and Bedrock Geology in the East Fork Regime $\ldots \ldots \ldots \ldots \ldots \ldots$ A-2

3 Fill Areas in the Y-12 Plant and Preconstruction Drainage Features $\ldots \ldots \ldots \ldots$ A-3

4 Seasonal Groundwater Elevations in the Water Table Interval, CY $1996 \ldots \ldots \ldots \ldots$ A-4

5 Influence on Groundwater Flow During Operation of the Lake Reality Sump . . . . . . A-5

6 Confirmed and Suspected Sources of Groundwater Contamination in the East Fork Regime

7 Overall Extent of Groundwater Contamination in the East Fork Regime $\ldots \ldots \ldots \ldots$ A-7

8 CY 1996 Groundwater and Surface Water Sampling Locations . . . . . . . . . . A-8

9 Concentrations of Selected GWPS Constituents in Groundwater at Point-of-Compliance

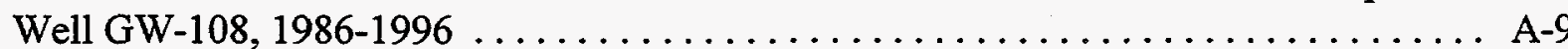




\section{List of Tables}

Table

1 Index of Post-Closure Permit Conditions for Groundwater Monitoring in the East Fork Regime

2 Confirmed and Suspected Sources of Groundwater Contamination in the East Fork Regime

3 Summary of Addenda to the CY 1996 Sampling and Analysis Plan for Sampling Locations in the East Fork Regime

4 CY 1996 Sampling Dates for Monitoring Wells, Springs, and Surface Water Stations . B-6

$5 \quad$ Laboratory Analytes and Field Measurements

6 Groundwater Elevations in the East Fork Regime, April 2-4, 1996 and September 30 - October 7, 1996

7 Summary of CY 1996 RCRA Post-Closure Corrective Action Monitoring Results for the Eastern S-3 Ponds Plume 


\section{List of Acronyms and Abbreviations}

AAS

ASO

$\mathrm{BCV}$

Bear Creek Regime

bgs

BT

CA

CERCLA

CY

DOE

DNAPL

DQO

East Fork Regime

EPA

ER

$\mathrm{ft}$

$\mathrm{ft} / \mathrm{d}$

GWPP

GWPS

ICP

$\mathrm{K}-25$

MDA

$\mu \mathrm{g} / \mathrm{L}$

$\mathrm{mg} / \mathrm{L}$

$\mathrm{msl}$

ORNL

ORR

PCE

$\mathrm{pCi} / \mathrm{L}$

PMS

Post-Closure Permit

QA/QC

RCRA

$\mathrm{RI}$

SAP

TDEC

TDS
Atomic Absorption Spectroscopy

Analytical Services Organization

Bear Creek Valley

Bear Creek Hydrogeologic Regime

below ground surface

buried tributary (Upper East Fork Poplar Creek)

characterization area (CERCLA)

Comprehensive Environmental Response, Compensation, and Liability Act

calendar year

U.S. Department of Energy

dense, nonaqueous phase liquids

data quality objective

Upper East Fork Poplar Creek Hydrogeologic Regime

U.S. Environmental Protection Agency

Environmental Restoration (Program)

feet

feet per day

Groundwater Protection Program

Groundwater Protection Standard (RCRA)

Inductively Coupled Plasma (Spectroscopy)

Oak Ridge K-25 Site

minimum detection activity

micrograms per liter

milligrams per liter

mean sea level

Oak Ridge National Laboratory

Oak Ridge Reservation

tetrachloroethene

picoCuries per liter

Plasma Mass Spectroscopy

RCRA Post-Closure Permit for the Upper East Fork Poplar Creek

Hydrogeologic Regime

quality assurance/quality control

Resource Conservation and Recovery Act

remedial investigation (CERCLA)

Sampling and Analysis Plan

Tennessee Department of Environment and Conservation

total dissolved solids 
List of Acronyms and Abbreviations (cont'd)

UEFPC

VOC

${ }^{99} \mathrm{Tc}$

${ }^{234} \mathrm{U}$

${ }^{238} \mathrm{U}$
Upper East Fork Poplar Creek

volatile organic compound

Technetium-99

Uranium-234

Uranium-238 


\section{Certification}

I certify under penalty of law that this document and all attachments were prepared under my direction and supervision in accordance with a system designed to assure that qualified personnel properly gather and evaluate the information submitted. Based on my inquiry of the person or persons who manage the system, or those persons directly responsible for gathering the information, the information submitted is, to the best of my knowledge and belief, true, accurate, and complete. I am aware that there are significant penalties for submitting false information, including the possibility of fine and imprisonment for knowing violations.

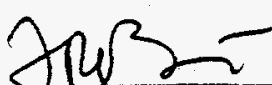

Permittee Signature

$2 / 27 / 97$

Date

\section{DISCLAIMER}

This report was prepared as an account of work sponsored by an agency of the United States Government. Neither the United States Government nor any agency thereof, nor any of their employees, makes any warranty, express or implied, or assumes any legal liability or responsibility for the accuracy, completeness, or usefulness of any information, apparatus, product, or process disclosed, or represents that its use would not infringe privately owned rights. Reference herein to any specific commercial product, process, or service by trade name, trademark, manufacturer, or otherwise does not necessarily constitute or imply its endorsement, recommendation, or favoring by the United States Government or any agency thereof. The views and opinions of authors expressed herein do not necessarily state or reflect those of the United States Government or any agency thereof. 


\subsection{INTRODUCTION}

This annual monitoring report contains groundwater and surface water monitoring data obtained in the Upper East Fork Poplar Creek Hydrogeologic Regime (East Fork Regime) during calendar year (CY) 1996. The East Fork Regime encompasses several confirmed and suspected sources of groundwater contamination within industrialized areas of the U.S. Department of Energy (DOE) Oak Ridge Y-12 Plant in Bear Creek Valley (BCV) southeast of Oak Ridge, Tennessee (unless otherwise noted, directions are in reference to the Y-12 Plant administrative grid) (Figure 1). Groundwater and surface water monitoring in the East Fork Regime are performed under the auspices of the Y-12 Plant Groundwater Protection Program (GWPP).

Included herein are the groundwater monitoring data obtained in compliance with the Resource Conservation and Recovery Act (RCRA) post-closure permit for the East Fork Regime (post-closure permit) issued by the Tennessee Department of Environment and Conservation (TDEC) on August 30, 1996 (permit no. TNHW-089). The post-closure permit addresses postclosure monitoring requirements for two closed RCRA-regulated surface impoundments: the S-3 Ponds and New Hope Pond. Besides the signed certification statement (Page vi) and the RCRA facility information summarized below, condition II.C. 6 of the post-closure permit requires annual reporting of RCRA post-closure corrective action monitoring performed in accordance with requirements specified for the Eastern S-3 Ponds (Table 1).

\begin{tabular}{|c|c|}
\hline \multicolumn{2}{|c|}{ RCRA FACIMYY MTORMATION } \\
\hline $\begin{array}{r}\text { Facility: } \\
\text { Facility Identification No.: } \\
\text { Facility Address: }\end{array}$ & $\begin{array}{l}\text { Y-12 Plant } \\
\text { TN3 } 890090001 \\
\text { P.O. Box } 2001 \\
\text { Oak Ridge, Tennessee } 37831\end{array}$ \\
\hline
\end{tabular}

Section $V$ of the post-closure permit specifies monitoring requirements for the portion of the S-3 Ponds groundwater contaminant plume that has migrated into the East Fork Regime. Post-closure maintenance requirements for the S-3 Ponds are specified in the RCRA post-closure permit for the Bear Creek Hydrogeologic Regime (Bear Creek Regime). The post-closure permit does not currently specify groundwater monitoring requirements for New Hope Pond; only post-closure 
maintenance requirements are defined. This site does not discernibly contribute to the extensive plume of groundwater contamination emanating from numerous sources in the East Fork Regime, and RCRA post-closure groundwater monitoring is deferred to the risk-based requirements to be defined in the Comprehensive Environmental Response, Compensation, and Liability Act (CERCLA) record of decision for the Upper East Fork Poplar Creek (UEFPC) Characterization Area (CA).

In addition to the RCRA post-closure corrective action monitoring data, this annual monitoring report contains CY 1996 groundwater and surface water monitoring data obtained under the auspices of the Y-12 Plant GWPP for the purposes of: (1) RCRA interim status assessment monitoring, (2) sampling performed in support of the CERCLA remedial investigation (RI) for the UEFPC CA, (3) DOE Order 5400.1 exit pathway/perimeter monitoring, (4) DOE Order 5400.1 surveillance monitoring, and (5) monitoring performed as a best management practice of the Y-12 Plant GWPP. These data are incorporated to provide a comprehensive presentation of groundwater and surface water monitoring results obtained during CY 1996 for the multiple programmatic purposes of the Y-12 Plant GWPP. The following narrative sections of the report:

- $\quad$ provide background information regarding the S-3 Ponds and New Hope Pond, an overiview of the hydrogeologic system in the East Fork Regime, and a brief description of the extent of groundwater contamination in the regime (Section 2.0);

- $\quad$ summarize the CY 1996 groundwater and surface water sampling and analysis activities, including quality assurance/quality control (QA/QC) sampling and data management (Section 3.0);

- $\quad$ present the evaluation of RCRA post-closure corrective action monitoring data required annually under condition V.G of the post-closure permit (Section 4.0); and

- provide a brief summary of monitoring activities and findings (Section 5.0).

Documents cited for more detailed operational, regulatory, or technical information regarding the East Fork Regime are listed in Section 6.0.

Narrative sections of the report reference a series of appendices. Illustrations (maps and trend graphs), data summary tables, and monitoring well construction details are presented in 
Appendix A, Appendix B, and Appendix C, respectively. Results of laboratory analyses and field measurements for each groundwater and surface water sampling location are presented in several subsections of Appendix D (organized by groups of related analytical parameters/measurements). Data for the QA/QC samples associated with each groundwater and surface water sample are presented in respective subsections of Appendix E. Appendix F describes the process used to identify CY 1996 groundwater and surface water data that do not meet applicable data quality objectives (DQOs) of the Y-12 Plant GWPP. 


\subsection{BACKGROUND INFORMATION}

The East Fork Regime includes the section of BCV encompassing the Y-12 Plant industrial facilities and support structures located between Scarboro Road to the east of the plant and Old Bear Creek Road at the west end of the plant (Figure 1). For the purposes of this report, the East Fork Regime is divided into: (1) the Western Plant Area, defined as the portion of the regime west of the Y-12 Plant grid coordinate easting 55,000, (2) the Central Plant Area, defined as the part of the regime between grid coordinate eastings 55,000 and 62,000, and (3) the Eastern Plant Area, defined as the portion of the regime east of grid coordinate easting 62,000 . The following sections provide an overview of the hydrogeologic framework in the East Fork Regime, a brief description of confirmed and suspected sources of contamination, and the extent of groundwater contamination in the regime.

\subsection{Hydrogeologic Framework}

The following overview of the hydrogeologic system in the East Fork Regime is based on: (1) the conceptual groundwater flow models described in Science Applications International Corporation (1996); (2) the general hydrogeologic framework and associated nomenclature described in Solomon et al. (1992); (3) hydraulic properties and flow characteristics presented in Moore (1988 and 1992), and Moore and Toran (1992); and (4) results of hydrologic studies and investigations in BCV, including Drier et al. (1987), Shevenell (1994), Shevenell et all. (1993), and Goldstrand (1995).

Key aspects of the geology in the East Fork Regime, the principal hydrogeologic units and respective groundwater flow characteristics, and the general hydrology of UEFPC are summarized in the following subsections.

\subsubsection{Topography and Bedrock Geology}

Bear Creek Valley is flanked to the north by Pine Ridge and to the south by Chestnut Ridge. Ground elevations range from about 1,300 feet ( $\mathrm{ft}$ ) above mean sea level (msl) on the ridge crests to $900 \mathrm{ft}$ msl along the exposed channel of UEFPC. The most prominent topographic feature is the gap in Pine Ridge cut by UEFPC northeast of the Y-12 Plant (Figure 2). 
Alternating sequences of clastic and carbonate strata that form the distinctive topography of the Valley and Ridge Physiographic Province characterize the bedrock geology in the East Fork Regime. Shale and siltstone beds of the Rome Formation form Pine Ridge to the north, limestone and shale formations of the Conasauga Group form $\mathrm{BCV}$, and the primarily dolostone formations of the Knox Group form Chestnut Ridge to the south (Figure 2). Strike and dip of bedding are generally $\mathrm{N} 55^{\circ} \mathrm{E}$ and $45^{\circ} \mathrm{SE}$, respectively (as referenced to true north). Bedrock is overlain by up to $40 \mathrm{ft}$ of several materials, including man-made fill, alluvium, colluvium, fine-grained residuum from the weathering of the bedrock, and saprolite (weathered bedrock). Where undisturbed, the saprolite often retains primary textural features of the unweathered bedrock, including fractures (Solomon et al. 1992).

Extensive cut-and-fill areas within the Y-12 Plant have substantially altered the shallow subsurface throughout much of the East Fork Regime (Figure 3). Most of the fill, which generally consists of a heterogeneous mixture of building debris and recompacted soil/residuum that contains many voids, was placed within the tributaries and main channel of UEFPC (Sutton and Field 1995). In areas where the fill is below the unsaturated zone, the heterogeneous composition and varying thickness ( 5 to $25 \mathrm{ft}$ ) of the fill significantly influence shallow groundwater flow directions and contaminant migration patterns. Extensive physical structures and underground utilities also influence shallow groundwater movement throughout the majority of the regime.

\subsubsection{Groundwater System}

On the Oak Ridge Reservation (ORR), the Rome Formation, the Conasauga Group, and the Knox Group comprise two basic hydrogeologic units: (1) the Aquifer, consisting of the Maynardville Limestone (upper Conasauga Group) and the Knox Group, and (2) the Aquitard, consisting of the remaining Conasauga Group formations (Nolichucky Shale, Maryville Limestone, Rogersville Shale, Rutledge Limestone, and Pumpkin Valley Shale) and the Rome Formation (Figure 2). The Aquifer (Maynardville Limestone) functions as a hydrologic drain in $\mathrm{BCV}$, and provides the principal avenues for contaminant transport in the East Fork Regime. The Aquitard formations underlie most of the contaminant source areas in the regime, and are hydraulically upgradient of the Aquifer. 
Fractures provide the primary groundwater flowpaths in the Aquitard and the Aquifer, but dissolution of carbonates in the Aquifer has enlarged fractures and produced solution cavities and conduits that greatly enhance its hydraulic conductivity relative to the Aquitard. Although negligible in both units, flow through the porous rock matrix plays an important role in contaminant migration because of matrix diffusion processes. Most of the flow in both units is primarily parallel to bedding (along strike and dip), which in the Aquitard may or may not coincide with the direction of maximum horizontal hydraulic gradient inferred from groundwater elevation isopleths. Flow tangent to bedding occurs primarily along permeable zones formed by cross-cutting fractures or fracture zones (and possibly small faults). Some of these cross-cutting structures may act as barriers to lateral flow, causing groundwater from deeper intervals to upwell and discharge to the shallower flow system in each hydrogeologic unit. Others may serve as preferential pathways for migration of contaminants from the Aquitard into the Aquifer (Maynardville Limestone), particularly in the shallow flow system.

Nearly all groundwater flow in the Aquitard occurs within a highly permeable interval near the bedrock/residuum interface (the water table interval). Below the water table interval, flow is most active at depths less than 100-ft below ground surface (bgs); however, contaminants in groundwater more than $100-\mathrm{ft}$ bgs clearly indicate permeable flowpaths at depth. Flow occurs in response to precipitation when flowpaths in the residual soils become saturated and rapidly transmit water laterally (stormflow) toward nearby drainage features, and vertically (recharge) to the water table interval. Inflow into the water table interval promotes strike-parallel groundwater flow toward discharge areas in nearby cross-cutting streams. Only a small percentage of total flow ultimately recharges to the deeper bedrock, where upward hydraulic gradients predominate.

Decreasing groundwater flux with depth in the Aquitard also is reflected by distinct changes in groundwater geochemistry. Most water table interval and shallow (i.e., $<100-\mathrm{ft}$ bgs) bedrock wells monitor calcium-magnesium-bicarbonate groundwater. Based primarily on data obtained from the Bear Creek Regime, a fairly abrupt change to sodium-bicarbonate groundwater occurs at a depth of about $100-\mathrm{ft} \mathrm{bgs}$, and is interpreted to be a function of longer groundwater residence time related to reduced fracture aperture or increased fracture spacing (Solomon et. al. 1992). Another geochemical boundary indicative of reduced groundwater flux is denoted by a transitional change 
from sodium-bicarbonate groundwater to sodium-chloride groundwater. This transition typically occurs at a depth of about 400 - $\mathrm{ft}$ bgs, and is usually accompanied by increased total dissolved solids (TDS).

Most groundwater flow in the Aquifer occurs at shallow depths (i.e., $<100 \mathrm{ft}$ bgs) in an extensively interconnected maze of solution conduits and cavities (karst network). Flow in the shallow karst network is relatively rapid, and during rainfall may occur as "quickflow" recharge/discharge toward springs or nearby surface drainage features (Shevenell 1994). Fractures provide the primary flowpaths below the shallow karst network, and there are important lithologic controls on groundwater flow (Goldstrand 1995). Lithologic characteristics differentiate seven distinct stratigraphic zones (numbered from bottom to top) in the Maynardville Limestone. The more permeable zones lie at the bottom (Zone 2) and top (Zone 6) of the formation (Shevenell et al. 1993). Because of vugular porosity related to dissolution of gypsum nodules, Zone 6 is the most permeable interval and probably transmits the bulk of the groundwater in this formation (Goldstrand 1995).

Active groundwater circulation occurs at greater depth in the Aquifer than in the Aquitard, and is reflected by the fairly homogeneous geochemistry of the groundwater; virtually every monitoring well in the Maynardville Limestone, regardless of depth, monitors calcium-magnesiumbicarbonate groundwater. Some shallow wells in the Aquifer monitor sulfate-enriched groundwater, which probably reflects dissolution of gypsum and/or locally disseminated sulfides. Several deep wells monitor calcium-magnesium-sulfate groundwater with TDS above 1,000 milligrams per liter $(\mathrm{mg} / \mathrm{L})$.

The water table in the East Fork Regime, under both seasonally high and low flow conditions, is a subdued replica of the ground surface with steep gradients along the flanks of Pine Ridge and Chestnut Ridge and a gentle slope down the axis of BCV (Figure 4). In both the Western Plant Area and Central Plant Area, groundwater generally flows south (across-strike) from the Aquitard toward the Aquifer (Maynardville Limestone), and eastward along strike in the Maynardville Limestone toward the east end of the Y-12 Plant. Flow directions diverge from this general pattern in the Eastern Plant Area. In the Aquitard, flow is more directly east (strike parallel) 
toward UEFPC, and in the Aquifer, flow components are north toward the water gap in Pine Ridge, and east along strike toward Union Valley (Figure 4).

Groundwater flow directions in the Eastern Plant Area are periodically influenced when a 6-ft diameter, 20-ft deep sump is operated to reduce hydraulic pressure on the synthetic liner in Lake Reality. Water level data obtained from nearby water table and shallow bedrock monitoring wells during operation of the sump in July 1995 (Jago 1995) generally define an elongated water table depression in the Aquitard (Nolichucky Shale) oriented parallel with strike, and decreased water levels in the Aquifer (Maynardville Limestone) along the main channel of UEFPC (Figure 5). The elongated water-table depression in the Aquitard reflects greater strike-parallel permeability, and decreased water levels in the Aquifer indicates enhanced, cross-strike permeability along a fracture zone potentially associated with the UEFPC channel. Data obtained as part of the RI for the UEFPC CA show that several other sumps within the Y-12 Plant, such as the O-12 Sump in Building 9201-2, similarly influence groundwater directions (Lockheed Martin Energy Systems, Inc. 1996).

Shallow groundwater flow directions in the vicinity of New Hope Pond and Lake Reality are also influenced by an underdrain system beneath the concrete diversion channel of UEFPC. The underdrain consists of gravel with a slotted-plastic drain line. As part of the RI for the UEFPC CA, a short-term pumping test was performed in May 1986 using a shallow (12 ft bgs), six-inch diameter well (GW-832) installed into the underdrain. Two hours of pumping at 60 gallons per minute produced one foot of drawdown in the well. Water levels in the Lake Reality Sump also decreased in response to pumping, indicating a direct hydraulic connection between the underdrain and sump.

\subsubsection{Surface Water System}

Surface water in the East Fork Regime is drained by UEFPC, which was extensively altered and modified during construction of the Y-12 Plant. The headwaters and several thousand feet of the main channel in the upper reach of the creek, including all the northern tributaries of the creek in the Western Plant Area and Central Plant Area, were filled and replaced with an extensive network of underground storm drains (Figure 3). For reference purposes, each buried tributary (BT) of UEFPC is designated with a value representing the tributary number counted downstream from the headwaters (e.g., BT-1). 
The underground network of storm drains in the Western Plant Area and Central Plant Area direct surface runoff into the exposed portion of the UEFPC channel at a point (North-South Pipe) about 3,500-ft upstream of Lake Reality (Figure 2). Lake Reality is a lined surface impoundment that serves to regulate the flow and quality of surface water exiting the Y-12 Plant. With a total surface area of about 2.5-acres, and an average water depth of 7-ft, Lake Reality contains approximately 6-million gallons of water during normal operations. Water enters Lake Reality from an extension of the New Hope Pond inlet diversion ditch, and exits through a weir in the western berm. From the outfall at Lake Reality, UEFPC flows north through a gap in Pine Ridge and exits the ORR.

The bulk ( $70 \%$ ) of dry-weather flow in UEFPC is attributable to once-through non-contact cooling water, condensate, and cooling tower blowdown. The remaining $30 \%$ is from groundwater discharge (CDM Federal Programs Corporation 1994).

\subsection{Contaminant Source Areas}

There are multiple confirmed and suspected sources of groundwater contamination within the East Fork Regime (Figure 6), including hazardous and nonhazardous waste treatment, storage, or disposal sites; bulk product transfer, storage, and use areas, including petroleum-fuel underground storage tanks and associated dispensing facilities; waste and product spill areas; and the many process pipelines, effluent drains, and utilities associated with the industrial operations at the Y-12 Plant (Table 2). Contaminant sources include the plume of groundwater contamination in the East Fork Regime that resulted from operation of the S-3 Ponds, which is located in the Bear Creek Regime but is addressed as the Eastern S-3 Ponds Plume in the post-closure permit. The postclosure permit also addresses maintenance requirements for New Hope Pond, although this site is not a discernable source of groundwater contamination in the East Fork Regime. Brief descriptions of both sites are provided below.

\section{Eastern S-3 Ponds}

The S-3 Ponds are a closed RCRA-regulated surface impoundment located just west of the topographic and hydrologic divide separating the Bear Creek Regime and the East Fork Regime 
(Figure 6). This site consisted of four contiguous surface impoundments, each $400 \times 400 \times 17-\mathrm{ft}$, that were used from 1951 to 1983 primarily for percolation/evaporation of nitric acid effluent (with depleted uranium in solution) discharged into the ponds via the (Abandoned) Nitric Acid Pipeline, but also received technetium- $99\left({ }^{99} \mathrm{Tc}\right)$ wastes generated at other DOE facilities. Operation of the S-3 Ponds created a mound in the water table that enabled eastward, strike-parallel contaminant migration into the East Fork Regime. The mound abated after the S-3 Ponds were closed and capped, and the shallow groundwater flow divide between the East Fork Regime and the Bear Creek Regime re-emerged. Groundwater contaminants associated with the site are nitrate, ${ }^{99} \mathrm{Tc}$, uranium isotopes (primarily ${ }^{234} \mathrm{U}$ and ${ }^{238} \mathrm{U}$ ), trace metals (e.g., barium); and several volatile organic compounds (VOCs), including tetrachloroethene (PCE), acetone, chloroform, and methylene chloride. Because the off-site ${ }^{99} \mathrm{Tc}$ wastes were disposed only at the former S-3 Ponds, ${ }^{99} \mathrm{Tc}$ is a "signature" S-3 Ponds groundwater contaminant in the East Fork Regime. Confirmed detection of ${ }^{99} \mathrm{Tc}$ in groundwater elsewhere in the regime is therefore attributable to migration from the Eastern S-3 Ponds Plume.

\section{New Hope Pond}

New Hope Pond is located at the east end of the Y-12 Plant (Figure 6). Constructed in 1963, New Hope Pond served to regulate the flow and quality of surface water in UEFPC, functions now performed by Lake Reality. Sediments containing polychlorinated biphenols, mercury, and uranium were periodically removed from New Hope Pond, but testing indicated that they did not exhibit the characteristics of a hazardous waste. Approximately 25,000 cubic yards of sediment remained in New Hope Pond when it was closed, which was certified by the TDEC in December 1990. Closure involved stabilizing the remaining sediments with coarse aggregate and covering the pond with a multi-layer, low-permeability cap (Martin Marietta Energy Systems, Inc. 1988a).

\subsection{Groundwater Contamination}

Conceptual models for groundwater flow and contaminant transport in the Aquitard and the Aquifer, as described in the Remedial Investigation Report for Bear Creek Valley (Science Applications International Corporation 1996), and groundwater quality data obtained through 
implementation of the Comprehensive Groundwater Monitoring Plan for the U.S. Department of Energy Y-12 Plant (Comprehensive Monitoring Plan) (Geraghty \& Miller, Inc. 1990) provide the basis for the following overview of groundwater contamination in the East Fork Regime. As described in the following sections, the extent of nitrate essentially illustrates groundwater transport patterns in the Aquitard, dissolved VOC plumes generally reflect multiple source areas and illustrate groundwater transport patterns in the Aquifer, and transport of trace metals and radionuclides is generally less extensive compared to that of nitrate and VOCs.

\section{Nitrate}

A plume of nitrate contamination originating from the S-3 Ponds extends vertically in the Aquitard at least 100-ft bgs, and laterally at least 2,000-ft into the Western Plant Area (Figure 7). Nitrate (as N) concentrations (hereafter synonymous with "nitrate" concentrations) within the plume exceed $10,000 \mathrm{mg} / \mathrm{L}$. Concentrations within the plume suggest the following general migration pattern in the Aquitard.

- Eastward, strike-parallel transport in the water table interval, shallow bedrock (i.e., $<100$-ft bgs), and deeper bedrock toward the buried headwaters of UEFPC located about 500 -ft east of the former S-3 Ponds;

- Upward migration from the deep bedrock into the shallow bedrock, and from the shallow bedrock to the water table interval, and discharge from the water table interval into the buried UEFPC headwaters, which channels contaminated groundwater into the Aquifer to the southeast;

- Eastward, strike-parallel transport in the water table interval and shallow bedrock toward a buried tributary of UEFPC (BT-1) located between the Y-12 Plant Salvage Yard and the Waste Coolant Processing Area about 1,800-ft east of the S-3 Ponds (Figure 3);

- Discharge from the water table interval into BT-1, which channels the contaminated groundwater toward the southeast into the Aquifer; and eastward strike-parallel transport in the shallow bedrock beneath the buried tributary; and

- Eastward, strike-parallel transport in the shallow bedrock toward a buried tributary of UEFPC (BT-2) located between Building 9204-4 and Building 9204-5, about 2,700-ft east of the S-3 Ponds (Figure 3). 
Because it is chemically stable and highly mobile in groundwater, nitrate probably traces the overall migration pattern for other groundwater contaminants from the S-3 Ponds, including ${ }^{99} \mathrm{Tc}$.

In the Bear Creek Regime, nitrate concentrations exceed $10 \mathrm{mg} / \mathrm{L}$ in Aquifer monitoring wells more than 9,000-ft southwest of the S-3 Ponds. In the East Fork Regime, however, nitrate concentrations are below $5 \mathrm{mg} / \mathrm{L}$ in Aquifer monitoring wells only 2,500-ft southeast of the site (Figure 7). Considering the similarly high nitrate concentrations $(>10,000 \mathrm{mg} / \mathrm{L})$ in the Aquitard both east and west of the S-3 Ponds, the general lack of nitrate in the Aquifer east of the site suggests less directly connected migration pathways, and/or greater flux to the west during site operations. The low nitrate concentrations in the Aquifer east of the S-3 Ponds also probably reflect dilution from nitrate-free surface runoff and daily process water discharge from the Y-12 Plant (which provides the bulk of dry-weather flow in UEFPC).

\section{Volatile Organic Compounds}

Because of their relative mobility in groundwater and influx from multiple sources, several VOCs are the most pervasive contaminants in the East Fork Regime. Chloroethenes, primarily PCE, trichloroethene, and 1,2-dichloroethene, are the principal components of dissolved VOC plumes in the Western Plant Area and the Central Plant Area. Chloromethanes (primarily carbon tetrachloride and chloroform) are primary plume components in the Eastern Plant Area. Concentrations of plume constituents exceed $1 \%$ of respective maximum solubilities and indicate the presence of dense, non-aqueous phase liquids (DNAPL) in the Aquitard at the Waste Coolant Processing Area and an unspecified source area upgradient of Tank 0134-U, and in the Aquifer near unspecified source(s) of carbon tetrachloride upgradient of New Hope Pond.

The distribution of dissolved VOCs in the Aquitard generally reflects the migration patterns indicated by the nitrate plume, with strike-parallel transport in the water table interval and shallow bedrock toward the headwaters and buried tributaries of UEFPC, which direct the VOCs into the Aquifer (Figure 7). Limited cross-strike migration in areas between these buried drainage features, which is suggested by the apparently separate, strike-oriented plume of dissolved chloroethenes in the shallow groundwater at the Salvage Yard Drum Deheader, further indicates the strong influence these features have on contaminant transport patterns. Also, the upward vertical hydraulic gradients 
characteristic of the Aquitard in many areas indicate upward migration from sources in the deeper bedrock, which further supports evidence of widespread DNAPL in the subsurface.

Although VOC data for the Central Plant Area are limited, results from the current network of Aquifer monitoring wells indicate a relatively continuous plume of dissolved VOCs in the water table interval/shallow bedrock that extends eastward from the Fire Training Facility in the Western Plant Area, underneath New Hope Pond in the Eastern Plant Area, up to 2,000-ft east of the ORR boundary (Figure 7).

Available data show vertical segregation of the VOC plume in the groundwater at the east end of the Y-12 Plant near New Hope Pond. In general, chloroethenes are more prevalent in the water table and shallow bedrock intervals, whereas chloromethanes (primarily carbon tetrachloride) generally dominate the dissolved VOC plume in the deeper bedrock. The different types of VOCs in the shallow and deep groundwater suggest separate sources of chloroethenes and chloromethanes, and possibly indicate that the transport of chloroethenes is more closely associated with UEFPC (and the altered stream channel).

\section{$\underline{\text { Radioactivity }}$}

Results for gross alpha and gross beta activity indicate groundwater contamination in: (1) the Aquitard east of the S-3 Ponds in the Western Plant Area, (2) the Aquifer at the S-2 Site in the Western Plant Area, (3) in the Aquitard and near the Tank 2331-U in the Central Plant Area, and (4) the Aquifer upgradient of New Hope Pond in the Eastern Plant Area (Figure 7). The S-3 Ponds are confirmed sources of uranium isotopes $\left({ }^{234} \mathrm{U}\right.$ and $\left.{ }^{238} \mathrm{U}\right)$ and ${ }^{99} \mathrm{Tc}$ in the Aquitard in the Western Plant Area. The migration of these isotopes generally mirrors that of nitrate from the site: eastward, strike-parallel transport in the water table interval, shallow bedrock, and deep bedrock toward the headwaters of UEFPC and the buried tributary (BT-1) west of the Waste Coolant Processing Area. Limited transport (or extensive dilution) in the Aquifer is indicated by the greatly decreased gross alpha and gross beta activity in the groundwater downgradient of confirmed source areas (e.g., S-2 Site), which suggests that the alpha activity in the groundwater at Tank 2331-U and the area upgradient of New Hope Pond reflect similarly limited migration of uranium isotopes from the upgradient, unspecified source areas. 


\section{Trace Metals}

Low $\mathrm{pH}$ groundwater within about $1,000 \mathrm{ft}$ of the S-3 Ponds contains a diverse mix of trace metal contaminants, including metal ions and/or ion-complexes that are usually not mobile (or more readily attenuated) in less acidic groundwater (beryllium, cadmium, cobalt, manganese, mercury, and nickel), as wells as metals that are mobile under a wider range of groundwater $\mathrm{pH}$ conditions (barium, boron, strontium, and uranium). Some of these metals were entrained in the acidic wastes disposed at the site (e.g., uranium), and others were dissolved from the underlying saprolite and bedrock (e.g., barium). Maximum concentrations within the plume exceed applicable drinking water standards by an order-of-magnitude or more.

Elevated concentrations of boron, cadmium, cobalt, copper, lead, mercury, strontium, and uranium occur in the groundwater elsewhere in the East Fork Regime, but as shown in the following summary, only the S-2 Site is a confirmed source area.

\begin{tabular}{|c|c|c|c|c|c|c|c|c|c|}
\hline \multirow{2}{*}{ Krownisuspected } & \multicolumn{9}{|c|}{ Trace Metal } \\
\hline & B & cd & co. & Ca. & Po & Mn. & Hg. & St & U \\
\hline $\begin{array}{r}\text { S-2 Site } \\
\text { Tank 0134-U } \\
\text { Tank 2331-U } \\
\text { Unspecified (Comprehensive Monitoring } \\
\text { Plan Grid E3 and F3) } \\
\text { Building 9754-2 Fuel Facility } \\
\text { Oil Skimmer Basin }\end{array}$ & $\begin{array}{l}\text { ? } \\
\text {; }\end{array}$ & $\begin{array}{l}\star \\
\dot{.} \\
\dot{ } \\
\dot{?} \\
.\end{array}$ & $\begin{array}{l}\star \\
\checkmark \\
\dot{ } \\
\dot{ } \\
\text {. }\end{array}$ & $\begin{array}{l}\star \\
\cdot \\
\cdot \\
. \\
. \\
.\end{array}$ & $\begin{array}{l}\star \\
\dot{\cdot} \\
\dot{.} \\
\dot{\therefore}\end{array}$ & $\begin{array}{l}\dot{\gamma} \\
\dot{?} \\
\dot{ }\end{array}$ & $\begin{array}{l}\star \\
\dot{\cdot} \\
\dot{\bullet} \\
\dot{\sigma}\end{array}$ & $\begin{array}{l}\dot{.} \\
\dot{.} \\
\dot{\sigma}\end{array}$ & $\begin{array}{l}\star \\
\checkmark \\
\checkmark\end{array}$ \\
\hline
\end{tabular}

Available data do not indicate extensive transport in the groundwater from any of the above confirmed or suspected source areas. 



\subsection{CY 1996 GROUNDWATER PROTECTION PROGRAM}

Collection and laboratory analysis of groundwater and surface water samples in the East Fork Regime was performed during CY 1996 for the multiple programmatic purposes of: (1) RCRA interim status assessment monitoring, (2) RCRA post-closure corrective action monitoring, (3) CERCLA RI sampling, (4) DOE Order 5400.1 Exit Pathway/Perimeter monitoring, (5) DOE Order 5400.1 Surveillance Monitoring, and (6) monitoring performed as a best management practice of the Y-12 Plant GWPP. Sampling and analysis activities associated with each monitoring program were performed in general accordance with the CY 1996 Sampling and Analysis Plan (SAP) (HSW Environmental Consultants, Inc. 1995). Addenda to the SAP were issued by the Y-12 Plant GWPP Manager throughout the year to document modifications to the planned sampling/analysis activities necessitated by new monitoring priorities and regulatory requirements (Table 3 ). The following sections provide an overview of the sampling and analysis activities performed during CY 1996, including descriptions of the monitoring well networks, sampling frequency, sample collection and transportation, chain-of-custody control, field measurements and laboratory analytical parameters, and data management.

\subsection{Sampling Locations and Frequency}

Groundwater and surface water samples were collected from a total of 82 monitoring wells, ten springs, and four surface water stations (Table 4). As shown in the following summary, the bulk (60) of the monitoring wells were sampled in compliance with DOE Order 5400.1 (many monitoring wells were sampled under more than one program).

\begin{tabular}{|c|c|c|c|}
\hline \multirow[b]{2}{*}{ Q1 1996 Monitorng Program } & \multicolumn{3}{|c|}{ Number of Sampling Locations } \\
\hline & Montongrs & Springs & $\begin{array}{l}\text { surtare } \\
\text { water } \\
\text { stations }\end{array}$ \\
\hline RCRA Post-Closure Corrective Action Monitoring & 6 & . & . \\
\hline RCRA Interim Status Assessment Monitoring & 13 & . & . \\
\hline CERCLA RI Sampling & 7 & 10 & 3 \\
\hline DOE 5400.1 Exit Pathway/Perimeter Monitoring & 12 & . & 1 \\
\hline DOE Order 5400.1 Surveillance Monitoring & 48 & - & . \\
\hline Best-Management Practice Monitoring & 12 & . & . \\
\hline
\end{tabular}


Some of the sampling locations are outside the East Fork Regime, including one well (GW-115) in the Bear Creek Regime, and several wells, springs, and surface water stations east of the ORR boundary in Union Valley and on Chestnut Ridge (Figure 8). Descriptions of the respective monitoring well networks and sampling frequencies for each monitoring program are provided in the following sections.

\subsubsection{RCRA Post-Closure Corrective Action Monitoring}

As noted in section 1.0, the post-closure permit for the East Fork Regime became effective August 30, 1996, and groundwater samples were collected in the fourth quarter of 1996 (SAP Addendum 96-42) from the following well network designated for RCRA post-closure corrective action monitoring: background well GW-115, point-of-compliance well GW-108, and plume boundary wells GW-193, GW-605, GW-606, and GW-733 (Table 4). Background well GW-115 is located in the Bear Creek Regime, near the East Fork Regime boundary, about $500 \mathrm{ft}$ north (upgradient) of the S-3 Ponds. Point-of-compliance well GW-108 is located in the Western Plant Area about $800 \mathrm{ft}$ southeast of the S-3 Ponds. The plume boundary wells are located in the Central Plant Area near Tank 2331-U (GW-193) and in the Eastern Plant Area upgradient (GW-605 and GW-606) and downgradient (GW-733) of New Hope Pond (Figure 8). Wells GW-108 and GW-115 are completed at shallow depths ( $<100 \mathrm{ft} \mathrm{bgs)} \mathrm{in} \mathrm{the} \mathrm{Aquitard.} \mathrm{Wells} \mathrm{GW-193,} \mathrm{GW-605,}$ GW-606, and GW-733 monitor bedrock intervals in the Aquifer. Complete well construction details are provided in Appendix $\mathrm{C}$.

\subsubsection{RCRA Interim Status Assessment Monitoring}

Quarterly RCRA interim status assessment monitoring during CY 1996 involved thirteen monitoring wells located in the Eastern Plant Area immediately upgradient and downgradient of New Hope Pond (Figure 8). These wells are completed at shallow depths (i.e., $<100 \mathrm{ft}$ bgs) in both the Aquitard (Nolichucky Shale) and the Aquifer (Maynardville Limestone). Aquitard wells to the north of New Hope Pond include GW-148, GW-149, GW-383, GW-384, and GW-385. Aquifer wells are located west (GW-154, GW-222, GW-223, and GW-380), south (GW-153 and GW-240), and east (GW-151 and GW-220) of the site (see Appendix C for well construction details). 
Groundwater samples were collected from each well in January/March, May/June, and July/August 1996 prior to the effective date of the post-closure permit, and again in September, October, or November 1996 as part of the DOE 5400.1 Surveillance Monitoring program (Table 4).

\subsubsection{CERCLA RI Sampling}

At the request of the Y-12 Environmental Restoration (ER) Program, samples were collected under the auspices of the Y-12 Plant GWPP from the following monitoring wells, springs, and surface water stations located east of the ORR boundary (Figure 8).

\begin{tabular}{|c|c|c|}
\hline \multicolumn{3}{|c|}{ Union Valley Offsite Exit Pathway Special Sampling Locations } \\
\hline Monitoring Wells & Springs & Surface Water Stations \\
\hline $\begin{array}{l}\text { GW-169 } \\
\text { GW-170 } \\
\text { GW-171 } \\
\text { GW-172 } \\
\text { GW-230 } \\
\text { GW-232 }\end{array}$ & $\begin{array}{c}\text { SCR 7.1 SP } \\
\text { SCR 7.14 SP } \\
\text { SCR 7.16 SP } \\
\text { SCR 7.18 SP } \\
\text { SCR 7.8S SP } \\
\text { UV 8.5 SP } \\
\text { UV 8.6 SP } \\
\text { UV 8.7 SP } \\
\text { RQWW SP }\end{array}$ & $\begin{array}{l}\text { SCR 7.12 SW } \\
\text { SCR 7.9 SW } \\
\text { UV 8.2 SW }\end{array}$ \\
\hline
\end{tabular}

Sampling and analysis requirements specified by the UEFPC RI project were initially defined in SAP Addendum 96-02 and modified in several subsequent addenda (Table 3). Samples were collected in the first (February/March), second (June), or third (September) quarter of 1996 (Table 4). Sampling was discontinued in July 1996 per SAP Addendum 96-27, or in September 1996 per SAP Addendum 96-38, at the request of the Y-12 ER Program.

In addition to the offsite sampling locations, monitoring wells and surface water stations within the East Fork Regime were sampled for the radiological parameters specified by the Y-12 ER Program. As shown in the following summary, samples were collected in February and March 1996. 


\begin{tabular}{|c|c|c|c|c|c|}
\hline \multicolumn{6}{|c|}{ SUMMARY OF CERCLA RI RADIOLOGLCA SA MP YING DURING CY 1996} \\
\hline $\begin{array}{l}\text { Sampling } \\
\text { Point }\end{array}$ & $\begin{array}{l}\text { Date } \\
\text { Sampled }\end{array}$ & $\begin{array}{l}\text { Sampling } \\
\text { Point }\end{array}$ & Sampled & Sampling & $\begin{array}{l}\text { Date } \\
\text { Sampled }\end{array}$ \\
\hline GW-108 & $02 / 21 / 92$ & GW-230 & $03 / 10 / 92$ & GW-735 & $03 / 04 / 92$ \\
\hline GW-115 & $02 / 22 / 92$ & GW-232 & $03 / 11 / 92$ & GW-744 & $02 / 12 / 92$ \\
\hline GW-134 & $03 / 13 / 92$ & GW-251 & $02 / 20 / 92$ & GW-745 & $02 / 12 / 92$ \\
\hline GW-135 & $03 / 14 / 92$ & GW-253 & $02 / 20 / 92$ & \multirow[t]{2}{*}{ GW-746 } & \multirow{2}{*}{$\begin{array}{l}02 / 13 / 92 \\
03 / 12 / 92\end{array}$} \\
\hline GW-154 & $02 / 22 / 92$ & GW-274 & $03 / 12 / 92$ & & \\
\hline GW-167 & $02 / 13 / 92$ & GW-276 & $02 / 28 / 92$ & GW-747 & $02 / 13 / 92$ \\
\hline \multirow[t]{2}{*}{ GW-169 } & \multirow{2}{*}{$\begin{array}{l}02 / 26 / 92 \\
03 / 12 / 92\end{array}$} & GW-284 & $02 / 26 / 92$ & GW-748 & $02 / 13 / 92$ \\
\hline & & GW-505 & $02 / 22 / 92$ & GW-749 & $02 / 13 / 92$ \\
\hline GW-170 & $03 / 17 / 92$ & GW-605 & $02 / 14 / 92$ & GW-754 & $02 / 14 / 92$ \\
\hline \multirow[t]{2}{*}{ GW-171 } & \multirow{2}{*}{$\begin{array}{l}02 / 28 / 92 \\
03 / 12 / 92\end{array}$} & GW-606 & $02 / 21 / 92$ & GW-756 & $02 / 13 / 92$ \\
\hline & & GW-617 & $02 / 19 / 92$ & GW-765 & $02 / 14 / 92$ \\
\hline GW-172 & $03 / 10 / 92$ & GW-633 & $02 / 26 / 92$ & GW-782 & $02 / 18 / 92$ \\
\hline GW-191 & $02 / 23 / 92$ & GW-633 & $03 / 12 / 92$ & \multirow[t]{2}{*}{ GW-816 } & \multirow{2}{*}{$\begin{array}{l}02 / 12 / 92 \\
02 / 12 / 92\end{array}$} \\
\hline \multirow[t]{2}{*}{ GW-193 } & \multirow{2}{*}{$\begin{array}{l}02 / 18 / 92 \\
03 / 12 / 92\end{array}$} & GW-687 & $03 / 04 / 92$ & & \\
\hline & & GW-692 & $02 / 29 / 92$ & Station 17 & $03 / 10 / 92$ \\
\hline GW-194 & $02 / 22 / 92$ & \multirow[t]{2}{*}{ GW-698 } & $02 / 29 / 92$ & NHP CEM SP & $03 / 10 / 92$ \\
\hline \multirow[t]{2}{*}{ GW-204 } & \multirow{2}{*}{$\begin{array}{l}02 / 23 / 92 \\
03 / 14 / 92\end{array}$} & & $03 / 12 / 92$ & North-South Pipe & $03 / 10 / 92$ \\
\hline & & GW-707 & $03 / 4 / 92$ & \multirow[t]{3}{*}{ LRSPW } & \multirow[t]{3}{*}{$02 / 19 / 92$} \\
\hline GW-207 & $02 / 19 / 92$ & \multirow[t]{2}{*}{ GW-722 } & $03 / 3 / 92$ & & \\
\hline GW-208 & $02 / 20 / 92$ & & $03 / 4 / 92$ & & \\
\hline
\end{tabular}

As noted in the preceding table, Appendix D.4 includes the gross alpha and gross beta results for sampling loctions used for other Y-12 Plant GWPP purposes during CY 1996. The remaining analytical results were requested specifically by the Y-12 ER Program and will be incorporated into the UEFPC RI report.

\subsubsection{DOE Order 5400.1 Exit Pathway/Perimeter Monitoring}

Exit Pathway/Perimeter monitoring is implemented under the Y-12 Plant GWPP to meet DOE Order 5400.1 requirements for monitoring groundwater that is or could be affected by operations at DOE facilities. Compliance with most of these requirements is achieved through continued implementation of ongoing permit- and regulatory-driven monitoring programs, and Exit Pathway/Perimeter monitoring is implemented to ensure monitoring where contamination is most 
likely to be transported beyond the ORR boundaries. Sampling for this purpose involved semiannual collection of samples from groundwater seepage points in the Lake Reality emergency overflow spillway (LRSPW), and quarterly collection of groundwater samples from twelve monitoring wells: Aquitard monitoring wells GW-207, GW-208, and GW-816 located along UEFPC in the gap through Pine Ridge; Aquifer monitoring wells that comprise Maynardville Limestone Picket E (GW-617 and GW-618) and Picket J (GW-603, GW-604, GW-735, and GW-750) (Figure 8); and RCRA plume boundary wells GW-605, GW-606, and GW-733 (Figure 8). Construction details for these wells are provided in Appendix C.

\subsubsection{DOE Order 5400.1 Surveillance Monitoring}

Groundwater samples were collected quarterly from 48 monitoring wells to satisfy DOE Order 5400.1 Surveillance Monitoring objectives (Table 4) to evaluate impacts of Y-12 Plant operations on groundwater quality and to monitor contaminant concentrations trends. The bulk of these wells are completed at shallow depths in the Aquitard in the Central Plant Area and Eastern Plant Area (Figure 8), and include: (1) one well each at the S-2 Site (GW-251) and the Waste Coolant Processing Area (GW-338); (2) two wells at the Fire Training Facility (GW-619 and GW-620); (3) four wells at the Beta-4 Security Pits (GW-191, GW-192, GW-194, and GW-195);

(4) 27 wells installed as part of the Grid Well Network recommended in the Comprehensive Monitoring Plan; and (5) beginning in September 1996, the thirteen wells previously used for RCRA interim status assessment monitoring at New Hope Pond. Detailed well construction information for these wells is provided in Appendix C. Groundwater samples were collected during the first, second, and fourth quarter of 1996; samples were not collected from most of the wells in the third quarter, per SAP Addendum 96-33, because of funding limitations.

\subsubsection{Best Management Practice Monitoring}

Groundwater samples were collected in June 1996 from 12 monitoring wells as a best management practice of the Y-12 Plant GWPP (Table 4). Samples were collected from Aquitard wells $55-1 \mathrm{~A}, 55-1 \mathrm{C}, 55-2 \mathrm{~B}$, and $55-2 \mathrm{C}$ to provide more recent data regarding nitrate and other contaminant concentrations in the groundwater upgradient (north) and downgradient (east) of the 
Waste Coolant Processing Area. Groundwater in Aquitard well 55-6A was sampled to determine nitrate concentrations in the groundwater near a sharp bend in the Abandoned Nitric Acid Pipeline in the Central Plant Area. Aquifer wells GW-218 at the Uranium Oxide Vault, GW-690, GW-691, and GW-692 at the Coal Pile Trench, and GW-698 and GW-700 at Building 8110 were sampled to provide more current groundwater quality data for these sites. Similarly, groundwater in Aquifer well GW-253 was sampled to determine current concentration trends within the contaminant plume originating from the S-2 Site. Locations of these wells are shown on Figure 8; well construction details are provided in Appendix C.

\subsection{Sample Collection, Transportation, and Chain-of-Custody Control}

Personnel from the Oak Ridge K-25 Site (K-25) Sampling and Environmental Support Department were responsible for collection, transportation, and chain-of-custody control of groundwater and surface water samples obtained for the multiple programmatic purposes of the Y-12 Plant GWPP. Sampling was performed in accordance with the Technical Procedure for Groundwater Sampling (Lockheed Martin Energy Systems, Inc. 1995), which is incorporated in and referenced by the post-closure permit; and the applicable methods and procedures specified in Environmental Surveillance Quality Control Program (Martin Marietta Energy Systems, Inc. 1988b), which have been approved by the U.S. Environmental Protection Agency (EPA) (Region IV) and the TDEC (Tennessee Department of Health and Environment 1988).

Groundwater samples were obtained from 23 monitoring wells using dedicated, gas-driven sampling equipment (Well Wizards ${ }^{\mathrm{TM}}$ ). Samples from the remaining 59 monitoring wells were obtained using portable Bennet Pumps ${ }^{\mathrm{TM}}$ and disposable bailers (Table 4). Surface water samples were collected using grab sample bottles.

Filtered and unfiltered samples were collected from each monitoring well, spring, and surface water station. Groundwater samples collected with Well Wizards ${ }^{\mathrm{TM}}$ and Bennet Pumps ${ }^{\mathrm{TM}}$ were filtered in the field using in-line 0.45 micron filters. Surface water samples, and groundwater samples collected with bailers, were filtered in the laboratory. All samples were labeled, logged, placed in ice-filled coolers, and transported to the appropriate analytical laboratory in accordance with chain-of-custody control requirements. 


\subsection{Field Measurements and Laboratory Analytes}

Field personnel measured the depth to water before purging and sampling groundwater in each monitoring well. This long-standing protocol of the Y-12 Plant GWPP complies with corresponding post-closure permit conditions for RCRA post-closure corrective action monitoring (Table 1). Sampling personnel also recorded field measurements of $\mathrm{pH}$, temperature, specific conductance, and dissolved oxygen for each groundwater and surface water sample (Table 5). Applicable measurements recorded for each sampling location, including groundwater elevations calculated from the depth-to-water measurements, are presented in Appendix D.1.

Laboratory analyses of the groundwater and surface water samples included the following standard suite of analytes: (1) pH, specific conductance, turbidity, total suspended solids, and TDS; (2) major ions and trace metals, which is the term used hereafter to differentiate metals that are typically minor constituents in groundwater (e.g., cobalt) from metals that are usually major ionic species (e.g., magnesium); (3) VOCs; and (4) gross alpha and gross beta activity (Table 5). This standard suite of analyses was modified in January 1996 (SAP Addendum 96-10) to include Inductively Coupled Plasma (ICP) spectroscopy analysis for lithium.

Some of the groundwater and surface water samples were analyzed for additional radiological parameters. Groundwater samples collected from wells specified for RCRA post-closure corrective action monitoring were analyzed for selected radioisotopes, as were the groundwater samples collected as a best management practice of the Y-12 Plant GWPP (Table 5). Additionally, the groundwater and surface water samples collected in support of the RI for the UEFPC CA were analyzed for the radioisotopes specified by the Y-12 ER Program.

Laboratory analyses were performed in accordance with the EPA- and TDEC-approved analytical methods listed in Table 5. However, new or revised analytical methods for several of the standard analytes were performed. Atomic Absorption Spectroscopy (AAS) for lead analyses (total and dissolved) was replaced with Plasma Mass Spectroscopy (PMS) in July 1996 (SAP Addendum 96-34). Similarly, beginning in October 1996, total and dissolved arsenic concentrations were determined using PMS instead of ICP spectroscopy (SAP Addendum 96-48). Also, beginning in October 1996, three separate methods used for VOC analyses were replaced with a revised procedure 
that captured most compounds required for the multiple programmatic purposes of the Y-12 Plant GWPP (SAP Addendum 96-44).

Most laboratory analyses of the groundwater and surface water samples were performed by the K-25 Analytical Service Organization (ASO). Selected radiochemical analyses were performed by the Y-12 Plant ASO and the Oak Ridge National Laboratory (ORNL) ASO. Analytical results are presented in Appendix D.1 (miscellaneous laboratory parameters), Appendix D.2 (inorganic analytes), Appendix D.3 (organic analytes), and Appendix D.4 (radiological analytes). Groundwater and surface water samples collected in support of the RI for the UEFPC CA were analyzed for multiple radioisotopes (Table 5), but only the results for gross alpha, gross beta, and ${ }^{99} \mathrm{Tc}$ (i.e., RCRA constituents) are included in Appendix D.4. Validation of the analytical results for the other radioanalytes will be combined in the RI report for the UEFPC CA.

\subsection{Quality Assurance/Quality Control Sampling}

Quality assurance/quality control samples included a total of 87 laboratory blanks, 124 trip blanks, 27 equipment rinsate samples, and four field blanks. Laboratory blanks were samples of deionized water analyzed along with several associated groundwater and/or surface water samples. Trip blanks were samples of deionized water transported in each cooler containing groundwater and surface water samples to be analyzed for organic compounds. Field blanks were samples of deionized water prepared when groundwater samples were collected from selected monitoring wells. Equipment rinsates were samples of the deionized water used to decontaminate the portable groundwater sampling equipment (i.e., Bennet Pumps ${ }^{\mathrm{TM}}$ ), and were collected after a sampling team had completed sampling at a site or finished each administrative well group (a series of sampling locations grouped in the SAP for data tracking and management purposes). If more than one sampling pump was used, an equipment rinsate sample was collected from each pump. Equipment rinsates for bailers were collected after they were unwrapped for use in the field.

Laboratory blanks, trip blanks, field blanks, and equipment rinsate samples were analyzed for VOCs; selected equipment rinsates also were analyzed for trace metals and radiochemical parameters. Analytical results for the QA/QC blanks and equipment rinsate samples are presented in respective subsections of Appendix $\mathrm{E}$. 
In addition to the blank samples and equipment rinsates, duplicate groundwater samples were collected for QA/QC purposes from one spring and 23 monitoring wells (see Appendix $F$ ), including at least one well in each administrative well group defined in the CY 1996 SAP (and associated addenda). Duplicate groundwater samples were analyzed for the constituents and parameters specified for the location from which they were collected; analytical results are included with the corresponding data presented in Appendix D.

\subsection{Data Management}

Analytical results for the groundwater and surface water samples were electronically downloaded directly into the Y-12 Plant GWPP SAS ${ }^{\mathrm{TM}}$ data sets from data files provided by the $\mathrm{K}-25, \mathrm{Y}-12$, and ORNL ASOs. Some data were manually input from hardcopy documentation (laboratory reports and field data sheets) by the database management subcontractor. Downloaded and manually input data were verified in accordance with the Y-12 Plant Groundwater Protection Program - Groundwater Monitoring Program Data Management Plan (Data Management Plan) (Martin Marietta Energy Systems, Inc. 1993). The database management subcontractor and the appropriate ASO worked to resolve any incomplete data transfers, irregular parameter names or reporting units, and discrepancies between electronic and hardcopy versions of the data.

A standardized data screening process was used to identify CY 1996 analytical data that do not meet the DQOs defined in the Data Management Plan. As shown in the following summary table, most of the DQO criteria apply to analytical results for inorganic analytes.

\begin{tabular}{|c|c|c|c|c|}
\hline Criteria & $\begin{array}{l}\text { Inorganic } \\
\text { Analytes }\end{array}$ & $\begin{array}{l}\text { Organic } \\
\text { Analytes }\end{array}$ & Radiological & Miscellaneous \\
\hline Duplicate Sample Data & - & - & - & 0 \\
\hline Filtered/Unfiltered Sample Data & - & . &. & . \\
\hline Ion Charge Balance & - & . & . & . \\
\hline False Positive Results & . & - & . & . \\
\hline Counting Errors & . & . & - & . \\
\hline
\end{tabular}


As described in Appendix F, the overwhelming majority of analytical results reported for the $C Y$ 1996 groundwater and surface water samples met applicable DQOs of the Y-12 Plant GWPP. Screened data include two duplicate sample results and eight total/dissolved trace metal concentrations that differ by an order-of-magnitude or more; 61 false positive results for VOCs, most of which probably reflect contamination from the laboratory environment; and six radioisotope results that exceed the respective minimum detectable activity (MDA), but are less than the associated counting errors. Additionally, principal ion data for 22 groundwater samples are not suitable for quantitative evaluation because of charge balance errors. 


\subsection{DATA EVALUATION}

This section presents data evaluations required annually for RCRA post-closure corrective action monitoring for the eastern S-3 Ponds plume. Conditions of the post-closure permit (Table 1) require evaluation of applicable monitoring data regarding: (1) the groundwater flow direction and rate in the uppermost aquifer, (2) performance of the low-permeability cap at the S-3 Ponds based on temporal concentration trends for Groundwater Protection Standard (GWPS) constituents in groundwater at the RCRA point-of-compliance, and (3) additional contaminant migration based on detection of ${ }^{99} \mathrm{Tc}$ in groundwater at the RCRA plume boundary wells. Results of these evaluations are described in the following sections.

\subsection{Groundwater Flow Direction and Rate}

Groundwater surface elevations determined from depth-to-water measurements recorded for 62 monitoring wells during April 2-4, 1996 (the seasonally high water table) and September 30 October 7, 1996 (the seasonally low water table) were used to evaluate groundwater flow directions in the East Fork Regime (Table 6). Depth-to-water measurements recorded during sampling events were not used because they were less contemporaneous, and may have been influenced by sampling activities (i.e., purging/sampling adjacent wells).

Rates of groundwater flow were estimated for the water table and shallow bedrock intervals in the Aquitard and the shallow karst network in the Aquifer. Flow rates were not estimated for the stormflow zone because the shallow subsurface throughout much of the Western Plant Area was substantially altered during construction of the Y-12 Plant (Figure 3). Estimated rates of flow in the intermediate and deep bedrock intervals also were not determined, but are probably as low as a few centimeters per year (Solomon et al. 1992).

\section{Groundwater Flow Directions}

Isopleths of seasonal groundwater surface elevations in the water table interval (Figure 4) generally indicate southeasterly (strike-normal) flow in the Aquitard toward the Aquifer (Maynardville Limestone), the hydrologic drain for the groundwater flow system in the East Fork 
Regime, and easterly (strike-parallel) flow in the Maynardville Limestone toward the east end of the Y-12 Plant. Seasonal water level fluctuations ranged from zero to $12.5 \mathrm{ft}$ throughout the regime (Table 6), but were generally less than one $\mathrm{ft}$ in the Western Plant Area east of the S-3 Ponds. Seasonal fluctuations influenced the magnitude of horizontal and vertical hydraulic gradients but did not significantly alter the overall directions of groundwater flow in the regime (Figure 4).

Water level data for selected Aquitard (GW-261 and GW-634) and Aquifer (GW-107 and GW-617) monitoring wells in the Western Plant Area were used to determine representative horizontal hydraulic gradients. Based on data for these wells, seasonal horizontal hydraulic gradients in the water table interval average about 0.047 across strike in the Aquitard, and average about 0.02 along strike in the Aquifer.

\section{Groundwater Flow Rates}

Rates of groundwater flow $(V)$ in the Aquitard and the Aquifer were estimated using the modified Darcy equation: $V=\mathbf{K} I / \eta$, where $\mathbf{K}$ is the hydraulic conductivity of the medium, $\boldsymbol{\eta}$ is the effective porosity, and $I$ is the horizontal hydraulic gradient. The calculated flow rates represent average velocities in fractured rock, assuming each hydrogeologic unit functions as an equivalent porous medium. However, depending on fracture aperture and wall roughness, flow rates in individual fractures may vary over several orders of magnitude (Freeze and Cherry 1979). Additionally, variation in the effective porosity would produce an inversely proportional variation in the calculated Darcy flow velocity.

In the Aquitard, calculated Darcy flow velocities for the water table interval range from 0.33 to about $36 \mathrm{ft}$ per day ( $\mathrm{ft} / \mathrm{d}$ ) based on a hydraulic conductivity of 0.03 to $3.25 \mathrm{ft} / \mathrm{d}$ for saturated regolith (Connell and Bailey 1989), a strike-normal horizontal hydraulic gradient of 0.047 , and an effective porosity of 0.0042 (Moore 1989). Calculated flow rates for the shallow bedrock interval range from 0.11 to about $80 \mathrm{ft} / \mathrm{d}$ based on a hydraulic conductivity of $0.0008 \mathrm{ft} / \mathrm{d}$ for matrix intervals (Moore 1989), $0.15 \mathrm{ft} / \mathrm{d}$ for permeable intervals (Moore 1989), and $0.6 \mathrm{ft} / \mathrm{d}$ for the continuum of permeable intervals (Moore and Toran 1992); a strike-normal hydraulic gradient of 0.047 ; and an effective porosity of 0.00035 (Moore and Toran 1992). The relatively limited extent of contaminant migration from the S-3 Ponds, particularly in light of its 30-year operational period, suggests that 
flow rates in the lower range probably dominate in the Aquitard, and that attenuation processes (e.g., matrix diffusion) greatly reduce contaminant transport rates relative to the groundwater flow velocity.

In the Aquifer, estimated rates of groundwater flow in the shallow karst network range from about 105 to $1,257 \mathrm{ft} / \mathrm{d}$ based on an average hydraulic conductivity of $22 \mathrm{ft} / \mathrm{d}$ determined from well test results (Geraghty \& Miller, Inc. 1989a), a strike-parallel horizontal hydraulic gradient of 0.02 , and the same range of effective porosity referenced for the Aquitard. These calculated rates are probably representative of conduit flow in the shallow karst network, and are comparable to those of typical karst terrains (Quinlan and Ewers 1985). Additionally, conduit flow rates in the lower range are supported by results of a dye-tracer test in the Bear Creek Regime, which indicated a transport rate of about $200 \mathrm{ft} / \mathrm{d}$ in the Maynardville Limestone (Geraghty \& Miller, Inc. 1989b).

\subsection{Point-of-Compliance Concentration Trends}

Results for GWPS constituents reported for point-of-compliance well GW-108, along with data obtained since CY 1990, were used to evaluate temporal concentration trends in the groundwater east of the S-3 Ponds. Assuming contaminant flushing during seasonal groundwater recharge/discharge cycles, and no additional influx of contamination since closure of the site in 1984, concentrations of GWPS constituents should decrease over the long term.

Well GW-108 is completed at a depth of 58.6-ft bgs in the Nolichucky Shale about $800 \mathrm{ft}$ southeast of the S-3 Ponds (Figure 8). Eight GWPS constituents were detected in the groundwater sample collected from the well in November 1996: barium, lead, nitrate, uranium, chloroform, gross alpha, gross beta, and ${ }^{99} \mathrm{Tc}$ (Table 7). Results for each constituent except chloroform met applicable DQO criteria. The chloroform result was screened as a false positive because of contamination in the trip blank sample associated with the well (see Appendix F).

The nitrate $(10,900 \mathrm{mg} / \mathrm{L})$ and total barium $(130 \mathrm{mg} / \mathrm{L})$ results for well $\mathrm{GW}-108$ both are representative of maximum contaminant concentrations within the plume originating from the S-3 Ponds. Extremely high concentrations in the groundwater at well GW-108 may be attributable to contaminated groundwater being channeled southeast toward the well through the buried headwaters of UEFPC, combined with greater contaminant flux associated with strike-parallel flowpaths within 
the middle and upper Nolichucky Shale that subcrop beneath the S-3 Ponds (AJA Technical Services, Inc. 1996). Historical results for both constituents define widely fluctuating concentrations, but clearly decreasing temporal trends (Figure 9). Concentration fluctuations do not consistently correlate with groundwater elevations in the well. The decreasing temporal trends probably reflect reduced contaminant flux after closure of the S-3 Ponds.

Gross beta activity $(5,960 \pm 700$ picoCuries per liter $[\mathrm{pCi} / \mathrm{L}])$ and elemental uranium $(0.016 \mathrm{mg} / \mathrm{L})$ results suggest increasing long-term temporal trends in the groundwater at well GW-108 (Figure 9). Gross beta reflects the ${ }^{99} \mathrm{Tc}$ concentration $(8,690 \pm 870 \mathrm{pCi} / \mathrm{L}$ ) in the groundwater at well GW-108, although other beta-emitting radionuclides (e.g., tritium) also are present. Under oxidizing conditions, ${ }^{99} \mathrm{Tc}$ occurs in groundwater as the pertechnetate anion $\left(\mathrm{TcO}_{4}^{-}\right)$, which is soluble and mobile (Gee et al. 1983). Uranium in the acidic (i.e., $\mathrm{pH}<6.0$ ) groundwater at well GW-108 is probably present as uranyl cations (+6 valence) which tend to form complexes with a variety of anions (e.g., carbonate) that are mobile in groundwater but are prone to $\mathrm{pH}$-sensitive sorption reactions (Fetter 1992).

The lead concentration $(0.0012 \mathrm{mg} / \mathrm{L})$ reported for the sample collected from well GW-108 in November 1996, compared to historical data for the well, does not suggest any clear temporal trend. Lead has been detected in only eight of the 20 groundwater samples collected from the well since January 1986 . One of these results $(2.28 \mathrm{mg} / \mathrm{L})$ is an obvious outlier, and the remaining results range from 0.0012 to $0.02 \mathrm{mg} / \mathrm{L}$.

Although the gross alpha $(700 \pm 180 \mathrm{pCi} / \mathrm{L})$ result for well $\mathrm{GW}-108$ exceeds the MDA, historical data for the well do not exhibit any discernable temporal trend. Gross alpha activity in the groundwater east of the S-3 Ponds is likely due to ${ }^{234} \mathrm{U}$ and ${ }^{238} \mathrm{U}$ concentrations, both of which were detected (above MDAs) in the groundwater sample from well GW-108 (see Appendix D.4).

As noted previously, the chloroform result for well GW-108 $(30 \mu \mathrm{g} / \mathrm{L})$ was screened as a false positive. Historical results for the well show chloroform concentrations ranging from 18 to $24 \mu \mathrm{g} / \mathrm{L}$ that do not exhibit any temporal trend.

Based on the preceding evaluation, results for point-of-compliance well GW-108 reflect increasing (gross beta and uranium), decreasing (nitrate and barium), or variable (lead, gross alpha, and chloroform) contaminant concentrations in the groundwater east of the S-3 Ponds. Different 
temporal trends probably reflect a combination of reduced contaminant flux after closure of the site, and the relative hydrochemical transport characteristics from the large secondary source contamination within the bedrock matrix.

\subsection{Plume Boundary Evaluation}

Under condition V.D.2 of the post-closure permit, additional migration of the contaminant plume originating from the S-3 Ponds is indicated by detection of ${ }^{99} \mathrm{Tc}$ (above MDAs) in the groundwater samples from plume boundary wells GW-193, GW-605, GW-606, or GW-733. Because there are multiple sources for other GWPS constituents within the Y-12 Plant, ${ }^{99} \mathrm{Tc}$ serves as the best indicator parameter for S-3 Ponds source contamination. Several GWPS constituents were detected in the samples collected from each of these wells, including nitrate, barium, lead, uranium, several VOCs, gross alpha, and gross beta (Table 7), but the ${ }^{99} \mathrm{Tc}$ activities did not exceed the respective MDAs (see Appendix D.4). The lack of ${ }^{99} \mathrm{Tc}$ in these samples suggests that each well monitors groundwater unaffected by migration of contaminants from the S-3 Ponds and effectively serves the plume boundary monitoring purposes of the post-closure permit. 


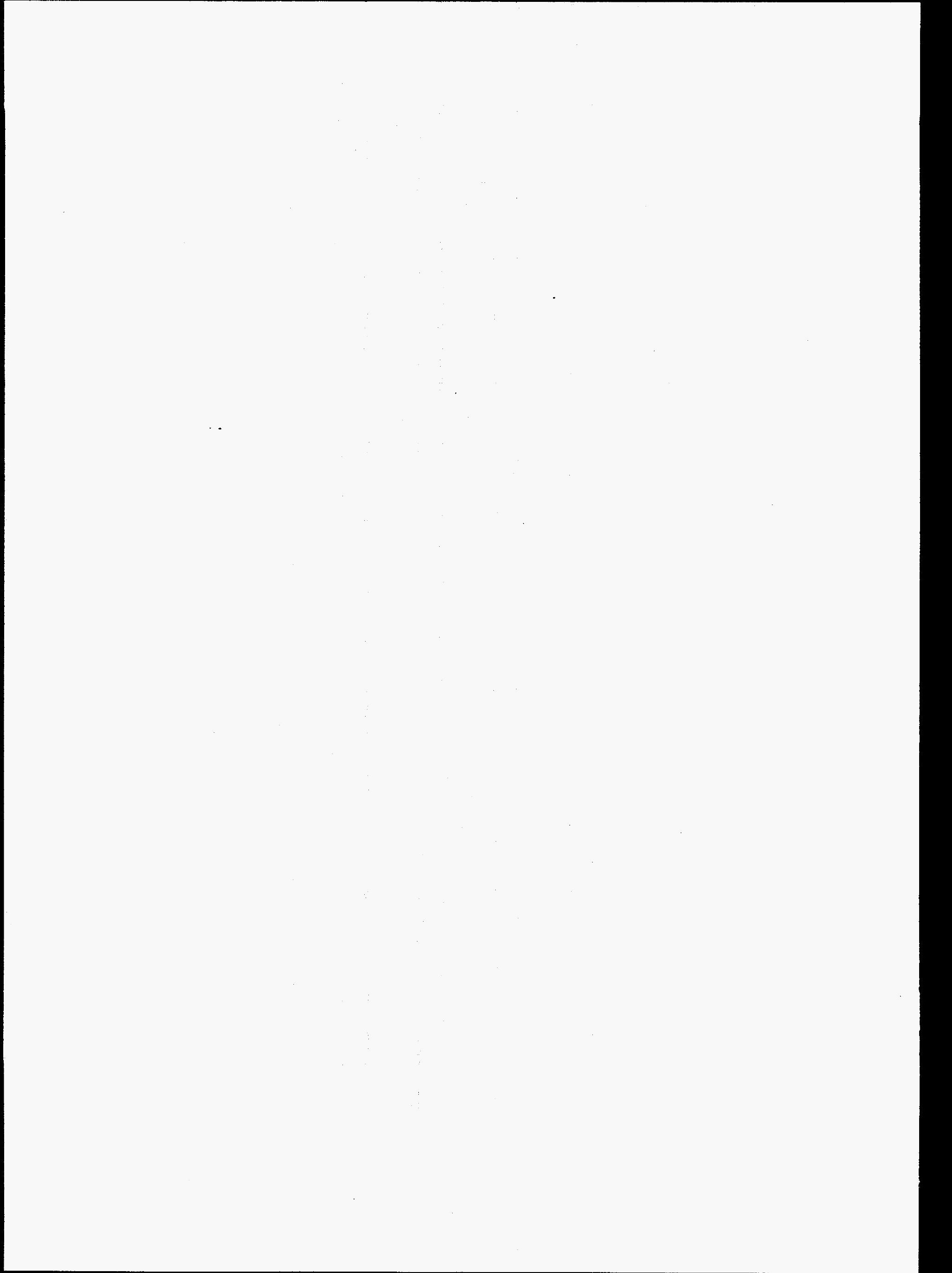




\subsection{SUMMARY AND CONCLUSIONS}

This CY 1996 annual monitoring report contains the groundwater and surface water monitoring data obtained under the auspices of the Y-12 Plant GWPP for the multiple programmatic purposes of: (1) RCRA post-closure corrective action monitoring, (2) RCRA interim status assessment monitoring, (3) CERCLA RI monitoring, (4) DOE Order 5400.1 exit pathway/perimeter monitoring, (5) DOE Order 5400.1 surveillance monitoring, and (6) monitoring performed as a best management practice of the Y-12 Plant GWPP.

Groundwater and surface water samples were collected from 82 monitoring wells, ten springs, and four surface water sampling stations. The sampling frequency (annual, semiannual, and quarterly) for each location varied depending on the requirements of the governing monitoring program. Most of the groundwater and surface water samples were analyzed for a standard suite of analytical parameters, including principal ions, trace metals, VOCs, radiological parameters, and several miscellaneous field and laboratory measurements. Samples collected from some locations were analyzed for several radioisotopes, including groundwater and surface water samples collected for RI purposes.

As required in the post-closure permit, the RCRA post-closure corrective action monitoring data were used to evaluate: (1) the groundwater flow rate and direction in the uppermost aquifer east of the S-3 Ponds, (2) the performance of the low-permeability cap at the site based on concentrations of GWPS constituents in groundwater at point-of-compliance well GW-108, and (3) evidence for additional migration of contaminants from the site based on the presence of ${ }^{99} \mathrm{Tc}$ in the groundwater at plume boundary wells GW-193, GW-605, GW-606, and GW-733.

In the Western Plant Area east of the S-3 Ponds, groundwater flow directions are generally southeasterly from the Aquitard toward the Aquifer, and easterly in the Aquifer toward the east end of the Y-12 Plant. Flow rates at shallow depths in both hydrogeologic units, as estimated using the modified Darcy equation, range over several orders-of-magnitude, but the lower rates probably dominate, particularly in the Aquitard.

Along with historical data, the CY 1996 RCRA corrective action monitoring results for GWPS constituents show increasing (gross beta and uranium), decreasing (nitrate and barium), or 
variable (gross alpha and chloroform) temporal trends in the groundwater at point-of-compliance well GW-108. These concentration trends indicate that the low permeability cap at the S-3 Ponds has had little influence on groundwater contaminant concentrations because of the large secondary source within the bedrock matrix.

Several GWPS constituents which are not unique to the S-3 Ponds contamination plume were detected in the groundwater at each of the plume boundary wells, including nitrate, trace metals, VOCs, gross alpha, and gross beta. However, ${ }^{99} \mathrm{Tc}$ results did not exceed respective MDAs reported for the groundwater samples from each well. The lack of ${ }^{99} \mathrm{Tc}$, which is unique to the S-3 Ponds and therefore the "signature" GWPS constituent for the site, shows that these wells effectively monitor the contaminant plume boundary for the purposes of the post-closure permit. 


\subsection{REFERENCES}

AJA Technical Services, Inc. 1996. Calendar Year 1995 Groundwater Quality Report for the Upper East Fork Poplar Creek Hydrogeologic Regime, Y-12 Plant, Oak Ridge, Tennessee. Prepared for Lockheed Martin Energy Systems, Inc. (Y/SUB/96-KDS115V/4)

Buckley, P. 1992. Letter from K-25 Analytical Services Organization to Paradigm Data Services, Inc., October 21, 1992.

CDM Federal Programs Corporation. 1994. Water Balance Report for the Oak Ridge Y-12 Plant. Prepared for Matin Marietta Energy Systems, Inc. (SUB/28B-99920C/92-4).

Connell, J.F. and Z.C. Bailey. 1989. Statistical and Simulation Analysis of Hydraulic-Conductivity Data For Bear Creek and Melton Valleys, Oak Ridge Reservation, Tennessee. U.S. Geological Survey Water-Resources Investigations Report 89-4062.

Dreier, R.B., D.K. Solomon, and C.M. Beaudoin. 1987. Fracture Characterization in the Unsaturated Zone of a Shallow Land Burial Facility. Reported in: Flow and Transport through Fractured Rock. American Geophysical Union Monograph 42.

Fetter, C.W. 1992. Contaminant Hydrology. Macmillan Publishing Company. New York, NY (pp 282-285).

Freeze, R.A. and J.A. Cherry. 1979. Groundwater. Prentice-Hall, Inc., Eaglewood Cliffs, NJ (pp. 408-409).

Gee, G.W., D. Rai, and R.J. Serne. 1983. Mobility of Radionuclides in Soil. In: Chemical Mobility and Reactivity in Soil Systems. Soil Science Society of America, Inc. Madison, WI (pp 203227).

Geraghty \& Miller, Inc. 1989a. Development of Ground-Water Flow Models for the S-3 Waste Management Area, Y-12 Plant, Oak Ridge, Tennessee. Prepared for Martin Marietta Energy Systems, Inc. (Y/SUB/89-00206C/1).

Geraghty \& Miller, Inc. 1989b. Tracer Study of the Hydrologic System of Upper Bear Creek, Y-12 Plant, Oak Ridge, Tennessee. Prepared for Martin Marietta Energy Systems, Inc. (Y/SUB/89-00206C/4).

Geraghty \& Miller, Inc. 1990. Comprehensive Groundwater Monitoring Plan for the Oak Ridge Y-12 Plant. Prepared for Martin Marietta Energy Systems, Inc. (Y/SUB/90-00206C/5). 
Goldstrand, P.M. 1995. Stratigraphic Variations and Secondary Porosity within the Maynardville Limestone in Bear Creek Valley, Y-12 Plant, Oak Ridge, Tennessee. Martin Marietta Energy Systems, Inc. (Y/TS-1093).

HSW Environmental Consultants, Inc. 1995. Sampling and Analysis Plan for Groundwater and Surface Water Monitoring at the Y-12 Plant during Calendar Year 1996. Prepared for Martin Marietta Energy Systems, Inc. (Y/SUB/95-EAQ10C/4).

Jago, W.K. 1995. Field notes and calculations from water-level monitoring during operation of the Lake Reality Sump.

Jones, S.B., B.K. Thompson, and S.M. Field. 1995. Updated Subsurface Data Base for Bear Creek Valley, Chestnut Ridge, and Parts of Bethel Valley on the U.S. Department of Energy Oak Ridge Reservation. Martin Marietta Energy Systems, Inc. (Y/TS-881/R3).

King, H.L. and C.S. Haase. 1987. Subsurface-Controlled Geological Maps for the Y-12 Plant and Adjacent Areas of Bear Creek Valley. Oak Ridge National Laboratory (ORNL/TM-10112).

Lockheed Martin Energy Systems, Inc. 1995. Technical Procedure for Groundwater Sampling. K-25 Analytical Services Organization, Procedure No. SESD-TP-8204.

Lockheed Martin Energy Systems, Inc. 1996. The Subsurface Hydrology Around Building 9201-2: Results of the July 1994 Water Level Recovery Test, Oak Ridge Y-12 Plant, Oak Ridge, Tennessee. (Y/ER-263).

Martin Marietta Energy Systems, Inc. 1988a. Revised RCRA Closure Plan for New Hope Pond. (Y/TS-389).

Martin Marietta Energy Systems, Inc. 1988b. Environmental Surveillance Procedures Quality Control Program. (ES/ESH/INT-14).

Martin Marietta Energy Systems, Inc. 1993. Y-12 Plant Groundwater Protection ProgramGroundwater Monitoring Program Data Management Plan. (Y/SUB/93-TK532C/1).

Moore, G.K. 1988. Concepts of Groundwater Occurrence and Flow Near Oak Ridge National Laboratory. Oak Ridge National Laboratory (ORNL/TM-10969).

Moore, G.K. 1989. Groundwater Parameters and Flow System near the Oak Ridge National Laboratory. Oak Ridge National Laboratory (ORNL/TM-11368).

Moore, G.K. 1992. Hydrograph analysis in fractured rock terrain. Ground Water, Vol. 30, No. 3, pp. 390-395. 
Moore, G.K. and L.E. Toran. 1992. Supplement to Hydrogeologic Framework for the Oak Ridge Reservation, Oak Ridge, Tennessee. Oak Ridge National Laboratory (ORNL/TM-12191).

Quinlan, J.F., and R.O. Ewers. 1985. Groundwater Flow in Limestone Terrains: Strategy, Rationale and Procedure for Reliable, Efficient Monitoring of Groundwater Quality in Karst Areas. National Symposium and Exposition on Aquifer Restoration and Groundwater Monitoring. Proceedings, National Water Well Association, Worthington, Ohio (pp. 197-234).

Science Applications International Corporation. 1996. Remedial Investigation Report for Bear Creek Valley. Volume 1. Prepared for Lockheed Martin Energy Systems, Inc. (Draft).

Shevenell, L.A. 1994. Chemical Characteristics of Waters in Karst Formations at the Oak Ridge Y-12 Plant. Oak Ridge National Laboratory (Y/TS-1001).

Shevenell, L.A., R.B Dreier, and W.K. Jago. 1993. Summary of Fiscal Years 1991 and 1992 Construction, Hydrologic, and Geological Data Obtained from the Maynardville Limestone Exit Pathway Monitoring Program. Oak Ridge National Laboratory. (Y/TS-814).

Solomon, D.K., G.K. Moore, L.E. Toran, R.B. Dreier, and W.M. McMaster. 1992. Status Report A Hydrologic Framework for the Oak Ridge Reservation. Oak Ridge National Laboratory (ORNL/TM-12053).

Sutton, G.E., and S.M. Field. 1995. Distribution of Anthropogenic Fill Material within the Y-12 Plant Area, Oak Ridge, Tennessee. Prepared for Lockheed Martin Energy Systems, Inc. (Y/TS-1387).

Tennessee Department of Health and Environment. 1988. Letter from T. Tiesler, Director of the Division of Solid Waste-Management, to J.L. Foutch, U.S. Department of Energy - Oak Ridge Operations, January 13, 1988.

U.S. Environmental Protection Agency. 1983. Methods for Chemical Analysis of Water and Wastes.

U.S. Environmental Protection Agency. 1986. Test Methods for Evaluating Solid Waste Physical/Chemical Methods.

U.S. Environmental Protection Agency. 1988. Laboratory Data Validation Functional Guidelines for Evaluating Organics Analyses. U.S. EPA, Office of Solid Waste. 


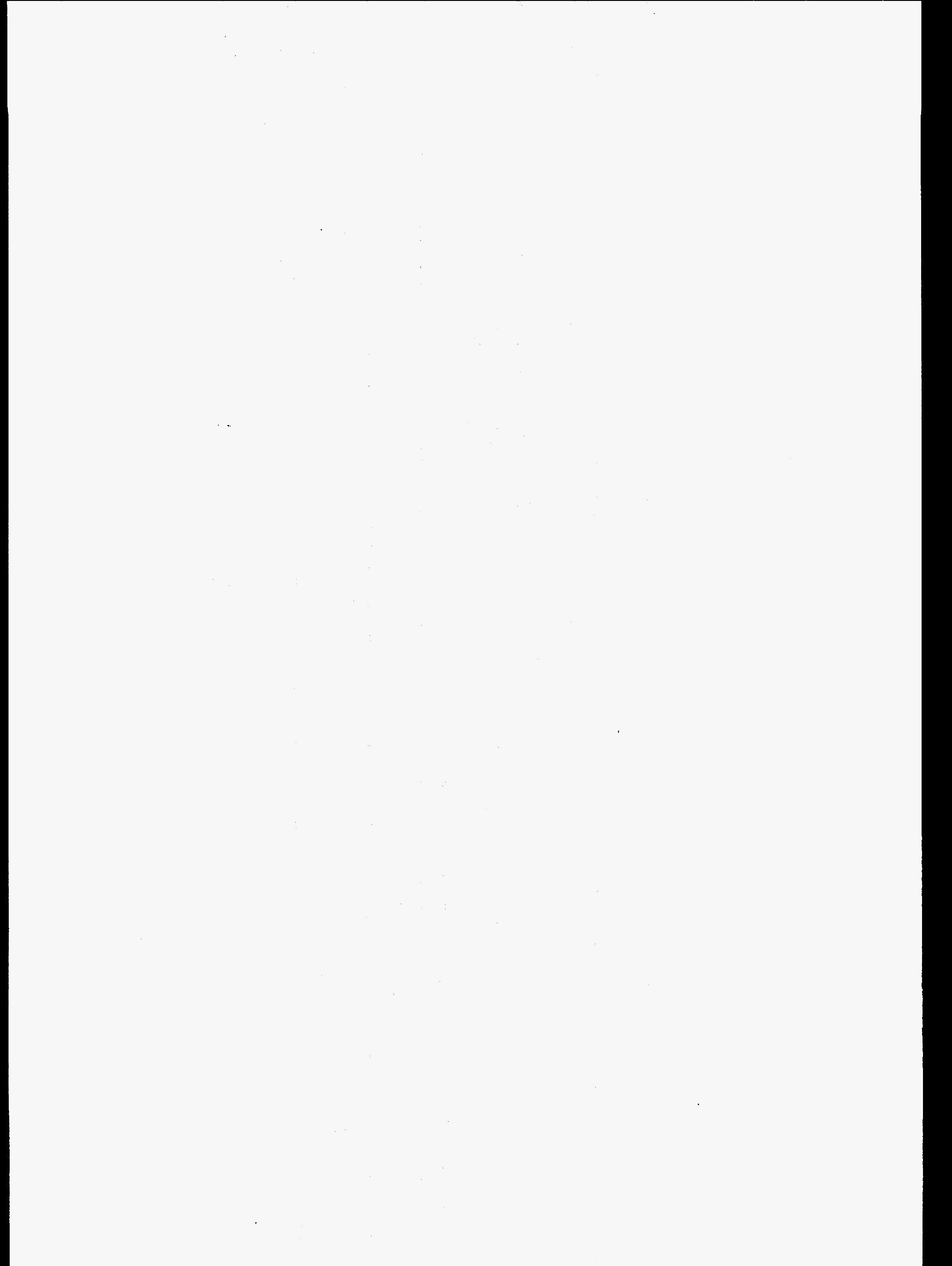




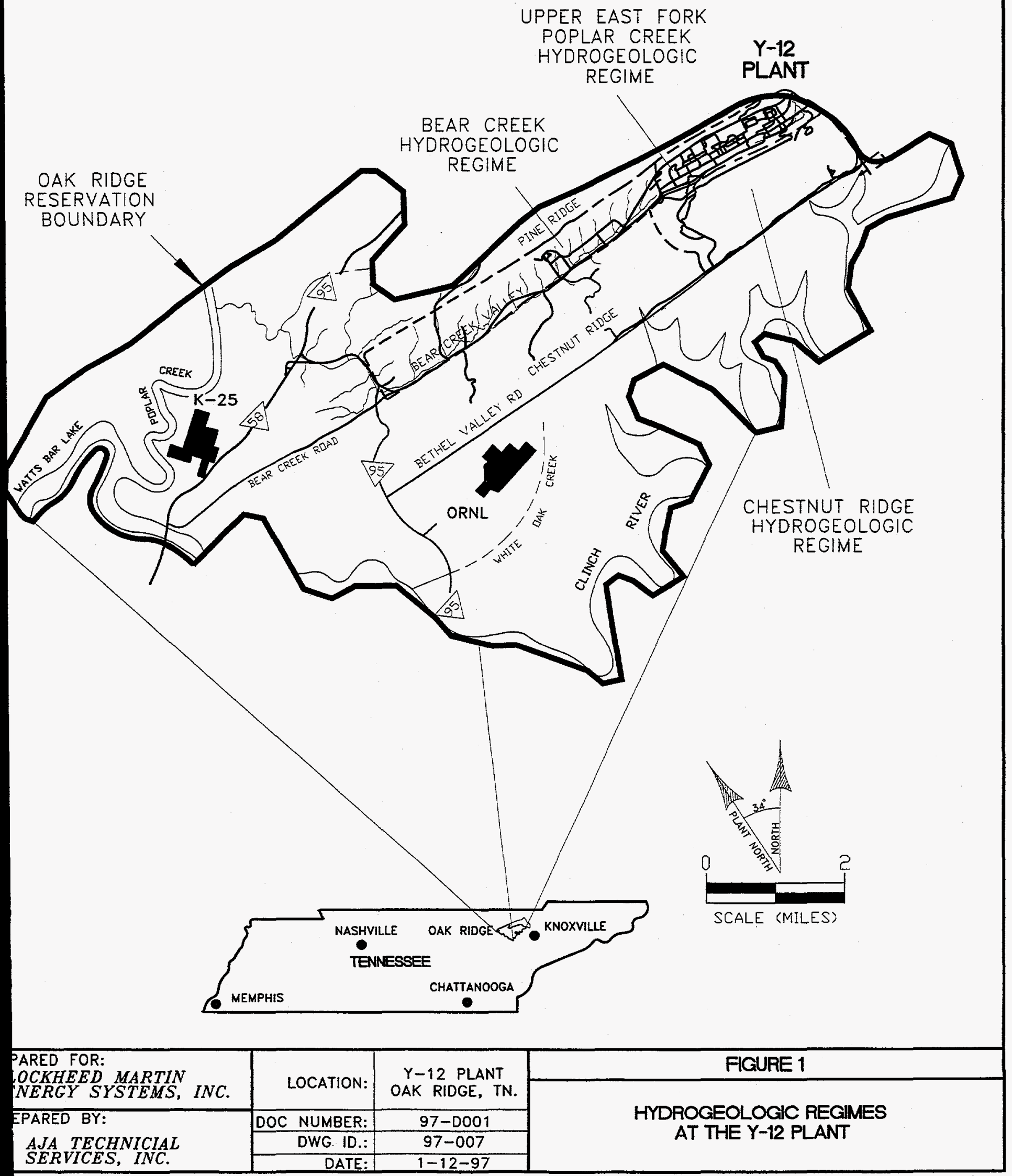




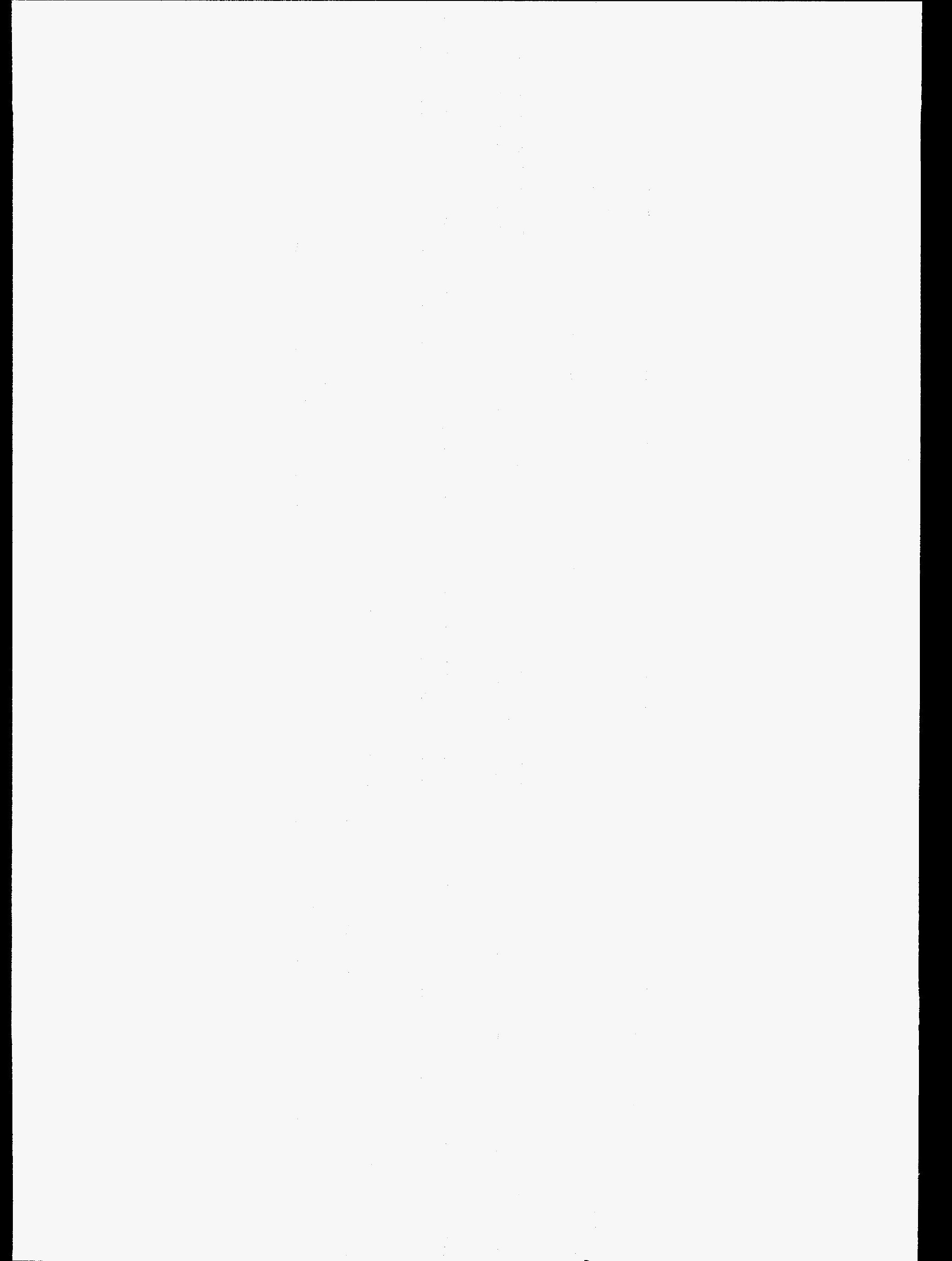




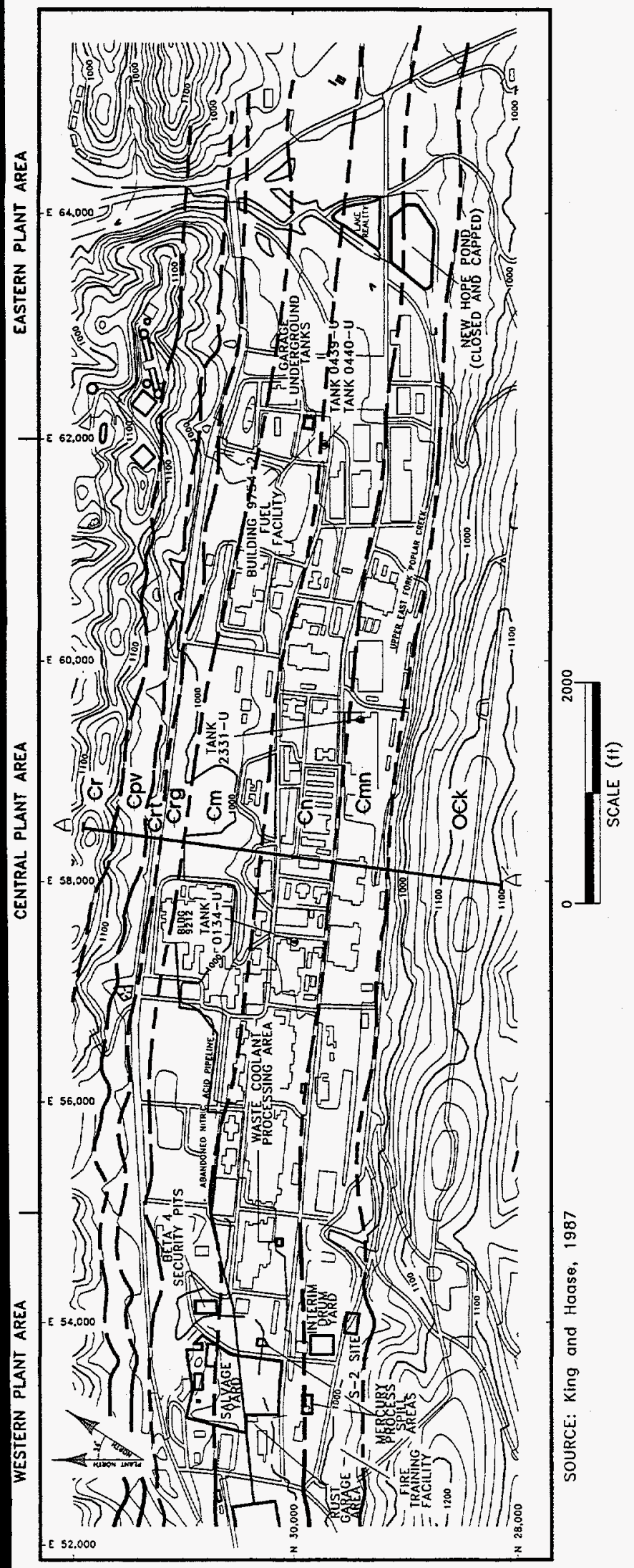

\begin{tabular}{|c|c|c|c|c|c|c|}
\hline 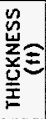 & 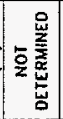 & 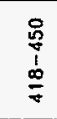 & $\begin{array}{l}\text { 今. } \\
\text { 1. } \\
\text { స̃ } \\
\text { ปn }\end{array}$ & $\begin{array}{l}\frac{n}{4} \\
\vdots \\
0 \\
0 \\
0\end{array}$ & 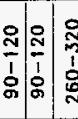 & 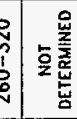 \\
\hline 等高 & $\ddot{\Phi}$ & E & $\Xi$ & 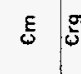 & $8=0$ & t) \\
\hline zog & 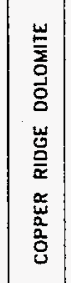 & 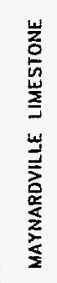 & 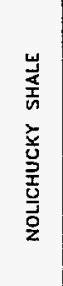 & 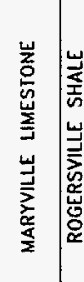 & 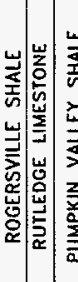 & 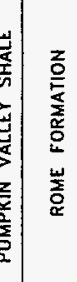 \\
\hline $\mid$ & \multicolumn{2}{|c|}{$\begin{array}{l}\text { yasinor } \\
\text { xoNX }\end{array}$} & \multicolumn{4}{|c|}{ soyruinov yуо } \\
\hline 总 & XONX & & \multicolumn{3}{|c|}{ צפกษSYNOJ } & \\
\hline \multirow[t]{2}{*}{$\overline{5}$} & \multirow{2}{*}{\multicolumn{2}{|c|}{ yЭddn }} & \multirow{2}{*}{\multicolumn{3}{|c|}{$37001 \mathrm{~W}$}} & $\triangle \exists M O$ \\
\hline & & & & & & \\
\hline
\end{tabular}

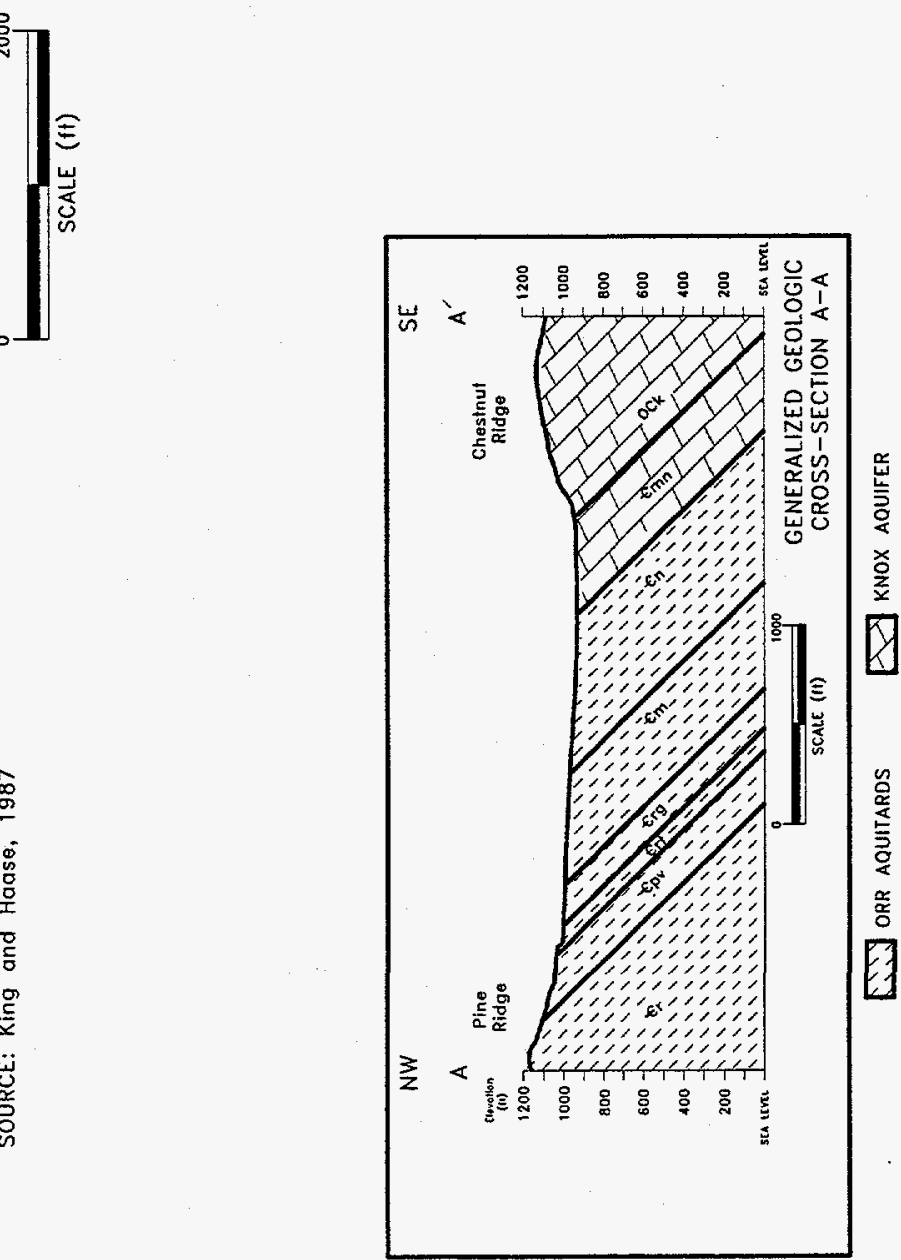

\begin{tabular}{l|r|c|}
\hline ARED FOR: & LOCATION: & $\begin{array}{c}\text { Y-12 PLANT } \\
\text { OAK RIDGE, TN. } \\
\text { OCKHEED MARTIN }\end{array}$ \\
\hline PARED BY: & & OATEMS, INC. \\
AJA TECHNICIAL & DOC NUMBER: & $96-0007$ \\
\cline { 2 - 3 } SERVICES, INC. & DWG ID.: & $96-071$ \\
\cline { 2 - 3 } & DATE: & $2-6-97$ \\
\hline
\end{tabular}

FIGURE 2

TOPOGRAPHY AND BEDROCK GEOLOGY IN THE EAST FORK REGIME 



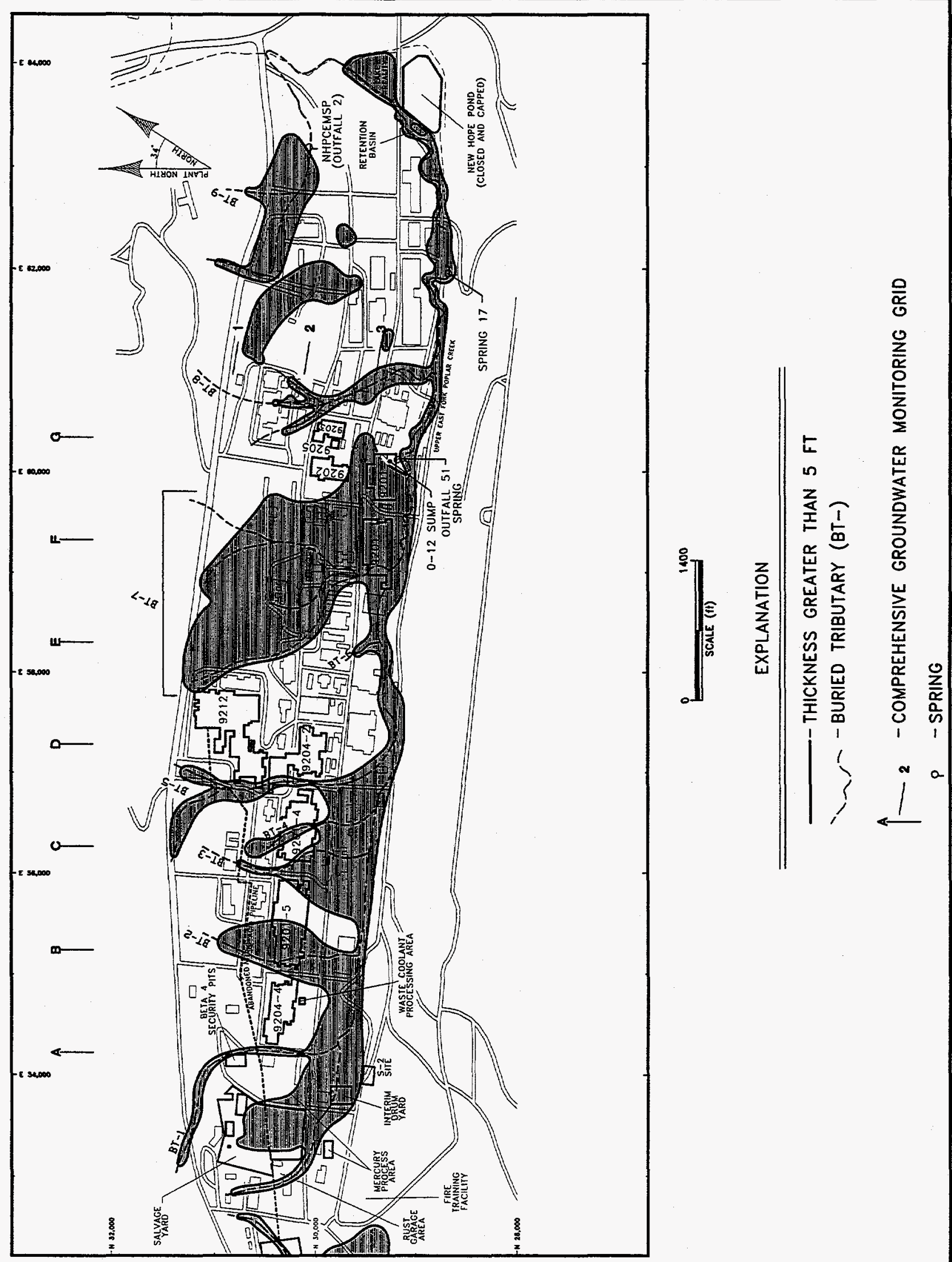

ARED FOR:

OCKHEED MARTIN

NERGY SYSTEMS, INC.

PARED BY:

LOCATION:

$Y-12$ PLANT

OAK RIDGE, TN. 


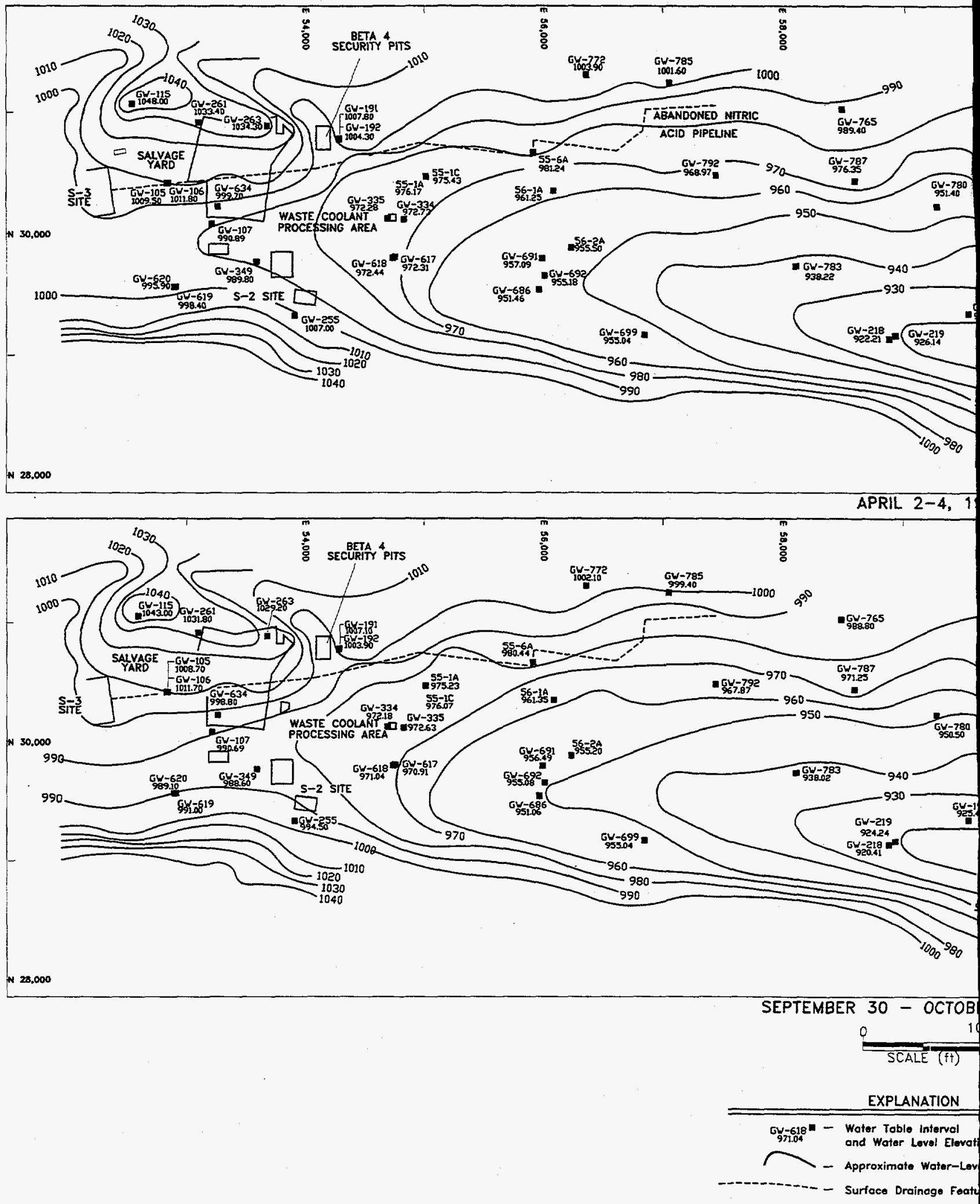


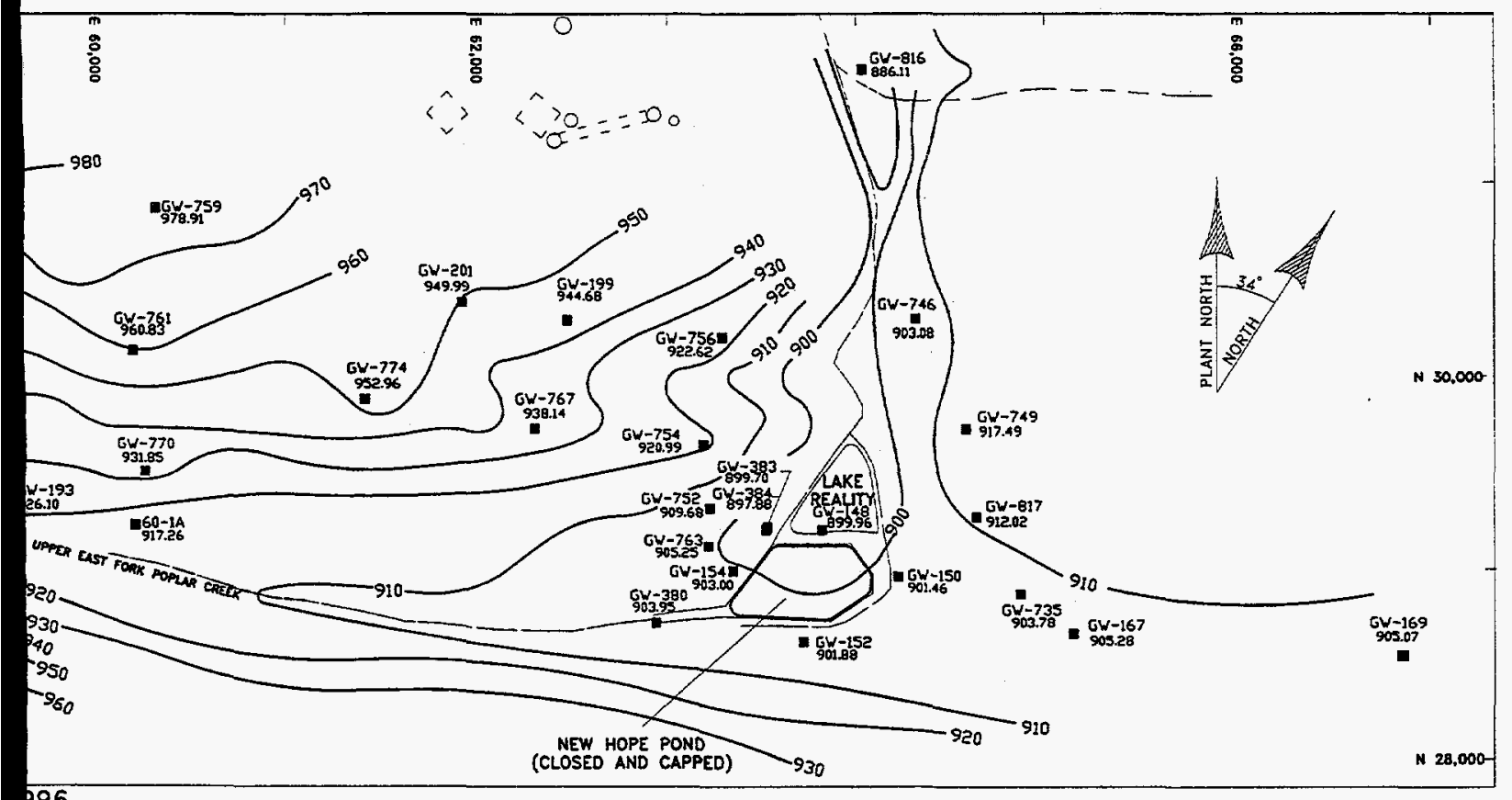

96
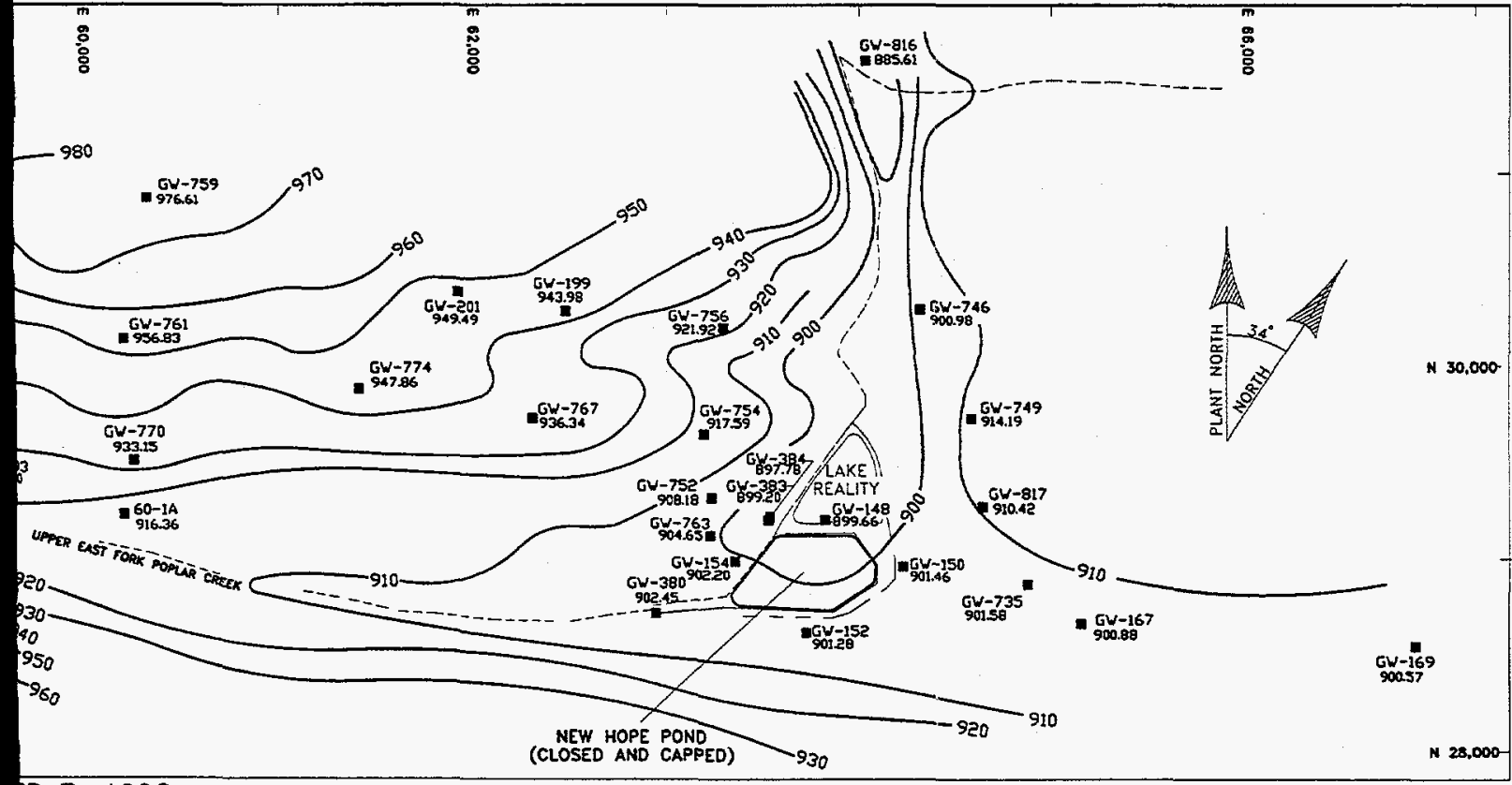

R 7, 1996

oo

( $f t \mathrm{msl}$ )

Isopleth (ft msl)

\begin{tabular}{|c|r|c|}
\hline $\begin{array}{c}\text { PREPARED FOR: } \\
\text { LOCKHEED MARTIN }\end{array}$ & $\begin{array}{c}Y-12 \text { PLANT } \\
\text { ENERGY SYSTEMS, INC. }\end{array}$ & LOCATION: \\
OAK RIDGE, TN. \\
\hline PREPARED BY: & DOC NUMBER: & $97-003$ \\
AJA TECHNICAL & DWG ID.: & $97-010$ \\
\cline { 2 - 3 } SERVICES, INC. & DATE: & $2-6-97$ \\
\hline
\end{tabular}

FIGURE 4

SEASONAL GROUNDWATER ELEVATIONS

IN THE WATER TABLE INTERVAL, CY 1996 


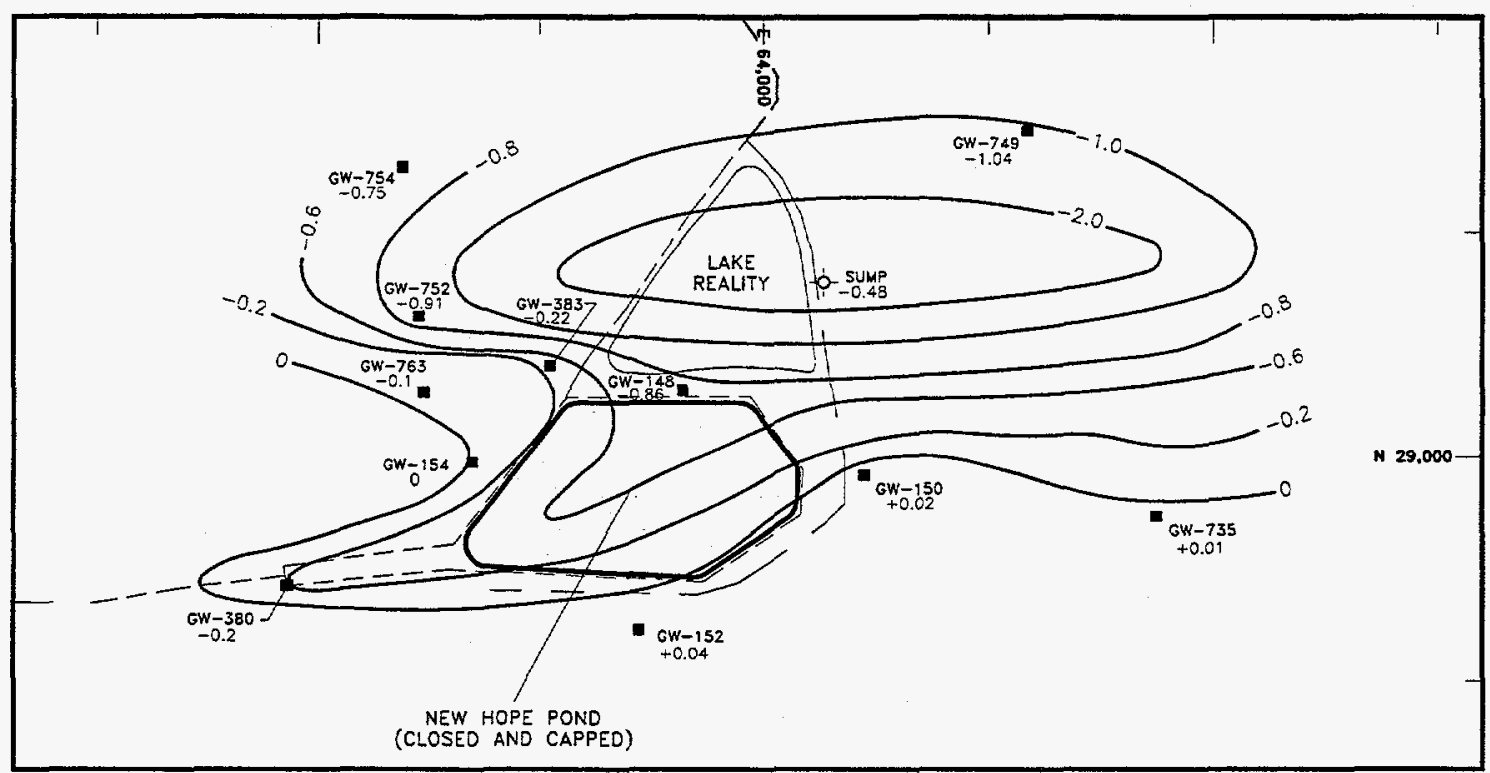

WATER TABLE INTERVAL

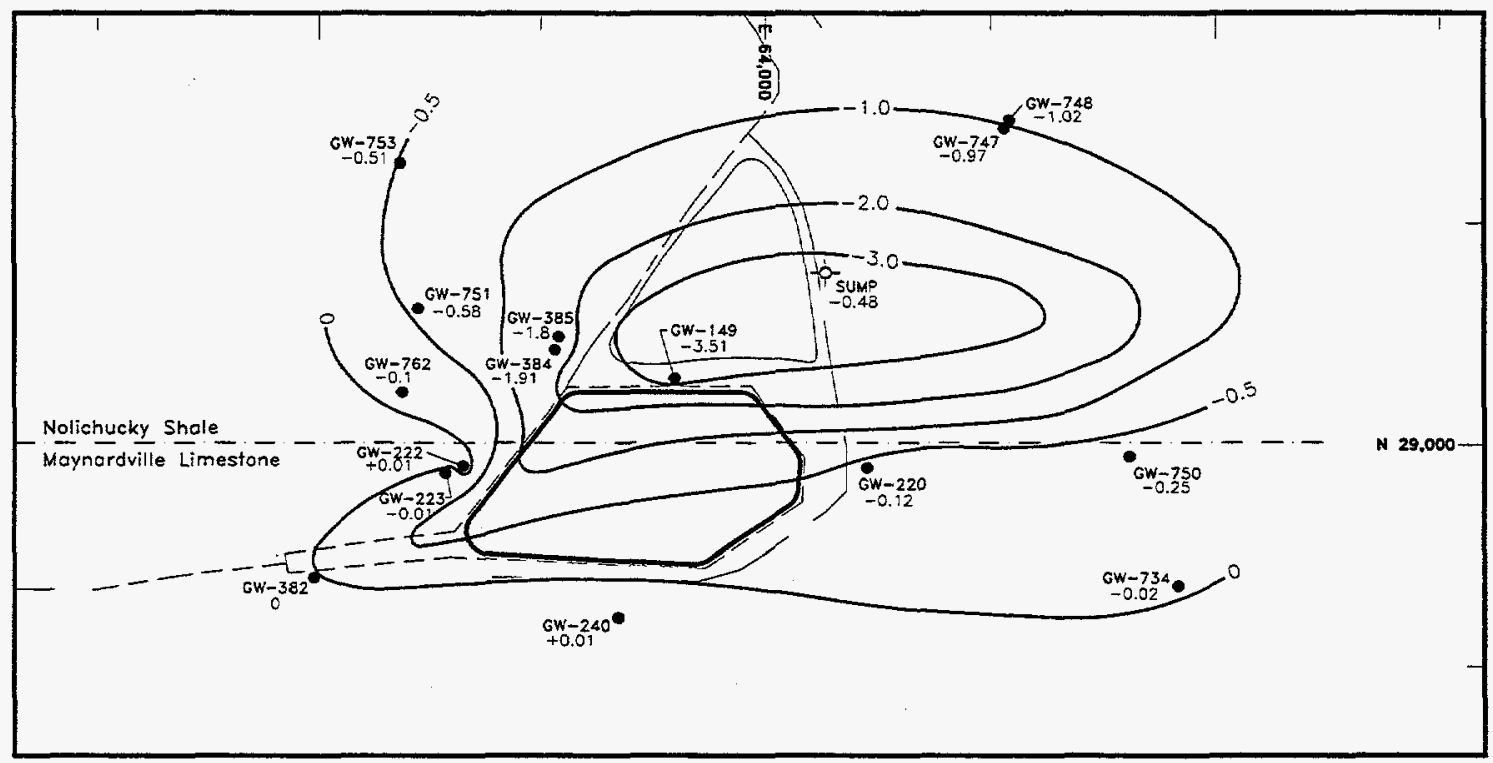

BEDROCK INTERVAL
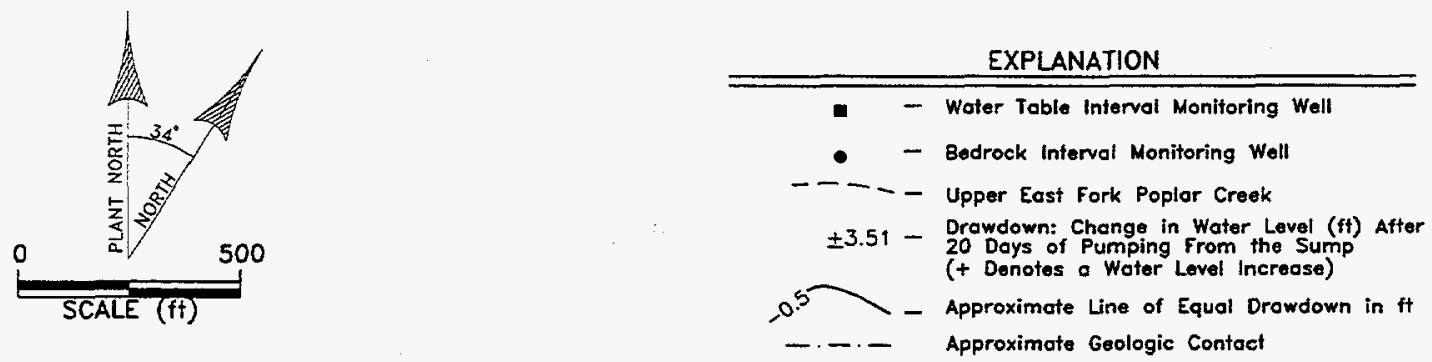

PARED FOR:

LOCKHEED MARTIN

ENERGY SYSTEMS, INC.

\begin{tabular}{|r|c|} 
LOCATION: & $\begin{array}{c}\text { Y-12 PLANT } \\
\text { OAK RIDGE, TN. }\end{array}$ \\
\hline DOC NUMBER: & $97-003$ \\
\hline DWG ID:: & $96-066$ \\
\hline DATE: & $2-6-97$ \\
\hline
\end{tabular}

FGURE 5

REPARED BY:

AJA TECHNICIAL

SERVICES, INC.

DATE: $2-6-97$

INFLUENCE ON GROUNDWATER

FLOW DURING OPERATION OF THE LAKE REALTTY SUMP 


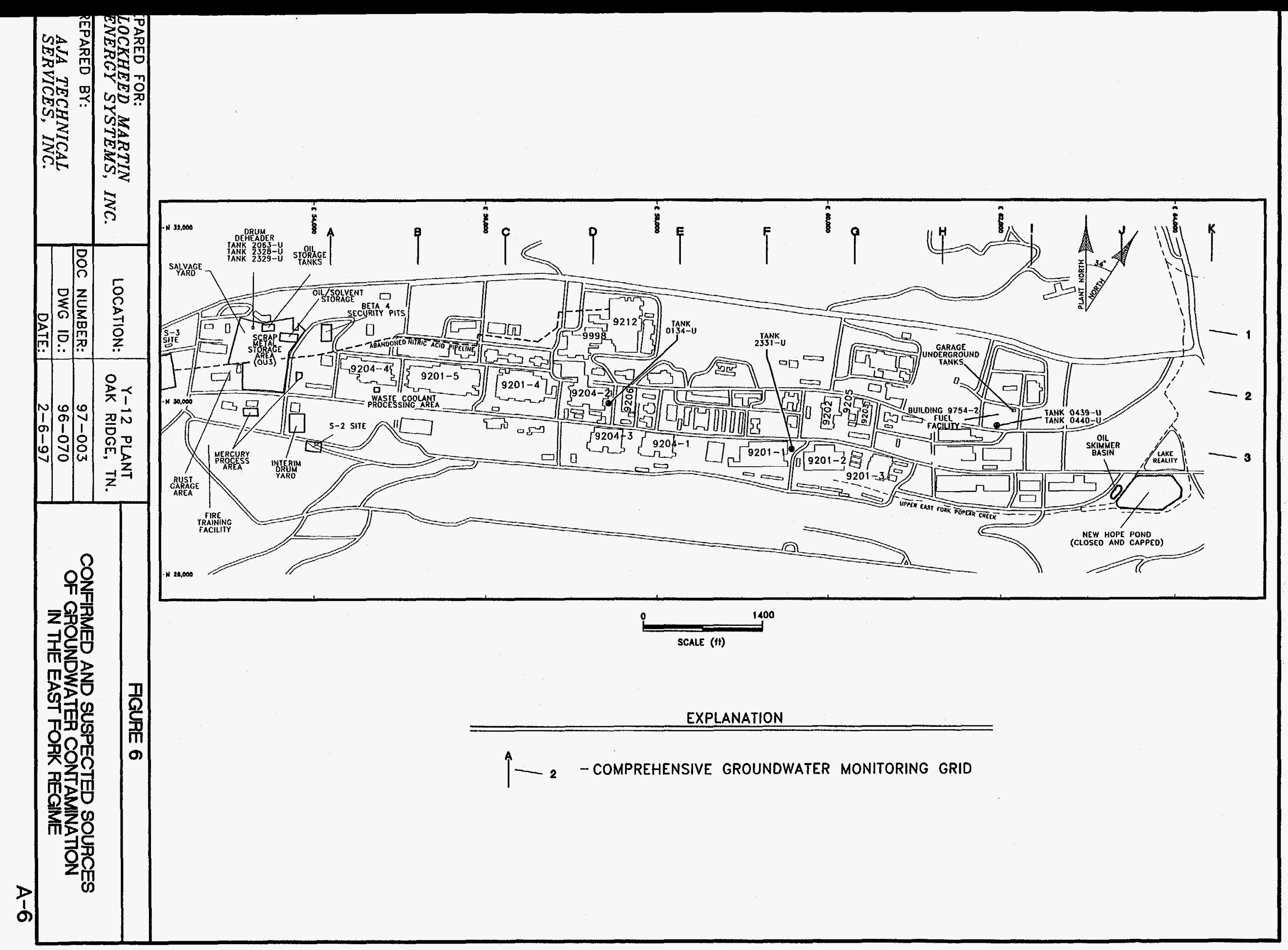




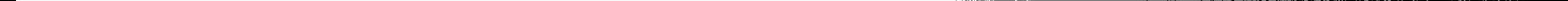




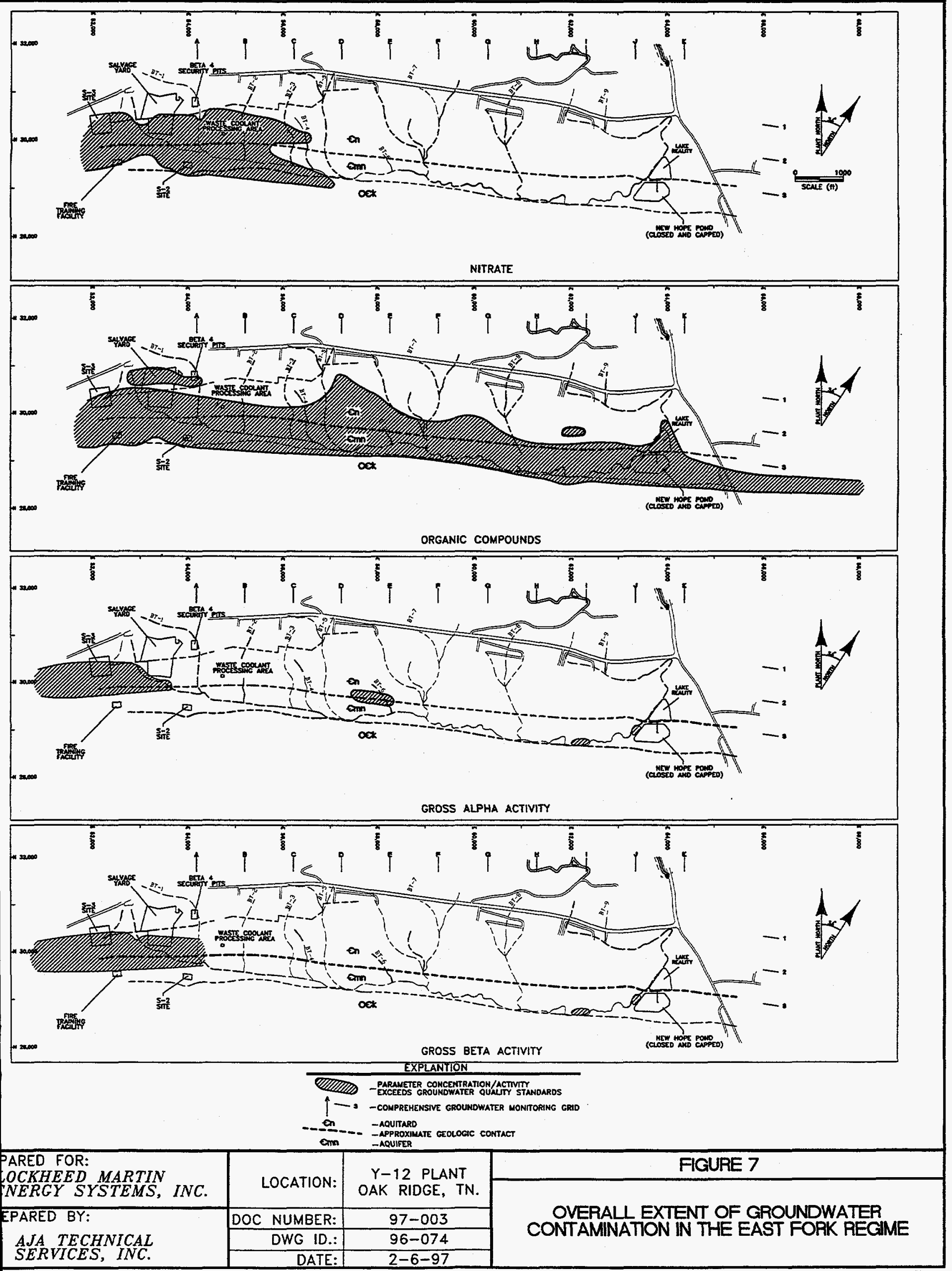




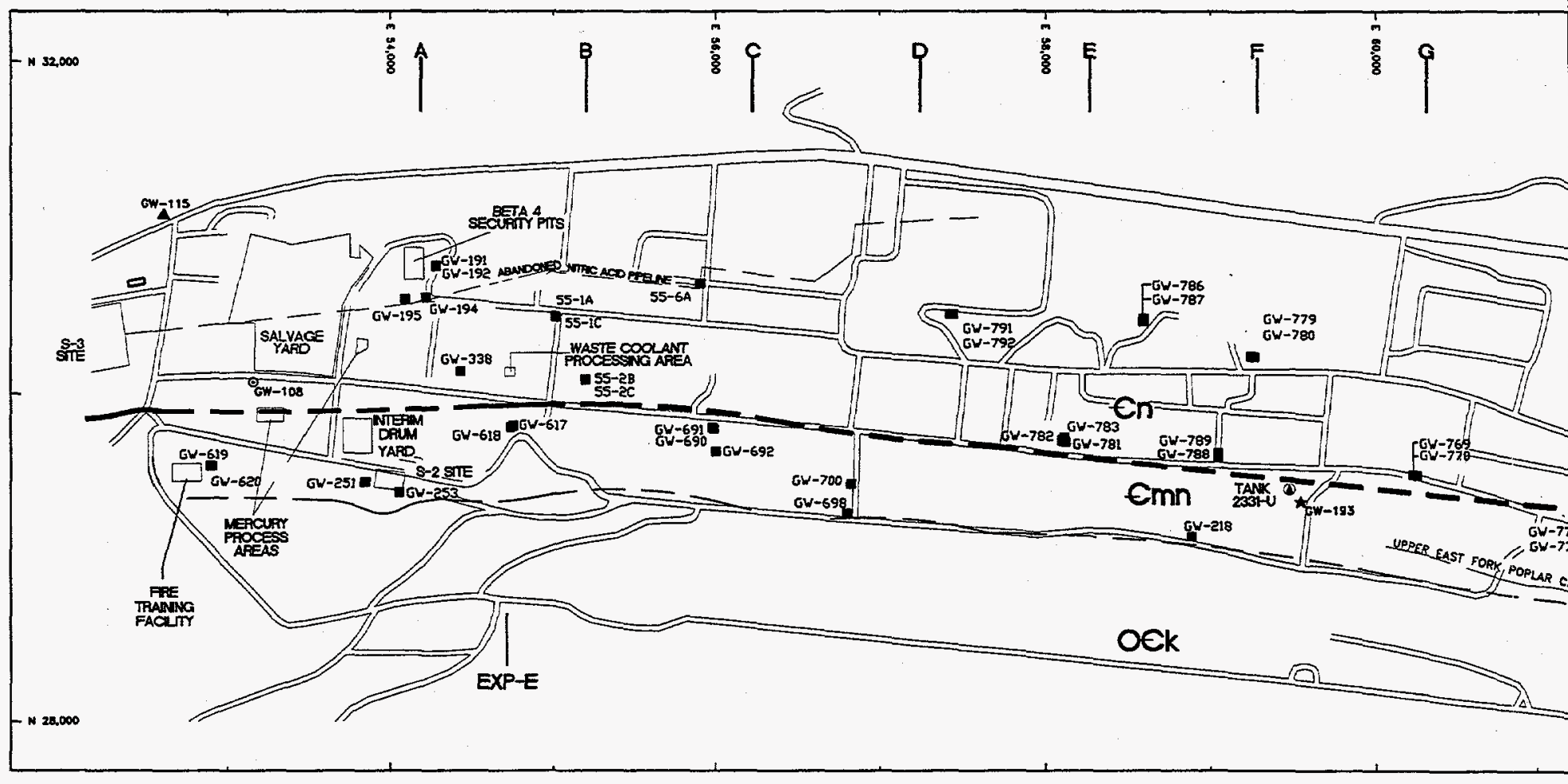

EXPLANAT

- -Monitoring Well

- - RCRA Backgrourid W

- -RCRA Point-of-Comp

* - Plume Boundary Wel

- - Spring (SP) or Surfo

LRsPw - Lake Reality Emerge

ExP-J - Exit Pathwoy, Mayna

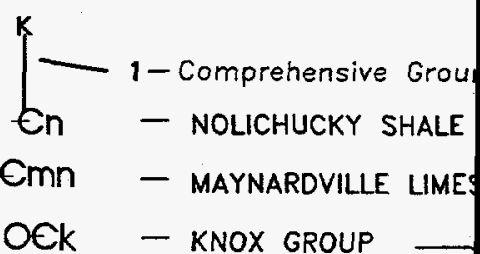



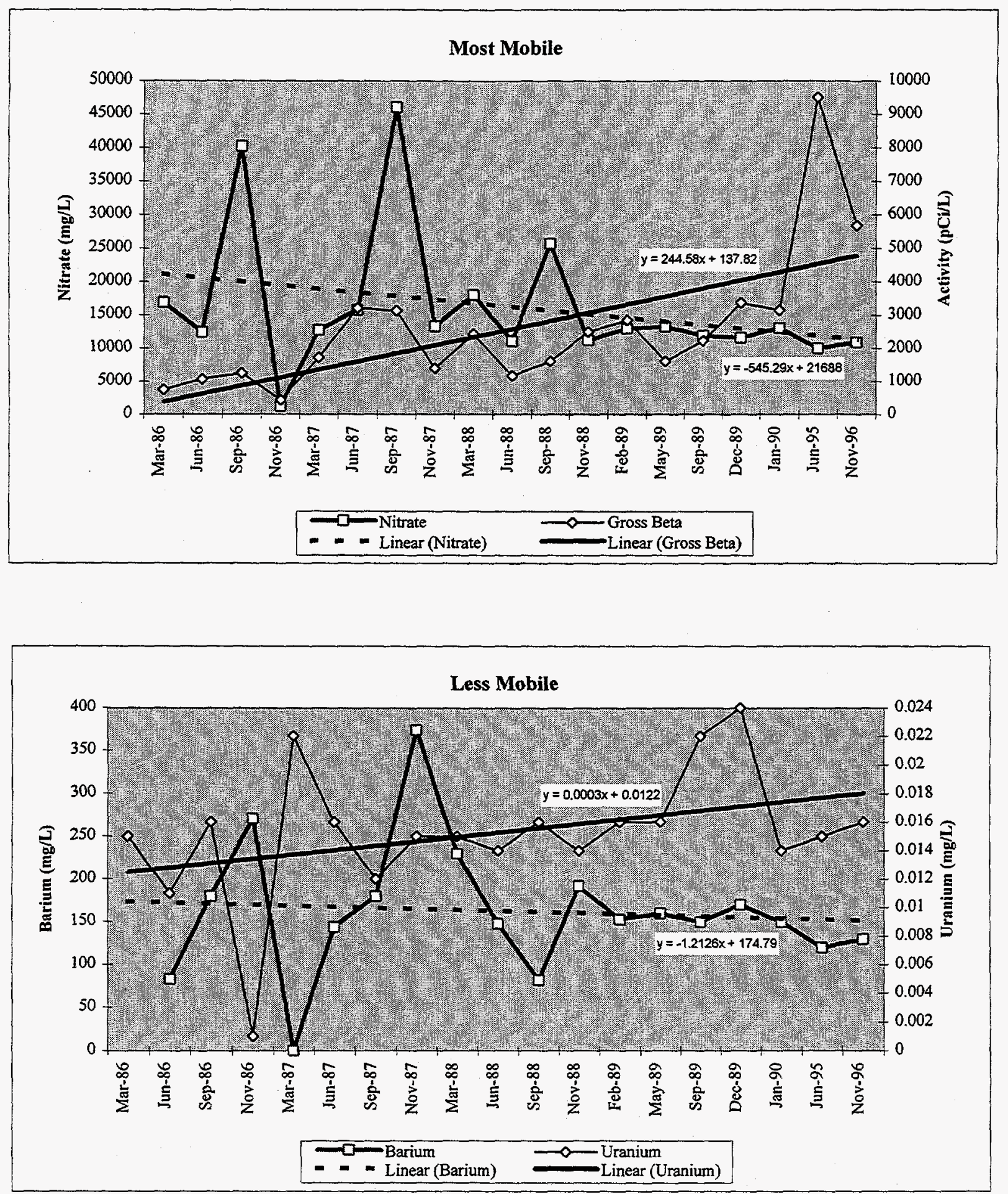

ARED FOR:

OCKHEED MARTIN

NERGY SYSTEMS, INC.

PARED BY:

AJA TECHNICAL

SERVICES, INC

\begin{tabular}{|r|c|}
\hline \multirow{2}{*}{ LOCATION: } & $\begin{array}{c}\text { Y-12 PLANT } \\
\text { OAK RIDGE, TN. }\end{array}$ \\
\hline DOC NUMBER: & $97-003$ \\
\hline DWG ID.: & $97-011$ \\
\hline DATE: & $2-6-97$ \\
\hline
\end{tabular}

FIGURE 9

CONCENTRATIONS OF

SELECTED GWPS CONSTITUENTS

IN GROUNDWATER AT POINT-OF-COMPLIANCE

WELL GW-108, 1986 - 1996 

APPENDIX B

TABLES 
Table 1.

Index of Post-Closure Permit Conditions for Groundwater Monitoring in the East Fork Regime

\begin{tabular}{|c|c|c|}
\hline $\begin{array}{l}\text { Monitoring: } \\
\text { Requirement }\end{array}$ & Condition & Annual Monitoring Report \\
\hline Monitoring Well Network & V.A & 3.0. \\
\hline Well Location, Installation, and Construction & V.B & Figure 8. Appendix 4 \\
\hline Background Wells & V.C.1 & 311. \\
\hline Point-of-Compliance Wells & V.C.2 & $31.1 \%$ \\
\hline Plume Boundary Wells & V.C.1 & $3.1 .1 \%$ \\
\hline Sampling and Analysis & V.E & 30 . \\
\hline Sampling Frequency & V.C.1 and C.2 & $3.1 \%$ \\
\hline Sample Collection & V.E.1 & 32 \\
\hline Sample Preservation & V.E.2 & 3.2 \\
\hline Sample Transportation & V.E.3 & 32 . \\
\hline Sample Chain-of-Custody Control & V.E.4 & 32. \\
\hline Analytical Parameters & V.C & 3.3 \\
\hline Analytical Methods & V.E.5 & 3.6 \\
\hline Groundwater Surface Elevation & V.F & 3.3 \\
\hline Data Evaluation & V.G & 4. \\
\hline Groundwater Flow Rate/Direction & V.G.3 & $4.1 \%$ \\
\hline Point-of-Compliance & V.D.3; V.G.4 & 42. \\
\hline Plume Boundary & V.D.2; V.G.2 & 4.3. \\
\hline
\end{tabular}


Table 2.

Confirmed and Suspected Sources of Groundwater Contamination in the East Fork Regime

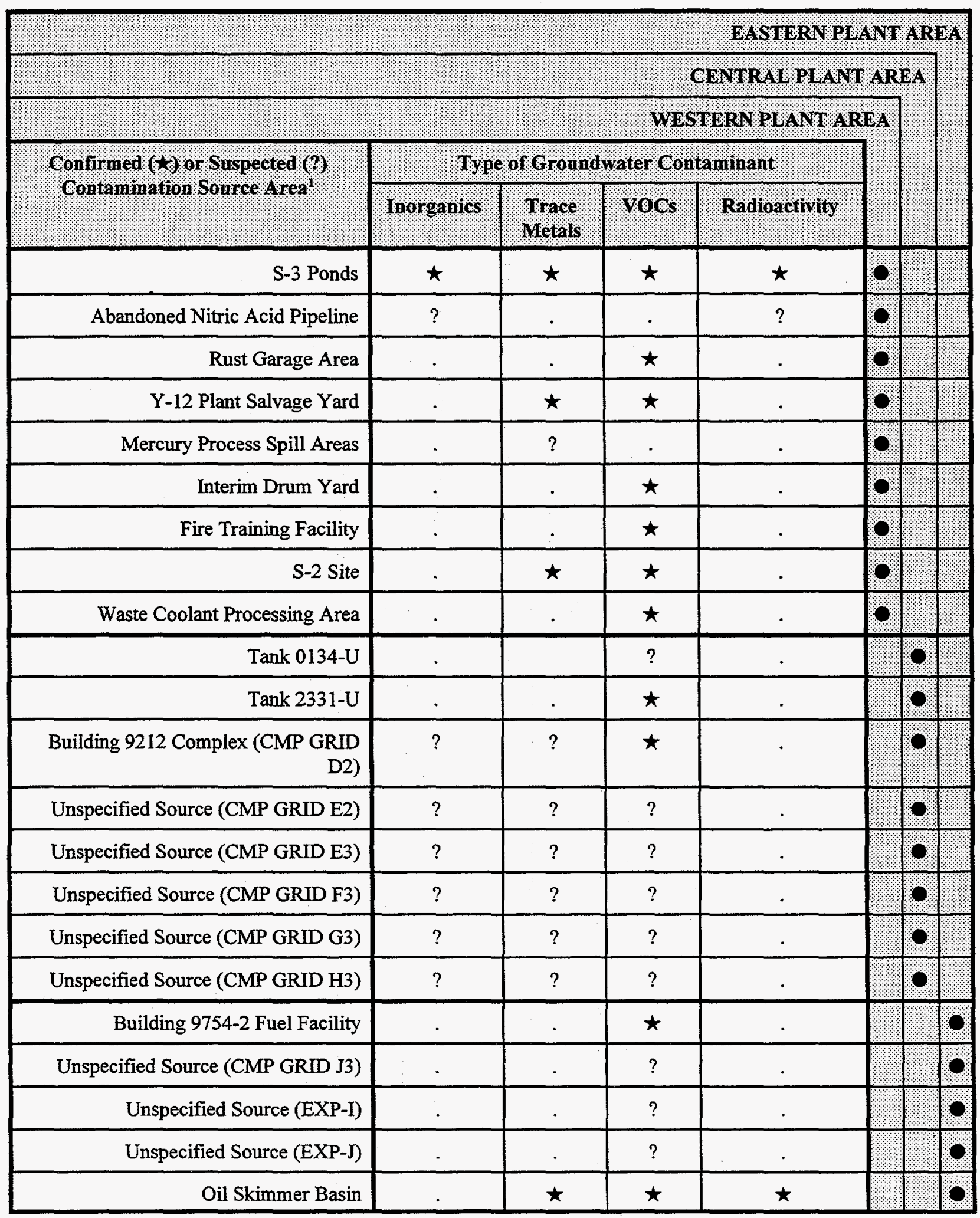


Table 2 (cont'd)

\section{Note:}

1 Unspecified sources of contamination indicated by groundwater quality data for Comprehensive Monitoring Plan (CMP) Grid Network monitoring wells, and Maynardville Limestone Exit-Pathway (EXP) Picket I and Picket J monitoring wells. 
Table 3.

Summary of Addenda to the CY 1996 Sampling and Analysis Plan

for Sampling Locations in the East Fork Regime

\begin{tabular}{|c|c|c|}
\hline मdendum & Effectue & Modification 10 the sampling and analysis plan \\
\hline 9602 & $01 / 03 / 96$ & $\begin{array}{l}\text { Specified sampling and analysis requirements requested by the } \mathrm{Y}-12 \text { Environmental } \\
\text { Restoration (ER) Program for special radiological sampling performed as part of the } \\
\text { remedial investigation (RI) for the Upper East Fork Poplar Creek (UEFPC) } \\
\text { Characterization Area (CA). }\end{array}$ \\
\hline 9603 & $01 / 03 / 96$ & $\begin{array}{l}\text { Added springs (UV 7.1 SP and RGQ West Wall SP) to the Union Valley Exit Pathway } \\
\text { offsite monitoring program as requested by the Y-12 ER Program. }\end{array}$ \\
\hline 9604 & $01 / 03 / 96$ & $\begin{array}{l}\text { Modified the list of radiological analytes for wells and springs included in the Union } \\
\text { Valley Exit Pathway offisite monitoring program. }\end{array}$ \\
\hline 9605 & $01 / 03 / 96$ & $\begin{array}{l}\text { Added radiological parameters requested by the Y-12 ER Program for special } \\
\text { radiological RI sampling performed for the UEFPC CA. }\end{array}$ \\
\hline $96-10$ & $01 / 04 / 96$ & $\begin{array}{l}\text { Added lithium to the suite of Inductively Coupled Plasma (ICP) analytes included in the } \\
\text { calendar year (CY) } 1996 \text { Sampling and Analysis Plan (SAP) administrative parameter } \\
\text { group MET(1). }\end{array}$ \\
\hline $96-1$ & $01 / 04 / 96$ & Discontinued sampling of well $56-4 \mathrm{C}$. \\
\hline 9613 & $01 / 13 / 96$ & $\begin{array}{l}\text { Defined new administrative parameter groups of radiological analytes requested by the } \\
\text { Y-12 ER Program for special radiological RI sampling performed for the UEFPC CA. }\end{array}$ \\
\hline 9614 & $01 / 27 / 96$ & $\begin{array}{l}\text { Required semiannual sampling of surface water from designated outfall at New Hope } \\
\text { Pond, and specified the analytical parameters. }\end{array}$ \\
\hline $96-15$ & $01 / 03 / 96$ & $\begin{array}{l}\text { Refined the suite of radiological analytes requested by the Y-12 ER Program for special } \\
\text { radiological RI sampling performed for the UEFPC CA. }\end{array}$ \\
\hline $96-16$ & $01 / 03 / 96$ & $\begin{array}{l}\text { Superseded Addendum 96-03 sampling and analysis requirements requested by the } Y-12 \\
\text { ER Program for springs and surface water stations included in the Union Valley Exit } \\
\text { Pathway offsite monitoring program. }\end{array}$ \\
\hline 9617 & $01 / 03 / 96$ & $\begin{array}{l}\text { Supplemented analytical parameters specified in Addendum } 96-04 \text { for the Union Valley } \\
\text { Exit Pathway offsite monitoring program. }\end{array}$ \\
\hline 9626 & $05 / 14 / 96$ & $\begin{array}{l}\text { Specified sampling/analysis requirements requested by the Y-12 ER Program for new } \\
\text { well GW-832 at New Hope Pond. }\end{array}$ \\
\hline 9627 & $06 / 18 / 96$ & $\begin{array}{l}\text { Removed wells GW-172, GW-232, and GW-169, and springs SCR } 7.12 \text { SW, SCR } 7.14 \\
\text { SP, SCR 7.16 SP, UV 8.2 SW, and SCR 7.9 SW from the Union Valley Exit Pathway } \\
\text { offisite monitoring program at the request of the Y-12 ER Program. }\end{array}$ \\
\hline 9628 & $06 / 18 / 96$ & $\begin{array}{l}\text { Modified the analytical parameters for wells GW-171, GW-170, and GW-230, and } \\
\text { springs SCR 7.1 SP, SCR 7.18 SP, and SCR 7.8S SP at the request of the Y-12 ER } \\
\text { Program. }\end{array}$ \\
\hline 9629 & $06 / 18 / 96$ & $\begin{array}{l}\text { Specified sampling and analyses requirements requested by } Y-12 \text { ER Program for spring } \\
\text { RGQ West Wall SP under the Union Valley Exit Pathway offsite monitoring program. }\end{array}$ \\
\hline
\end{tabular}




\section{Table 3 (cont'd)}

\begin{tabular}{|c|c|c|}
\hline Addenduin & Effective & Modification to the Sampling and Analysis Plan'? \\
\hline 9632 & $06 / 19 / 96$ & $\begin{array}{l}\text { Specified sampling and analysis requirements requested by the Y-12 ER Program for } \\
\text { one-time sampling of springs UV 8.5 SP, UV 8.6 SP, and UV 8.7 SP in Union Valley. }\end{array}$ \\
\hline $96-33$ & $07 / 09 / 96$ & $\begin{array}{l}\text { Discontinued quarterly surveillance sampling of the } 38 \text { monitoring wells that comprise } \\
\text { administrative well groups EF } 1 \text {, EF } 2 \text {, EF } 3 \text {, and EF } 6 \text {. }\end{array}$ \\
\hline 9634 & $07 / 01 / 96$ & $\begin{array}{l}\text { Required Plasma Mass Spectroscopy instead of Atomic Absorption Spectroscopy for } \\
\text { lead and thallium analyses included under administrative parameter groups MET(2) and } \\
\text { MET(3). }\end{array}$ \\
\hline $96-88$ & $09 / 05 / 96$ & $\begin{array}{l}\text { Discontinued sampling of springs and wells used for the Union Valley Exit Pathway } \\
\text { offsite monitoring program at the request of the Y-12 ER Program. }\end{array}$ \\
\hline 9641 & $09 / 05 / 96$ & $\begin{array}{l}\text { Reassigned a field blank sample from administrative well group } C R 3 \text { to administrative } \\
\text { well group EF } 7 \text {. }\end{array}$ \\
\hline 9642 & $08 / 30 / 96$ & $\begin{array}{l}\text { Specified sampling and analysis requirements for RCRA post-closure corrective action } \\
\text { monitoring, and created two associated administrative well groups. }\end{array}$ \\
\hline 9644 & $10 / 01 / 96$ & $\begin{array}{l}\text { Specified a new analytical method for VOCs, and modified the suite of VOCs included } \\
\text { in administrative parameter group VOC(2). }\end{array}$ \\
\hline 0648 & 09/01/96 & $\begin{array}{l}\text { Modified administrative parameter group MET(1) to specify Plasma Mass Spectroscopy } \\
\text { for arsenic analyses. }\end{array}$ \\
\hline
\end{tabular}

\section{Note:}

1 Sampling and Analysis Plan for Groundwater and Surface Water Monitoring at the Y-12 Plant During Calendar Year 1996 (HSW Environmental Consultants, Inc. 1995). 
Table 4.

CY 1996 Sampling Dates for Monitoring Wells, Springs, and Surface Water Stations

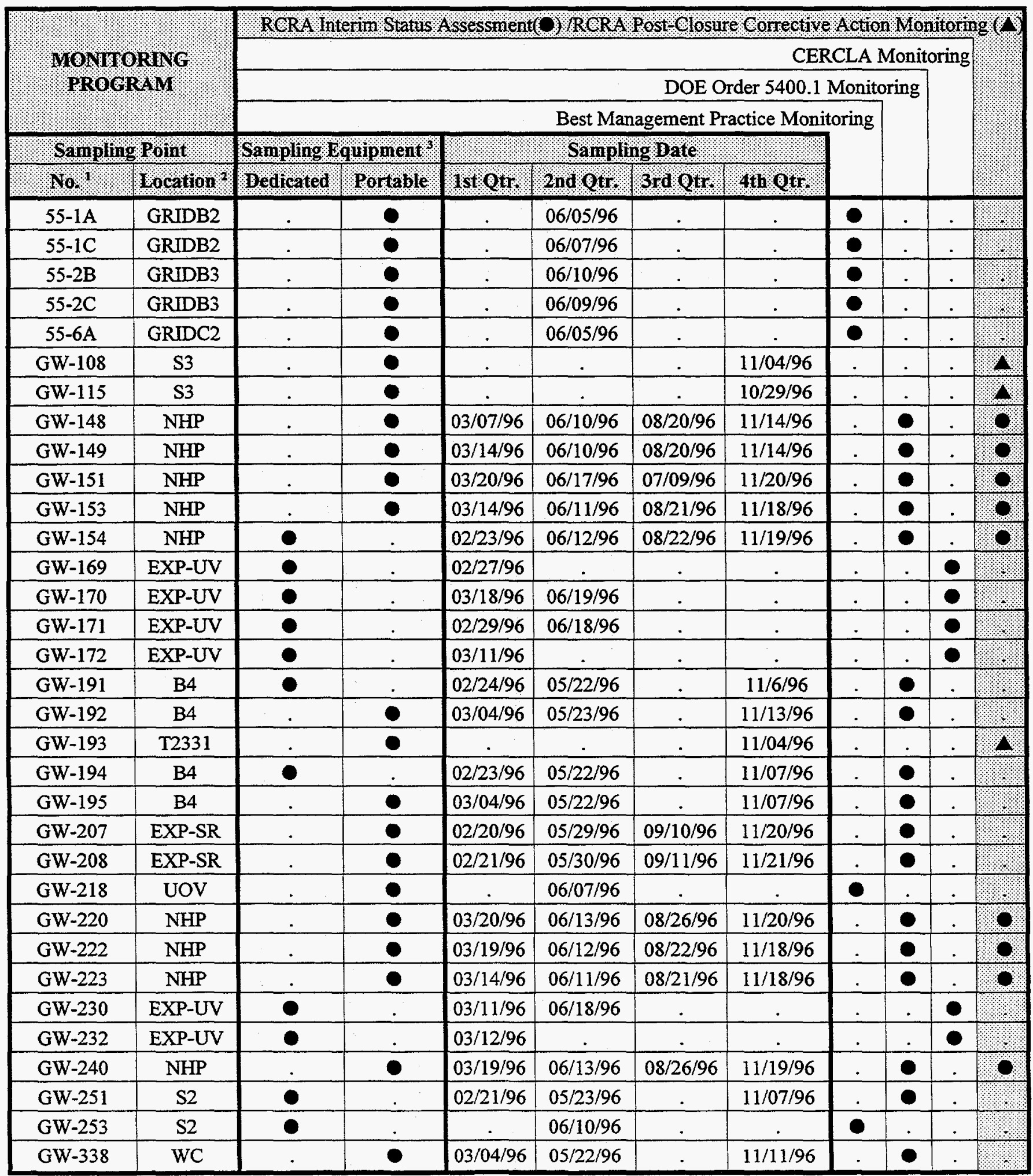


Table 4 (cont'd)

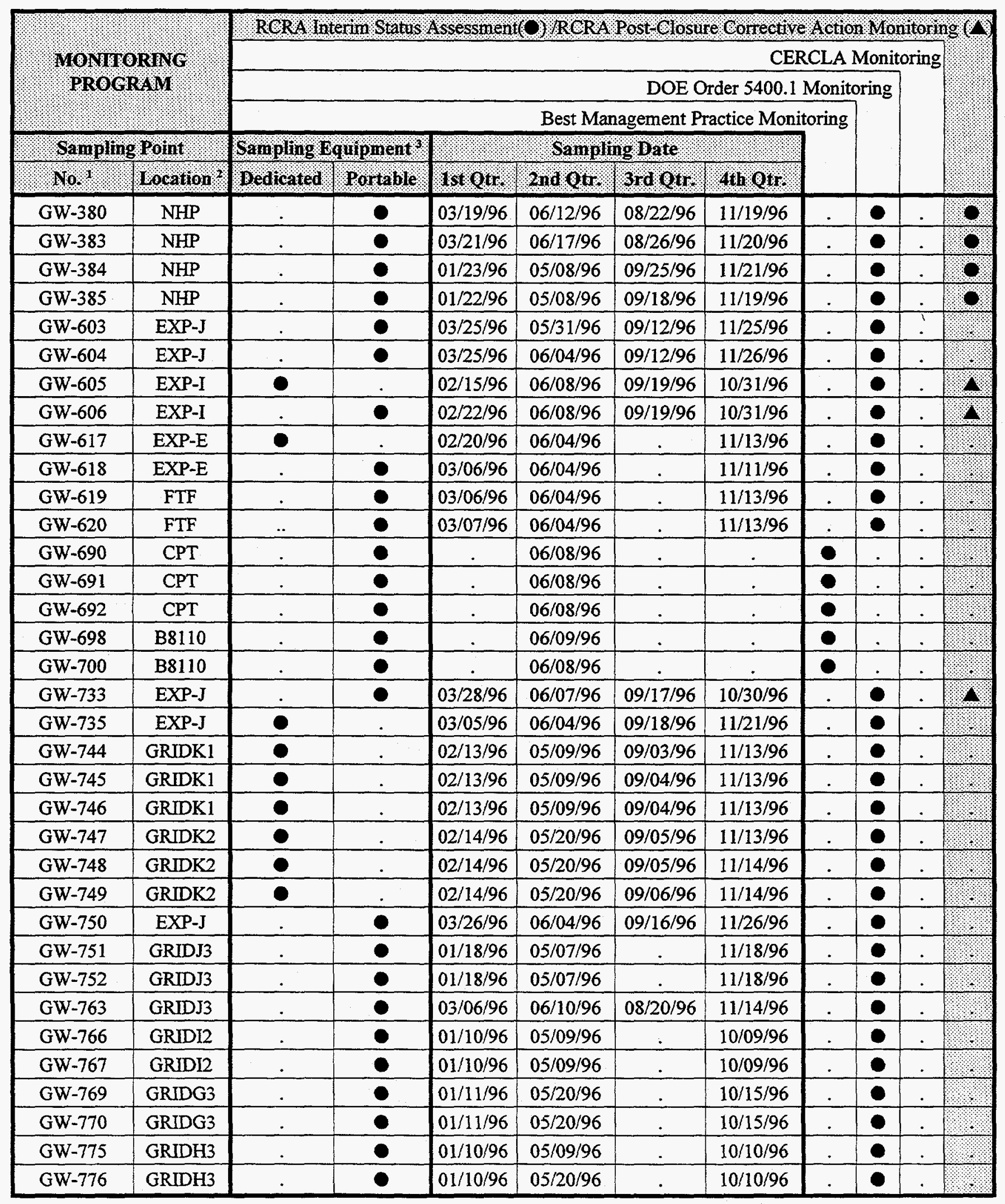


Table 4 (cont'd)

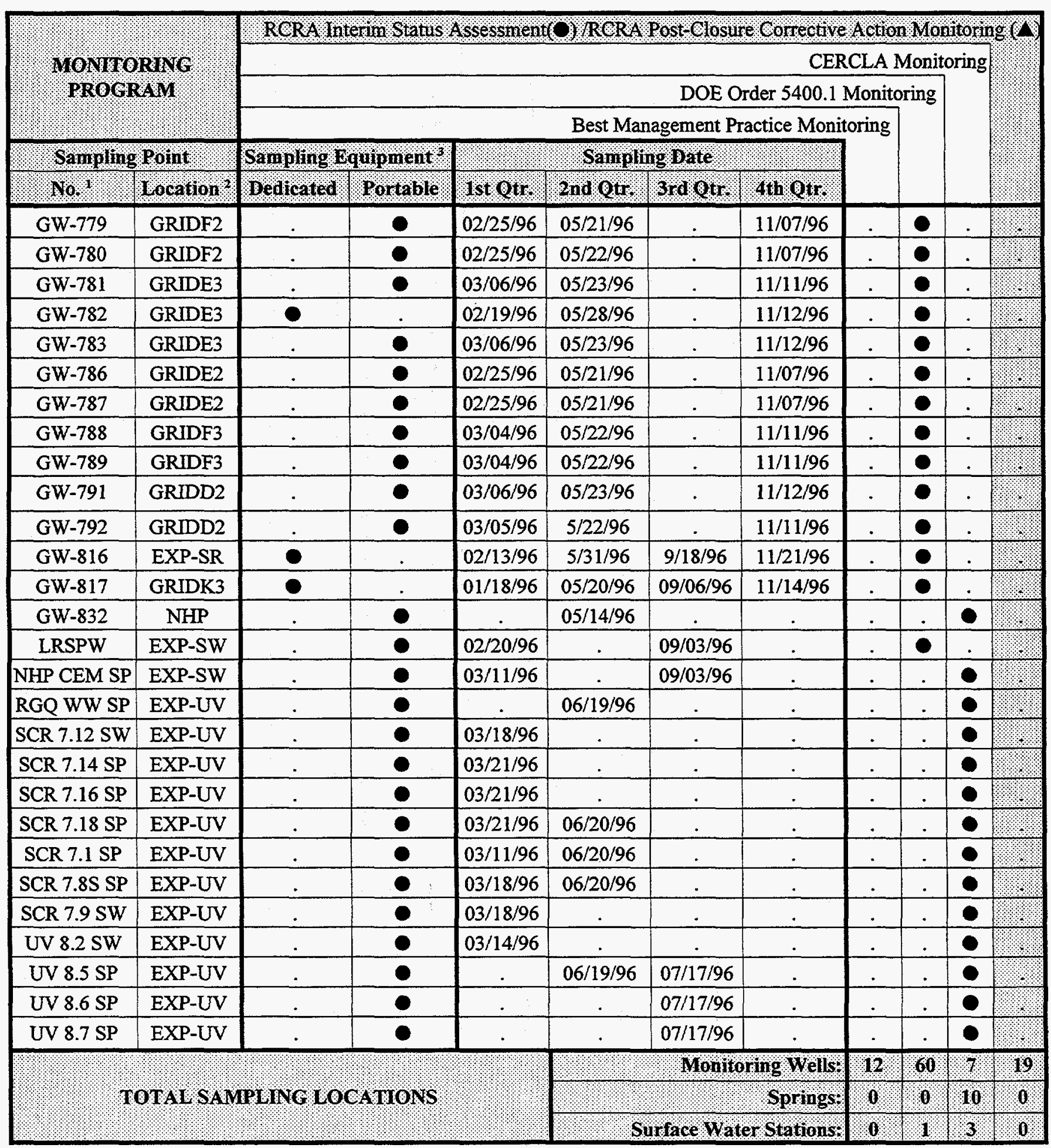


Table 4 (cont'd)

Notes:

1 Locations of monitoring wells, springs, and surface water stations shown on Figure 8.

2 B4 - Beta-4 Security Pits

B8110 - Building 8110

CPT - Coal Pile Trench

EXP - Exit Pathway (Maynardville Limestone) monitoring well

- -E, -I, or -J: Maynardville Limestone Traverse monitoring well.

- -SW: Onsite spring or surface water station

- -UV: Offsite spring or surface water station in Union Valley

- -SR: Along Scarboro Road in the gap through Pine Ridge

FTF - Fire Training Facility

GRID - Comprehensive Groundwater Monitoring Plan Grid Location

NHP - New Hope Pond

S2 - S-2 Site

S3 - S-3 Ponds Site

T2331 - Tank 2331-U

UOV - Uranium Oxide Vault

WC - Waste Coolant Processing Area

3 Dedicated: Well Wizard (bladder pump that remains in the well)

Portable: Bennet Pumps and disposable bailers (monitoring wells); grab sample bottles (springs and surface water stations) 
Table 5.

Laboratory Analytes and Field Measurements

\begin{tabular}{|c|c|c|c|c|c|c|c|c|}
\hline \multirow{4}{*}{ MONITORANG } & \multicolumn{8}{|c|}{ ReRA Interim Status Assessment(O) RCRA Post-Closure Corrective Action Monitoring $(\Delta)$} \\
\hline & \multicolumn{8}{|c|}{ CERCLA Monitoring $/ 1.1$} \\
\hline & \multicolumn{8}{|c|}{ DOE Order 5400.1 Monitoring } \\
\hline & & \multicolumn{4}{|c|}{ Best Management Practice Monitoring } & & & \\
\hline \multirow[t]{2}{*}{ PRINCPOLIONS } & \multirow{2}{*}{$\begin{array}{l}\text { Analytical } \\
\text { Method }\end{array}$} & \multirow{2}{*}{ Constituent? } & \multicolumn{2}{|c|}{ Sample Type ${ }^{3}$} & & & & \\
\hline & & & Filtered & Unfitered & & & & \\
\hline Alkalinity - $\mathrm{HCO} 3$ & SM-2320 B & . & . & e. & - & - & - & 0 \\
\hline Alkalinity - $\mathrm{CO} 3$ & SM-2320 B & . & . & 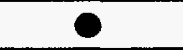 & - & - & - & 10 \\
\hline Calcium & EPA-6010 & . & - & 0 & 0 & 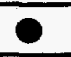 & - & 0 \\
\hline Chloride & EPA-300.0 & . & . & 9 & - & 0 & - & 8 \\
\hline Fluoride & EPA-340.2 & $\therefore$ & . & 요 & 9 & 2 & e & 0 \\
\hline Magnesium & EPA-6010 &. & 은 & 0 & 운 & 0 & 0 & $\mathrm{O}$ \\
\hline Nitrate (as N) & EPA-300.0 & 0 & . & 0 & 0 & 0 & 0 & $0 \%$ \\
\hline Potassium & EPA-6010 & . & 0 & 요 & 9 & - & ? & $\%$ \\
\hline Sodium & EPA-6010 & $\dot{-}$ & 9 & 0 & e & 0 & 을 & 0 \\
\hline Sulfate & EPA-300.0 &. &. & 9 & 0 & 0 & 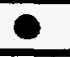 & 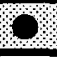 \\
\hline \multirow[t]{2}{*}{ MPACE METAISS } & \multirow{2}{*}{ Method } & \multirow{2}{*}{ Gonstituent } & \multicolumn{2}{|c|}{ Sample SYpe } & & & & \\
\hline & & & Fitered & Onfititered & & & & \\
\hline Aluminum & EPA-6010 & $\dot{.}$ & - & 0 & 0 & 0 & 2 & 8 \\
\hline Antimony & EPA-6010 & . & 0 & 은 & 9 & 은 & 0 & 0 \\
\hline \multirow[t]{2}{*}{ Arsenic } & EPA-6010 & - & 9 & 9 & 0 & 9 & 0 & 0 \\
\hline & EPA-200.8 &. & 9 & 9 & 0 & 0 &. & O. \\
\hline Barium & EPA-6010 & 9 & 9 & 9 & 9 & 9 & 9 & 0 \\
\hline Beryllium & EPA-6010 & . & 0 & 0 & 0 & 0 & 0 & 0 \\
\hline Boron & EPA-6010 & $\dot{.}$ & - & 9 & 0 & 0 & 0 & 0 \\
\hline Cadmium & EPA-6010 & 9 & 0 & 9 & 0 & 0 & 0 & 2 \\
\hline Chromium & EPA-6010 & 0 & 0 & 0 & 9 & 0 & 0 & 0. \\
\hline Cobalt & EPA-6010 &. & 은 & 0 & 9 & 0 & 0 & 8 \\
\hline Copper & EPA-6010 &. & 인 & 0 & 9 & 9 & 0 & 0 \\
\hline Iron & EPA-6010 & . & 은 & 을 & 9 & 9 & 0 & 8 \\
\hline \multirow[t]{3}{*}{ Lead } & EPA-6010 & 9 & 9 & 9 & 0 & 0 & 0 & 0 \\
\hline & EPA-7421 & 0 & 0 & 0 &. &. & 0 & 18 \\
\hline & EPA-200.8 & 0 & - & 9 & 0 & 0 & 0 & 8 \\
\hline Lithium & EPA-6010 & $\cdot$ & 인 & 0 & 0 & 9 & 0 & 8 \\
\hline Manganese & EPA-6010 &. & 9 & 0 & 0 & 0 & 0 & 0 \\
\hline Mercury & EPA-7470 & 0 & 0 & 9 & 9 & 0 & 0 & 0 \\
\hline Molybdenum & EPA-6010 &. & 은 & 9 & 0 & 2 & 0 & 8 \\
\hline Nickel & EPA-6010 & 0 & e & 0 & 0 & 0 & 0 & 0 \\
\hline Selenium & EPA-6010 & & 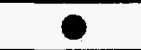 & 0 & 0 & 0 & 0 & 8 \\
\hline Silver & EPA-6010 & . & 0 & 0 & 0 & 0 & 0 & 0 \\
\hline Strontium & EPA-6010 & & 0 & 0 & 0 & 0 & 0 & 8 \\
\hline
\end{tabular}


Table 5 (cont'd)

\begin{tabular}{|c|c|c|c|c|c|c|c|c|}
\hline \multirow{4}{*}{$\begin{array}{l}\text { MONITORHNG } \\
\text { PROGRAM }\end{array}$} & \multicolumn{8}{|c|}{ RCRA Interin Status Assessment $(9)$ RCRA Post-Closure Cornective A ction Monitoring $(Y)$} \\
\hline & & & & & CLA & Moni & ring & \\
\hline & & & \multicolumn{4}{|c|}{ DOE Order 5400.1 Monitoring } & & \\
\hline & \multirow{3}{*}{$\begin{array}{l}\text { Analytical } \\
\text { Method" }\end{array}$} & \multicolumn{4}{|c|}{ Best Management Practice Monitoring } & & & \\
\hline \multirow{2}{*}{$\begin{array}{l}\text { TRACE METAIS } \\
\text { (contda) }\end{array}$} & & \multirow{2}{*}{$\begin{array}{l}\text { GWPS } \\
\text { Constituent? }\end{array}$} & \multicolumn{2}{|c|}{ Sample Type 3 : } & & & & \\
\hline & & & Fitered & Unnitered. & & & & \\
\hline Thallium & EPA-200.8 & & - & - & - & - & - & o. \\
\hline Thorium & EPA-6010 & & $\mathbf{0}$ & e & - & - & e & o. \\
\hline Uranium & EPA-200.8 & - & - & - & - & - & - & O. \\
\hline Vanadium & EPA-6010 & $\dot{r}$ & - & - & - & - & - & 0. \\
\hline Zinc & EPA-6010 & & - & - & - & - & - & o. \\
\hline \multirow{2}{*}{$\begin{array}{l}\text { VOLATIME ORGANIC } \\
\text { COMPOUNDS }\end{array}$} & \multirow{2}{*}{$\begin{array}{l}\text { Analytical } \\
\text { Method }\end{array}$} & \multirow{2}{*}{$\begin{array}{l}\text { GWPS } \\
\text { Constituent }\end{array}$} & \multicolumn{2}{|c|}{ Sample Type } & & & & \\
\hline & & & Filtered. & Unfiltered & & & & \\
\hline Acetone & ACD-240040 & & & - & - & - & - & Q. \\
\hline Benzene & ACD-240040 & - & & - & - & - & - & 0 \\
\hline Bromodichloromethane & ACD-240040 & & & - & - & - & - & 0. \\
\hline Bromoform & ACD-240040 & e & & - & - & 은 & - & 0 \\
\hline Bromomethane & ACD-240040 & - & . & - & - & - & - & Q) \\
\hline 2-Butanone & ACD-240040 & . & . & - & - & $\mathbf{e}$ & - & o. \\
\hline Carbon Disulfide & ACD-240040 & & & - & - & 은 & - & 0 \\
\hline Carbon Tetrachloride & ACD-240040 & - & & - & - & - & - & 0 \\
\hline Chlorobenzene & ACD-240040 & & & - & 으 & - & - & O. \\
\hline Chlorodibromomethane & ACD-240040 & $\dot{\sim}$ & $\dot{-}$ & - & - & - & 은 & Q. \\
\hline Chloroethane & ACD-240040 & & & - & - & - & - & 0. \\
\hline Chloroform & ACD-240040 & 으 & . & 으 & 으 & e & 인 & \% \\
\hline Chloromethane & ACD-240040 & & . & - & 은 & - & - & Q. \\
\hline 1,1-Dichloroethane & ACD-240040 & & $\therefore$ & - & - & - & - & 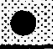 \\
\hline 1,2-Dichloroethane & ACD-240040 & & . & - & - & - & - & 6 \\
\hline 1,1-Dichloroethene & ACD-240040 & 으 & . & - & - & - & - & 0. \\
\hline 1,2-Dichloroethene & ACD-240040 & & - & 으 & - & - & 으 & 9 \\
\hline Trans-1,2-Dichloroethene & ACD-240040 & - & . & 은 & - & e & - & 0 \\
\hline 1,2-Dichloropropane & ACD-240040 & & & 으 & - & 으 & - & Q. \\
\hline Cis-1,3-Dichloropropene & ACD-240040 & & . & - & - & - & - & 0 \\
\hline Trans-1,3-Dichloropropene & ACD-240040 & & $\therefore$ & - & 은 & - & 으 & 0. \\
\hline Ethylbenzene & ACD-240040 & &. & 은 & - & 으 & 는 & 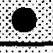 \\
\hline 2-Hexanone & ACD-240040 & & . & 은 & - & - & - & Q. \\
\hline 4-Methyl-2-Pentanone & ACD-240040 & - & . & - & - & - & - & 0 \\
\hline Methylene Chloride & ACD-240040 & 으 & & 으 & - & - & 으 & O. \\
\hline Styrene & ACD-240040 & & & 으 & - & 은 & - & O. \\
\hline Tetrachloroethene & ACD-240040 & 으 & & 으 & - & 은 & 으 & 0 \\
\hline 1,1,2,2-Tetrachloroethane & ACD-240040 & & & - & - & - & - & ?o. \\
\hline Toluene & ACD-240040 & e & & e & e & 으 & $\underline{e}$ & o. \\
\hline
\end{tabular}

B-11 
Table 5 (cont'd)

\begin{tabular}{|c|c|c|c|c|c|c|c|c|}
\hline \multirow{4}{*}{$\begin{array}{l}\text { MonTORING } \\
\text { PROGRAY }\end{array}$} & \multicolumn{8}{|c|}{ RCRA interim Status A ssessment(O)RCRA Post Closure Corrective A ction Monitoning ( $\nabla$ ) } \\
\hline & & & & \multicolumn{4}{|c|}{ CERCLA Monitoring } & \\
\hline & & & \multicolumn{4}{|c|}{ DOE Order 5400.1 Monitoring } & & \\
\hline & & \multicolumn{4}{|c|}{ Best Management Practice Monitoring } & & & \\
\hline \multirow{2}{*}{$\begin{array}{l}\text { WOI AIIE ORGANIC } \\
\text { COMPOUNDS (cont) }\end{array}$} & \multirow{2}{*}{ Analytical } & \multirow{2}{*}{ Gousturent? } & \multicolumn{2}{|c|}{ Sample Type } & & & & \\
\hline & & & Giltered & Unfiltered & & & & \\
\hline 1,1,1-Trichloroethane & ACD-24004 & - & . & - & - & $\mathbf{0}$ & - & 0 \\
\hline 1,1,2-Trichloroethane & ACD-24004 & . & . & 은 & - & - & ? & (1) \\
\hline Trichloroethene & ACD-24004 & 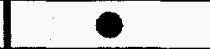 & . & - & $\mathbf{9}$ & $\mathbf{9}$ & 0 & \$. \\
\hline Vinyl Acetate & ACD-24004 & . & $\dot{.}$ & 은 & 0 & 9 & 9 & 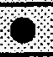 \\
\hline Vinyl Chloride & ACD-24004 & . & . & e & 은 & - & 0 & Q. \\
\hline .. Xylenes & ACD-24004 & . & . & - & $\mathbf{9}$ & - & $\mathbf{0}$ & O. \\
\hline \multirow{2}{*}{ RADTOLOSICA } & \multirow{2}{*}{ Method } & \multirow{2}{*}{ Constituent } & \multicolumn{2}{|c|}{ Sample Spe } & & & & \\
\hline & & & Filtered & Unfitered & & & & \\
\hline Gross Alpha Activity & Y/P65-7162 & - & - & - & - & - & - & 0 \\
\hline Gross Beta Activity & Y/P65-7162 & 은 & . & 9 & - & 은 & - & 8 \\
\hline Gamma Activity (Spectrum) & $\mathrm{Y} / \mathrm{P} 65-7171$ & . & - & e & . & . & - & \\
\hline Americium-241 & $\mathrm{Y} / \mathrm{P} 65-7157$ & $\dot{.}$ & . & 은 & . & . & 0 & (4. \\
\hline Iodine-129 & EPA-901.1 & . & . & 9 & . & - & $\therefore$ & 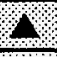 \\
\hline Neptunium-237 & Y/P65-7158 & . & . & 0 & . & . & 으 & 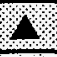 \\
\hline Plutonium-238 & Y/P65-7159 & . & . & 0 & $\dot{.}$ & . & 9 & 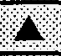 \\
\hline Plutonium-239/240 & Y/P65-7159 & . & . & e & . & . & 0 & 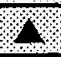 \\
\hline Radium-223/224/226 & EPA-903.0 & . & . & 0 & . & $\dot{.}$ & 은 & 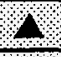 \\
\hline Radium-228 & Y/P65-7165 & 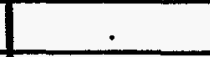 & $\dot{.}$ & 0 & . & . & 은 & 8 \\
\hline Strontium-89/90 & Y/P65-7196 & $\dot{.}$ & . & 을 & 은 & $\therefore$ & 9 & 10 \\
\hline Technetium-99 & Y/P65-7154 & 으 & $\therefore$ & 은 & 은 & - & 은 & $\$$ \\
\hline Thorium-228 & $\mathrm{Y} / \mathrm{P} 65-7150$ & - & . & 은 &. & . & 은 & 8 \\
\hline Thorium-230 & $\mathrm{Y} / \mathrm{P} 65-7150$ & - & . & 9 & . & . & 9 & 1. \\
\hline Thorium-232 & Y/P65-7150 & . & - & 9 & - & $\dot{-}$ & 9 & 9. \\
\hline Tritium & EPA-906.0 & . & . & 9 & . & . & - & 1 \\
\hline Uranium-234 & Y/P65-7161 & . & . & e & - & . & - & 8 \\
\hline Uranium-235 & $\mathrm{Y} / \mathrm{P} 65-7161$ & . & . & e & e & . & - & 8 \\
\hline Uranium-238 & $\mathrm{Y} / \mathrm{P} 65-7161$ & . & . & - & 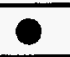 & . & 0 & $\$$ \\
\hline MSCEUIANEOUS & Analy tical & GWPS & Sam & Ie Type & & & & \\
\hline ANALYTES & & Eonsurtent & Fittered & Unilitered & & & & \\
\hline $\mathrm{pH}$ & EPA-150.1 & . & $\dot{.}$ & - & 운 & 으 & - & 8 \\
\hline Specific Conductance & EPA-129.1 & - & $\therefore$ & e & 은 & 은 & ? & Q \\
\hline Total Dissolved Solids & EPA-160.1 & - & . & 2 & 은 & e & 0 & Q \\
\hline Total Suspended Solids & EPA-160.2 & . & . & 0 & 0 & 은 & 은 & 0 \\
\hline Turbidity & EPA-180.1 & . & $\therefore$ & 0 & 0 & 0 & ? & 8 \\
\hline
\end{tabular}


Table 5 (cont'd)

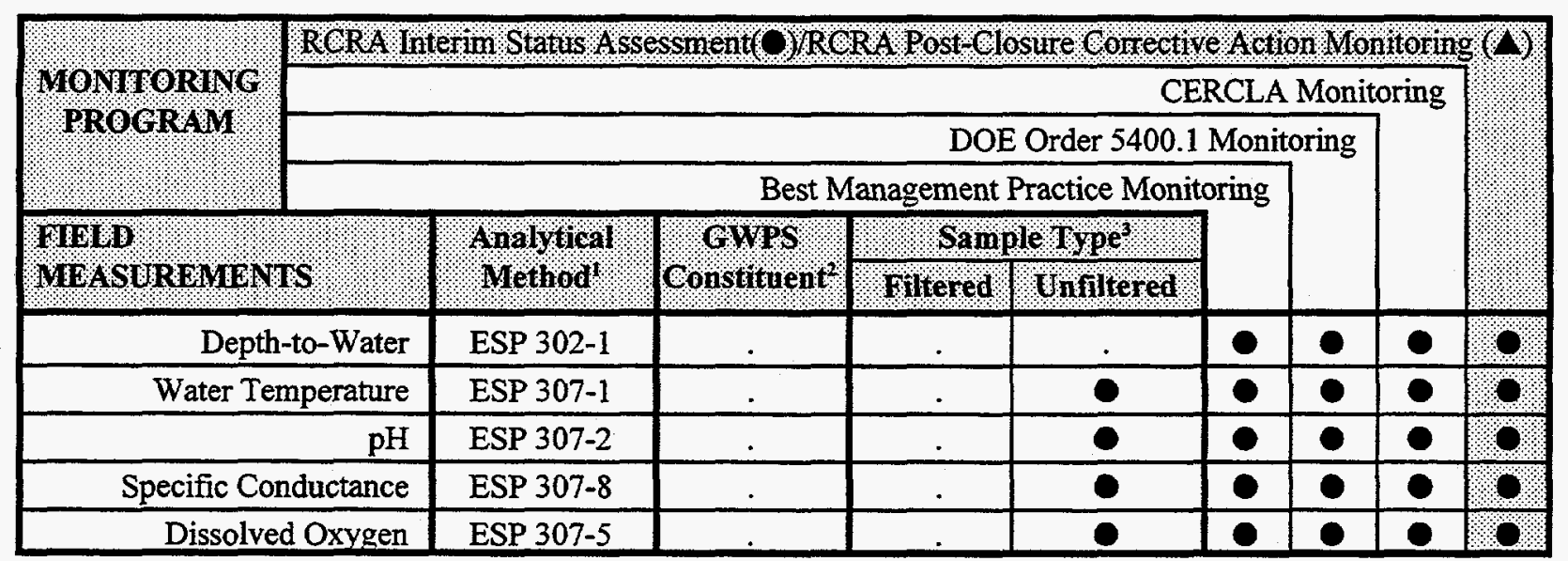

\section{Notes:}

1 Analytical/field methods and procedures from:

- Test Methods for Evaluating Solid Waste Physical/Chemical Methods (U.S. Environmental Protection Agency 1986)

- Methods for Chemical Analysis of Water and Wastes (U.S. Environmental Protection Agency 1983)

- Environmental Surveillance Procedures Quality Control Program (Martin Marietta Energy Systems, Inc. 1988b)

- Tennessee Department of Environment and Conservation, Division of Underground Storage Tanks, Reference Handbook, Section 5.0.

- K-25 Site Analytical Chemsitry Department Procedures Manual

Volatile organic compound (VOC) analyses performed in accordance with the K-25 Analytical Service Organization method ACD-240040 until October 1, 1996; VOC analyses subsequently performed in accordance with EPA-8240.

The analytical method for arsenic changed September 1, 1996 from Inductively Coupled Plasma (ICP) method (EPA-6010) to Plasma Mass Spectroscopy (PMS) method (EPA-200.8).

The analytical method for lead changed July 1, 1996 from ICP (EPA-6010) or Atomic Absorption Spectroscopy (EPA-7841) methods to PMS method (EPA-200.8).

2 Groundwater Protection Standard (GWPS) Constituent, as listed in Attachment 3, Section F of the RCRA Post-Closure Permit for Upper East Fork Poplar Creek Hydrogeologic Regime.

3 Groundwater samples collected with dedicated sampling equipment or portable Bennet Pumps (see Table 4) were filtered in the field; all other samples filtered in the laboratory. 
Table 6.

Groundwater Elevations in the East Fork Regime, April 2 - 4, 1996 and September 30 - October 7, 1996

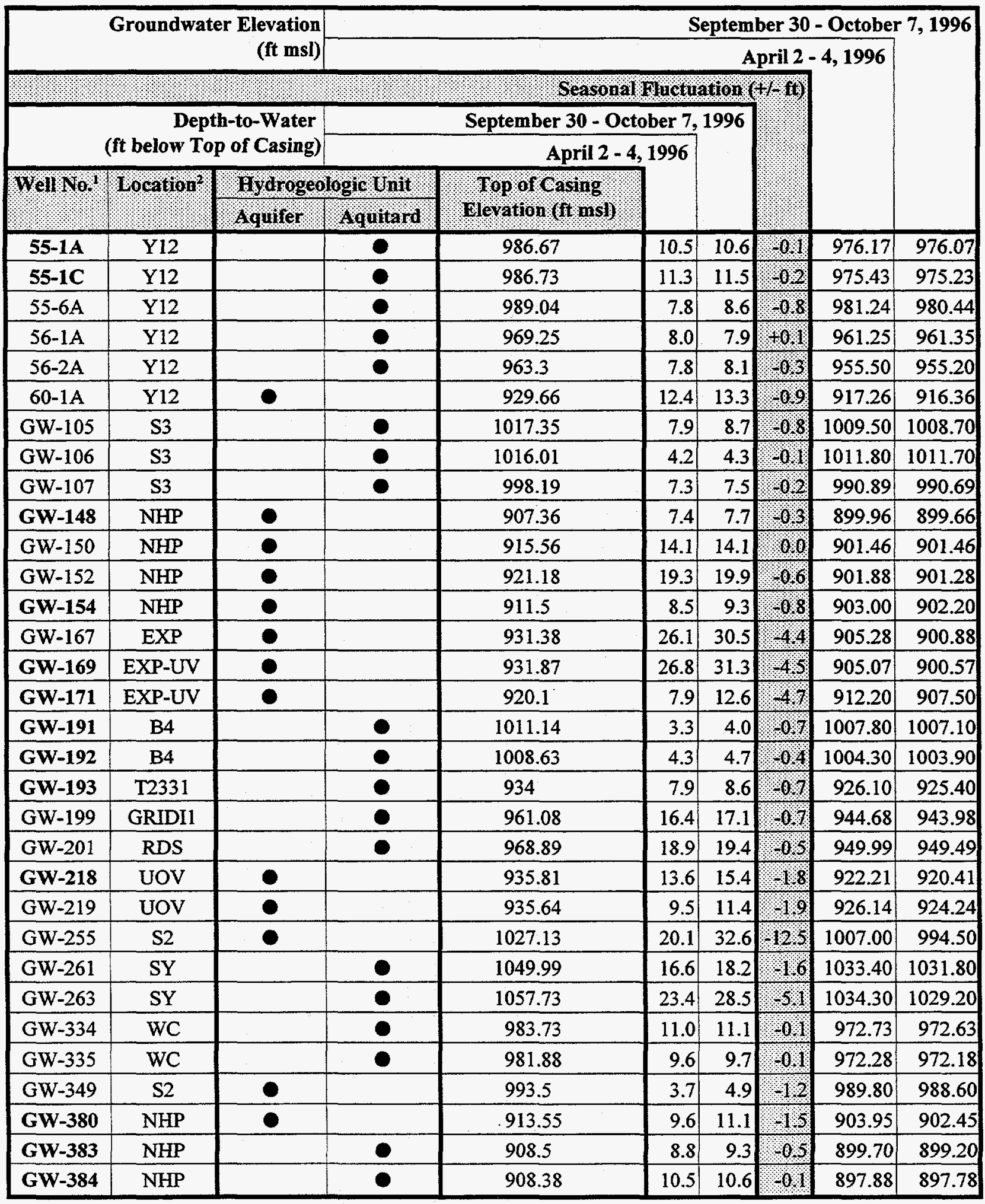


Table 6 (cont'd)

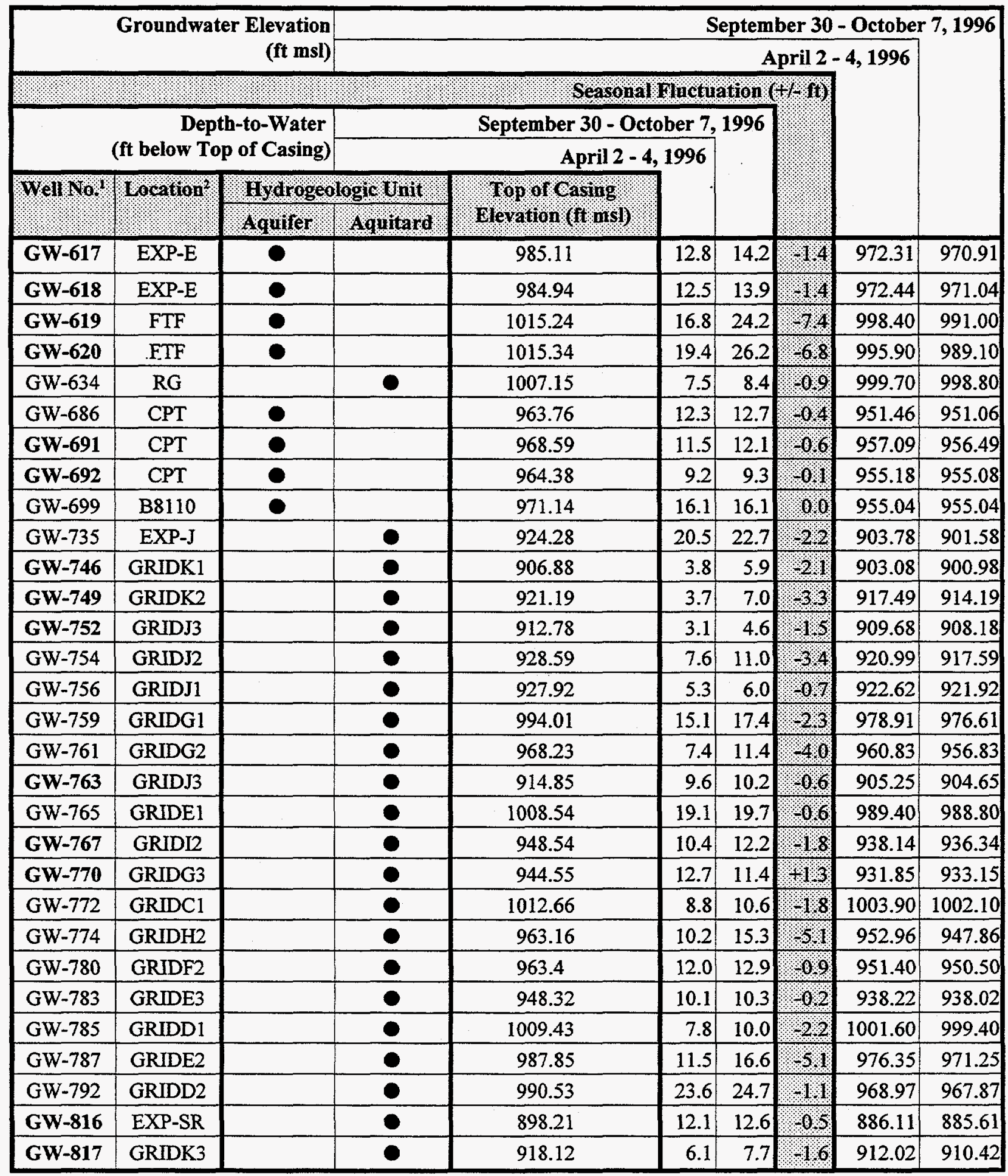


Table 6 (cont'd)

Notes:

1 Bold typeface denotes wells sampled during CY 1996 (see Table 4).

2 B4 - Beta-4 Security Pits

B8110 - Building 8110

CPT - Coal Pile Trench

EXP - Exit Pathway (Maynardville Limestone) monitoring well

- -E or -J: Maynardville Limestone Picket

- -UV: Offsite spring or surface water station in Union Valley

- -SR: Along Scarboro Road in the gap through Pine Ridge

FTF - Fire Training Facility

GRID - Comprehensive Groundwater Monitoring Plan Grid Location

NHP - New Hope Pond

RDS - Ravine Disposal Site

RG - Rust Garage Area

S2 - S-2 Site

S3 - S-3 Ponds Site

SY - Y-12 Plant Salvage Yard

T2331 - Tank 2331-U

UOV - Uranium Oxide Vault

WC - Waste Coolant Processing Area

Y12 - Y-12 Plant Complex 
Table 7.

Summary of CY 1996 RCRA Post-Closure Corrective Action Monitoring Results for the Eastern S-3 Ponds Plume

\begin{tabular}{|c|c|c|}
\hline RCRAGP & DWATER PROTECTIONS & DCONSTIMUENTS \\
\hline \multirow[t]{3}{*}{ Inorganics'? } & 10129996 & 110496 \\
\hline & Baclground WellGW-115. & Point-of-Complance Well GW 108 \\
\hline & Total Concentration (mg M) & Total Concentration (ng) \\
\hline Barium & 0.23 & 130 \\
\hline Cadmium & . & . \\
\hline Chromium & 0.035 & . \\
\hline Lead (PMS) & . & 0.0012 \\
\hline Mercury (CVAA) & . & . \\
\hline Nickel & 0.014 & - \\
\hline Nitrate (as N) & . & 10,900 \\
\hline Uranium (PMS) & . & 0.016 \\
\hline Colatile Organic & Concentration (jg//) & Goncentration (ug/) \\
\hline \multicolumn{3}{|l|}{ Benzene } \\
\hline \multicolumn{3}{|l|}{ Bromoform } \\
\hline Carbon Tetrachloride & . & . \\
\hline Chloroform & . & FP2 \\
\hline 1,1-Dichloroethene & . & . \\
\hline \multicolumn{3}{|l|}{ Trans-1,2-Dichloroethene } \\
\hline \multicolumn{3}{|l|}{ Tetrachloroethene } \\
\hline \multicolumn{3}{|l|}{ Trichloroethene } \\
\hline \multicolumn{3}{|l|}{ 1,1,1-Trichlorothene } \\
\hline $\begin{array}{l}\text { Radiochenical: } \\
\text { Parameters }\end{array}$ & Activity 1 Counting Error & $\begin{array}{l}\text { Aetrvity t Counting Error } \\
\text { (PCils) }\end{array}$ \\
\hline Gross Alpha & $<\mathrm{MDA}$ & $700 \pm 180$ \\
\hline Gross Beta & $<\mathrm{MDA}$ & $5,690 \pm 700$ \\
\hline Technetium-99 & $<\mathrm{MDA}$ & $8,690 \pm 870$ \\
\hline
\end{tabular}


Table 7 (cont'd)

\begin{tabular}{|c|c|c|}
\hline \multicolumn{3}{|c|}{ RCRA GROUNDW ATER PROTECTION STANDARD CONSTYTUENTS ? } \\
\hline Inorganics? & 110496 & 1013196 \\
\hline & Plume Boundary Well GW 193 & Pline Boundary Well GW 605 \\
\hline & Total Concentration (mg/) & Total Concentration (mgl) \\
\hline Barium & 0.12 & 0.071 \\
\hline Cadmium & . & . \\
\hline Chromium & . & . \\
\hline Lead (PMS) & . & 0.0012 \\
\hline Mercury (CVAA) & . & . \\
\hline Nickel & . & . \\
\hline Nitrate (as N) & . & 0.3 \\
\hline Uranium (PMS) & 0.018 & 0.23 \\
\hline $\begin{array}{l}\text { Yolatile Organic } \\
\text { Compounds' }\end{array}$ & Concentration (19gh) & Concentration (ugls) \\
\hline Benzene & 270 & . \\
\hline Bromoform & . & . \\
\hline Carbon Tetrachloride & . & 180 \\
\hline Chloroform & . & FP2 \\
\hline 1,1-Dichloroethene & . & . \\
\hline Trans-1,2-Dichloroethene & . & . \\
\hline Tetrachloroethene & . & 15 \\
\hline Trichloroethene & . & 6 \\
\hline 1,1,1-Trichlorothene & . & . \\
\hline $\begin{array}{l}\text { Radiochemical } \\
\text { Parameters' }\end{array}$ & Activity = Counting Error & $\begin{array}{l}\text { Activity } 1 \text { Counting Error } \\
\text { (peil) }\end{array}$ \\
\hline Gross Alpha & $9.7 \pm 3.7$ & $103 \pm 16$ \\
\hline Gross Beta & $<\mathrm{MDA}$ & $53.9 \pm 9.9$ \\
\hline Technetium-99 & $<\mathrm{MDA}$ & $<$ MDA \\
\hline
\end{tabular}


Table 7 (cont'd)

\begin{tabular}{|c|c|c|}
\hline \multirow[t]{3}{*}{ Inorganics? } & 1029996 & $10 / 30196$ \\
\hline & Plume Boundary Well GW-606 & Plume Boundary Well GW-733 \\
\hline & Total Concentration (mg/l) & Total Concentration (mgl) \\
\hline Barium & 0.089 & 0.026 \\
\hline Cadmium & . & . \\
\hline Chromium & . & . \\
\hline Lead (PMS) & . & 0.0034 \\
\hline \multicolumn{3}{|l|}{ Mercury (CVAA) } \\
\hline Nickel & . & . \\
\hline Nitrate (as N) & 0.78 & 0.32 \\
\hline Uranium (PMS) & 0.0067 & 0.00074 \\
\hline $\begin{array}{l}\text { Volatile Organic } \\
\text { Compounds }\end{array}$ & Concentration (ug/) & Concentration (agr) \\
\hline Benzene & . & . \\
\hline Bromoform & . & . \\
\hline Carbon Tetrachloride & 850 & 46 \\
\hline Chloroform & 240 & FP2 \\
\hline 1,1-Dichloroethene & . & . \\
\hline Trans-1,2-Dichloroethene & . & . \\
\hline Tetrachloroethene & 12 & 1 \\
\hline \multicolumn{3}{|l|}{ Trichloroethene } \\
\hline 1,1,1-Trichlorothene & . & . \\
\hline $\begin{array}{l}\text { Radiochemical: } \\
\text { Parameters': }\end{array}$ & Activiti: ( Counting Error & Activity = Counting Error \\
\hline Gross Alpha & $4.56 \pm 2.7$ & $<\mathrm{MDA}$ \\
\hline Gross Beta & $<\mathrm{MDA}$ & $<\mathrm{MDA}$ \\
\hline Technetium-99 & $<\mathrm{MDA}$ & $<\mathrm{MDA}$ \\
\hline
\end{tabular}


Table 7 (cont'd)

\section{Notes:}

1 As specified in Attachment 3, Section F, of the RCRA Post-Closure Permit for the Upper East Fork Poplar Creek Hydrogeologic Regime.

2 Total concentrations reported for unfiltered groundwater samples ("." = less than reporting limit). All results by Inductively Coupled Plasma (ICP) Spectroscopy except mercury: Cold Vapor Atomic Absorption (CVAA) Spectroscopy; lead and uranium: Plasma Mass Spectroscopy (PMS); and nitrate (as N): wet chemistry method.

3 Concentration in micrograms per liter $(\mu \mathrm{g} / \mathrm{L}) ; "$ " " = not detected; FP2 = false positive result based on trip blank contamination (see Appendix F).

4 Minimum detectable activity (MDA) in picoCurries per liter ( $\mathrm{pCi} / \mathrm{L})$; see Appendix D.4. 
APPENDIX C

MONITORING WELL CONSTRUCTION DETAILS 


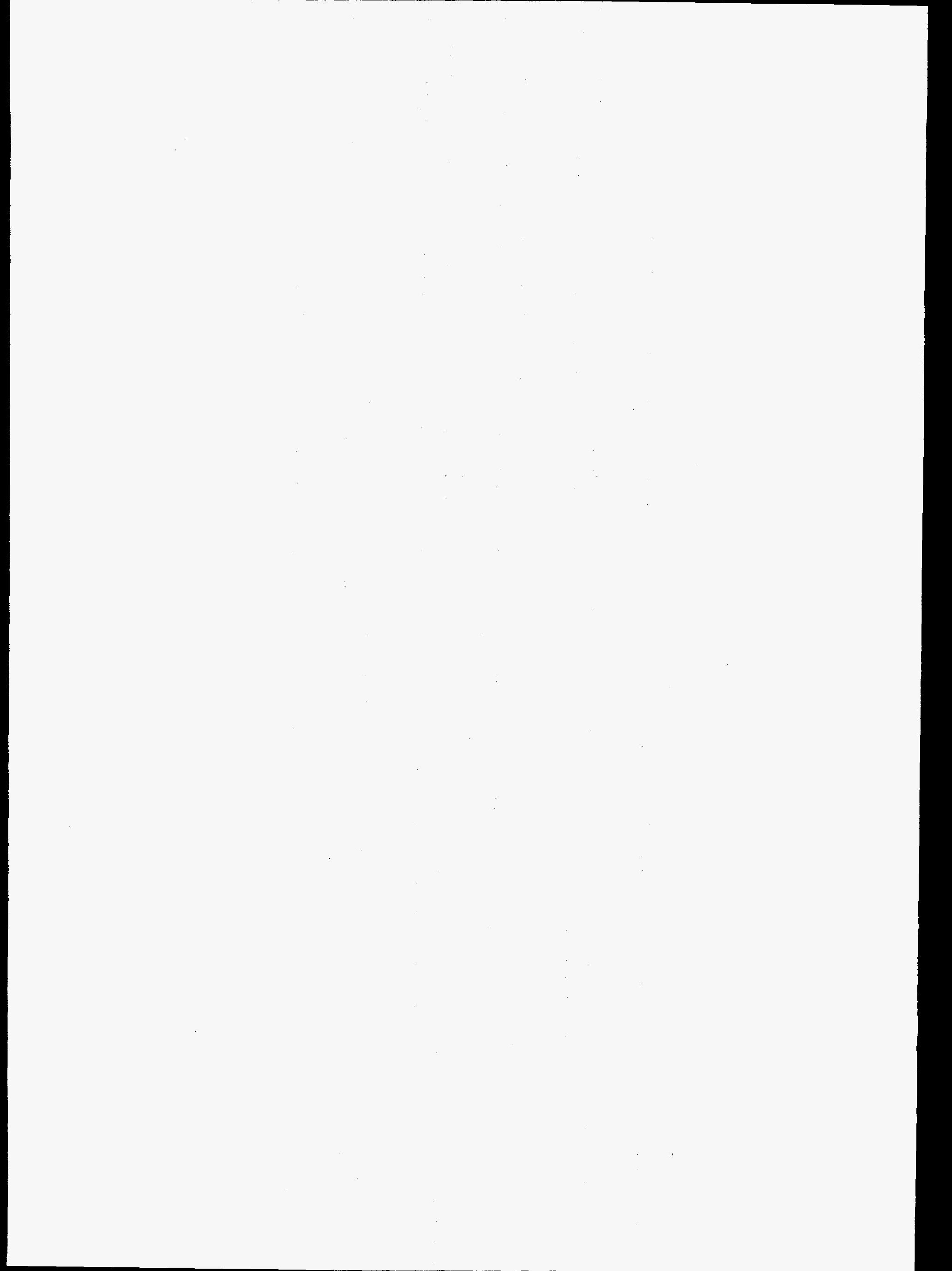




\section{EXPLANATION}

LOCATION:

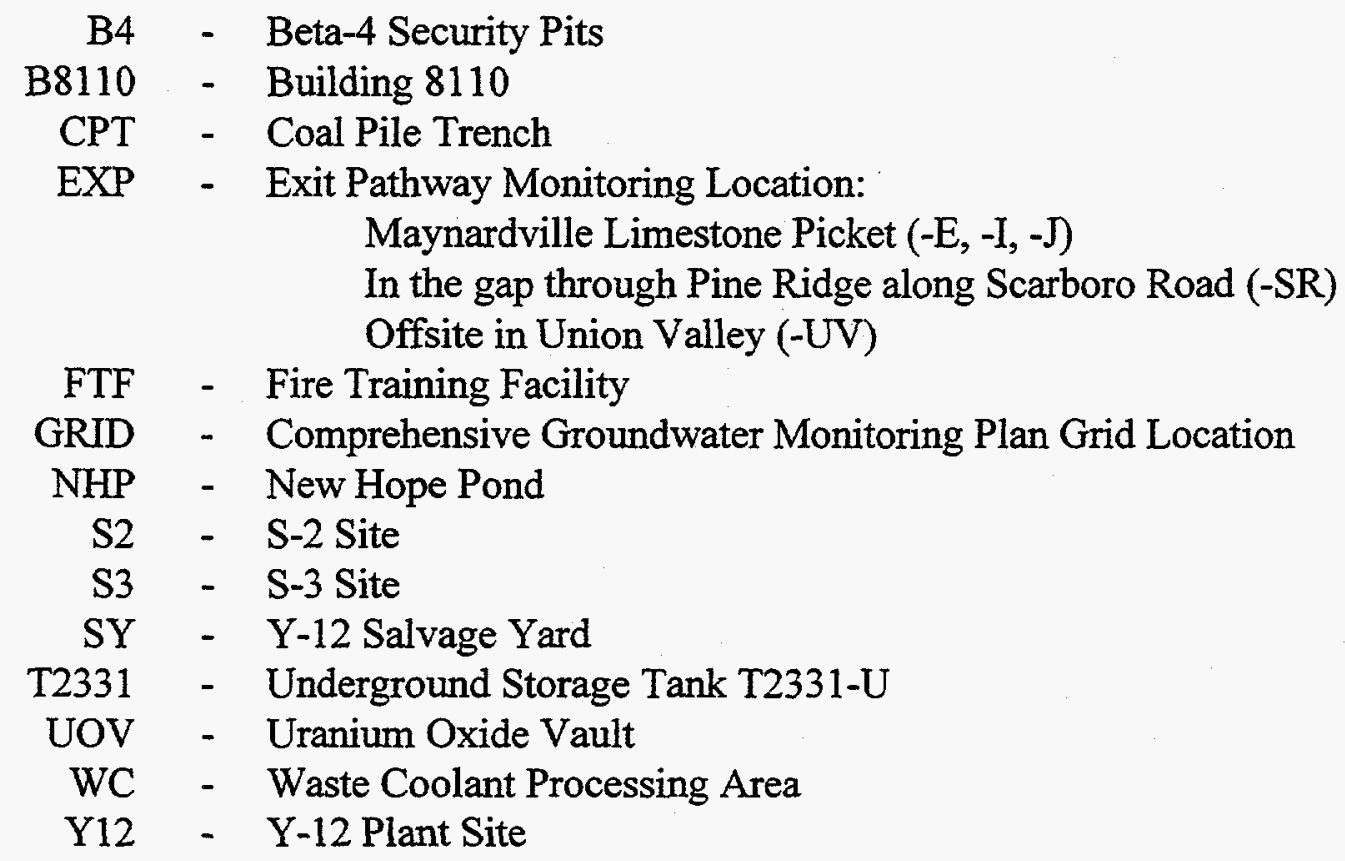

PROGRAM:

AMP - RCRA Interim Status Assessment Monitoring

AMP/S - Switched to SMP in the fourth quarter

BMP - Best Management Plan Monitoring

CERCLA - Monitoring for the Union Valley Focus Area and the UEFPC RI

CMP - RCRA Corrective Action Monitoring (plume delineation well)

Background well (-B)

Point-of-compliance well (-C)

EXP - DOE Order 5400.1 Monitoring: exit pathway

$\mathrm{EXP} / \mathrm{C}$ - Switched to CMP in the fourth quarter

SMP - DOE Order 5400.1 Monitoring: surveillance

\section{GENERAL INFORMATION:}

Coordinates - Y-12 Plant grid system

Elevations - Feet above mean sea level

Depths - Feet below ground surface 


\title{
EXPLANATION (cont'd)
}

GENERAL INFORMATION (cont'd):

$\begin{array}{rll}\text { AQF } & - & \text { Knox Aquifer } \\ \text { AQT } & - & \text { ORR Aquitards } \\ \text { BDR } & - & \text { Bedrock Interval } \\ \text { WT } & - & \text { Water Table Interval } \\ \text { OCk } & - & \text { Knox Group } \\ \mathrm{Cm} & - & \text { Maryville Limestone } \\ \mathrm{Cn} & - & \text { Nolichucky Shale } \\ \mathrm{Cmn} & - & \text { Maynardville Limestone } \\ \mathrm{Cpv} & - & \text { Pumpkin Valley Shale } \\ \mathrm{Crg} & - & \text { Rogersville Shale } \\ . & - & \text { Not Applicable or not available }\end{array}$

CASING:

Diameters - Outside dimensions, in inches (nominal)

Casing Material:

PVC/\#40 - Polyvinyl chloride, schedule 40

SS/\#304 - Stainless steel, schedule 304

Steel - Carbon steel

F-25/J-55 - American Petroleum Institute Grade

\section{MONITORED INTERVAL:}

\author{
Top - Depth to top of filter pack or open-hole \\ Bottom - Depth to bottom of filter pack or open-hole \\ Screen Material: \\ PVC/sl - PVC/slotted \\ PVC/sw/.01 - PVC, spiral wound, 0.01 inch slot size \\ SS/sw/.01 - Stainless steel, spiral wound, 0.01 inch slot size \\ $\mathrm{SS} / \mathrm{pp} / .01$ - Stainless steel prepack screen, spiral wound, 0.01 inch slot size
}

Length of screen and open hole interval is in feet.

NOTE:

Data Compiled from Updated Subsurface Data Base for Bear Creek Valley, Chestnut Ridge, and parts of Bethel Valley on the U.S. Department of Energy Oak Ridge Reservation (Jones et al. 1995). 
APPENDIX C

Monitoring Well Construction Details

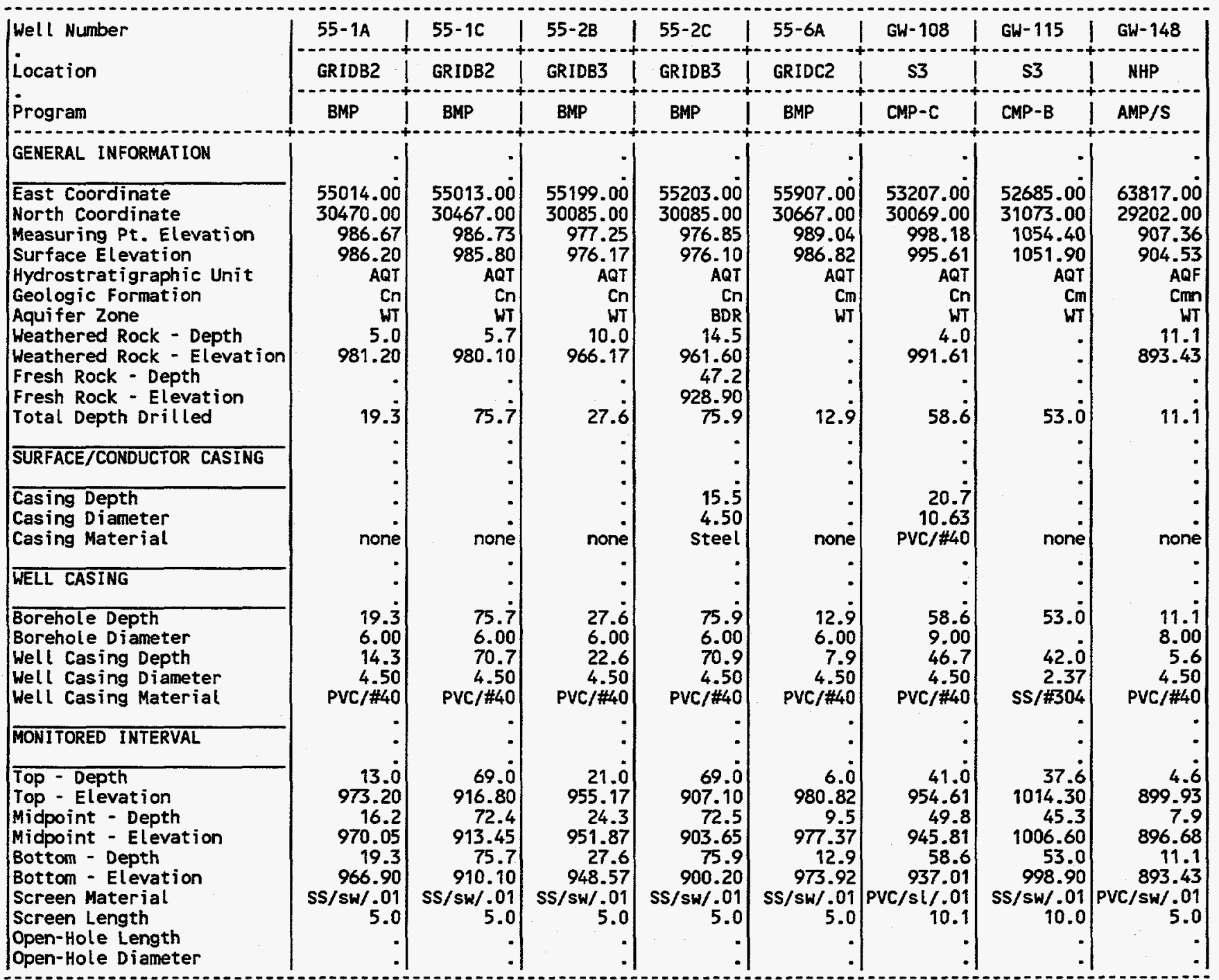

(CONT INUED) 
APPENDIX C

Monitoring Well Construction Details

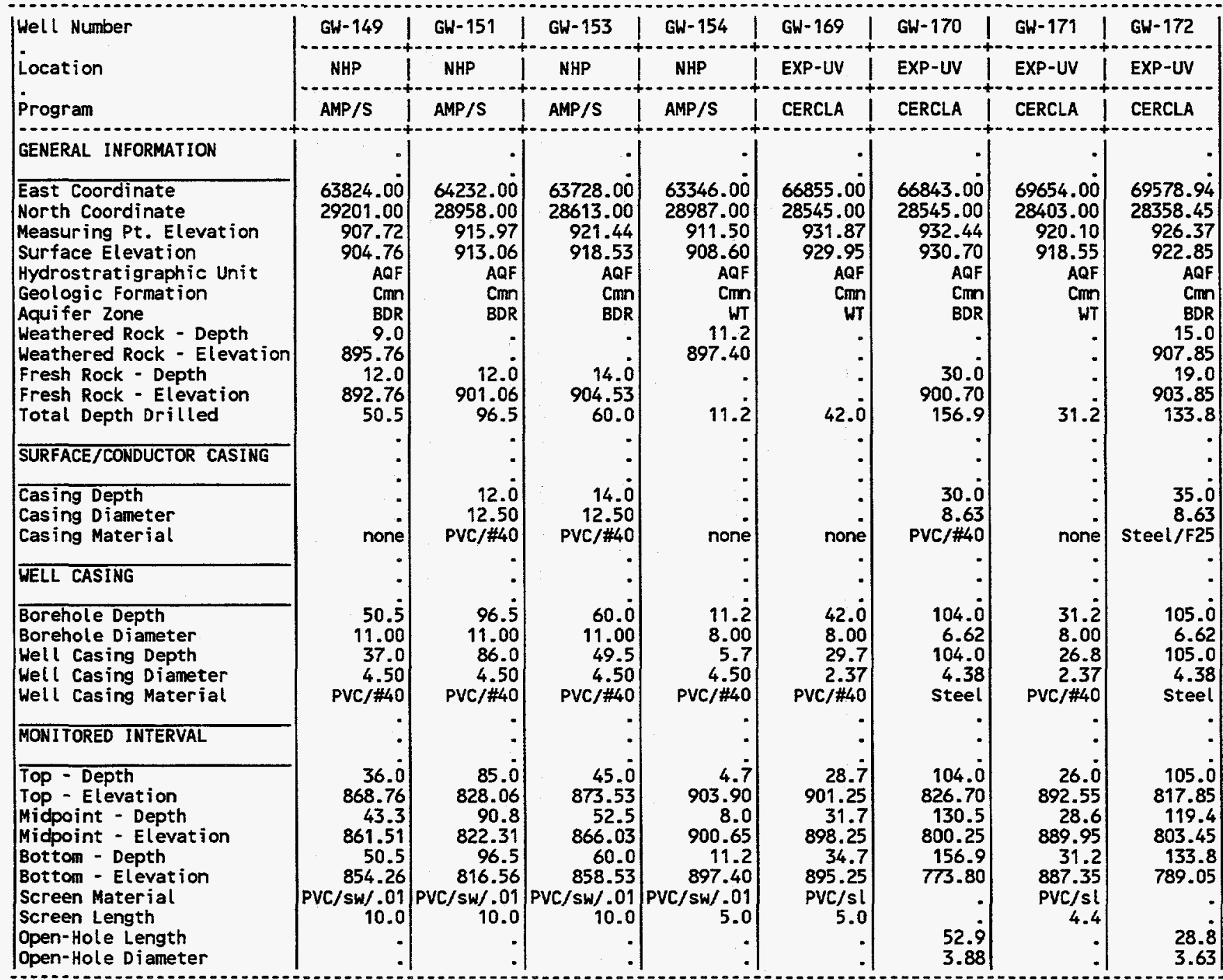

(CONT INUED) 
APPENDIX C

Monitoring Well Construction Details

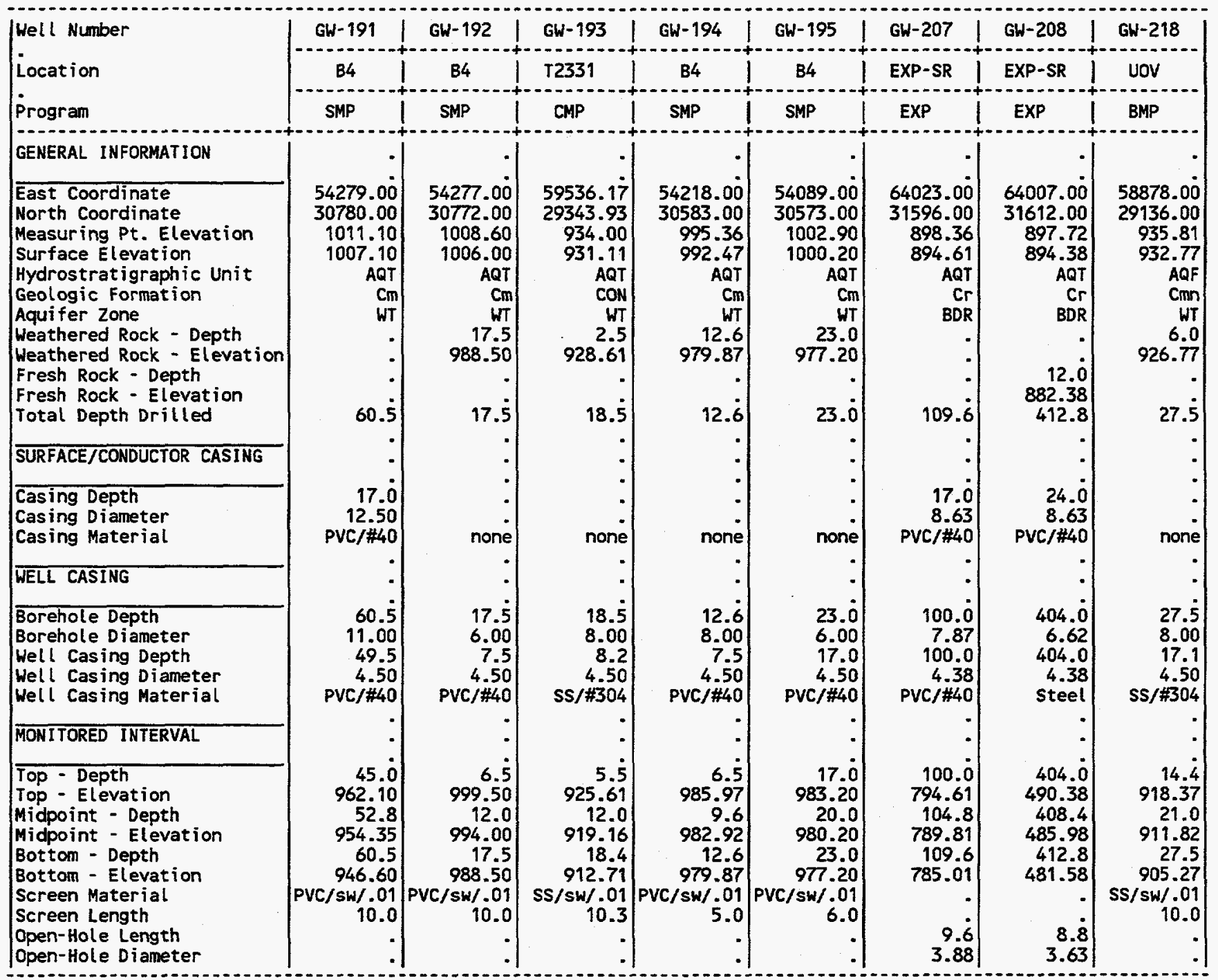

(CONTINUED) 
APPENDIX C

Monitoring Well Construction Details

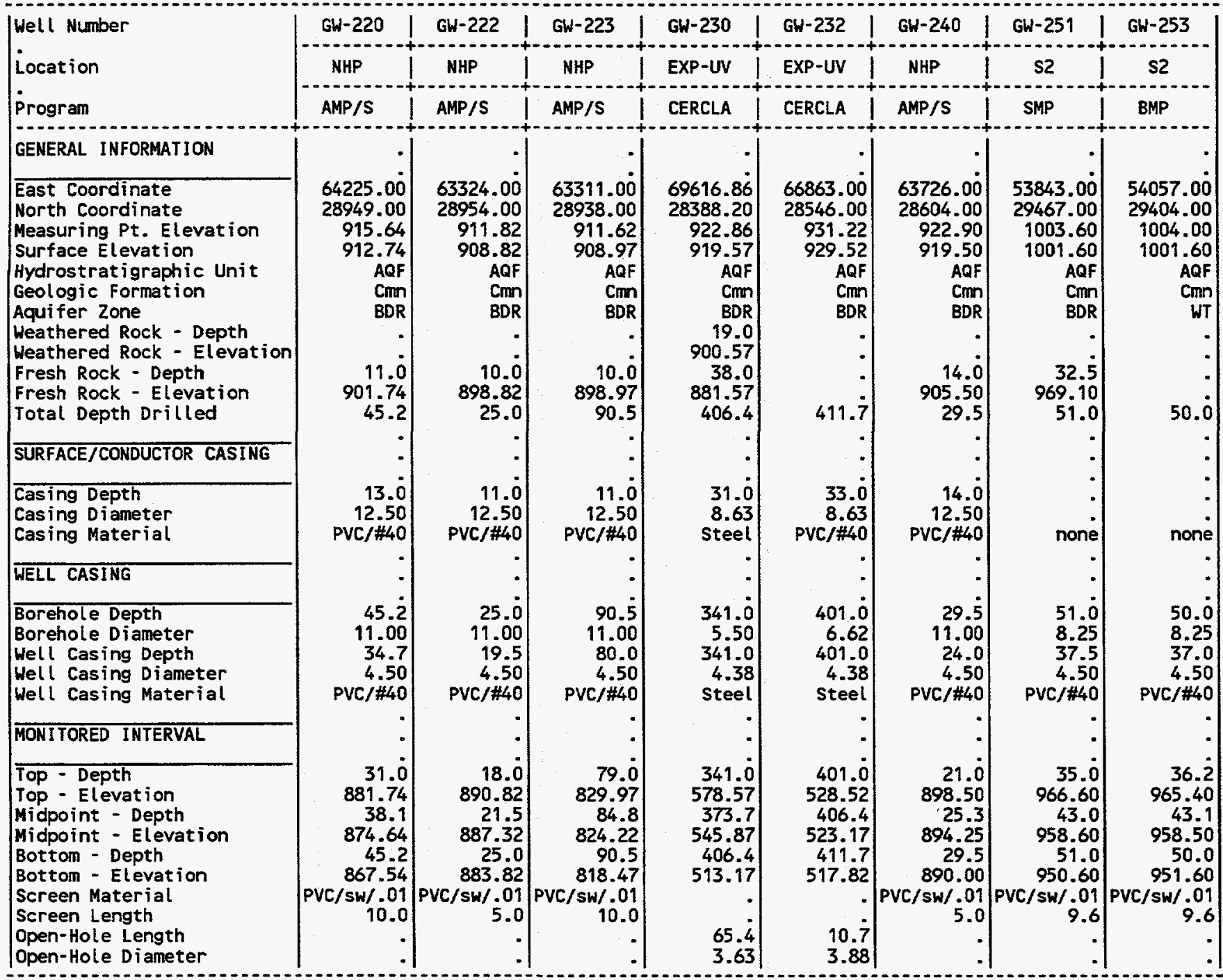

(CONTINUED) 
APPENDIX $C$

Monitoring Well Construction Details

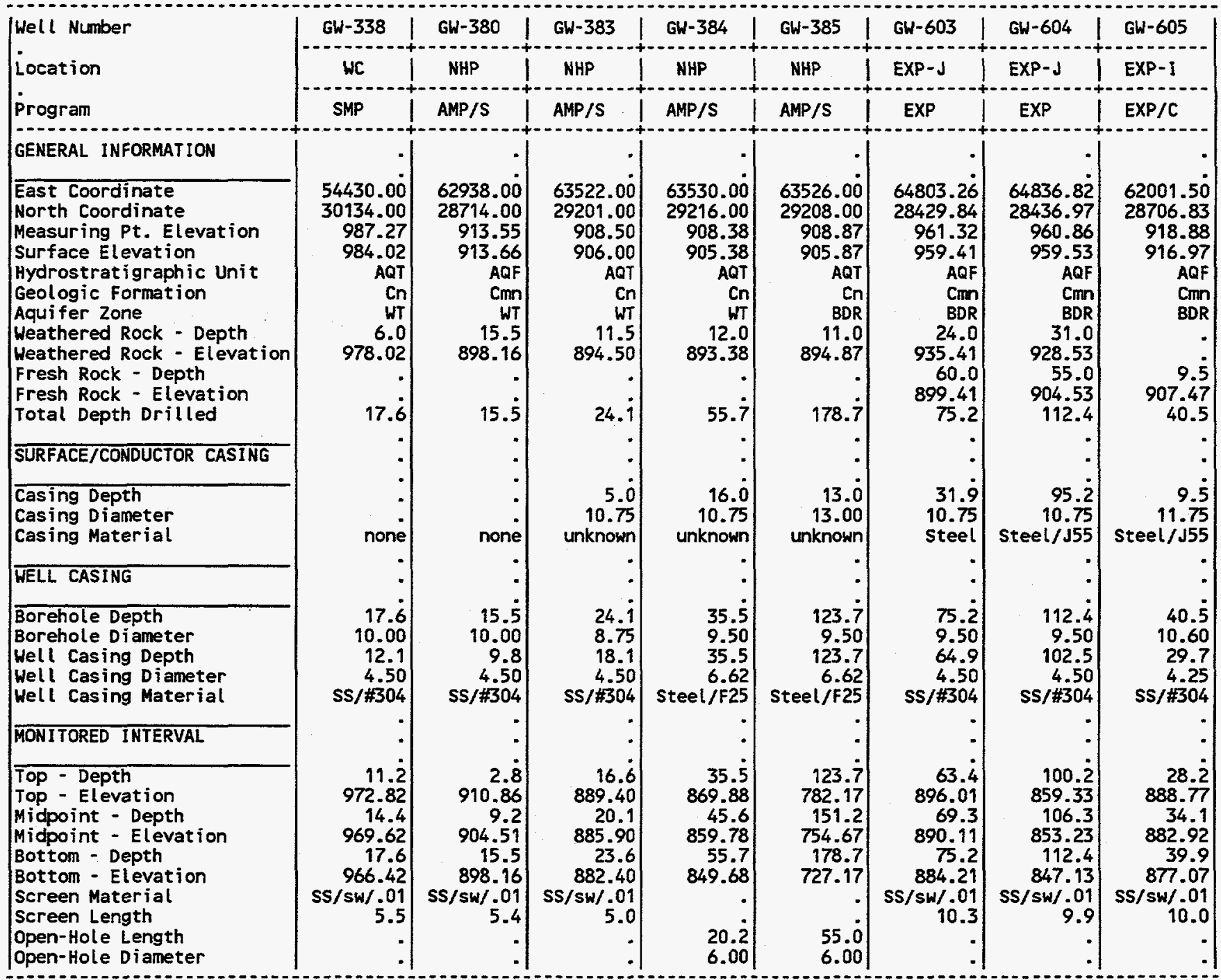

(CONTINUED) 
APPENDIX C

Monitoring Well Construction Details

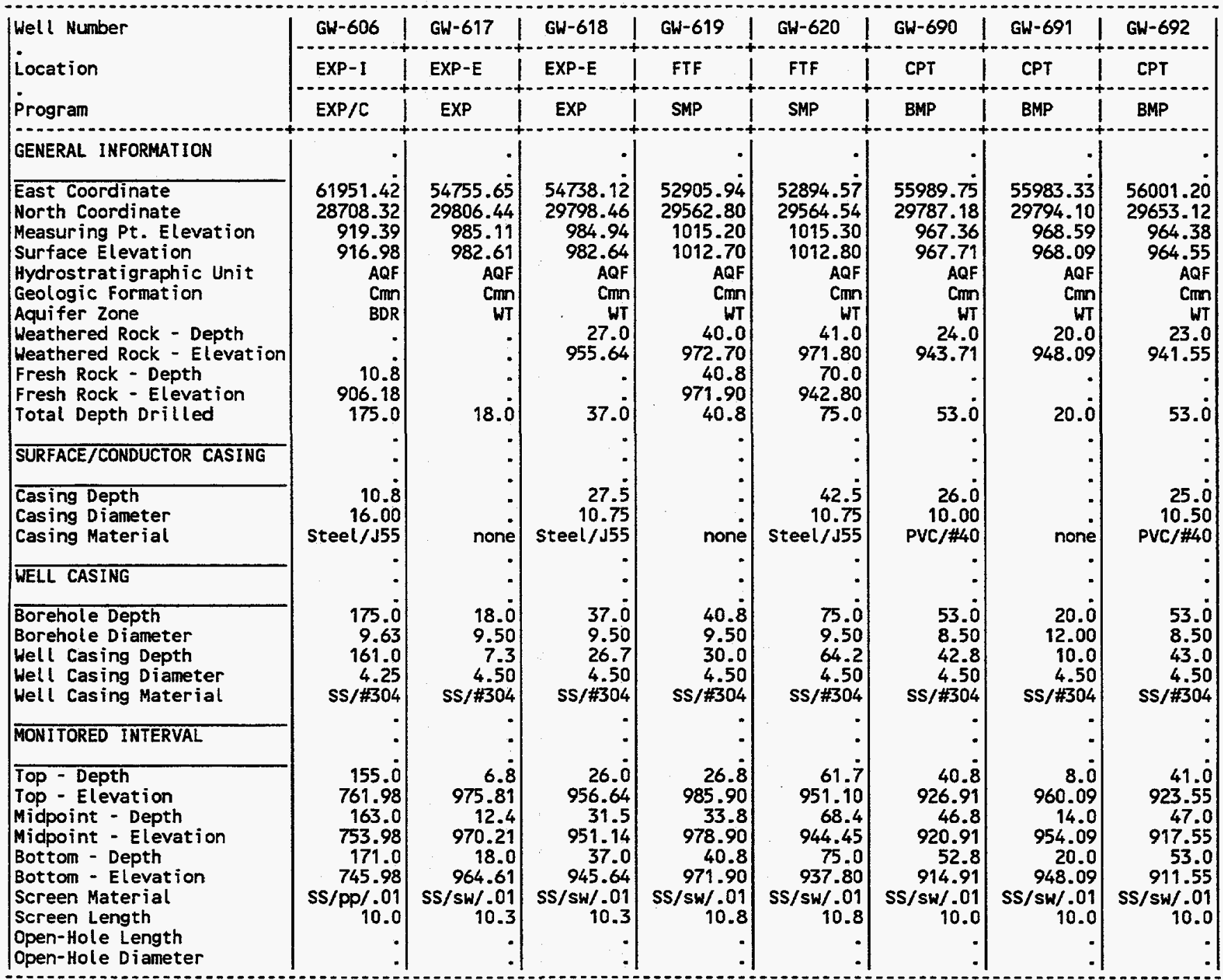

(CONT INUED) 
APPENDIX C

Monitoring Well Construction Details

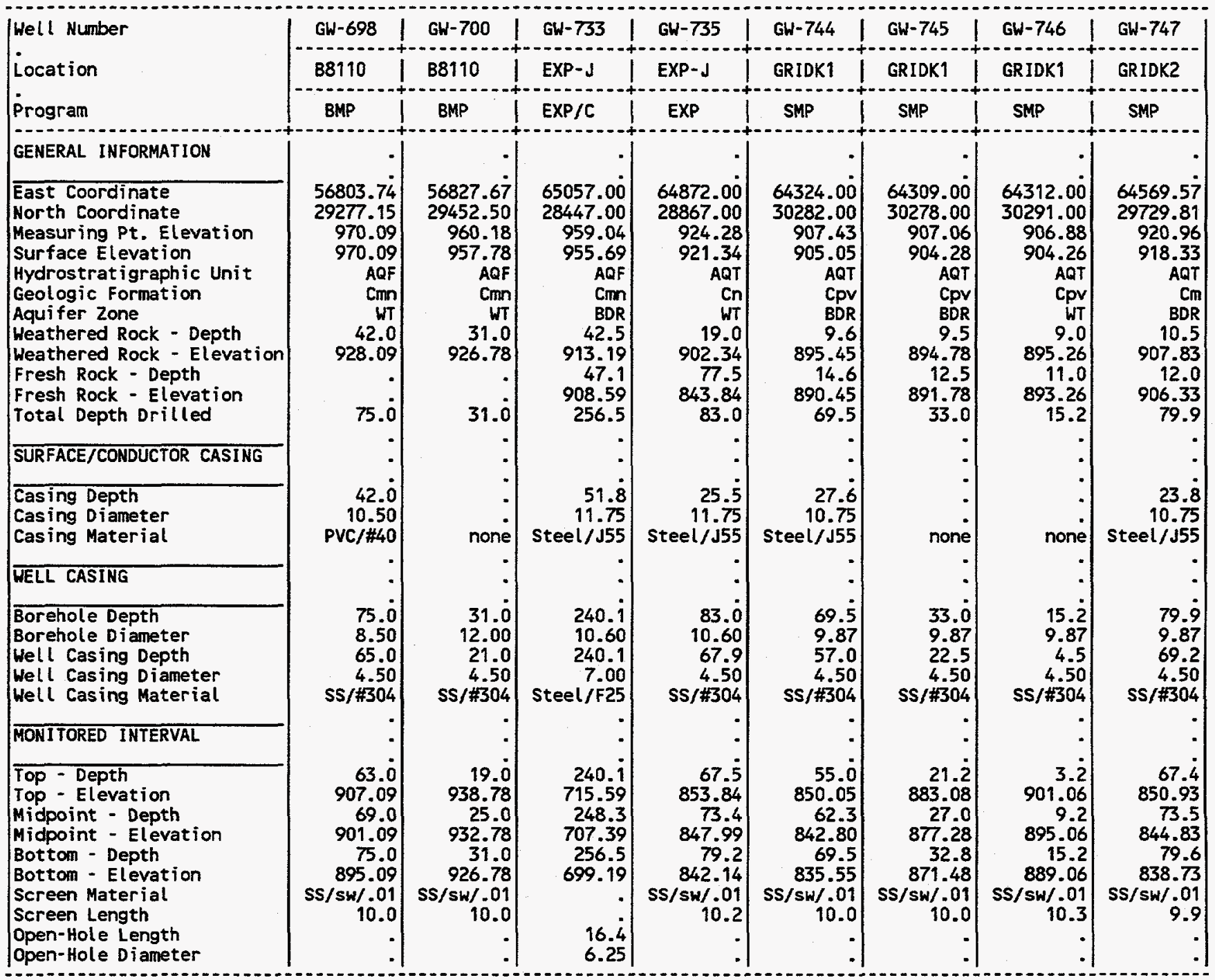

(CONTINUED) 
APPENDIX C

Monitoring Well Construction Details

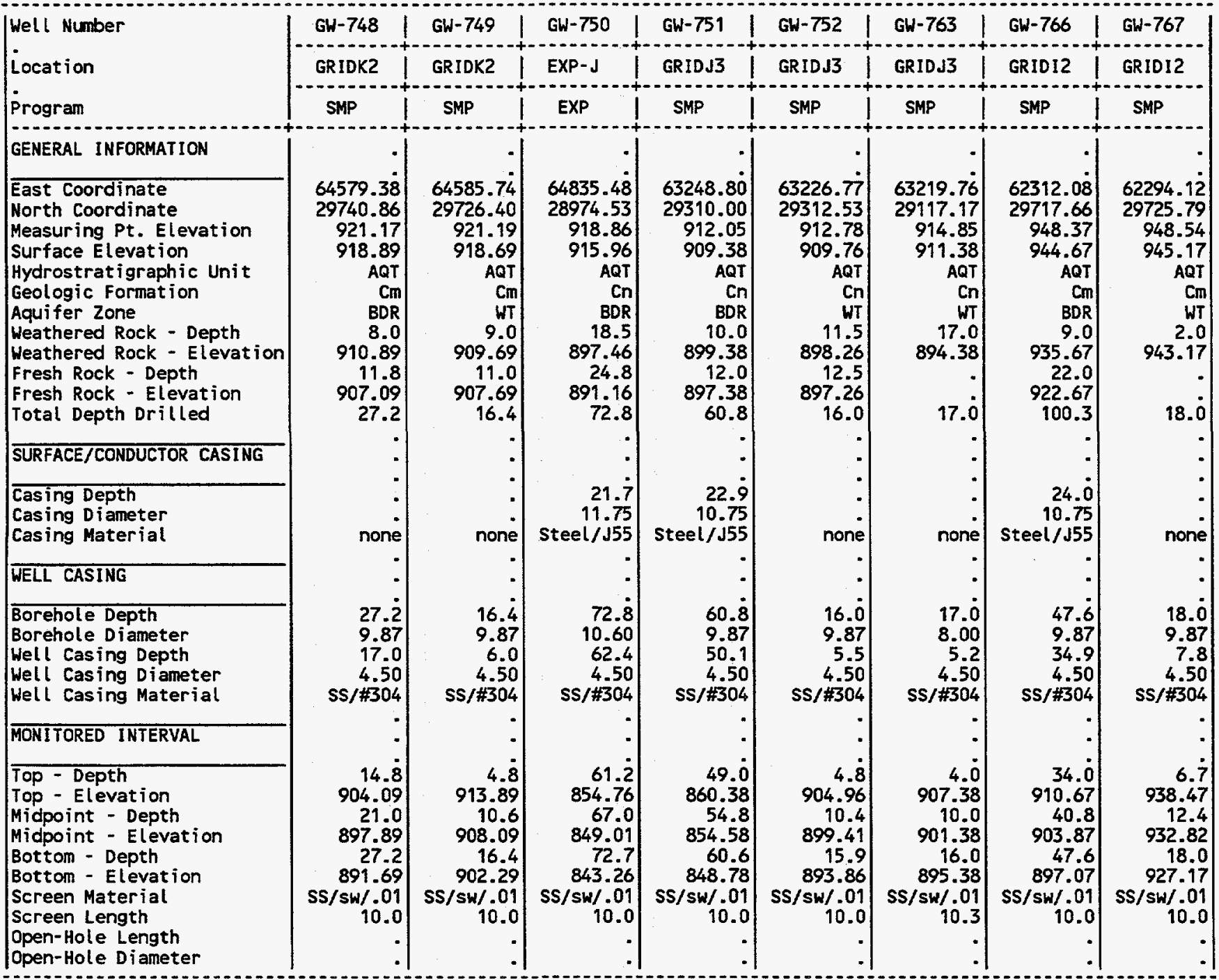

(CONTINUED) 
APPENDIX C

Monitoring Well Construction Details

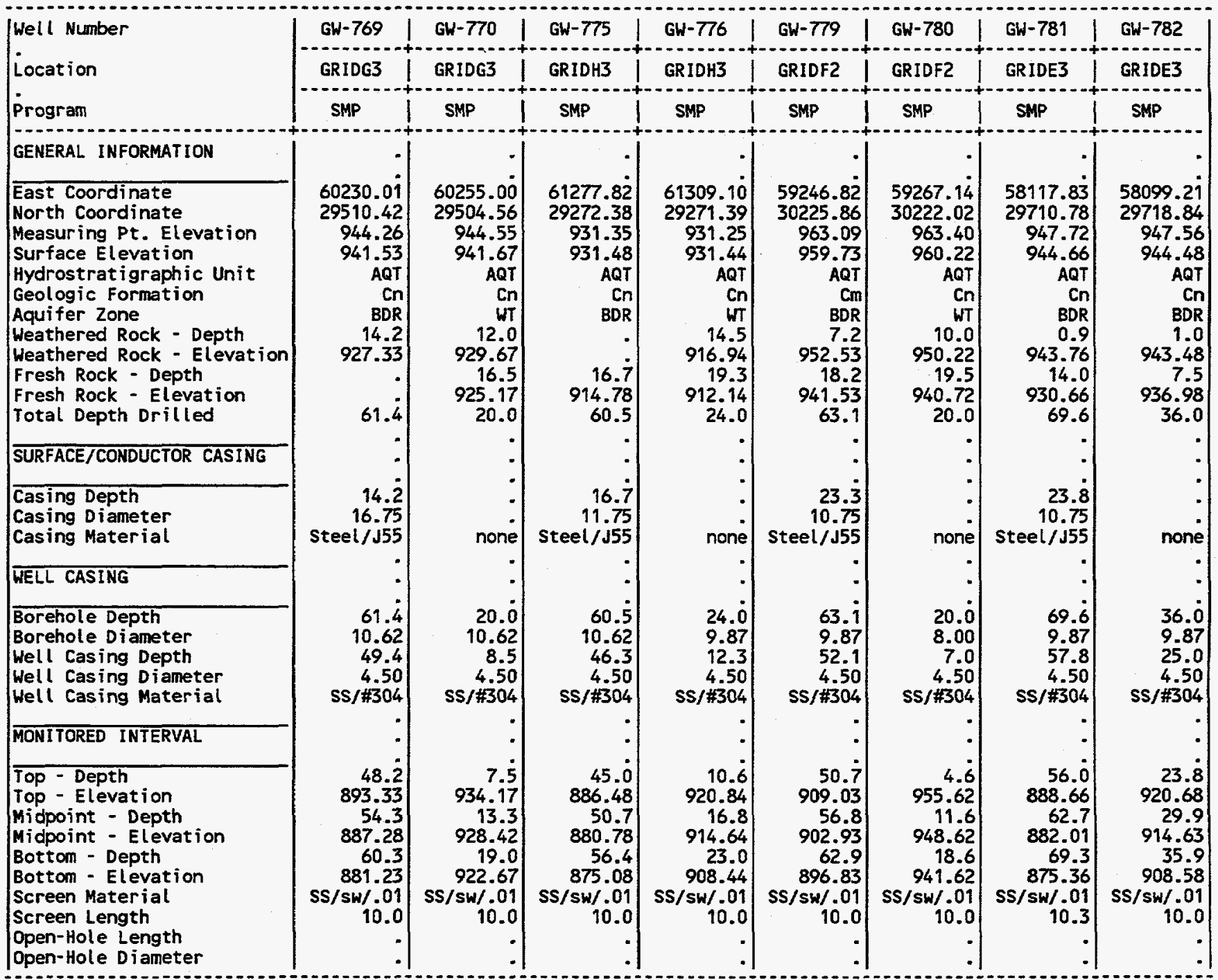

(CONTINUED) 
APPENDIX $\mathrm{C}$

Monitoring Well Construction Details

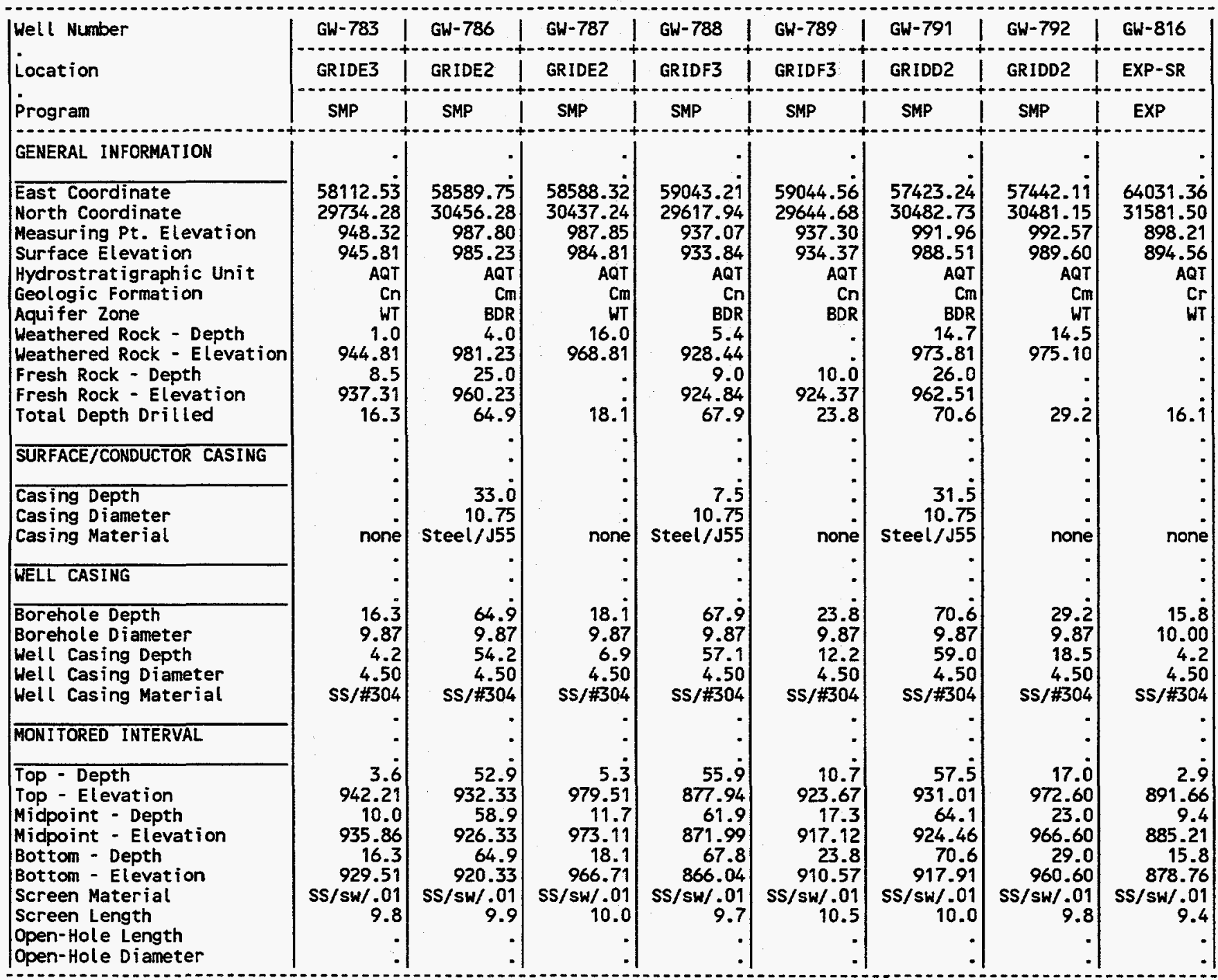

(CONTINUED) 
Monitoring Well Construction Details

\begin{tabular}{|c|c|c|}
\hline $\begin{array}{l}\text { Well Number } \\
\text { Location } \\
\text { Program } \\
\text { GENERAL INFORMATION }\end{array}$ & $\begin{array}{c}\text { GW-817 } \\
\text { GRIDK3 } \\
\text { SMP } \\
\end{array}$ & $\begin{array}{c}\text { GW-832 } \\
\text { NHP } \\
\text { CERCLA }\end{array}$ \\
\hline $\begin{array}{l}\text { East Coordinate } \\
\text { North Coordinate } \\
\text { Measuring Pt. Elevation } \\
\text { Surface Elevation } \\
\text { Hydrostratigraphic Unit } \\
\text { Geologic Formation } \\
\text { Aquifer Zone } \\
\text { Heathered Rock - Depth } \\
\text { Weathered Rock - Elevation } \\
\text { Fresh Rock - Depth } \\
\text { Fresh Rock - Elevation } \\
\text { Total Depth Drilled }\end{array}$ & $\begin{array}{r}64643.00 \\
29269.15 \\
918.12 \\
914.61 \\
A Q T \\
\mathrm{Cn} \\
\mathrm{WT} \\
11.6 \\
903.01 \\
18.4 \\
896.21 \\
23.0\end{array}$ & $\begin{array}{r}64133.61 \\
29141.95 \\
906.18 \\
906.83 \\
\text { AQF } \\
\text { Cmn } \\
\text { WT } \\
= \\
. \\
: \\
11.9\end{array}$ \\
\hline SURFACE/CONDUCTOR CASING & F & - \\
\hline $\begin{array}{l}\text { Casing Depth } \\
\text { Casing Dianeter } \\
\text { Casing Material }\end{array}$ & none & none \\
\hline WELL CASING & * & - \\
\hline $\begin{array}{l}\text { Borehole Depth } \\
\text { Borehole Diameter } \\
\text { Wel l Casing Depth } \\
\text { Hel l Casing Diameter } \\
\text { Wel C Casing Material }\end{array}$ & $\begin{array}{r}23.0 \\
10.75 \\
1.0 \\
4.50 \\
s s / \# 304\end{array}$ & $\begin{array}{r}11.9 \\
12.00 \\
5.9 \\
6.63 \\
\text { PVC/ } \$ 40\end{array}$ \\
\hline MONITORED INTERVAL & . & - \\
\hline $\begin{array}{l}\text { Top - Depth } \\
\text { Top - Elevation } \\
\text { Midpoint - Depth } \\
\text { Midpoint - Elevation } \\
\text { Bottom - Depth } \\
\text { Bottom - Elevation } \\
\text { Screen Material } \\
\text { Screen Length } \\
\text { Open-Hole Length } \\
\text { Open-Hole Diameter }\end{array}$ & $\begin{array}{r}0.6 \\
914.01 \\
11.8 \\
902.81 \\
23.0 \\
891.61 \\
\text { ss/sw/.01 } \\
21.3\end{array}$ & $\begin{array}{r}4.0 \\
902.83 \\
7.9 \\
898.93 \\
11.8 \\
895.03 \\
\text { PVC/sl/.01 } \\
5.0 \\
.\end{array}$ \\
\hline
\end{tabular}




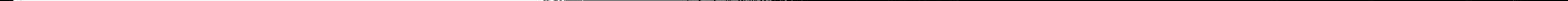


APPENDIX D

CY 1996 DATA FOR

GROUNDWATER AND SURFACE WATER SAMPLES 


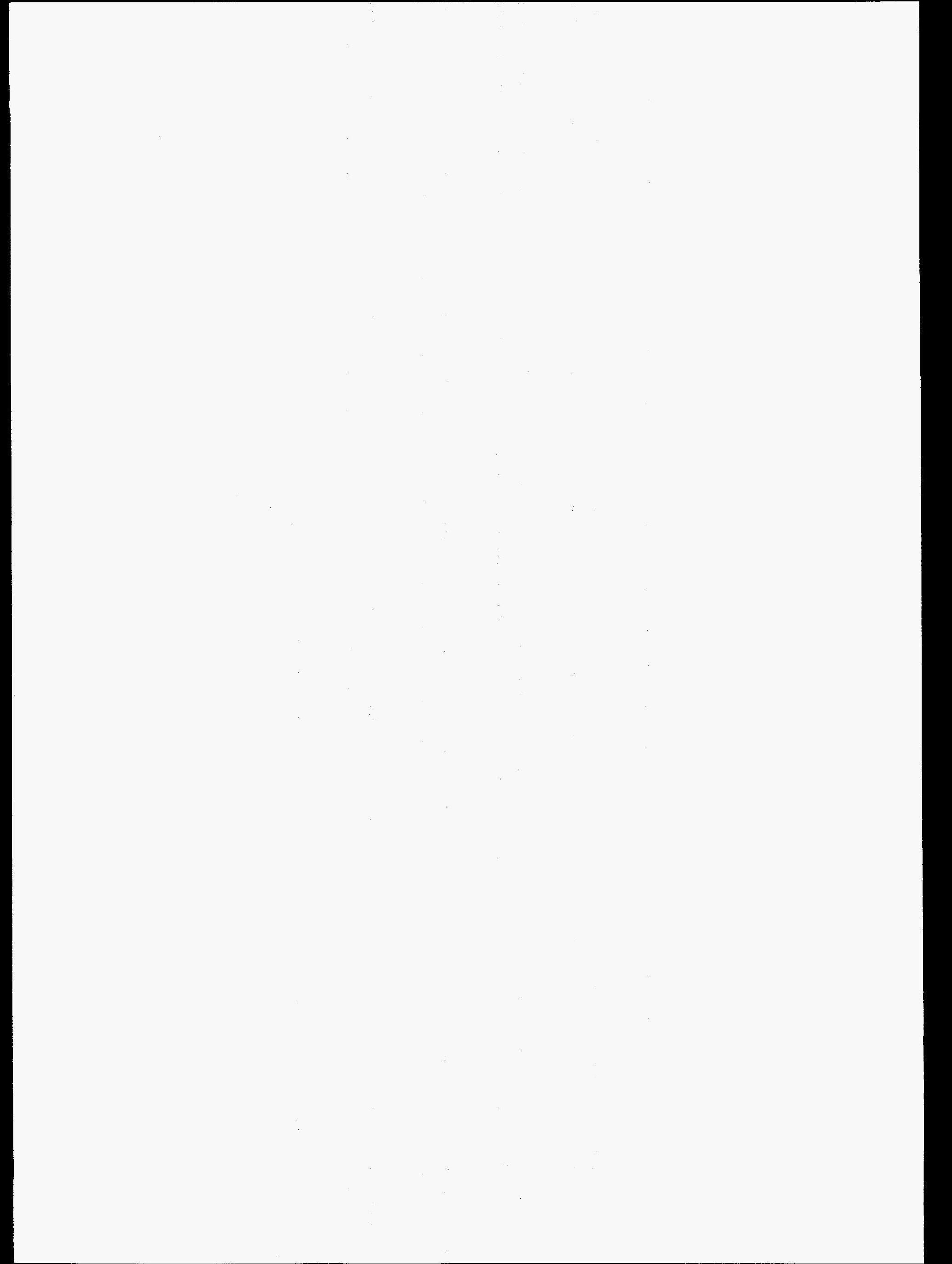




\section{EXPLANATION}

\section{SAMPLING POINT:}

55- - Monitoring Well (installed for the Mercury Study, 1984)

GW - Monitoring Well

LRSPW - Lake Reality Emergency Spillway, seep

NHPCEMSP - Spring at the New Hope Pond Cemetery

RQWWSP - Offsite spring in the west wall of Rogers Quarry in Union Valley

SCR - Offsite spring and surface water sampling locations:

Scarboro Creek along South Illinois Avenue

UV - Offsite spring in Union Valley east of South Illinois Avenue

PROGRAM:

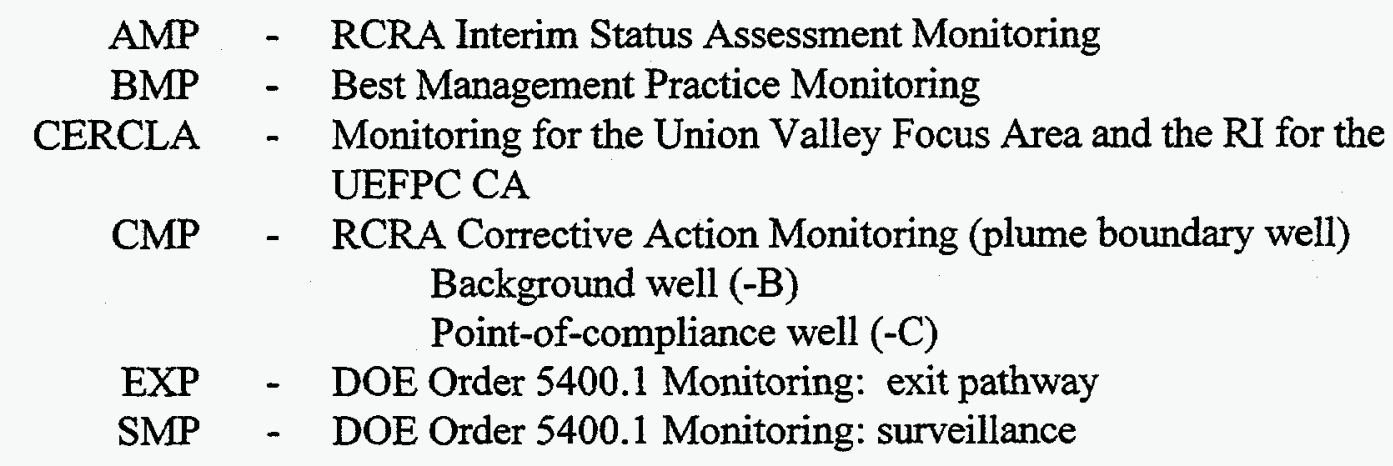

LOCATION:

B4 - Beta-4 Security Pits

B8110 - Building 8110

CPT - Coal Pile Trench

EXP - Exit Pathway Monitoring Location:

Maynardville Limestone Picket (-E, -I, -J)

In the gap through Pine Ridge along Scarboro Road (-SR)

Offsite in Union Valley (-UV)

FTF - Fire Training Facility

GRID - Comprehensive Groundwater Monitoring Plan Grid Location

NHP - New Hope Pond

S2 - S-2 Site

S3 - S-3 Site

SY - Y-12 Salvage Yard

T2331 - Underground Storage Tank T2331-U

UOV - Uranium Oxide Vault

WC - Waste Coolant Processing Area

Y12 - Y-12 Plant Site 


\section{EXPLANATION (cont'd)}

SAMPLE TYPE:

$\begin{array}{rll}\text { DUP } & - & \text { Field Duplicate Sample } \\ \text { DIS } & - & \text { Dissolved concentration (Filtered Sample) } \\ \text { TOT } & - & \text { Total concentration (Unfiltered Sample) } \\ \text { ACT } & - & \text { Activity } \\ \text { ERR } & - & \text { Counting Error (two standard deviations) } \\ \text { MDA } & - \text { Minimum Detectable Activity }\end{array}$

NOTES:

Bicarbonate $(\mathrm{HCO} 3)$ and carbonate $(\mathrm{CO} 3)$ alkalinity were reported as calcium carbonate.

All trace metal and cation analyses were performed using the inductively coupled plasma spectroscopy method unless otherwise noted.

$$
\begin{array}{rll} 
& - & \text { Not analyzed } \\
\text { AAS } & - & \text { Atomic Absorption Spectroscopy } \\
\text { CVAA } & - \text { Cold Vapor Atomic Absorption } \\
\text { PMS } & - \text { Plasma Mass Spectroscopy } \\
\text { TDS } & - \text { Total Dissolved Solids } \\
\text { TSS } & - \text { Total Suspended Solids } \\
\text { Sp. Cond. } & - \text { Specific Conductance }
\end{array}
$$

\section{UNITS:}

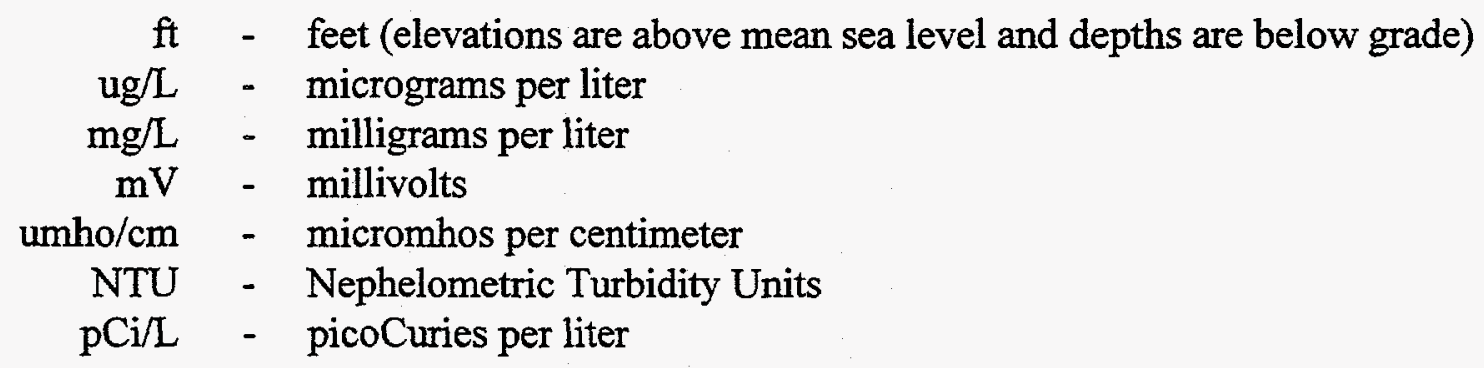

\section{DATA QUALIFICATION:}

The following laboratory qualifiers are presented with results in this appendix:

$<\quad$ - Inorganic compound not detected at the minimum attainable detection limit.

U - Organic compound not detected at the minimum attainable detection limit. 


\section{EXPLANATION (cont'd)}

\section{Miscellaneous Parameters:}

The following results were reported with a "**" qualifier, indicating that results of replicate analyses were outside control limits.

\begin{tabular}{|c|c|c|}
\hline Sampling Location & Sampling Date & Parameter \\
\hline GW-169 & $02 / 27 / 96$ & Total suspended solids \\
GW-194 & $02 / 23 / 96$ & Total suspended solids \\
GW-208 & $09 / 11 / 96$ & Total suspended solids \\
GW-220 & $03 / 20 / 96$ & Total suspended solids \\
GW-384 D & $09 / 25 / 96$ & Total suspended solids \\
GW-605 & $10 / 31 / 96$ & Total suspended solids \\
GW-752 & $05 / 07 / 96$ & Dissolved solids \\
GW-766 & $05 / 09 / 96$ & Turbidity \\
GW-767 & $10 / 09 / 96$ & Sulfate \\
GW-776 & $10 / 10 / 96$ & Total suspended solids \\
GW-779 & $11 / 07 / 96$ & Total suspended solids \\
GW-781 & $03 / 06 / 96$ & Dissolved solids \\
GW-783 & $11 / 12 / 96$ & Total suspended solids \\
GW-789 & $03 / 04 / 96$ & Dissolved solids \\
GW-789 & $11 / 11 / 96$ & Nitrate (as N) \\
GW-816 & $11 / 21 / 96$ & Total suspended solids \\
SCR7.12SW & $03 / 18 / 96$ & Dissolved solids \\
SCR7.8SSP & $06 / 20 / 96$ & Turbidity \\
SCR7.8SSP & $06 / 20 / 96$ & Total suspended solids \\
\hline
\end{tabular}

Inorganic Analytes:

PMS - All samples were diluted before analysis to obtain an optimal matrix; reporting limits were set with a five-fold dilution. Results less than the reporting limits were reported with a "d" qualifier.

ICP - The following unfiltered and filtered samples were diluted before analysis to obtain accurate results:

\begin{tabular}{|c|c|c|}
\hline Sampling Location & Sampling Date & Dilution Factor \\
\hline GW-108 & $11 / 04 / 96$ & 50 \\
GW-253 & $06 / 10 / 96$ & 2 \\
\hline
\end{tabular}




\section{EXPLANATION (cont'd)}

\section{Organic Analytes:}

All results less than $10 \mathrm{ug} / \mathrm{L}$ were estimated values below the reporting limit, and were reported with a "J" qualifier.

Forty-four results for volatile organic samples collected in the East Fork Regime during CY 1996 were reported with a "B" qualifier, indicating that an organic compound also was detected in the associated laboratory blank. All false positive results that were screened by data reported for the laboratory or trip blanks (not indicated by a qualifier) are presented in Appendix F. Additionally, the semi-volatile compound di-n-butylphthalate, detected in the first quarter sample from LRSPW (4 $\mathrm{ug} / \mathrm{L}$ ), was reported with a " $\mathrm{B}$ " qualifier.

Groundwater samples collected from wells located in areas known or suspected to have high concentrations of dissolved organics were diluted before analysis to obtain accurate results. Results for these samples are qualitative because the detection limits are elevated, and some compounds may be present at low levels but not reported. The dilution factor for these samples are identified in the bottom row of the data table (Appendix D.3).

Results for some organic compounds exceeded the instrument calibration, and were reported with an "E" qualifier. Another aliquot, at a secondary dilution, was usually analyzed to obtain an accurate result for that specific compound. The following results were reported with an "E" qualifier and were replaced in Appendix D.3 with the result from the diluted sample, if available.

\begin{tabular}{|c|c|c|c|c|}
\hline $\begin{array}{c}\text { Sampling } \\
\text { Location }\end{array}$ & $\begin{array}{c}\text { Sampling } \\
\text { Date }\end{array}$ & Compound & $\begin{array}{c}\text { Result } \\
(\mu \mathrm{g} / \mathrm{L})\end{array}$ & $\begin{array}{c}\text { Replacement } \\
(\mu \mathrm{g} / \mathrm{L})\end{array}$ \\
\hline 55-2B & $06 / 10 / 96$ & Tetrachloroethene & 540 & 550 \\
$55-2 \mathrm{~B}$ & $06 / 10 / 96$ & 1,2-Dichloroethene & 1800 & 2200 \\
$55-2 \mathrm{~B}$ & $06 / 10 / 96$ & Trichloroethene & 280 & 300 \\
GW-151 & $03 / 20 / 96$ & Carbon tetrachloride & 750 & 410 \\
GW-151 & $06 / 17 / 96$ & Carbon tetrachloride & 480 & 400 \\
GW-193 & $11 / 04 / 96$ & Benzene & 270 & NA \\
GW-193 D & $11 / 04 / 96$ & Benzene & 250 & NA \\
GW-605 & $02 / 15 / 96$ & Carbon tetrachloride & 230 & 190 \\
GW-605 & $06 / 08 / 96$ & Carbon tetrachloride & 250 & NA \\
GW-606 & $10 / 31 / 96$ & Carbon tetrachloride & 850 & NA \\
GW-606 & $10 / 31 / 96$ & Chloroform & 240 & NA \\
GW-782 & $02 / 19 / 96$ & Tetrachloroethene & 230 & 220 \\
\hline D=Duplicate sample & NA=Not available \\
\hline
\end{tabular}




\section{EXPLANATION (cont'd)}

\section{Radiological Analytes:}

Radionuclide activities reported with a " $\mathrm{J}$ " qualifier indicate that a chemical tracer recovery was less than $50 \%$ or greater than $125 \%$. This information is reflected in the counting error associated with the activity. The following results were associated with a "J" qualifier.

\begin{tabular}{|c|c|c|c|c|c|c|}
\hline \multirow{2}{*}{$\begin{array}{l}\text { Sampling } \\
\text { Location }\end{array}$} & \multirow{2}{*}{$\begin{array}{l}\text { Sampling } \\
\text { Date }\end{array}$} & \multicolumn{5}{|c|}{ Results (pCi/L) } \\
\hline & & Pu 238 & Pu 239 & U 234 & U 235 & U 238 \\
\hline $55-1 C$ & $06 / 07 / 96$ & . & . & 0.608 & 0.0188 & 0.129 \\
\hline $55-2 \mathrm{~B}$ & $06 / 10 / 96$ & . & . & 0.0983 & -0.0326 & 0.337 \\
\hline $55-2 \mathrm{C}$ & $06 / 09 / 96$ & . & . & 0.311 & 0.0692 & 0.222 \\
\hline GW-108 & $11 / 04 / 96$ & . & . & 13.1 & 0.637 & . \\
\hline GW-115 & $10 / 29 / 96$ & -0.245 & 0 & -0.197 & -0.0688 & 0 \\
\hline GW-170 & $06 / 19 / 96$ & . & . & 0.385 & 0.181 & 0.0222 \\
\hline GW-193 & $11 / 04 / 96$ & . & . & 4.5 & 0.319 & 6.93 \\
\hline GW-193 D & $11 / 04 / 96$ & . & . & 4.52 & 0.165 & 6.35 \\
\hline GW-230 & $06 / 18 / 96$ & . & . & 0.367 & 0.0264 & 0.229 \\
\hline GW-230 D & $06 / 18 / 96$ & . & . & 0.174 & -0.0654 & 0.303 \\
\hline GW-605 & $10 / 31 / 96$ & . & . & 74.4 & 3.69 & 73.5 \\
\hline GW-606 & $10 / 31 / 96$ & 0.0954 & 0.118 & 3.76 & 0.173 & 1.78 \\
\hline GW-698 & $06 / 09 / 96$ & . & . & 0.814 & 0.0597 & 0.845 \\
\hline GW-698 D & $06 / 09 / 96$ & . & . & 0.868 & 0.0451 & 0.87 \\
\hline GW-733 & $10 / 30 / 96$ & 0.202 & -0.0389 & . & . & - \\
\hline NHPCEMSP & $09 / 03 / 96$ & 0.175 & 0.0671 & . & . & . \\
\hline RGQWWSP & $06 / 19 / 96$ & . & . & 0.332 & 0.0238 & 0.188 \\
\hline SCR7.18SP & $06 / 20 / 96$ & . & . & 0.52 & 0.0926 & 0.395 \\
\hline SCR7.1SP & $06 / 20 / 96$ & & & 0.0848 & 0.081 & 0.105 \\
\hline \multicolumn{7}{|c|}{$\mathrm{D}=$ duplicate sample $\quad \mathrm{Pu}=$} \\
\hline
\end{tabular}




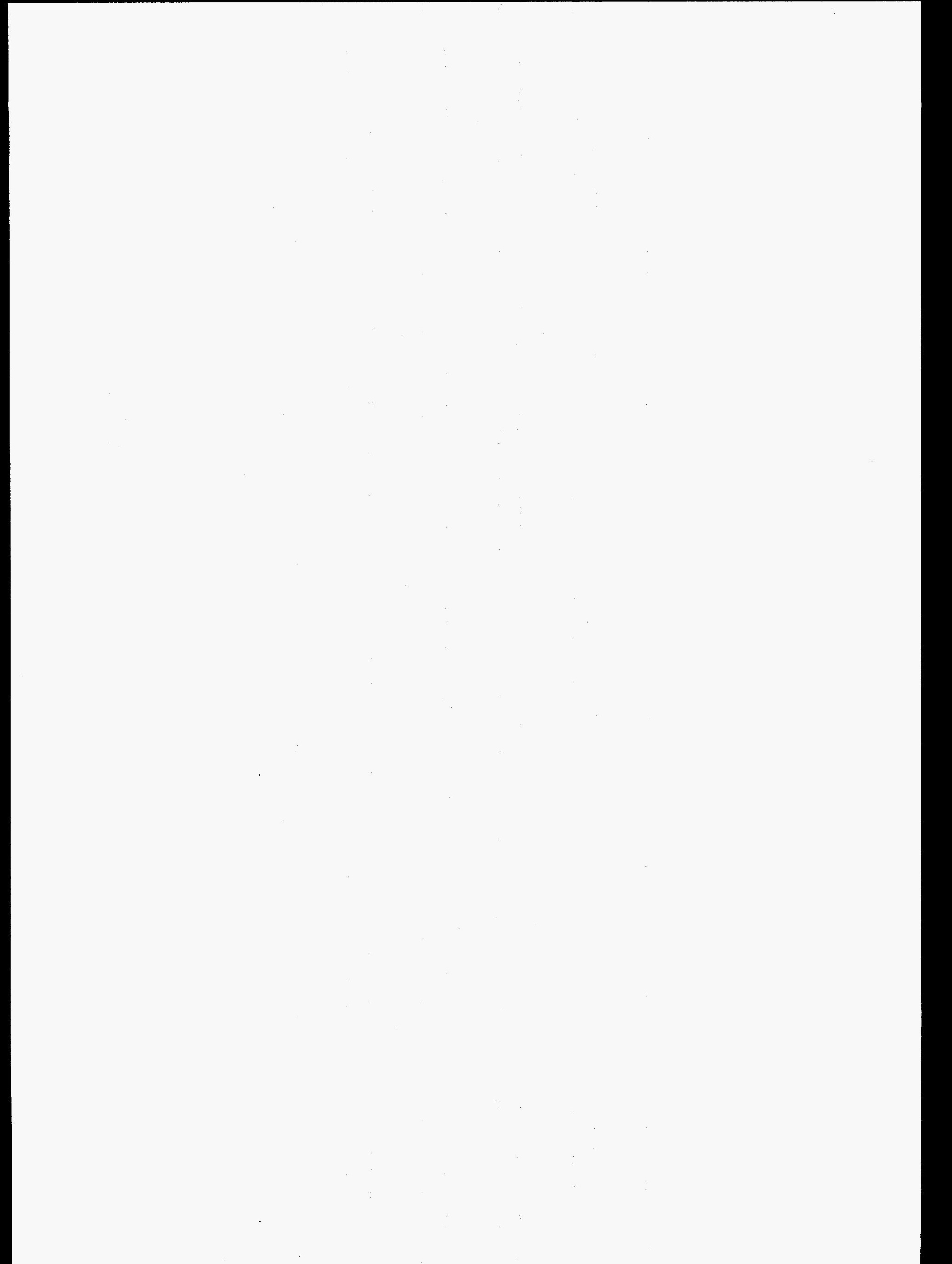


APPENDIX D.1

FIELD MEASUREMENTS AND MISCELLANEOUS PARAMETERS 


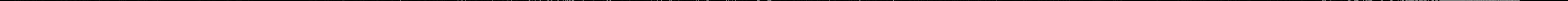


APPENDIX D. 1

Field Measurements and Miscellaneous Parameters, CY 1996

\begin{tabular}{|c|c|c|c|c|c|c|c|c|c|}
\hline Sampling Point & $55-1 A$ & $55-1 c$ & $\begin{array}{l}55-2 B \\
-\end{array}$ & $55-2 C$ & $55-6 A$ & GW-108 & GW-115 & \multicolumn{2}{|c|}{$G W-148$} \\
\hline Program & BMP & BMP & BMP & BMP & BMP & CMP-C & CMP-B & \multicolumn{2}{|l|}{ AMP } \\
\hline Location & GRIDB2 & GRIDB2 & GRIDB3 & GRIDB3 & GRIDC2 & s3 & s3 & \multicolumn{2}{|c|}{ NHP } \\
\hline $\begin{array}{l}\text { Date Sampled } \\
\text { Sample Type }\end{array}$ & $06 / 05 / 96$ & $06 / 07 / 96$ & & & $36 / 05 / 9$ & $11 / 04 /$ & $10 / 2$ & $7 / 96$ & \\
\hline FIELD MEASUREMENTS & & & & & & & & & \\
\hline $\begin{array}{l}\text { Top-of-Casing Elev. (ft) } \\
\text { Depth to Water (ft) } \\
\text { Water-Level Elev. (ft) } \\
\text { Water Temp (degrees C) } \\
\text { pH (pH units) } \\
\text { Sp. Cond. (umho/cm) } \\
\text { Dissolved Oxygen (ppm) } \\
\text { Oxidation/Reduction (mv) }\end{array}$ & $\begin{array}{r}986.67 \\
10.62 \\
976.05 \\
23 \\
7.5 \\
832 \\
7.6 \\
209\end{array}$ & $\begin{array}{r}986.73 \\
11.88 \\
974.85 \\
20.9 \\
6.8 \\
711 \\
7 \\
178\end{array}$ & $\begin{array}{r}977.25 \\
6.95 \\
970.3 \\
18.7 \\
6.3 \\
1156 \\
1.6 \\
201\end{array}$ & $\begin{array}{r}976.85 \\
6.81 \\
970.04 \\
20.6 \\
6.8 \\
1254 \\
5.2 \\
184\end{array}$ & $\begin{array}{r}989.04 \\
8.29 \\
980.75 \\
19.4 \\
6.5 \\
355 \\
6.2 \\
221\end{array}$ & $\begin{array}{r}998.18 \\
8.42 \\
989.76 \\
17.2 \\
5.7 \\
45600 \\
1.5 \\
130\end{array}$ & $\begin{array}{r}1054.4 \\
13.36 \\
1041.04 \\
17.5 \\
7.3 \\
454 \\
0.8 \\
-24\end{array}$ & $\begin{array}{r}907.36 \\
6.93 \\
900.43 \\
10.4 \\
7 \\
791 \\
3.8 \\
201\end{array}$ & $\begin{array}{r}907.36 \\
7.16 \\
900.2 \\
19.9 \\
6.7 \\
701 \\
9 \\
40\end{array}$ \\
\hline MISCELLANEOUS PARAMETERS & & & & & & & $\cdot$ &. & \\
\hline $\begin{array}{l}\text { pH (pH units) } \\
\text { Sp. Cond. (umho/cm) } \\
\text { TDS (mg/L) } \\
\text { TSS (mg/L) } \\
\text { Turbidity (NTU) }\end{array}$ & $\begin{array}{r}8.26 \\
1019 \\
1000 \\
310 \\
441\end{array}$ & $\begin{array}{r}7.14 \\
753 \\
582 \\
17 \\
25.2\end{array}$ & $\begin{array}{r}6.64 \\
1351 \\
1486 \\
2 \\
11.7\end{array}$ & $\begin{array}{r}6.89 \\
1406 \\
1216 \\
1.5 \\
4.25\end{array}$ & $\begin{array}{r}6.83 \\
410 \\
304 \\
11.6 \\
21.7\end{array}$ & $\begin{array}{r}5.73 \\
53700 \\
57316 \\
8 \\
2.08\end{array}$ & $\begin{array}{r}7.38 \\
511 \\
324 \\
<1 \\
5.67\end{array}$ & $\begin{array}{r}6.87 \\
843 \\
374 \\
18 \\
20.6\end{array}$ & $\begin{array}{r}6.95 \\
887 \\
566 \\
17 \\
21.6\end{array}$ \\
\hline
\end{tabular}

(CONT INUED)

\begin{tabular}{|c|c|c|c|c|c|c|c|c|c|}
\hline \multirow{4}{*}{$\begin{array}{l}\text { Sampling Point } \\
\text { Program } \\
\text { Location } \\
\text { Date Sampled } \\
\text { Sample Type } \\
\end{array}$} & \multicolumn{2}{|c|}{ GW-148 } & \multicolumn{4}{|c|}{ GW-149 } & \multicolumn{3}{|c|}{ GW-151 } \\
\hline & AMP & SMP & & AMP & & SMP & & AMP & \\
\hline & NHP & NHP & & NHP & & NHP & & NHP & \\
\hline & $08 / 20 / 961$ & $1 / 14 / 96$ & $/ 14 / 96$ & $6 / 10 / 9$ & 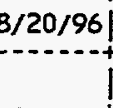 & $1 / 14 / 9$ & $03 / 20$ & DUP & $1 / 17 /$ \\
\hline FIELD MEASUREMENTS & & & & & & & -1 & & \\
\hline $\begin{array}{l}\text { Top-of-Casing Elev, (ft) } \\
\text { Depth to Water (ft) } \\
\text { Water-Level Elev. (ft) } \\
\text { Water Temp (degrees C) } \\
\text { pH (pH units) } \\
\text { Sp. Cond. (umho/cm) } \\
\text { Dissolved Oxygen (ppm) } \\
\text { oxidation/Reduction (mv) }\end{array}$ & $\begin{array}{r}907.36 \\
7.74 \\
899.62 \\
23.5 \\
6 \\
714 \\
1.3 \\
54\end{array}$ & $\begin{array}{r}907.36 \\
7.60 \\
899.76 \\
10 \\
7.5 \\
722 \\
6.2 \\
57\end{array}$ & $\begin{array}{r}907.72 \\
10.17 \\
897.55 \\
16.1 \\
7.8 \\
570 \\
2.9 \\
30\end{array}$ & $\begin{array}{r}907.72 \\
9.93 \\
897.79 \\
18.4 \\
7.6 \\
481 \\
6.4 \\
5\end{array}$ & $\begin{array}{r}907.72 \\
10.15 \\
897.57 \\
19.5 \\
5.1 \\
416 \\
2.5 \\
20\end{array}$ & $\begin{array}{r}907.72 \\
9.65 \\
898.07 \\
13 \\
7.6 \\
486 \\
3.2 \\
-32\end{array}$ & $\begin{array}{r}915.97 \\
14.40 \\
901.57 \\
13.5 \\
7.3 \\
467 \\
3.4 \\
217\end{array}$ & $\begin{array}{r}915.97 \\
14.40 \\
901.57 \\
13.3 \\
7.4 \\
451 \\
2.9 \\
214\end{array}$ & $\begin{array}{r}915.97 \\
13.85 \\
902.12 \\
17.4 \\
6.1 \\
445 \\
1.5 \\
144\end{array}$ \\
\hline MISCELLANEOUS PARAMETERS & & & & &. & & . &. & \\
\hline $\begin{array}{l}\text { pH (pH units) } \\
\text { Sp. Cond. (umho/cm) } \\
\text { TDS (mg/L) } \\
\text { TSS (mg/L) } \\
\text { Turbidity (NTU) }\end{array}$ & $\begin{array}{r}6.86 \\
900 \\
594 \\
17 \\
52.6\end{array}$ & $\begin{array}{r}6.55 \\
897 \\
522 \\
9 \\
16.3\end{array}$ & $\begin{array}{r}7.71 \\
555 \\
304 \\
6.5 \\
32.9\end{array}$ & $\begin{array}{r}7.86 \\
579 \\
470 \\
12.5 \\
93.3\end{array}$ & $\begin{array}{r}7.53 \\
519 \\
320 \\
<1 \\
2.87\end{array}$ & $\begin{array}{r}7.28 \\
563 \\
344 \\
5 \\
9.13\end{array}$ & $\begin{array}{r}7.56 \\
498 \\
268 \\
<1 \\
0.847\end{array}$ & $\begin{array}{r}7.57 \\
494 \\
280 \\
2 \\
0.91\end{array}$ & $\begin{array}{r}7.55 \\
503 \\
294 \\
<1 \\
1.57\end{array}$ \\
\hline
\end{tabular}

(CONTINUED) 
APPEND IX D. 1

Field Measurements and Miscellaneous Parameters, CY 1996

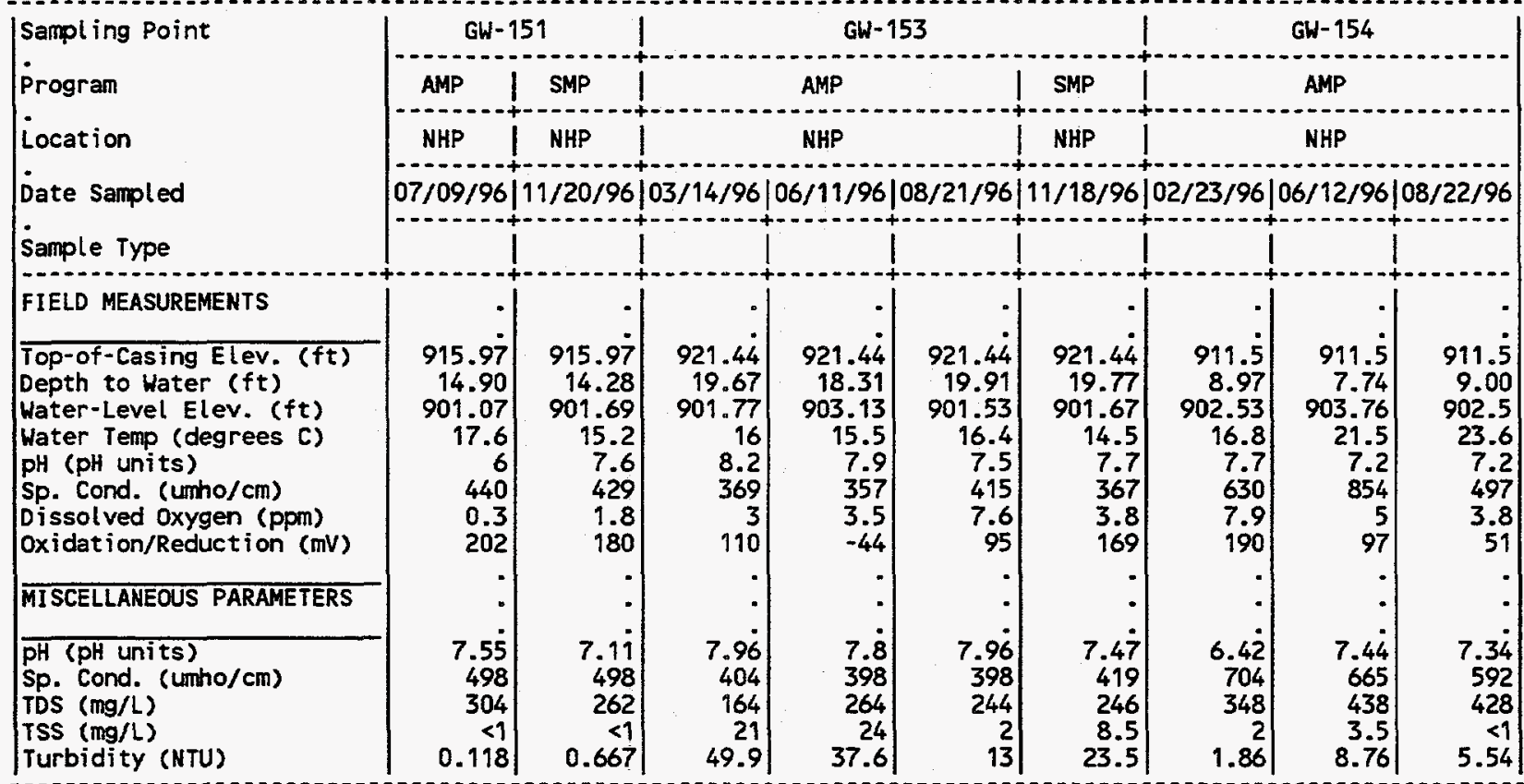

(CONTINUED)

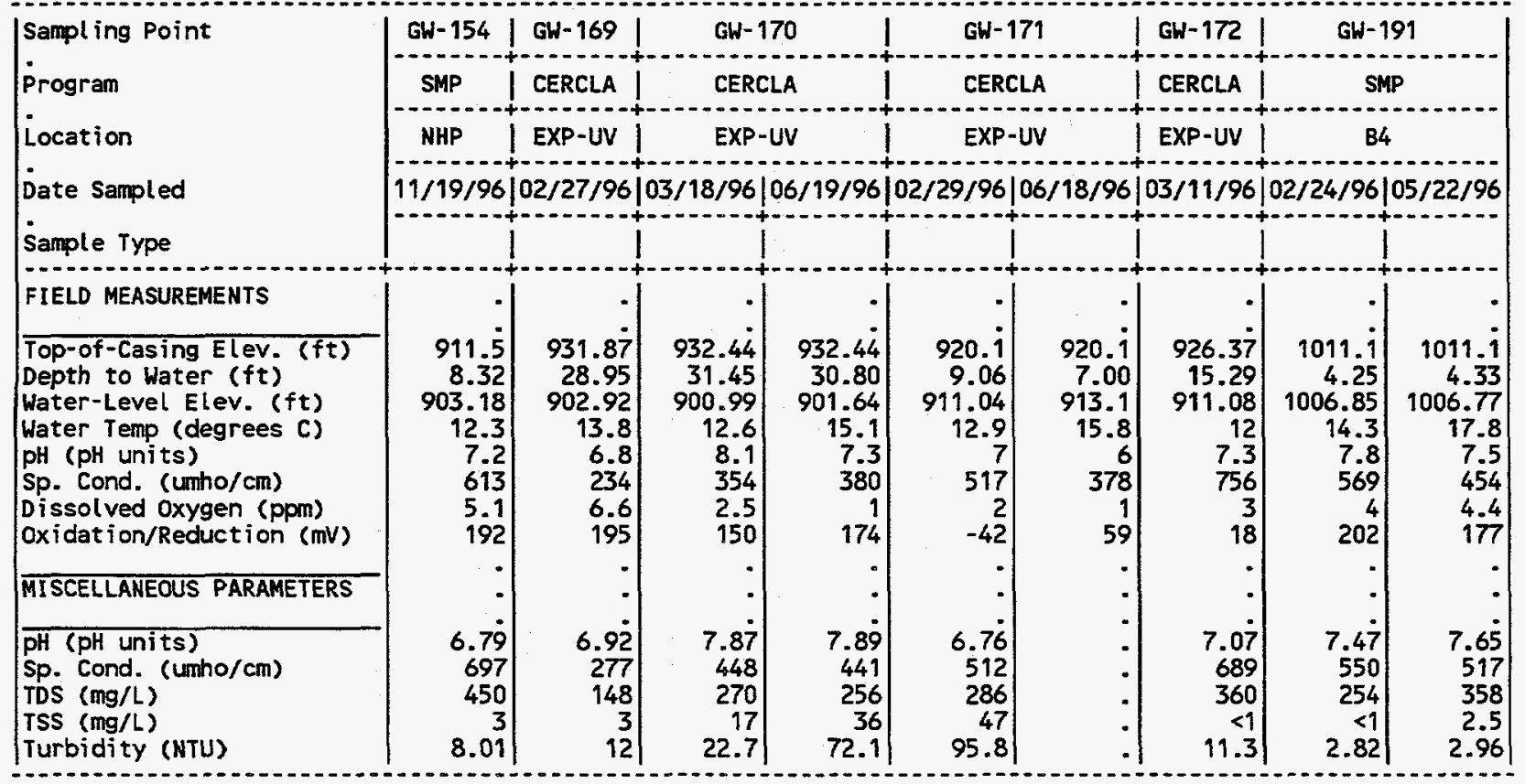

(CONTINUED) 
APPENDIX D.1

Field Measurements and Miscellaneous Parameters, CY 1996

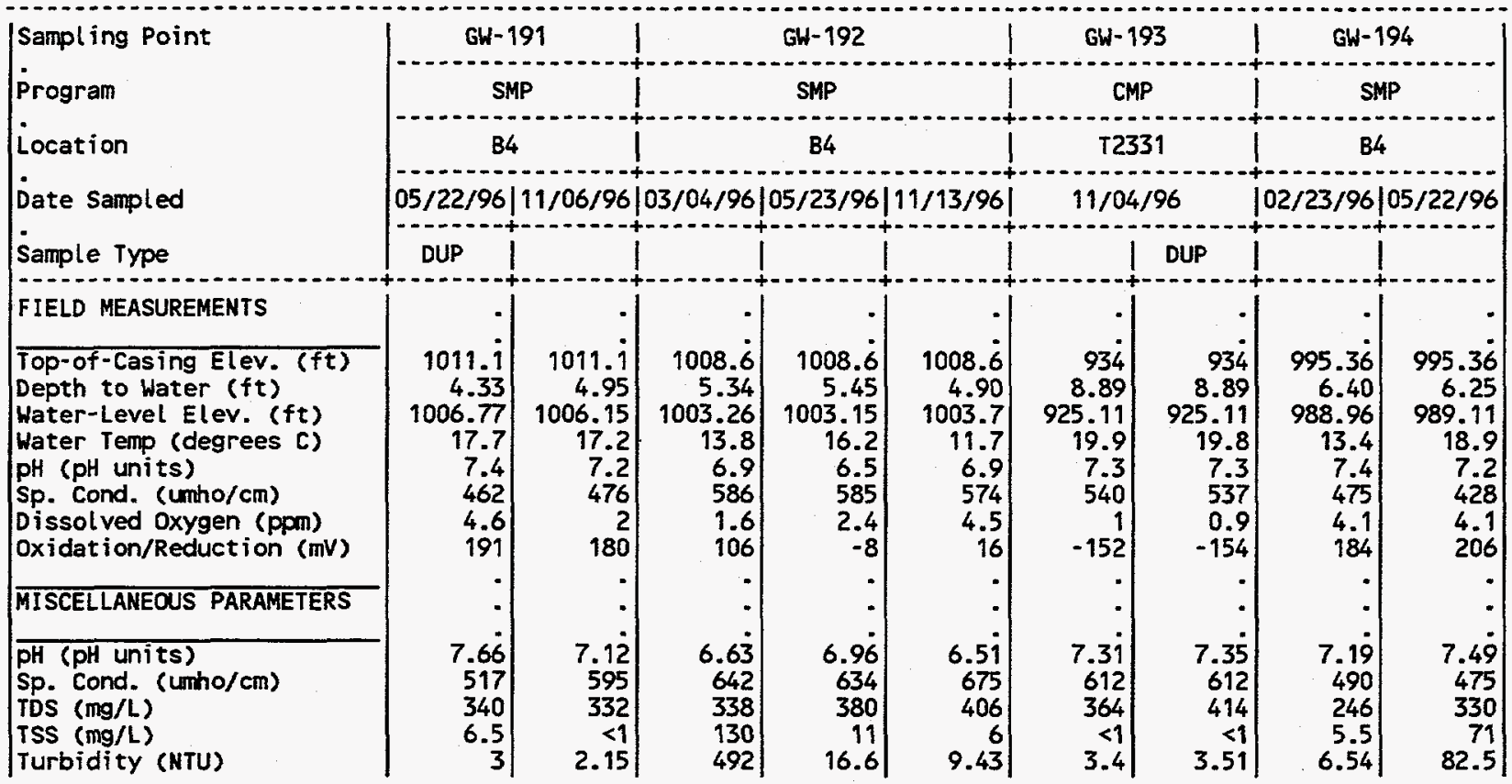

\section{(CONTINUED)}

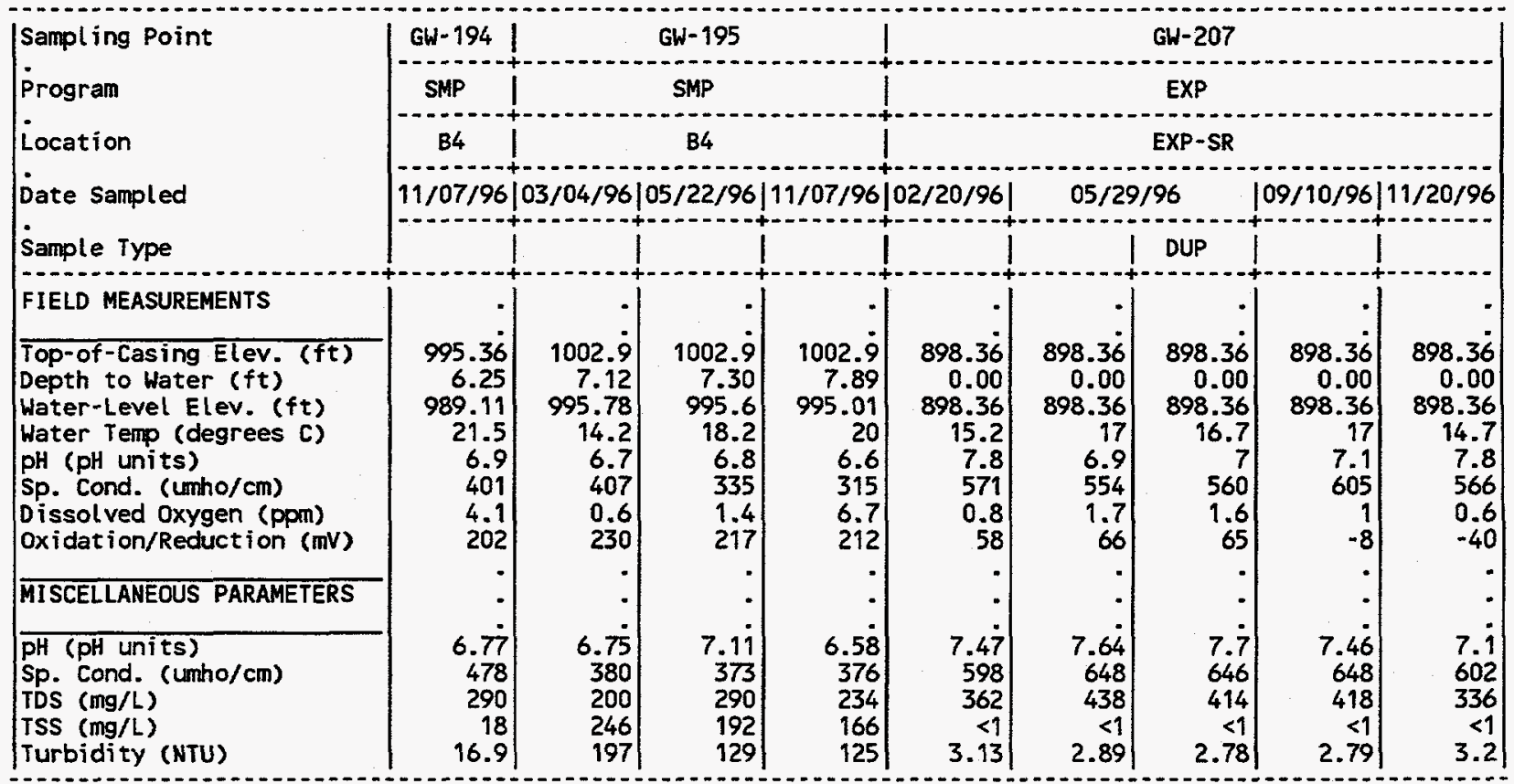

(CONTINUED) 
APPENDIX D.1

Field Measurements and Miscellaneous Parameters, CY 1996

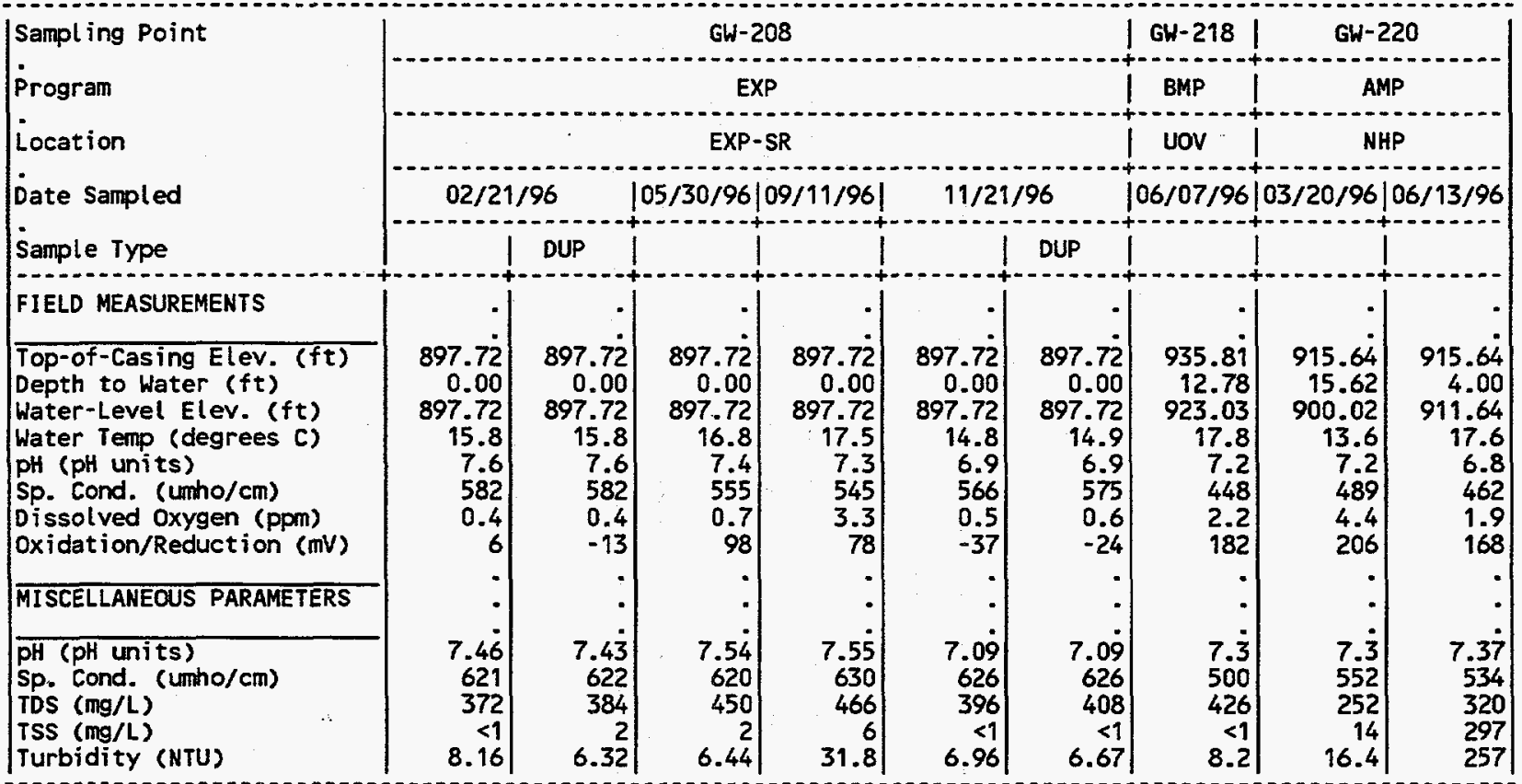

(CONTI INUED)

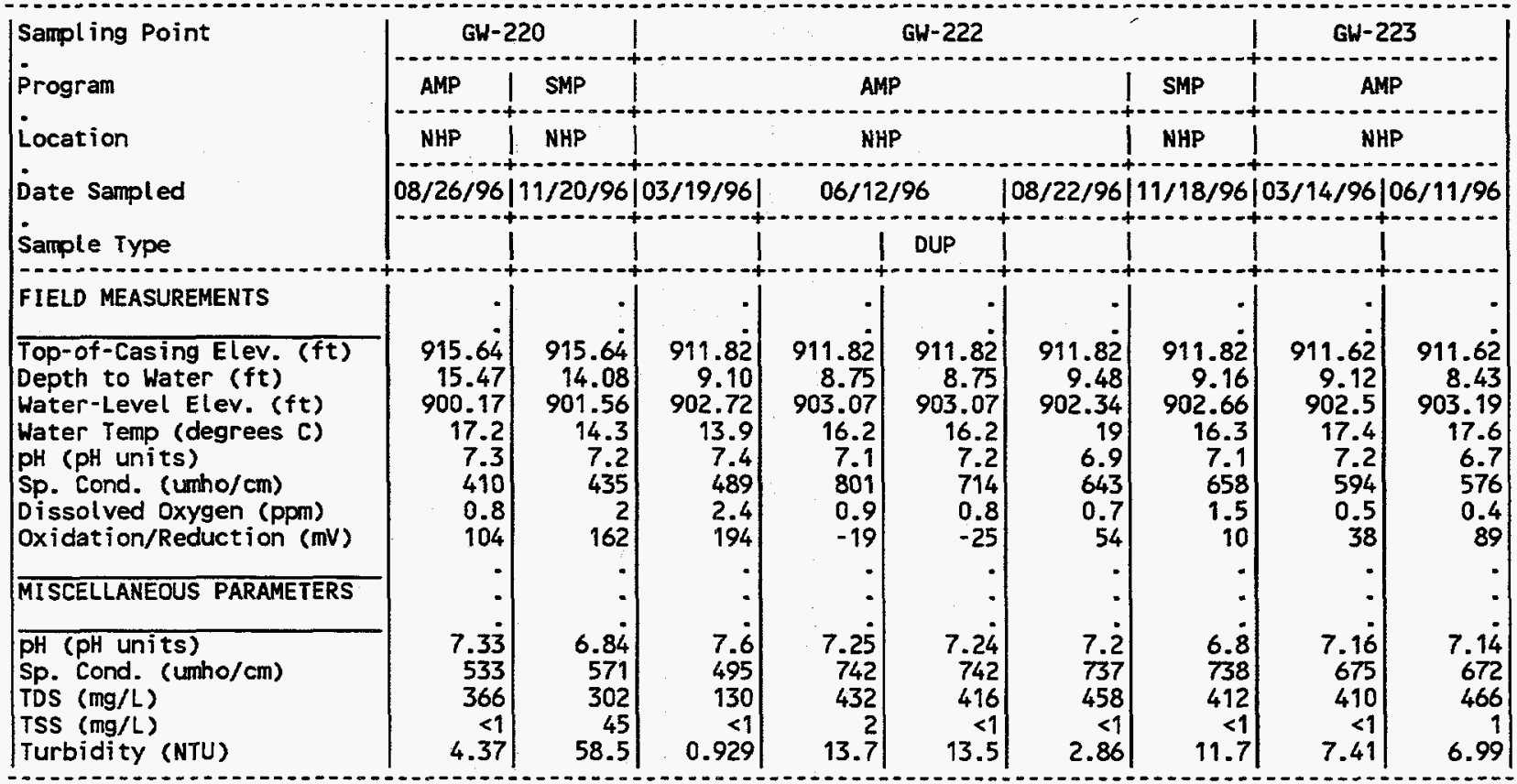

(CONTINUED) 
APPENDIX 0.1

Field Measurements and Miscellaneous Parameters, CY 1996

\begin{tabular}{|c|c|c|c|c|c|c|c|c|c|}
\hline \multirow{4}{*}{$\begin{array}{l}\text { Sampl ing Point } \\
\text { Program } \\
\text { Location } \\
\text { Date Sampled } \\
\text { Sample Type }\end{array}$} & \multicolumn{3}{|c|}{$G W-223$} & \multicolumn{4}{|c|}{ GW-230 } & GW-232 & GW-240 \\
\hline & AMP & SMF & & & CERC & & & CERCLA & AMP \\
\hline & NHP & NHF & & & EXP & & & $Y D-11 Y$ & NHP \\
\hline & $38 / 21 / 96$ & $11 / 18 /$ & & $03 / 11$ & DUP & $06 / 18$ & DUP & $03 / 12 / 9$ & $3 / 19 / 9$ \\
\hline FIELD MEASUREMENTS & & & & & & $\cdot$ & & & \\
\hline $\begin{array}{l}\text { Top-of-Casing Elev, (ft) } \\
\text { Depth to Water (ft) } \\
\text { Water-Level Elev. (ft) } \\
\text { Water Temp (degrees C) } \\
\text { pH (pH units) } \\
\text { Sp. Cond. (umho/cm) } \\
\text { Dissolved Oxygen (ppm) } \\
\text { Oxidation/Reduction (mv) }\end{array}$ & $\begin{array}{r}911.62 \\
9.32 \\
902.3 \\
20.4 \\
5 \\
659 \\
0.5 \\
52\end{array}$ & $\begin{array}{r}911.62 \\
9.22 \\
902.4 \\
15.4 \\
7 \\
614 \\
1.7 \\
108\end{array}$ & $\begin{array}{r}911.62 \\
9.22 \\
902.4 \\
15.5 \\
7 \\
610 \\
1.5 \\
105\end{array}$ & $\begin{array}{r}922.86 \\
13.60 \\
909.26 \\
12.6 \\
7.1 \\
1096 \\
2.8 \\
122\end{array}$ & $\begin{array}{r}922.86 \\
13.60 \\
909.26 \\
12 \\
7.2 \\
1071 \\
2.8 \\
115\end{array}$ & $\begin{array}{r}922.86 \\
13.23 \\
909.63 \\
16.5 \\
6.8 \\
901 \\
2.4 \\
68\end{array}$ & $\begin{array}{r}922.86 \\
13.23 \\
909.63 \\
16.1 \\
6.8 \\
901 \\
2.4 \\
65\end{array}$ & $\begin{array}{r}931.22 \\
29.43 \\
901.79 \\
12.1 \\
9.3 \\
870 \\
3.9 \\
184\end{array}$ & $\begin{array}{r}922.9 \\
20.65 \\
902.25 \\
12.4 \\
7.6 \\
500 \\
7.5 \\
189\end{array}$ \\
\hline MISCELLANEOUS PARAMETERS & & & & & &. & & & \\
\hline $\begin{array}{l}\text { pH (pH units) } \\
\text { Sp. Cond. (umho/cm) } \\
\text { TDS (mg/L) } \\
\text { TSS (mg/L) } \\
\text { Turbidity (NTU) }\end{array}$ & $\begin{array}{r}7.15 \\
683 \\
460 \\
17.5 \\
10.3\end{array}$ & $\begin{array}{r}6.72 \\
685 \\
422 \\
<1 \\
1.52\end{array}$ & $\begin{array}{r}6.76 \\
685 \\
422 \\
<1 \\
1.78\end{array}$ & $\begin{array}{r}7.12 \\
991 \\
478 \\
2.5 \\
28\end{array}$ & $\begin{array}{r}7.05 \\
992 \\
470 \\
1 \\
28.2\end{array}$ & $\begin{array}{r}7.19 \\
1000 \\
546 \\
11 \\
72.2\end{array}$ & $\begin{array}{r}7.19 \\
1002 \\
570 \\
52 \\
70.1\end{array}$ & $\begin{array}{r}9.27 \\
918 \\
520 \\
<1 \\
2.39\end{array}$ & $\begin{array}{r}7.5 i \\
512 \\
280 \\
<1 \\
1.77\end{array}$ \\
\hline
\end{tabular}

(CONTINUED)

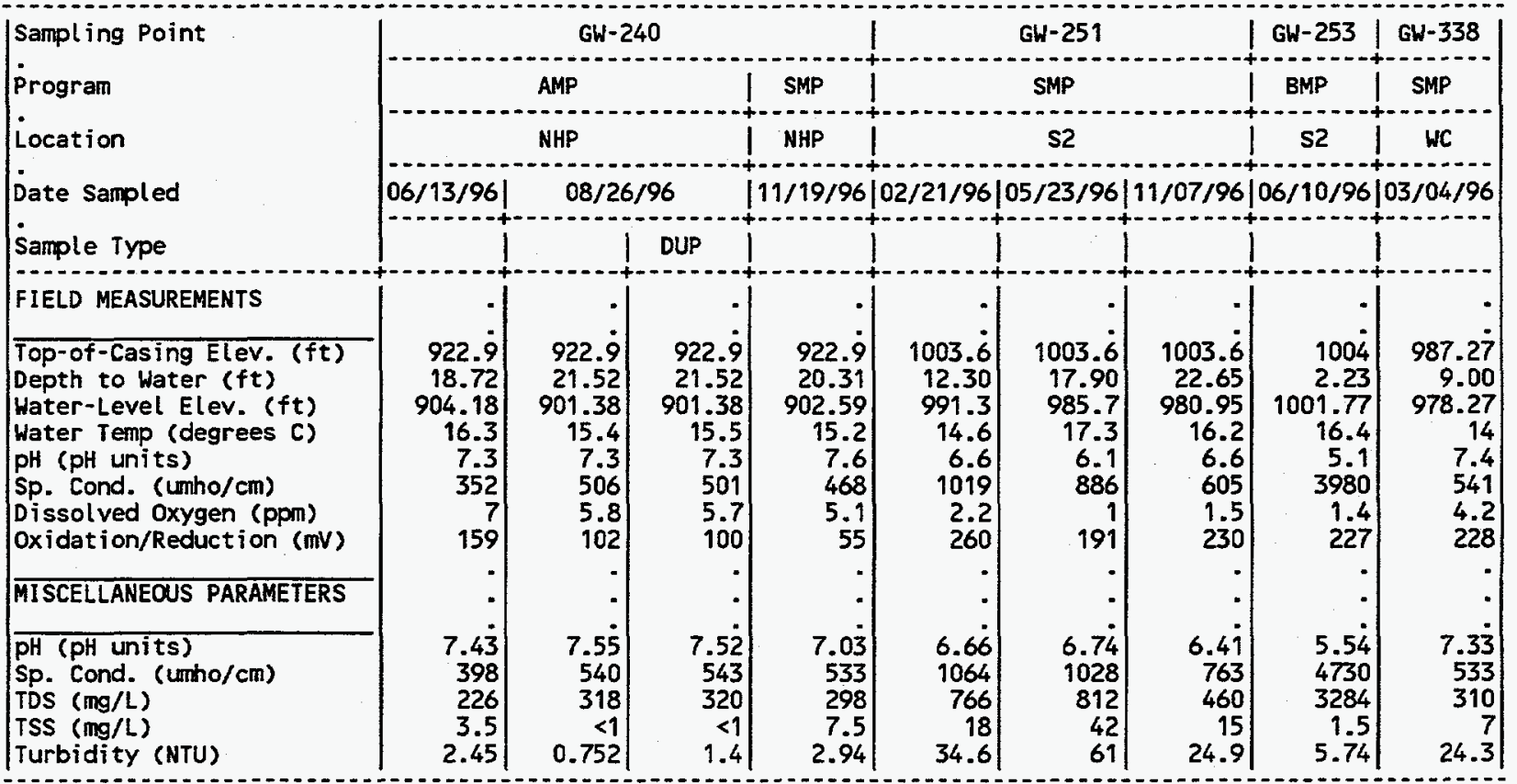

(CONTINUED) 
APPENDIX D.

Field Measurements and Miscel Laneous Parameters, CY 1996

\begin{tabular}{|c|c|c|c|c|c|c|c|c|c|}
\hline \multirow{4}{*}{$\begin{array}{l}\text { Sampling Point } \\
\text { Program } \\
\text { Location } \\
\text { Date Sampled } \\
\text { Sample Type } \\
\end{array}$} & \multirow{2}{*}{\multicolumn{2}{|c|}{$\begin{array}{c}\text { GW-338 } \\
\text { SMP }\end{array}$}} & \multicolumn{4}{|c|}{ GW-380 } & \multicolumn{3}{|c|}{ GW-383 } \\
\hline & & & & AMP & & SMP & & AMP & \\
\hline & WC & & & NHP & & NHP & & NHP & \\
\hline & $|5 / 22 / 96|$ & $1 / 11 / 96$ & 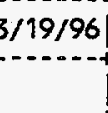 & $16 / 12 / 9$ & 27 & $1 / 19$ & & $6 / 17$ & \\
\hline FIELD MEASUREMENTS & & & & & & & & & \\
\hline $\begin{array}{l}\text { Top-of-Casing Elev. (ft) } \\
\text { Depth to Water (ft) } \\
\text { Water-Level Elev. (ft) } \\
\text { Water Temp (degrees C) } \\
\text { pH (ph units) } \\
\text { Sp. Cond. (umho/cm) } \\
\text { Dissolved Oxygen (ppm) } \\
\text { Oxidation/Reduction (mv) }\end{array}$ & $\begin{array}{r}987.27 \\
8.70 \\
978.57 \\
17.3 \\
7.5 \\
467 \\
5 \\
212\end{array}$ & $\begin{array}{r}987.27 \\
8.32 \\
978.95 \\
12.2 \\
7.3 \\
499 \\
5.4 \\
219\end{array}$ & $\begin{array}{r}913.55 \\
9.55 \\
904 \\
10.1 \\
6.9 \\
694 \\
6.6 \\
189\end{array}$ & $\begin{array}{r}913.55 \\
8.91 \\
904.64 \\
17 \\
6.9 \\
530 \\
4.9 \\
115\end{array}$ & $\begin{array}{r}913.55 \\
10.10 \\
903.45 \\
24.3 \\
6.4 \\
870 \\
3.2 \\
155\end{array}$ & $\begin{array}{r}913.55 \\
10.15 \\
903.4 \\
15.8 \\
6.5 \\
576 \\
4 \\
129\end{array}$ & $\begin{array}{r}908.5 \\
8.87 \\
899.63 \\
13.9 \\
7.4 \\
536 \\
2.7 \\
116\end{array}$ & $\begin{array}{r}908.5 \\
8.97 \\
899.53 \\
17.6 \\
5.8 \\
511 \\
1.1 \\
10\end{array}$ & $\begin{array}{r}908.5 \\
9.38 \\
899.12 \\
19.2 \\
7.1 \\
440 \\
0.5 \\
35\end{array}$ \\
\hline MISCELLANEOUS PARAMETERS & & & & & & & 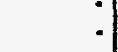 & & \\
\hline $\begin{array}{l}\text { pH (pH units) } \\
\text { Sp. Cond. (umho/cm) } \\
\text { TDS (mg/L) } \\
\text { TSS (mg/L) } \\
\text { Turbidity (NTU) }\end{array}$ & $\begin{array}{r}7.64 \\
527 \\
358 \\
20 \\
21.8\end{array}$ & $\begin{array}{r}6.83 \\
538 \\
310 \\
7.5 \\
24.9\end{array}$ & $\begin{array}{r}7.11 \\
729 \\
388 \\
4.5 \\
34.7\end{array}$ & $\begin{array}{r}7.09 \\
1009 \\
538 \\
89 \\
152\end{array}$ & $\begin{array}{r}7.01 \\
1013 \\
562 \\
26 \\
62.7\end{array}$ & $\begin{array}{r}6.21 \\
615 \\
354 \\
10 \\
89.4\end{array}$ & $\begin{array}{r}7.39 \\
559 \\
212 \\
<1 \\
13.6\end{array}$ & $\begin{array}{r}7.37 \\
556 \\
314 \\
<1 \\
14.2\end{array}$ & $\begin{array}{r}7.48 \\
550 \\
358 \\
<1 \\
8.89\end{array}$ \\
\hline
\end{tabular}

(CONT I NUED)

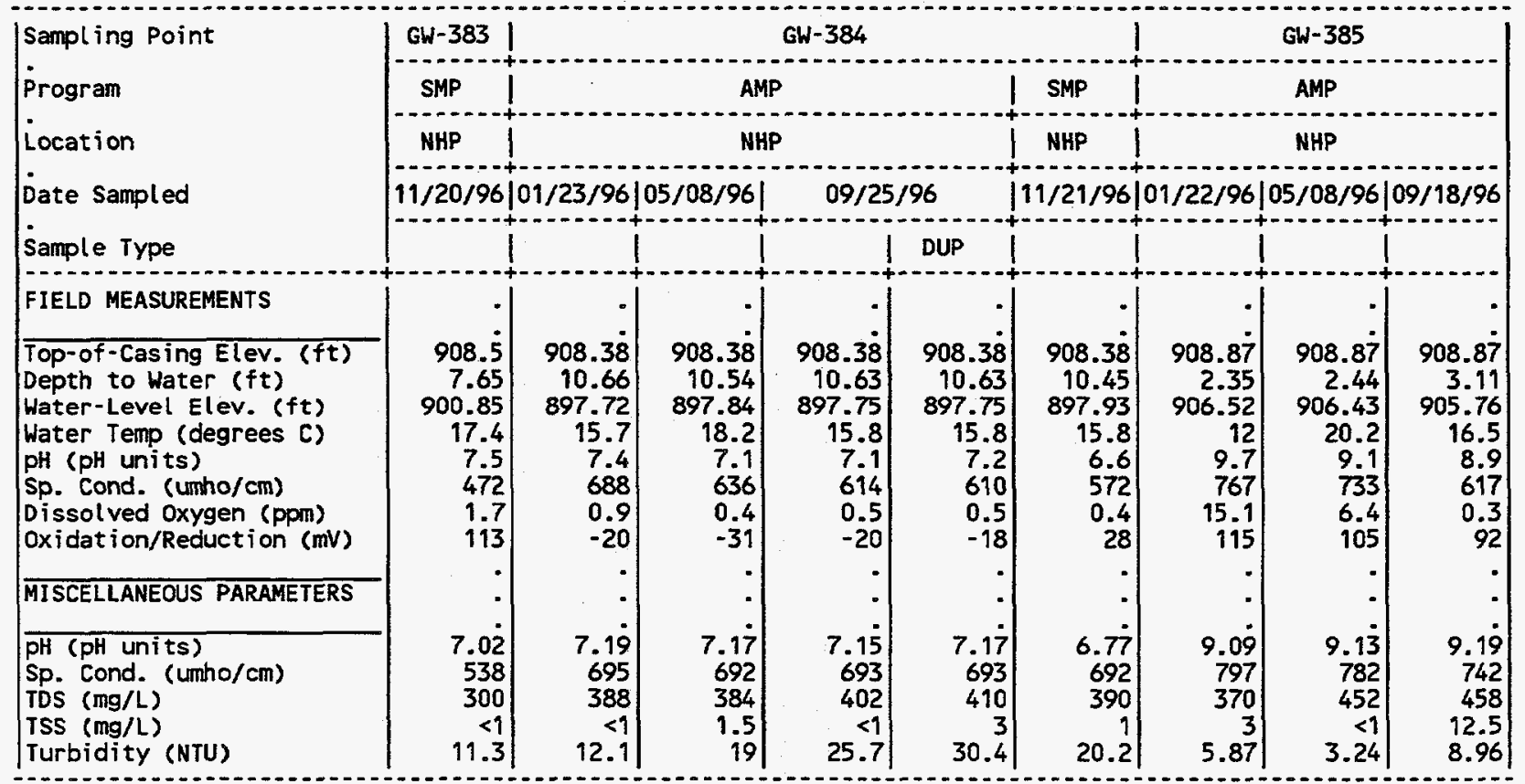

(CONTINUED) 
APPENDIX 0.1

Field Measurements and Miscel laneous Parameters, CY 1996

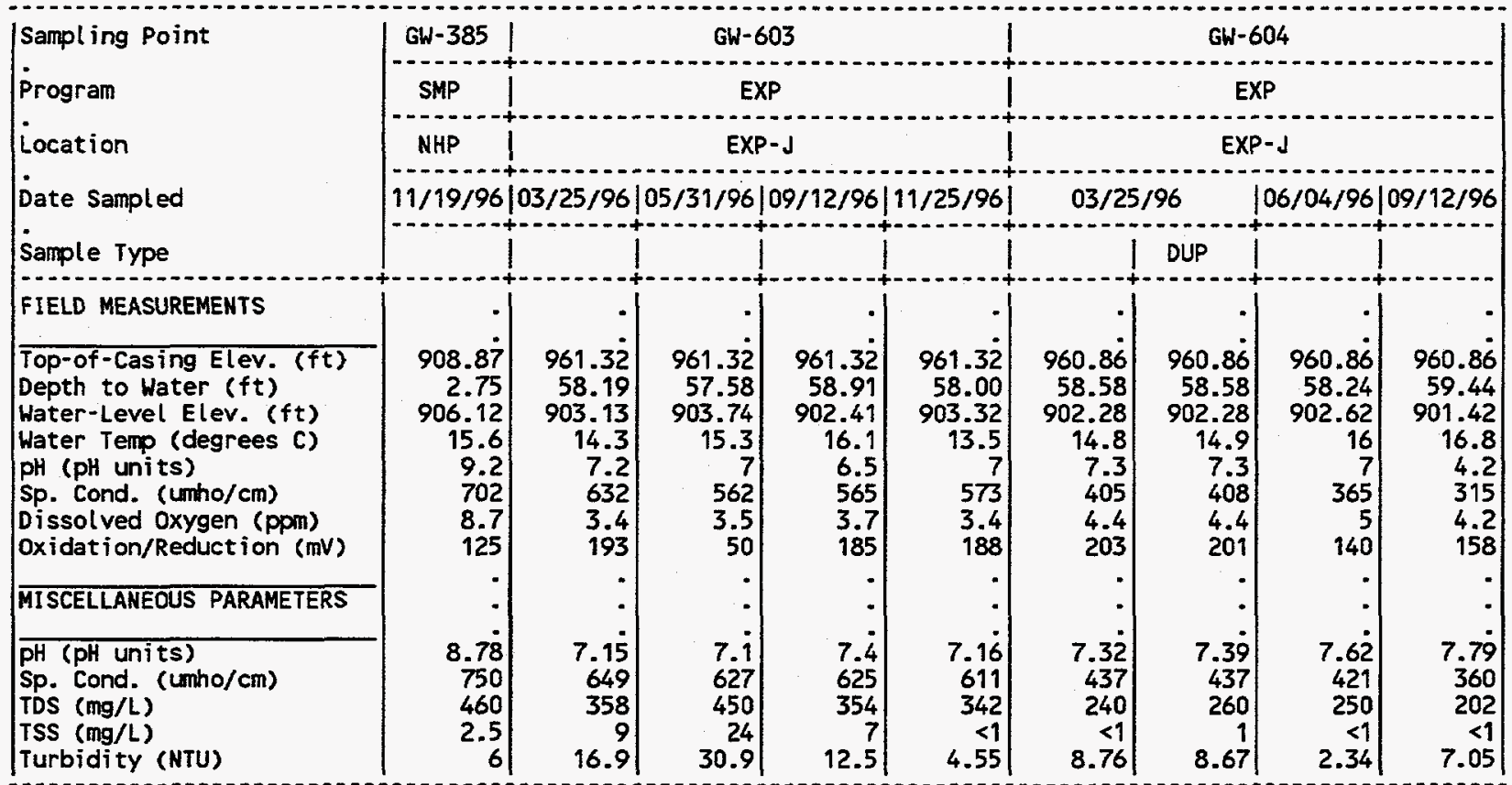

\section{(CONTINUED)}

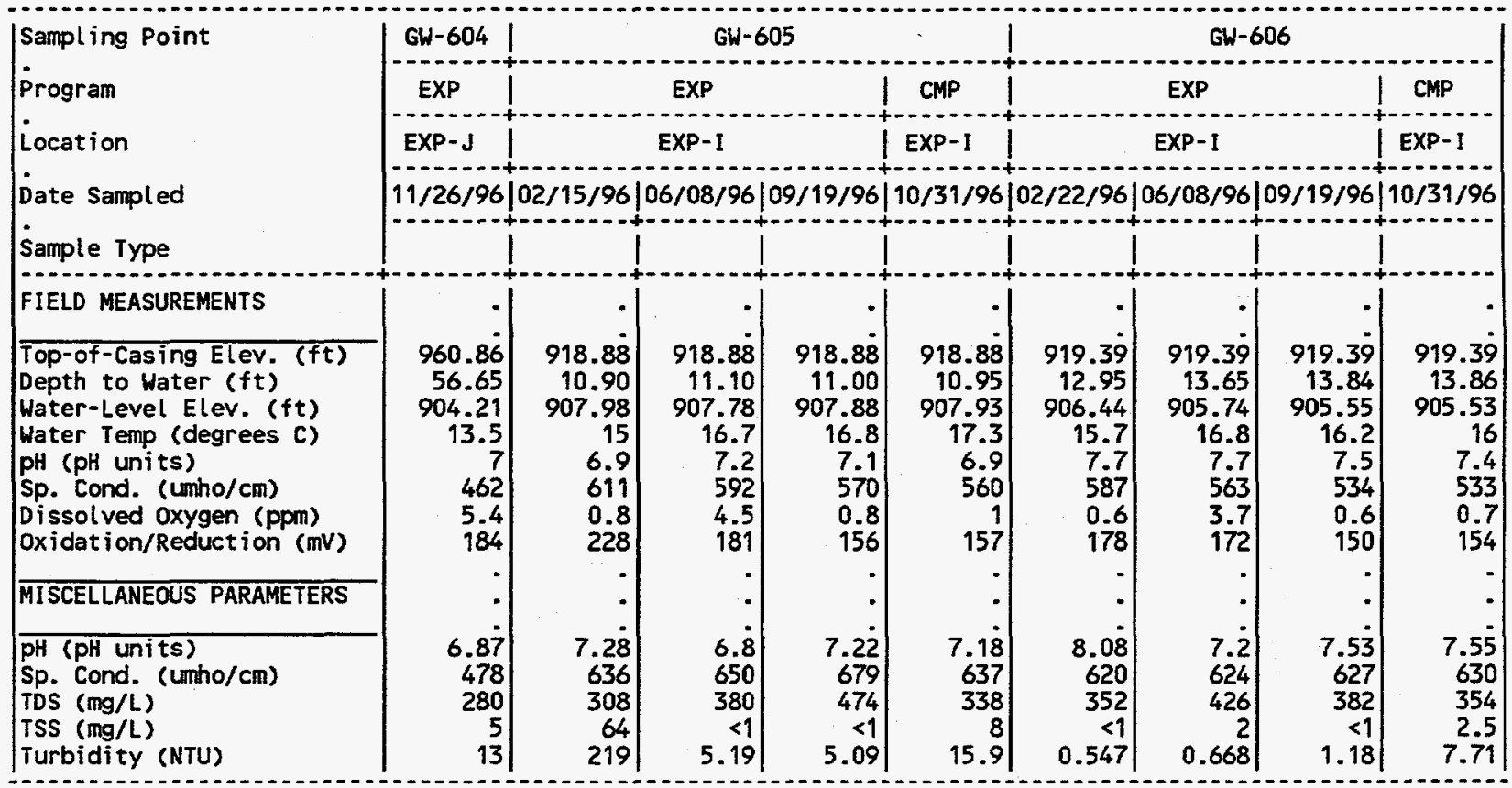

(CONTINUED) 
APPENDIX D. 1

Field Measurements and Miscellaneous Parameters, CY 1996

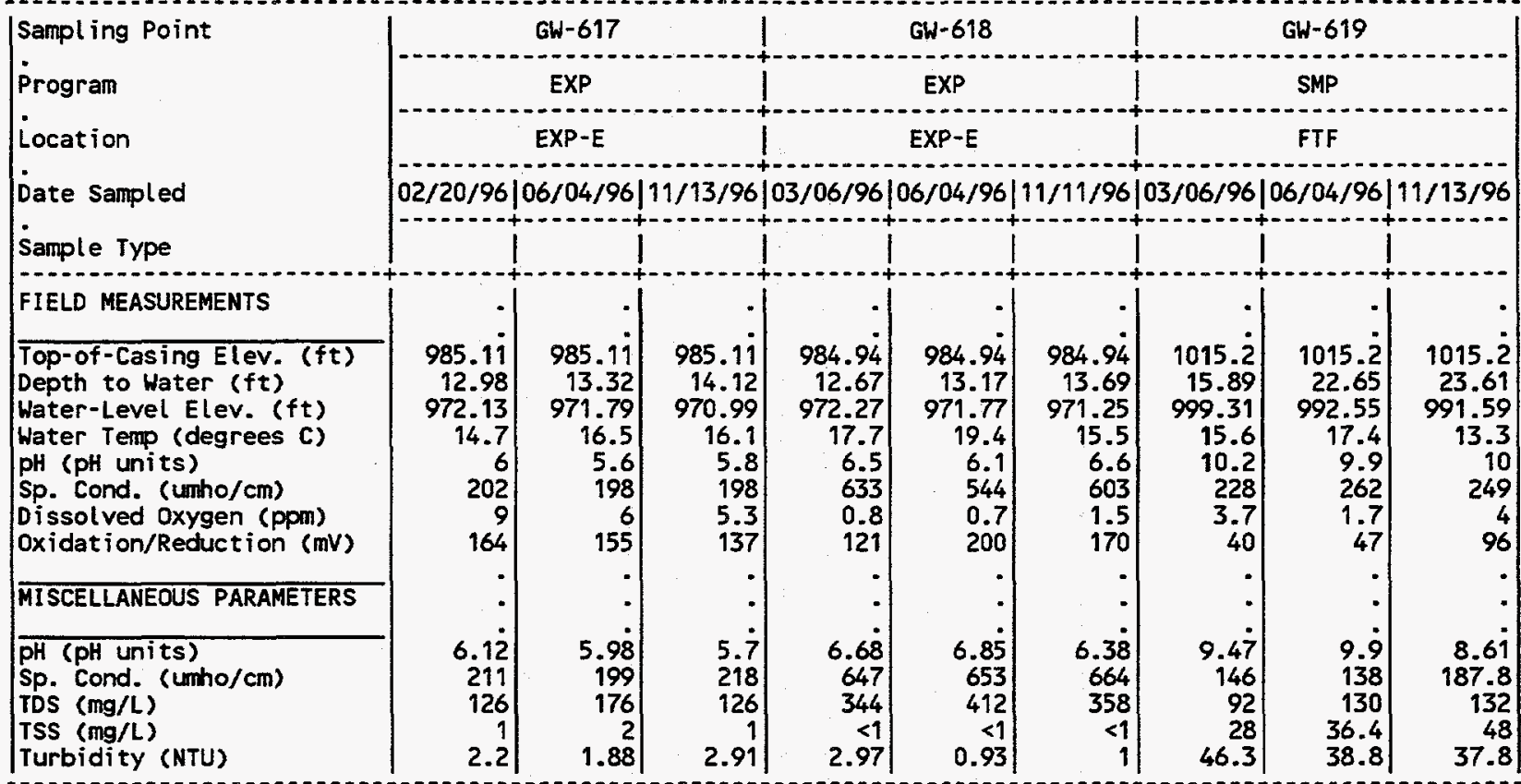

(CONTINUED)

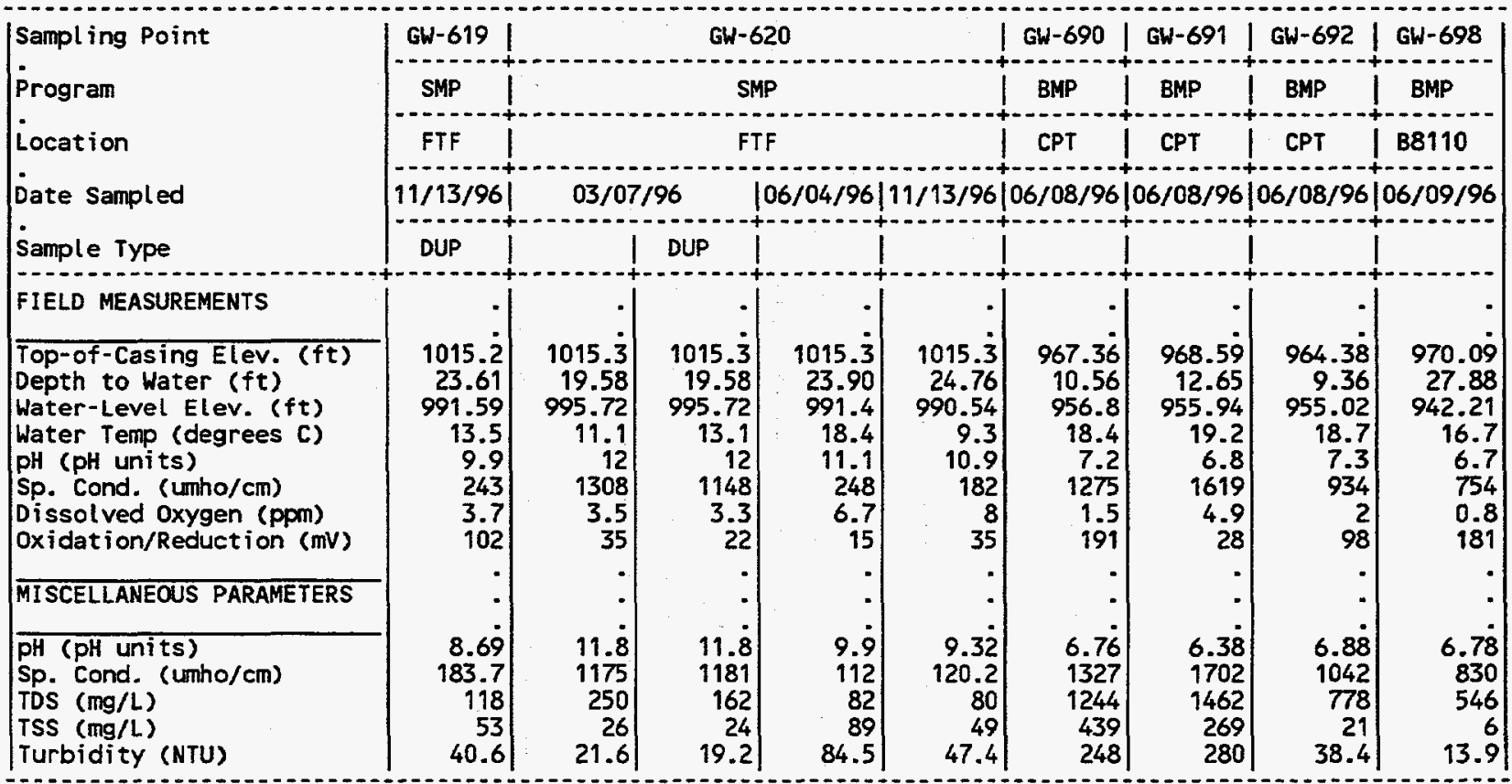

(CONT INUED) 
Field Measurements and Miscel laneous Parameters, CY 1996

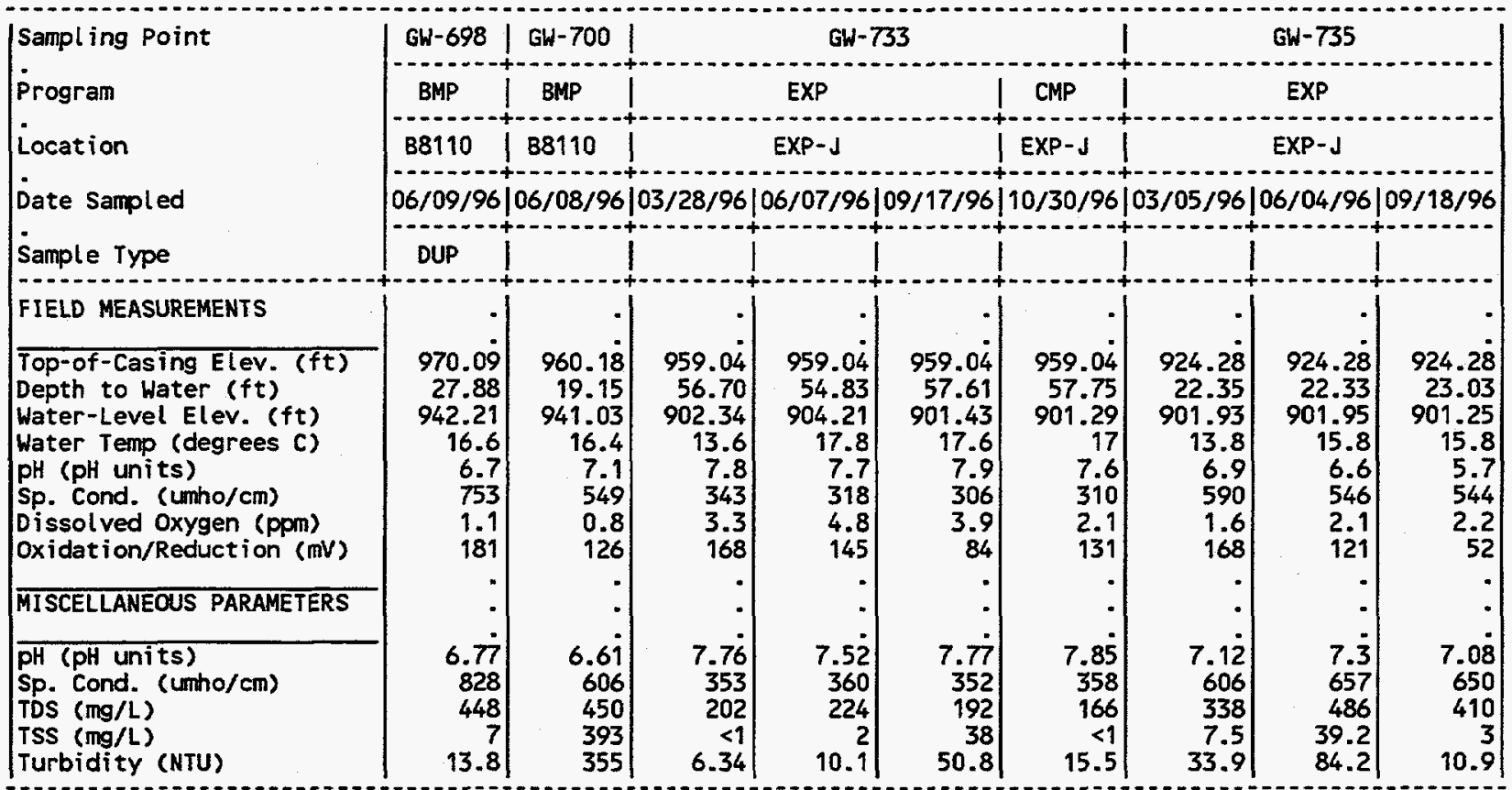

(CONTINUED)

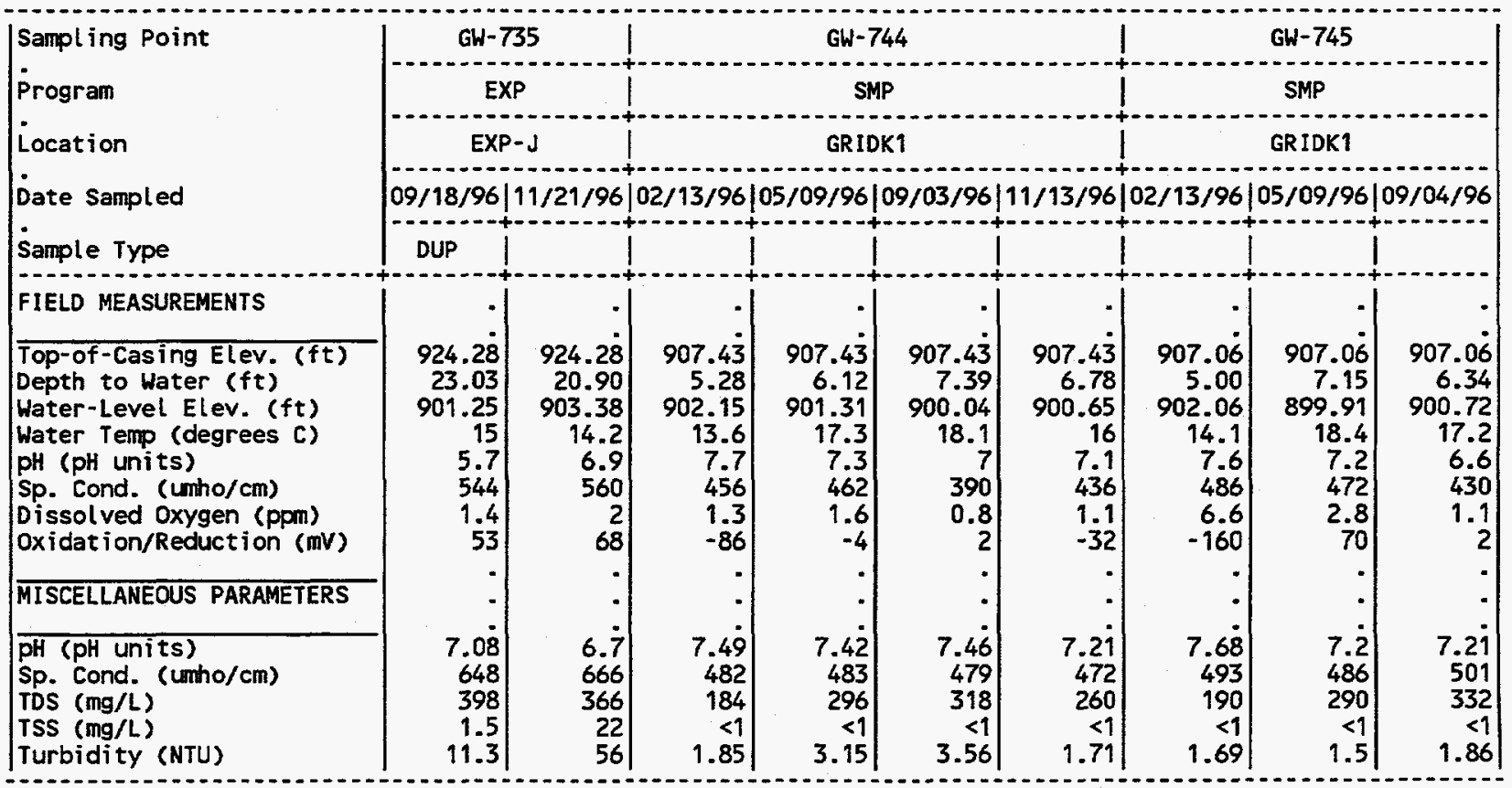

(CONTINUED) 
APPENDIX D. 1

Field Measurements and Miscellaneous Parameters, CY 1996

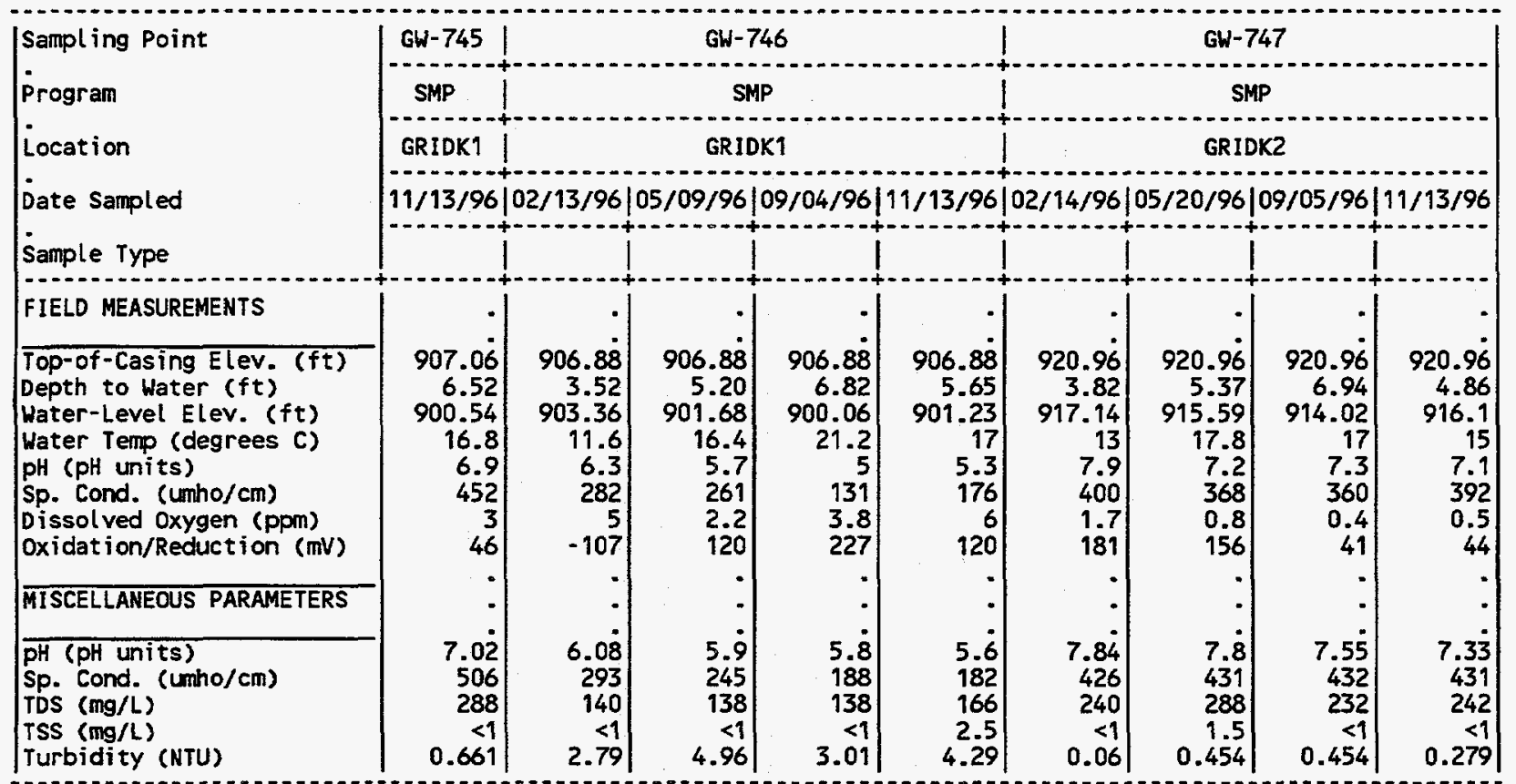

(CONT INUED)

\begin{tabular}{|c|c|c|c|c|c|c|c|c|c|}
\hline $\begin{array}{l}\text { Sampl ing Point } \\
\text { Program } \\
\text { Location } \\
\text { Date Sampled } \\
\text { Sample Type }\end{array}$ & \multirow{5}{*}{\multicolumn{2}{|c|}{\begin{tabular}{r|r|} 
& \\
921.17 & \\
5.25 & 921.17 \\
915.92 & 6.78 \\
12.5 & 914.39 \\
7.6 & 16.5 \\
526 & 7.1 \\
4.5 & 505 \\
204 & 1.8 \\
. & 151 \\
& -14 \\
7.55 & 7.52 \\
559 & 573 \\
332 & 378 \\
2.12 & 7.5 \\
1 & 10
\end{tabular}}} & \multirow{5}{*}{\multicolumn{2}{|c|}{$\begin{array}{r}\text { GW } 748 \\
\text { SMP } \\
9 R I D K 2 \\
921.17 \\
7.64 \\
913.53 \\
17.6 \\
7.1 \\
457 \\
2 \\
162 \\
. \\
. \\
7.37 \\
565 \\
386 \\
2 \\
6.37\end{array}$}} & \multirow{5}{*}{$\begin{array}{r}96 \\
914.94 \\
16.23 \\
6.8 \\
479 \\
4.7 \\
160 \\
. \\
.17 \\
6.88 \\
597 \\
364 \\
7.5 \\
16.7\end{array}$} & \multirow{5}{*}{\multicolumn{2}{|c|}{$\begin{array}{r} \\
916.19 \\
4.51 \\
9.9 \\
8.6 \\
471 \\
2.6 \\
199 \\
. \\
. \\
7.15 \\
474 \\
288 \\
<1 \\
3\end{array}$}} & \multirow{5}{*}{$\begin{array}{r}9 \\
921.19 \\
7.85 \\
913.34 \\
19.8 \\
6.6 \\
478 \\
1.5 \\
-101 \\
. \\
= \\
6.94 \\
648 \\
434 \\
41 \\
4.25\end{array}$} & \multirow{5}{*}{$\begin{array}{r} \\
\\
14 / 96 \\
921.19 \\
5.68 \\
915.51 \\
16 \\
6.3 \\
495 \\
1.9 \\
130 \\
. \\
. \\
6.62 \\
569 \\
334 \\
1.36 \\
\end{array}$} \\
\hline FIELD MEASUREMENTS & & & & & & & & & \\
\hline $\begin{array}{l}\text { Top-of-Casing Elev. (ft) } \\
\text { Depth to Water (ft) } \\
\text { Water-Level Elev. (ft) } \\
\text { Water Temp (degrees c) } \\
\text { pH (pH units) } \\
\text { Sp. Cond. (Lmho/cm) } \\
\text { Dissolved Oxygen (ppm) } \\
\text { Oxidation/Reduction (mV) }\end{array}$ & & & & & & & & & \\
\hline MISCELLANEOUS PARAMETERS & & & & & & & & & \\
\hline $\begin{array}{l}\text { pH (pH units) } \\
\text { Sp. Cond. (umho/cm) } \\
\text { TDS (mg/L) } \\
\text { TSS (mg/L) } \\
\text { Turbidity (NTU) }\end{array}$ & & & & & & & & & \\
\hline
\end{tabular}

(CONTINUED) 


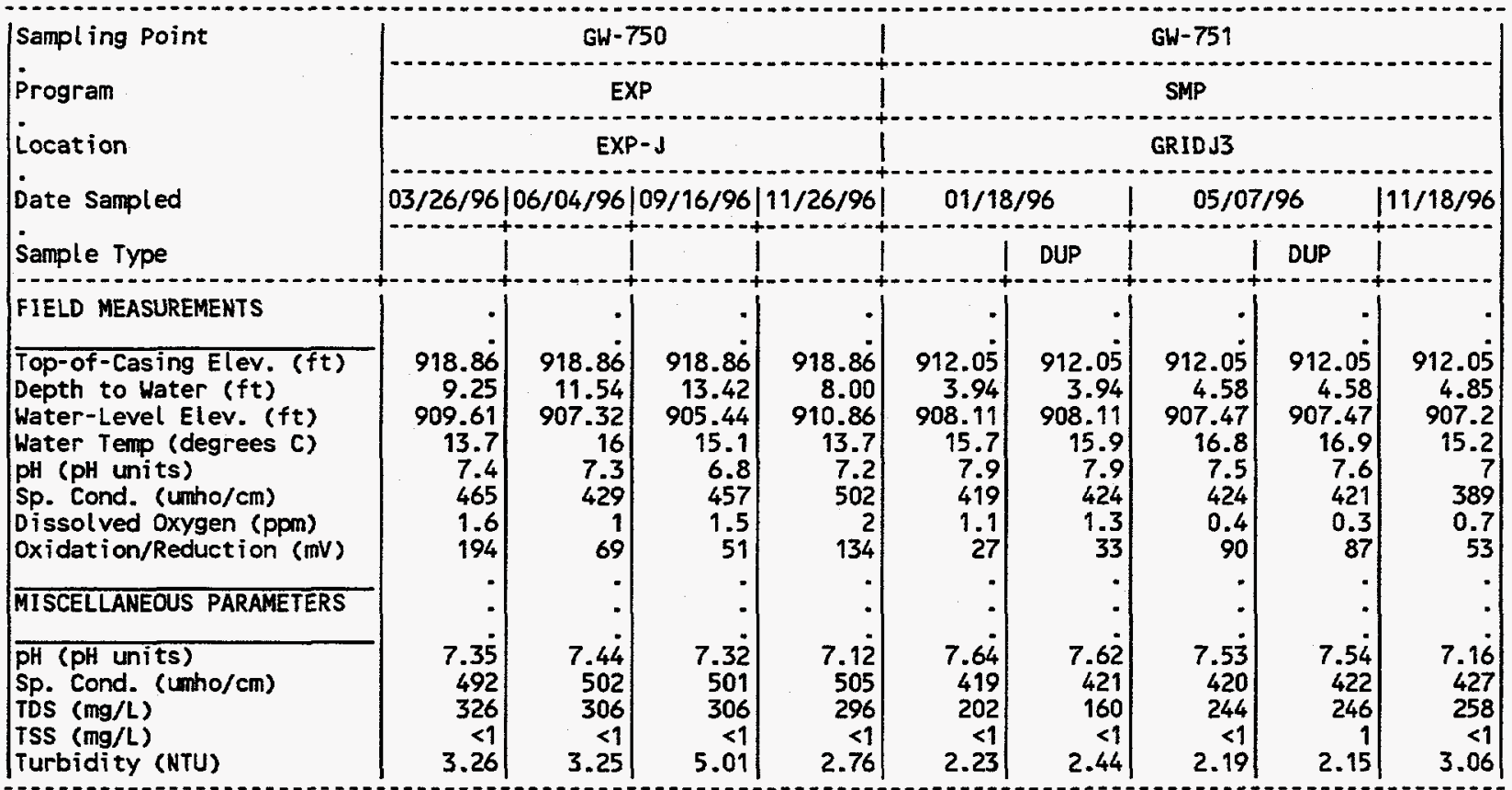

(CONT INUED)

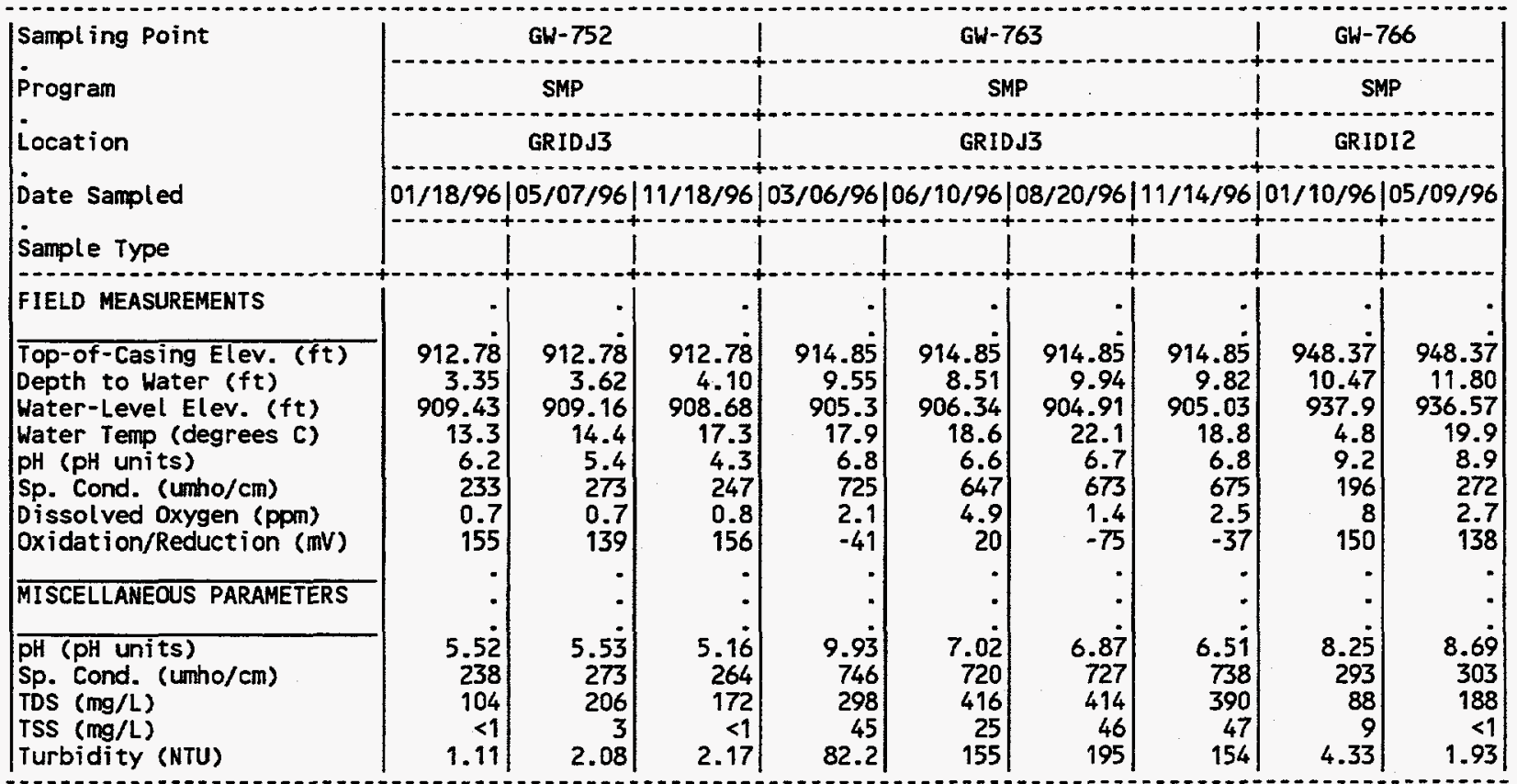

(CONTINUED) 
APPENDIX D.1

Field Measurements and Miscel laneous Parameters, CY 1996

\begin{tabular}{|c|c|c|c|c|c|c|c|c|c|}
\hline \multirow{5}{*}{$\mid \begin{array}{l}\text { Sampling Point } \\
\text { Program } \\
\text { Location } \\
\text { Date Sampled } \\
\text { Sample Type }\end{array}$} & \multirow{3}{*}{$\mid \begin{array}{c}\text { GW-766 } \\
\text { SMP } \\
\text { GRIDI2 } \\
\end{array}$} & \multicolumn{3}{|c|}{ GW-767 } & \multicolumn{4}{|c|}{ GW-769 } & GW- 770 \\
\hline & & & SMP & & \multicolumn{4}{|c|}{ SMP } & SMP \\
\hline & & & GRIDI2 & & \multicolumn{4}{|c|}{ GRIDG3 } & GRIDG3 \\
\hline & & $10 / 96 \mid$ & $5 / 09 / 96$ & $3 / 09 / 96$ & $1 / 96$ & $5 / 20 / 96$ & $10 / 15$ & & $01 / 11 / 96$ \\
\hline & & & & & & & & DUP & \\
\hline FIELD MEASUREMENTS & & & & & & & & & \\
\hline $\begin{array}{l}\text { Top-of-Casing Elev; (ft) } \\
\text { Depth to Water (ft) } \\
\text { Hater-Level Elev. (ft) } \\
\text { Water Temp (degrees C) } \\
\text { pH (pH units) } \\
\text { Sp. Cond. (umho/cm) } \\
\text { Dissolved Oxygen (ppm) } \\
\text { Oxidation/Reduction (mV) }\end{array}$ & $\begin{array}{r}948.37 \\
12.28 \\
936.09 \\
19.8 \\
9.5 \\
204 \\
7.4 \\
145\end{array}$ & $\begin{array}{r}948.54 \\
10.93 \\
937.61 \\
11.8 \\
5.3 \\
45 \\
6.3 \\
243\end{array}$ & $\begin{array}{r}948.54 \\
12.90 \\
935.64 \\
18 \\
5.3 \\
41 \\
5.4 \\
231\end{array}$ & $\begin{array}{r}948.54 \\
13.45 \\
935.09 \\
17.9 \\
4.8 \\
55 \\
4 \\
240\end{array}$ & $\begin{array}{r}944.26 \\
9.95 \\
934.39 \\
16.2 \\
7.5 \\
466 \\
1 \\
110\end{array}$ & $\begin{array}{r}944.26 \\
11.30 \\
932.96 \\
20.5 \\
7.3 \\
430 \\
1.2 \\
93\end{array}$ & $\begin{array}{r}944.26 \\
11.94 \\
932.32 \\
18.6 \\
7.3 \\
443 \\
0.6 \\
134\end{array}$ & $\begin{array}{r}944.26 \\
11.94 \\
932.32 \\
18.6 \\
7.2 \\
440 \\
0.7 \\
131\end{array}$ & $\begin{array}{r}944.55 \\
12.45 \\
932.1 \\
16.4 \\
7.1 \\
340 \\
4.9 \\
187\end{array}$ \\
\hline MISCELLANEOUS PARAMETERS & & & - & & - & - &. & $\cdot$ & \\
\hline $\begin{array}{l}\text { pH (pH units) } \\
\text { Sp. Cond. (umho/cm) } \\
\text { TDS (mg/L) } \\
\text { TSS (mg/L) } \\
\text { Turbidity (NTU) }\end{array}$ & $\begin{array}{r}8.27 \\
321 \\
184 \\
4.5 \\
2.07\end{array}$ & $\begin{array}{r}5.51 \\
36.6 \\
42 \\
8 \\
5.55\end{array}$ & $\begin{array}{r}5.5 \\
47.4 \\
66 \\
<1 \\
2.82\end{array}$ & $\begin{array}{r}5.26 \\
54.1 \\
46 \\
<1 \\
5.16\end{array}$ & $\begin{array}{r}7.43 \\
456 \\
290 \\
<1 \\
0.929\end{array}$ & $\begin{array}{r}7.62 \\
479 \\
310 \\
2 \\
1.18\end{array}$ & $\begin{array}{r}7.42 \\
490 \\
290 \\
<1 \\
0.981\end{array}$ & $\begin{array}{r}7.43 \\
491 \\
306 \\
<1 \\
1.7\end{array}$ & $\begin{array}{r}7.23 \\
353 \\
190 \\
30.5 \\
36.8\end{array}$ \\
\hline
\end{tabular}

(CONT INUED)

\begin{tabular}{|c|c|c|c|c|c|c|c|c|c|}
\hline \multirow{5}{*}{$\begin{array}{l}\text { Sampling Point } \\
\text { Program } \\
\text { Location } \\
\text { Date Sampled } \\
\text { Sample Type } \\
\text { FIELD MEASUREMENTS }\end{array}$} & \multicolumn{2}{|c|}{ GW-770 } & \multicolumn{5}{|c|}{$G W-T 75$} & \multicolumn{2}{|c|}{$6 W-776$} \\
\hline & \multicolumn{2}{|c|}{ SMP } & \multicolumn{5}{|c|}{ SMP } & \multicolumn{2}{|c|}{ SMP } \\
\hline & \multicolumn{2}{|c|}{ GRIDG3 } & \multicolumn{4}{|c|}{ GRIDH3 } & & \multicolumn{2}{|c|}{ GRIDH3 } \\
\hline & \multicolumn{2}{|c|}{$|05 / 20 / 96| 10 / 15 / 96 \mid$} & \multicolumn{2}{|c|}{$01 / 10 / 96$} & \multicolumn{2}{|c|}{$05 / 09 / 96$} & $0 / 10 / 96$ & $|/ 10 / 96|$ & \\
\hline & & & & & & & & - & \\
\hline $\begin{array}{l}\text { Top-of-Casing Elev. (ft) } \\
\text { Depth to Water (ft) } \\
\text { Water-Level Elev. (ft) } \\
\text { Water Temp (degrees C) } \\
\text { pH (pH units) } \\
\text { Sp. Cond. (umho/cm) } \\
\text { oissolved Oxygen (ppm) } \\
\text { Oxidation/Reduction (mv) }\end{array}$ & $\begin{array}{r}944.55 \\
13.50 \\
931.05 \\
17.9 \\
7 \\
315 \\
5.7 \\
146\end{array}$ & $\begin{array}{r}944.55 \\
14.82 \\
929.73 \\
19.5 \\
6.7 \\
365 \\
3.4 \\
163\end{array}$ & $\begin{array}{r}931.35 \\
10.97 \\
920.38 \\
17 \\
7.5 \\
477 \\
1.2 \\
212\end{array}$ & $\begin{array}{r}931.35 \\
10.97 \\
920.38 \\
17.3 \\
7.5 \\
477 \\
1 \\
203\end{array}$ & $\begin{array}{r}931.35 \\
8.75 \\
922.6 \\
20.1 \\
7.6 \\
446 \\
1.7 \\
193\end{array}$ & $\begin{array}{r}931.35 \\
8.75 \\
922.6 \\
19.8 \\
7.6 \\
455 \\
1.7 \\
199\end{array}$ & $\begin{array}{r}931.35 \\
12.55 \\
918.8 \\
17.8 \\
7.2 \\
454 \\
1.7 \\
173\end{array}$ & $\begin{array}{r}931.25 \\
11.34 \\
919.91 \\
12.6 \\
7.3 \\
574 \\
11.1 \\
196\end{array}$ & $\begin{array}{r}931.25 \\
15.80 \\
915.45 \\
19 \\
7 \\
569 \\
2.9 \\
-18\end{array}$ \\
\hline MISCELLANEOUS PARAMETERS & & & & & & & & & \\
\hline $\begin{array}{l}\text { pH (pH units) } \\
\text { Sp. Cond. (umho/cm) } \\
\text { TDS (mg/L) } \\
\text { TSS (mg/L) } \\
\text { Turbidity (NTU) }\end{array}$ & $\begin{array}{r}7.41 \\
355 \\
250 \\
1 \\
6.72\end{array}$ & $\begin{array}{r}7.23 \\
402 \\
236 \\
17 \\
23.9\end{array}$ & $\begin{array}{r}7.74 \\
485 \\
270 \\
<1 \\
1.02\end{array}$ & $\begin{array}{r}7.61 \\
486 \\
186 \\
<1 \\
0.92\end{array}$ & $\begin{array}{r}7.48 \\
505 \\
292 \\
<1 \\
1.31\end{array}$ & $\begin{array}{r}7.48 \\
504 \\
290 \\
<1 \\
1.67\end{array}$ & $\begin{array}{r}7.41 \\
508 \\
294 \\
<1 \\
1.24\end{array}$ & $\begin{array}{r}7.31 \\
557 \\
214 \\
3.5 \\
24.1\end{array}$ & $\begin{array}{r}7.38 \\
623 \\
438 \\
41 \\
111\end{array}$ \\
\hline
\end{tabular}

(CONTINUED) 
APPENDIX D. 1

Field Measurements and Miscellaneous Parameters, CY 1996

\begin{tabular}{|c|c|c|c|c|c|c|c|c|c|}
\hline $\begin{array}{l}\text { Sampling Point } \\
\text { Program }\end{array}$ & GW-776 & & GW-779 & & & $6 W-780$ & & GW- & \\
\hline Location & GRIDH3 & & GRIDF2 & & & GRIDF2 & & GRII & \\
\hline $\begin{array}{l}\text { Date Sampled } \\
\text { Sample Type }\end{array}$ & $10 / 10 / 96$ & $/ 25 / 9$ & $05 / 21 / 96$ & 107 & & $5 / 22$ & & $3 / 06 / 96$ & \\
\hline FIELD MEASUREMENTS & & & & & & & & & \\
\hline $\begin{array}{l}\text { Top-of-Casing Elev. (ft) } \\
\text { Depth to Water (ft) } \\
\text { Water-Level Elev. (ft) } \\
\text { Water Temp (degrees C) } \\
\text { pH (pH units) } \\
\text { Sp. Cond. (umho/cm) } \\
\text { Dissolved Oxygen (ppm) } \\
\text { Oxidation/Reduction (mv) }\end{array}$ & $\begin{array}{r}931.25 \\
16.90 \\
914.35 \\
16.9 \\
7 \\
509 \\
6.1 \\
84\end{array}$ & $\begin{array}{r}963.09 \\
9.65 \\
953.44 \\
16.9 \\
8.9 \\
375 \\
3 \\
184\end{array}$ & $\begin{array}{r}963.09 \\
9.71 \\
953.38 \\
19.9 \\
8 \\
359 \\
5.2 \\
140\end{array}$ & $\begin{array}{r}963.09 \\
9.84 \\
953.25 \\
18.3 \\
8.2 \\
316 \\
2.4 \\
129\end{array}$ & $\begin{array}{r}963.4 \\
12.20 \\
951.2 \\
16.5 \\
7.2 \\
773 \\
2.9 \\
189\end{array}$ & $\begin{array}{r}963.4 \\
12.38 \\
951.02 \\
19.9 \\
7.1 \\
848 \\
6.8 \\
161\end{array}$ & $\begin{array}{r}963.4 \\
12.58 \\
950.82 \\
19.5 \\
6.7 \\
797 \\
2 \\
11\end{array}$ & $\begin{array}{r}947.72 \\
7.28 \\
940.44 \\
18.1 \\
8.2 \\
407 \\
1.2 \\
160\end{array}$ & $\begin{array}{r}947.72 \\
8.57 \\
939.15 \\
20.3 \\
7.9 \\
364 \\
2.2 \\
137\end{array}$ \\
\hline MISCELLANEOUS PARAMETERS & & & & & & & & $\dot{.}$ & \\
\hline $\begin{array}{l}\text { pH (pH units) } \\
\text { Sp. Cond. (umho/cm) } \\
\text { TDS (mg/L) } \\
\text { TSS (mg/L) } \\
\text { Turbidity (NTU) }\end{array}$ & $\begin{array}{r}7.25 \\
618 \\
368 \\
12 \\
99.7\end{array}$ & $\begin{array}{r}8.71 \\
398 \\
270 \\
75 \\
103\end{array}$ & $\begin{array}{r}9.04 \\
402 \\
302 \\
87 \\
110\end{array}$ & $\begin{array}{r}8.37 \\
395 \\
236 \\
12 \\
27.2\end{array}$ & $\begin{array}{r}7.25 \\
829 \\
446 \\
96 \\
8.29\end{array}$ & $\begin{array}{r}7.36 \\
907 \\
630 \\
5 \\
10\end{array}$ & $\begin{array}{r}6.94 \\
1003 \\
590 \\
5.5 \\
7.33\end{array}$ & $\begin{array}{l}8 . \dot{2} \\
425 \\
228 \\
101 \\
108\end{array}$ & $\begin{array}{r}8.58 \\
415 \\
310 \\
1.5 \\
3.38\end{array}$ \\
\hline
\end{tabular}

(CONTINUED)

\begin{tabular}{|c|c|c|c|c|c|c|c|c|c|}
\hline Sampl ing Point & GW-781 & \multicolumn{4}{|c|}{ GW-782 } & \multicolumn{3}{|c|}{$6 W-783$} & $6 W-786$ \\
\hline Program & SMP & \multicolumn{4}{|c|}{ SMP } & \multicolumn{3}{|c|}{ SMP } & SMP \\
\hline Location & GRIDE3 & \multicolumn{3}{|c|}{ GRIDE3 } & & \multicolumn{2}{|r|}{ GRIDE3 } & & GRIDE2 \\
\hline $\begin{array}{l}\text { Date Sampled } \\
\text { Sample Type }\end{array}$ & $11 / 11 / 96$ & $02 / 19$ & DUP & $15 / 28 / 96$ & $1 / 12 / 96$ & $3 / 06 / 96$ & $05 / 23 / 96$ & 11219 & $12 / 25 /$ \\
\hline FIELD MEASUREMENTS & & & - & - & • & - & & & \\
\hline $\begin{array}{l}\text { Top-of-Casing Elev. (ft) } \\
\text { Depth to Water (ft) } \\
\text { Water-Level Elev. (ft) } \\
\text { Water Temp (degrees C) } \\
\text { pH (pH units) } \\
\text { Sp. Cond. (umho/cm) } \\
\text { Dissolved Oxygen (ppm) } \\
\text { Oxidation/Reduction (mv) }\end{array}$ & $\begin{array}{r}947.72 \\
7.99 \\
939.73 \\
15.2 \\
8.2 \\
373 \\
2.7 \\
169\end{array}$ & $\begin{array}{r}947.56 \\
9.52 \\
938.04 \\
14.8 \\
7.8 \\
556 \\
2.7 \\
181\end{array}$ & $\begin{array}{r}947.56 \\
9.52 \\
938.04 \\
14.8 \\
7.8 \\
562 \\
2.6 \\
179\end{array}$ & $\begin{array}{r}947.56 \\
7.95 \\
939.61 \\
18.6 \\
7 \\
516 \\
0.7 \\
165\end{array}$ & $\begin{array}{r}947.56 \\
9.33 \\
938.23 \\
16.6 \\
7 \\
500 \\
1.1 \\
82\end{array}$ & $\begin{array}{r}948.32 \\
8.69 \\
939.63 \\
14.7 \\
7.4 \\
516 \\
6.5 \\
150\end{array}$ & $\begin{array}{r}948.32 \\
10.37 \\
937.95 \\
18.4 \\
7.1 \\
535 \\
5 \\
129\end{array}$ & $\begin{array}{r}948.32 \\
10.36 \\
937.96 \\
15.1 \\
7 \\
498 \\
7 \\
154\end{array}$ & $\begin{array}{r}987.8 \\
7.25 \\
980.55 \\
16 \\
7.7 \\
481 \\
7.7 \\
204\end{array}$ \\
\hline MISCELLANEOUS PARAMETERS & & - & & - & - & - & - & - & \\
\hline $\begin{array}{l}\text { pH (pH units) } \\
\text { Sp. Cond. (umho/cm) } \\
\text { TDS (mg/L) } \\
\text { TSS (mg/L) } \\
\text { Turbidity (NTU) }\end{array}$ & $\begin{array}{r}8.01 \\
412 \\
262 \\
23 \\
40\end{array}$ & $\begin{array}{r}7.39 \\
573 \\
314 \\
<1 \\
2.75\end{array}$ & $\begin{array}{r}7.36 \\
575 \\
324 \\
<1 \\
2.45\end{array}$ & $\begin{array}{r}7.45 \\
573 \\
342 \\
<1 \\
1.63\end{array}$ & $\begin{array}{r}6.93 \\
572 \\
314 \\
2 \\
3.99\end{array}$ & $\begin{array}{r}7.42 \\
538 \\
288 \\
13 \\
80.9\end{array}$ & $\begin{array}{r}7.66 \\
615 \\
354 \\
19 \\
59.1\end{array}$ & $\begin{array}{r}7.06 \\
594 \\
324 \\
10 \\
49.3\end{array}$ & $\begin{array}{r}7.57 \\
481 \\
286 \\
34 \\
62.8\end{array}$ \\
\hline
\end{tabular}

(CONTINUED) 
APPENDIX 0.1

Field Measurements and Miscellaneous Parameters, CY 1996

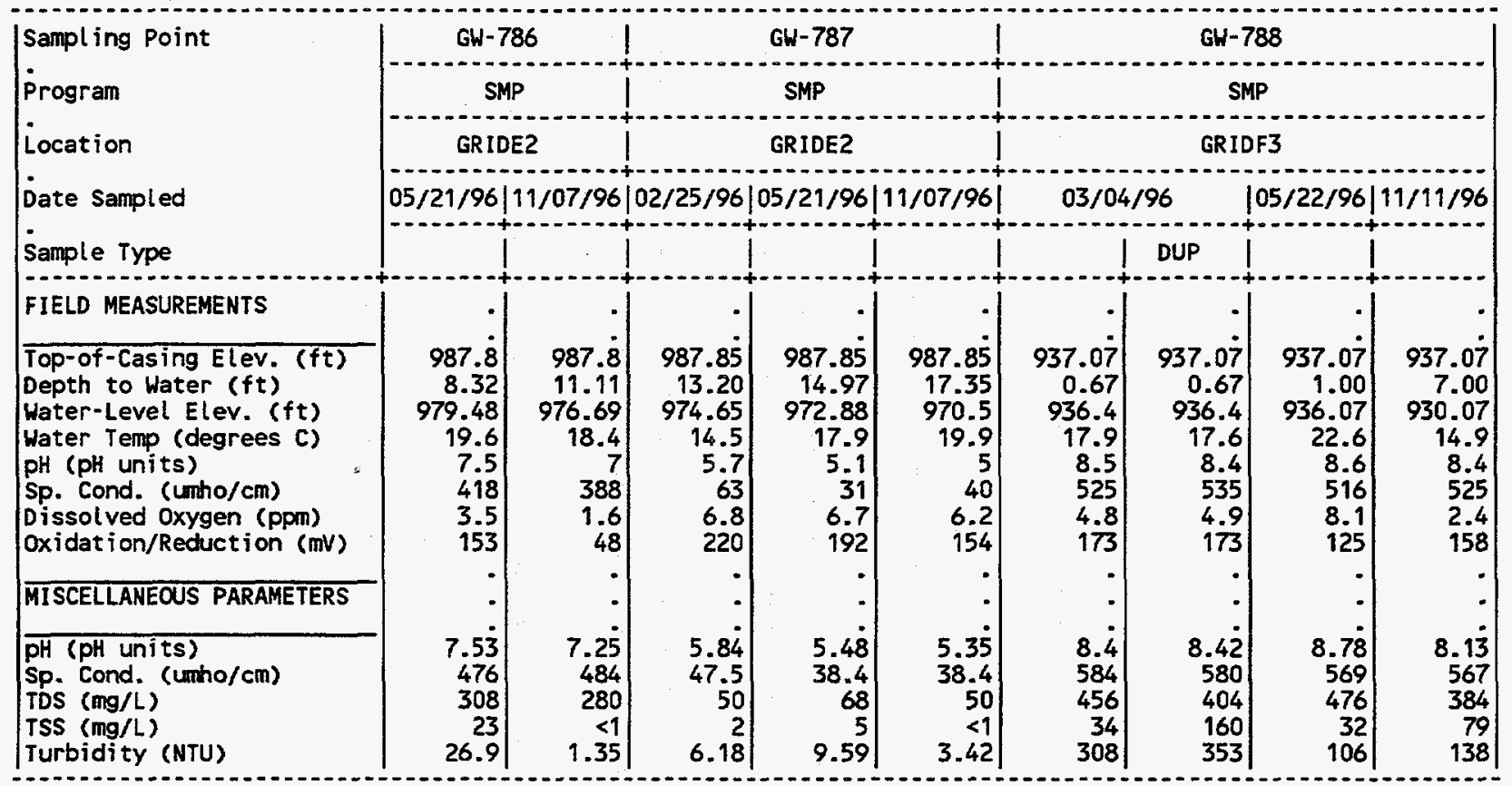

(CONTINUED)

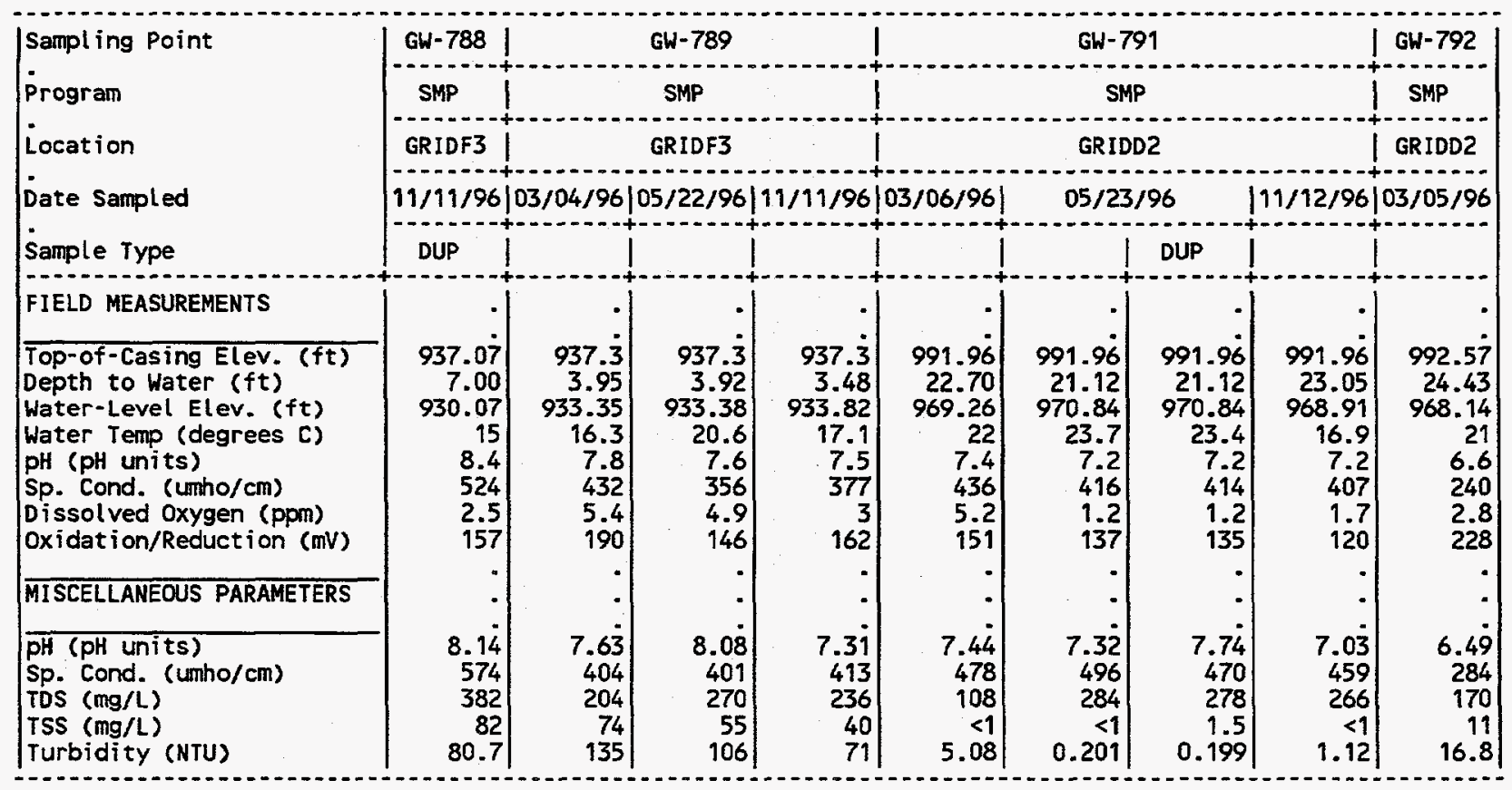

(CONTINUED) 
APPENDIX D. 1

Field Measurements and Miscellaneous Parameters, CY 1996

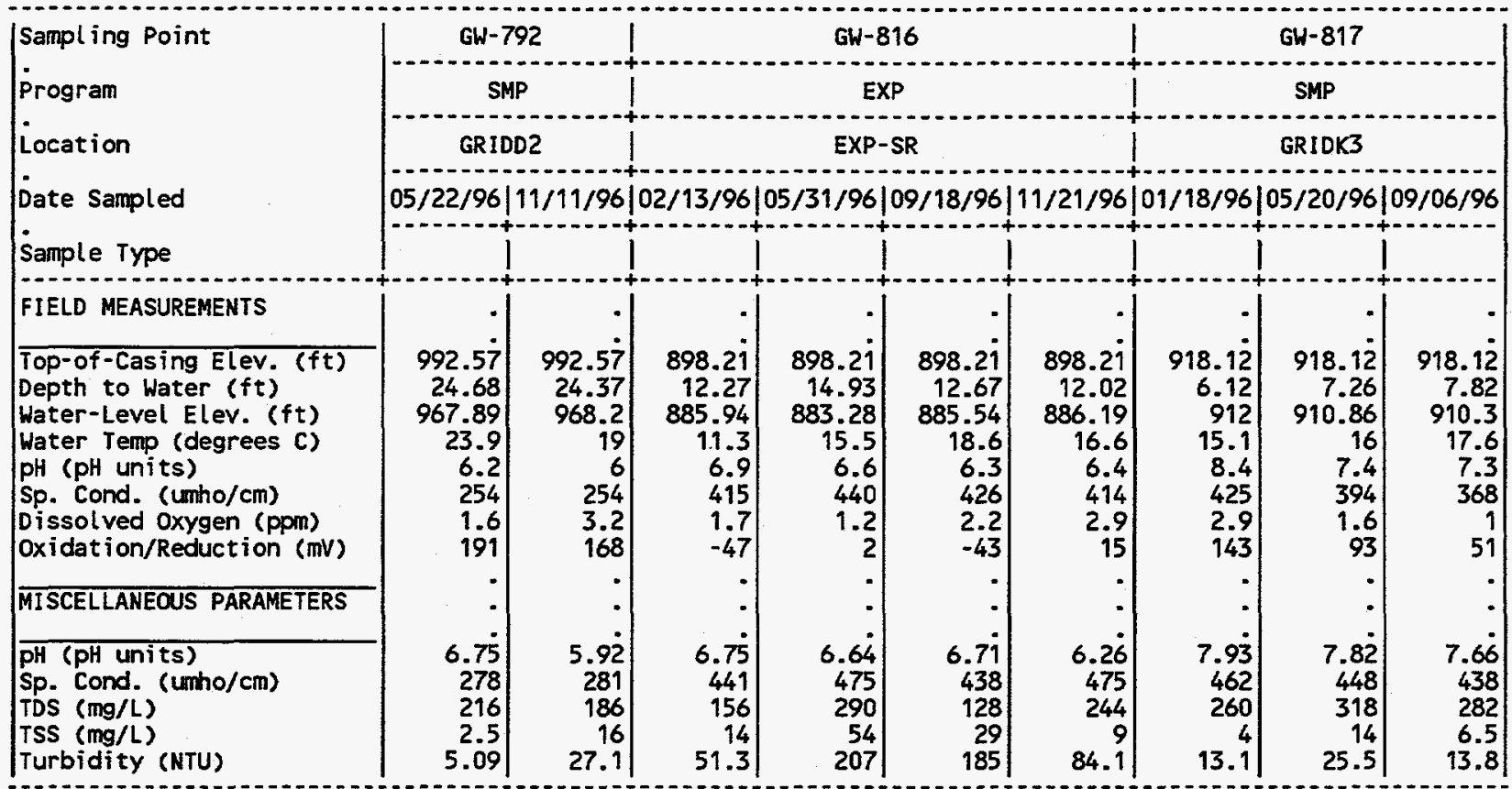

(CONTINUED)

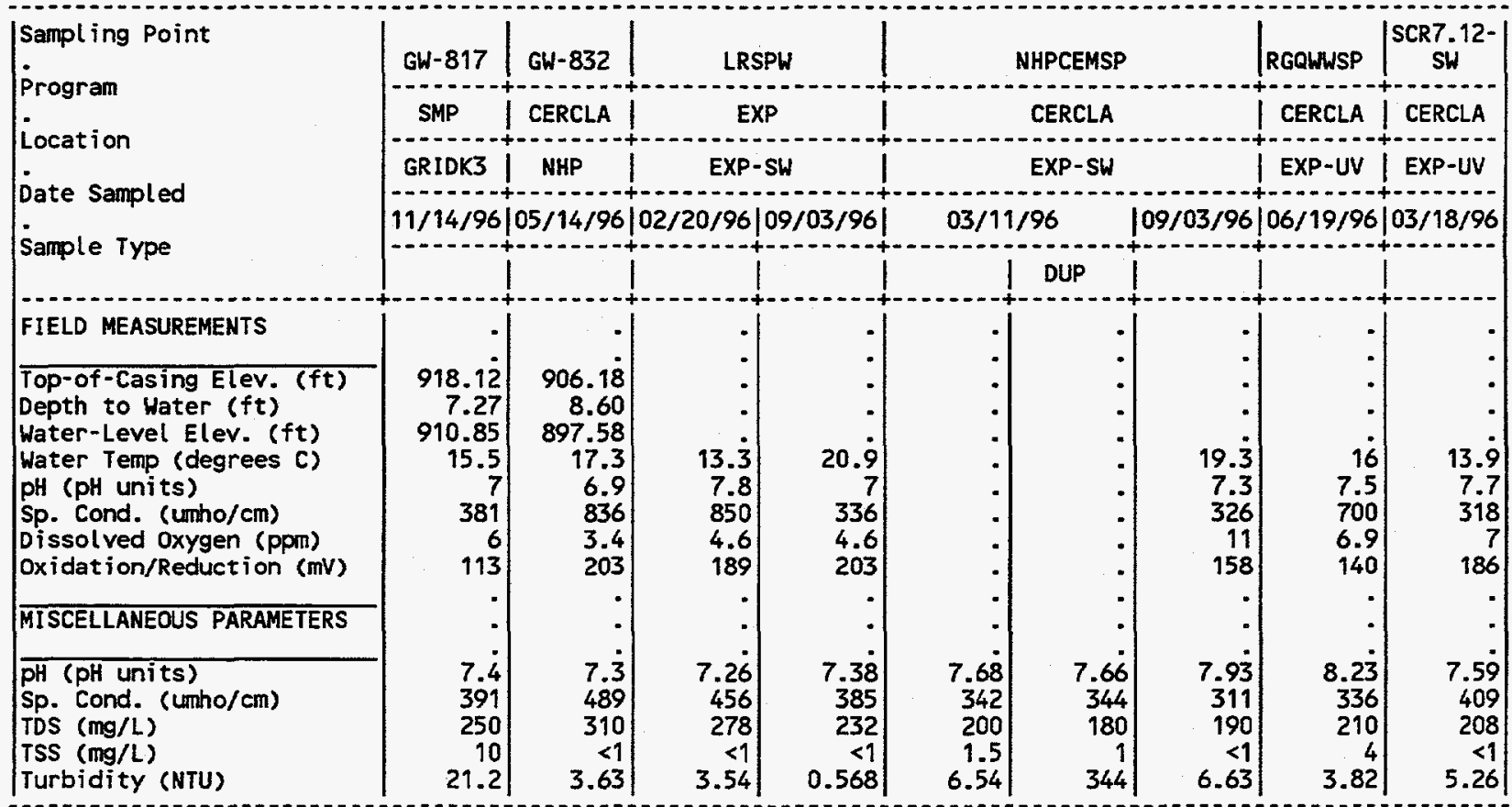

(CONTINUED) 
APPEND IX D. 1

Field Measurements and Miscellaneous Parameters, CY 1996

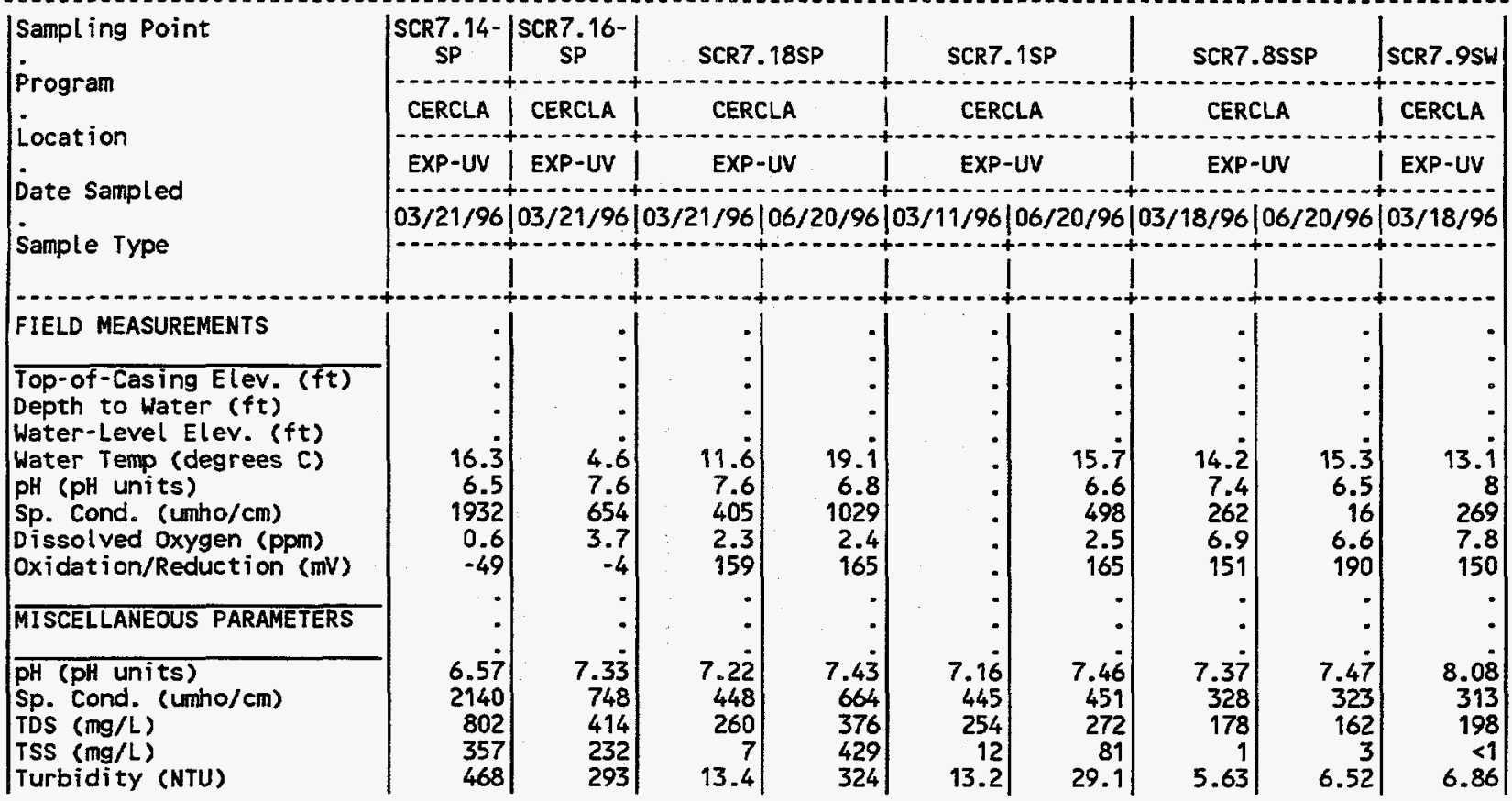

\section{(CONT INUED)}

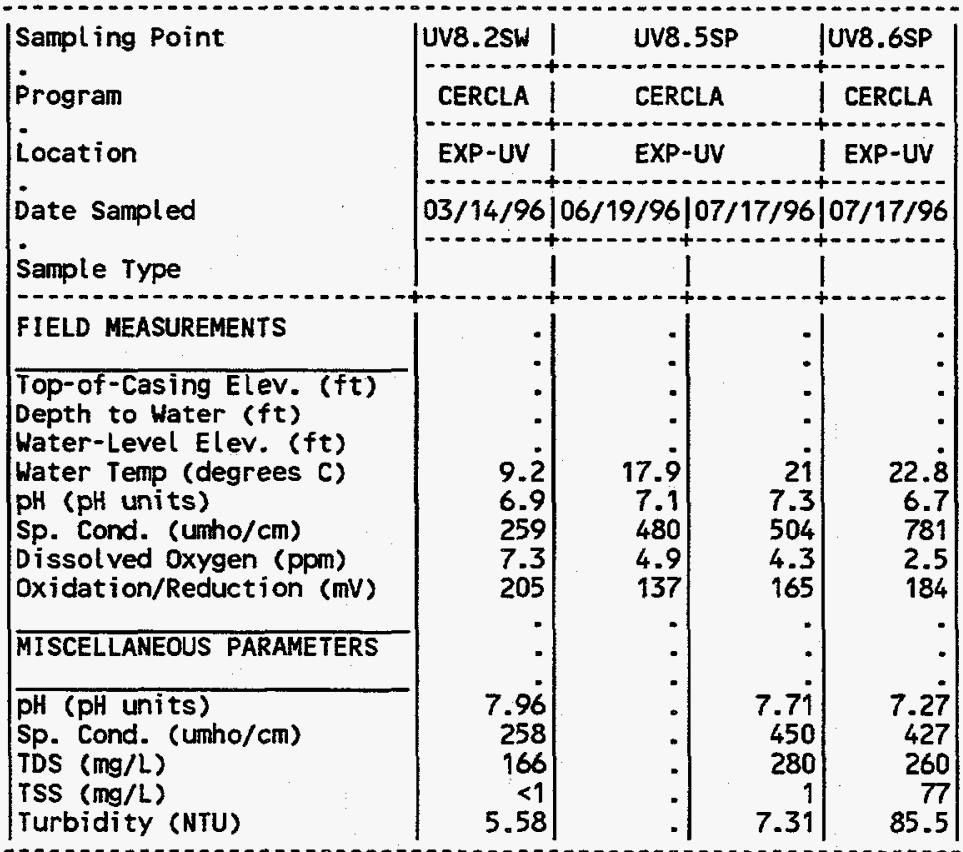


APPENDIX D.2

INORGANIC ANALYTES 
APPENDIX 0.2

Inorganic Analytes, CY 1996

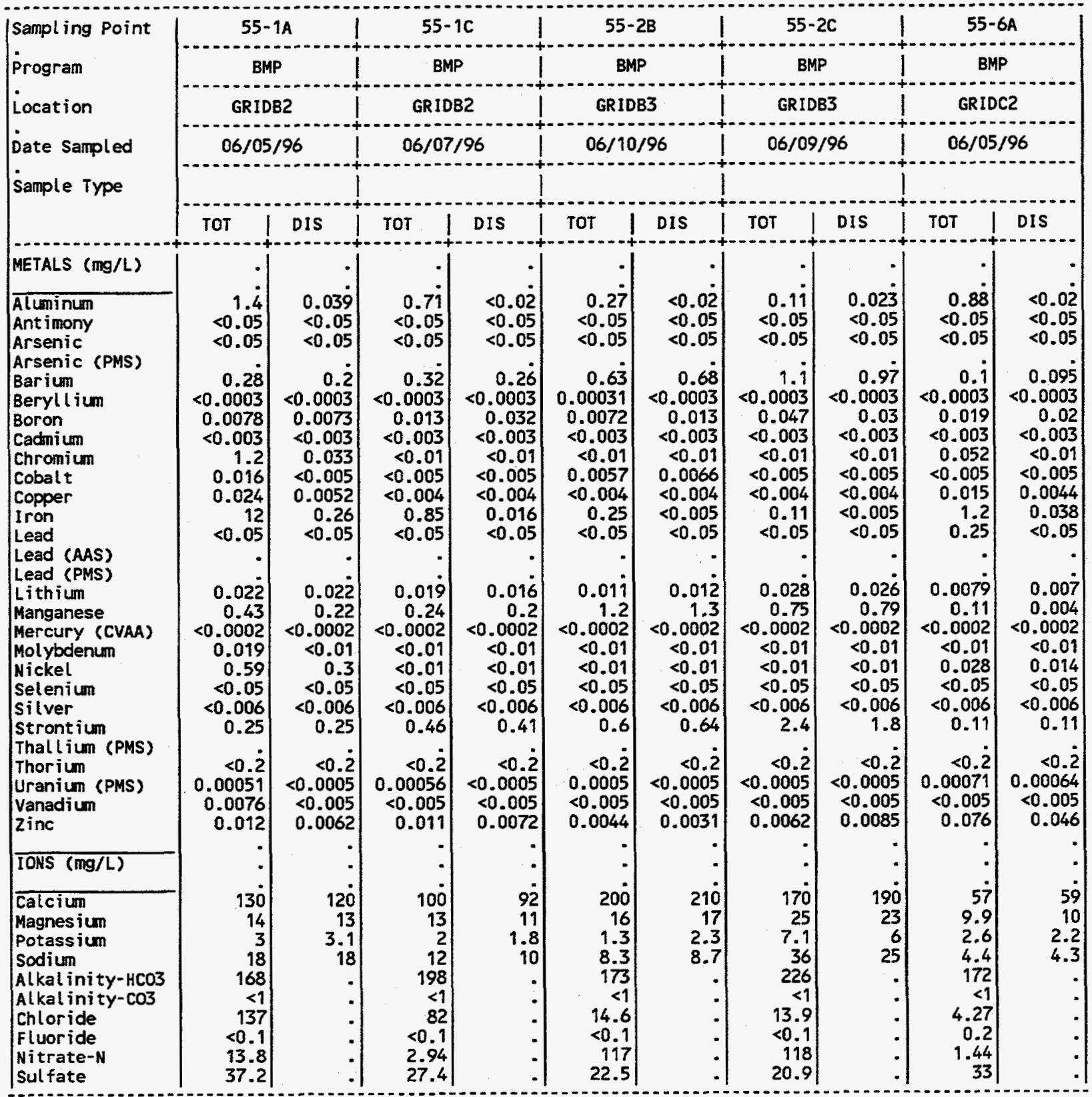

(CONT INUED) 
APPENDIX 0.2

Inorganic Analytes, CY 1996

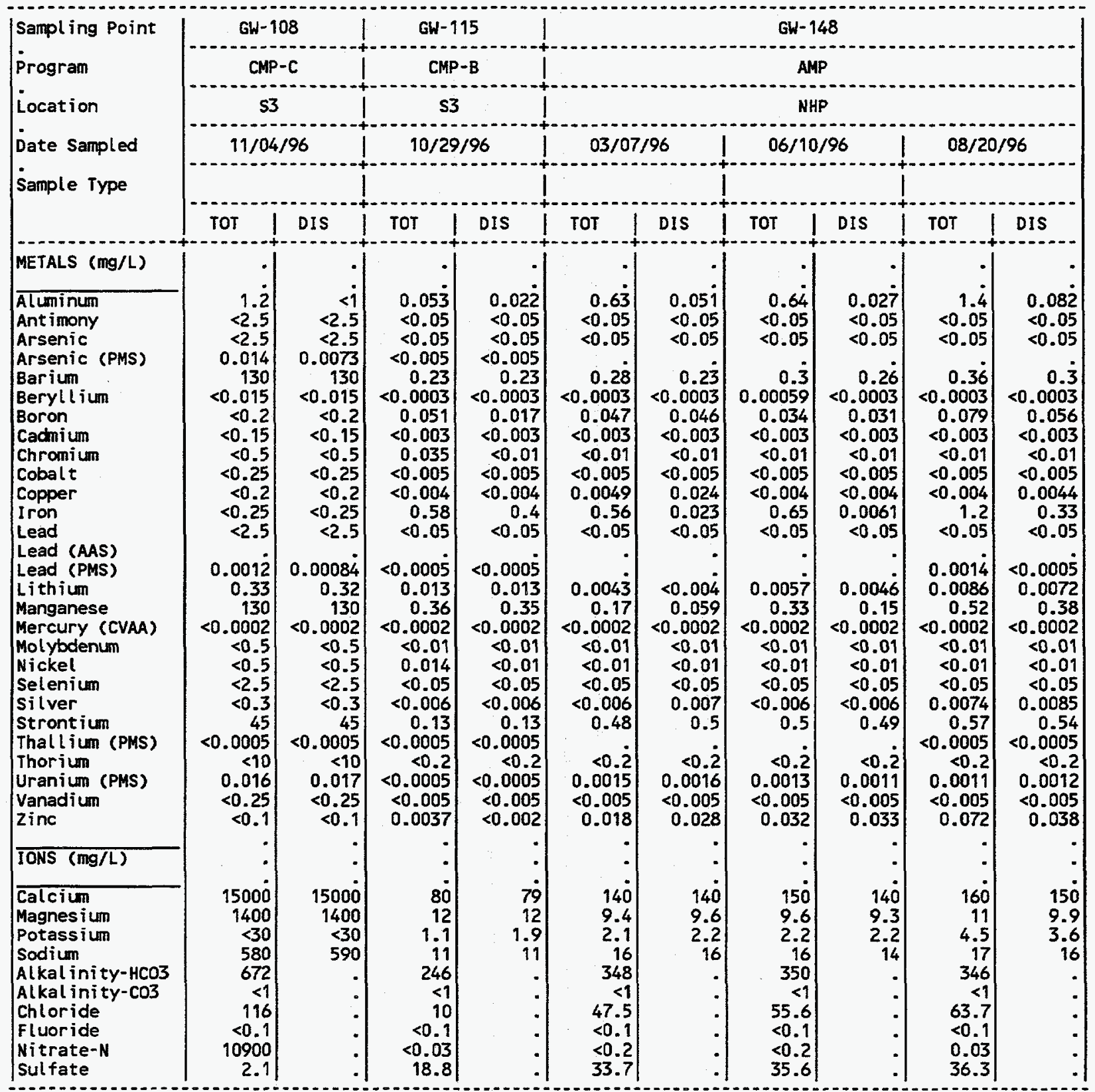

(CONT INUED) 
APPENDIX 0.2

Inorganic Analytes, CY 1996

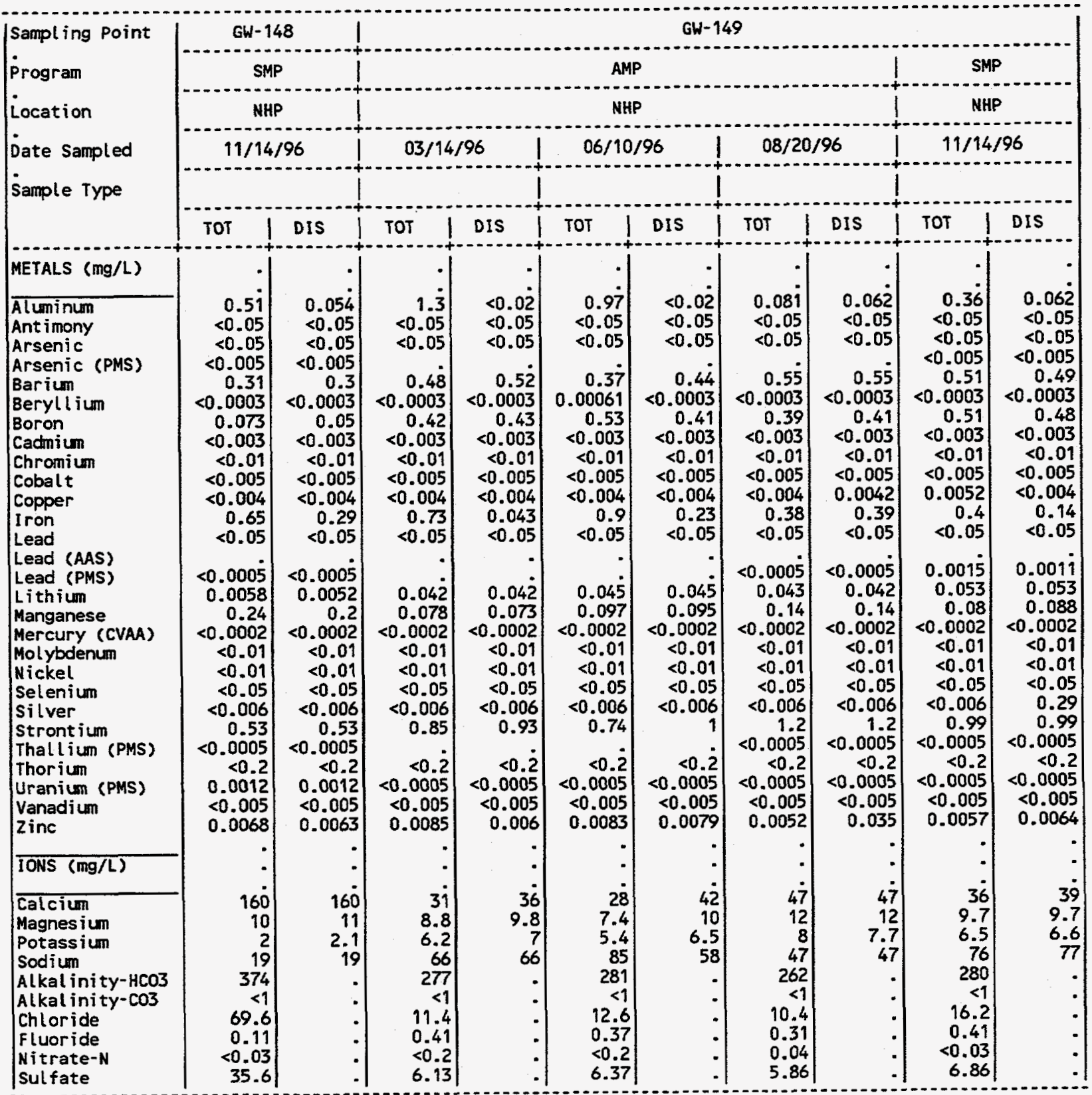

(CONTINUED) 
APPENDIX 0.2

Inorganic Analytes, CY 1996

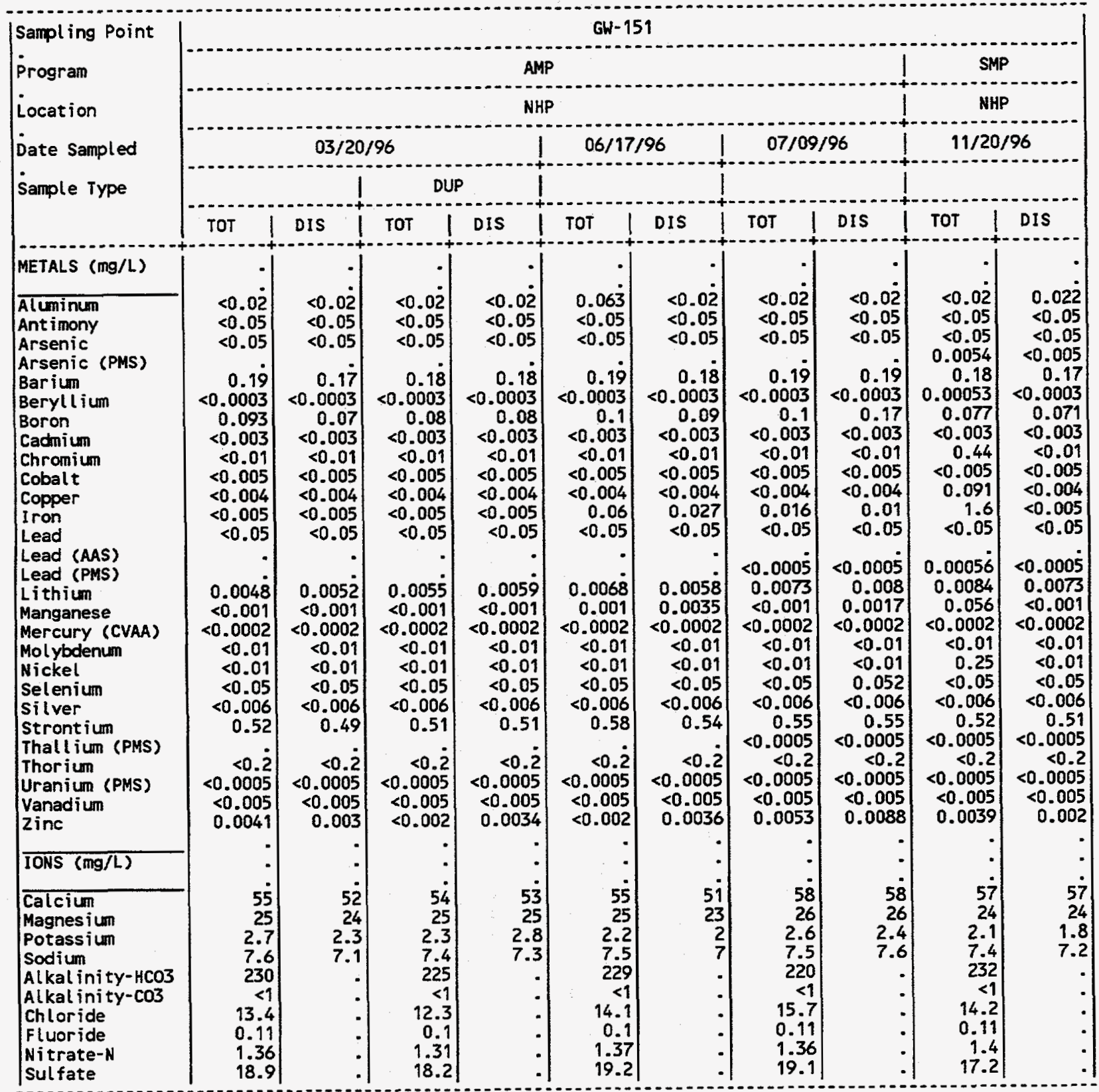

(CONTINUED) 
APPENDIX 0.2

Inorganic Analytes, CY 1996

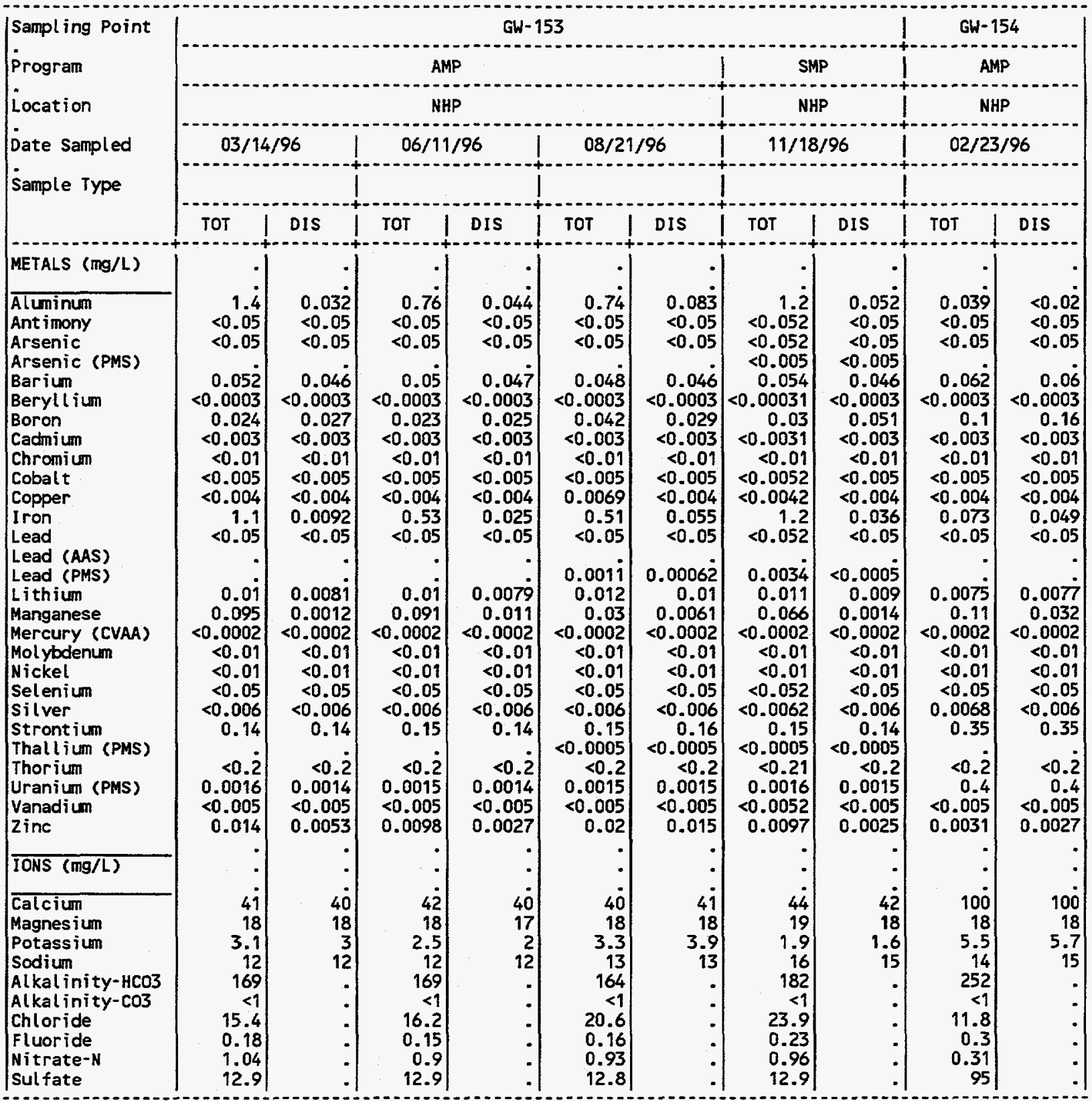

(CONTINUED) 
APPENDIX 0.2

Inorganic Analytes, CY 1996

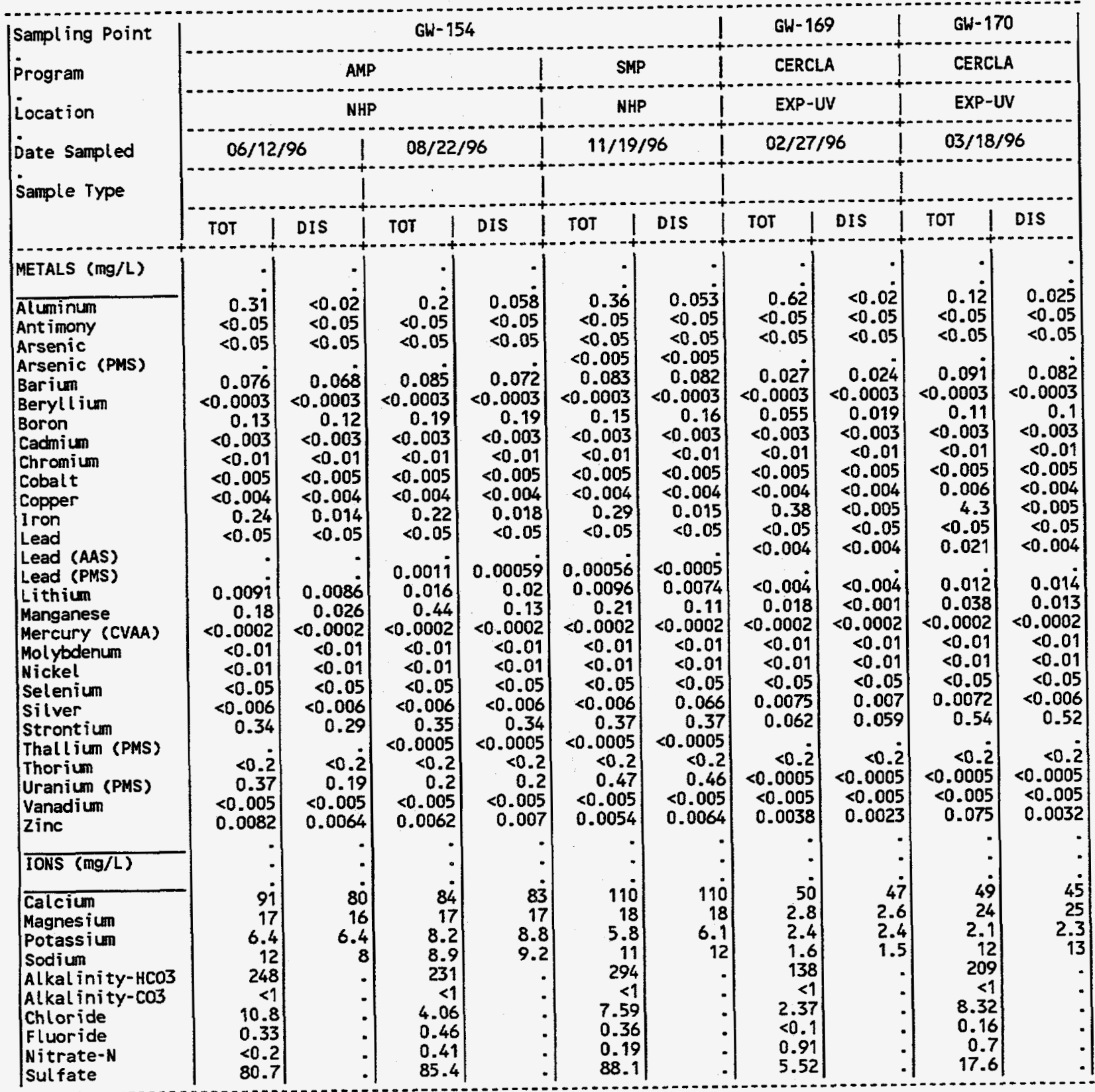

(CONT INUED) 
APPENDIX 0.2

Inorganic Analytes, Cy 1996

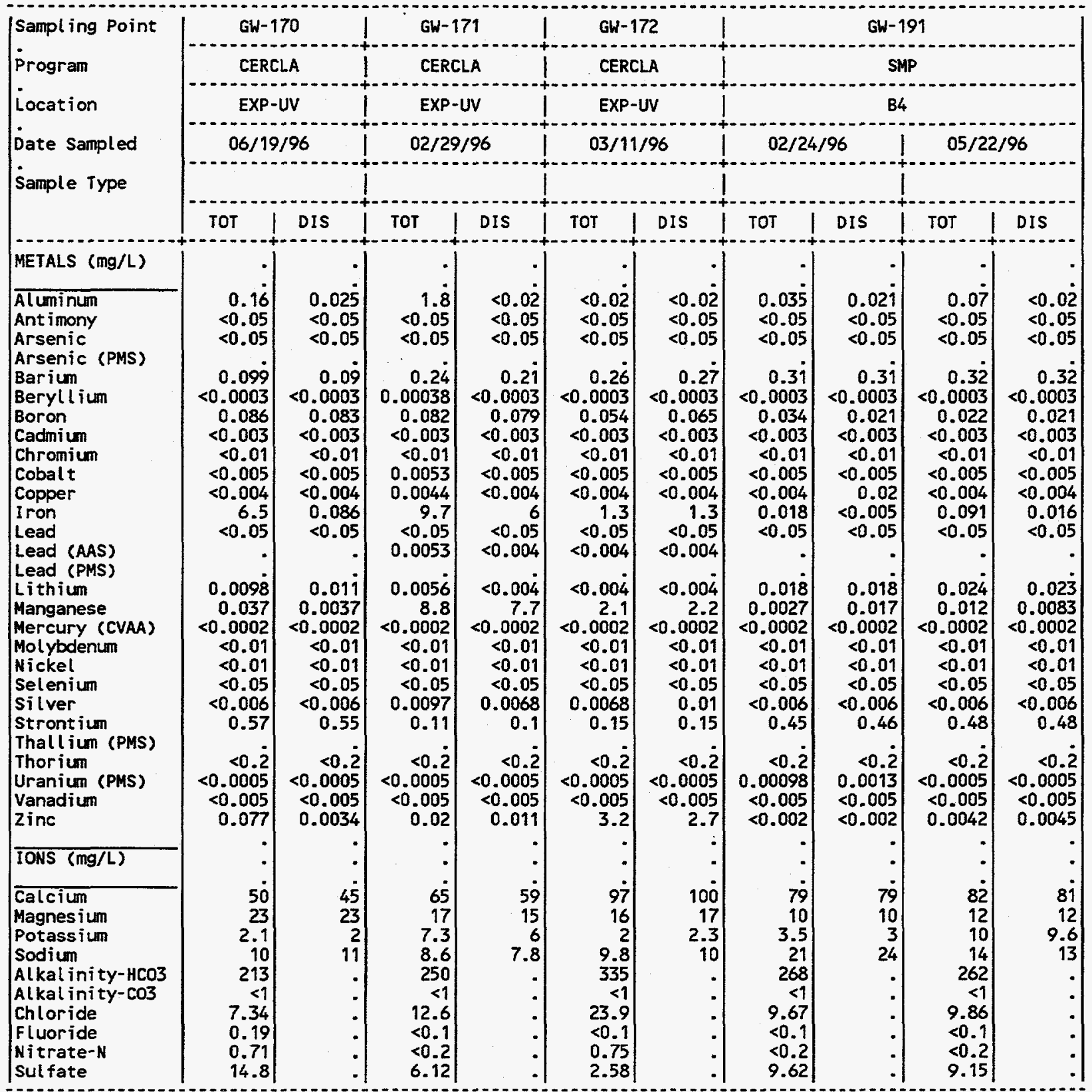

(CONT INUED) 
APPENDIX 0.2

Inorganic Analytes, CY 1996

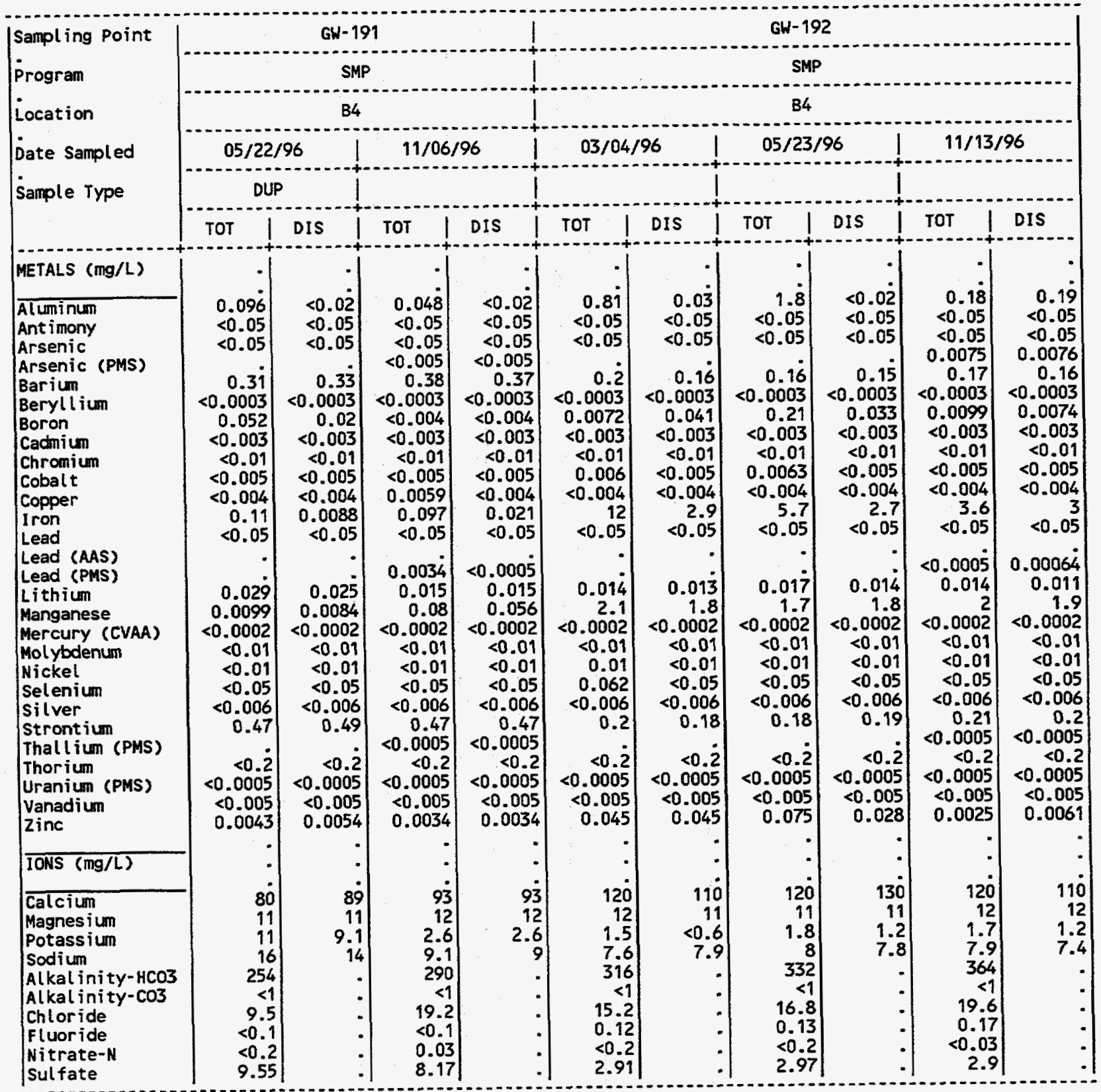

(CONTINUED) 
APPENDIX D.2

Inorganic Analytes, CY 1996

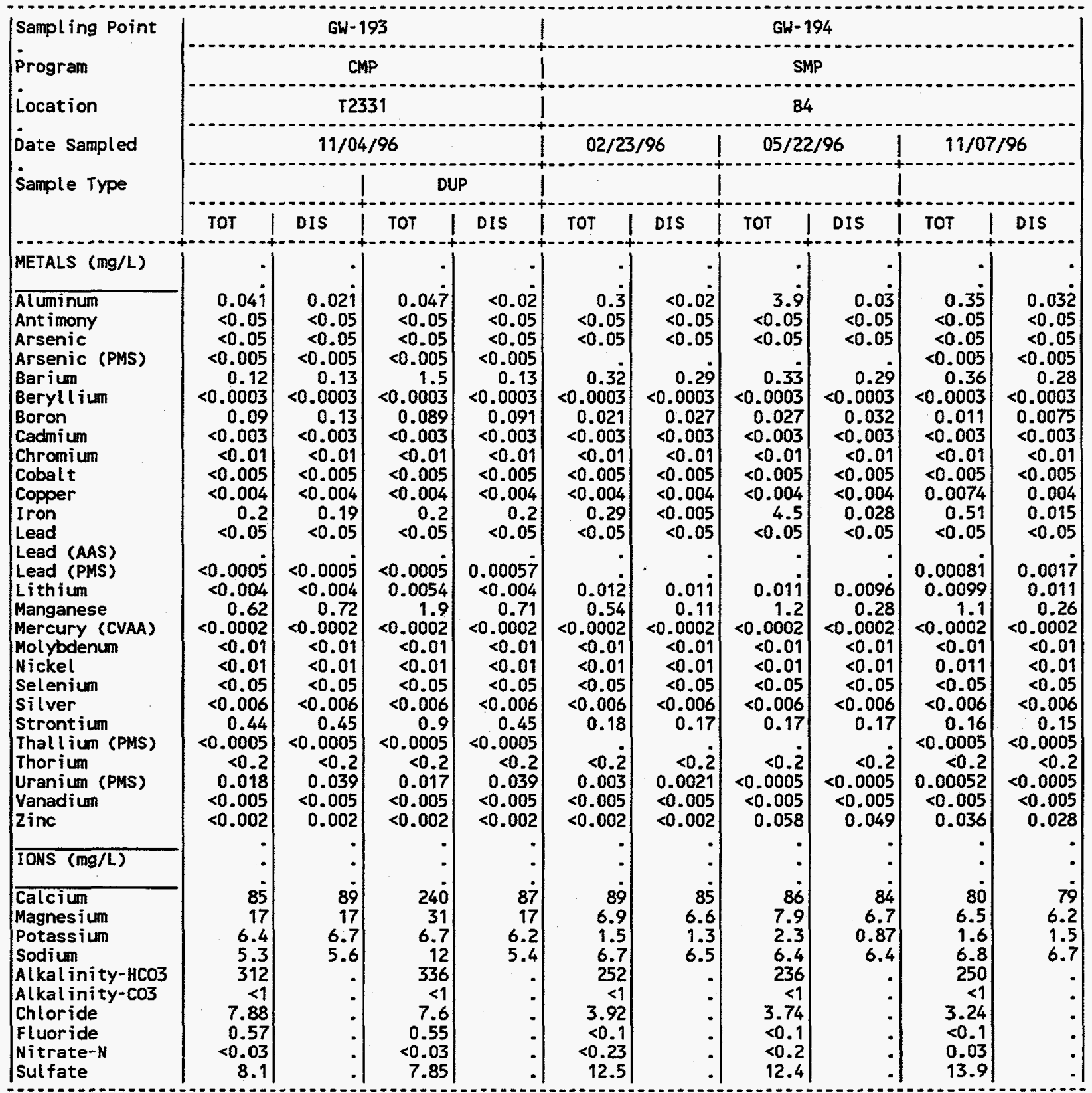

(CONT INUED) 
APPEND IX D.2

Inorganic Analytes, CY 1996

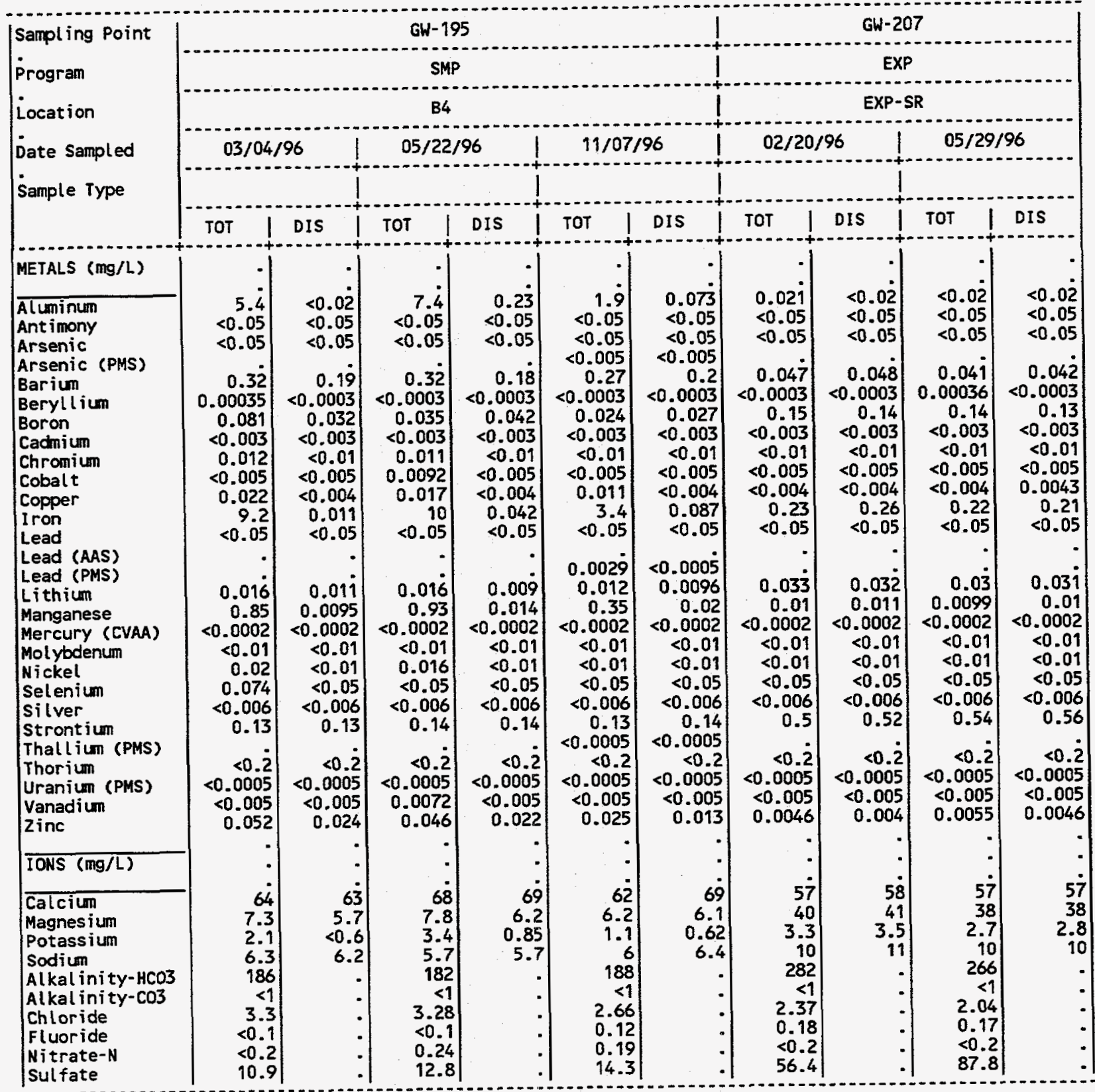

(CONTINUED) 
APPENDIX 0.2

Inorganic Analytes, CY 1996

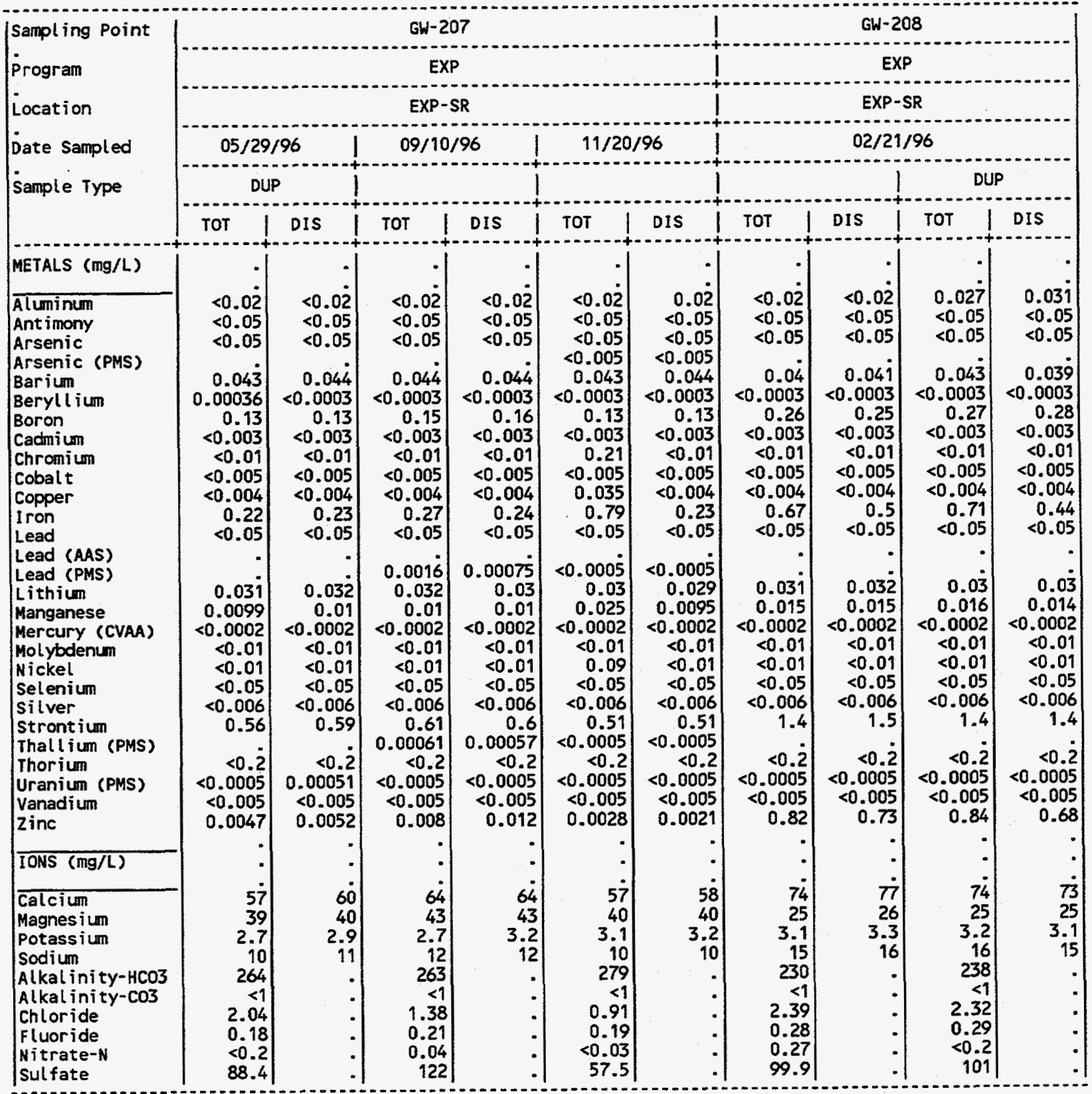

(CONT I NUED) 
APPENDIX 0.2

Inorganic Analytes, CY 1996

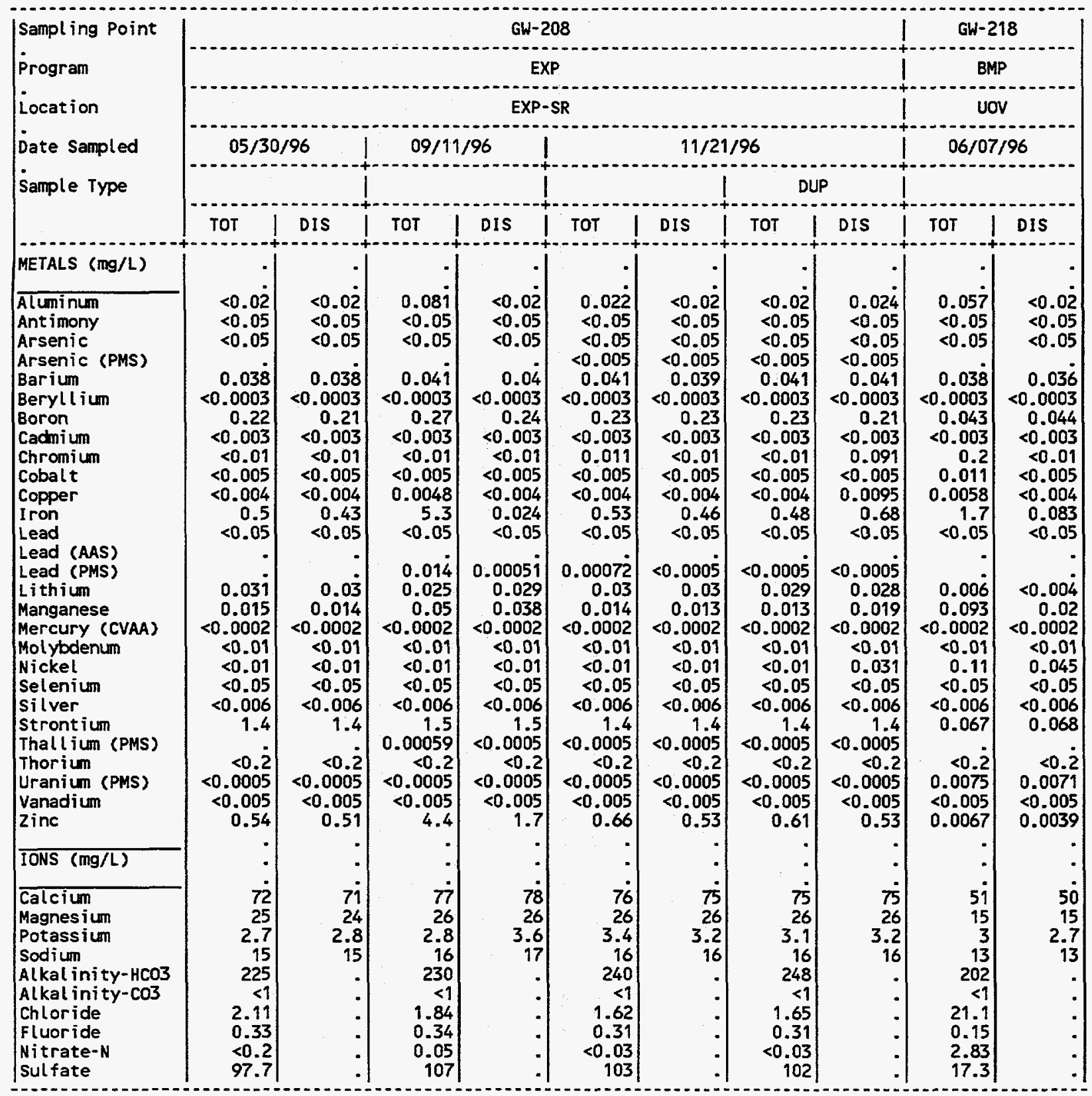

(CONTINUED) 
APPENDIX 0.2

Inorganic Analytes, CY 1996

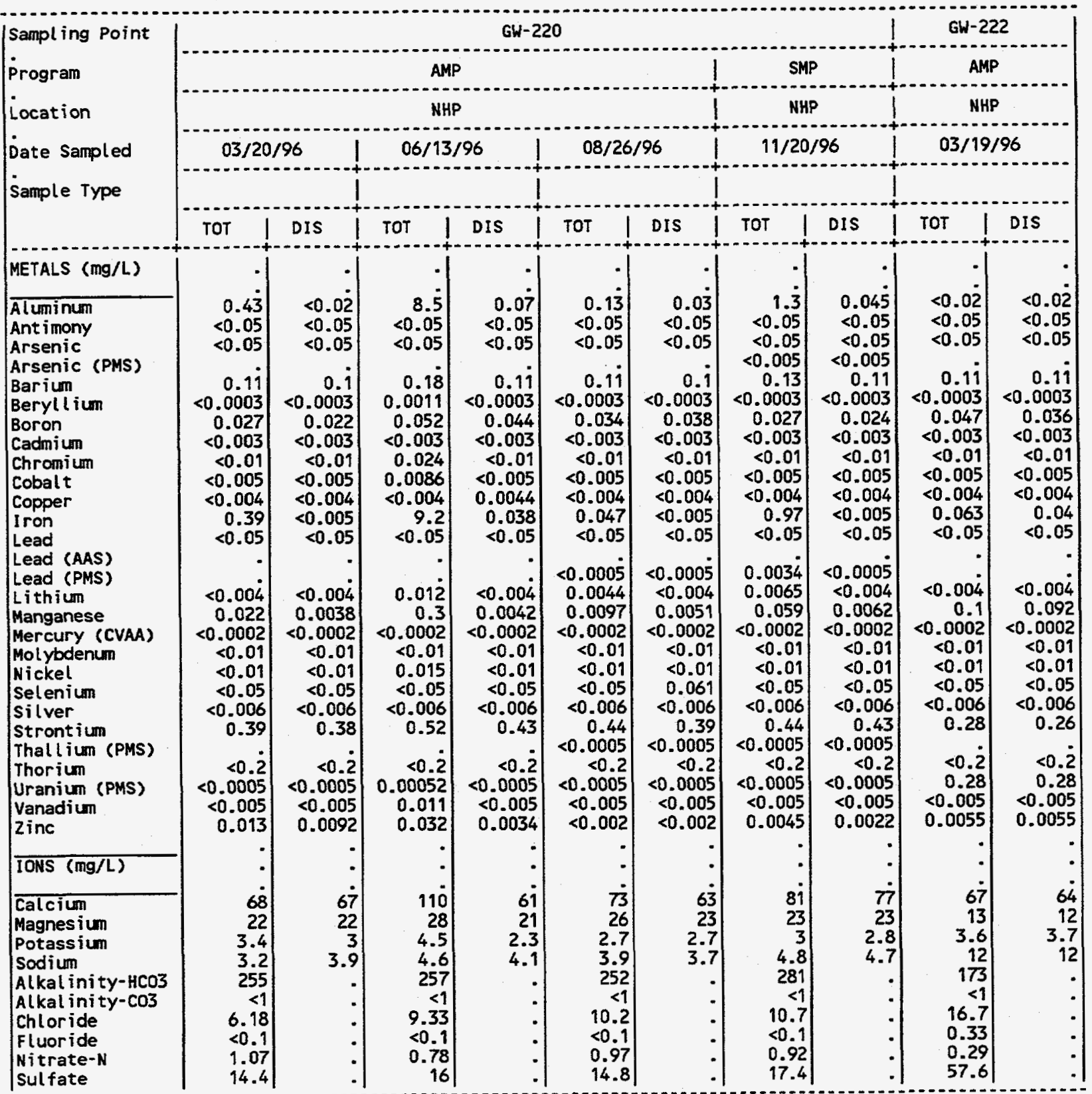

(CONT I NUED) 
APPENDIX 0.2

Inorganic Analytes, CY 1996

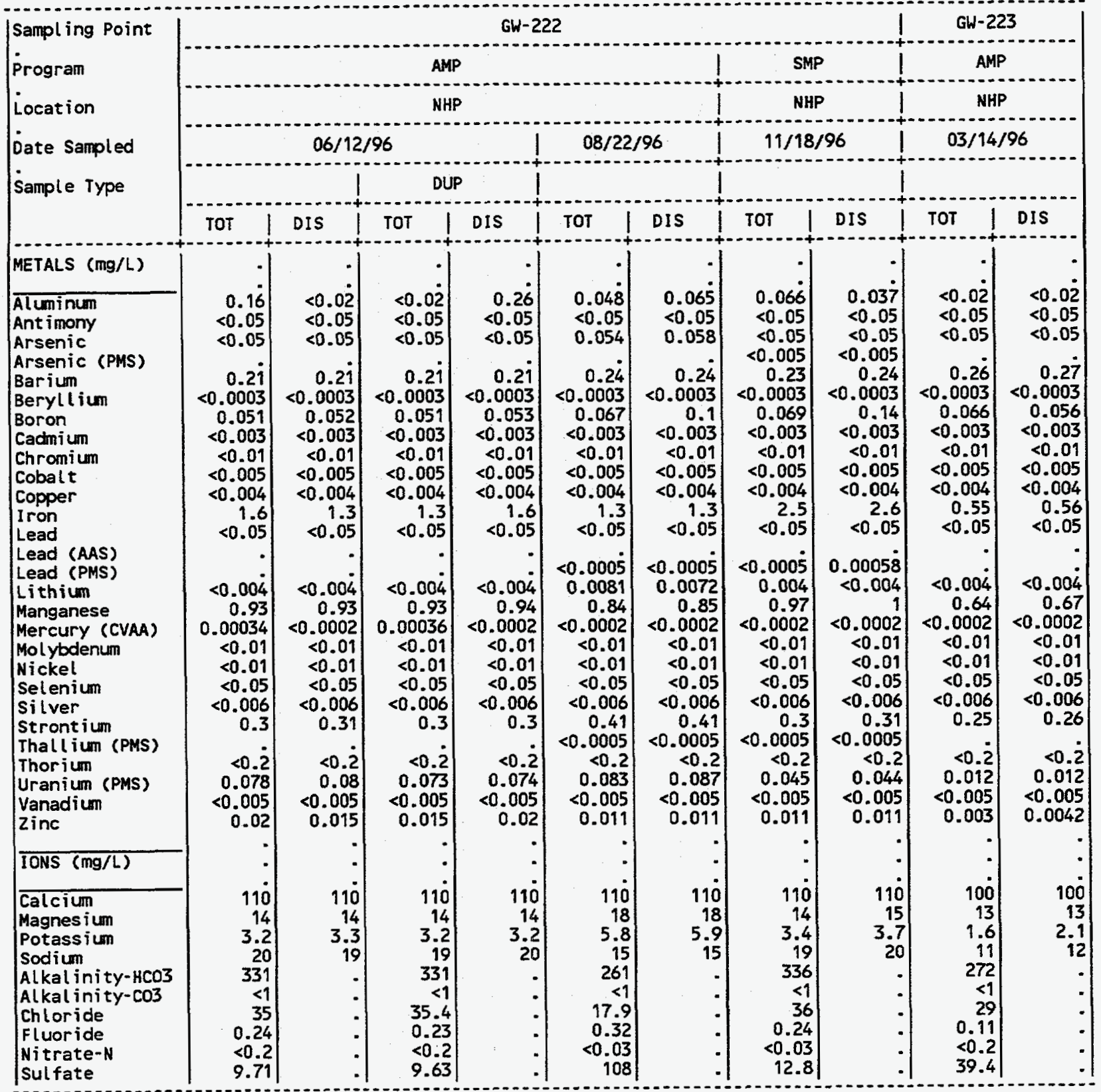

(CONT I NUED) 
APPENDIX 0.2

Inorganic Analytes, CY 1996

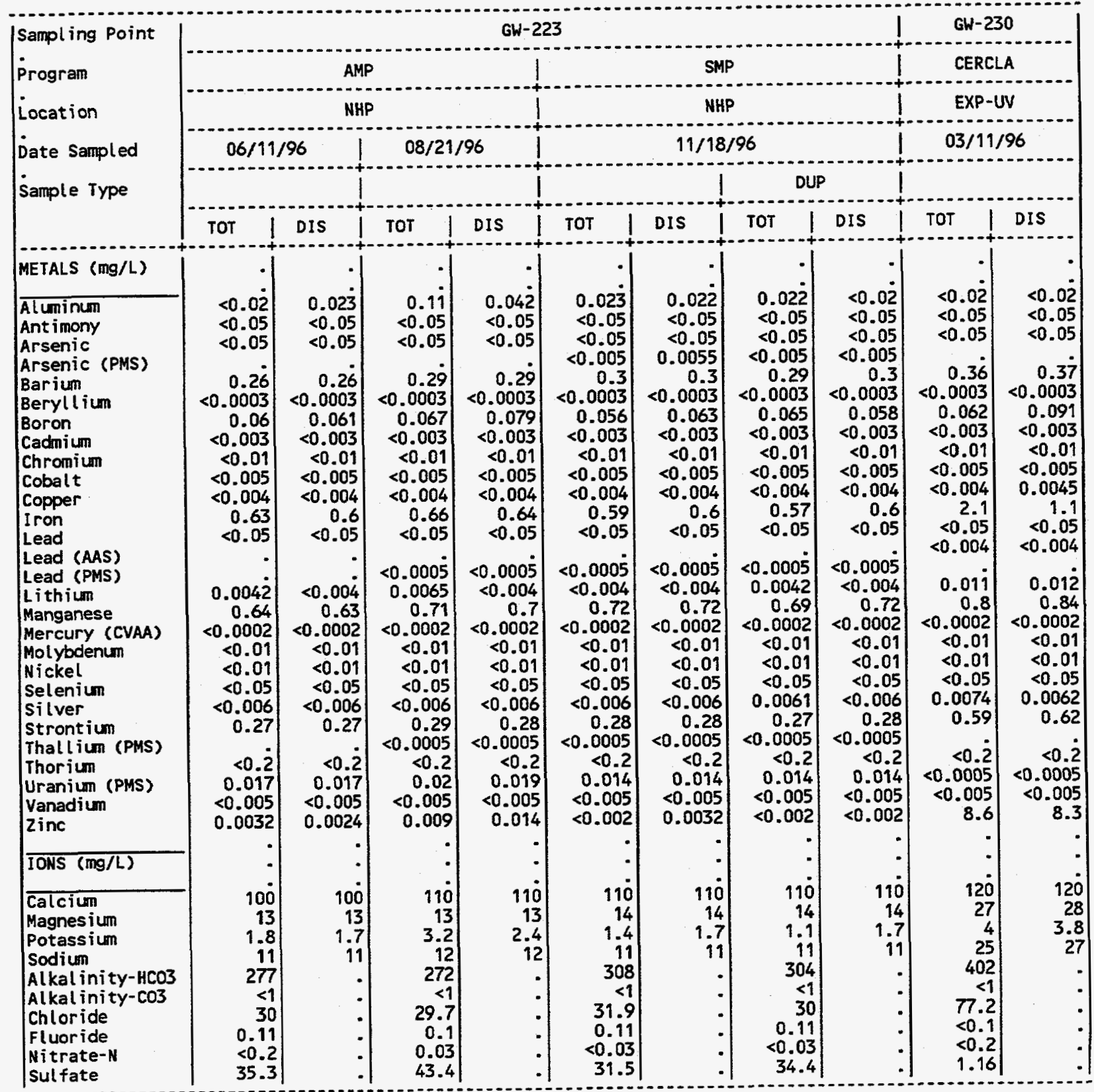

(CONT I NUED) 
APPENDIX 0.2

Inorganic Analytes, CY 1996

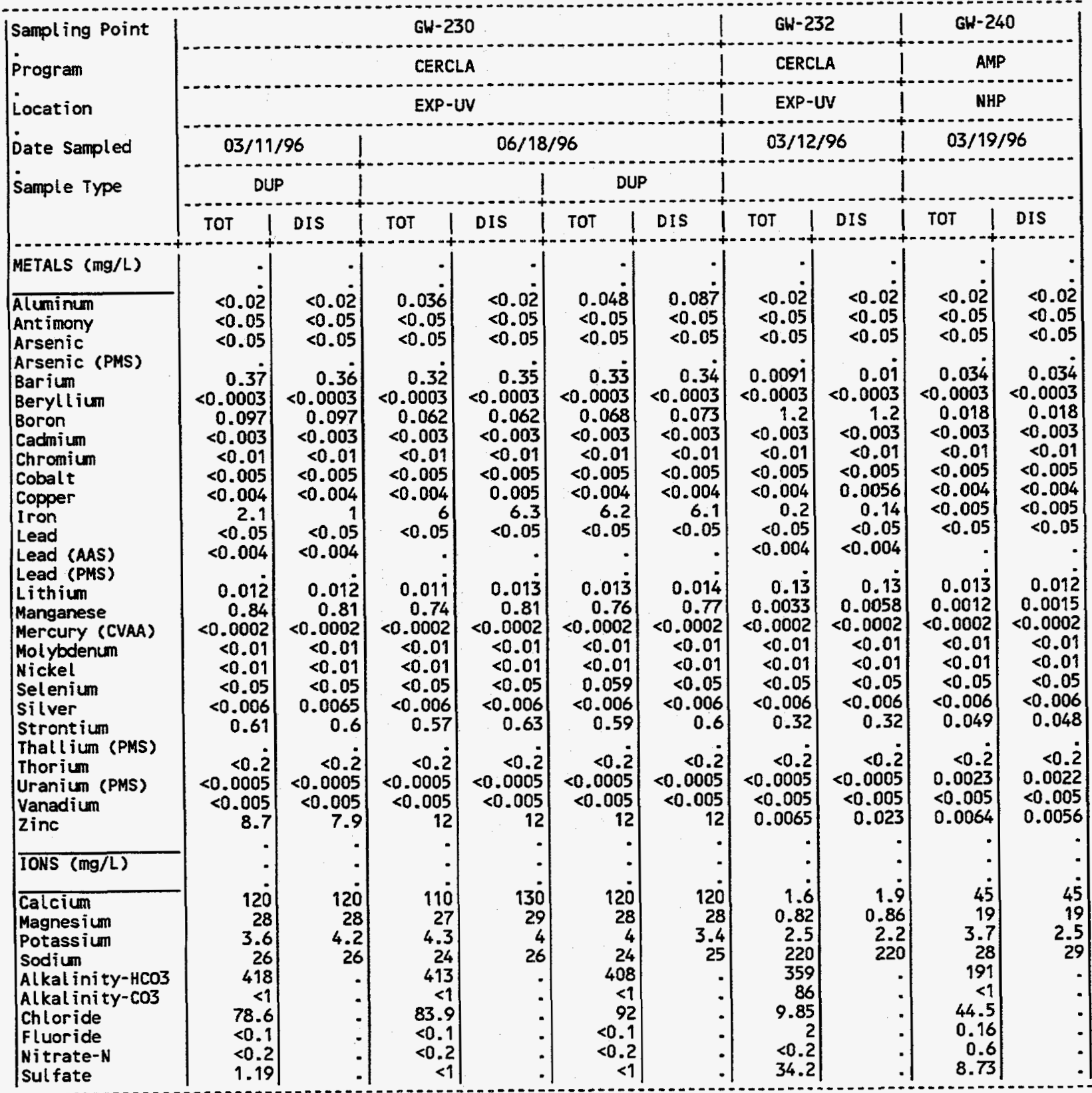

(CONT INUED) 
APPENDIX D.2

Inorganic Analytes, CY 1996

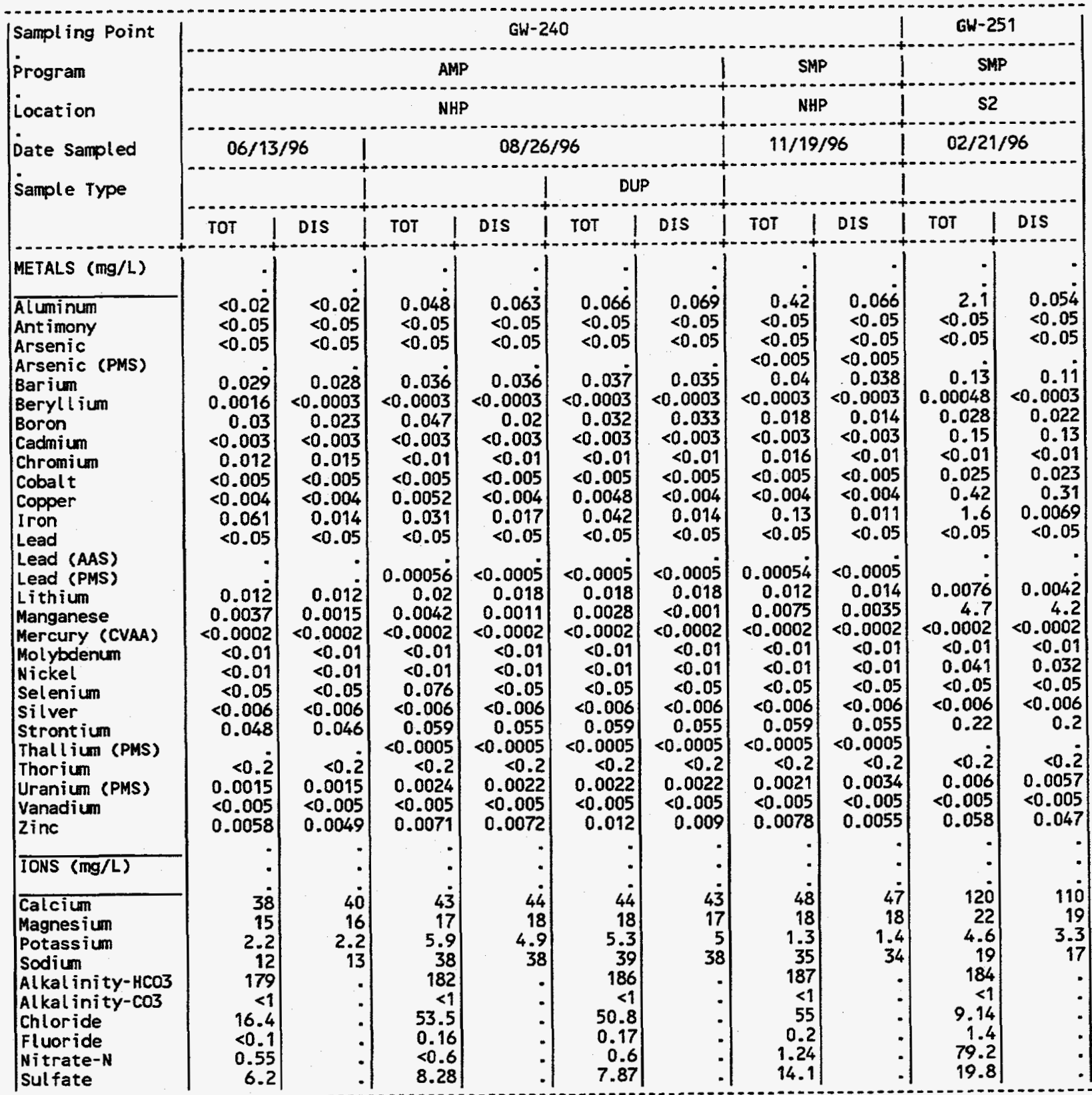

(CONTINUED) 
APPENDIX 0.2

Inorganic Analytes, CY 1996

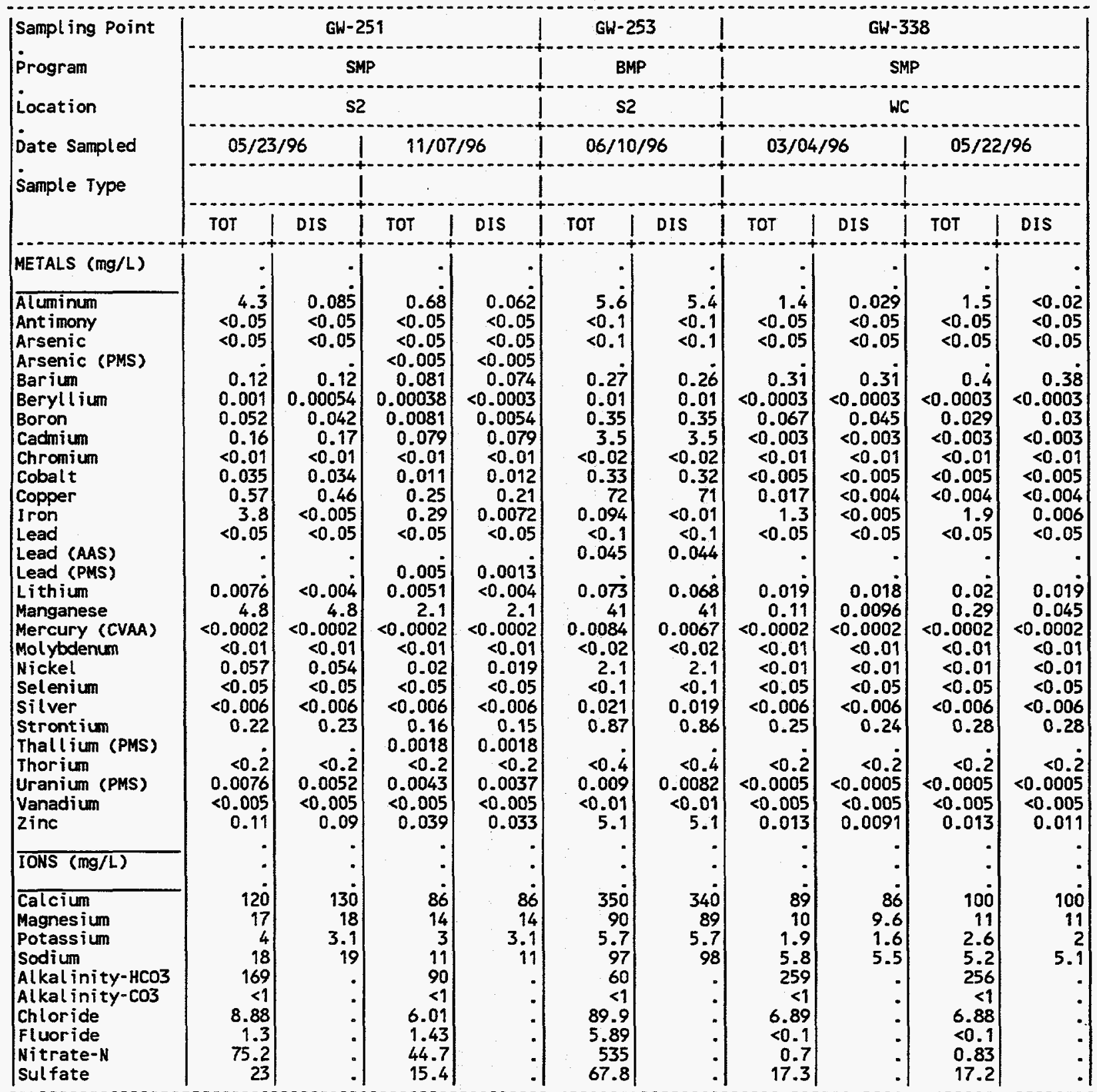

(CONTINUED) 
APPENDIX 0.2

Inorganic Analytes, CY 1996

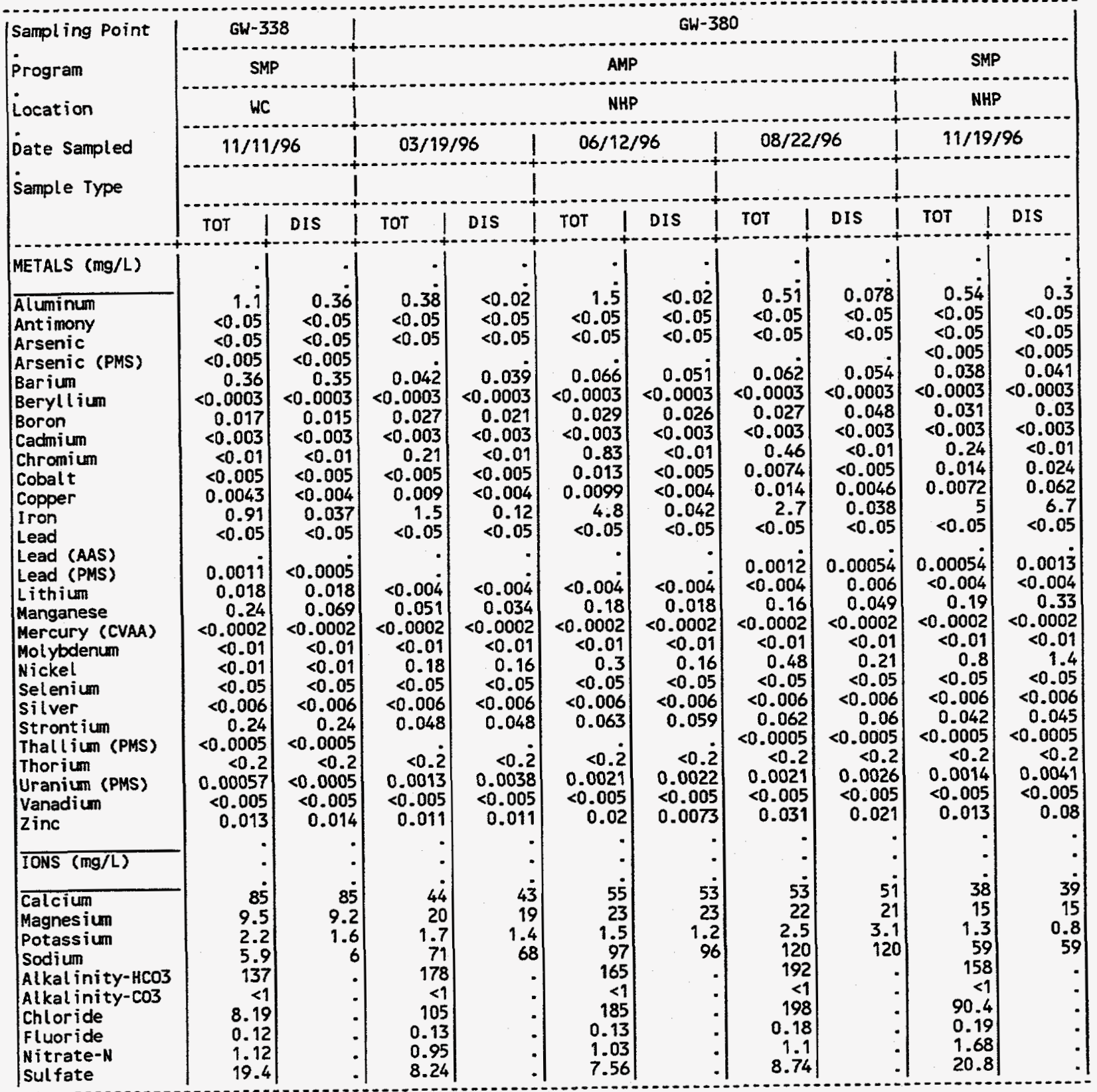

(CONT I NUED) 
APPENDIX 0.2

Inorganic Analytes, CY 1996

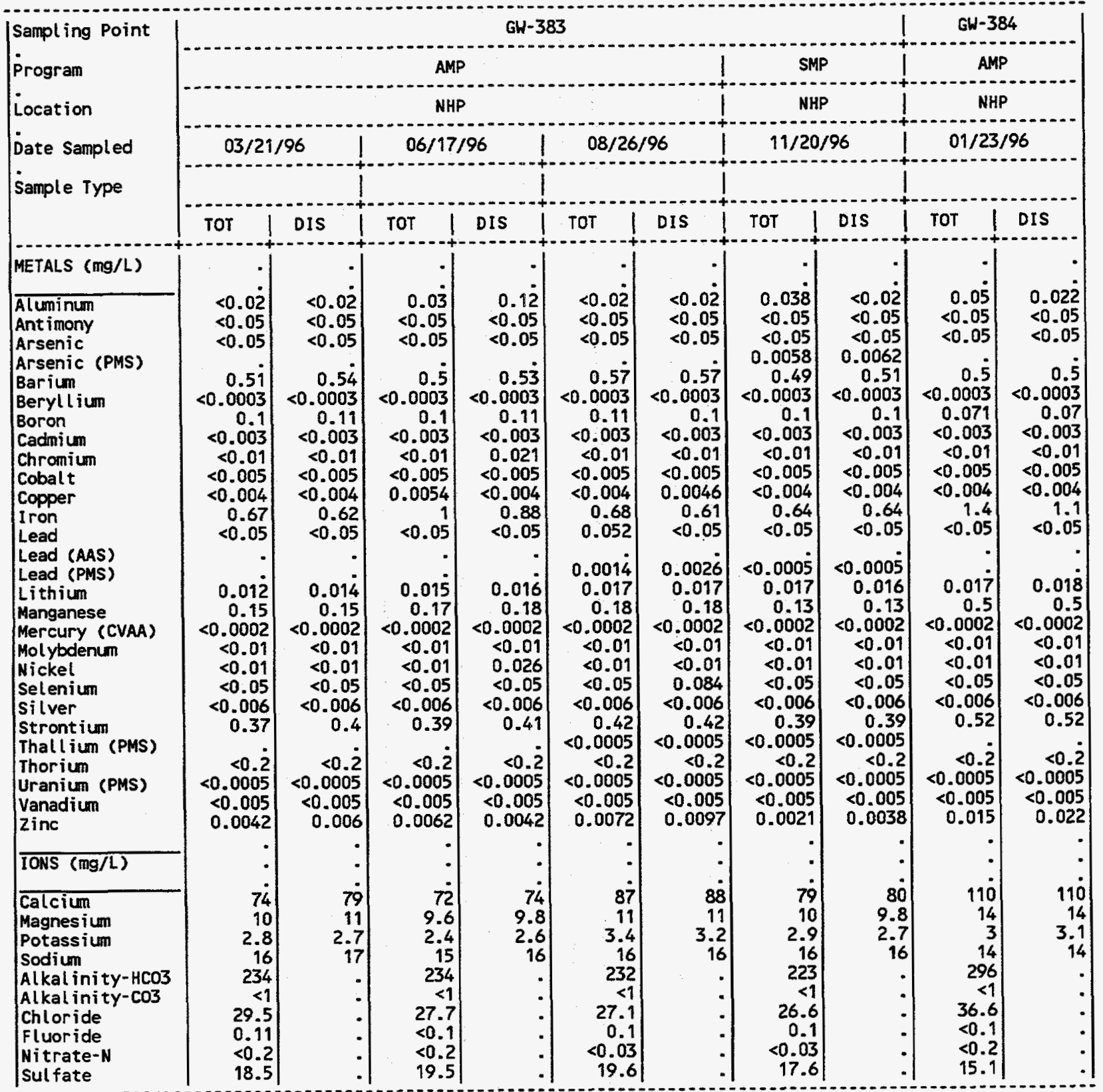

(CONTINUED) 
APPENDIX 0.2

Inorganic Analytes, CY 1996

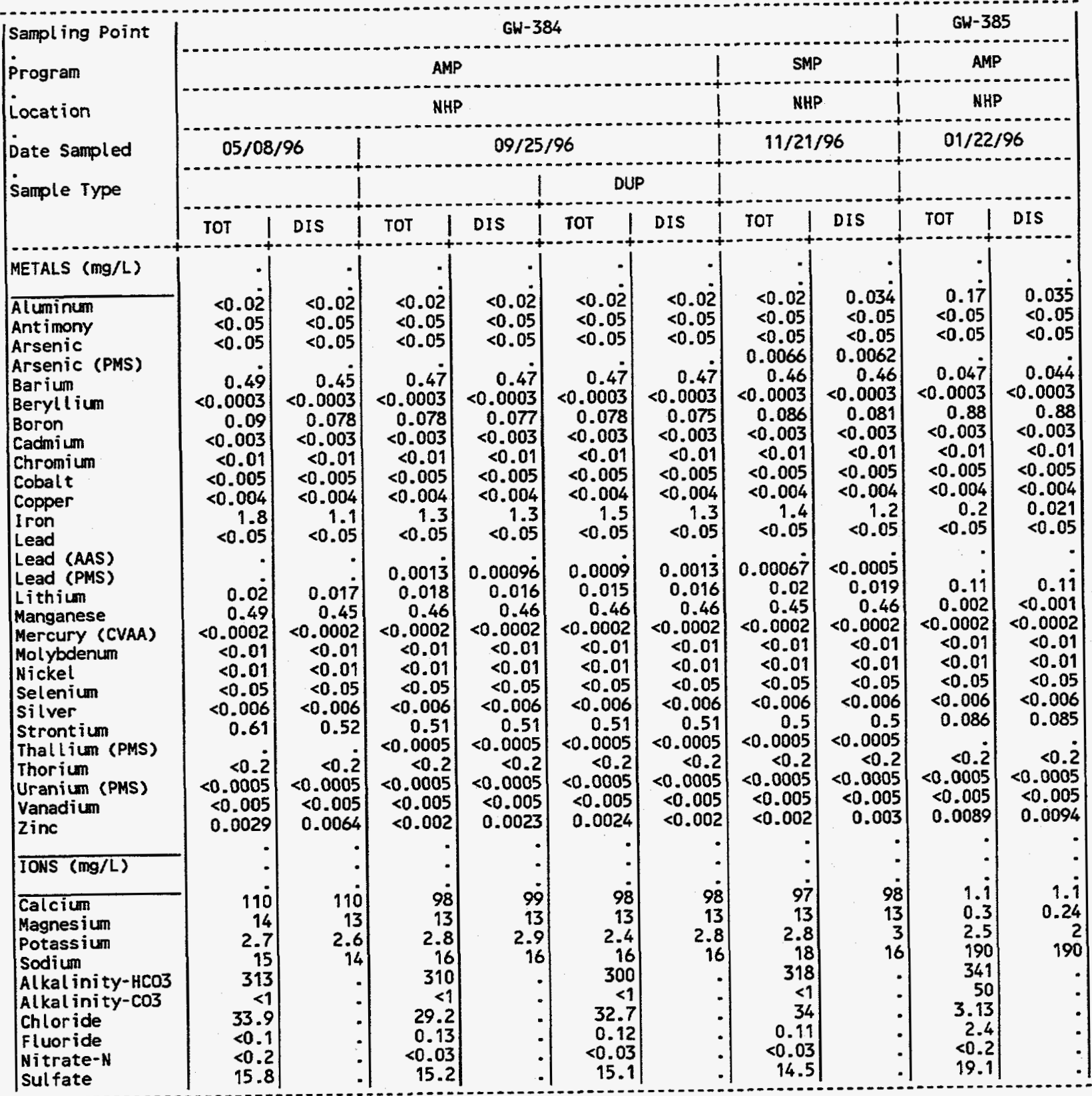

(CONTINUED) 
APPENDIX D.2

Inorganic Analytes, CY 1996

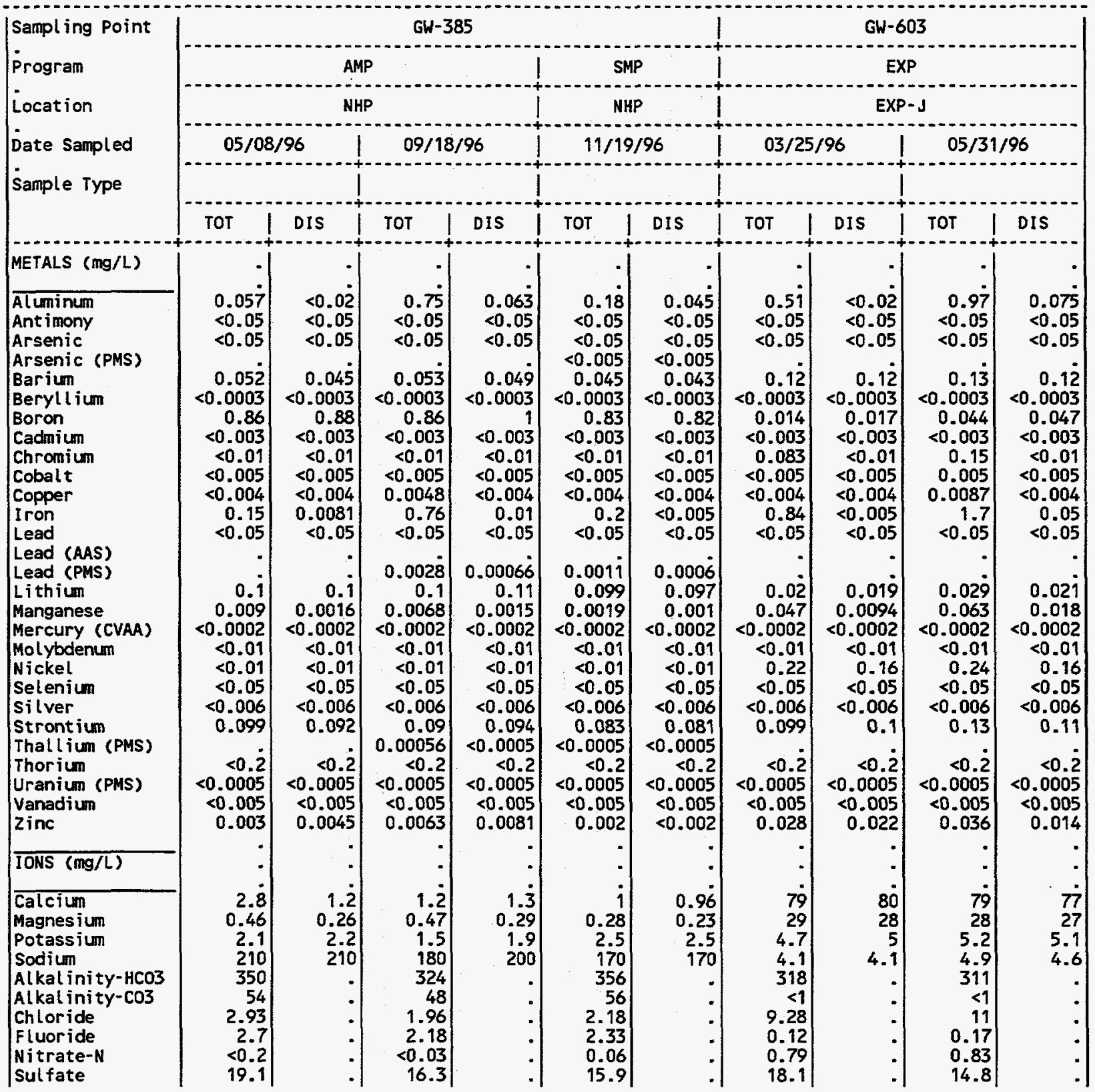

(CONT I NUED) 
Inorganic Analytes, CY 1996

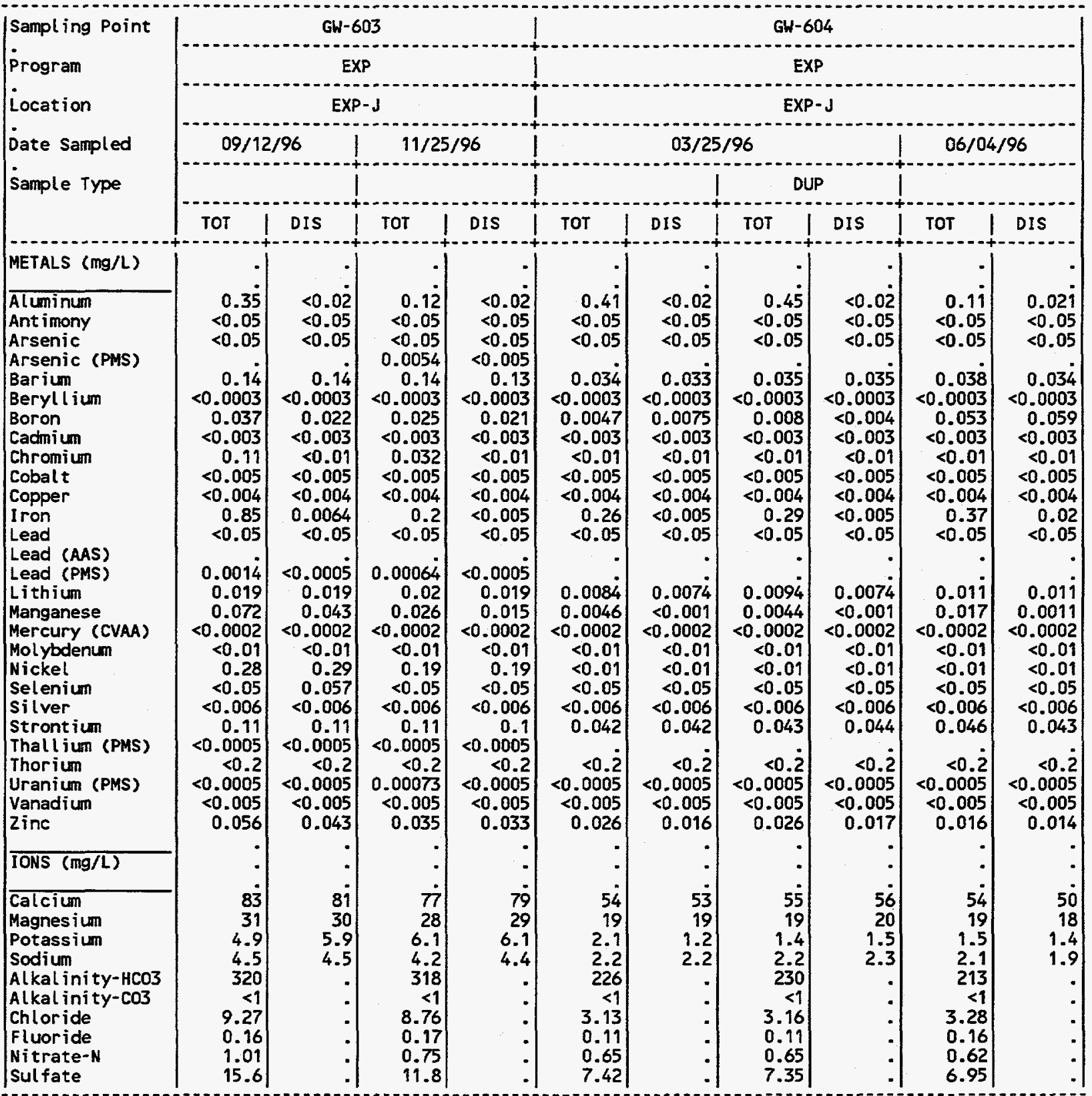

(CONT INUED) 
APPENDIX 0.2

Inorganic Analytes, CY 1996

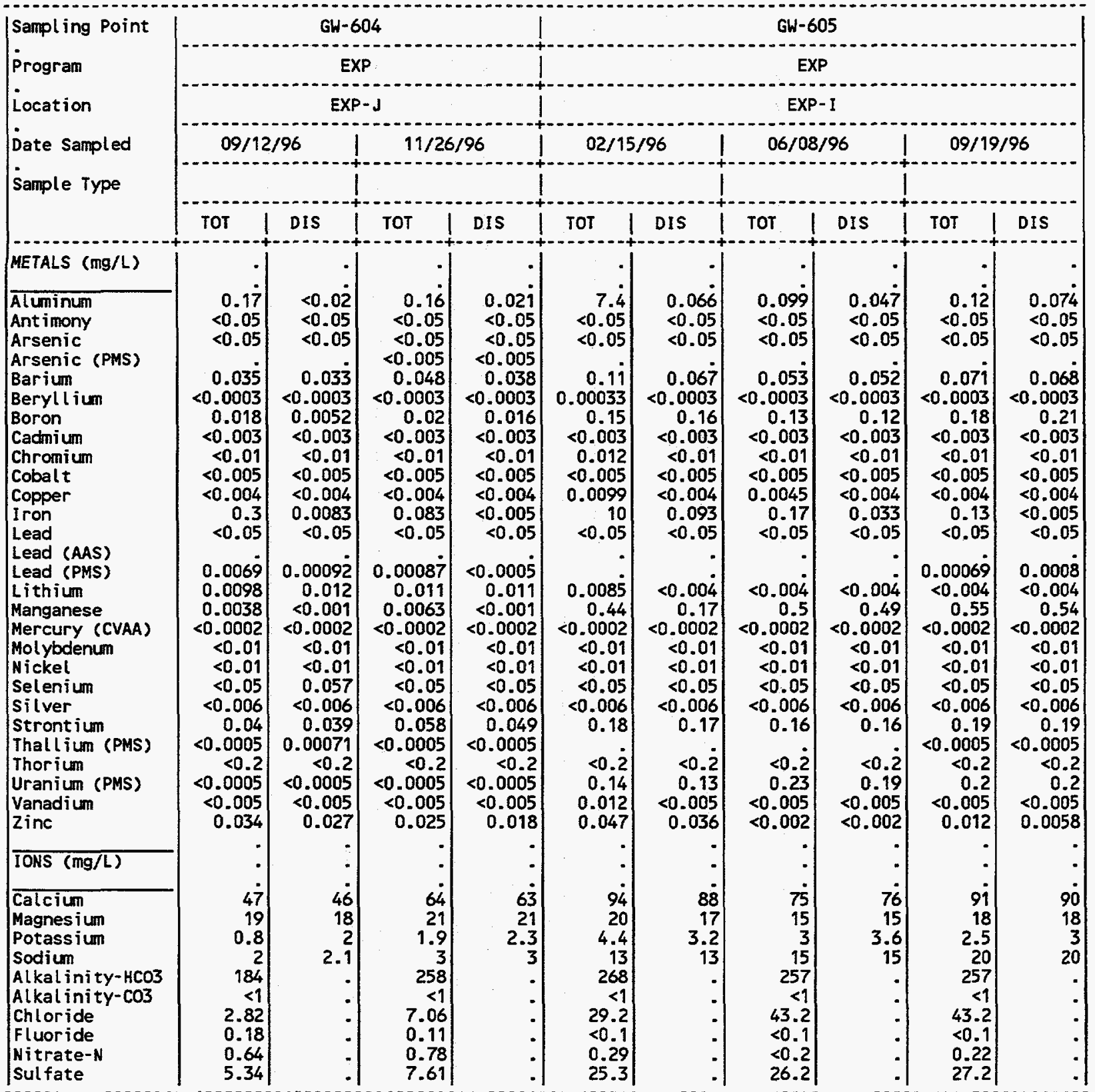

(CONTINUED) 
APPENDIX D.2

Inorganic Analytes, CY 1996

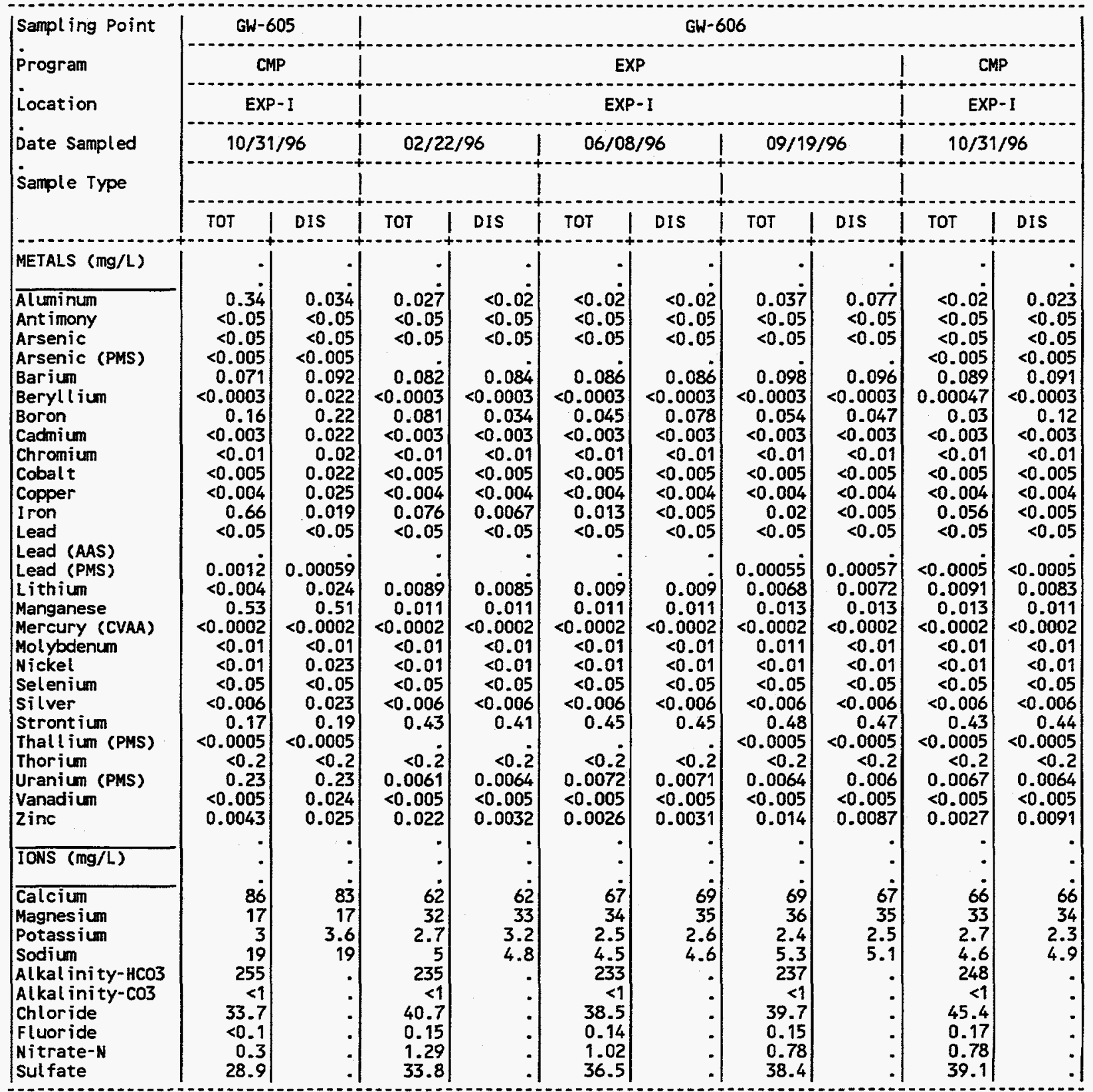

(CONT INUED) 
APPENDIX 0.2

Inorganic Analytes, CY 1996

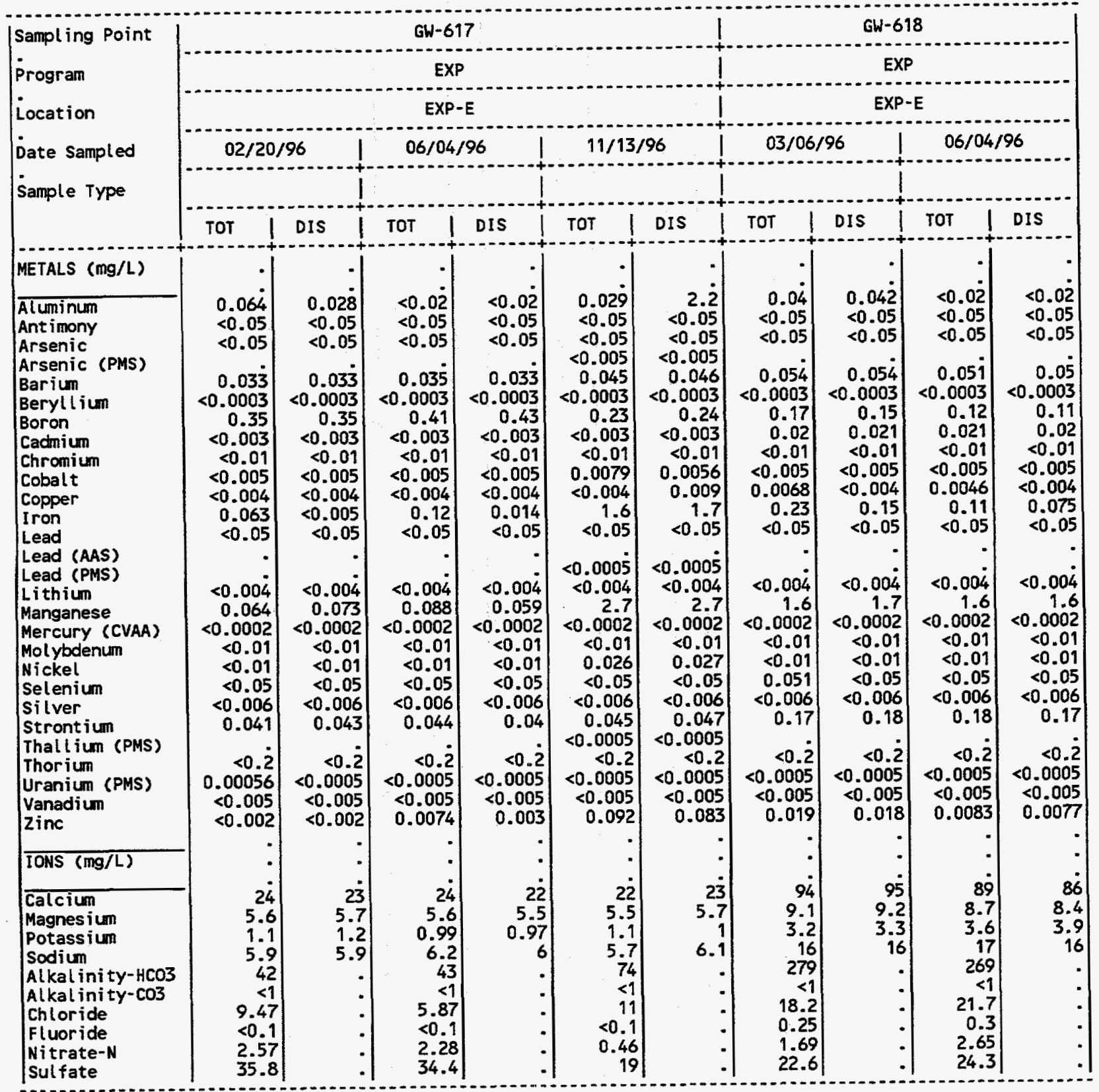

(CONTINUED) 
APPENDIX 0.2

Inorganic Analytes, CY 1996

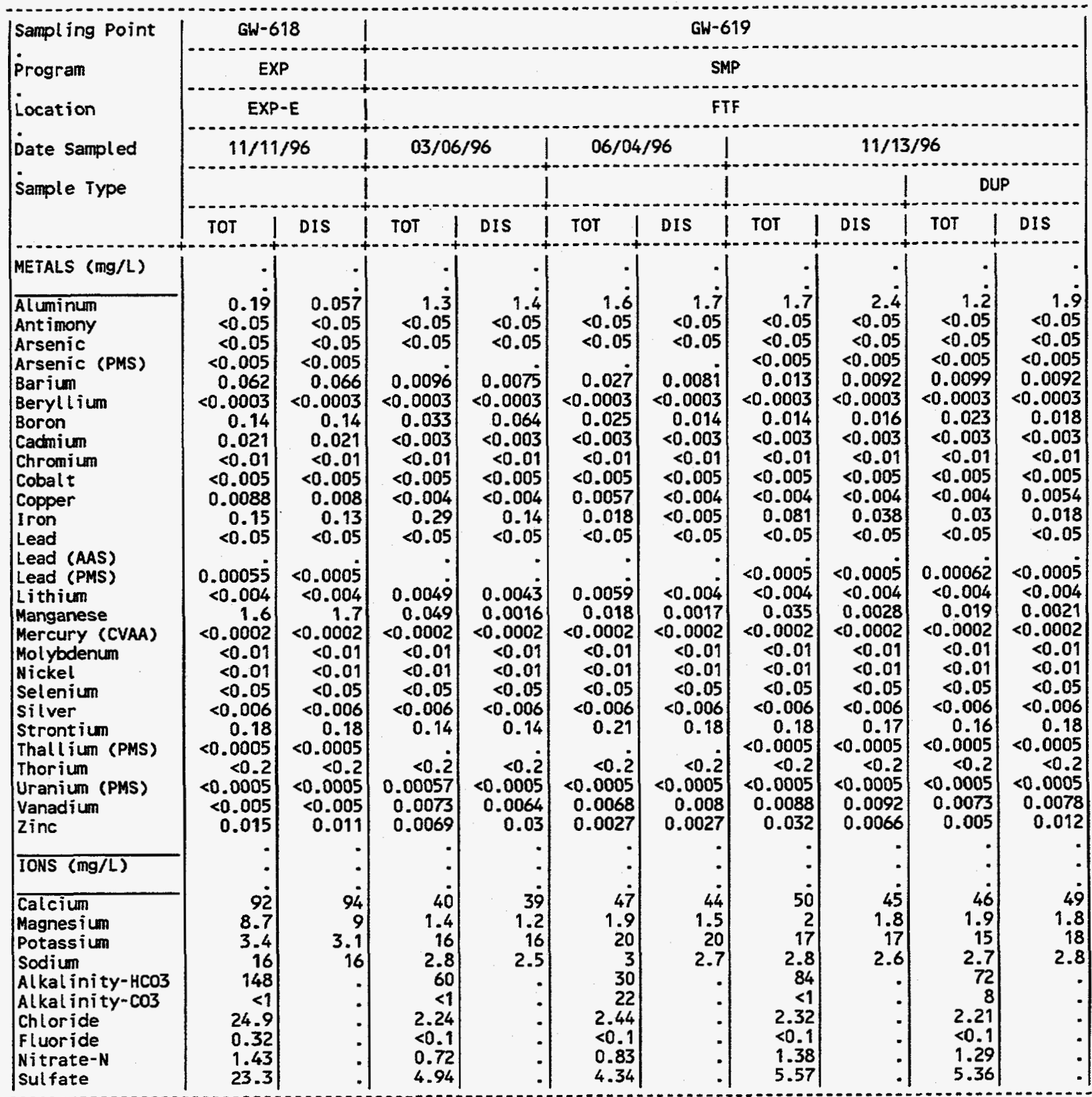

(CONTINUED) 
APPENDIX 0.2

Inorganic Analytes, CY 1996

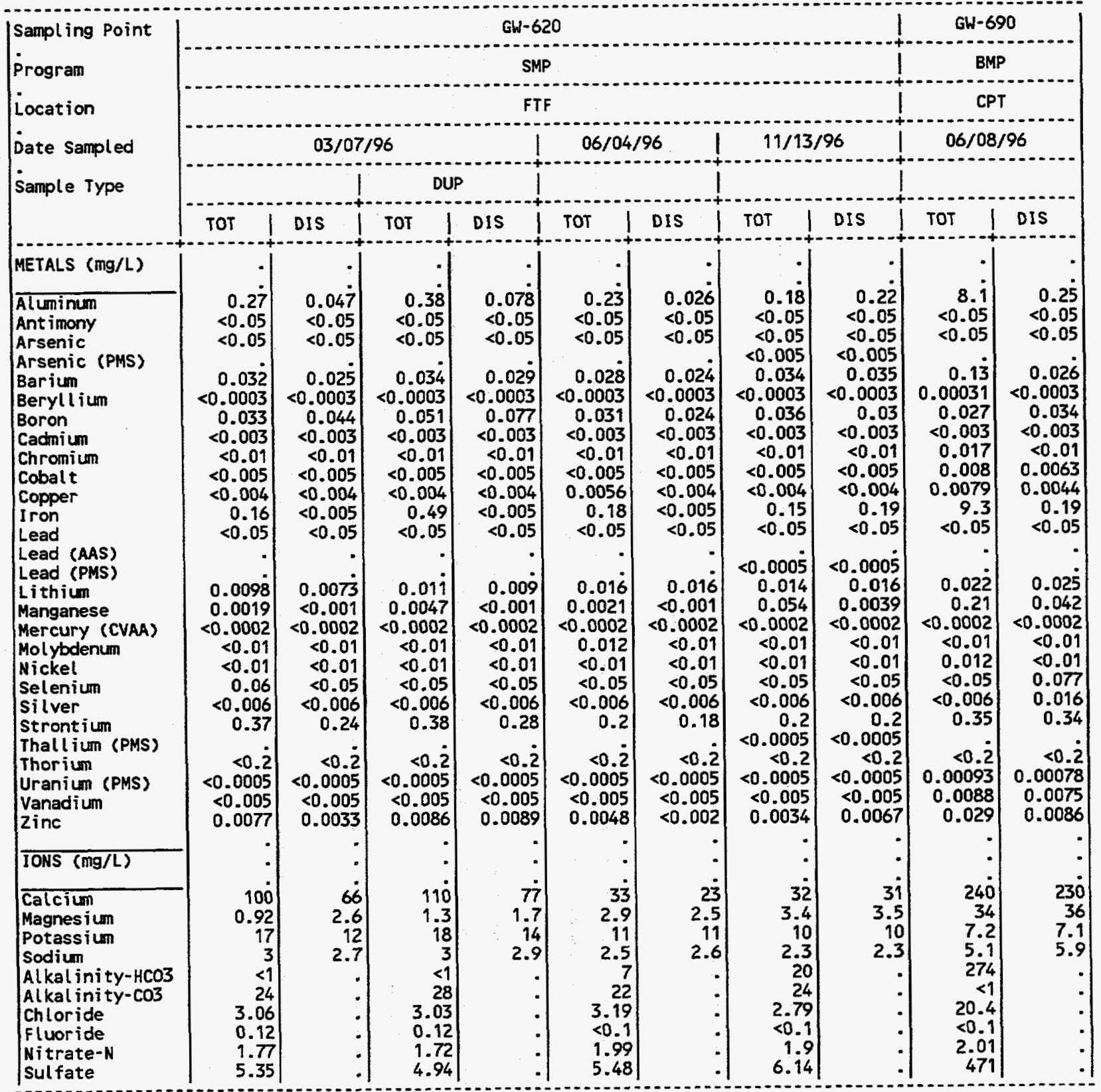

(CONTINUED) 
APPENDIX D.2

Inorganic Analytes, CY 1996

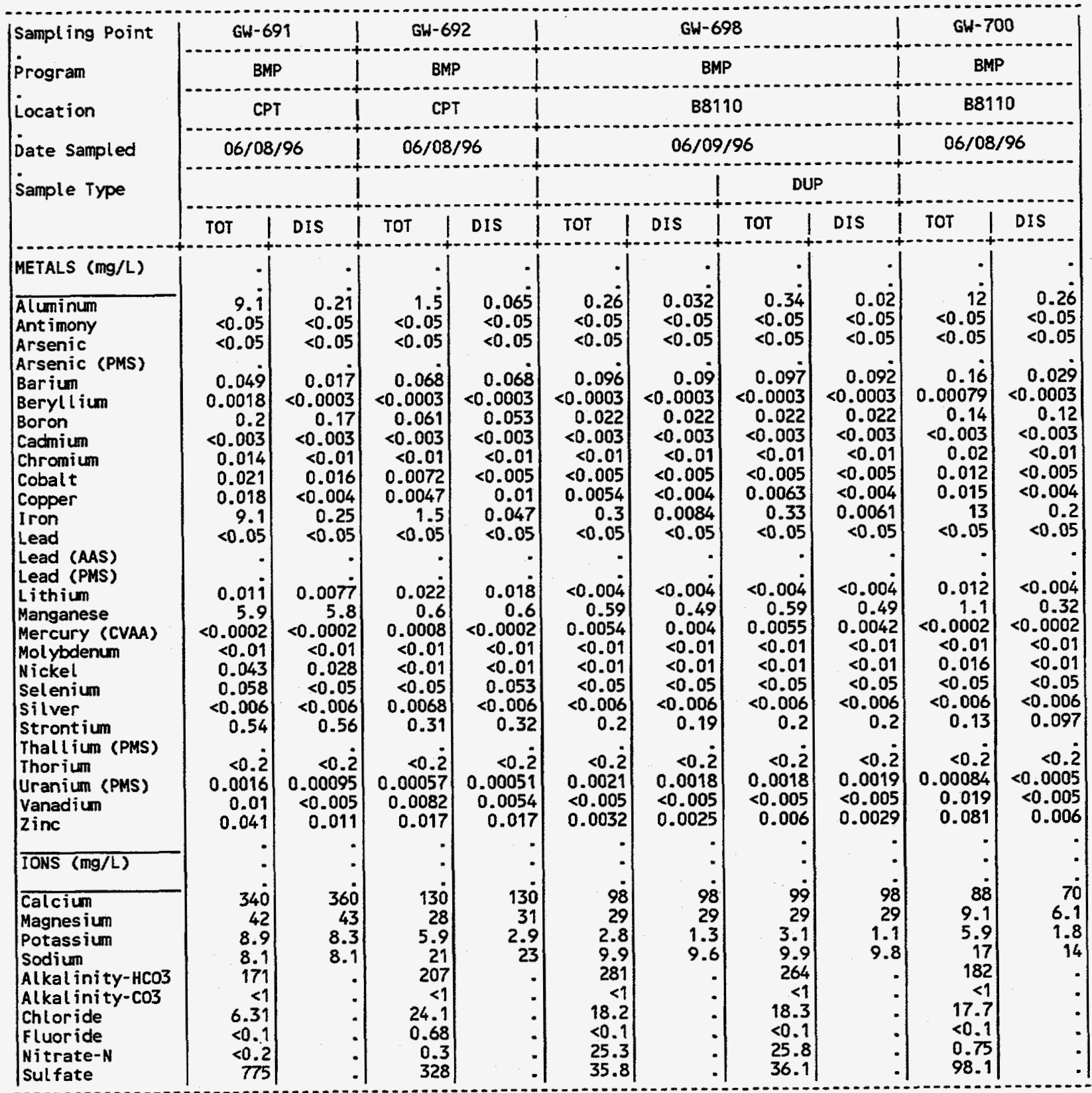

(CONTINUED) 
APPENDIX D.2

Inorganic Analytes, CY 1996

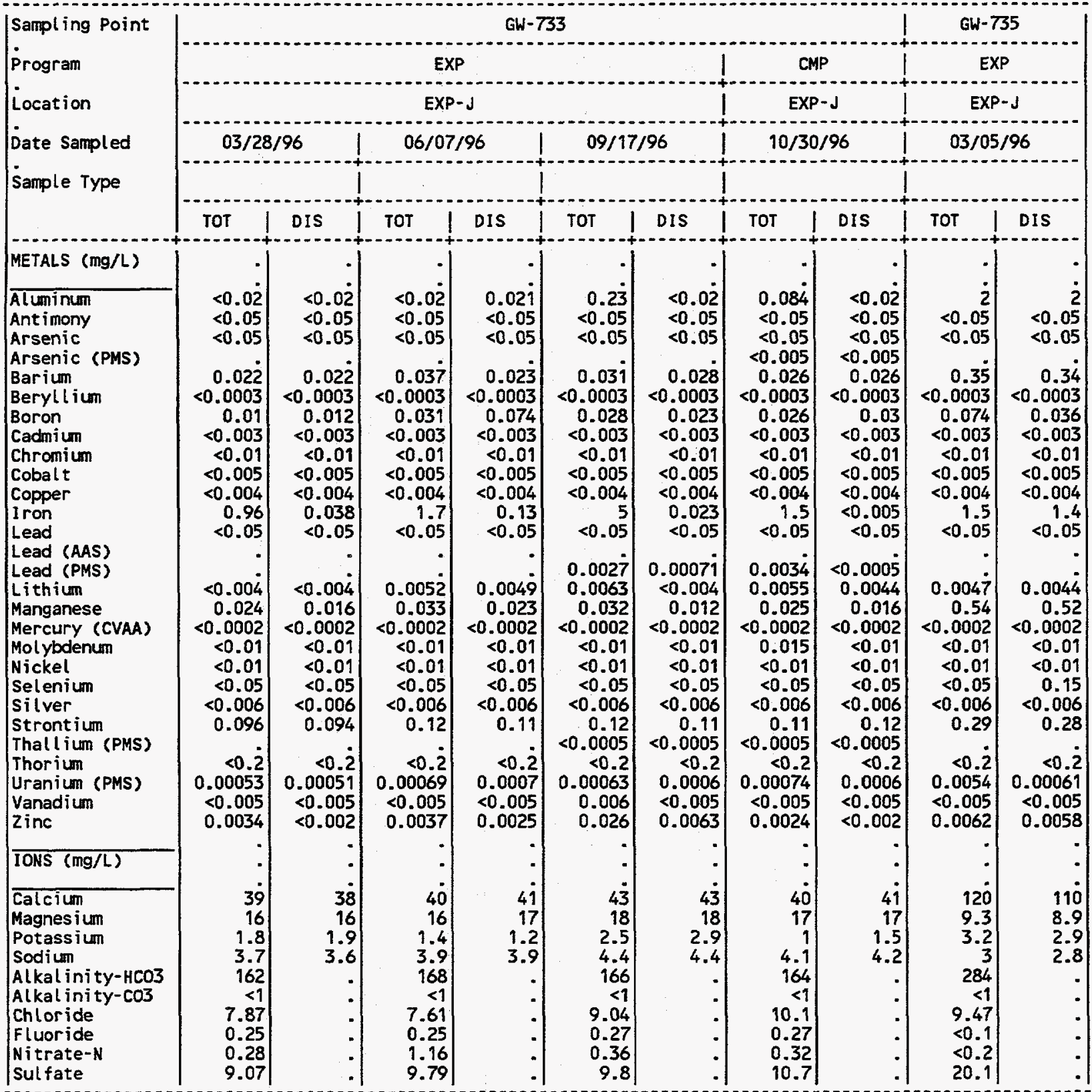

(CONTINUED) 
APPEND IX 0.2

Inorganic Analytes, Cy 1996

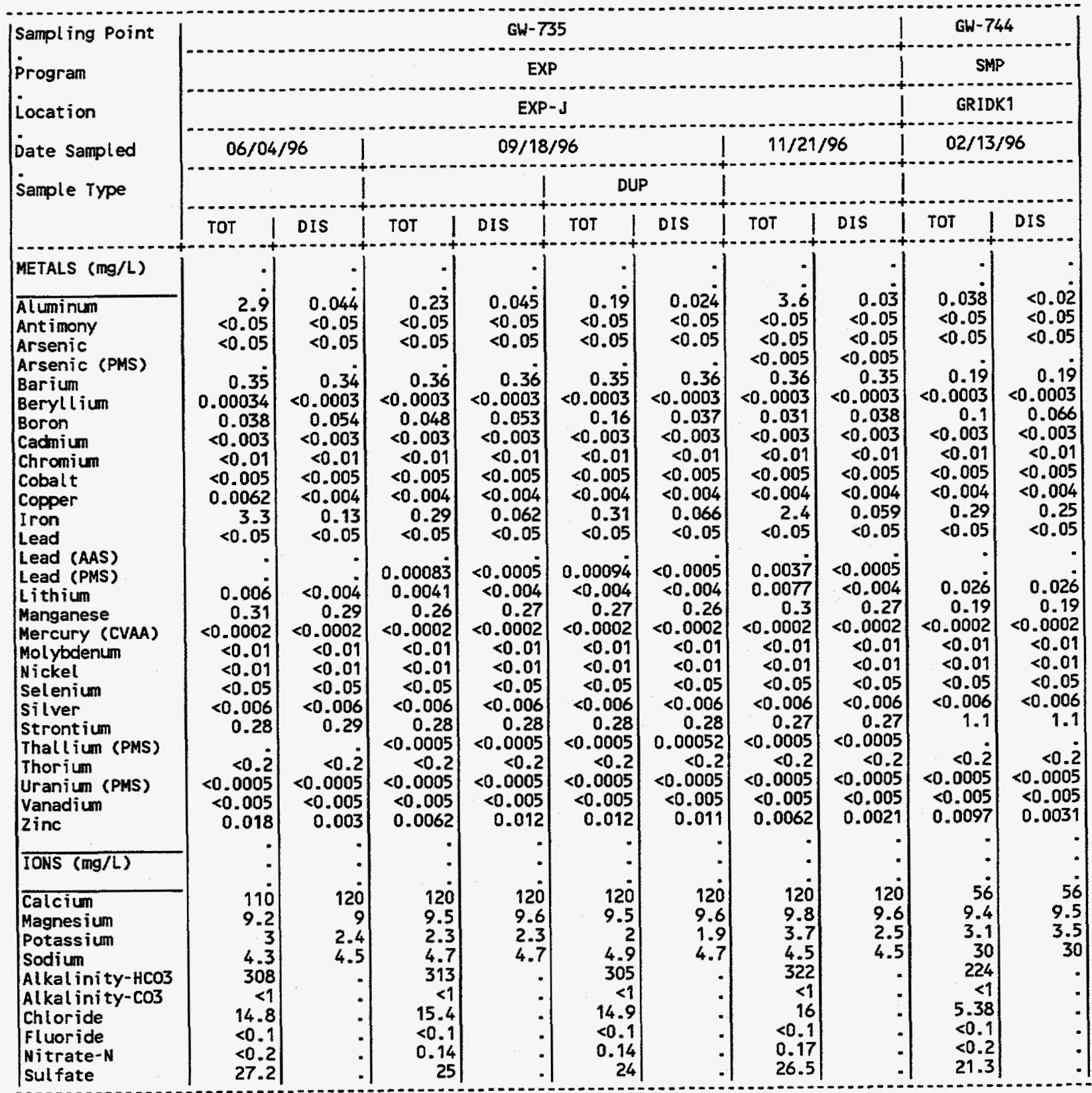

(CONT INUED) 
APPENDIX 0.2

Inorganic Analytes, cr 1996

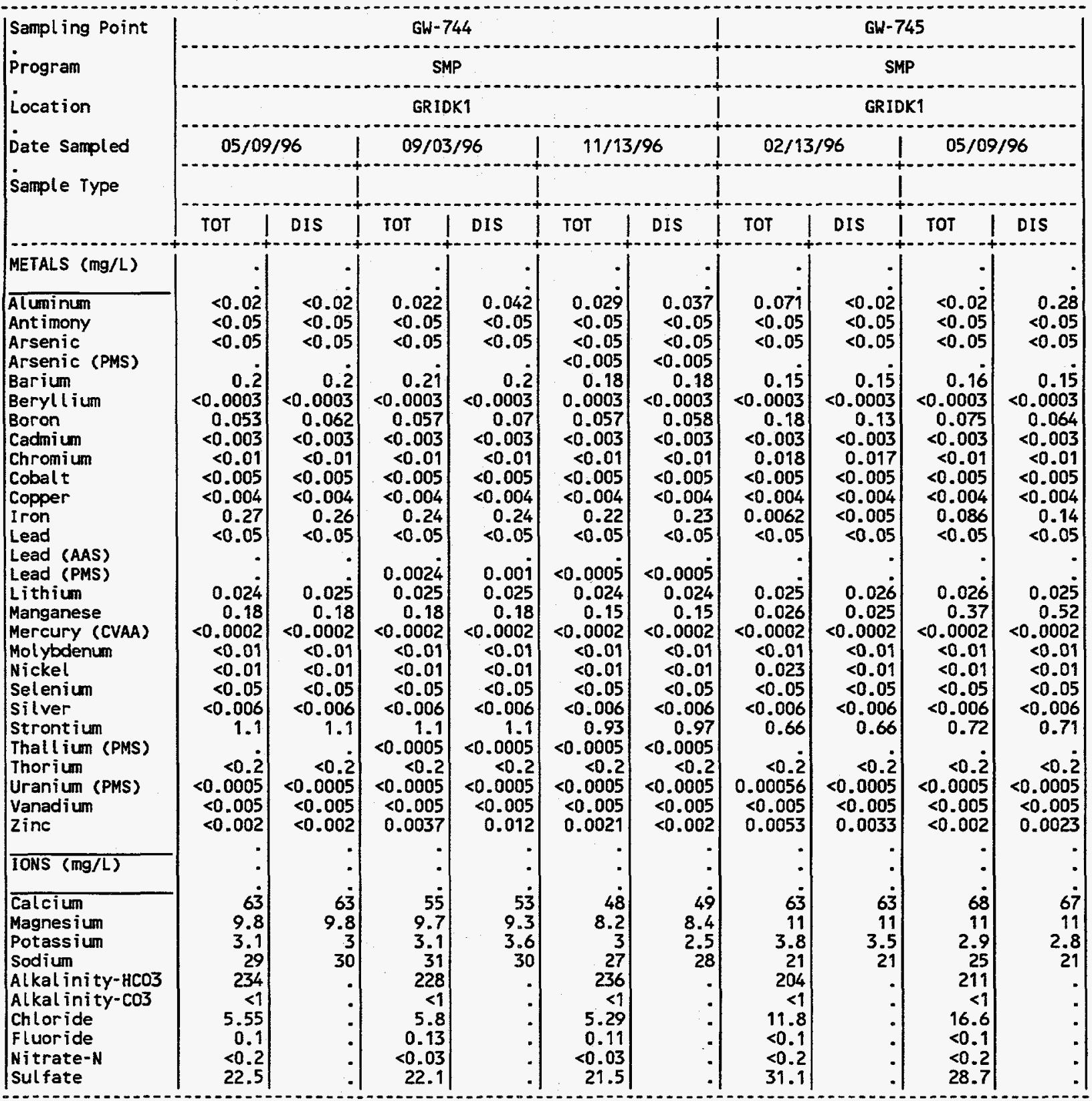

(CONTINUED) 
APPENDIX D.2

Inorganic Analytes, CY 1996

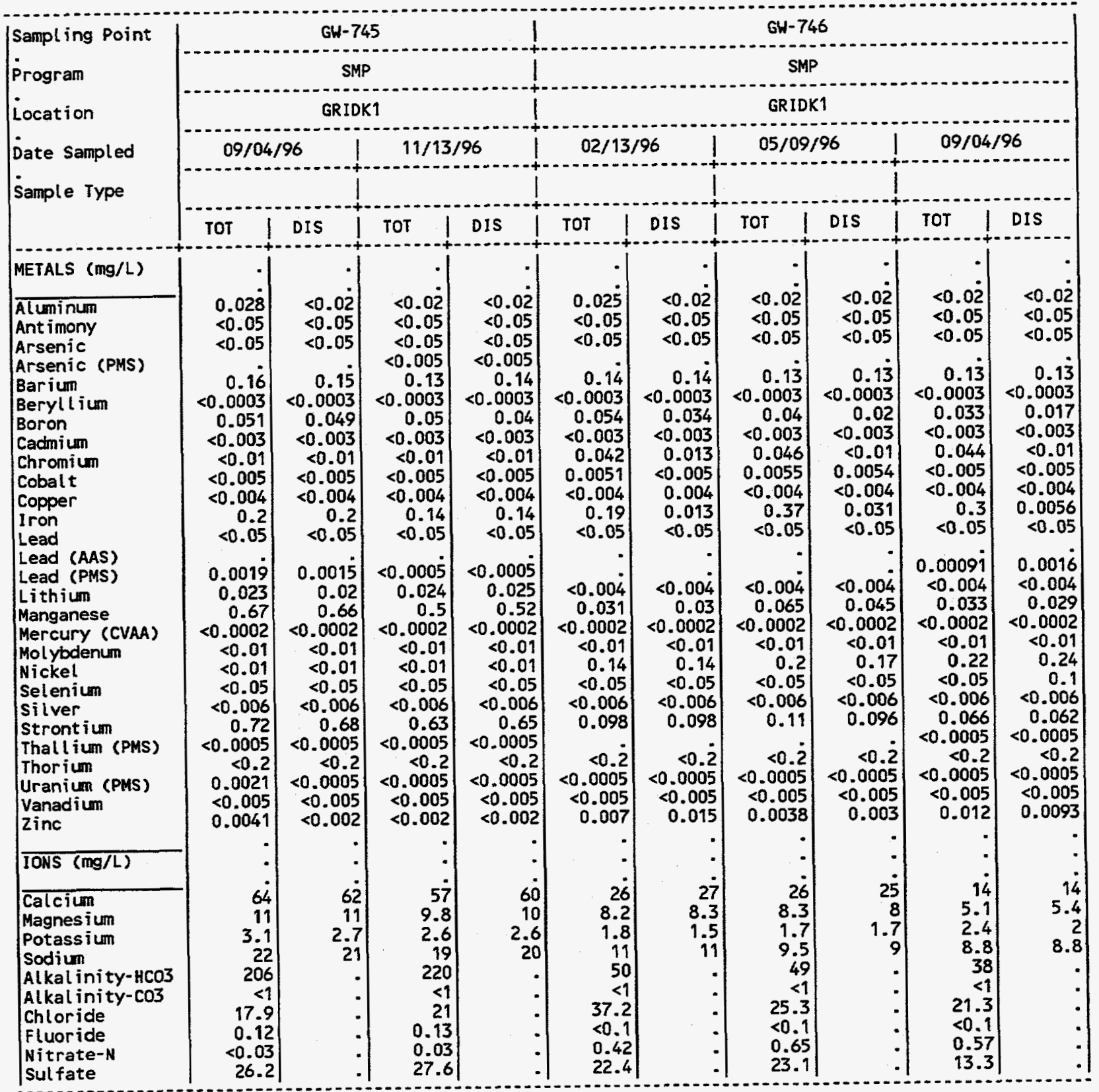

(CONTINUED) 
APPENDIX 0.2

Inorganic Analytes, CY 1996

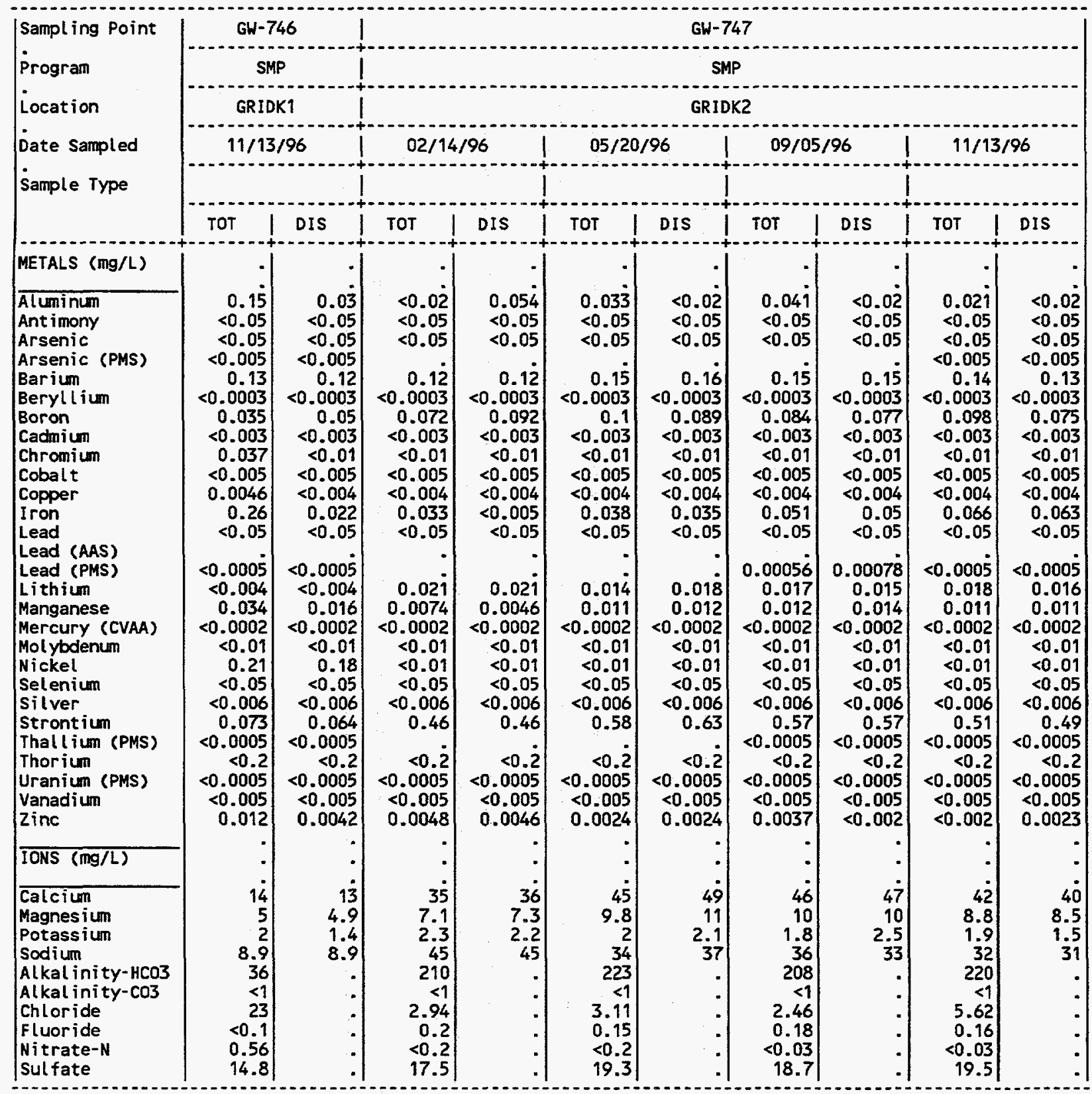

(CONTINUED) 
Inorganic Analytes, CY 1996

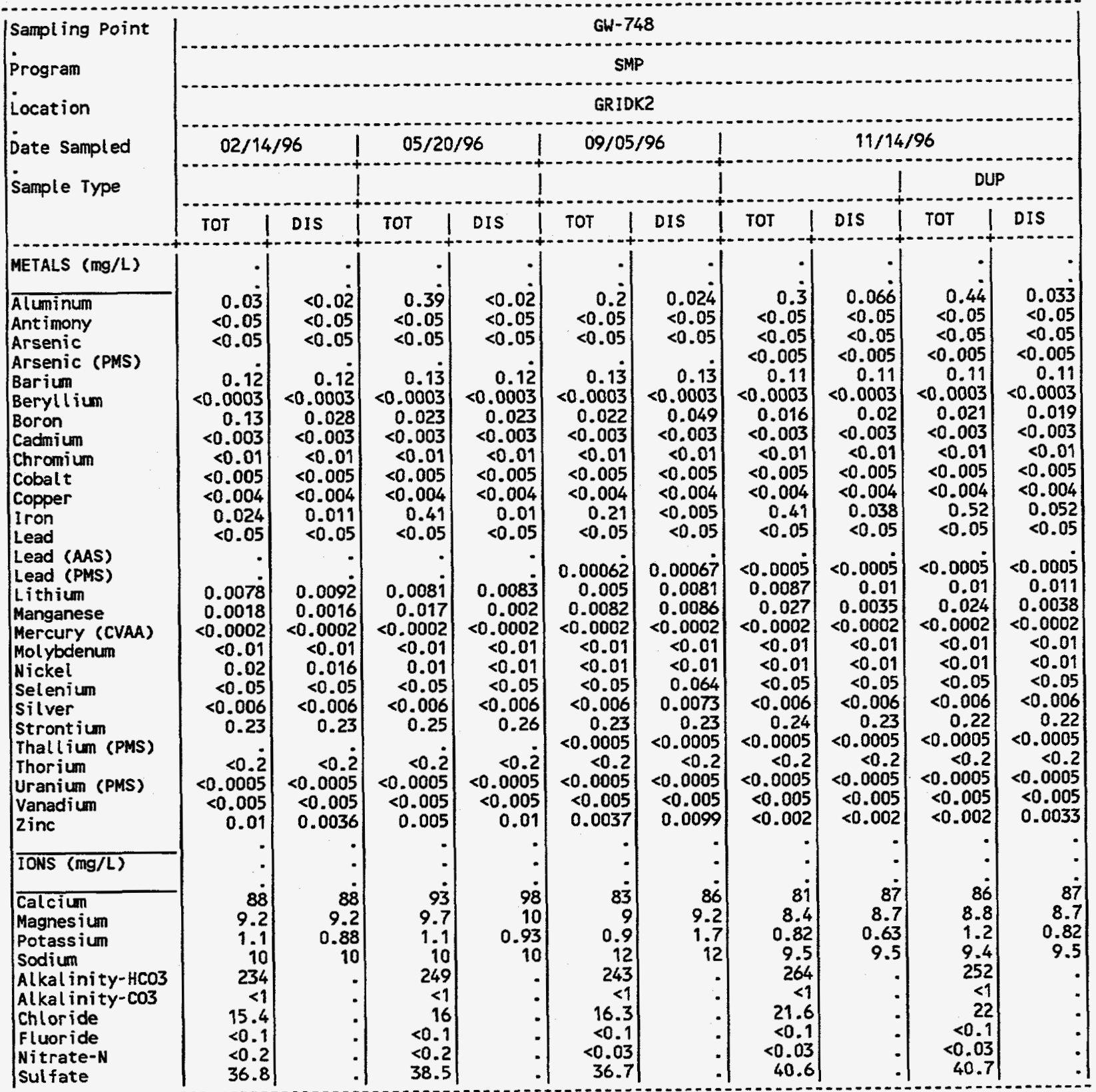

(CONTINUED) 
APPENDIX 0.2

Inorganic Analytes, Cr 1996

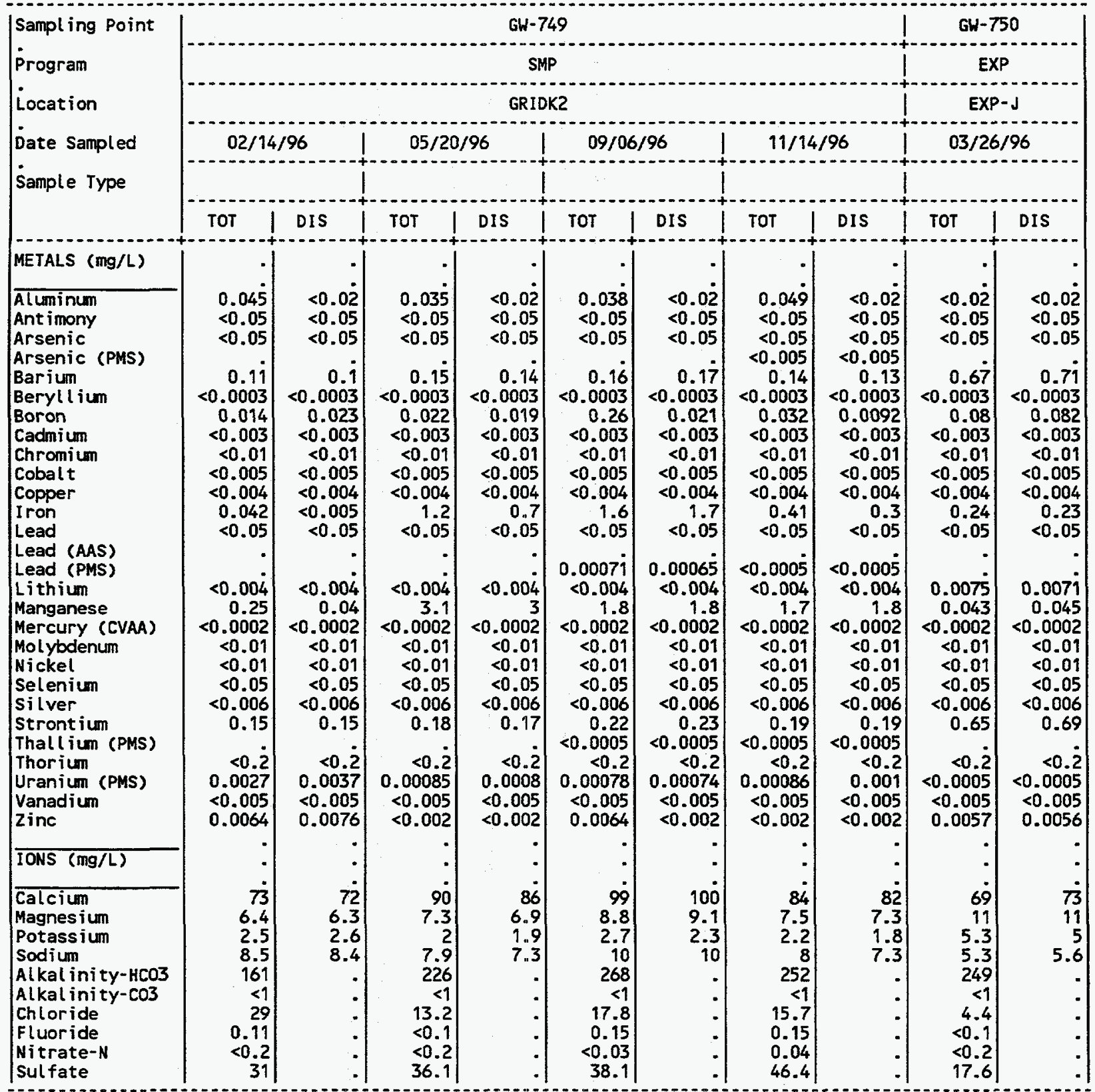

(CONTINUED) 
Inorganic Analytes, CY 1996

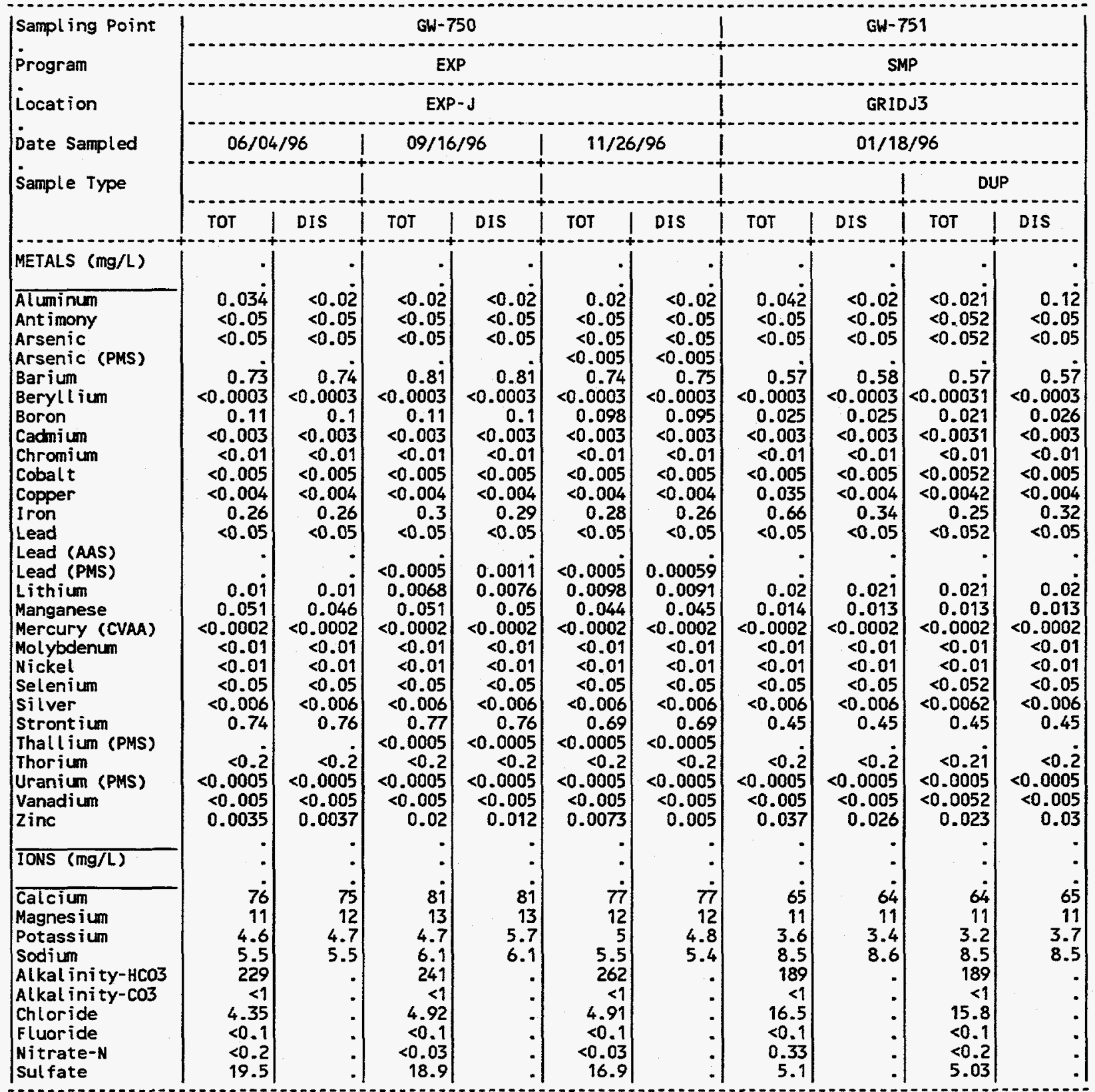

(CONTINUED) 
APPENDIX 0.2

Inorganic Analytes, CY 1996

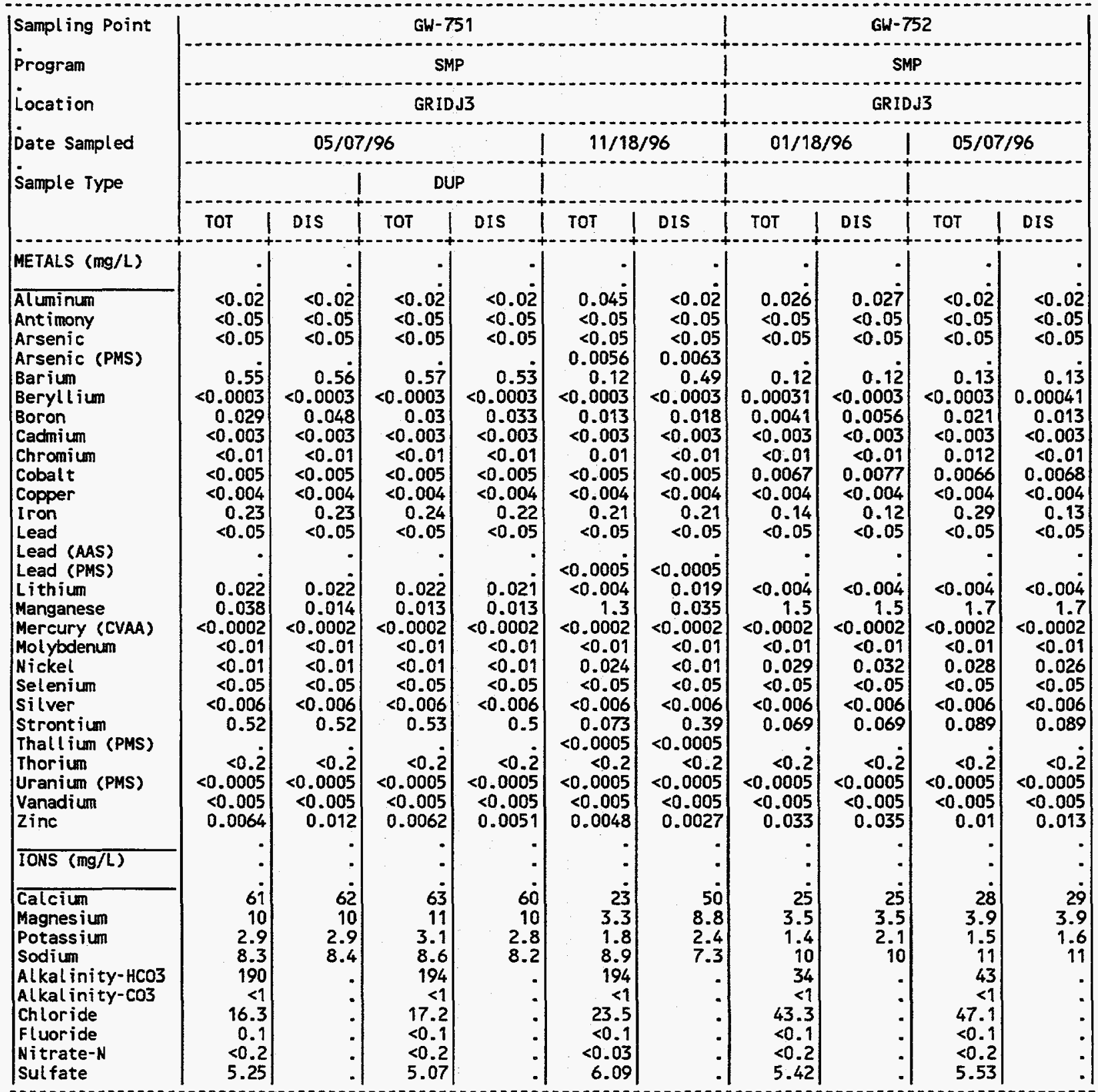

(CONTINUED) 
APPENDIX 0.2

Inorganic Analytes, CY 1996

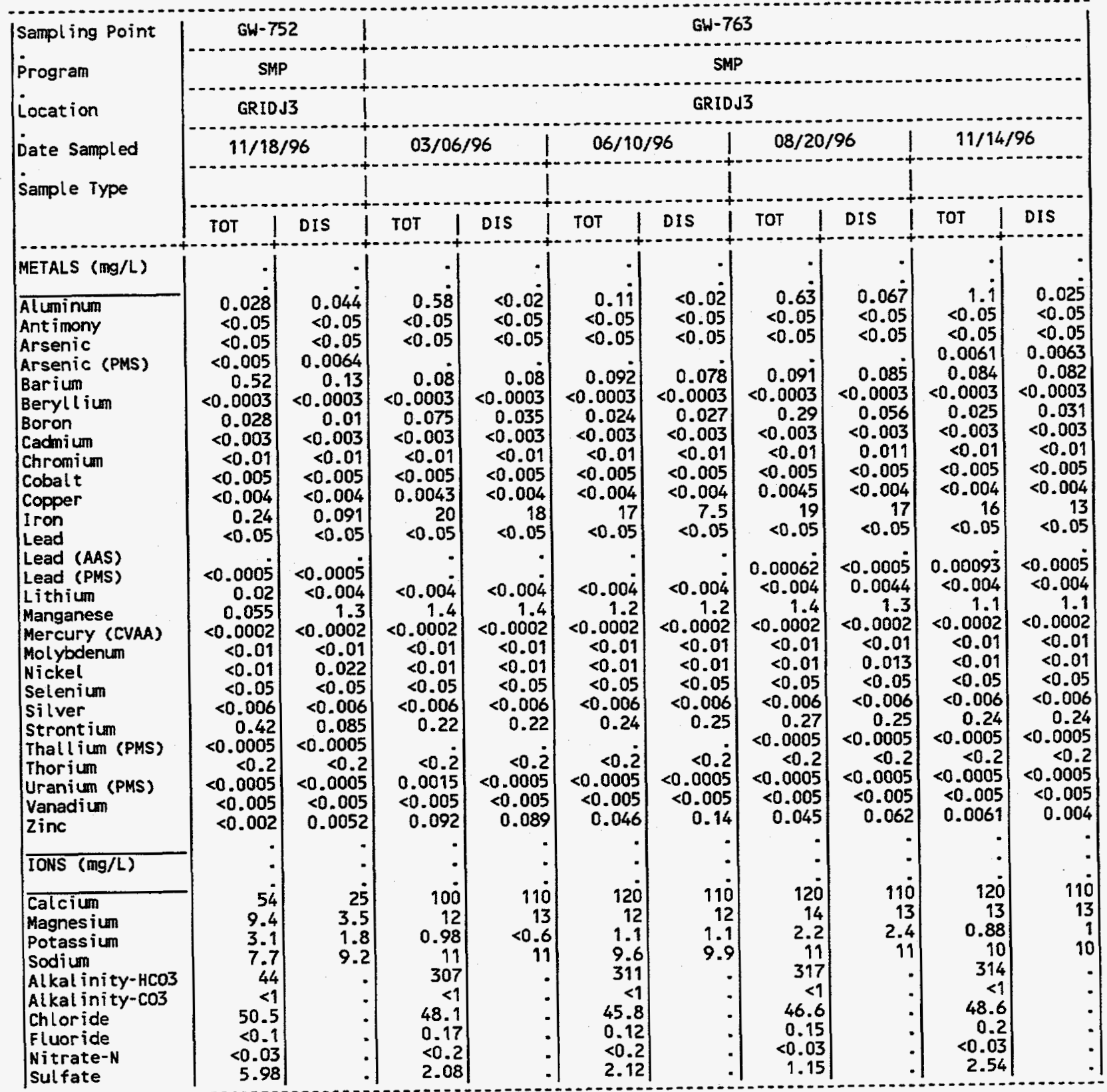

(CONT I NUED) 
APPENDIX D.2

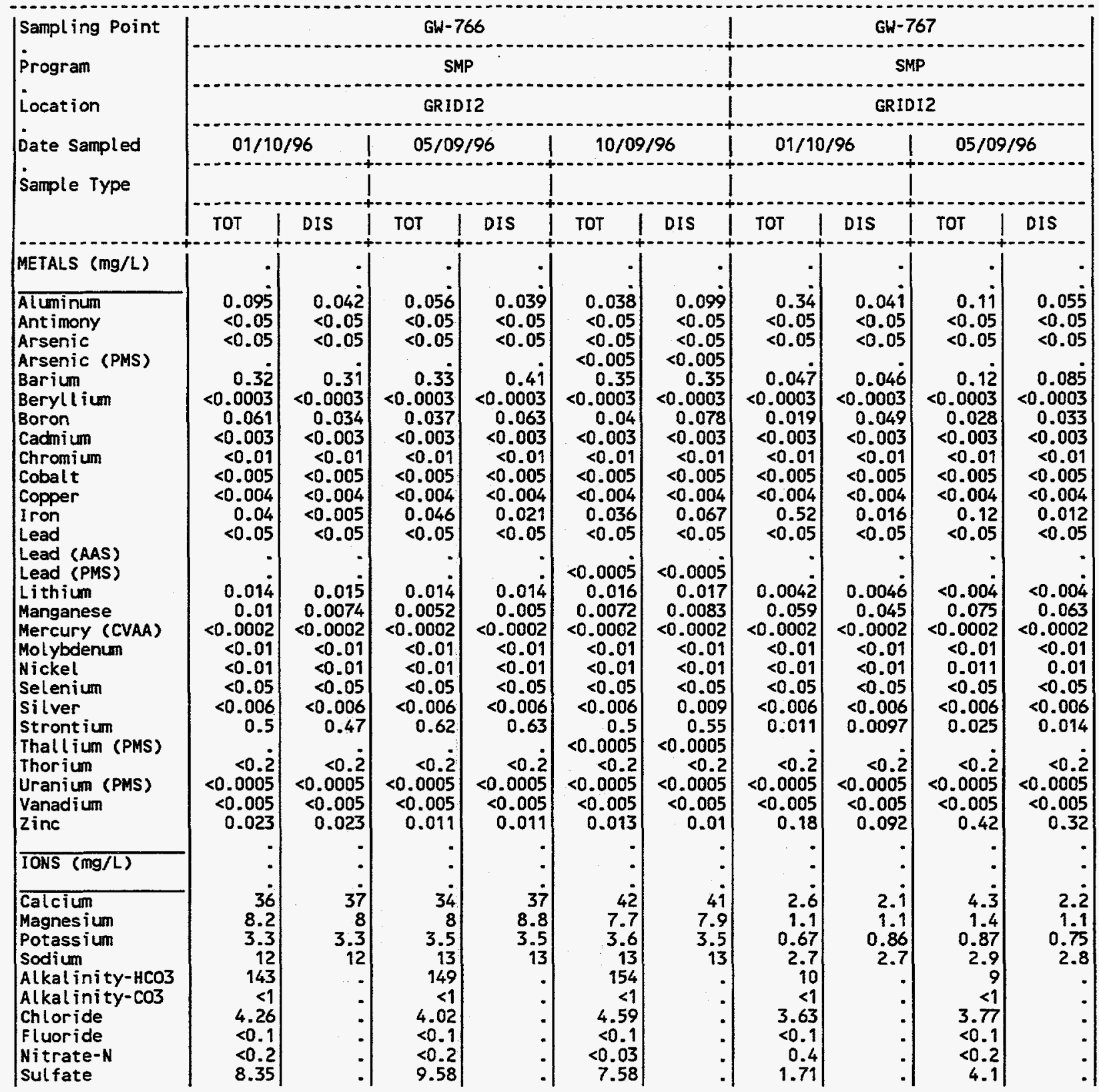


APPENDIX 0.2

Inorganic Analytes, CY 1996

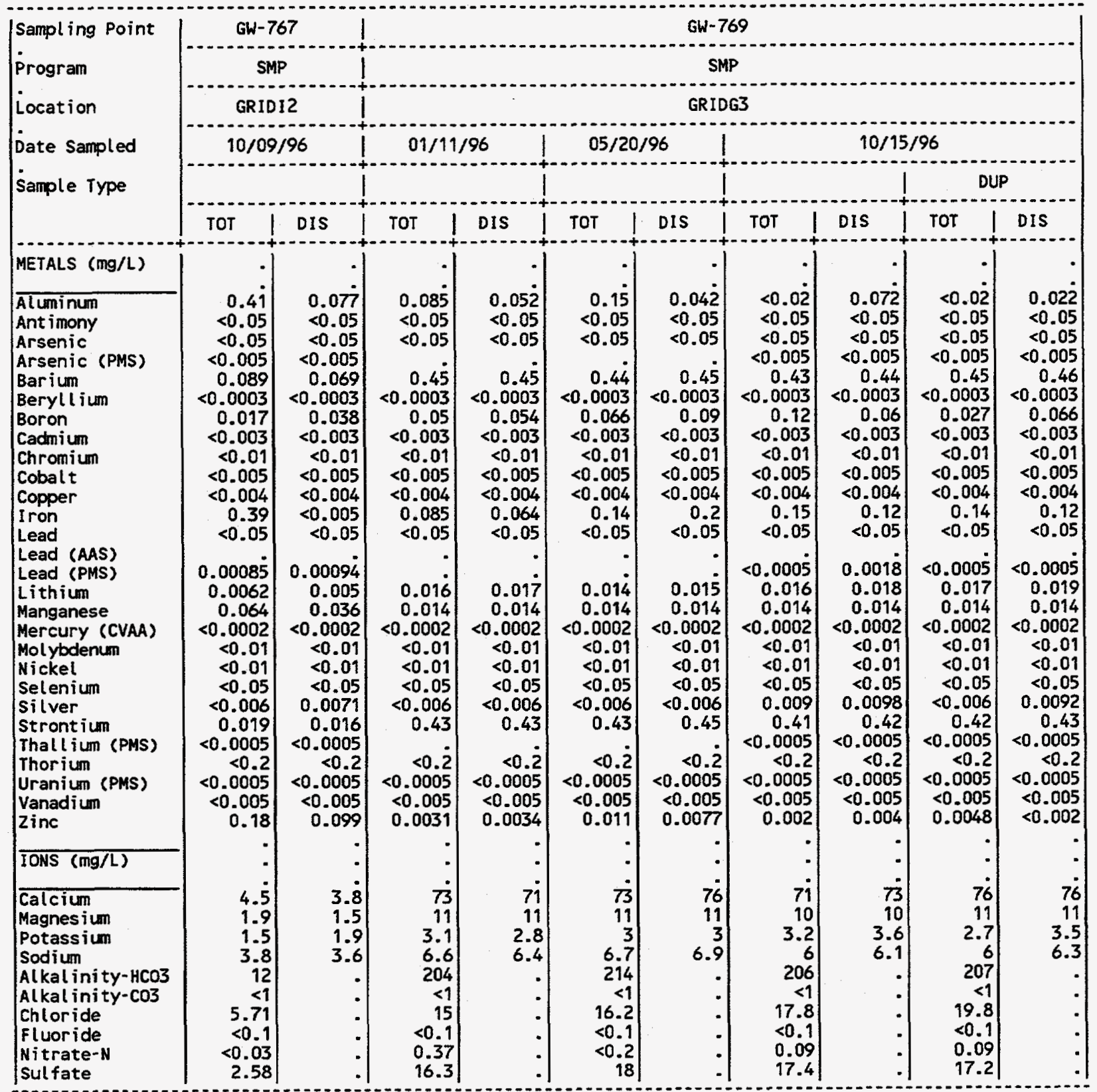

(CONTINUED) 
APPENDIX 0.2

Inorganic Analytes, CY 1996

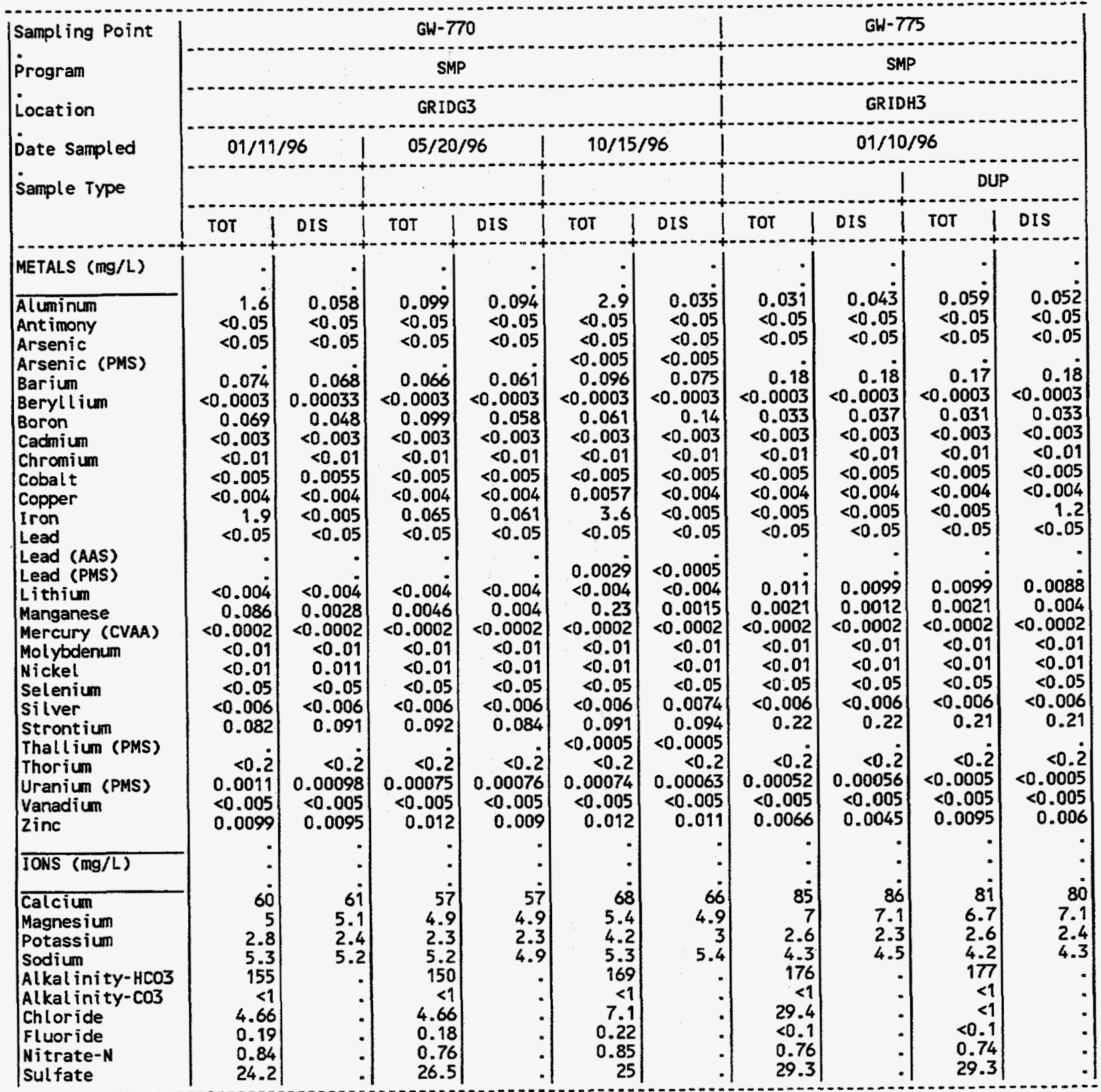

(CONTINUED) 
APPENDIX 0.2

Inorganic Analytes, CY 1996

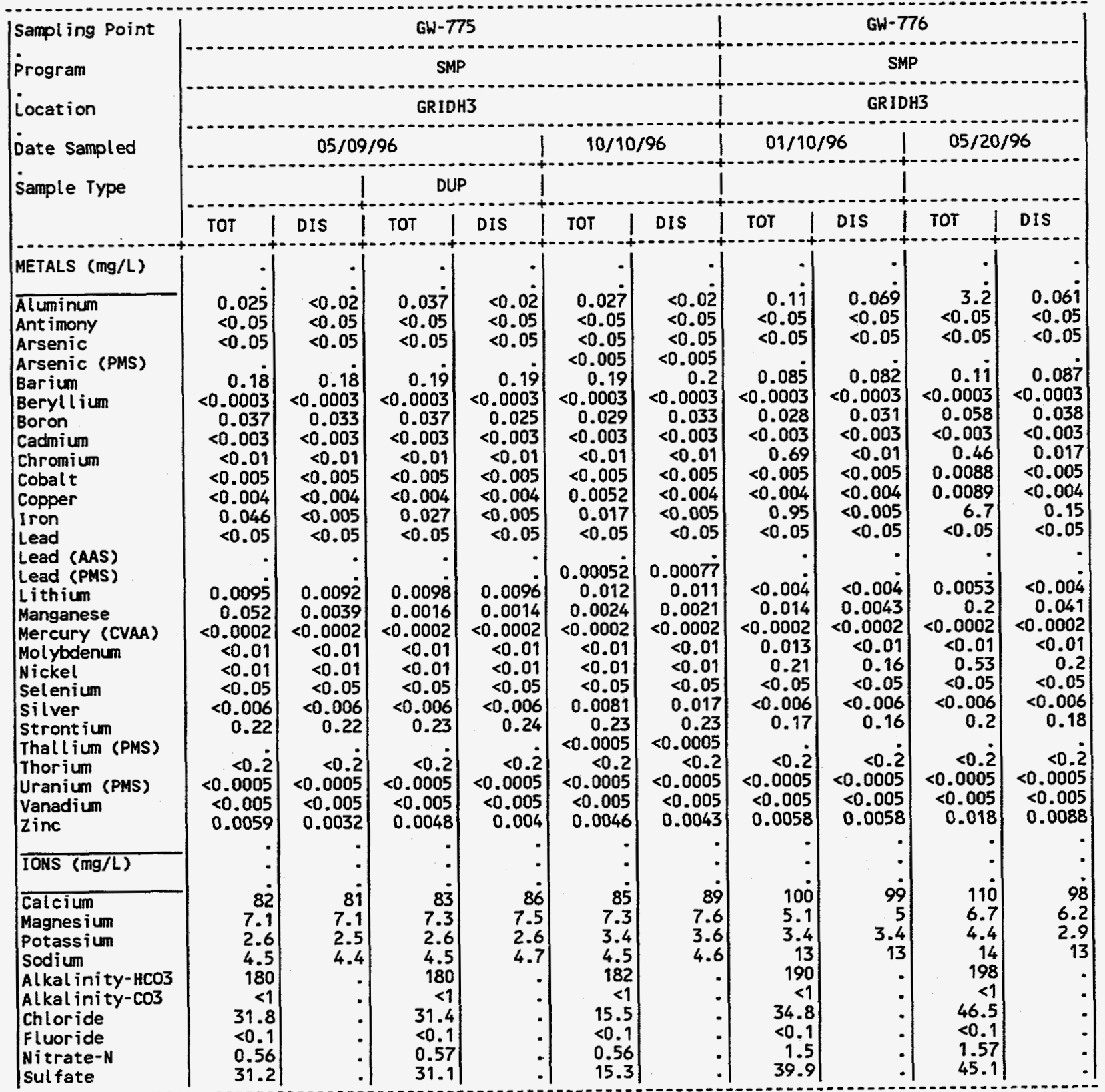

(CONT INUED) 
APPENDIX 0.2

Inorganic Analytes, CY 1996

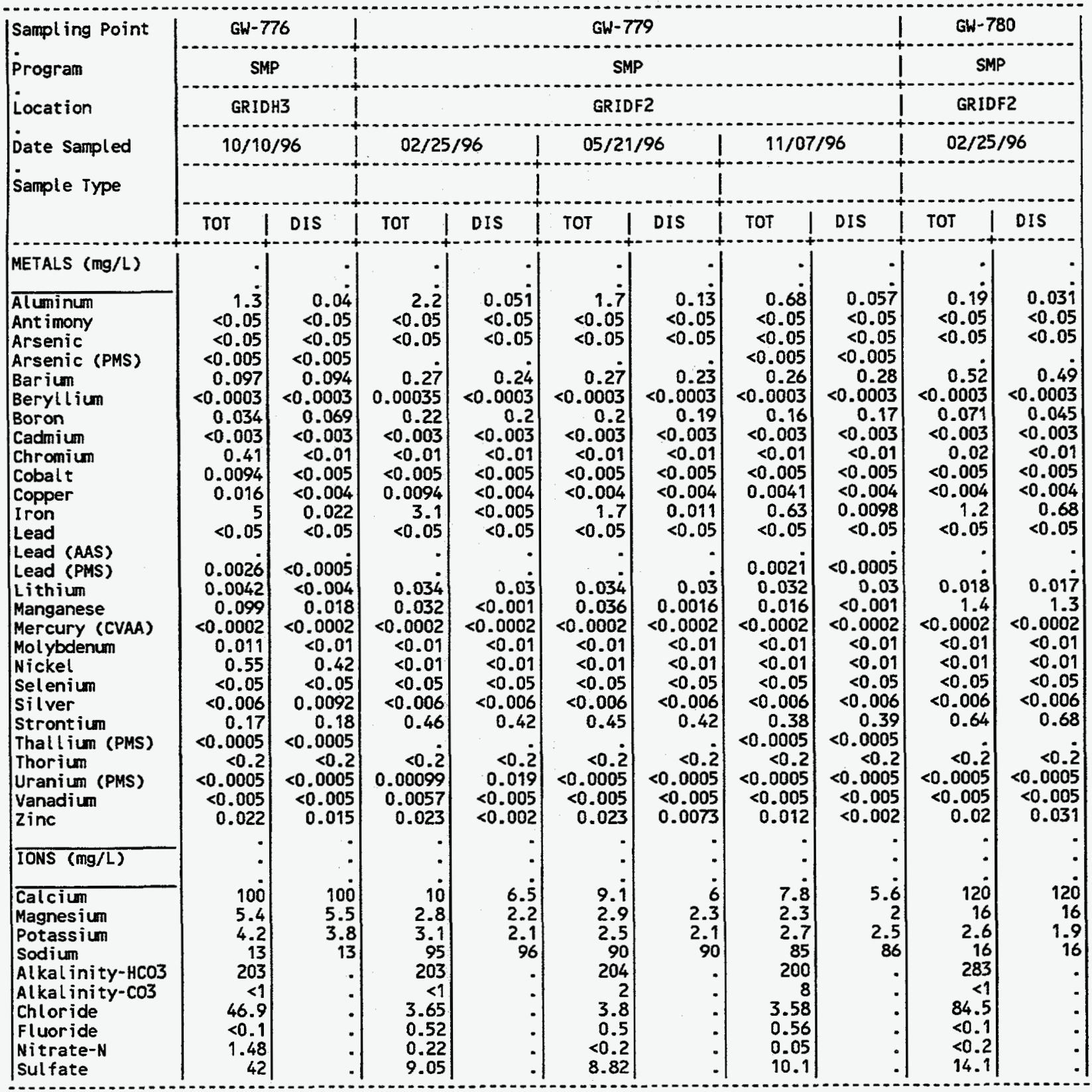

(CONTI INUED) 
APPENDIX 0.2

Inorganic Analytes, CY 1996

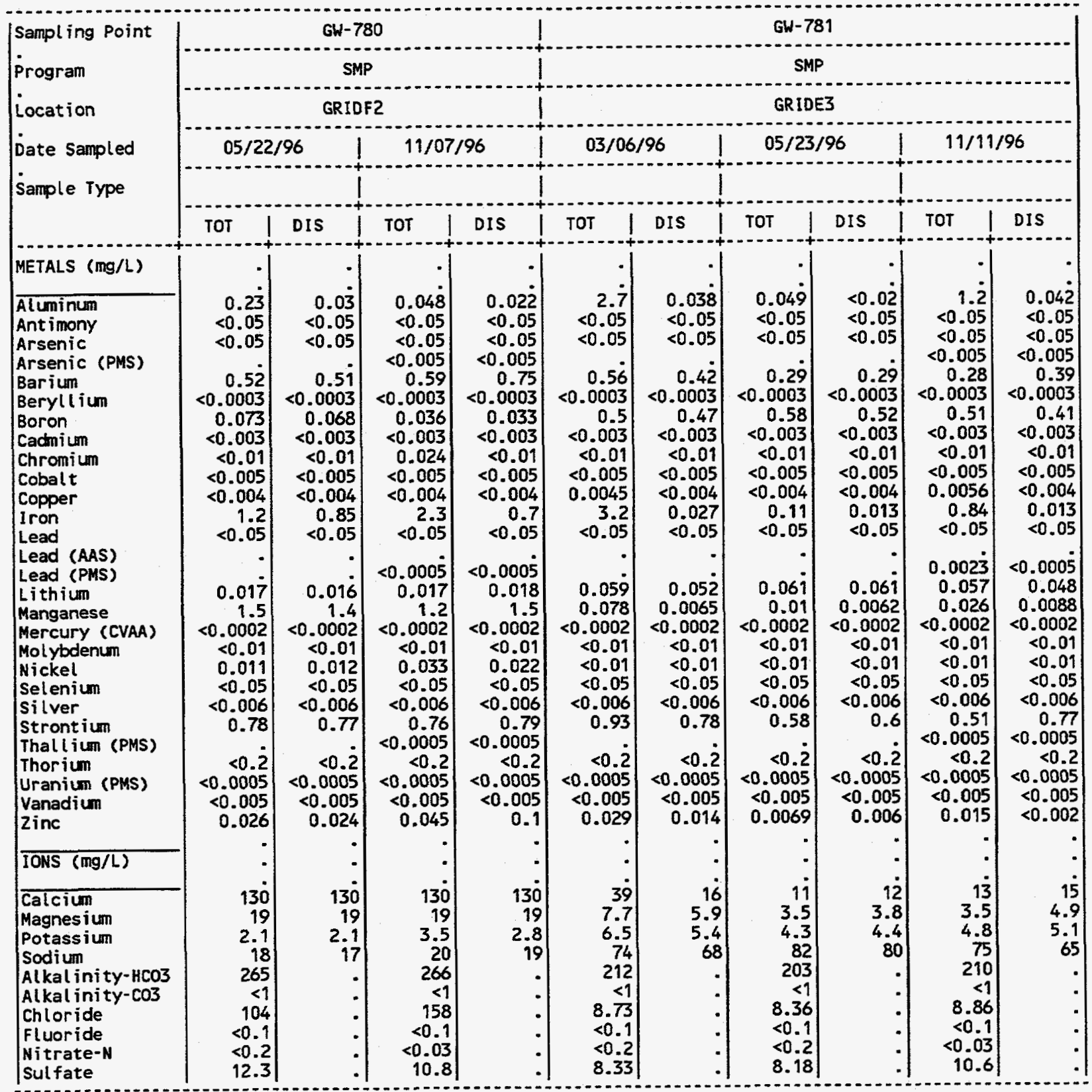

(CONT INUED) 
APPENDIX 0.2

Inorganic Analytes, CY 1996

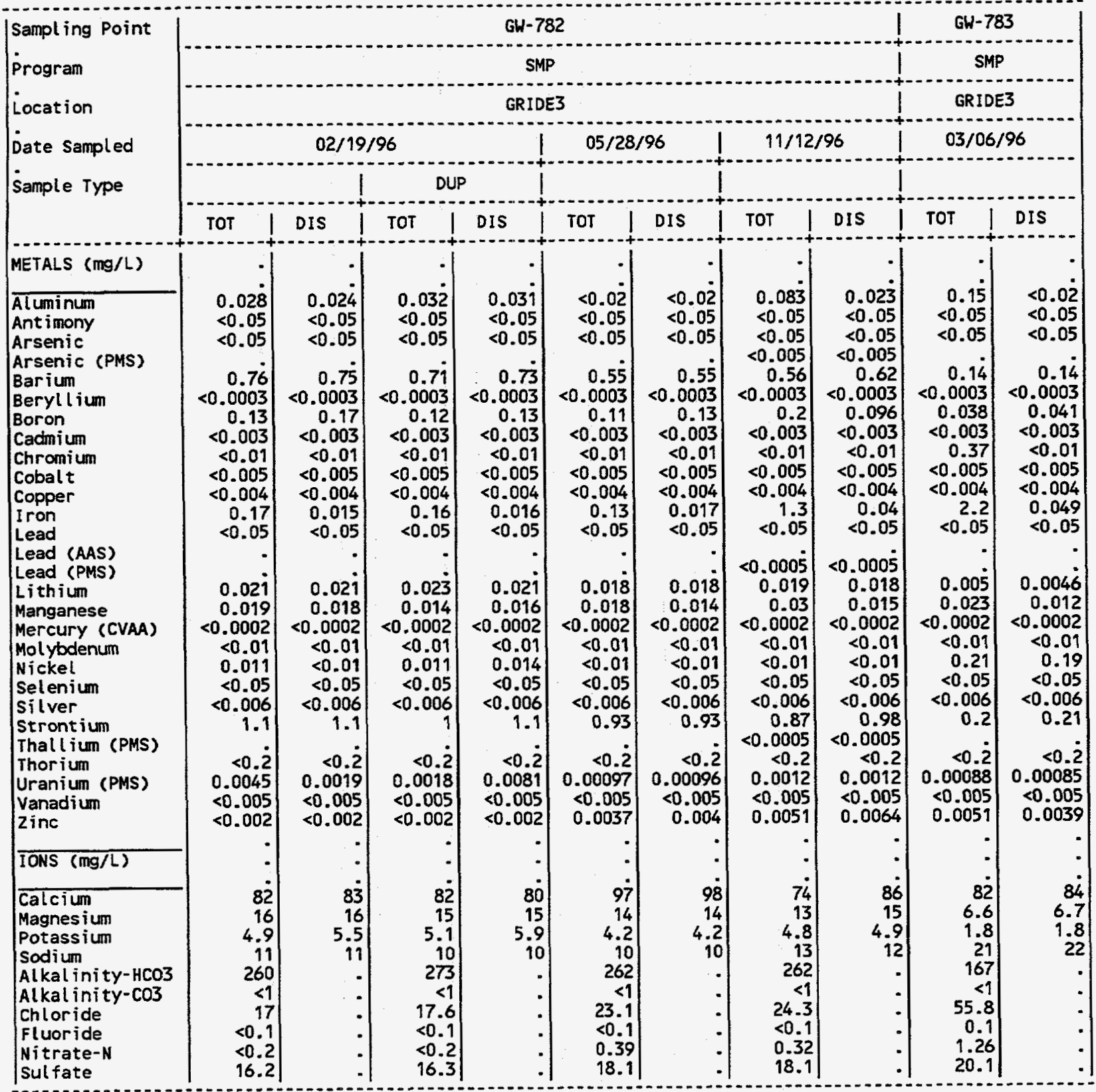

(CONTINUED) 
Inorganic Analytes, CY 1996

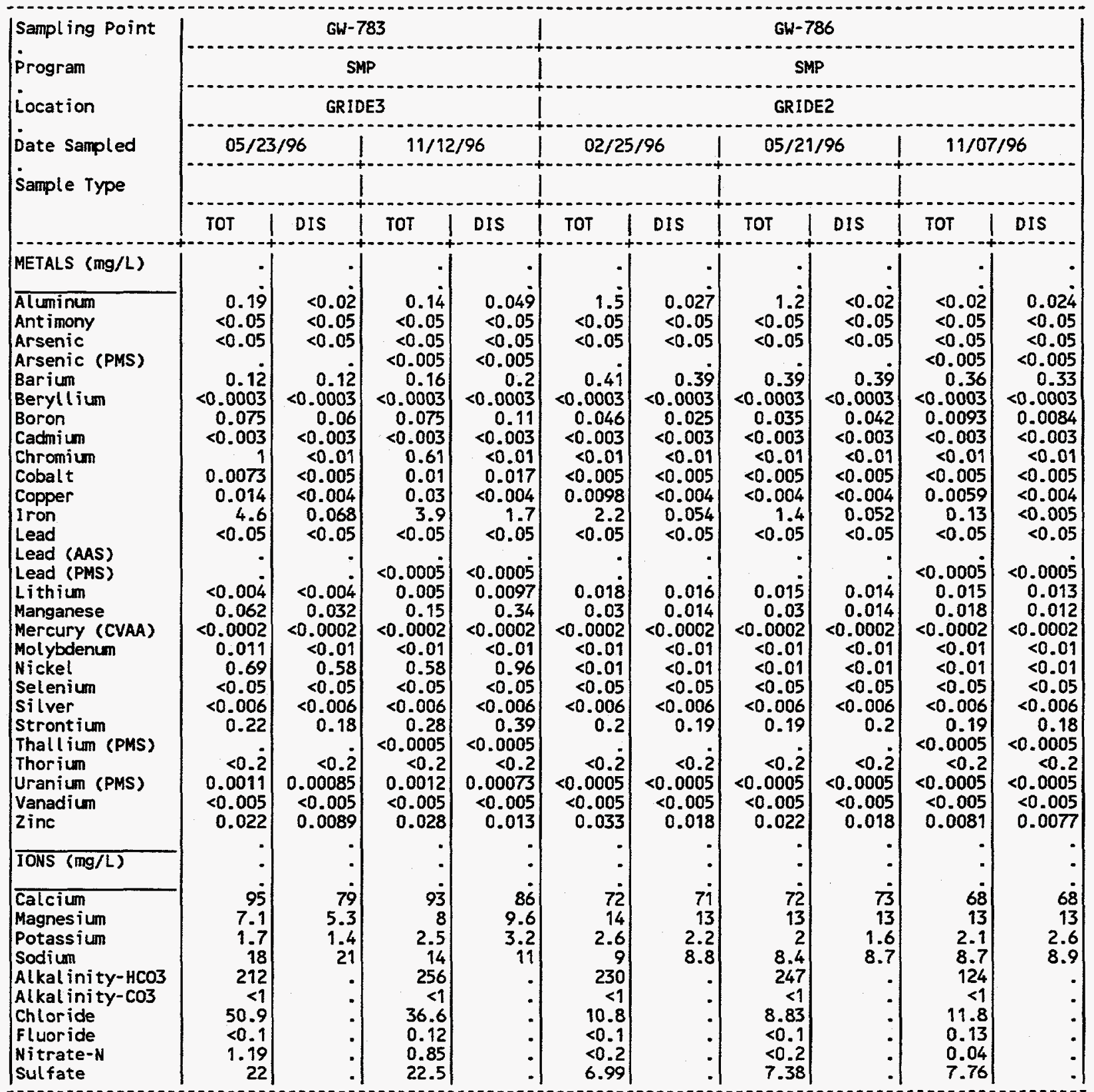

(CONTINUED) 
APPENDIX 0.2

Inorganic Analytes, Cr 1996

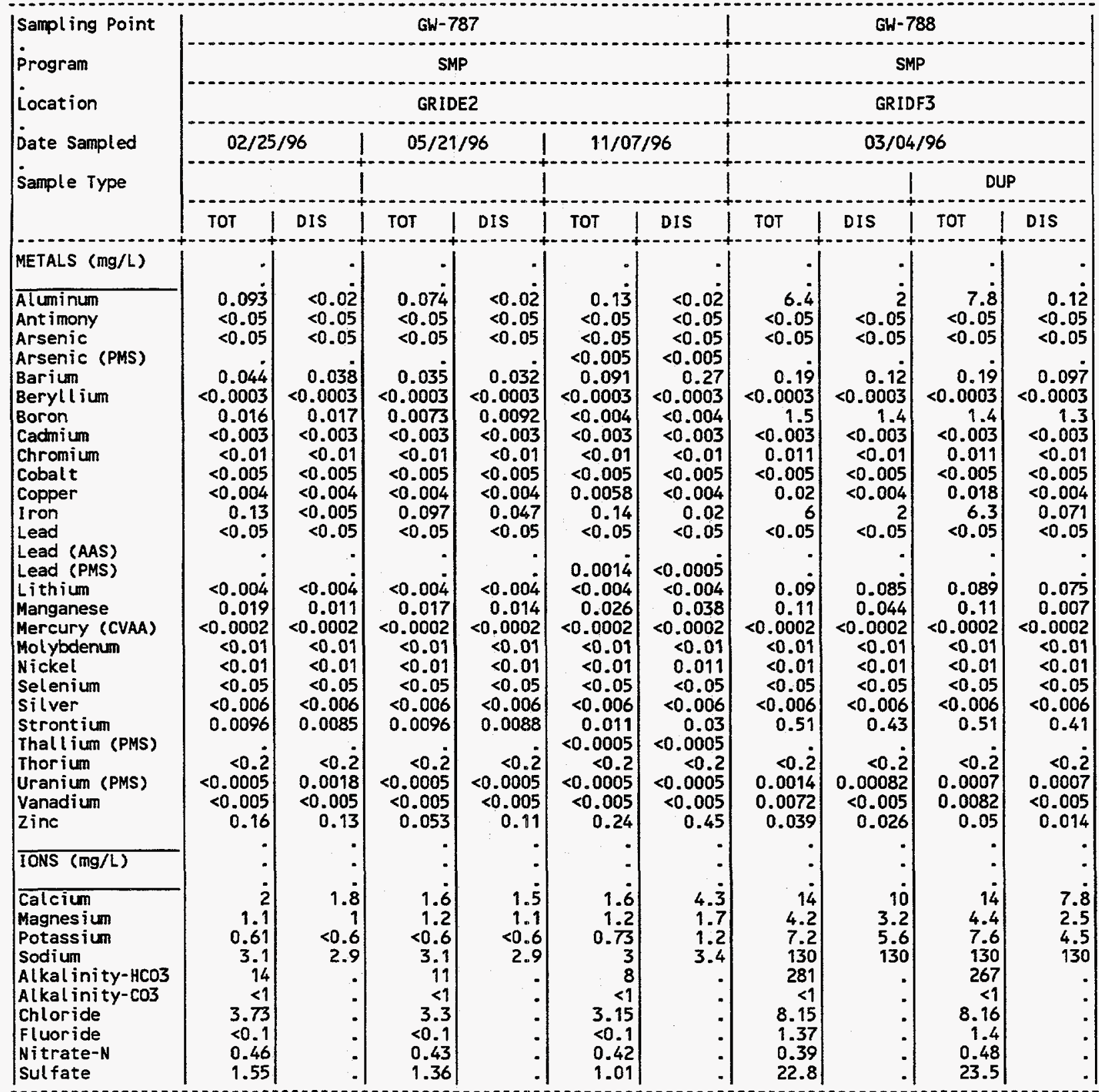

(CONTINUED) 
APPENDIX D. 2

Inorganic Analytes, CY 1996

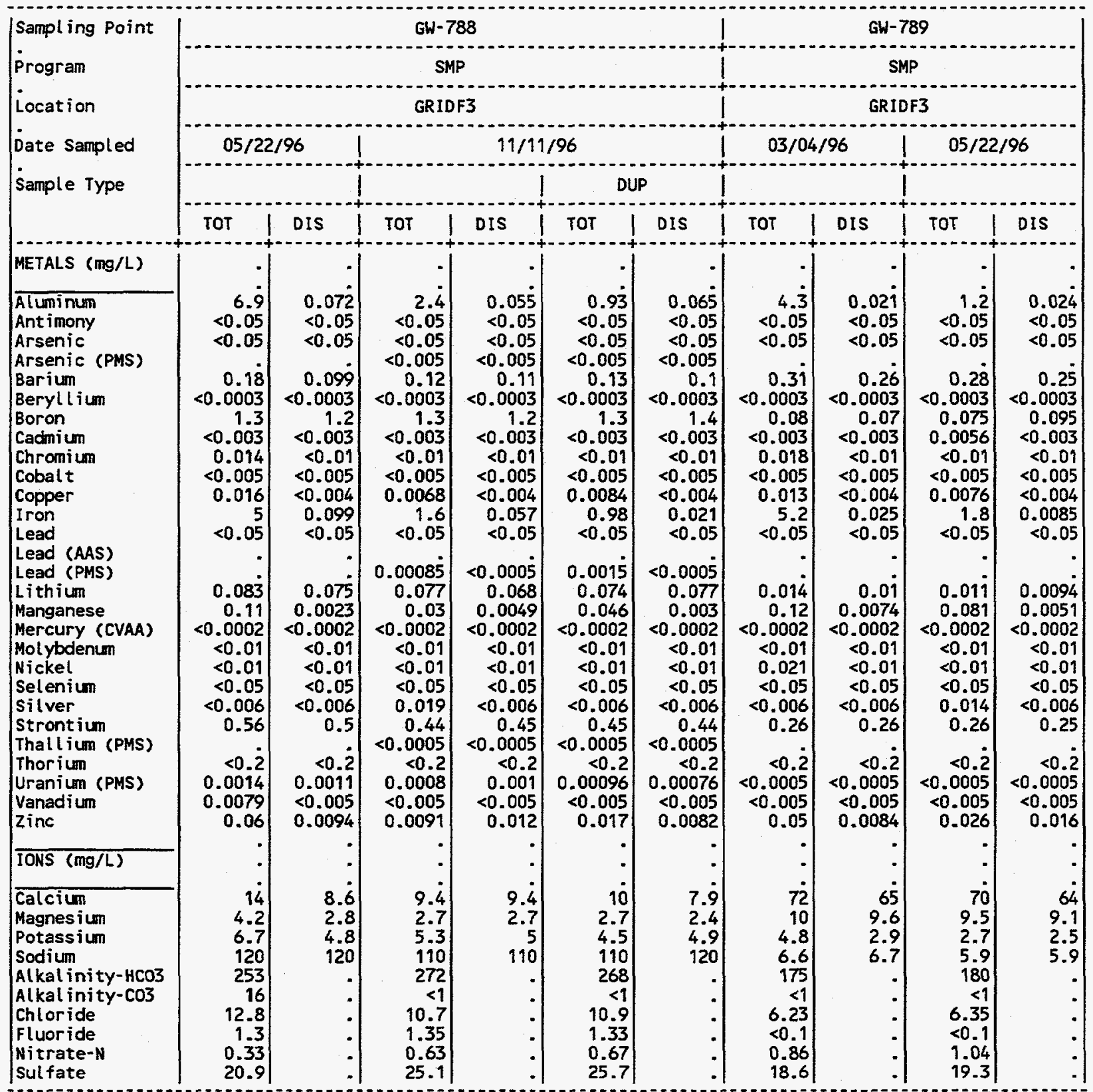

(CONT I NUED) 
APPENDIX 0.2

Inorganic Analytes, CY 1996

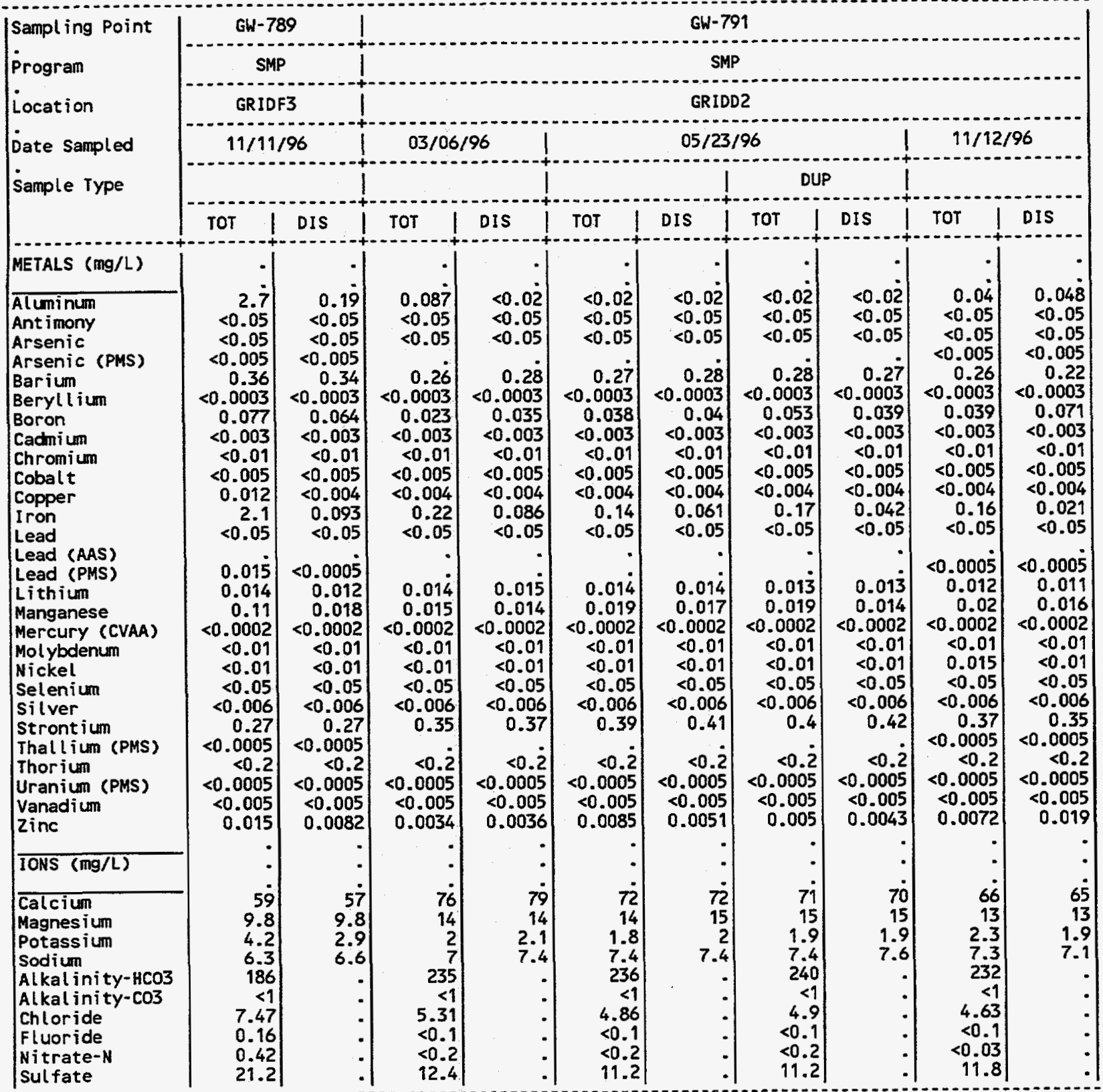

(CONT INUED) 
Inorganic Analytes, CY 1996

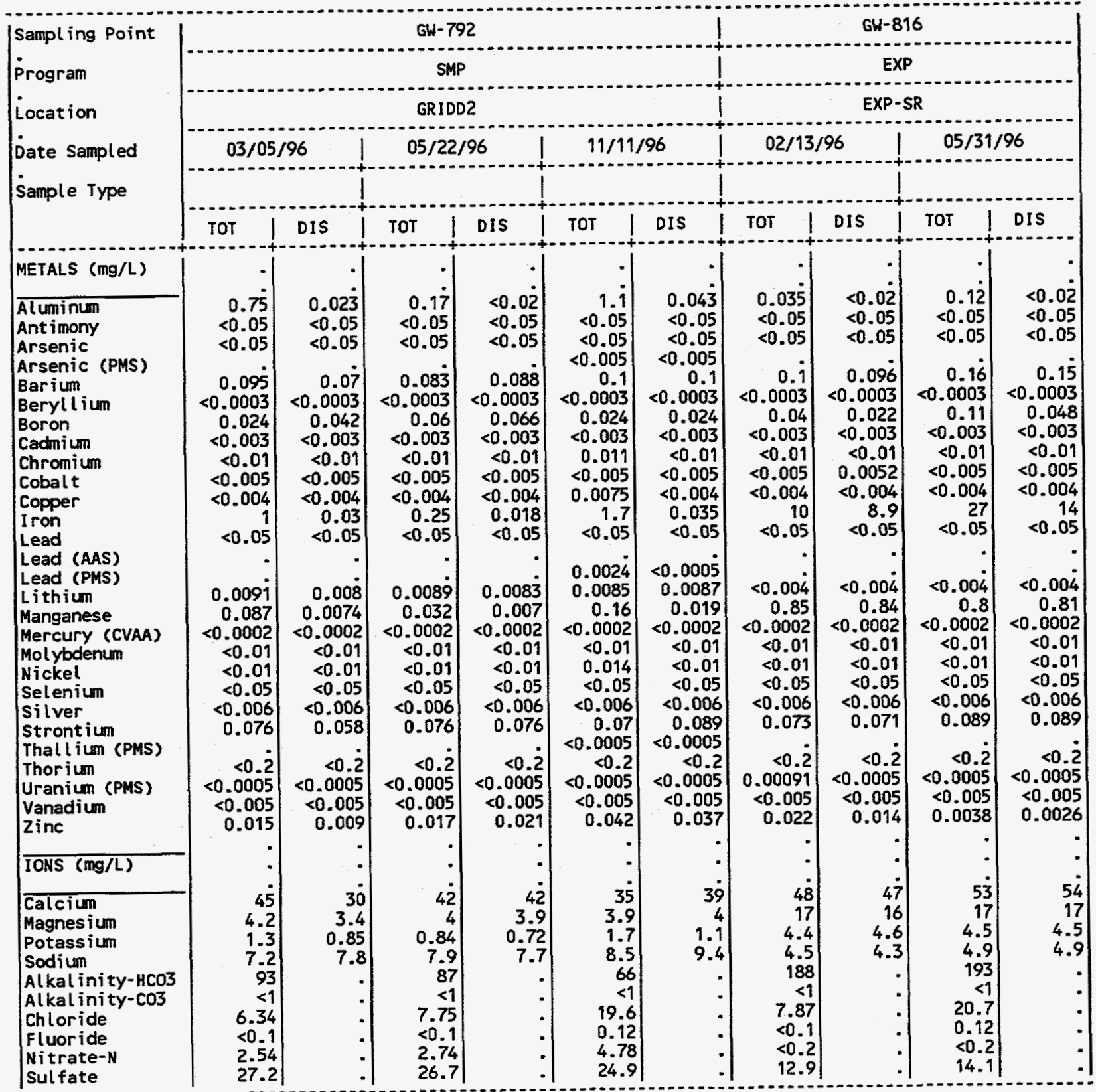

(CONT INUED) 
APPENDIX 0.2

Inorganic Analytes, CY 1996

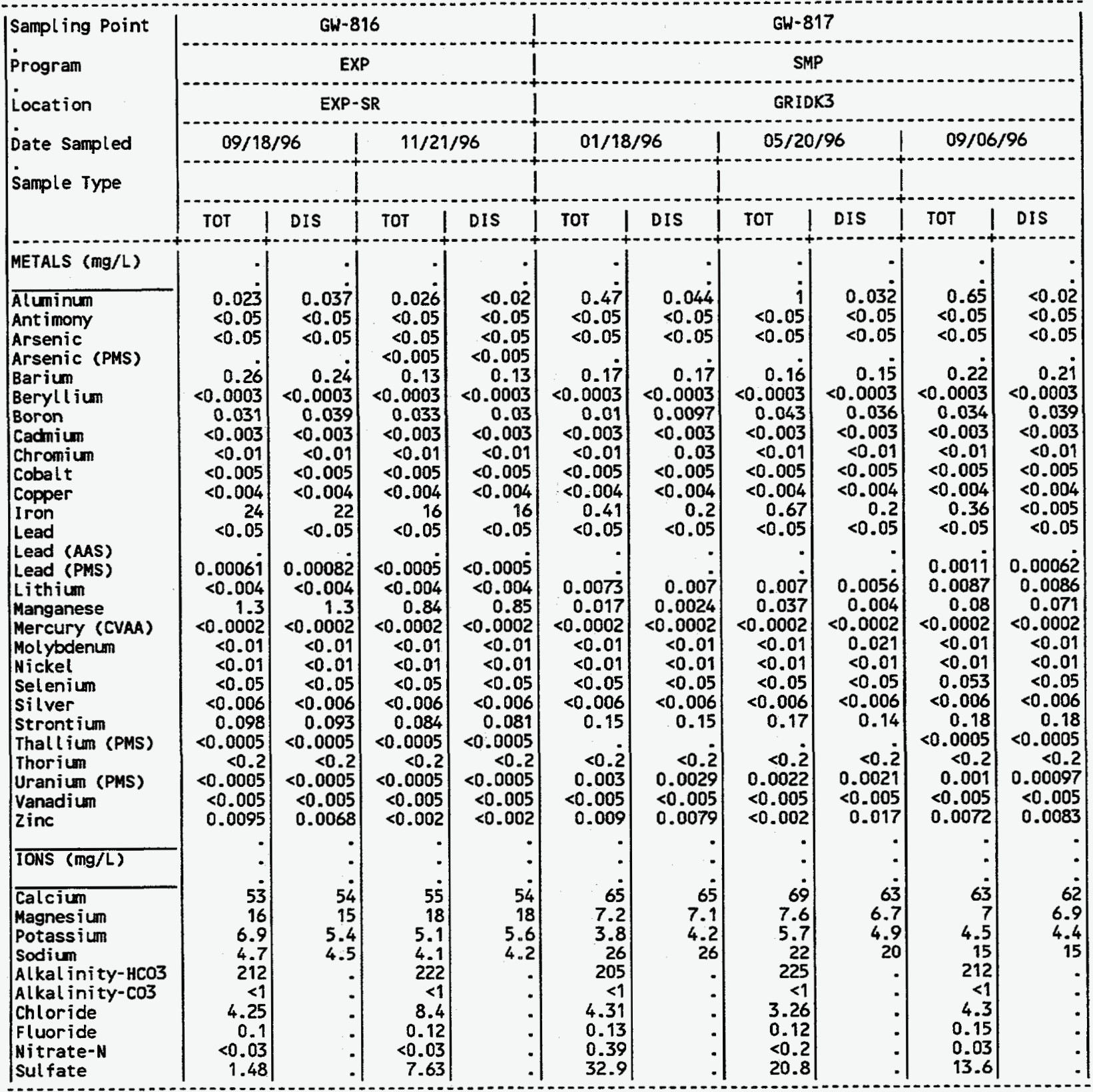

(CONT INUED) 
APPENDIX 0.2

Inorganic Analytes, CY 1996

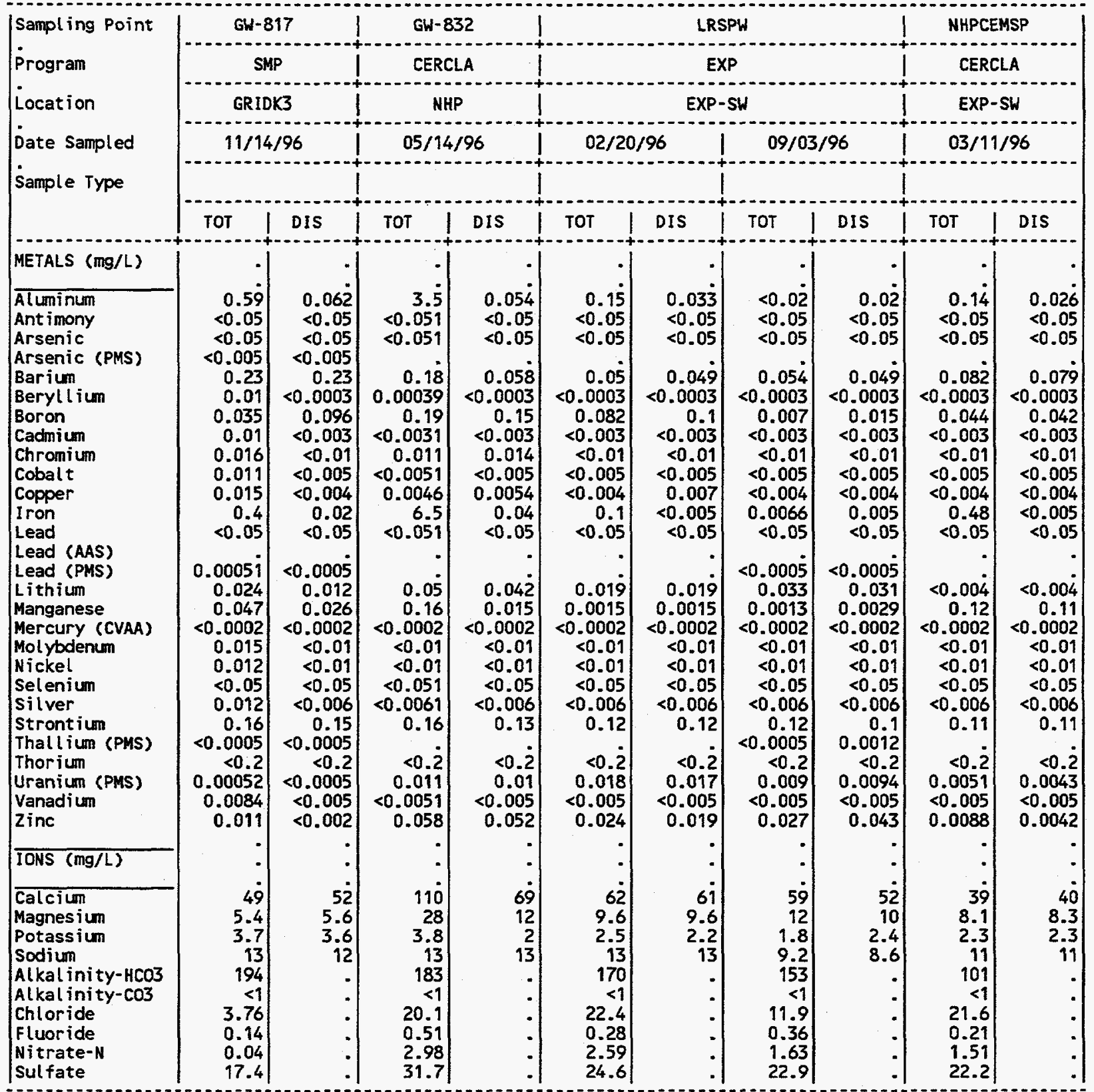

(CONTI INUED) 
APPENDIX 0.2

Inorganic Analytes, CY 1996

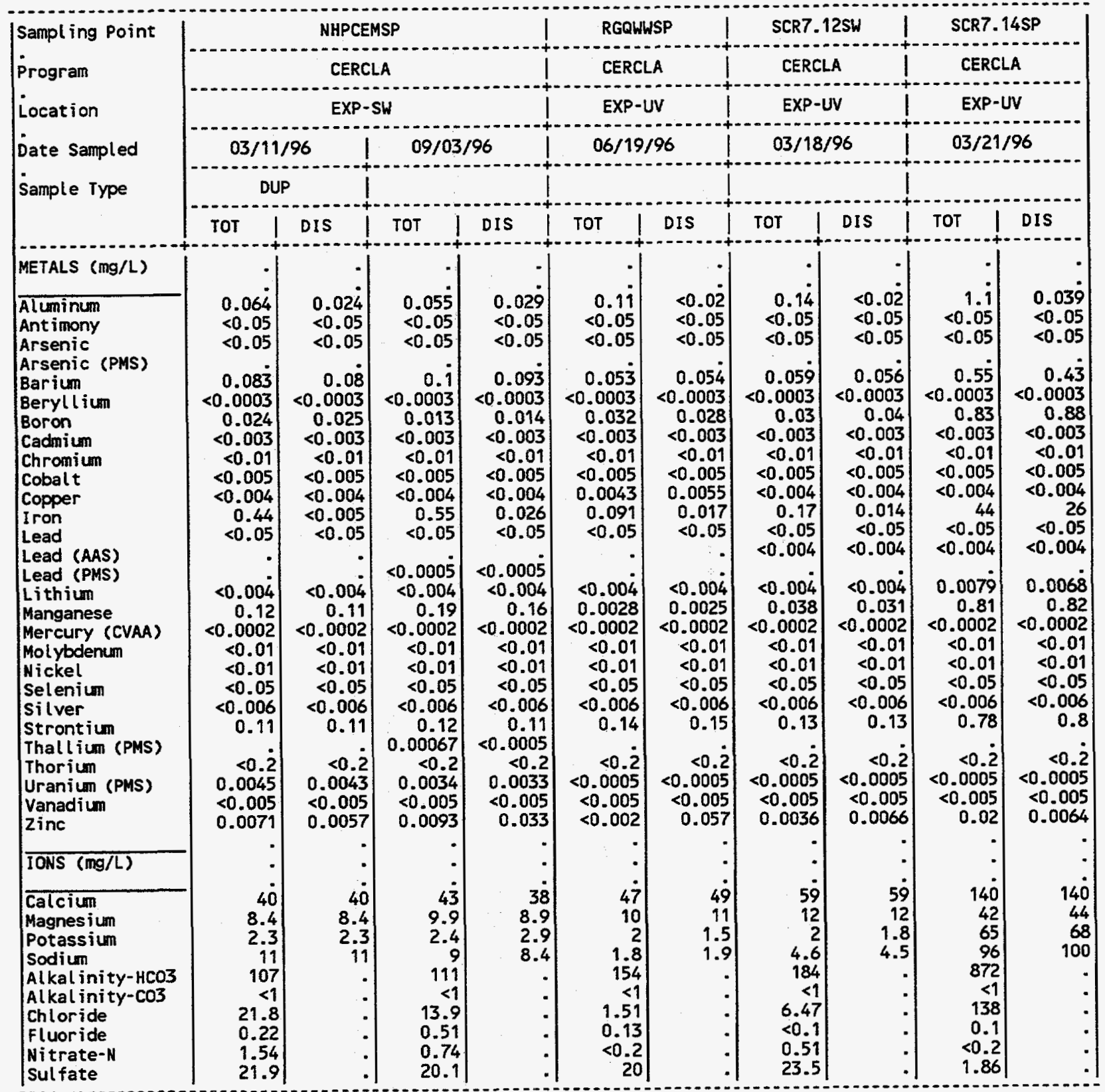

(CONTINUED) 
APPENDIX 0.2

Inorganic Analytes, CY 1996

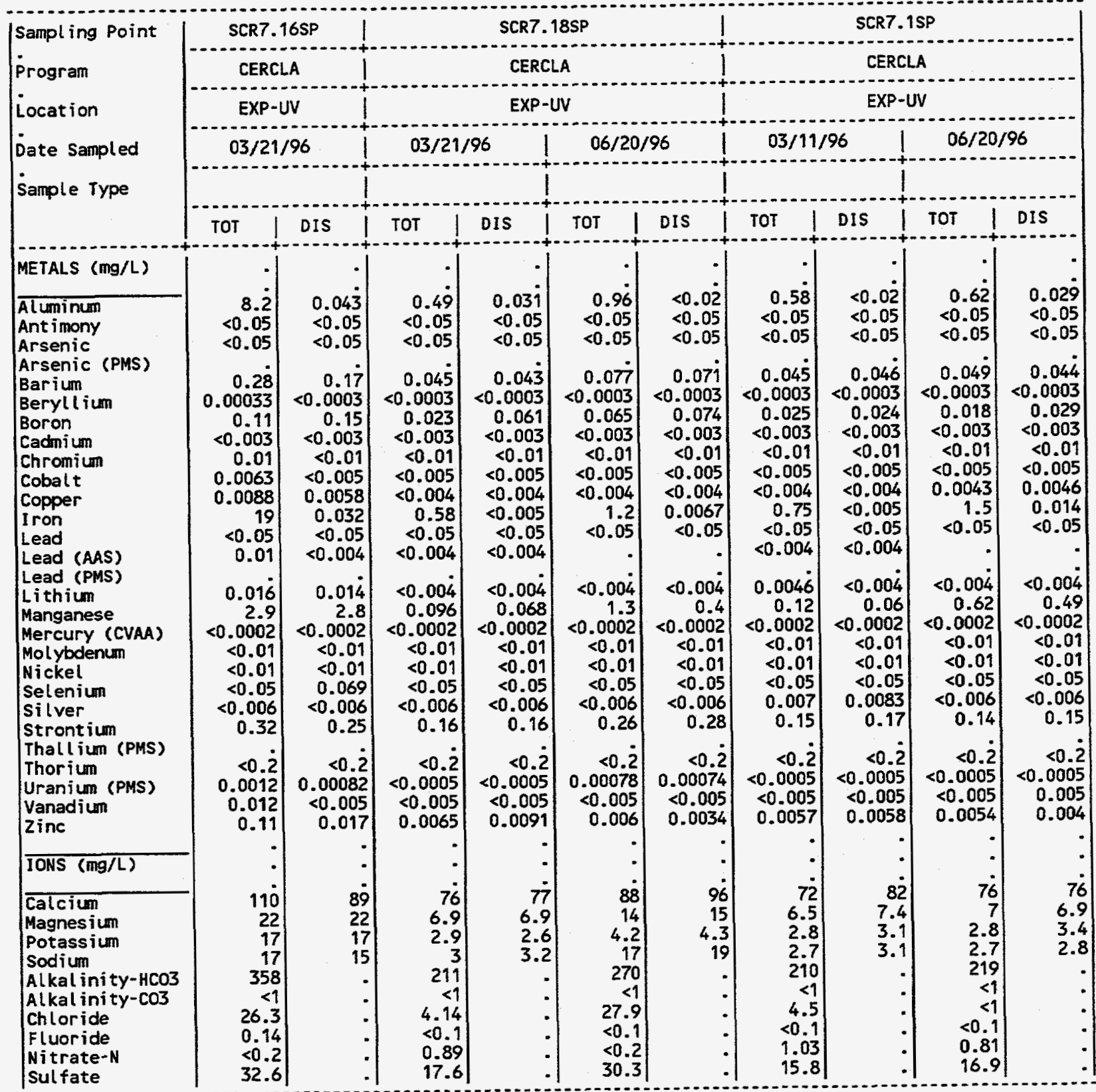

(CONT INUED) 
APPENDIX 0.2

Inorganic Analytes, CY 1996

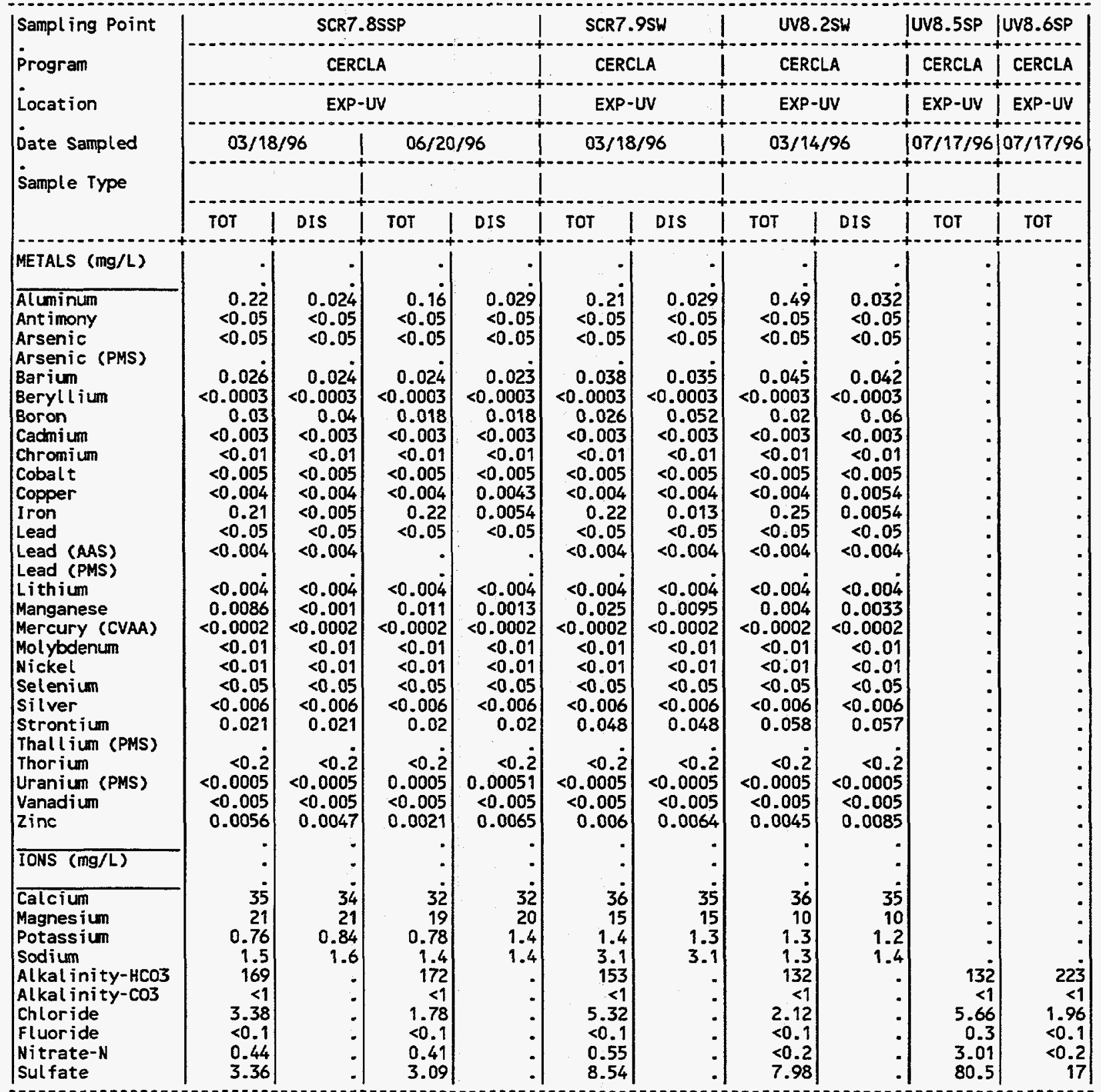


APPENDEX D.3

\section{ORGANIC ANALYTES}


APPENDIX 0.3

Organic Analytes, CY 1996

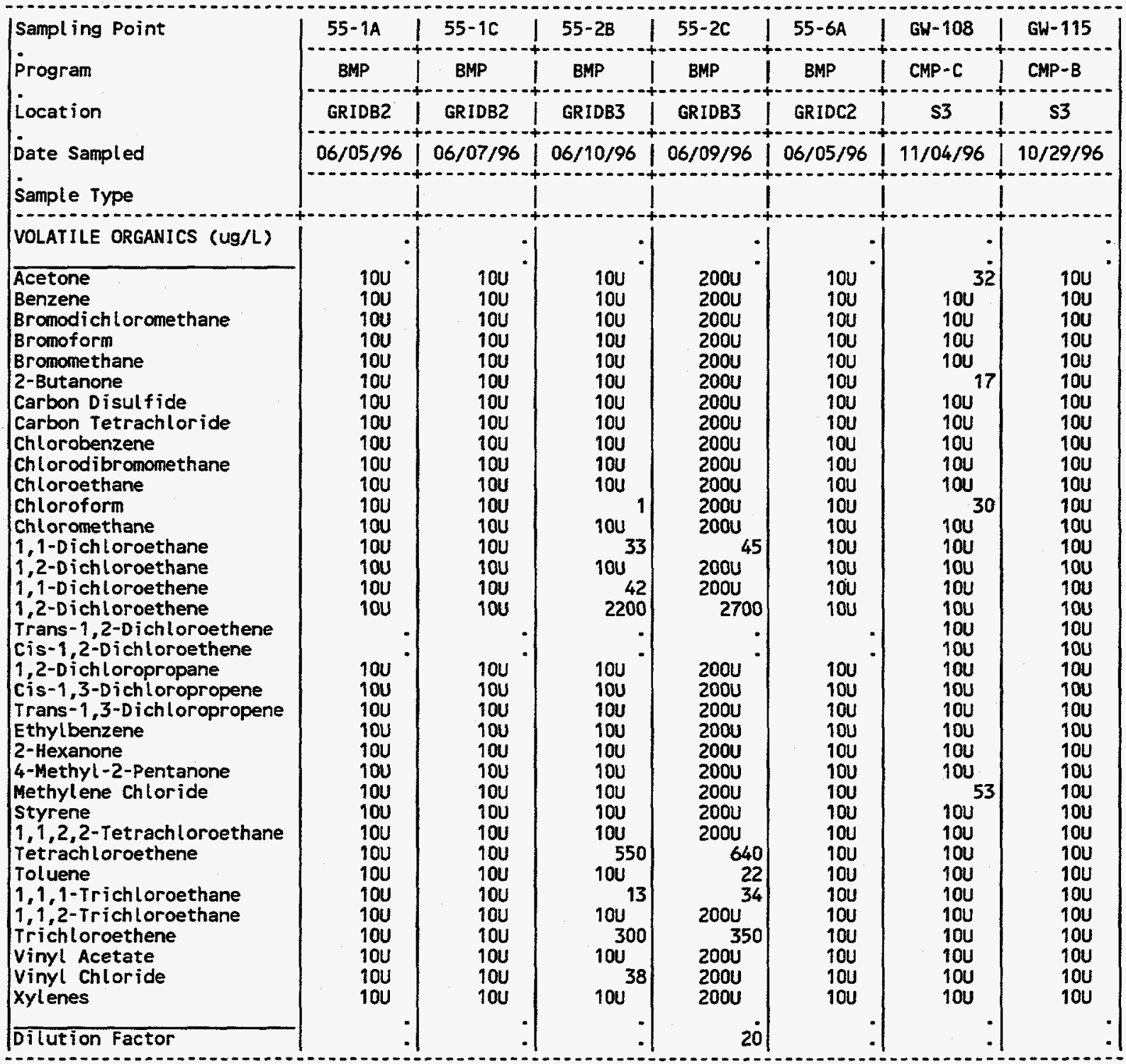

(CONT INUED) 
(OBNNILNOS)

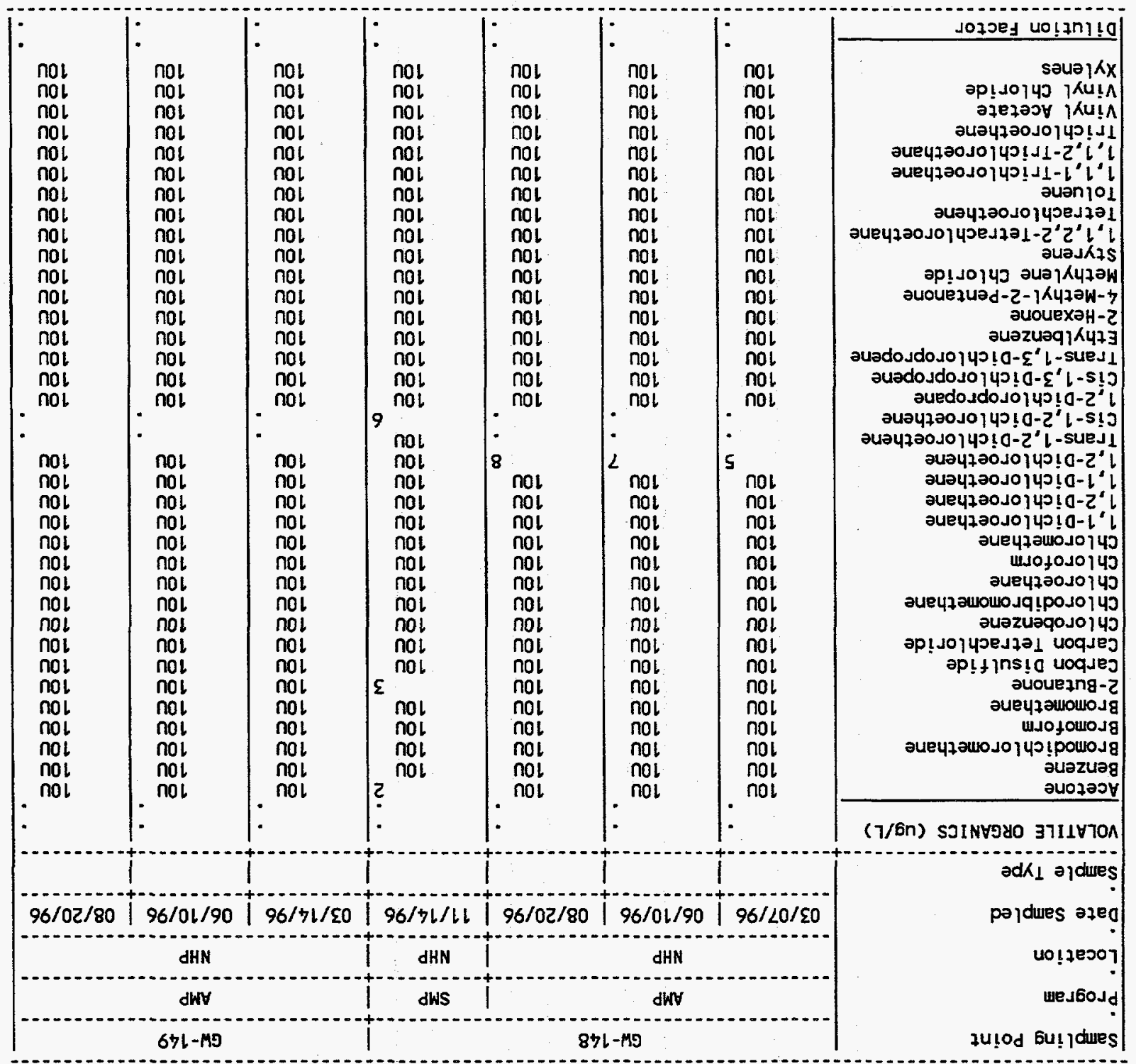

9661 lJ 'sazkpeuy ว!̣e6so ร. 0 XIONGddY 
APPENDIX 0.3

Organic Analytes, CY 1996

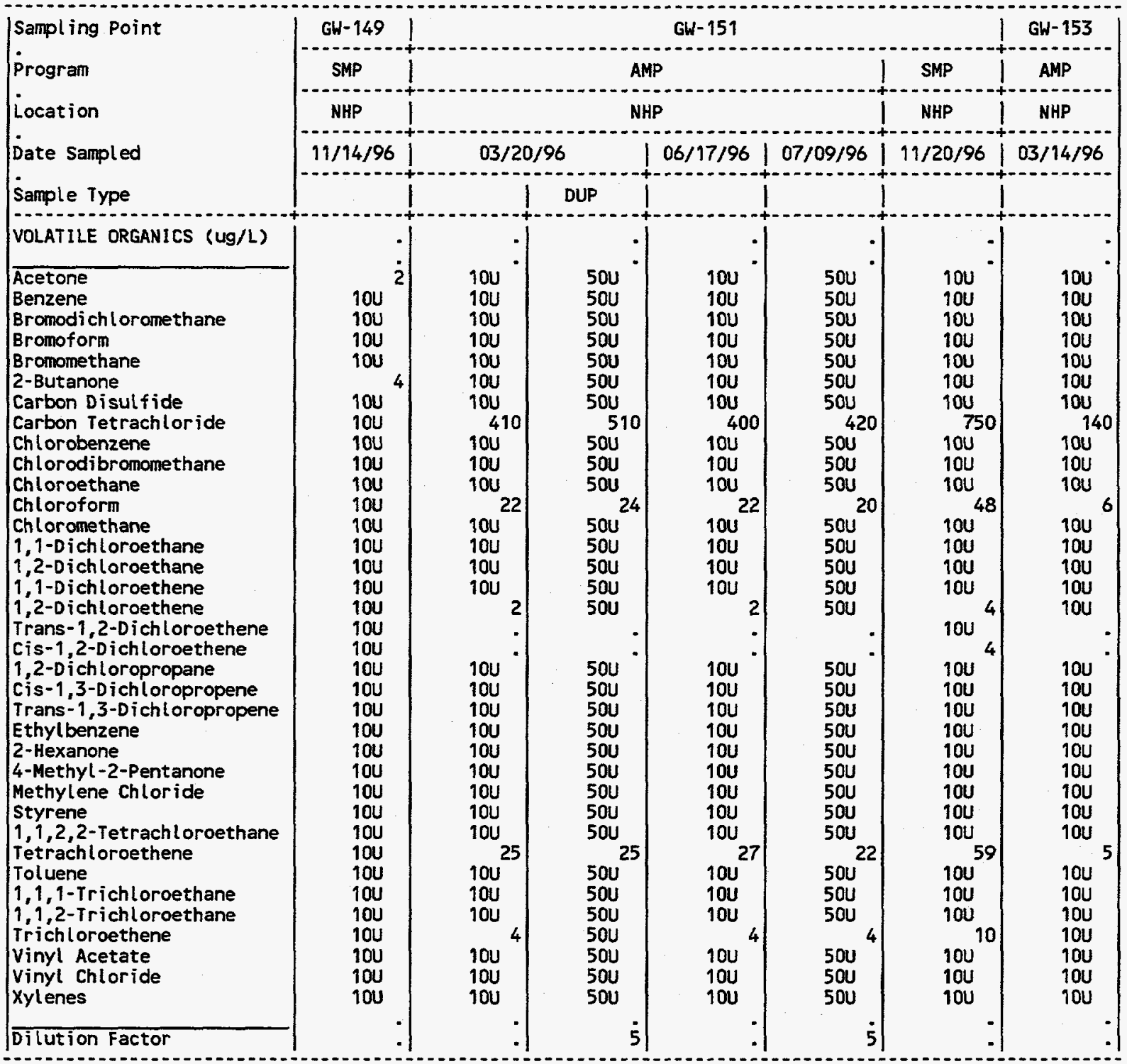

(CONT INUED) 
(OJกNI 1NOJ)

\begin{tabular}{|c|c|c|c|c|c|c|c|}
\hline & : & $\bullet$ & - & . & - & $\because$ & Jo70ey $40 ! 3 n 1 ! 0$ \\
\hline กol & nol & nol & nol & nol & nol & nol & səuə $) \wedge x$ \\
\hline nol & nol & nol & nol & nol & nol & nol & 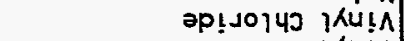 \\
\hline nol & nol & nol & nol & noi & nol & nol. & 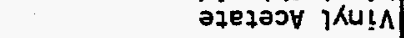 \\
\hline nol & nol & nol & nol & nol & l & nol & 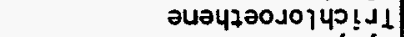 \\
\hline nol & nol & nol & nol & nol & nol & nol & 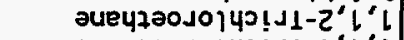 \\
\hline nol & nol & nol & nol & nol & nol & nol & 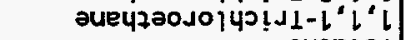 \\
\hline not & nol & nol & nol & nol & nol & nol & 2uen101 \\
\hline nol & nol & 2 & nol & 8 & 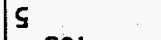 & $\varsigma$ & 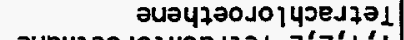 \\
\hline nol & nol & nol & nol & nol & nol & not & 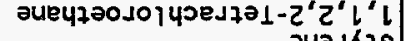 \\
\hline nol & nol & nol & nol & nol & nol & nol & 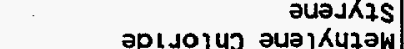 \\
\hline nol & nol & not & nol & nol & nol & nol & 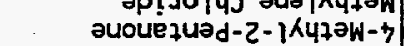 \\
\hline nol & nol & nol & nol & nol & nol & nol. & әUOUеXәH-टे \\
\hline nol & nol & not & nol & nol & nol & nol & auəzuəq)<47 \\
\hline nol & noi & noi & nol & nol & nol & nol & auədoJdoJo| $40 ! 0-\varepsilon^{\prime} l-$-sueJI \\
\hline nol & not & nol & nol & nol & nol & nol & auadoJdojo ju \\
\hline nol & nol & nol & nol & nol & nol & nol & 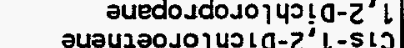 \\
\hline not & & & & nol & & & 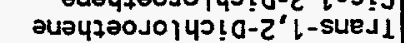 \\
\hline nol & nol & nol & nol & nol & nol & nol. & 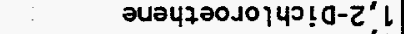 \\
\hline nol & nol & nol & nol & nol & nol & nol & 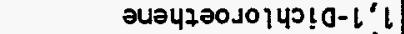 \\
\hline nol & nol & nol & nol & nol & not & nol & әนечนวО \\
\hline nol & nol & nol & nol & nol & not & nol & 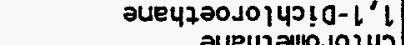 \\
\hline nol & nol & nol & nol & nol & nol & nol & әue472แ0 \\
\hline nol & nol & nol & nol & & 9 & s & แ10 †0دO \\
\hline nol & nol & nol & nol & nol & nol & nol & วueपz20د014ว \\
\hline nol & nol & nol & nol & nol & nol & nol & Jue 47 owowo Jq!poso 140 \\
\hline nol & nol & nol & nol & nol & nol & nol & auəzueqojo/40 \\
\hline nol & nol & nol & nol & $0 \angle 2$ & Oll & $0+1$ & 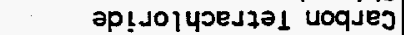 \\
\hline nol & nol & noi & nol & nol & nol & nol & әp $\lfloor$ ths!o uoquej \\
\hline nol & nol & noi & nol & nol & noi & nol & auouezng-z \\
\hline nol & not & nol & nol & nol & nol & nol & aueyzawowodg \\
\hline nol & nol & nol & nol & nol & nol & nol & wjofowoJg \\
\hline nol & nol & nol & nol & nol & nol & nol & 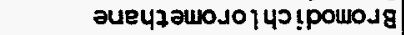 \\
\hline nol & nol & nol & nol & nol & nol & nol & әuәzuəg \\
\hline nol & nol & nol & nol & กot & nol & nol & auołasy \\
\hline & & - & - & & & - & (7/6n) SJINYפYO $37 I L \forall 7 O \Lambda$ \\
\hline & & & & & & & ad $K_{\perp}$ әןdures \\
\hline $96 / 6 \mathrm{l} / \mathrm{ll}$ & $96 / 22 / 80$ & $96 / 21 / 90$ & $96 / \varepsilon 2 / 20$ & $96 / 8 \downarrow / \downarrow \downarrow$ & $96 / l 2 / 80$ & $96 / l l /$ & pojclues azeq \\
\hline dHN & & dHN & & dHN & & HN & 40!7e007 \\
\hline dWS & & dWH & & dWS & & & wes6osd \\
\hline & & 19 & & & ESL -Mפ & & zu!Od bu! ldwes \\
\hline
\end{tabular}

9661 15 'so7k jeu甘 o!ve6.10 
APPENDIX 0.3

Organic Analytes, CY 1996

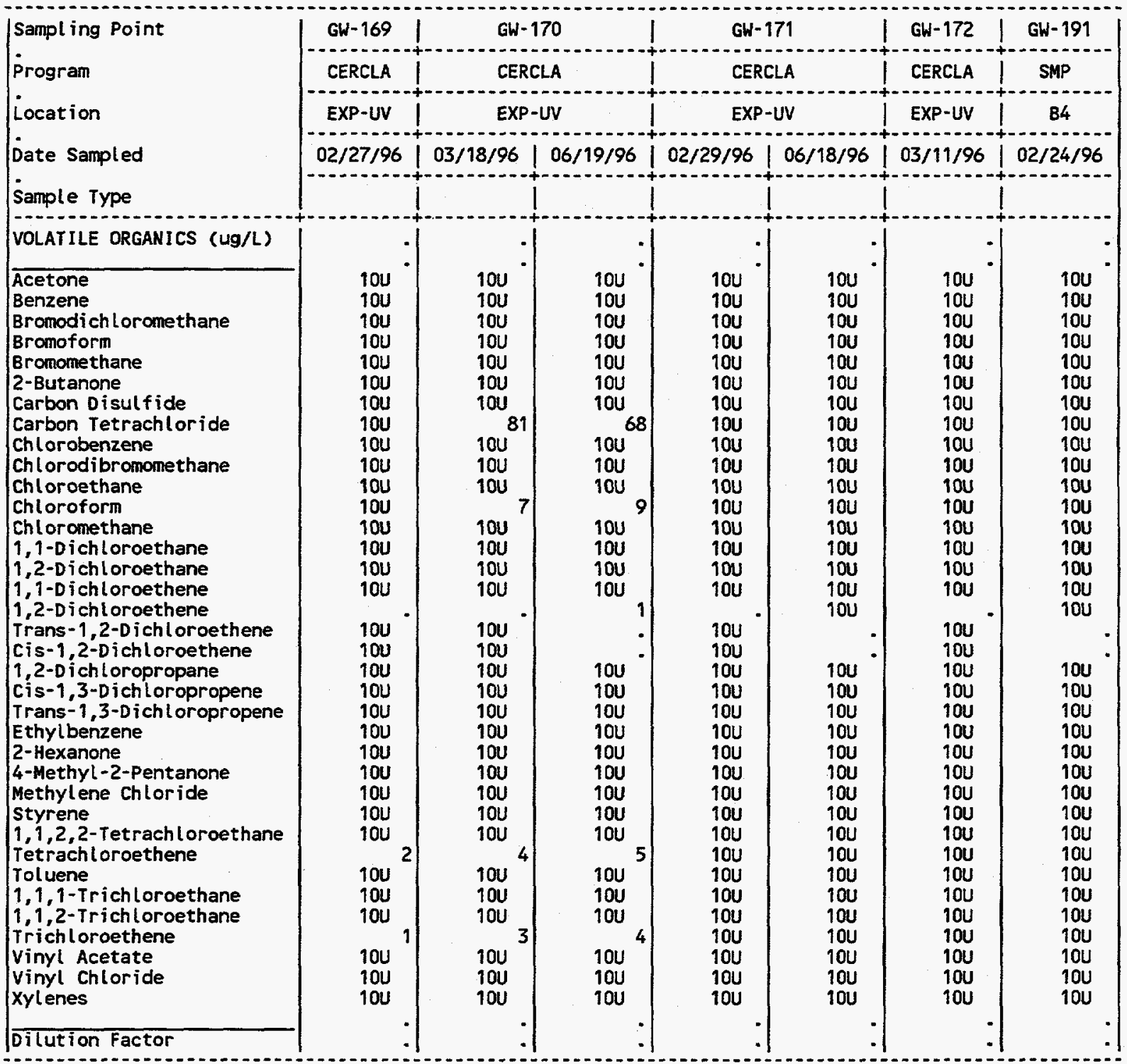

(CONTINUED) 
APPENDIX 0.3

Organic Analytes, CY 1996

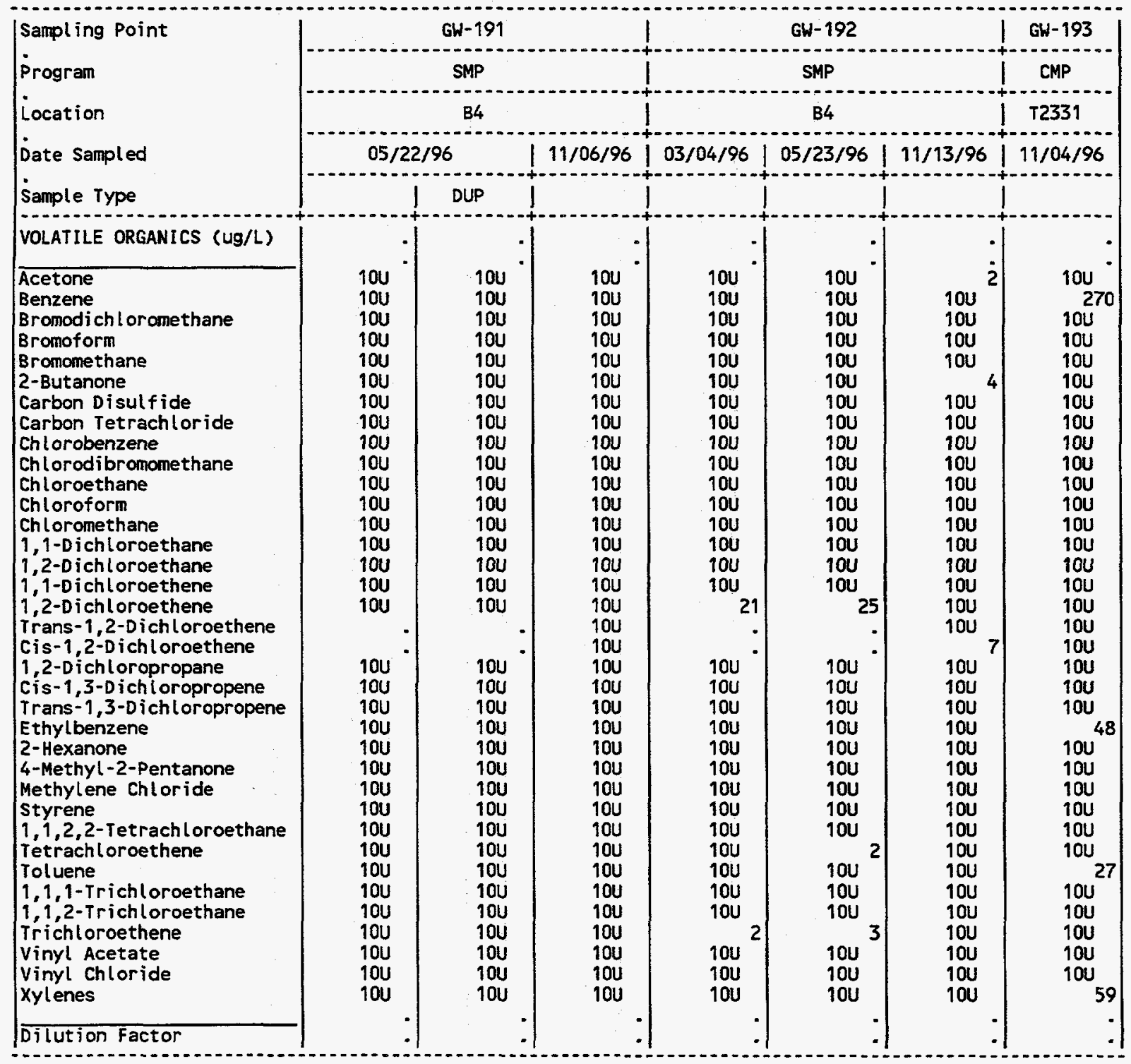

(CONT INUED) 
APPEND $1 X \quad 0.3$

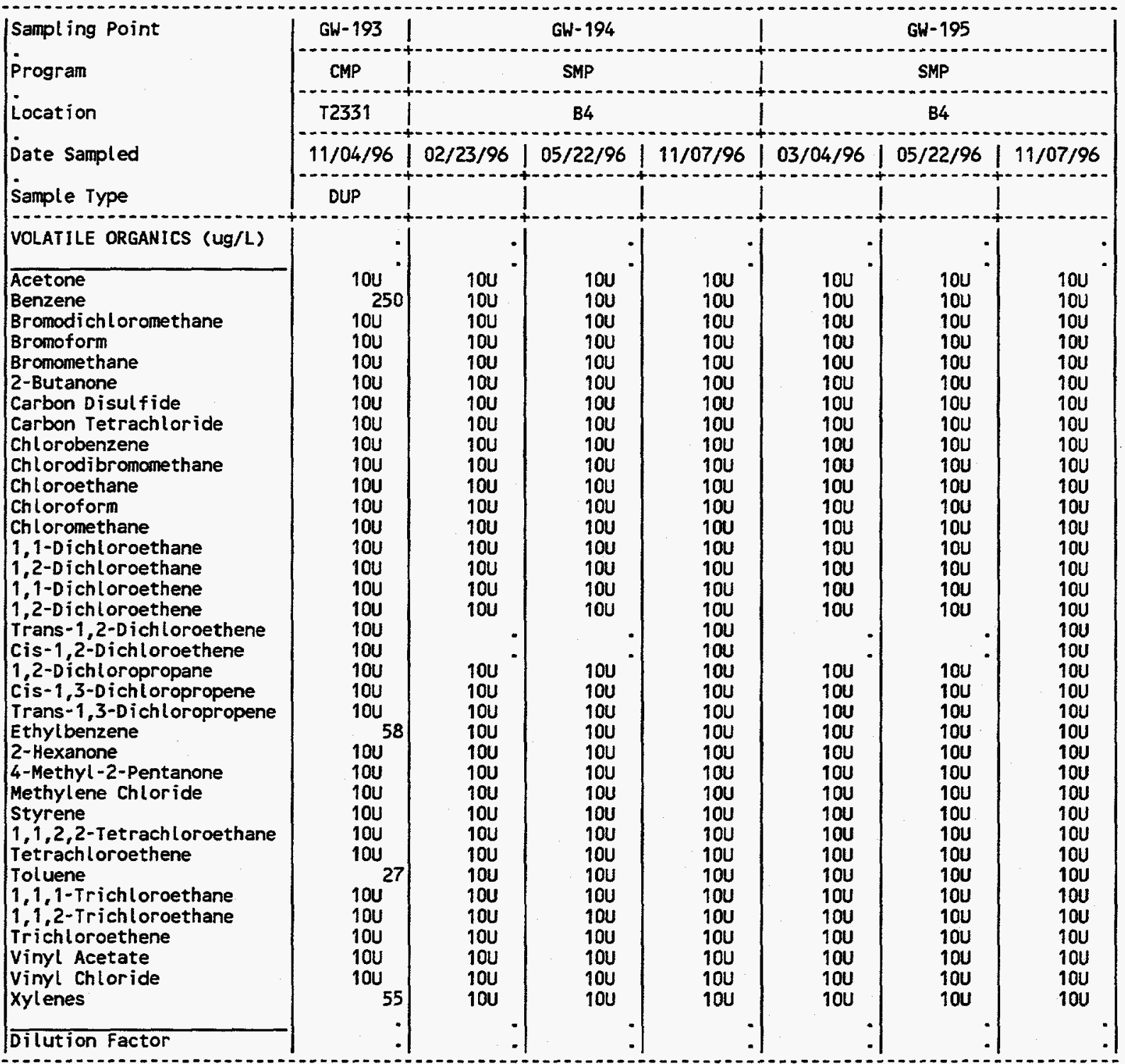

(CONTINUED) 
APPENDIX 0.3

Organic Analytes, CY 1996

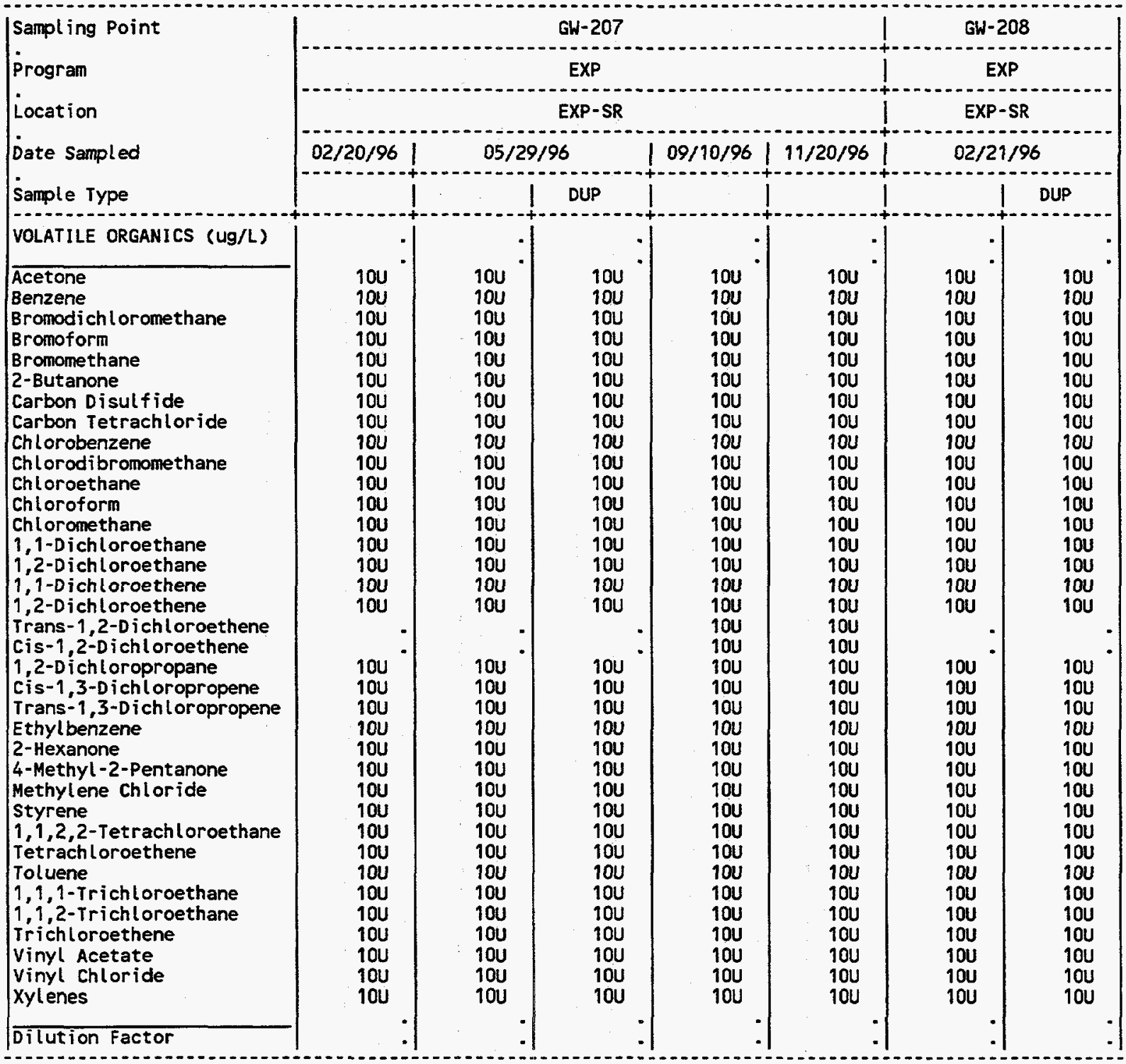

(CONT INUED) 
APPENDIX 0.3

Organic Analytes, CY 1996

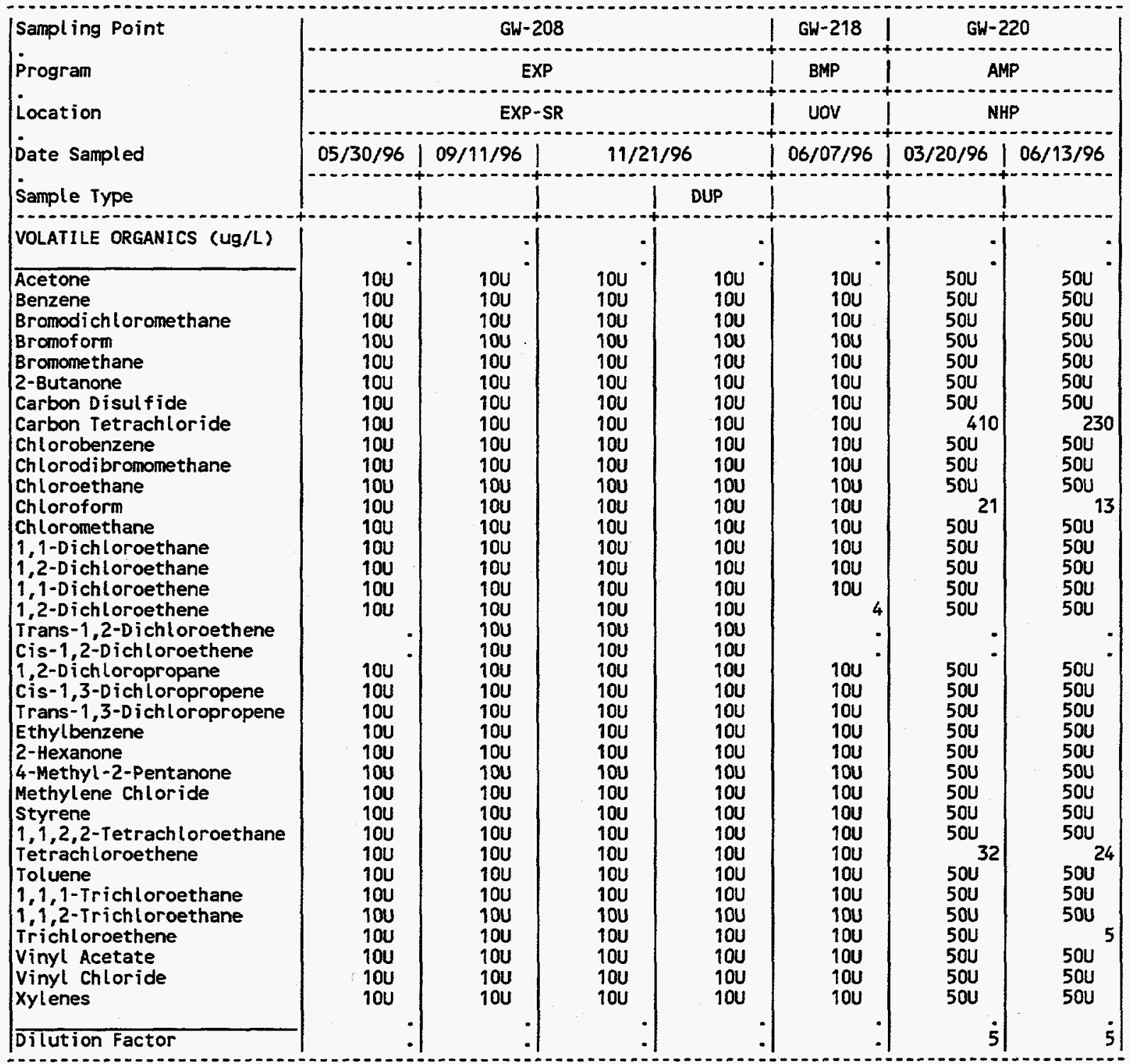

(CONT INUED) 
APPENDIX 0.3

Organic Analytes, CY 1996

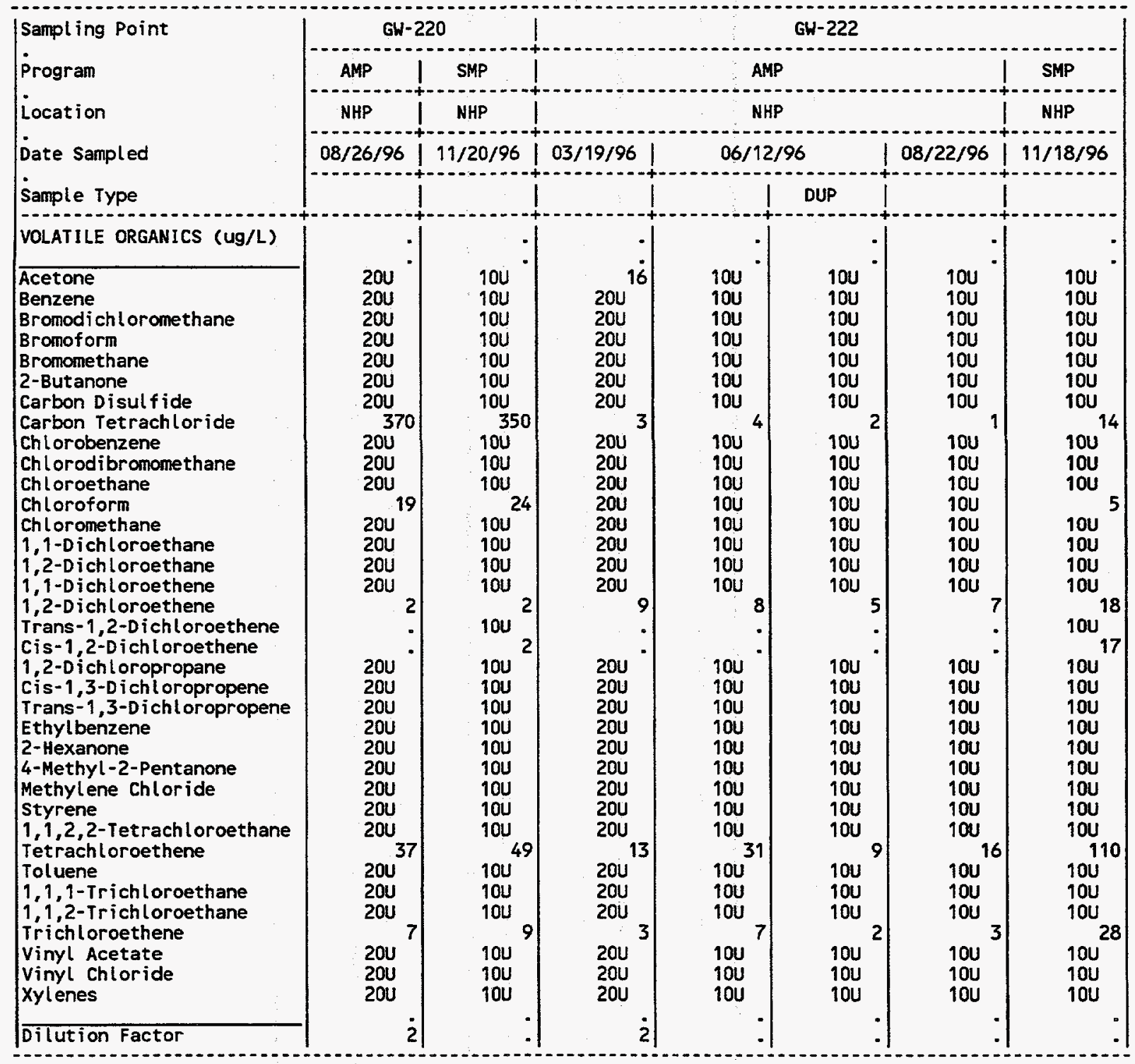

(CONT INUED) 


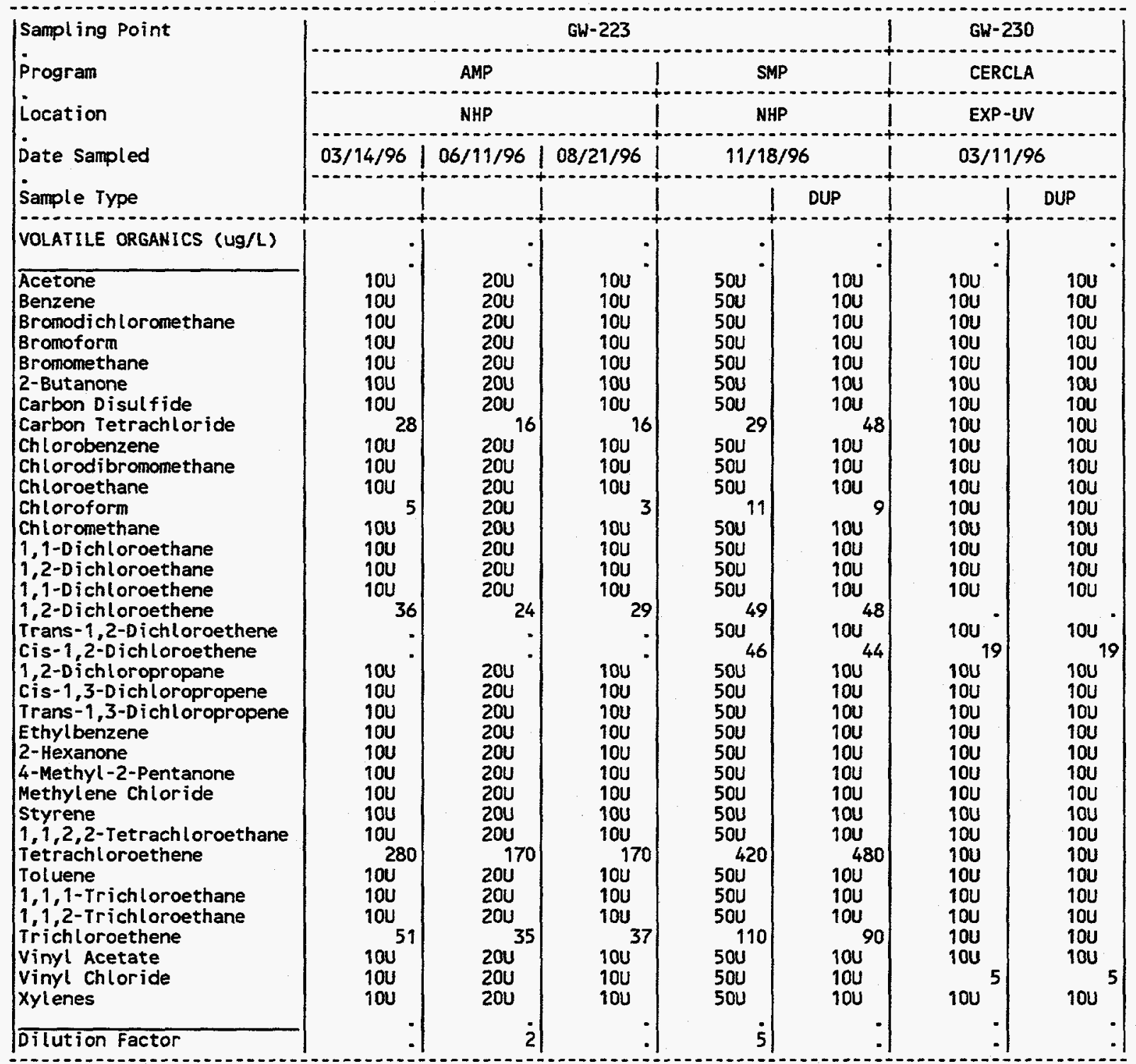

(CONTINUED) 
APPENDIX D.3

Organic Analytes, CY 1996

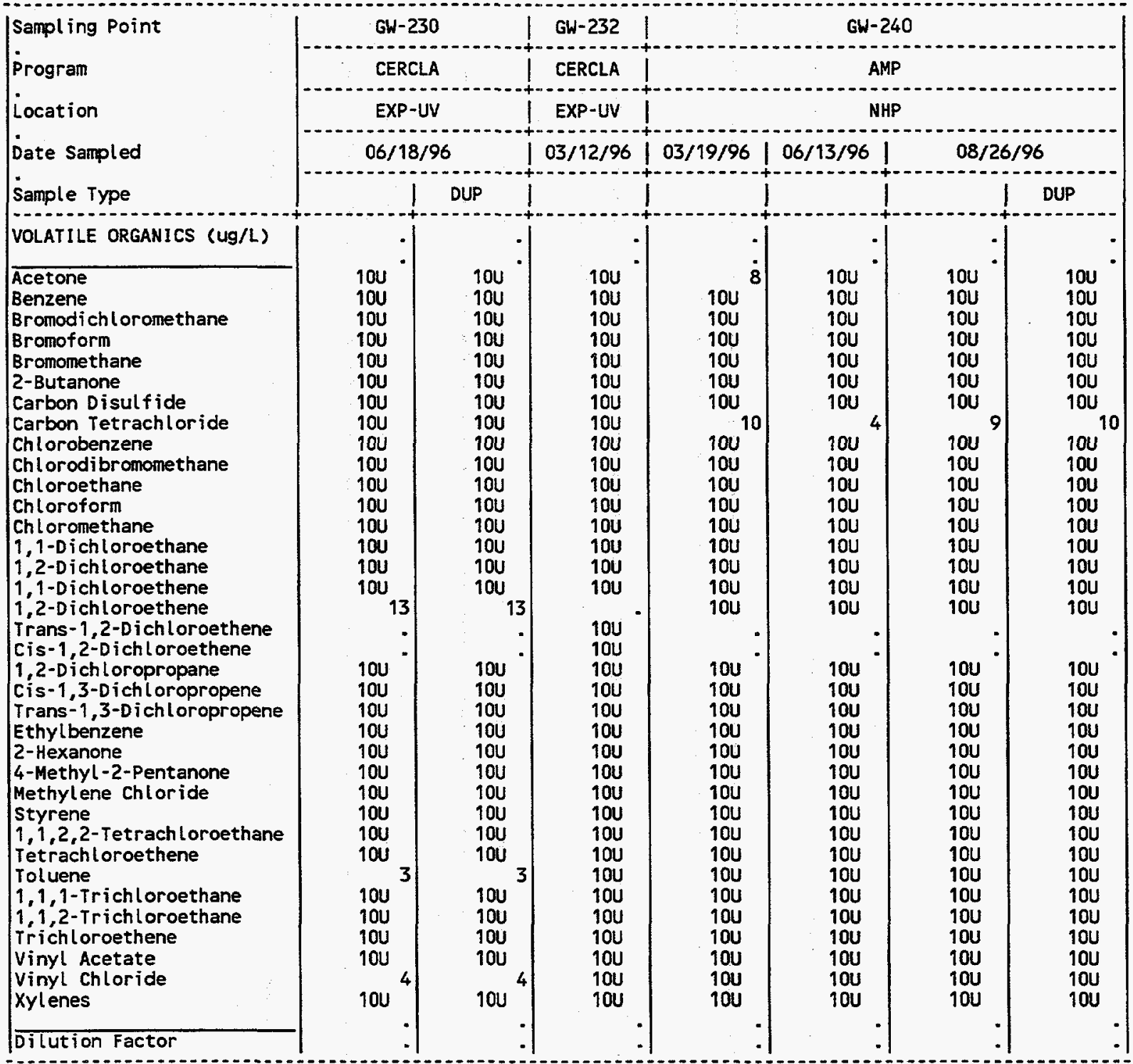

(CONTINUED) 
APPENDIX 0.3

Organic Analytes, CY 1996

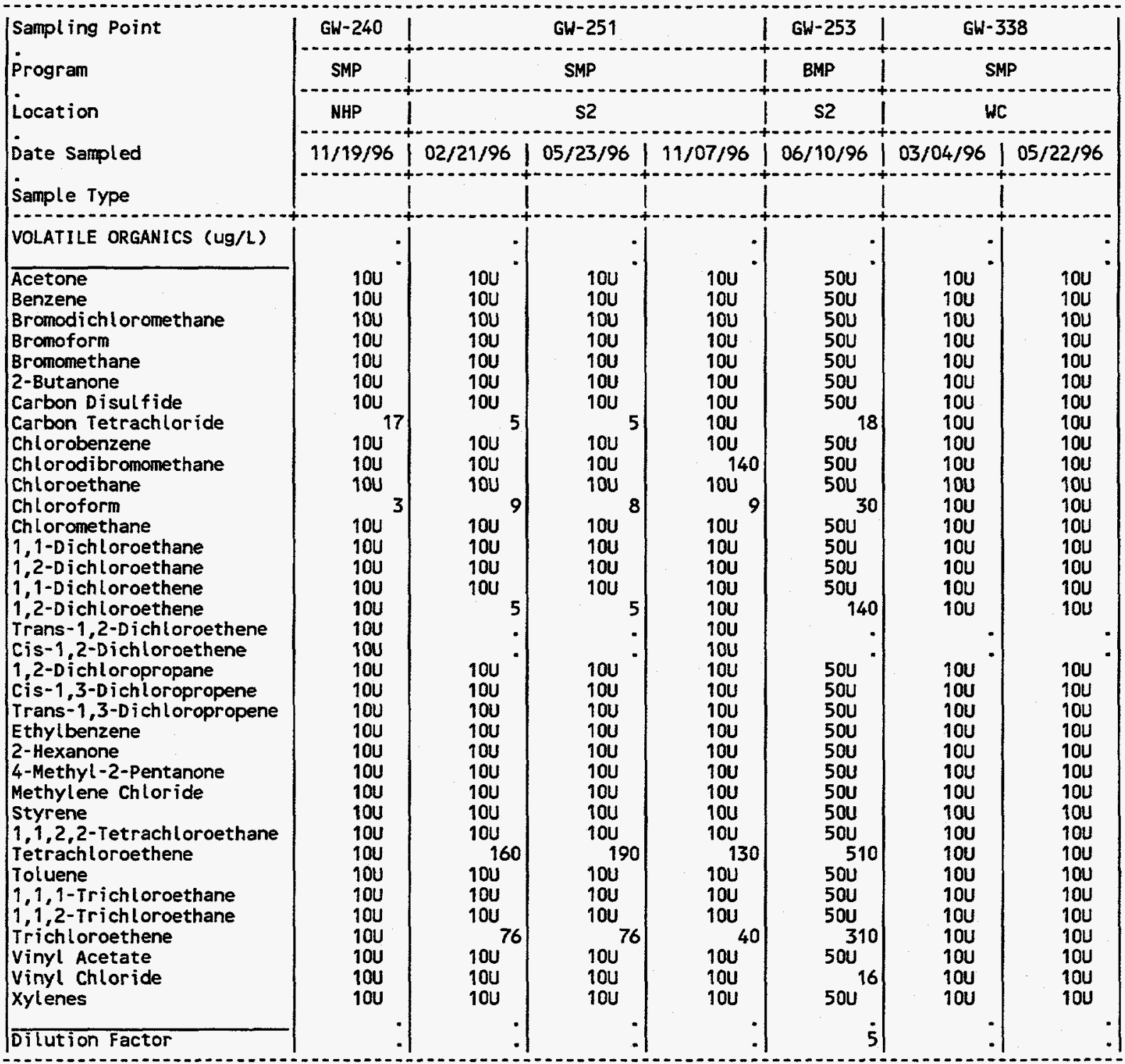

\section{(CONT INUED)}


APPENDIX 0.3

Organic Analytes, CY 1996

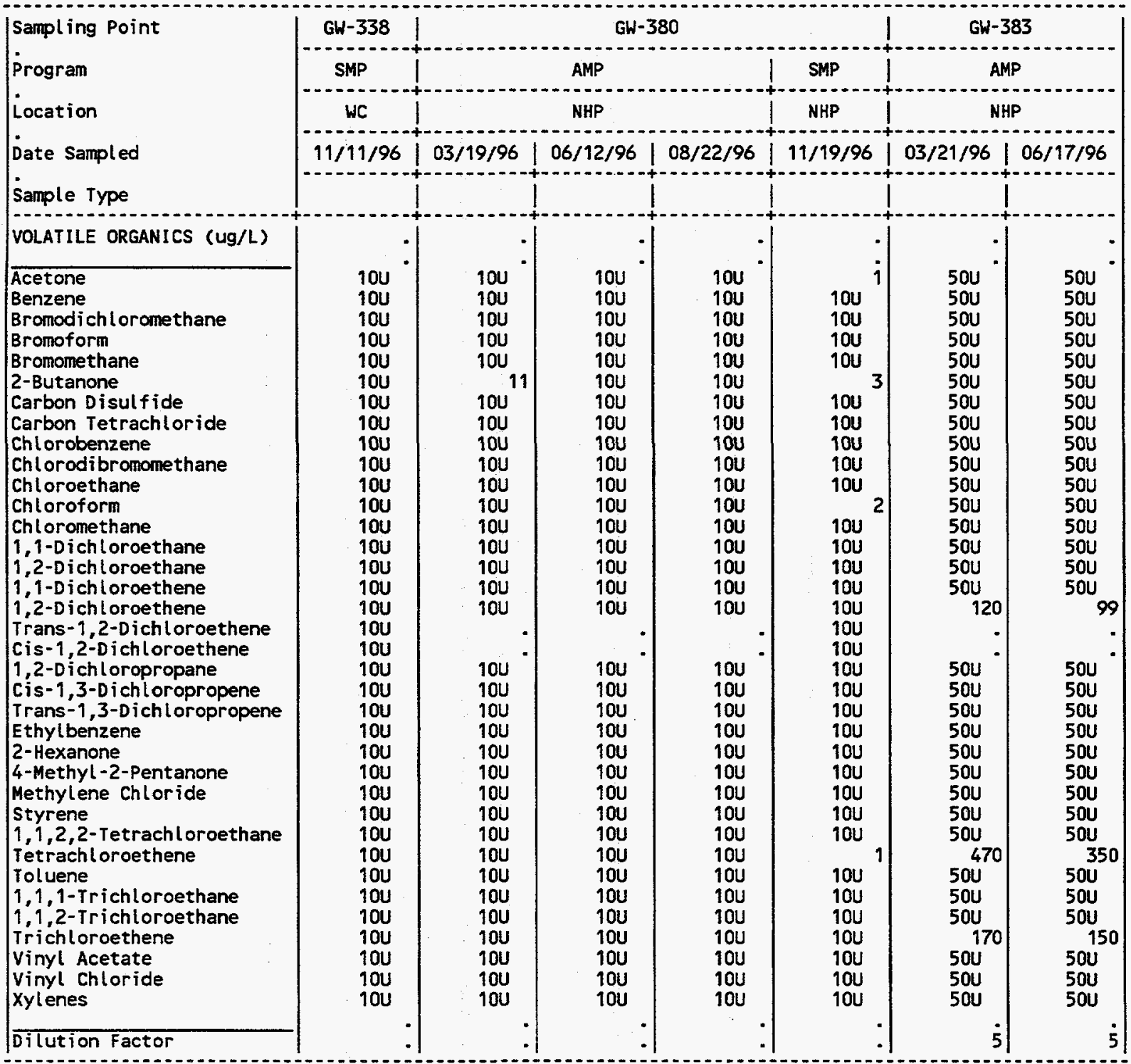

(CONT INUED) 
APPENDIX 0.3

Organic Analytes, CY 1996

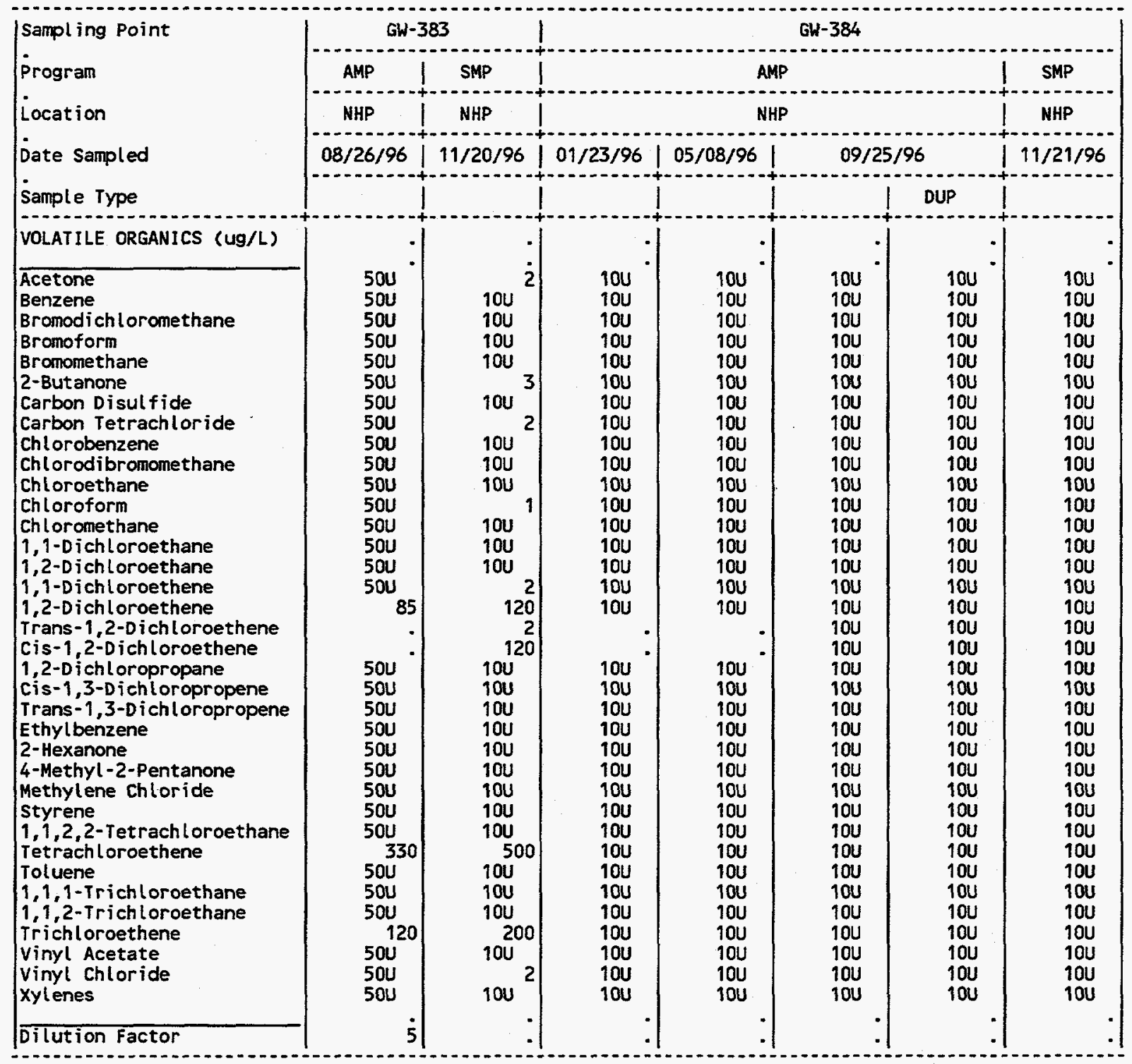

(CONTINUED) 
APPEND IX 0.3

Organic Analytes, CY 1996

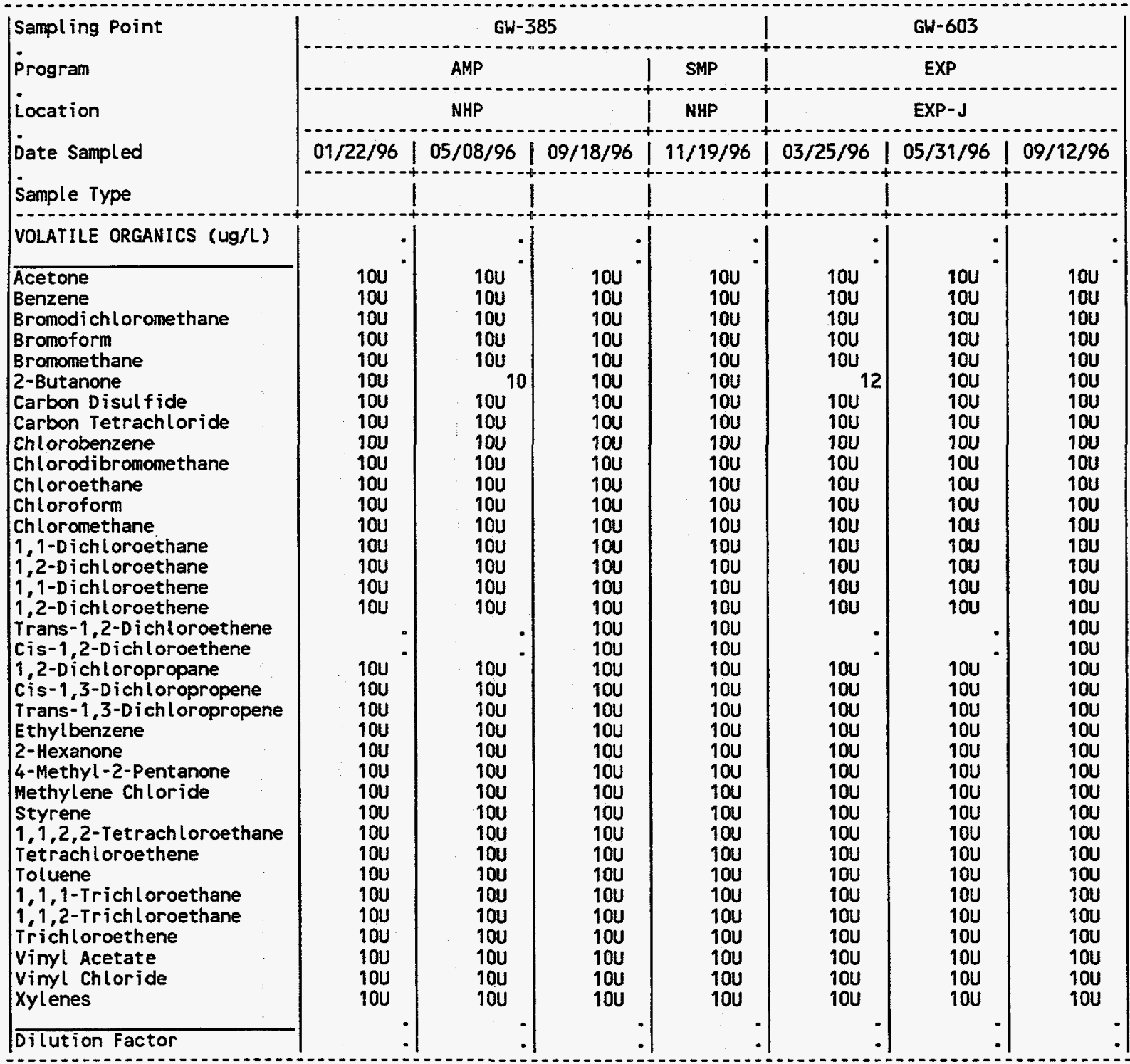

(CONT INUED) 
(QĐกNILNOJ)

\begin{tabular}{|c|c|c|c|c|c|c|c|}
\hline & 1. & . & - & . & & . & jolog」 Uo!7n! \\
\hline \multirow{15}{*}{$\begin{array}{c}\text { nol } \\
\text { nol } \\
\text { nol } \\
8 \\
\text { nol } \\
\text { nol } \\
\text { nol } \\
l 2 \\
\text { nol } \\
\text { nol } \\
\text { nol } \\
\text { nol } \\
\text { nol } \\
\text { nol } \\
\text { nol } \\
\text { nol } \\
\text { nol }\end{array}$} & \multirow{2}{*}{ nol } & nol & nol & \multirow{2}{*}{ nol } & \multirow{2}{*}{$\begin{array}{l}\text { nol } \\
\text { nol }\end{array}$} & nol & səuə $\mid \wedge x$ \\
\hline & & nol & nol & & & nol & 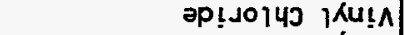 \\
\hline & nol & noi & nol & nol & nol & nol & 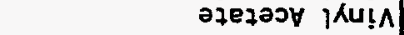 \\
\hline & nol & nol & nol & not & nol & nol & әนәчมә0งО \\
\hline & noi & nol & noi & nol & nol & nol & 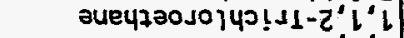 \\
\hline & nol & nol & nol & nol & nol & nol & 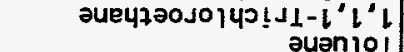 \\
\hline & nol & $\begin{array}{l}\text { nol } \\
\text { nol }\end{array}$ & $\begin{array}{l}\text { nol } \\
\text { nol }\end{array}$ & $\begin{array}{l}\text { nol } \\
\text { nol }\end{array}$ & $\begin{array}{l}\text { nol } \\
\text { not }\end{array}$ & $\begin{array}{l}\text { nol } \\
\text { nol }\end{array}$ & 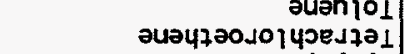 \\
\hline & nol & nol & nol & nol & noi & nol & әиеपдә0د०| \\
\hline & nol & nol & nol & nol & nol & nol & əuə.JAIS \\
\hline & nol & nol & nol & nol & not & nol & 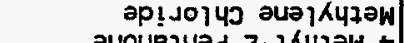 \\
\hline & $\begin{array}{l}\text { nol } \\
\text { nol }\end{array}$ & $\begin{array}{l}\text { nol } \\
\text { nol }\end{array}$ & $\begin{array}{l}\text { nol } \\
\text { nol }\end{array}$ & $\begin{array}{l}\text { nol } \\
\text { nol }\end{array}$ & $\begin{array}{l}\text { nol } \\
\text { nol }\end{array}$ & nol & 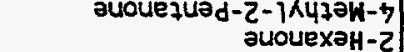 \\
\hline & nol & not & nol & nol & noi & nol. & 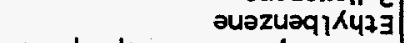 \\
\hline & nol & nol & nol & nol & nol & nol & auədosdojo| $40 ! 0-\Sigma^{\prime} l-$ sue 11 \\
\hline & nol & noi & nol & noi & nol & nol & әuədosdojo $\mid 40 ! 0-\varepsilon^{\prime} l-s ! j$ \\
\hline & $\begin{array}{l}\text { nol } \\
\text { nol }\end{array}$ & nol & nol & nol & nol & nol & 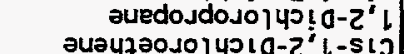 \\
\hline & not & not & $\cdot$ & $\cdot$ & - & nol & 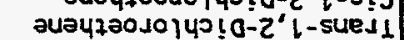 \\
\hline l2 & nol & nol & not & nol & nol & nol & วนอบวә0دо \\
\hline nol & nol & nol & nol & nol & nol & nol & 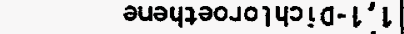 \\
\hline nol & nol & nol & nol & nol & nol & nol & 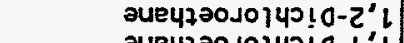 \\
\hline nol & not & nol & nol & nol & nol & nol & 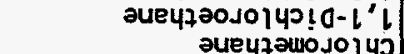 \\
\hline $92^{n O L}$ & $\begin{array}{l}\text { nol } \\
\text { nol }\end{array}$ & $l^{\text {not }}$ & $2^{\text {nol }}$ & $l^{\text {nol }}$ & nol & $\begin{array}{l}\text { nol } \\
\text { nol }\end{array}$ & 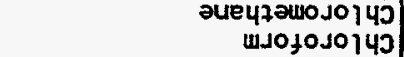 \\
\hline nol & noi & nol & nol & nol & not & noi & әueपtวo so 140 \\
\hline nol & nol & nol & nol & nol & nol & nol & 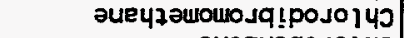 \\
\hline nol & nol & noi & nol & noi & nol & nol & auazueqosoluว \\
\hline 061 & not & nol & nol & nol & nol & nol & әp!so| पPedza1 uoquej \\
\hline nol & nol & nol & & nol & nol & nol & әp! + Ins!o uoqueJ \\
\hline $\begin{array}{l}\text { nol } \\
\text { nol }\end{array}$ & $\varepsilon_{\text {nol }}$ & $\begin{array}{l}\text { nol } \\
\text { nol }\end{array}$ & nol & 2l nol & nol & ${ }^{7}$ nol & $\begin{array}{r}\text { əuoue7ng-z } \\
\text { əue 47әwowoJg }\end{array}$ \\
\hline nol & nol & nol & nol & nol & nol & nol & wsofoliosg \\
\hline nol & not & nol & nol & nol & nol & nol & 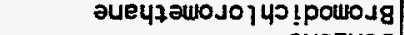 \\
\hline nol & nol & nol & nol & nol & not & nol & әuәzuəg \\
\hline & 2 & mul & nol & & & 2 & 2u012 \\
\hline - & - & - & - & - & - & * & 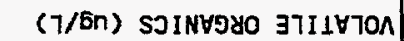 \\
\hline & & & & & & & ad/ 1 ә dures \\
\hline $96 / 5 \mathrm{~L} / 20$ & $96 / 92 / L b$ & $96 / 21 / 60$ & $96 / 70 / 90$ & & Z/乏O & $96 / \varsigma 2 /$ & pojdues әfeg \\
\hline $1-d \times 3$ & & & $r-d \times 3$ & & & $r-d \times 3$ & $40 ! 7 e 507$ \\
\hline dX $\exists$ & & & $d \times 3$ & & & dXヨ & we $360 . d_{d}$ \\
\hline SO9-M9 & & & $709-149$ & & & ع09-Mפ & qu!̣Od 6u! jolues \\
\hline
\end{tabular}


(GBกNILNOJ)

\begin{tabular}{|c|c|c|c|c|c|c|c|}
\hline & ? & 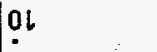 & OL & . & . & . & Jo70ey uo! tn! 10 \\
\hline nol & noz & nool & nool & nol & not & nol & seue 1 Kx \\
\hline nol & noz & nool & noot & nol & noi & nol & 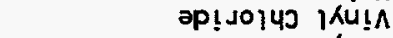 \\
\hline nol & กoz & nool & nool & nol & nol & nol & 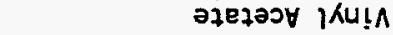 \\
\hline nol & noz & nool & nool & 9 & $\rightarrow$ & & 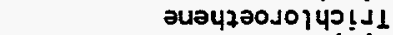 \\
\hline nol & noz & nool & nool & nol & nol & nol & 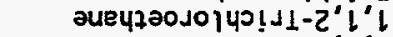 \\
\hline nol & noz & nool & nool & nol & nol & nol & 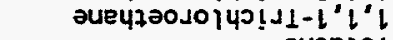 \\
\hline nol & noz & nool & nool & nol & nol & nol & auanjo1 \\
\hline $2 l$ & 9 & nool & nool & & & & әuวY720 \\
\hline nol & noz & nool & nool & nol & nol & nol & 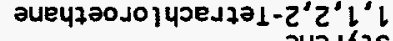 \\
\hline $\begin{array}{l}\text { nol } \\
\text { nol }\end{array}$ & $\begin{array}{l}\text { no2 } \\
\text { no2 }\end{array}$ & $\begin{array}{l}\text { nool } \\
\text { nool }\end{array}$ & $\begin{array}{l}\text { nool } \\
\text { noot }\end{array}$ & $\begin{array}{l}\text { not } \\
\text { not }\end{array}$ & nol & not & 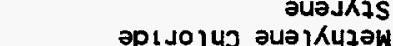 \\
\hline nol & noz & nool & nool & not & nol & not & 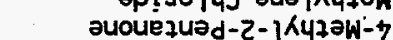 \\
\hline nol & noz & nool & nool & nol & nol & not & วUoueXəH-Z \\
\hline nol & noz & nool & nool & nol & nol & nol & auəzuəq)人uz \\
\hline nol & noz & nool & nool & nol & nol & nol & әuədo Jdo \\
\hline noi & noz & nool & noot & nol & nol & nol & auədoJdojo $\mid 4 \supset ! a-\Sigma^{\prime} l-s ! \jmath$ \\
\hline nol & กOZ & nool & nool & nol & nol & nol & auedosdoso 4 प $10-2^{i}$ \\
\hline nol & noz & & & & & & 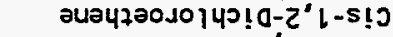 \\
\hline nol & noz & & & nol & nol & & 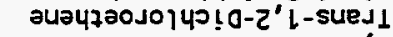 \\
\hline nol & noz & nool & nool & & nol & & aนว47ә0งо $140 ! 0-2^{\prime} !$ \\
\hline nol & noz & nool & nool & nol & nol & nol & auอ47аоло \\
\hline nol & noz & nool & nool & nol & nol & nol & 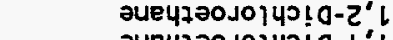 \\
\hline nol & $\begin{array}{l}\text { noz } \\
\text { noz }\end{array}$ & $\begin{array}{l}\text { nool } \\
\text { nool }\end{array}$ & $\begin{array}{l}\text { nool } \\
\text { nool }\end{array}$ & $\begin{array}{l}\text { nol } \\
\text { nol }\end{array}$ & $\begin{array}{l}\text { nol } \\
\text { nol }\end{array}$ & $e^{2}$ not & 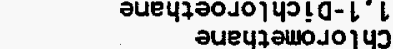 \\
\hline $0+2$ & & 022 & 012 & & & $\varepsilon 2$ & யJOfOJO|Yว \\
\hline nol & noz & nool & nool & not & nol & nol & 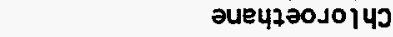 \\
\hline nol & noz & nool & nool & nol & nol & nol & 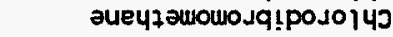 \\
\hline noi & noz & nool & nool & not & nol & nol & әuәzuəqojoj40 \\
\hline 058 & $08 \varepsilon$ & $0<9$ & 059 & 081 & 081 & osz & 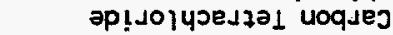 \\
\hline nol & noz & nool & nool & nol & nol & nol & әp!tjns!o uoqseJ \\
\hline & noz & nool & nool & & nol & nol & auouezng-2 \\
\hline nol & noz & nool & nool & nol & nol & nol & әueप32wowo Jg \\
\hline nol & noz & nool & nool & not & nol & nol & แ」० \\
\hline nol & noz & nool & nool & nol & noi & nol & 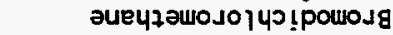 \\
\hline nol & noz & nool & nool & nol & nol & nol & aนəzuəg \\
\hline & noz & nool & nool & $\varepsilon l$ & nol & nol & วU0IәכY \\
\hline - & & & & & & • & 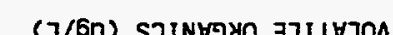 \\
\hline & & & & & & & dos aychues \\
\hline $96 / L E / O L$ & $96 / 61 / 60$ & $96 / 80 / 90$ & $96 / 22 / 20$ & $96 / L E / 0 \mathrm{~L}$ & $96 / 61 / 60$ & $96 / 80 /$ & pojdues әzea \\
\hline$I-d X]$ & & $1-d \times 3$ & & $1-9 \times 3$ & & $d X \exists$ & uolizeכo7 \\
\hline & & & & & & & \\
\hline dWอ & & $d \times \exists$ & & dWJ & & $X \exists$ & แej6odd \\
\hline & & - $M 9$ & & & SO९-MD & & 7utod 6u! joures \\
\hline
\end{tabular}


(OBกNILNOJ)

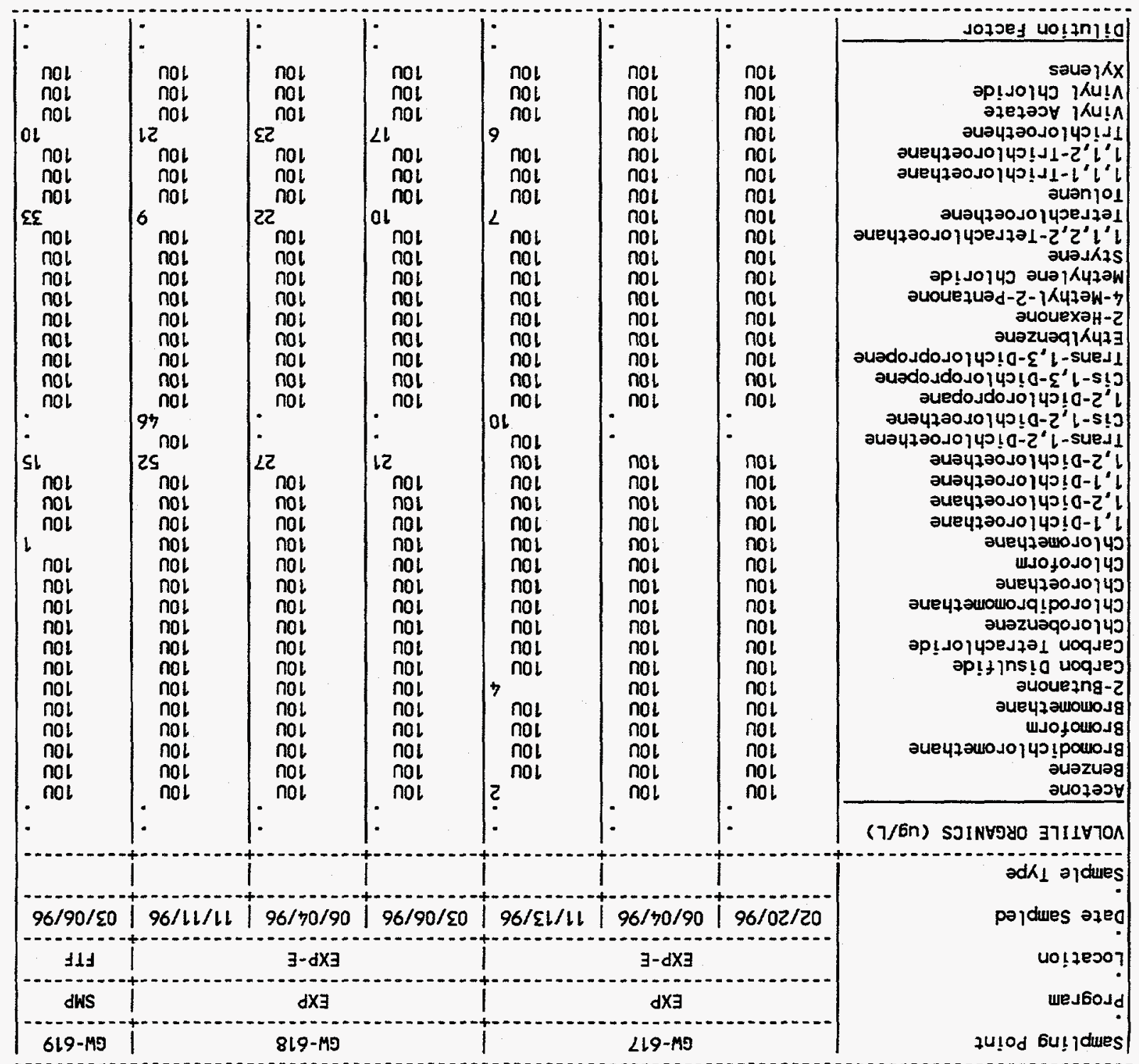


APPENDIX 0.3

Organic Analytes, or 1996

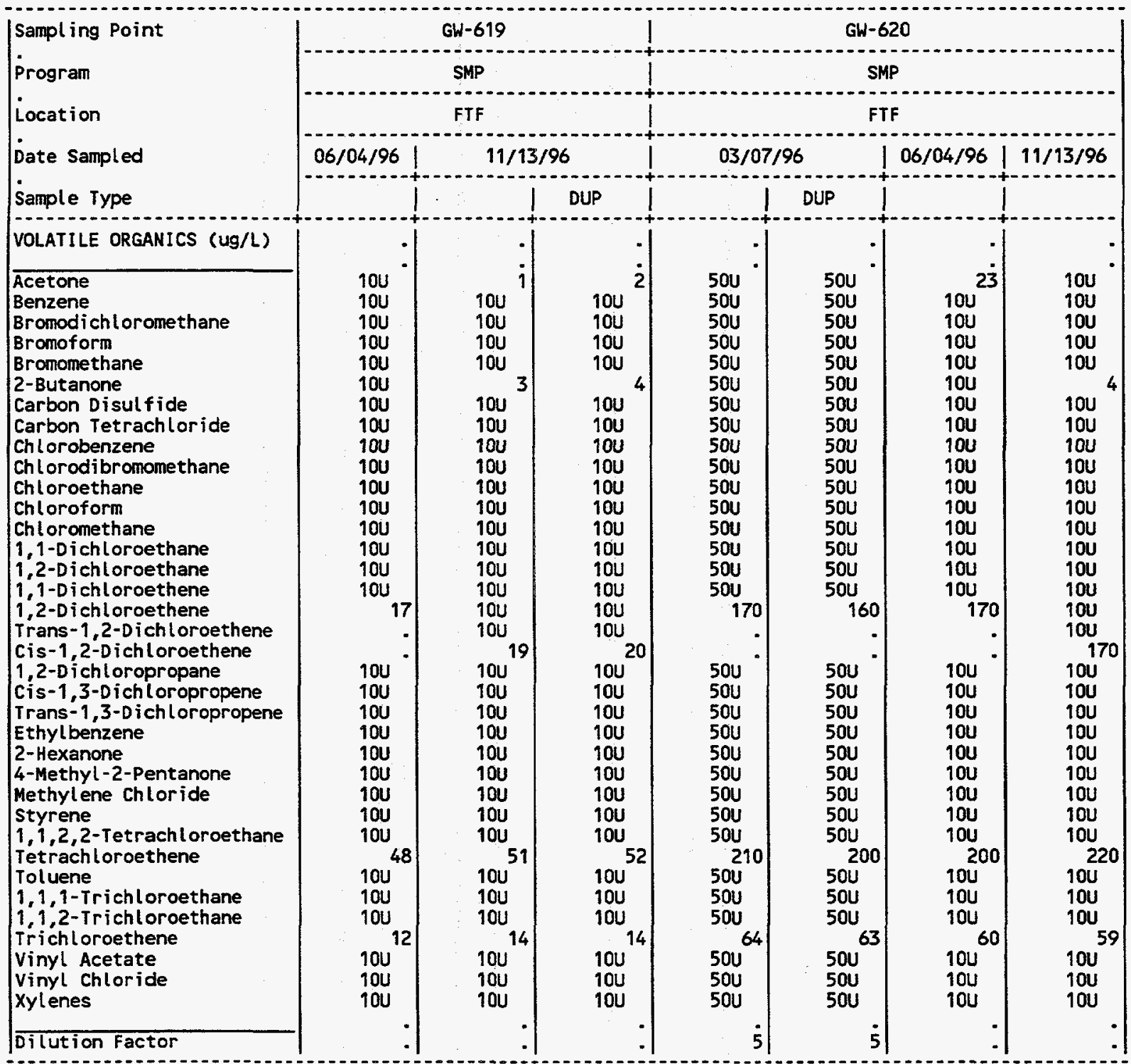

(CONTI NUED) 
APPEND IX 0.3

Organic Analytes, CY 1996

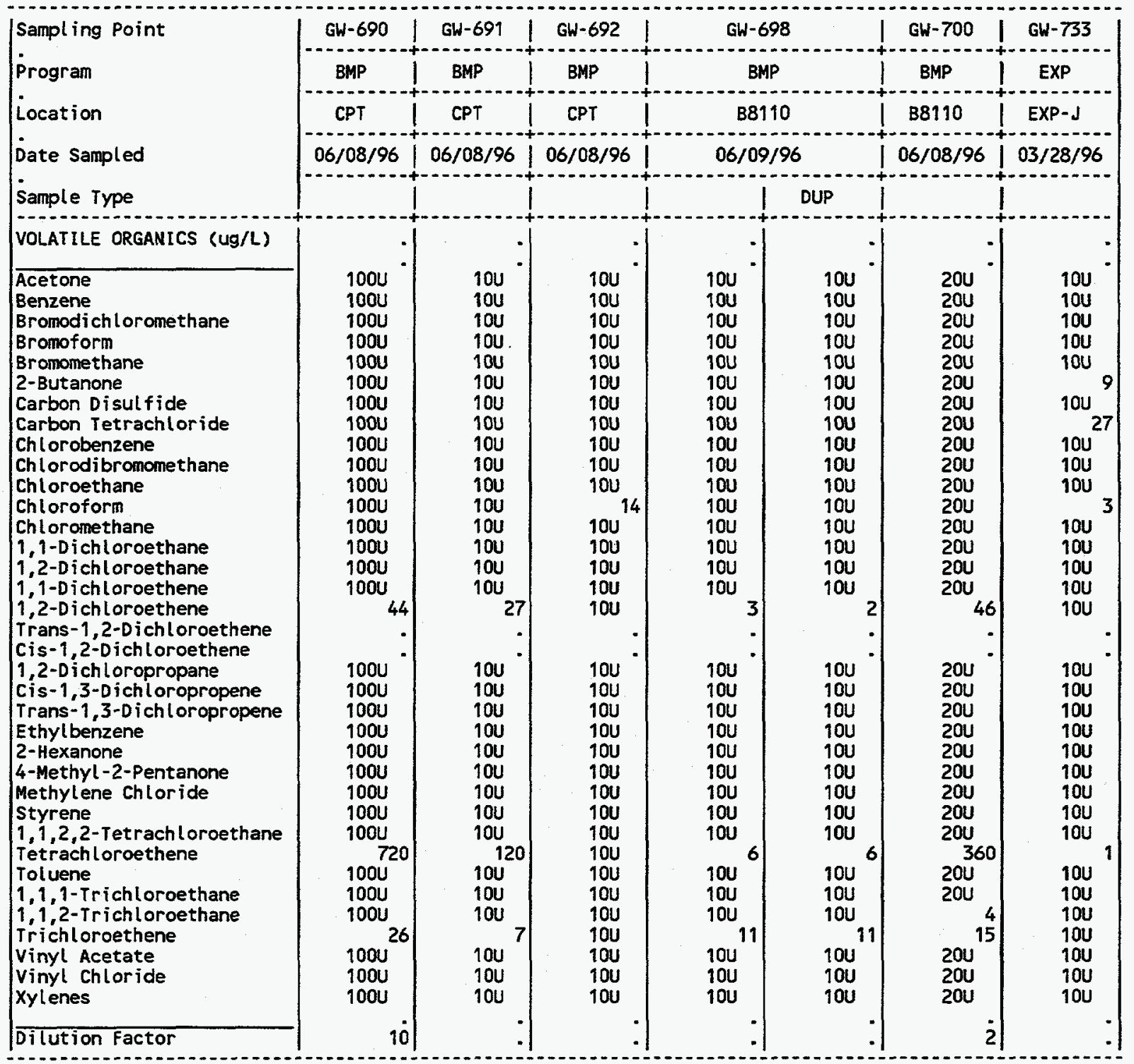

(CONTINUED) 
APPENDIX $D .3$

Organic Analytes, CY 1996

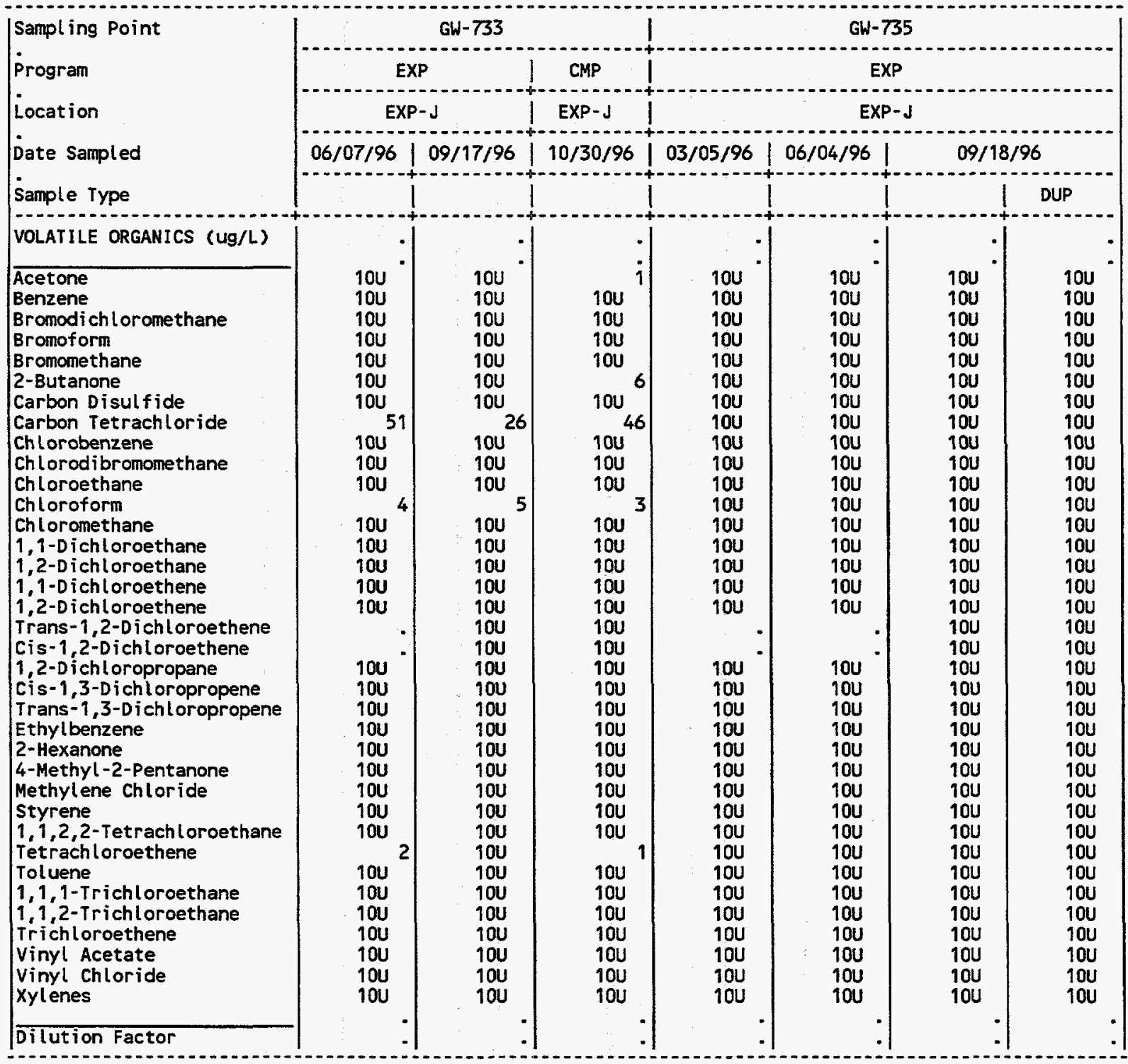

(CONT INUED) 
APPEND IX D.3

Organic Analytes, CY 1996

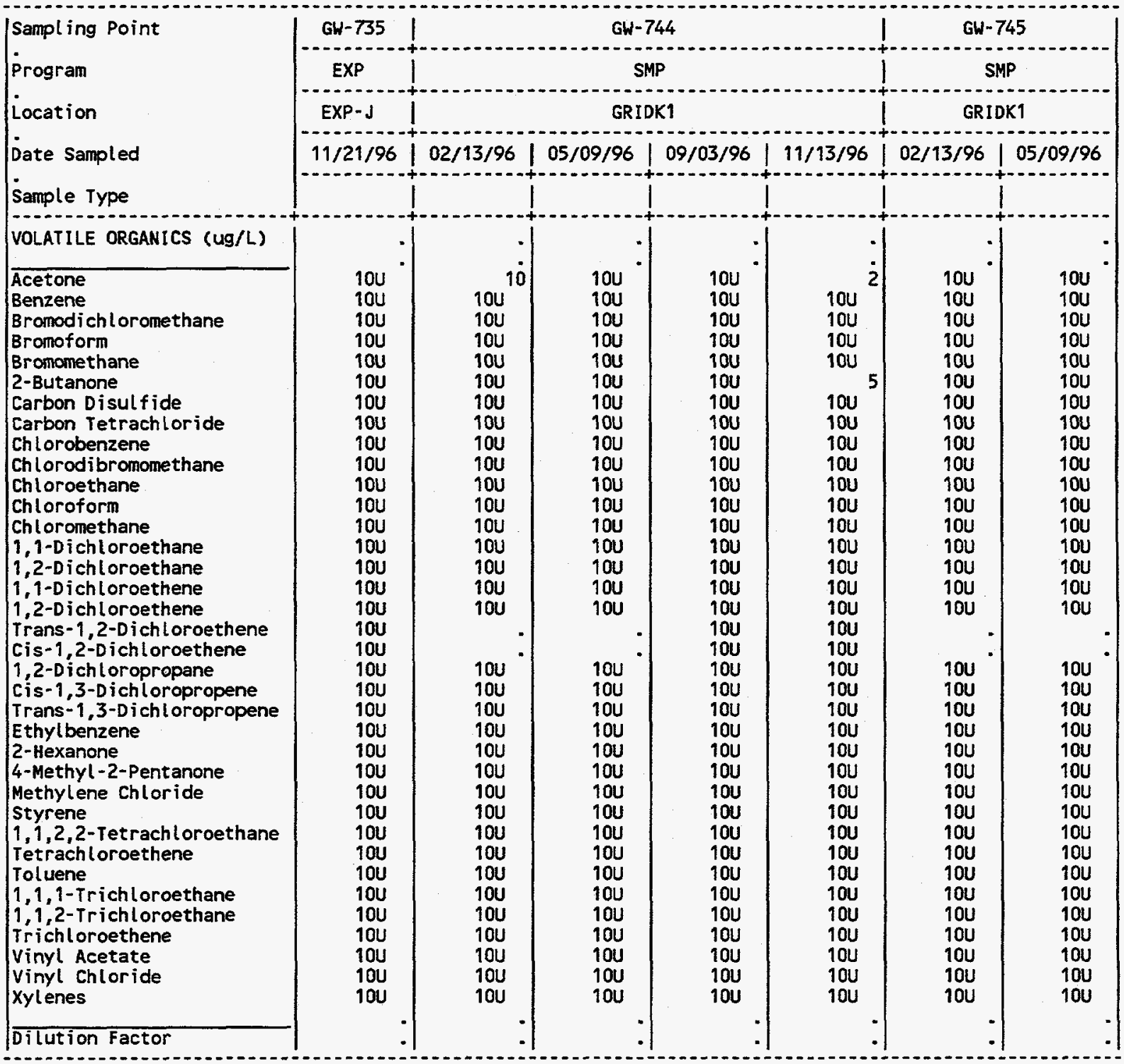

(CONT INUED) 


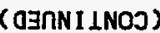

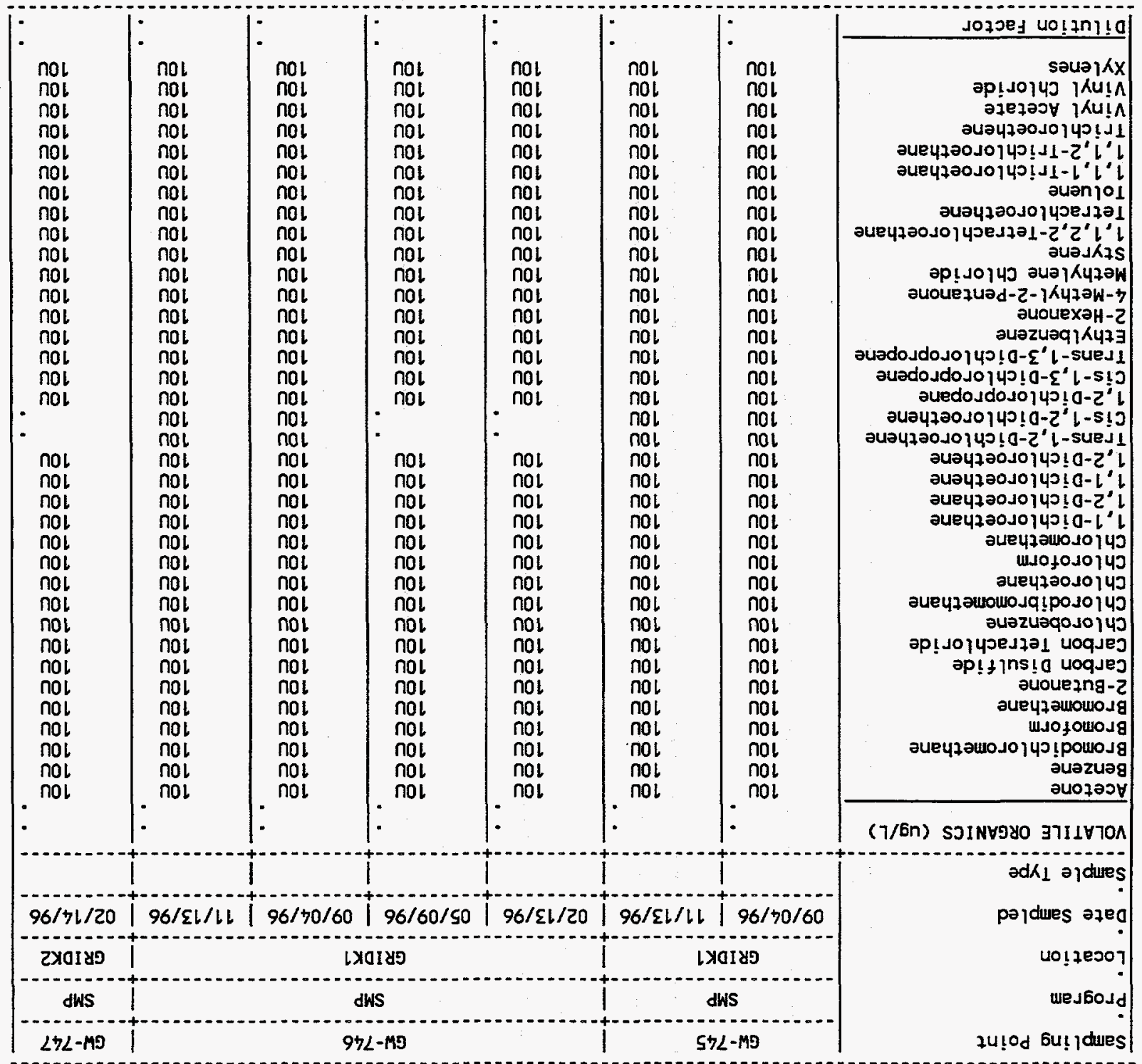

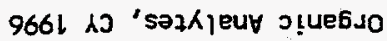


APPENDIX 0.3

Organic Analytes, CY 1996

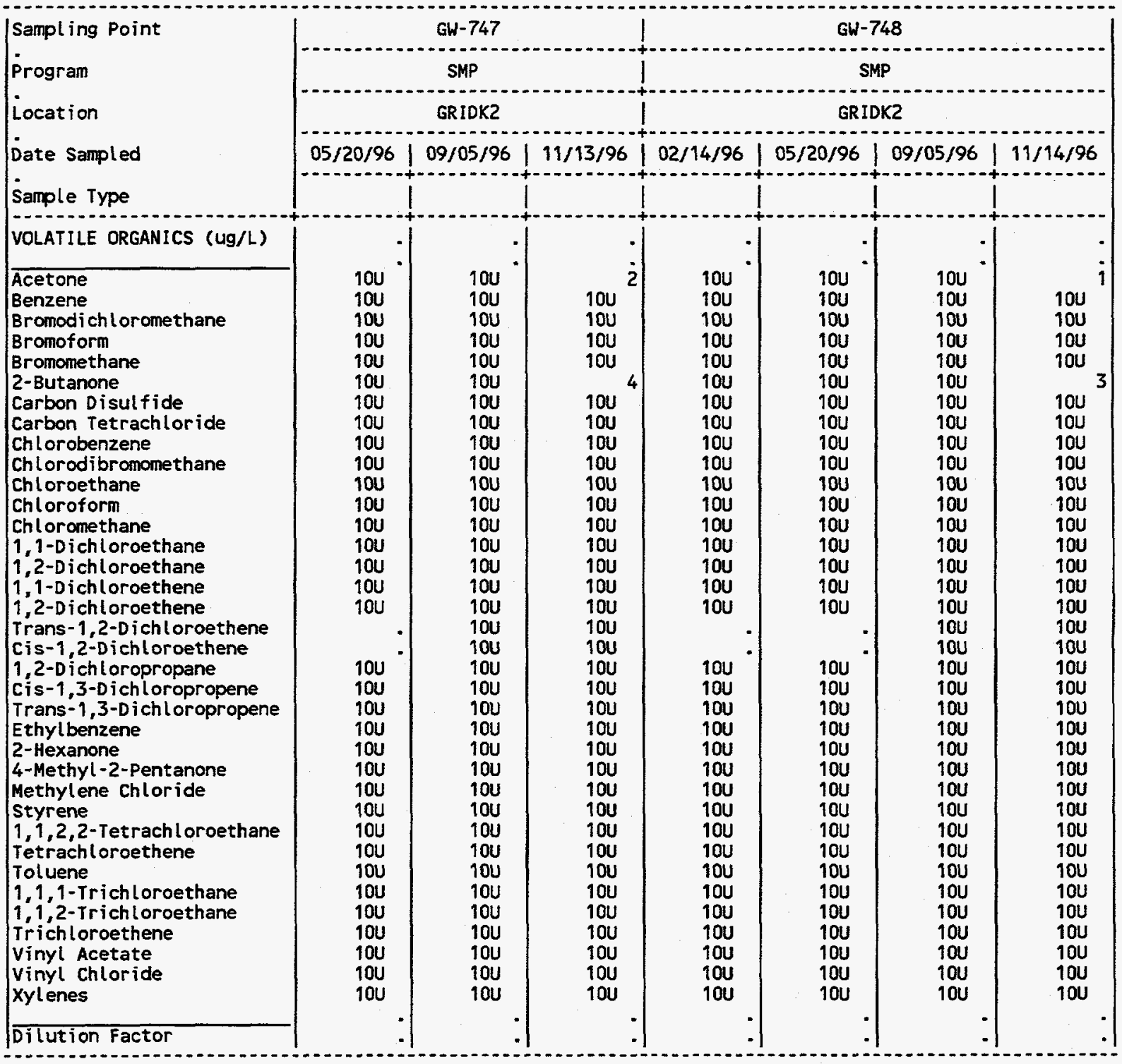

(CONTINUED) 
APPENDIX 0.3

Organic Analytes, CY 1996

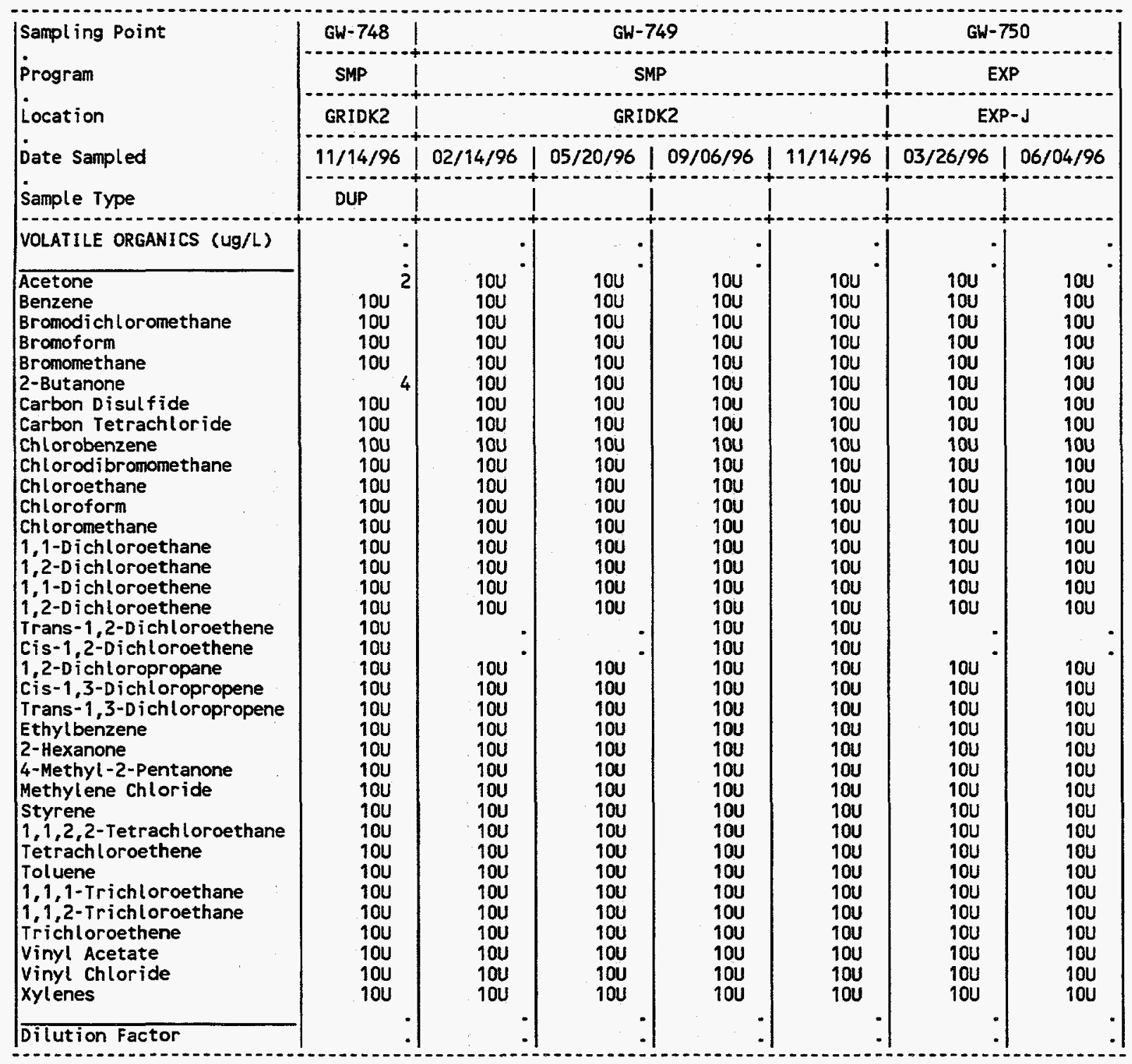

(CONTINUED) 


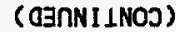

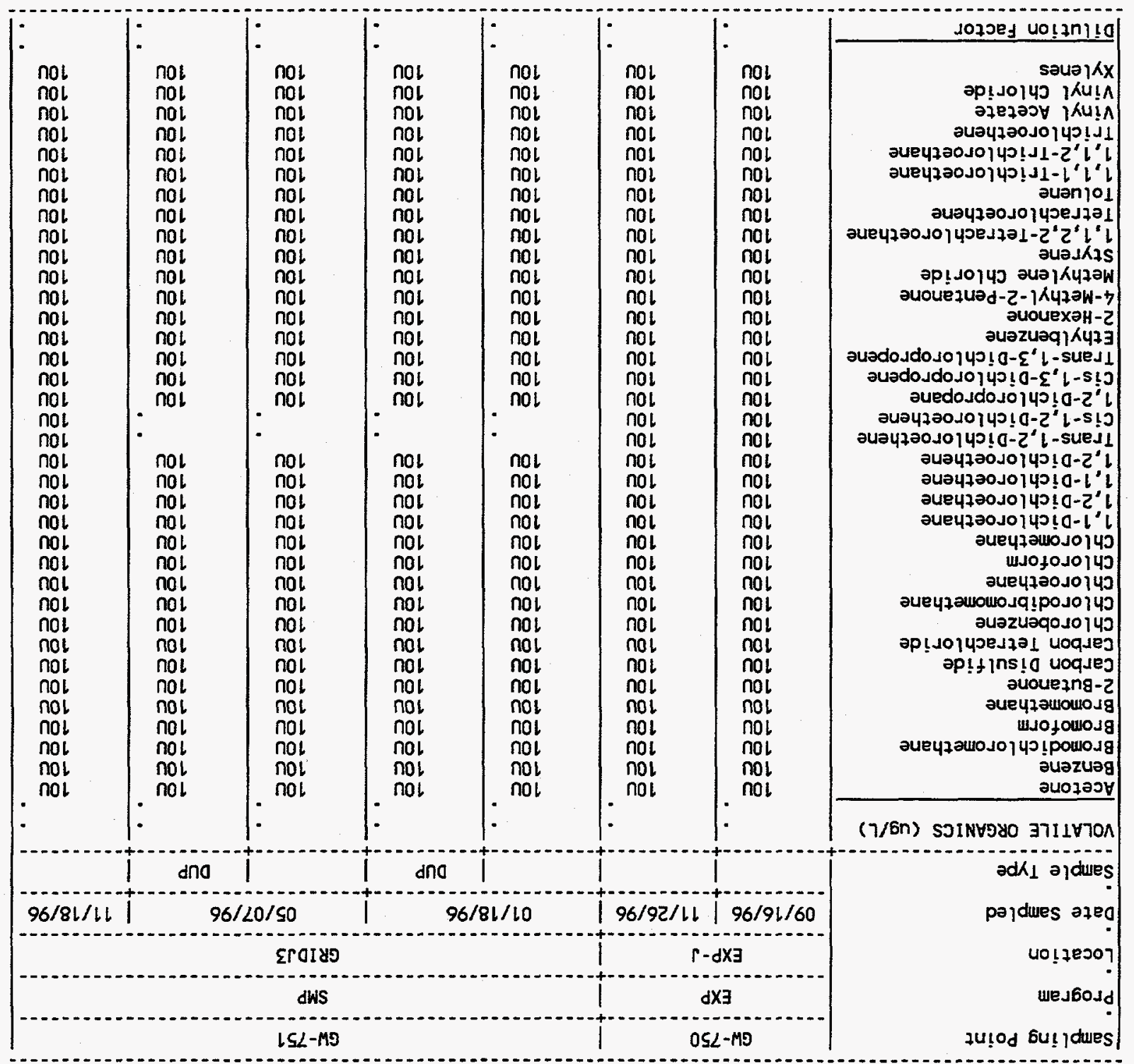


(QכกNI 1NOJ)

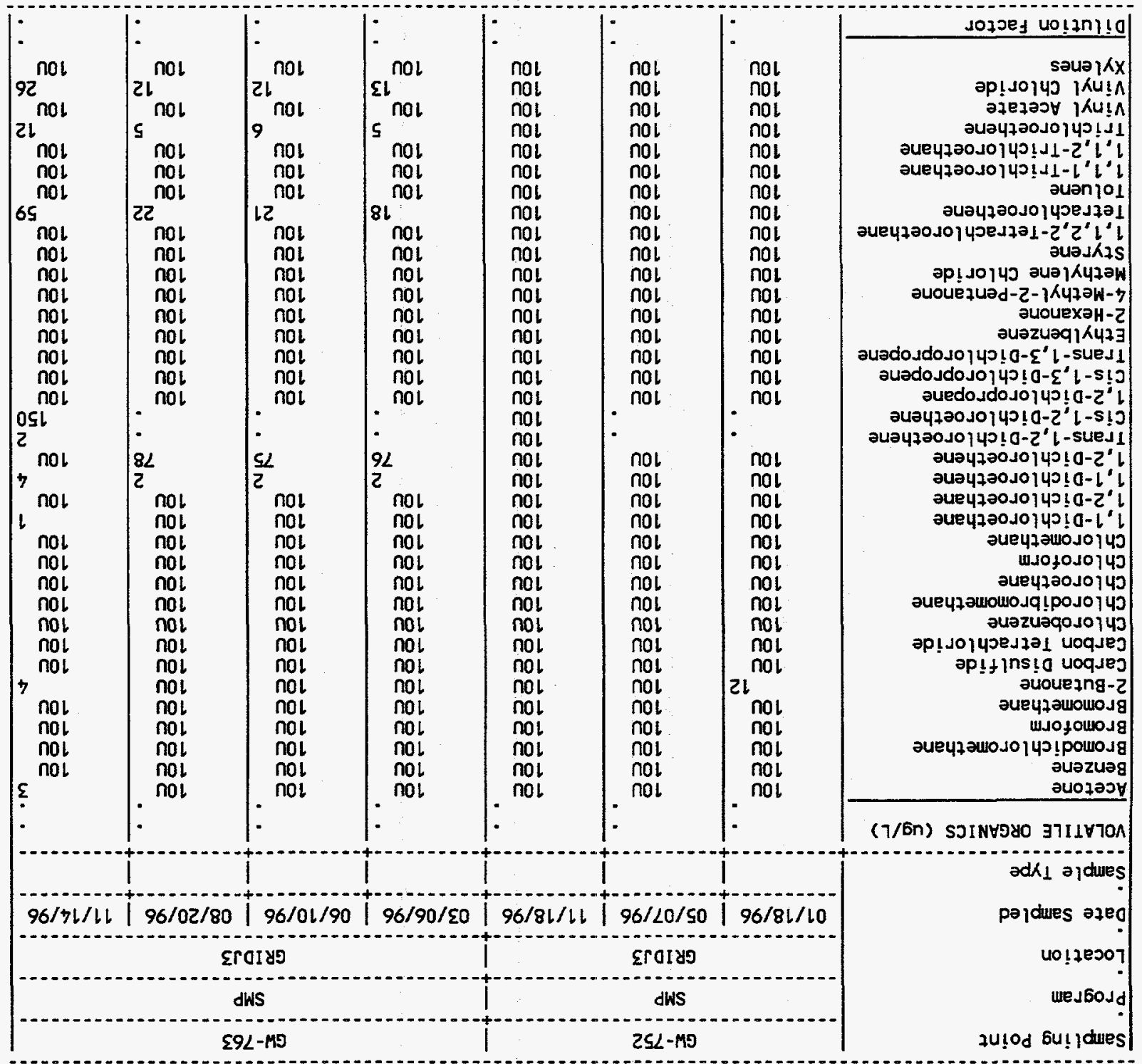


(OEnNI1NOJ)

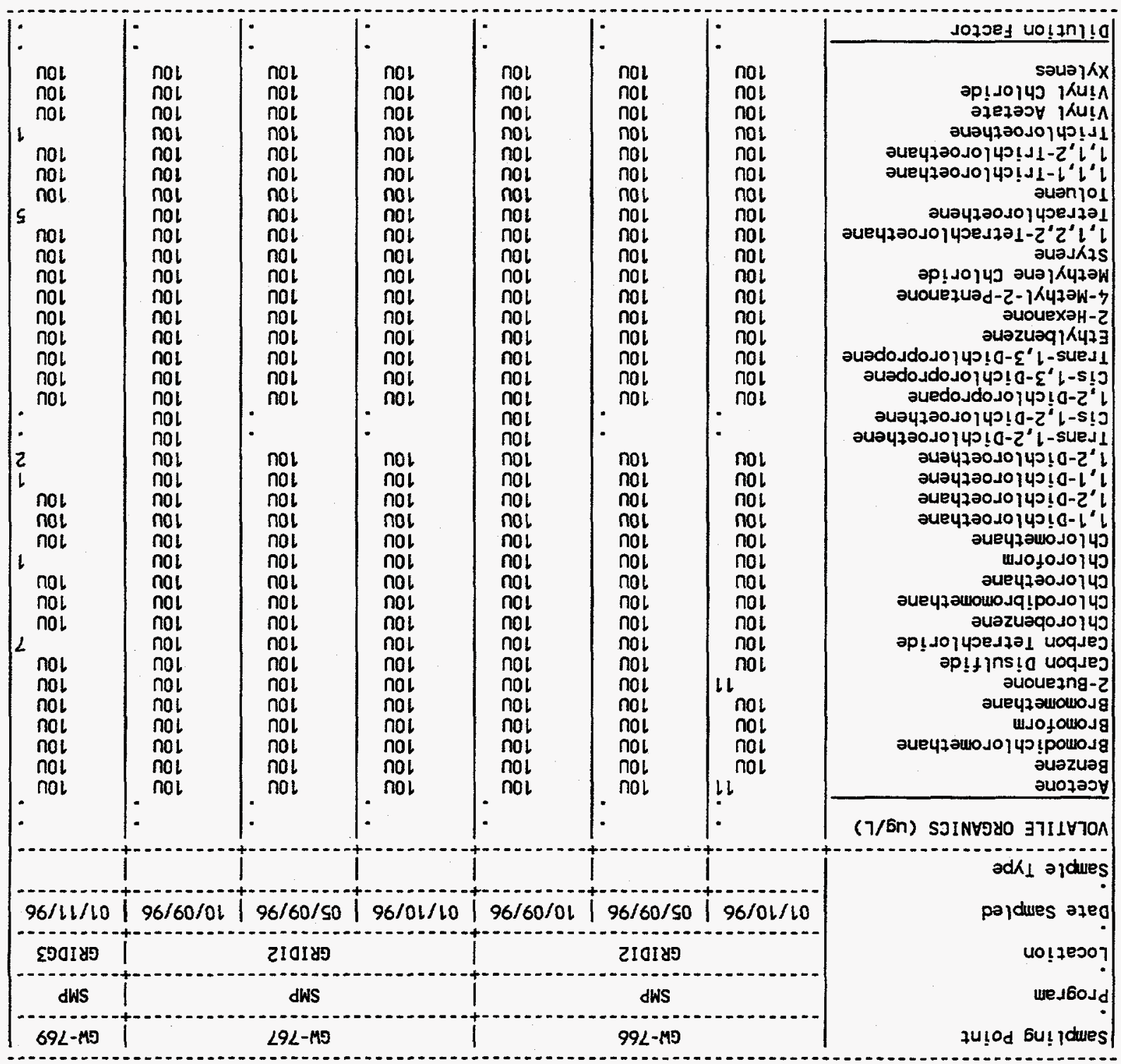


(OBNNILNOJ)

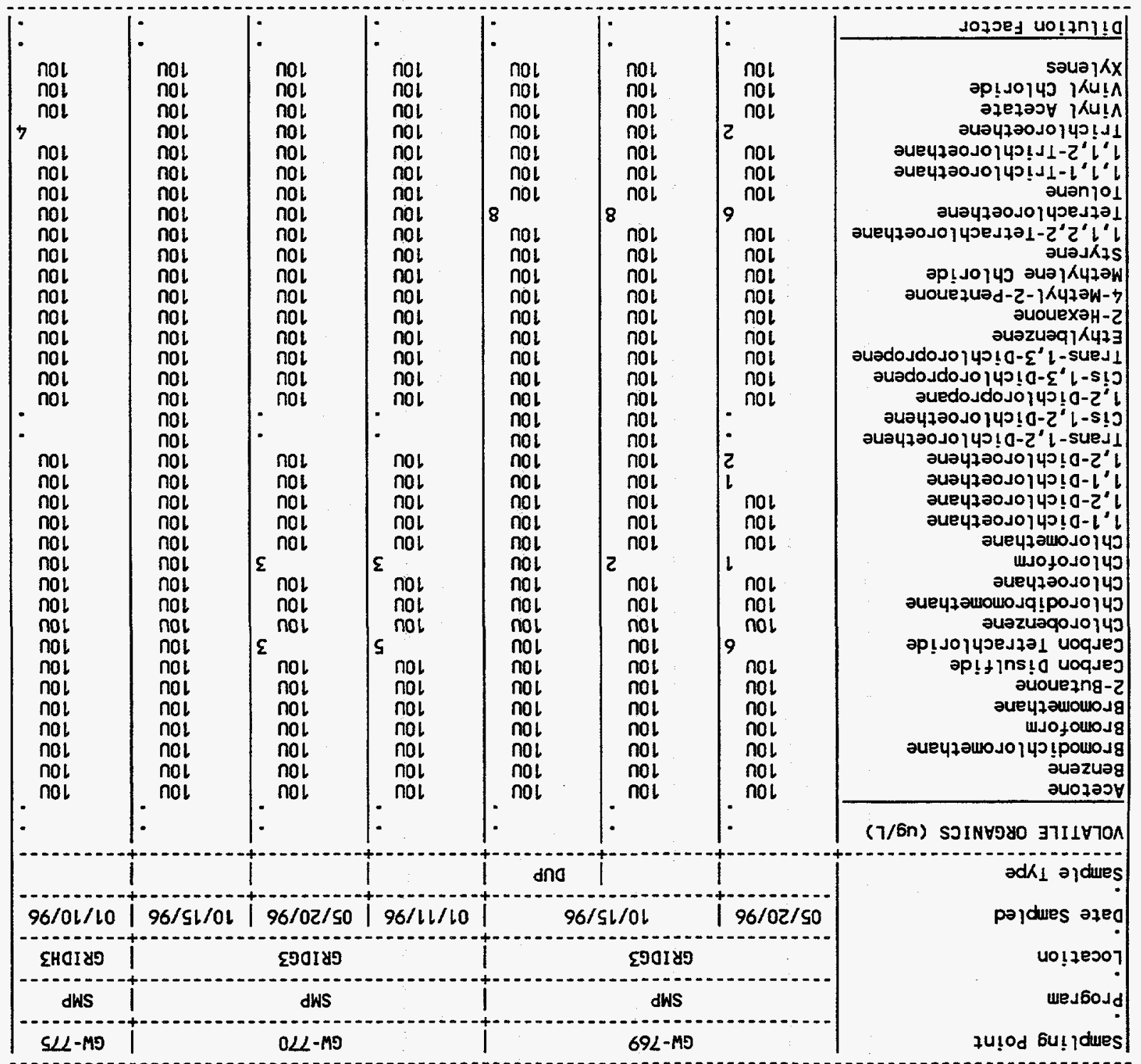


APPENDIX 0.3

Organic Analytes, CY 1996

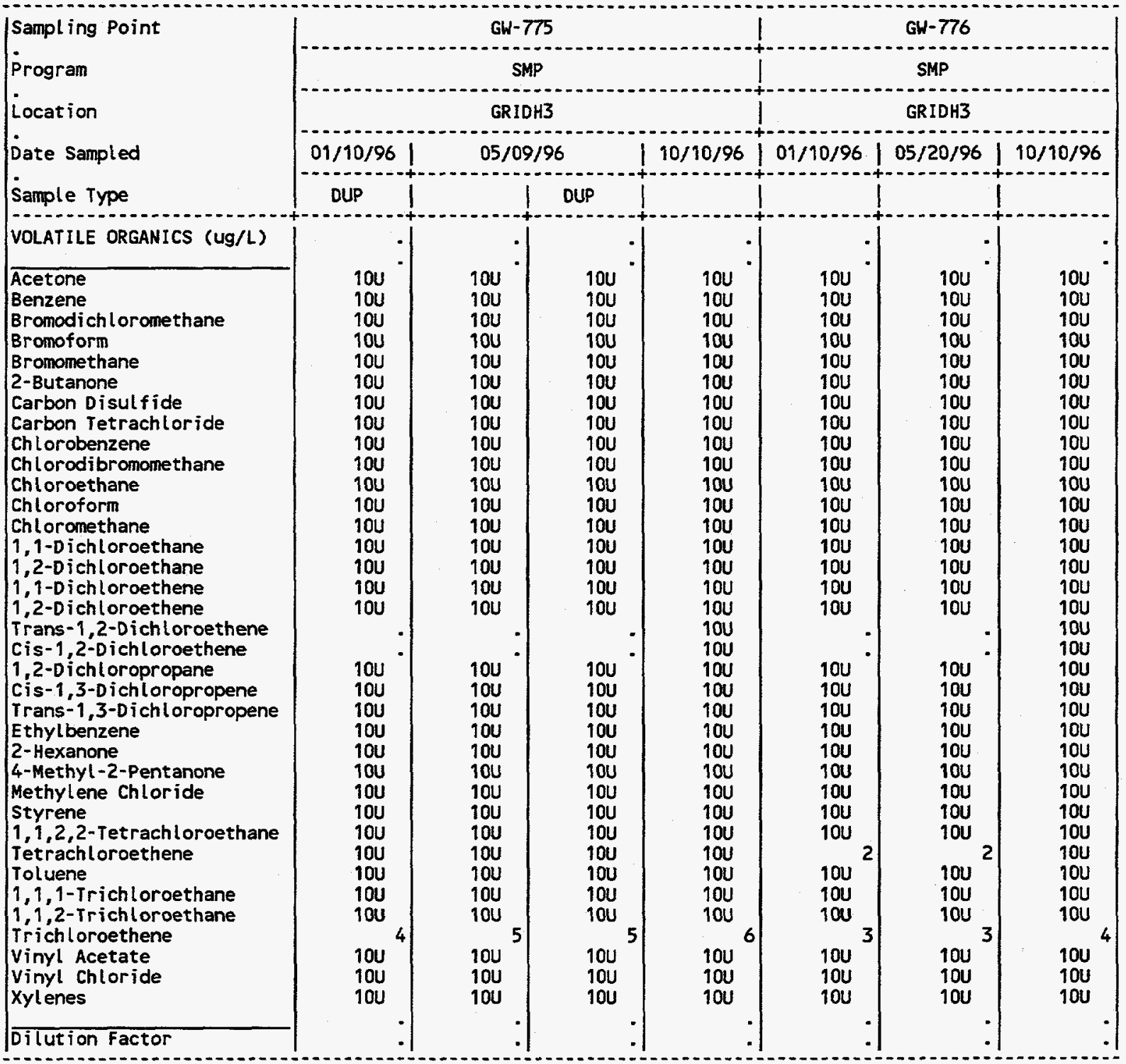

(CONT I NUED) 
(OBกNILNOJ)

\begin{tabular}{|c|c|c|c|c|c|c|c|}
\hline & & $\dot{.}$ & : & . & $\dot{*}$ & . & 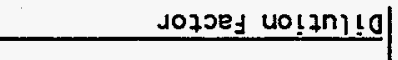 \\
\hline nol & nol & nol & nol & nol & nol & nol & sauə $\mathfrak{k x}$ \\
\hline nol & nol & nol & $\mathrm{nol}$ & กOL & nol & nol & 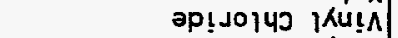 \\
\hline nol & nol & nol & nol & nol & nol & nol & әтедәว jKuin \\
\hline nol & nol & nol & nol & nol & nol & nol & 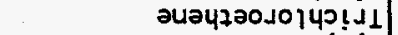 \\
\hline nol & not & nol & nol & กอᄂ & nol & nol. & 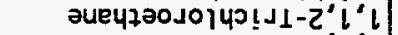 \\
\hline nol & nol & nol & nol & nol & nol & nol: & 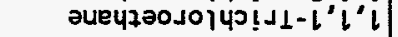 \\
\hline nol & nol & nol & nol & nol & nol & nol & auenioi \\
\hline nol & nol & noi & nol & nol & nol & nol & 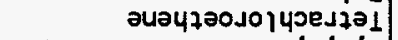 \\
\hline nol & nol & nol & nol & nol & nol & nol & 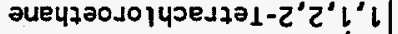 \\
\hline กOL & nol & nol & nol & nOL & nol & nol & วuองk7S \\
\hline nol & nol & nol & nol & nol & nol & nol & 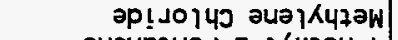 \\
\hline nol & nol & nol & nol & nol & nol & nol & 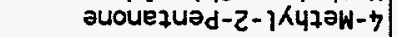 \\
\hline nol & nol & nol & nol & nol & nol & nol. & әuouexah-Z \\
\hline nol & nol & nol & nol & nol & nol & nol & auazuaqן人473 \\
\hline nol & nol & nol & nol & nol & nol & nol & auədosdoso 4 4 ! $0-\varepsilon^{\prime} \mid$-sued 1 \\
\hline nol & nol & nol & nol & nol & nol & nol & วuədosdojo $\mid 40 ! \bar{a}-\varepsilon^{\prime} l-s ! \jmath$ \\
\hline nol & nol & nol & nol & nol & nol & nol & 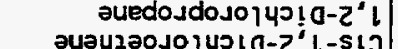 \\
\hline & nol & & $\cdot$. & nol & & - & 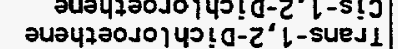 \\
\hline nol & nol & nol & nol & nol & nol & nol. & 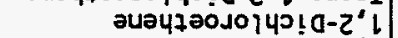 \\
\hline nol & nol & nol & nol & nol & nol & nol & әиәч7ә0ло \\
\hline nol & nol & nol & $\mathrm{nOl}$ & nol & nol & nol & aue47จ010 $45[0-2 ; i$ \\
\hline nol & nol & nol & nol & nol & nol & nol & 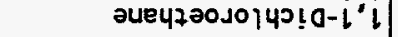 \\
\hline nol & nol & nol & nol & nol & nol & nol. & әueपfow०. \\
\hline nol & nol & nol & nol & noi & nol & nol. & 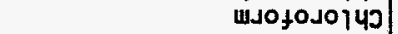 \\
\hline not & nol & nol & nol & nol & nol & nol & 2ue472010142 \\
\hline nol & nol & nol & nol & $\mathrm{nOl}$ & nol & nol & 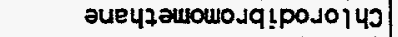 \\
\hline nol & nol & nol & nol & nol & กol & nol & әuәzuәgosoju3 \\
\hline nol & nol & nol & nol & nol & nol & noi & 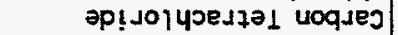 \\
\hline not & nol & nol & nol & nol & nol & nol & әр!+ \\
\hline nol & nol & nol & ก०L & nol & nOL & nol & suouezng-z \\
\hline nol & nol & nol & nol & nol & nol & nol & әUе47әแо山о \\
\hline not & nol & nol & nOL & nol & nol & nol & யisofoursg \\
\hline nol & nol & nol & nol & nol & nol & nol & 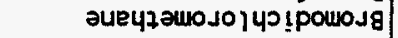 \\
\hline nol & nol & nol & nol & nol & nol & nol & äนzuəg \\
\hline nol & nOL & nol & $8 !$ & nol & nol & nol & auofasy \\
\hline & & & - & 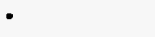 & - & - & 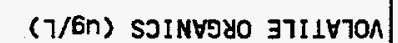 \\
\hline & & & & & & & əd $K_{\perp}$ ә \\
\hline $96 / 90 / \varepsilon 0$ & $96 / 20 /$ L & $96 / 22 / 50$ & $96 / \varsigma 2 / 20$ & $96 / \angle 0 / 16$ & $96 / \mathrm{LZ} / \mathrm{S0}$ & $96 / 52 / 20$ & pejcures azeo \\
\hline 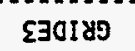 & & ZjoI8s & & & כ20I8כ & & uo!7es07 \\
\hline dWS & & dWS & & & dWS & & wed6odd \\
\hline 18L-MO & & $08 L-M 9$ & & & 6LL-M9 & & 7u!od 6u! jdues \\
\hline
\end{tabular}


APPENDIX 0.3

Organic Analytes, CY 1996

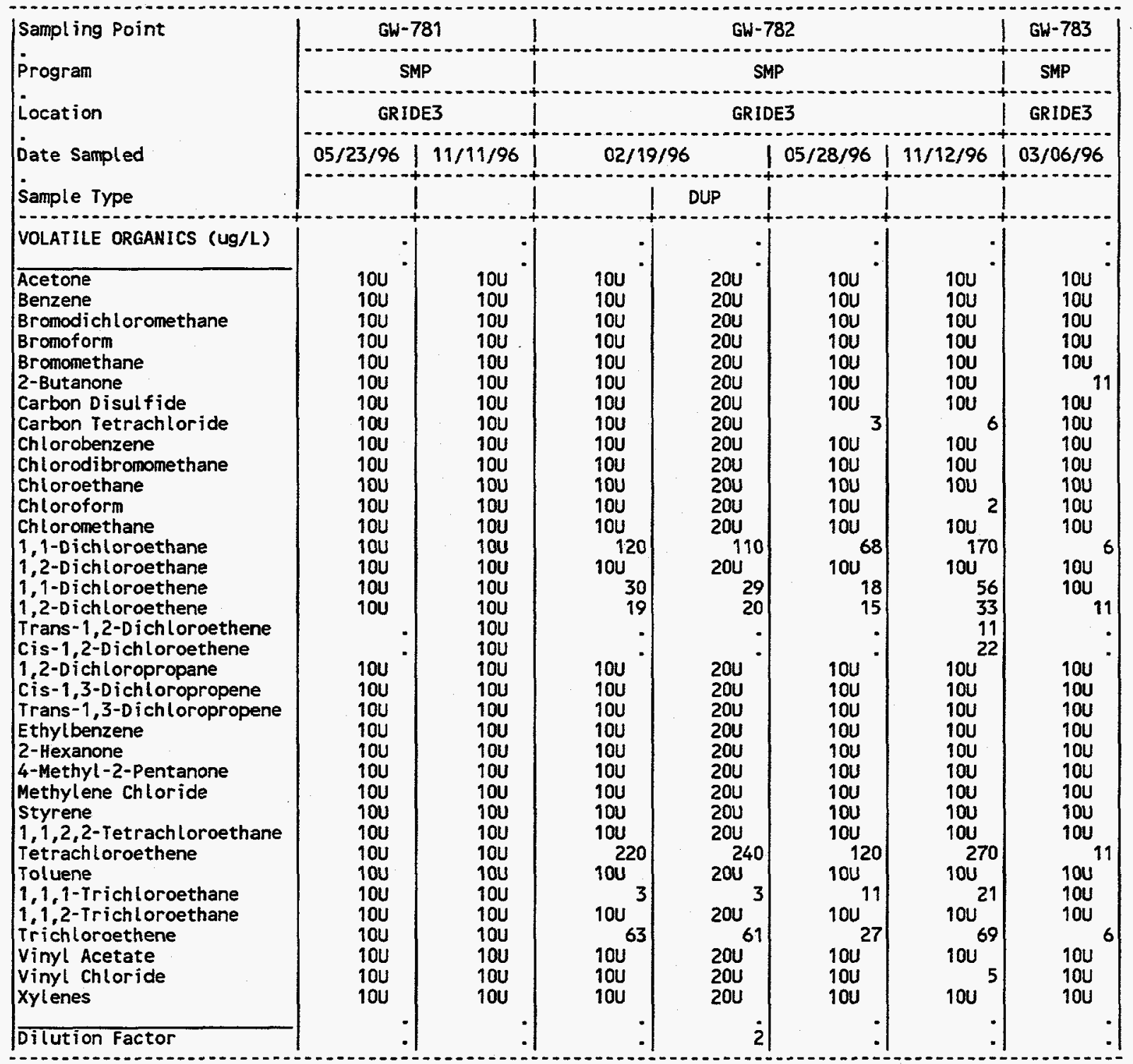

(CONTINUED) 
APPENDIX D. 3

Organic Analytes, CY 1996

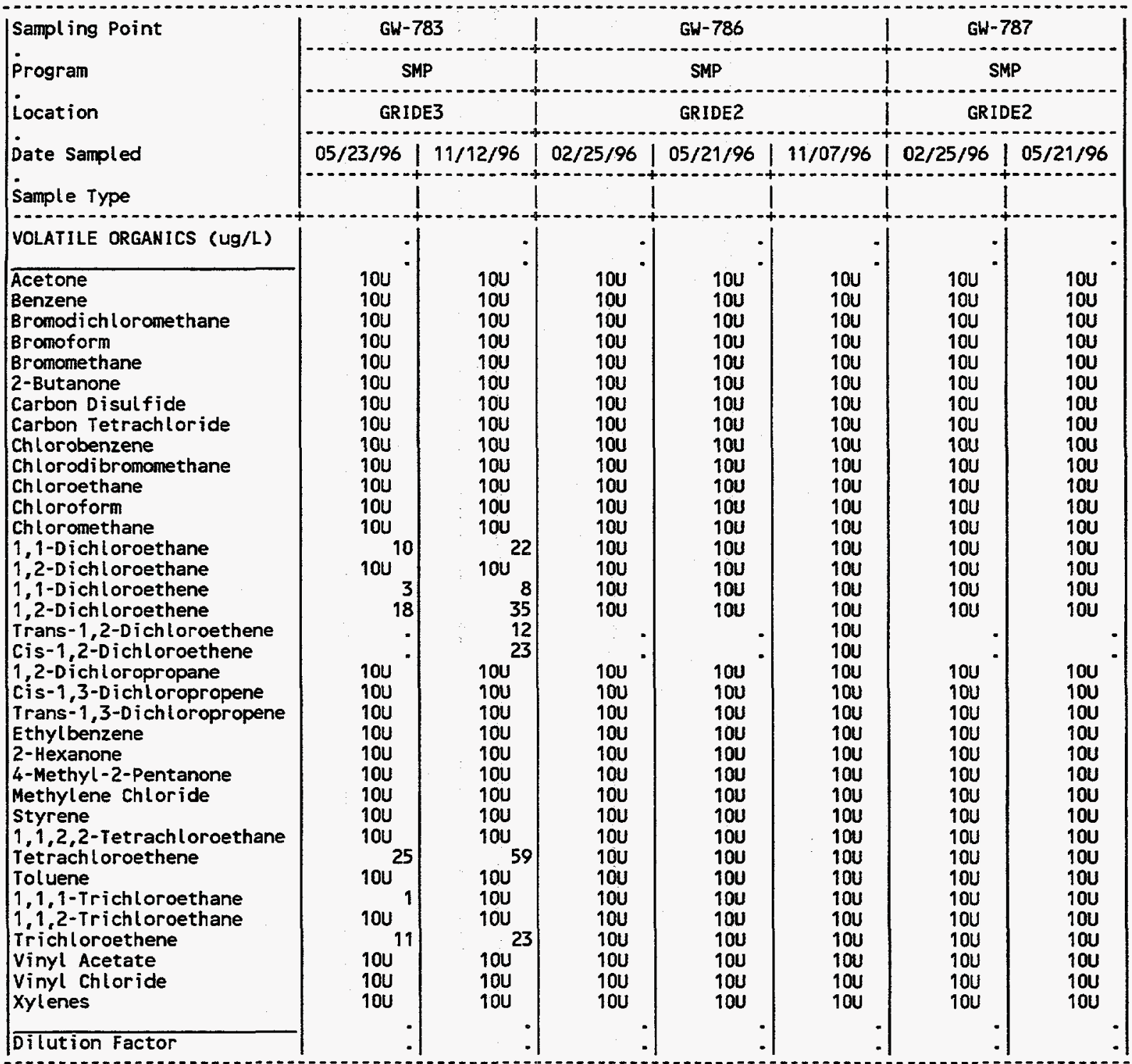

(CONTINUED) 
APPENDIX D.3

Organic Analytes, CY 1996

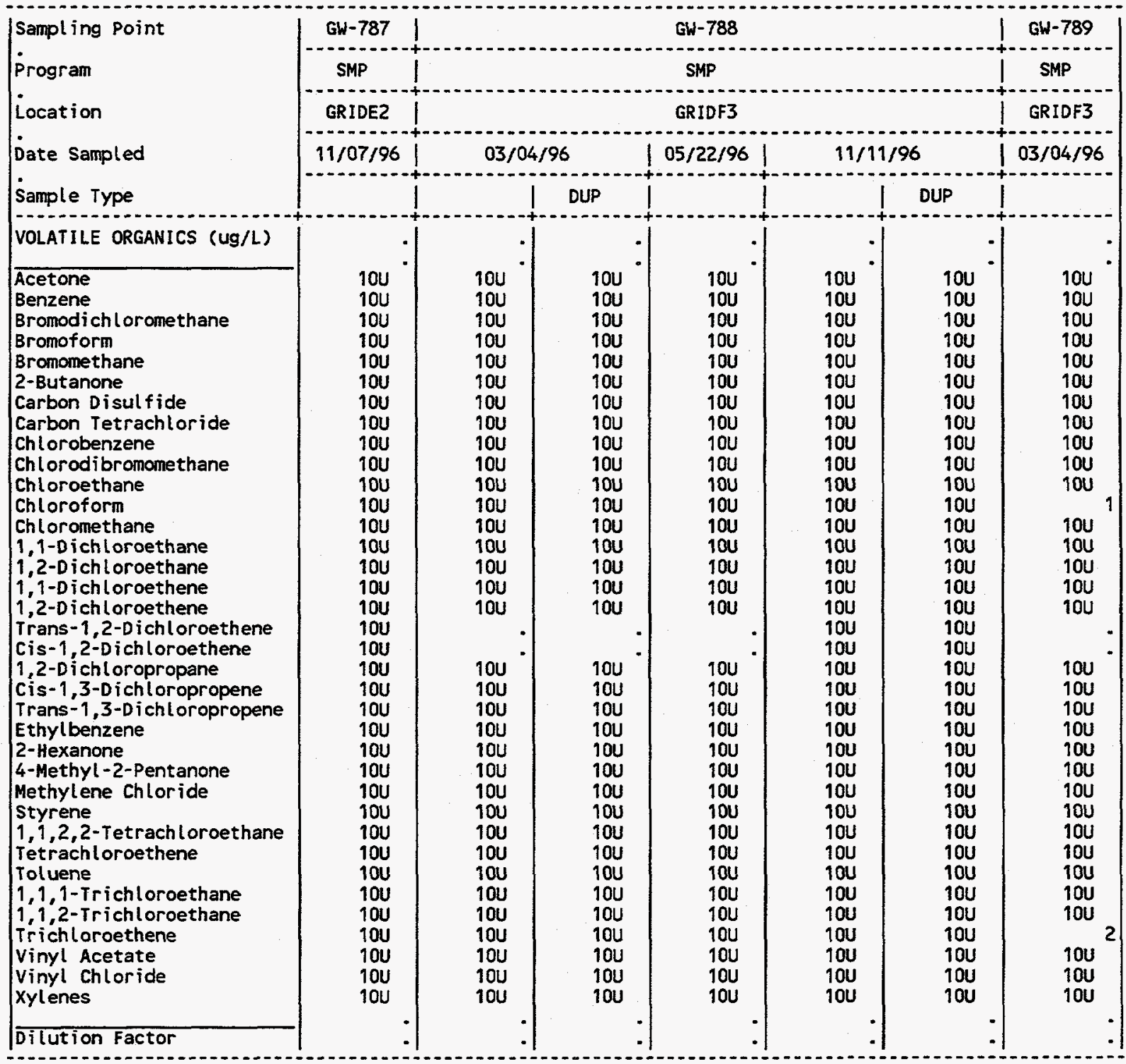

(CONTINUED) 
APPENDIX 0.3

Organic Analytes, CY 1996

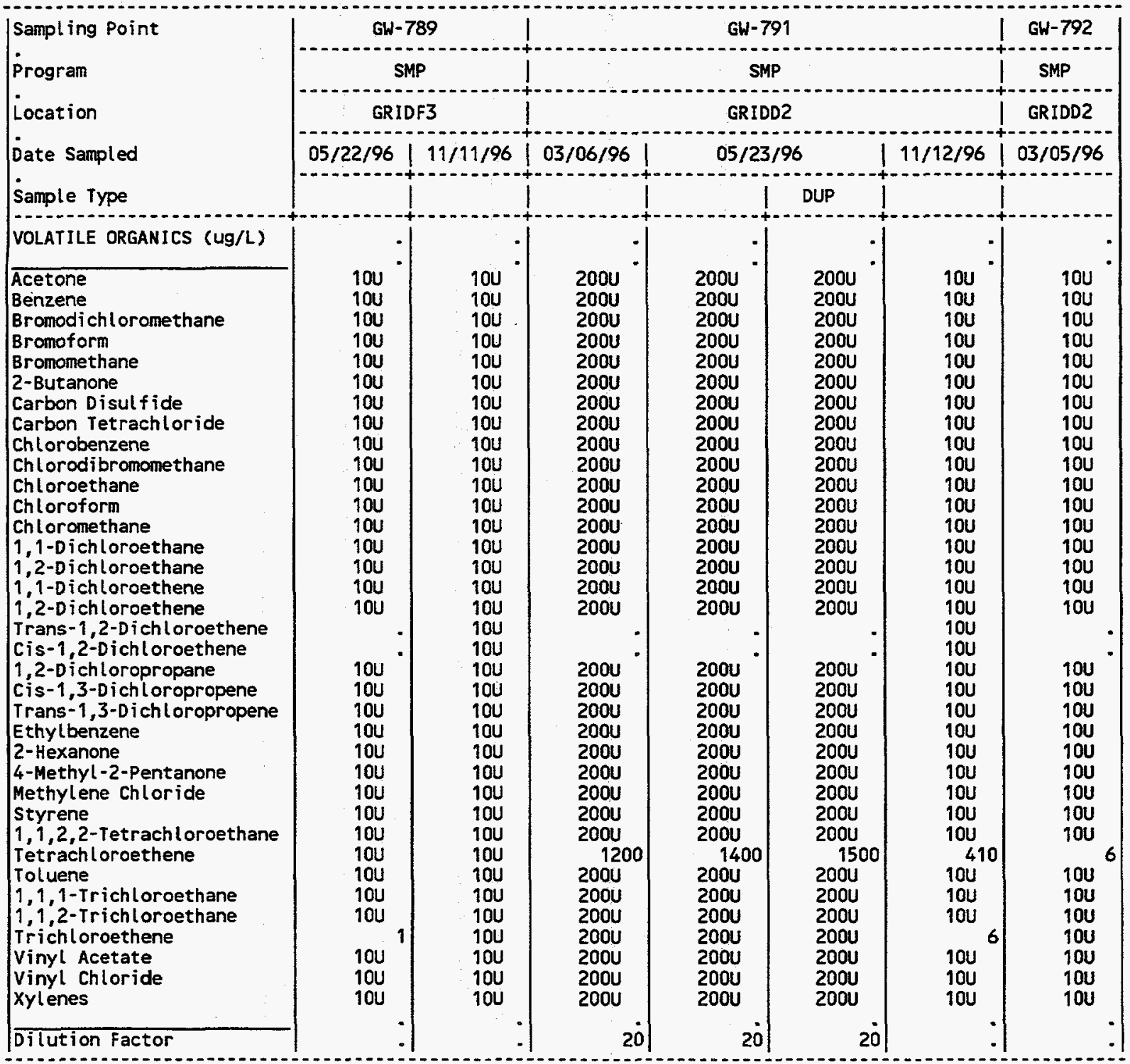

(CONT INUED) 
APPENDIX 0.3

Organic Analytes, CY 1996

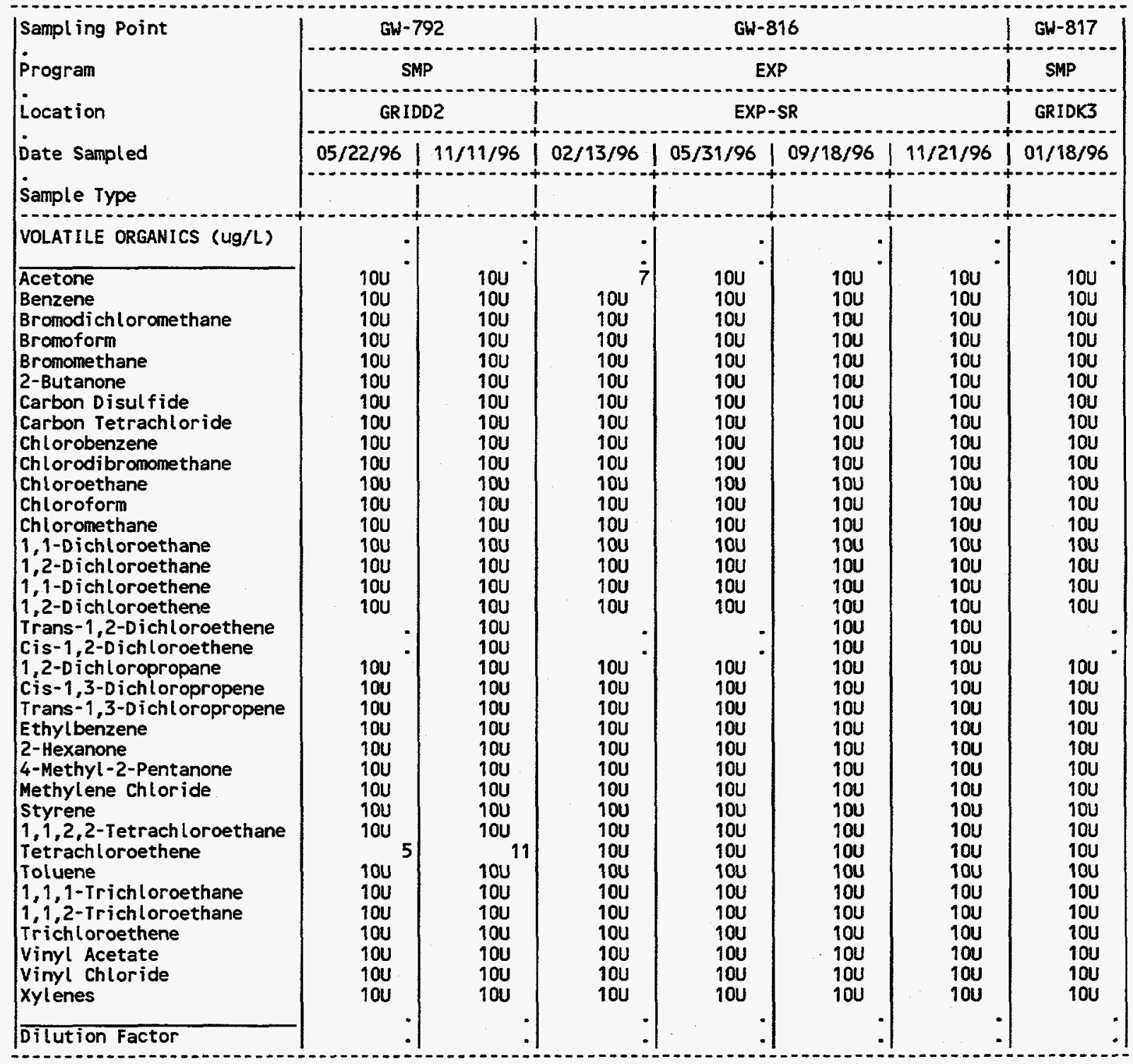

(CONTINUED) 
APPENDIX D.3

Organic Analytes, CY 1996

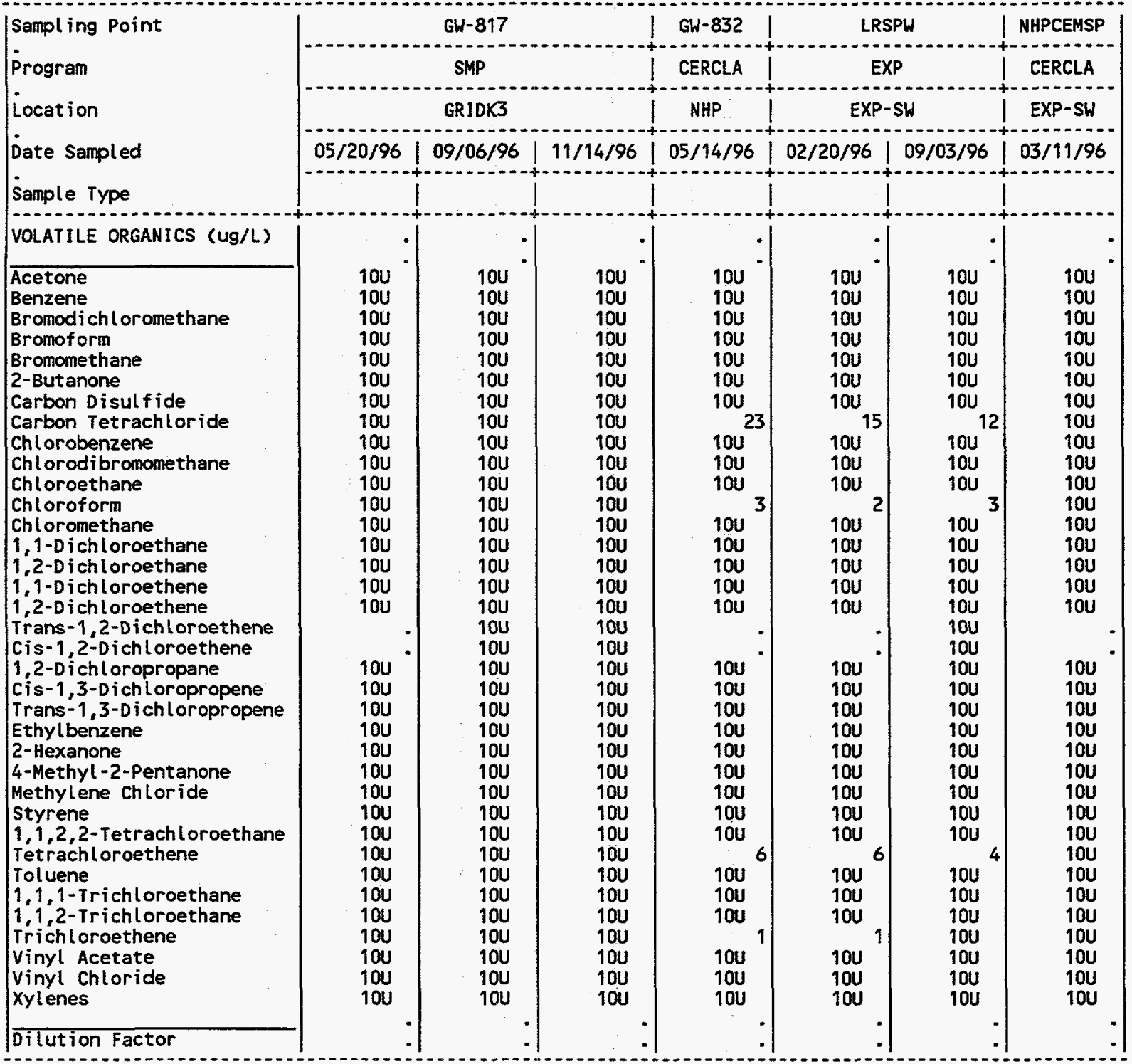

(CONT INUED) 
APPENDIX D.3

Organic Analytes, CY 1996

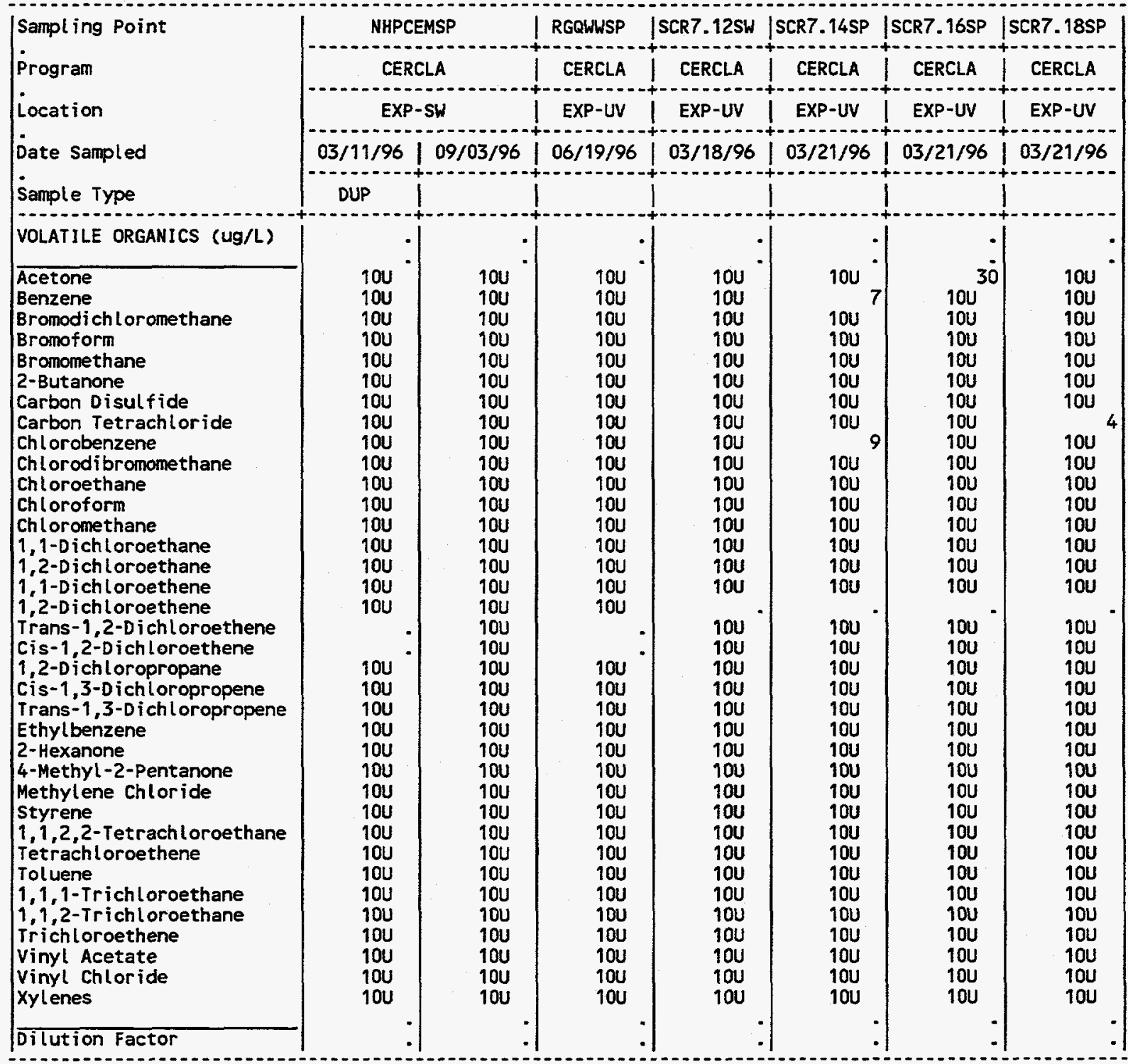

(CONT INUED) 
APPENDIX $D .3$

Organic Analytes, CY 1996

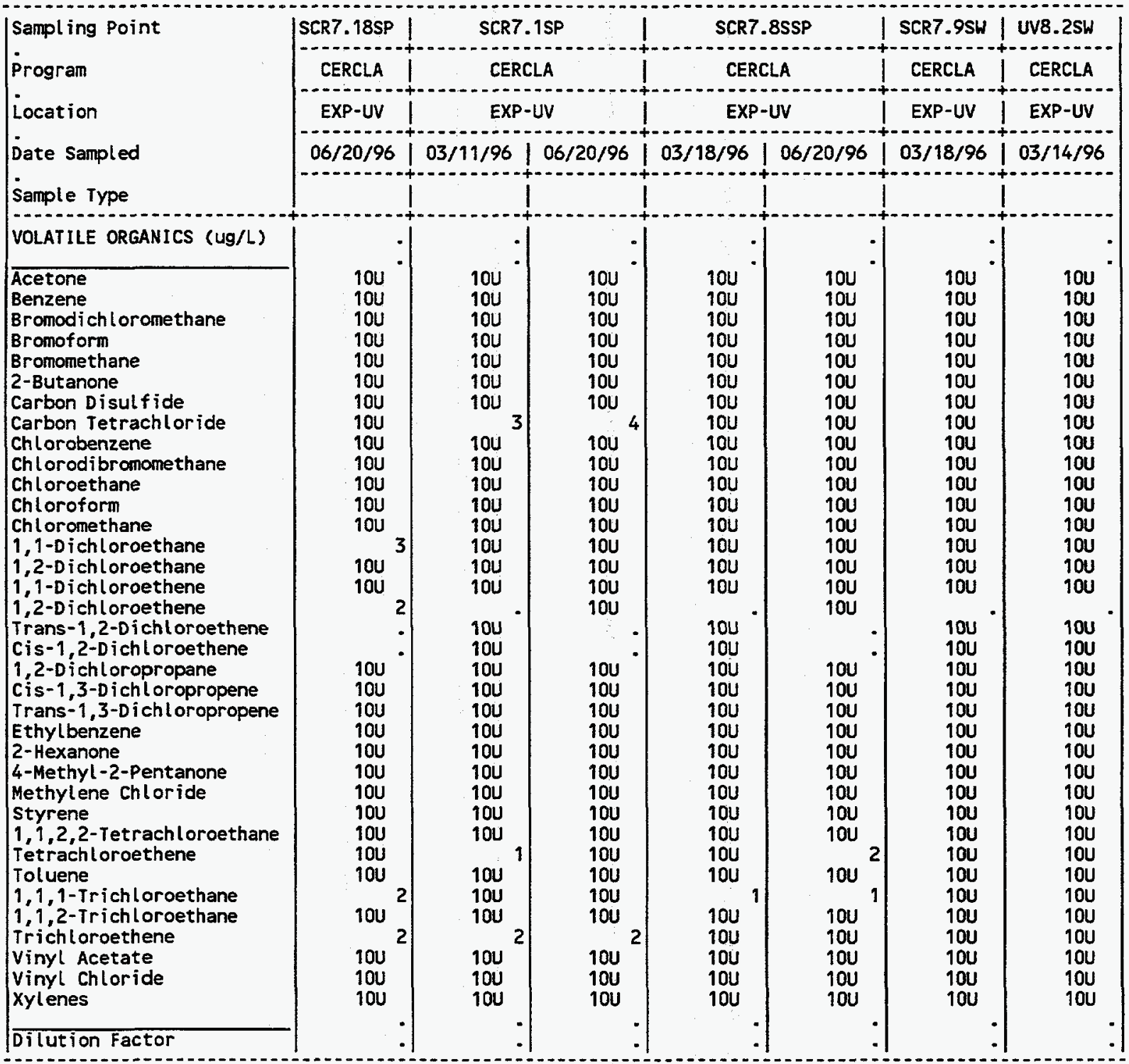

(CONT I NUED) 
APPENDIX D.3

Organic Analytes, CY 1996

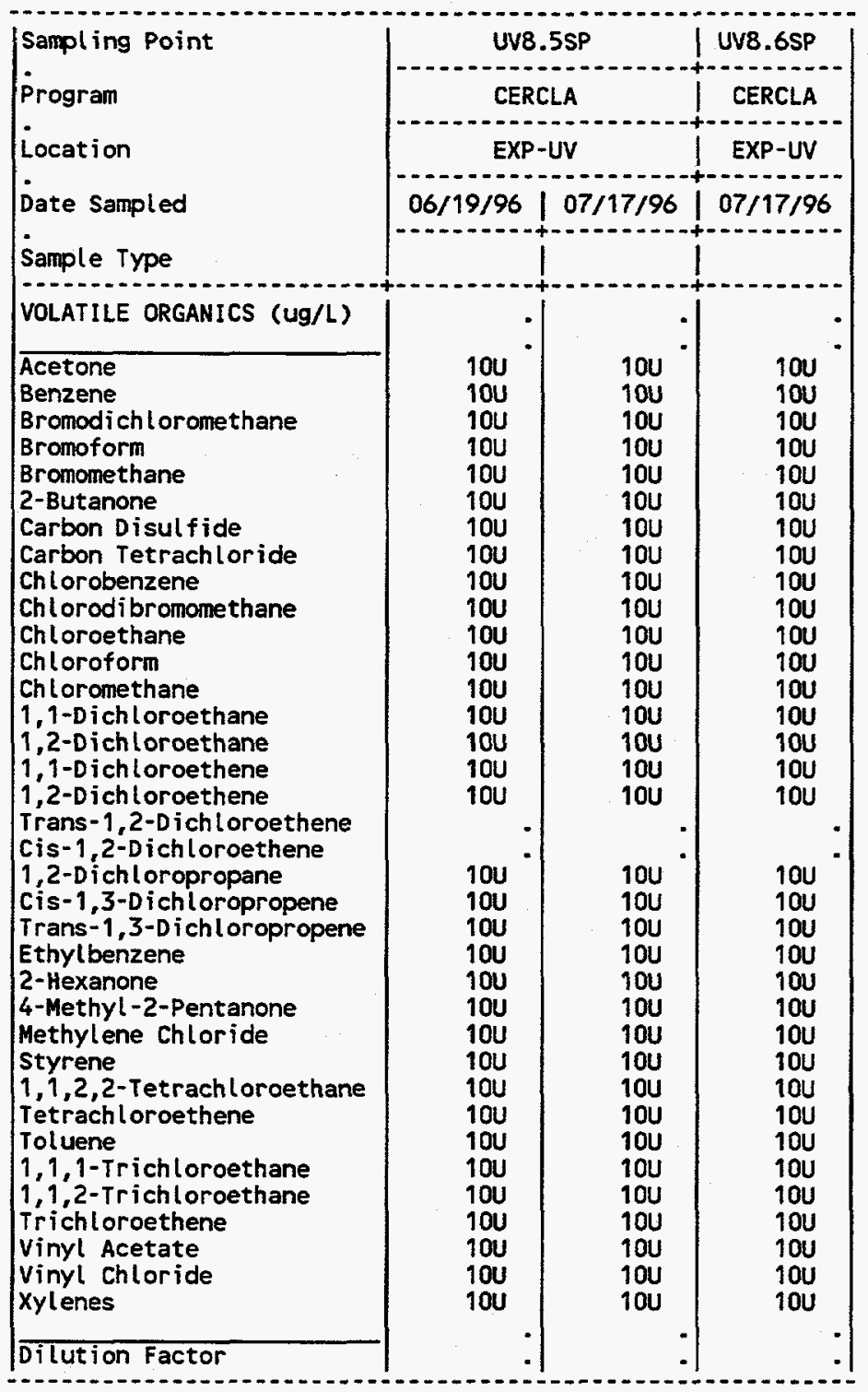


Base, Neutral, and Acid Extractable Organic Compounds, CY 1996

\begin{tabular}{|c|c|c|}
\hline $\begin{array}{l}\text { Sampling Point } \\
\text { Program } \\
\text { Location } \\
\text { - }\end{array}$ & LRS & SW \\
\hline Date Sample & $02 / 20 / 96$ & $09 / 03 / 96$ \\
\hline 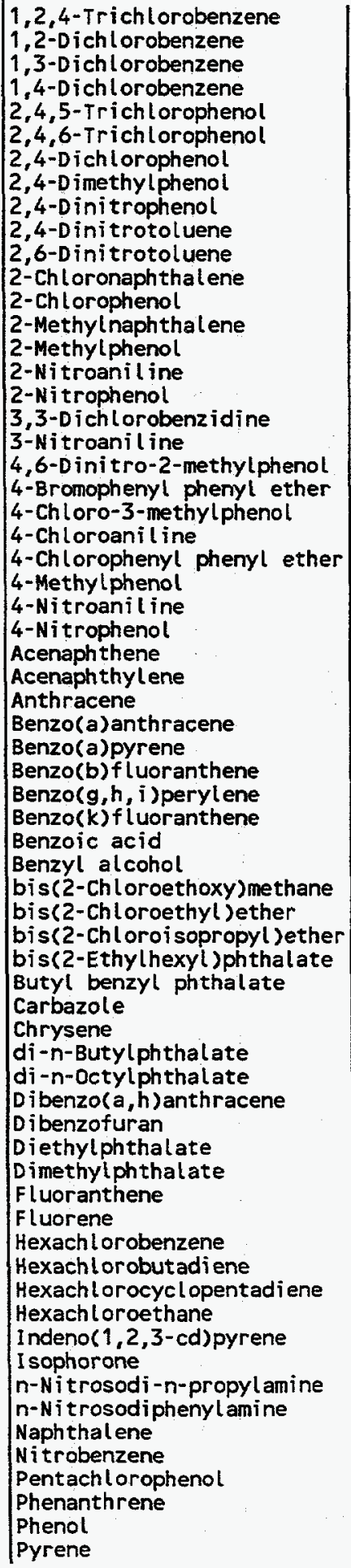 & $\begin{array}{l}14 U \\
14 U \\
14 U \\
14 U \\
36 U \\
14 U \\
14 U \\
14 U \\
36 U \\
14 U \\
14 U \\
14 U \\
14 U \\
14 U \\
14 U \\
36 U \\
14 U \\
14 U \\
36 U \\
36 U \\
14 U \\
14 U \\
14 U \\
14 U \\
14 U \\
36 U \\
14 U \\
14 U \\
14 U \\
14 U \\
14 U \\
14 U \\
14 U \\
14 U \\
14 U \\
14 U \\
14 U \\
14 U \\
14 U \\
14 U \\
14 U \\
14 U \\
14 U \\
4 \\
14 U \\
14 U \\
14 U \\
14 U \\
14 U \\
14 U \\
14 U \\
14 U \\
14 U \\
14 U \\
14 U \\
14 U \\
14 U \\
14 U \\
14 U \\
14 U \\
36 U \\
14 U \\
14 U \\
14 U \\
\end{array}$ & 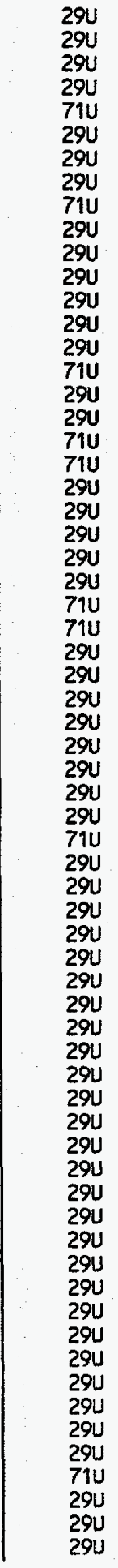 \\
\hline
\end{tabular}


APPENDIX D.4

RADIOLOGICAL ANAL YTES 


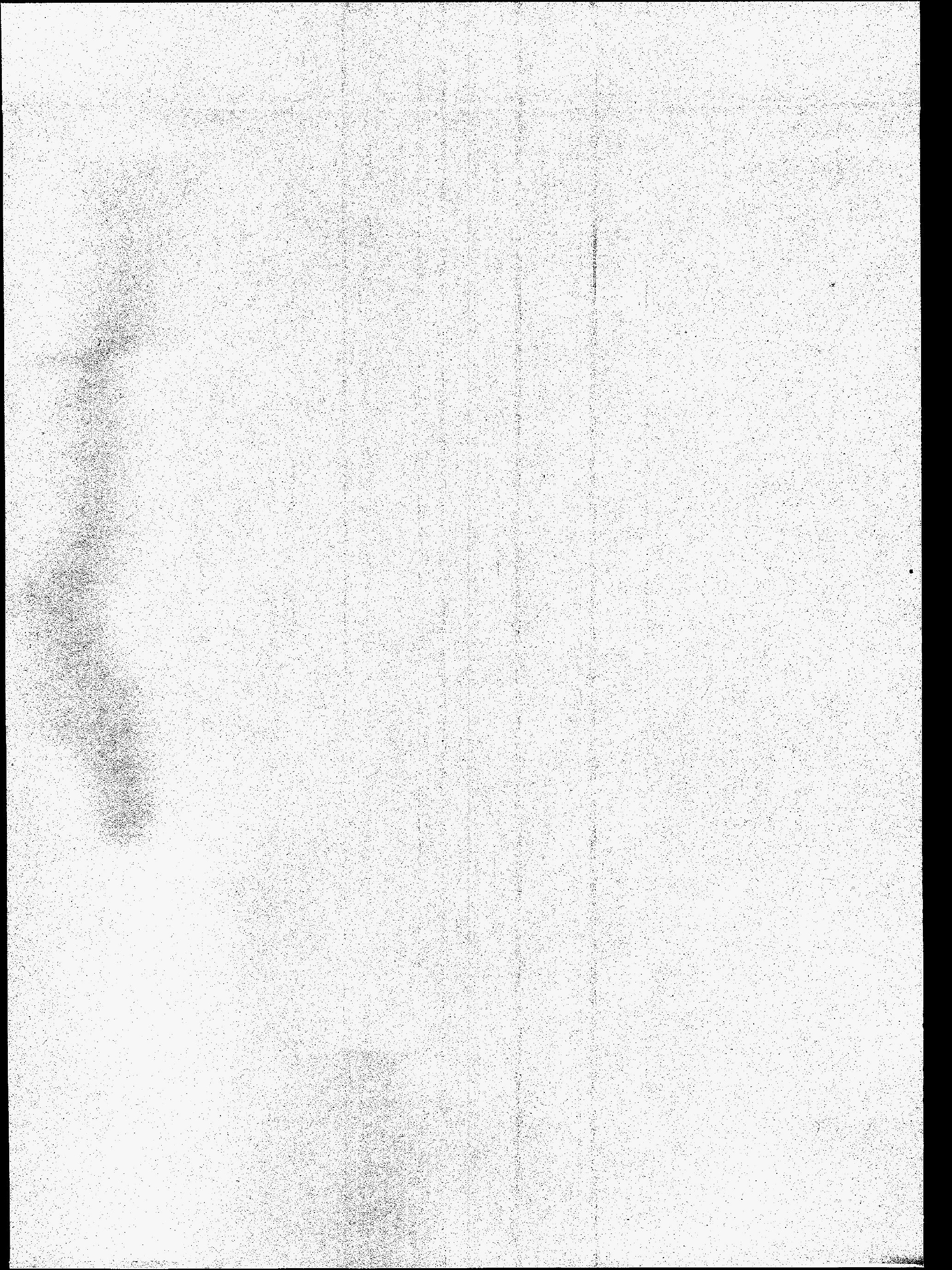


APPEND IX 0.4

Radiological Analytes, CY 1996

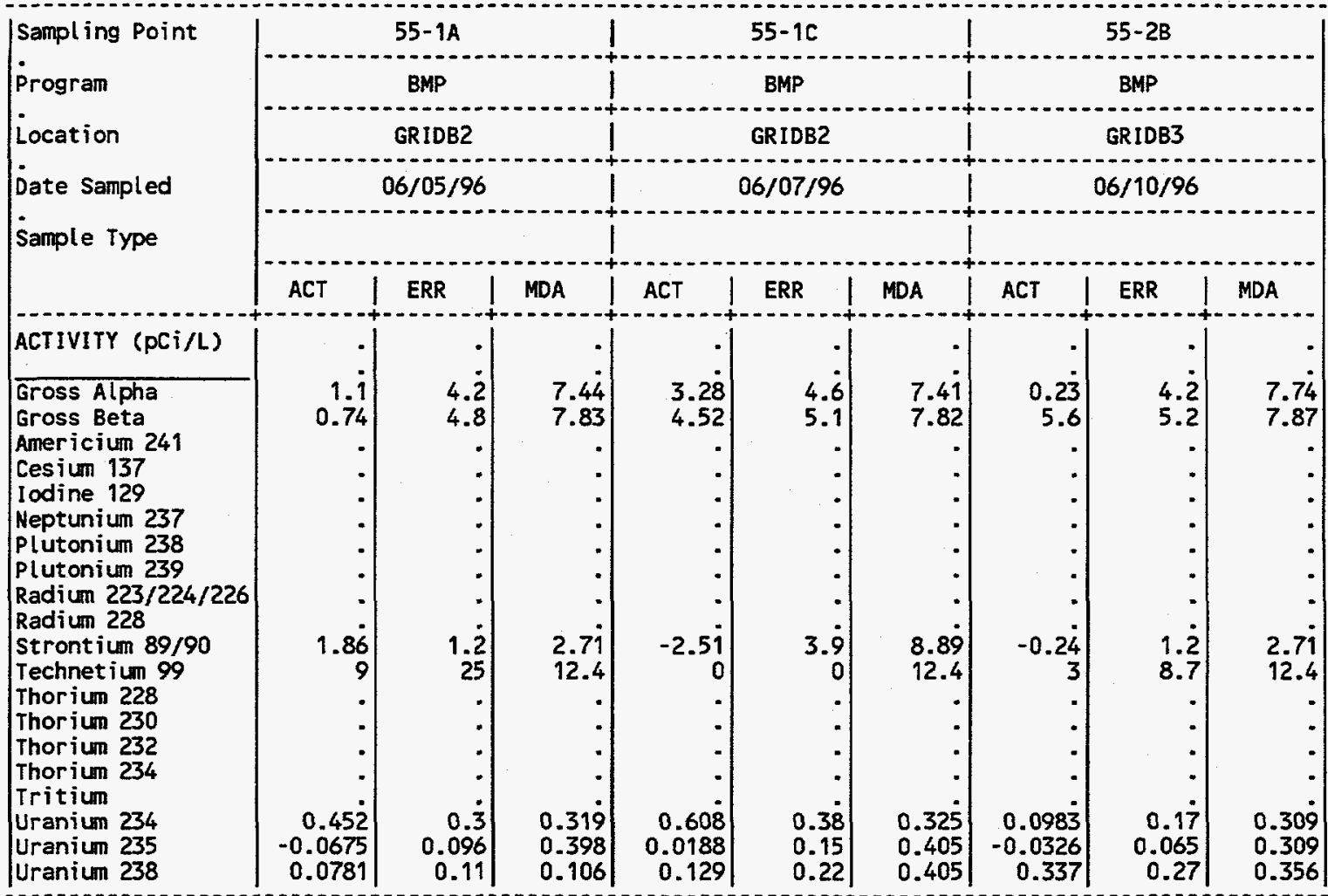

(CONT INUED)

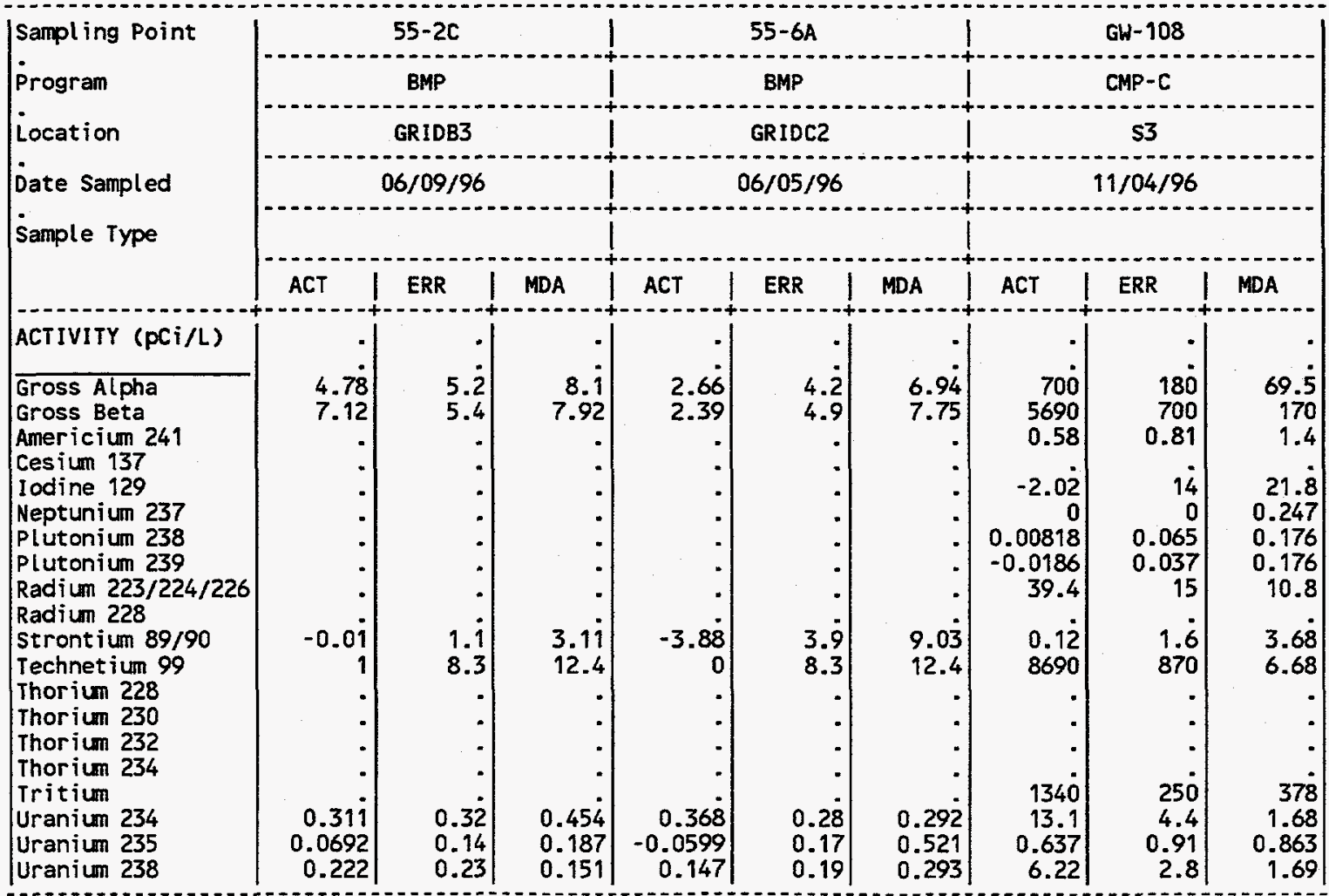

(CONTINUED) 
APPENDIX $D .4$

Radiological Analytes, CY 1996

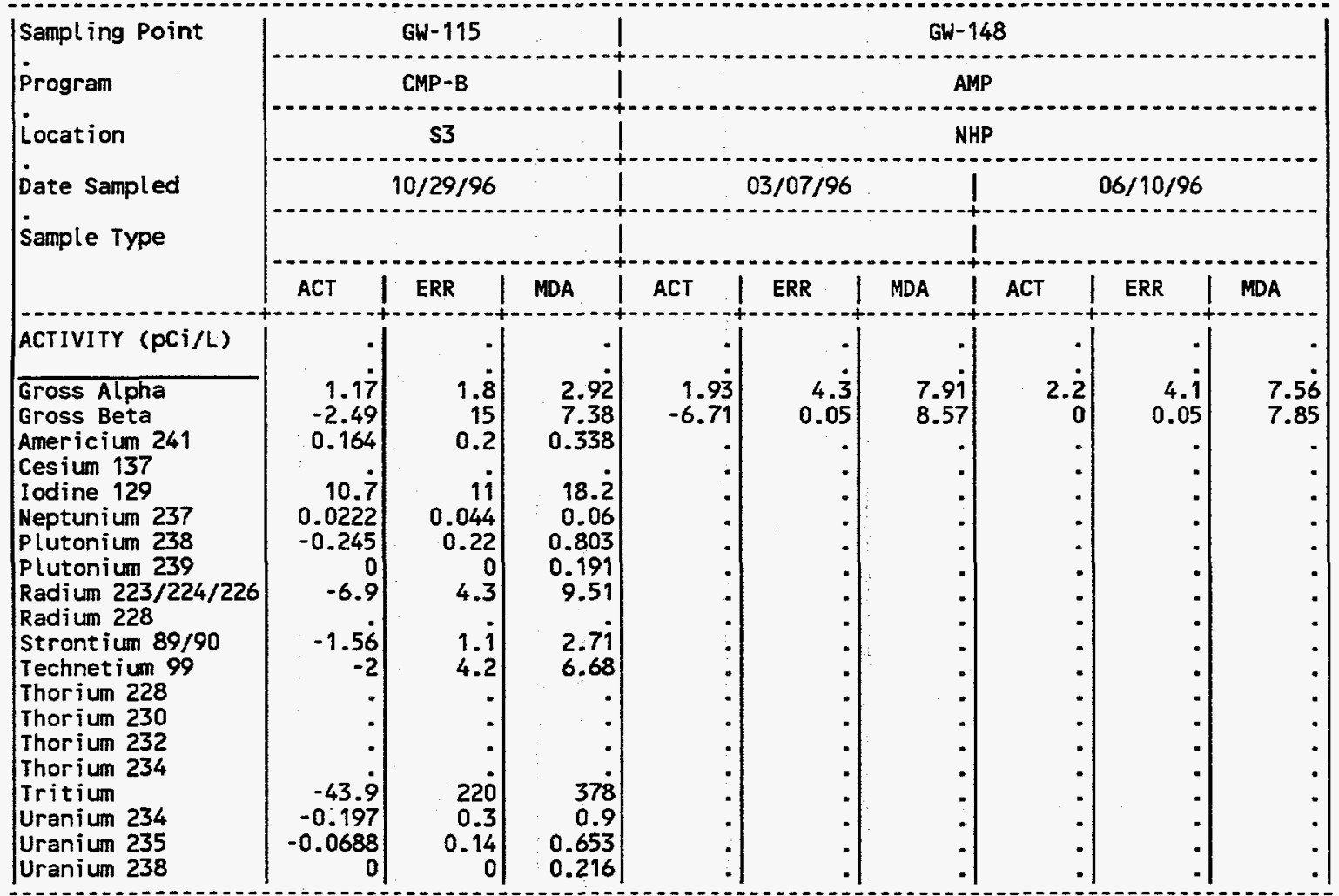

(CONTI INUED)

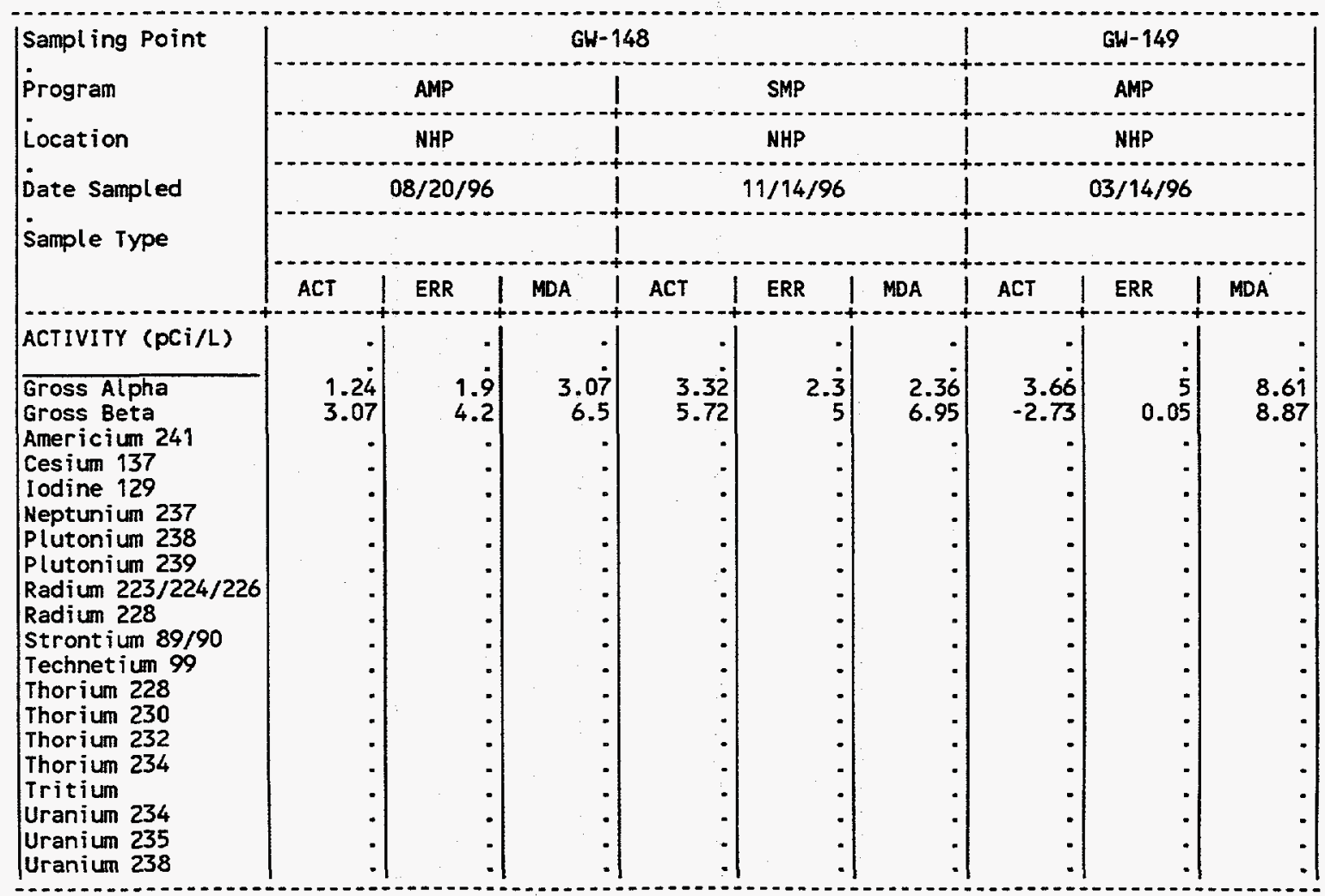

(CONTINUED) 
Radiological Analytes, CY 1996

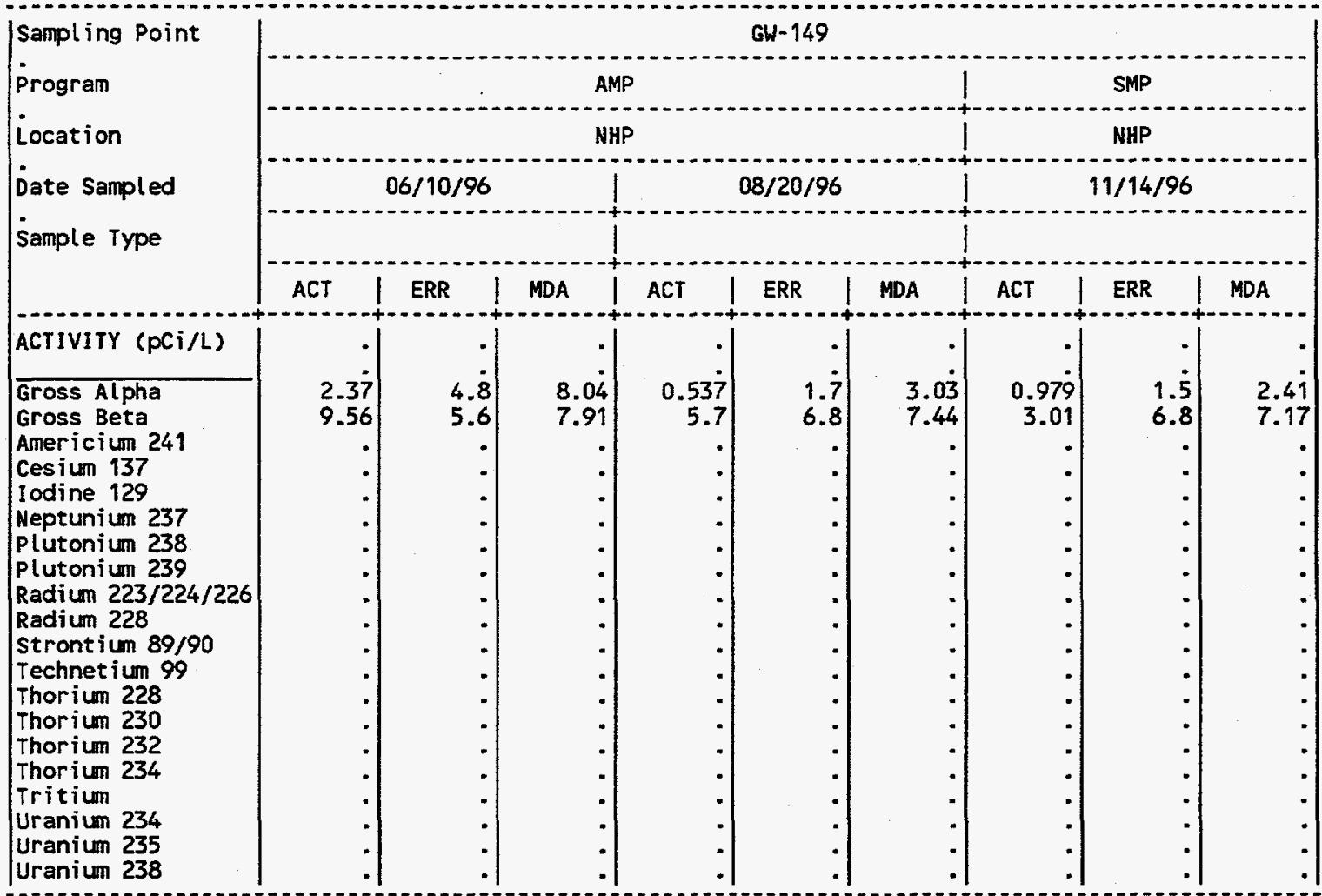

(CONT INUED)

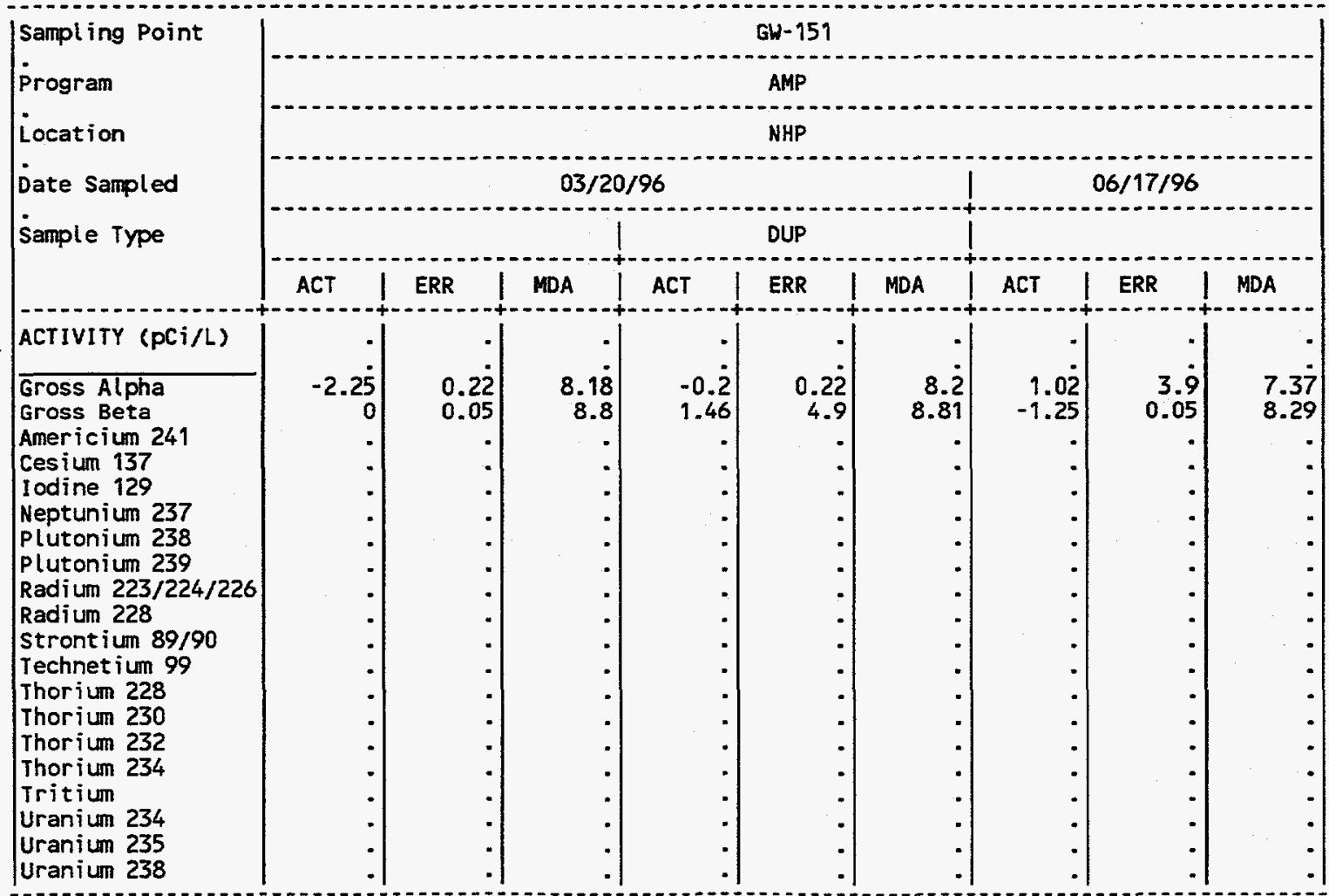

(CONT I NUED) 
APPENDIX 0.4

Radiological Analytes, CY 1996

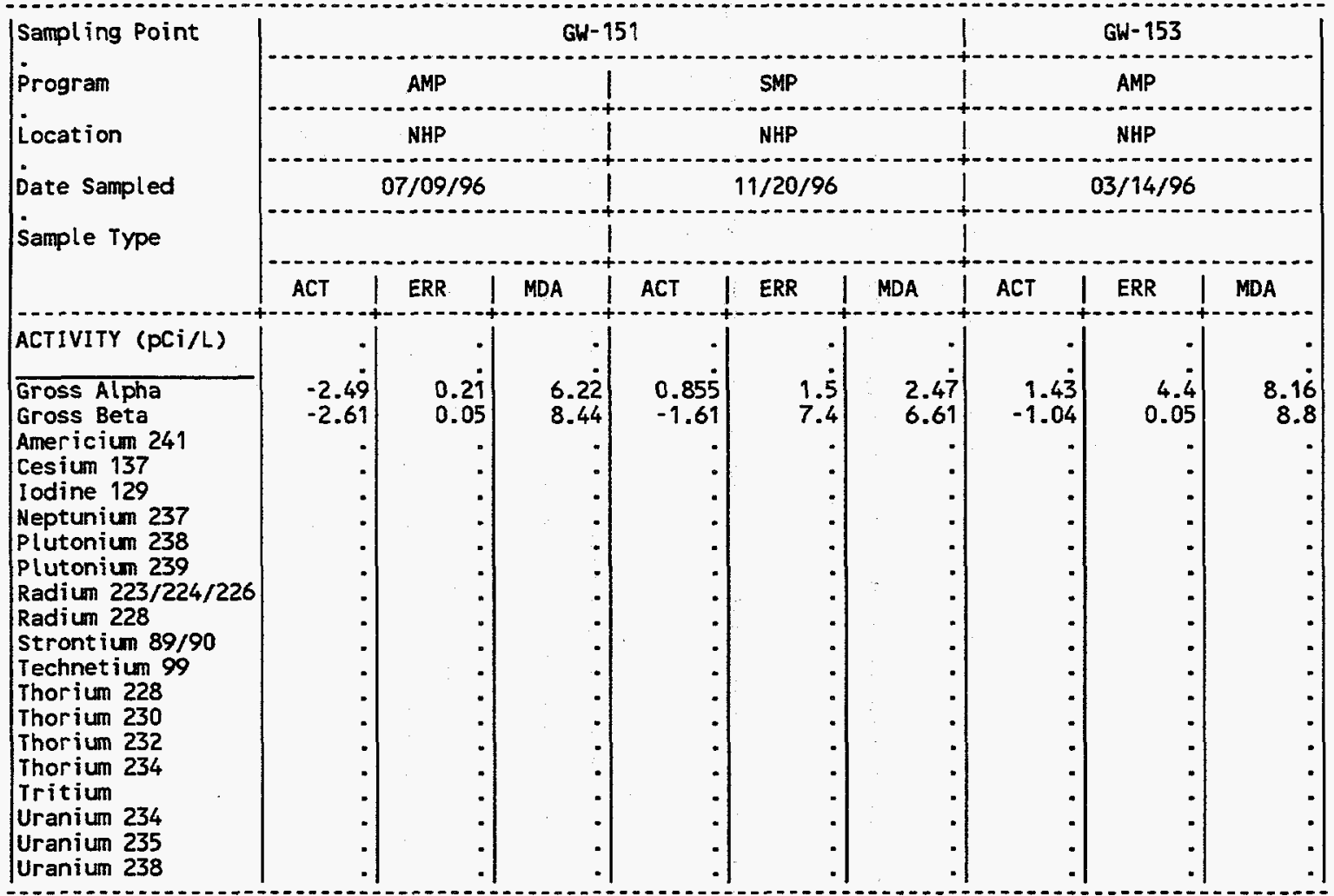

(CONT INUED)

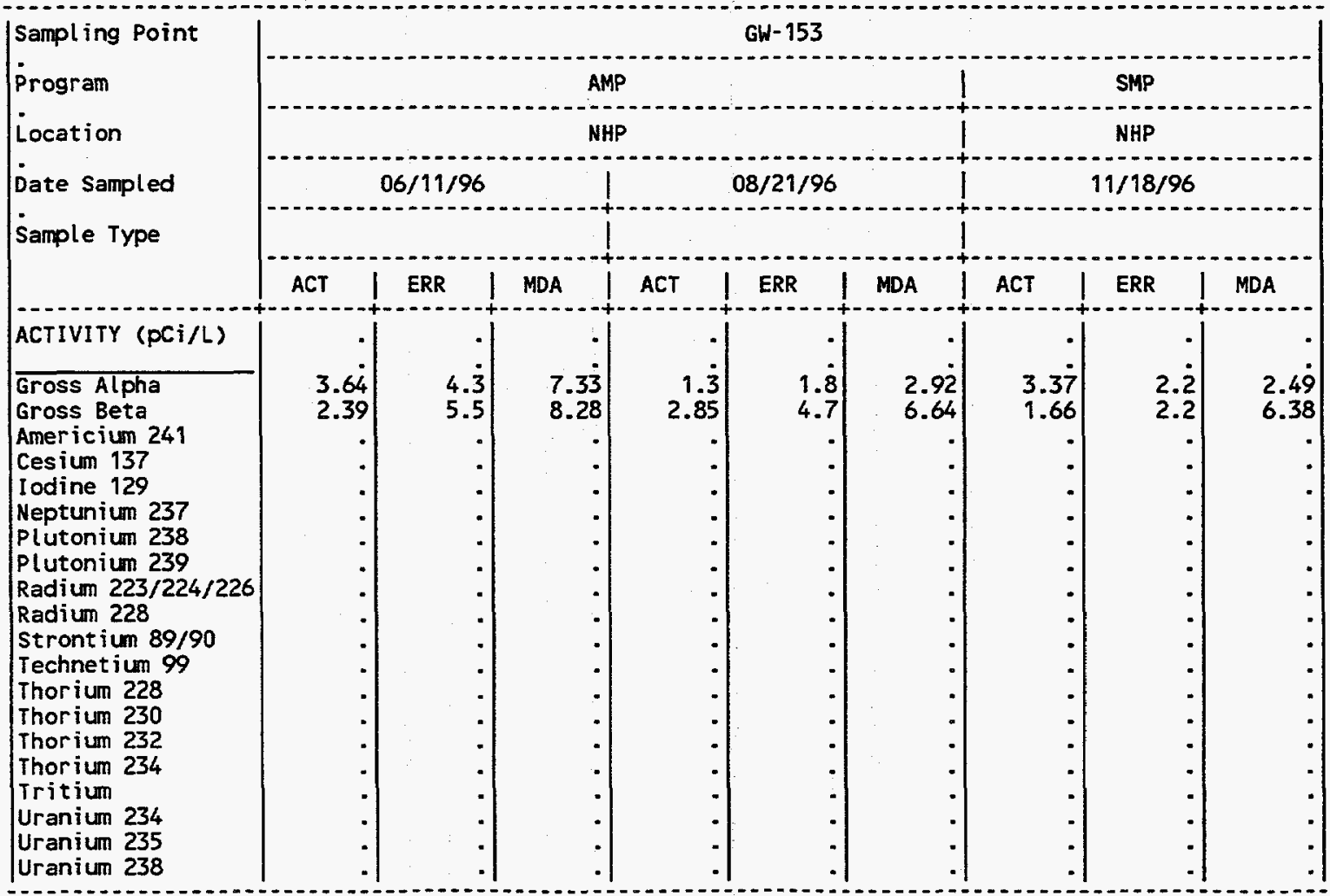

(CONTINUED) 
APPEND IX 0.4

Radiological Analytes, CY 1996

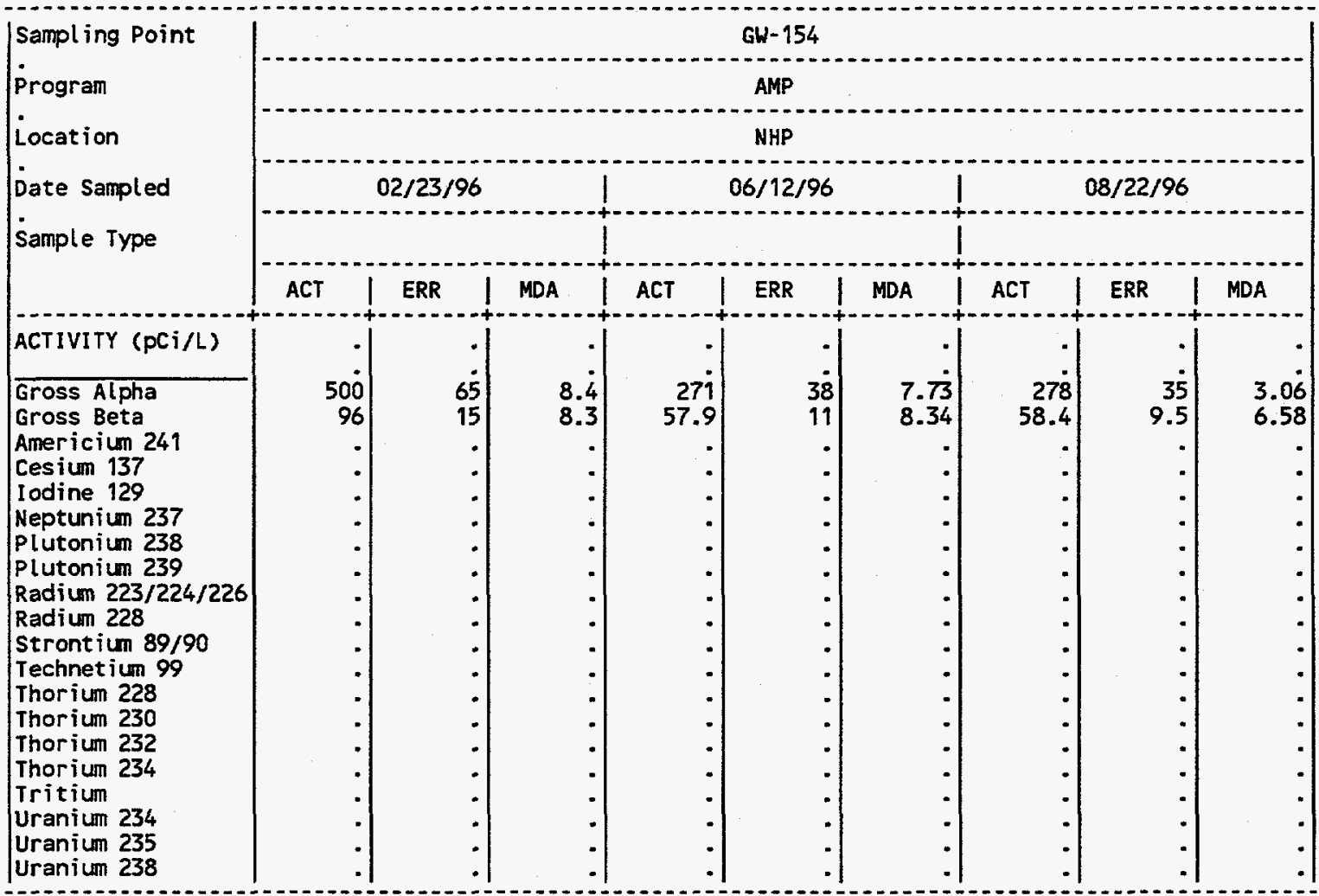

(CONTINUED)

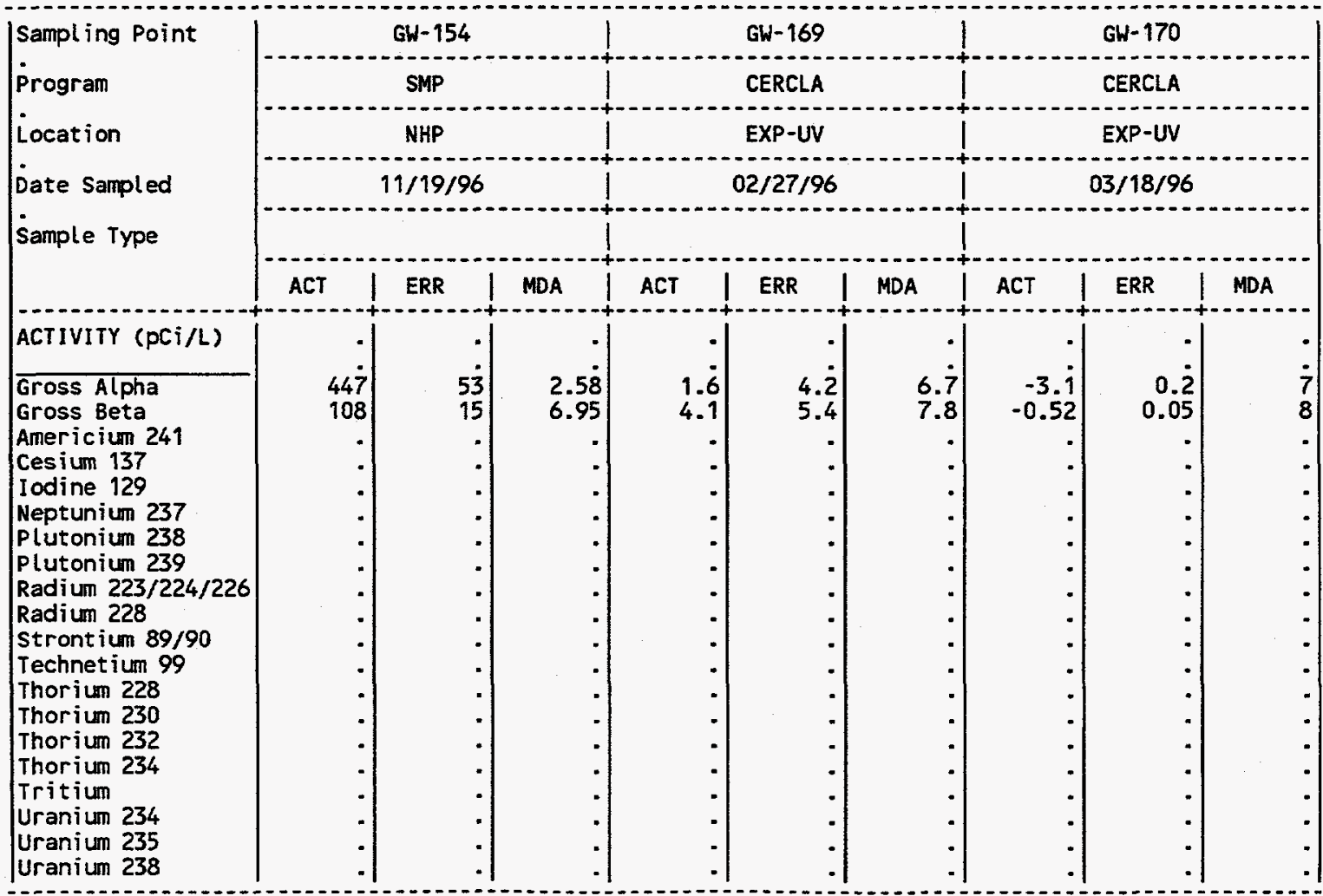

(CONTINUED) 
APPENDIX D.4

Radiological Analytes, CY 1996

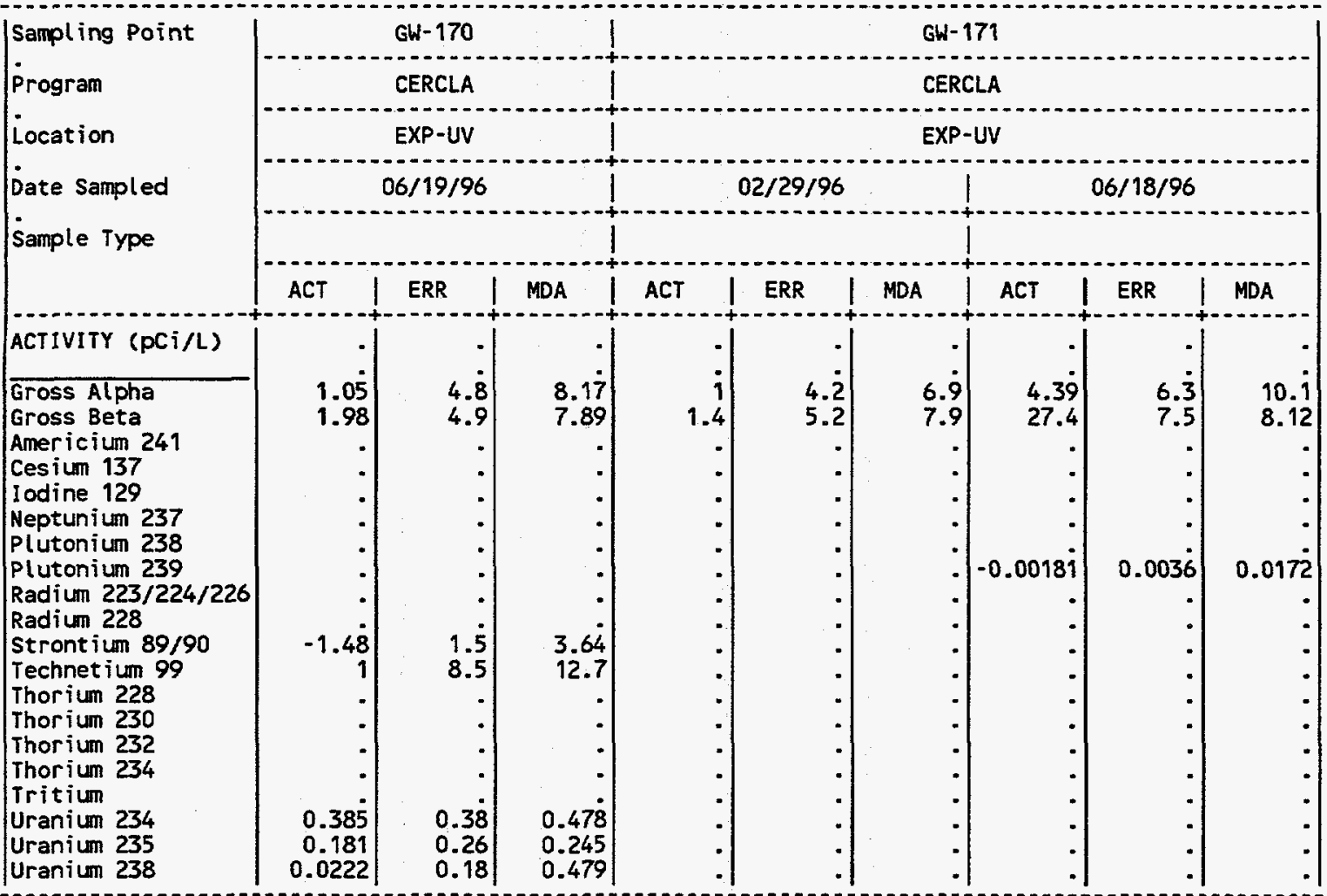

(CONTINUED)

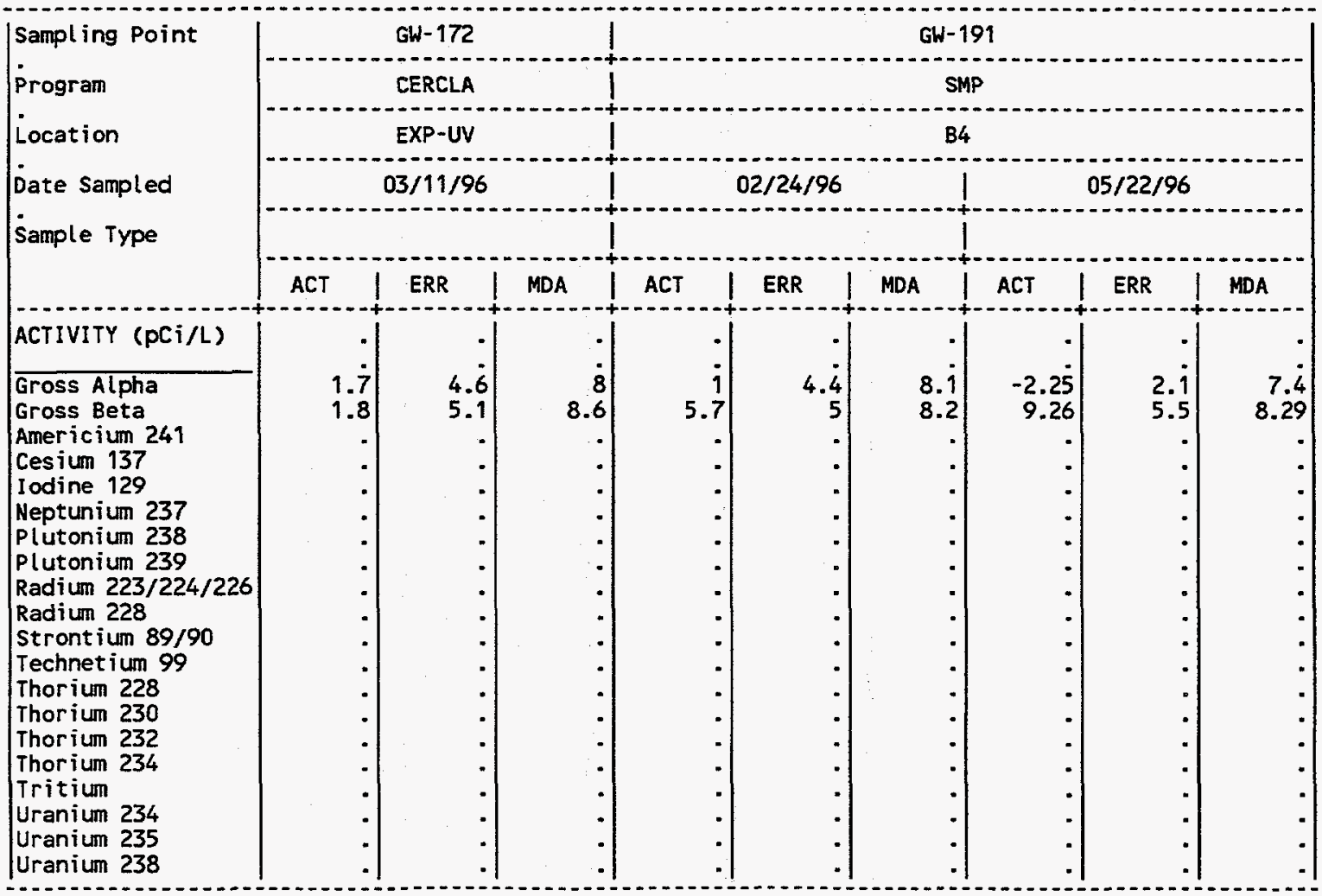

(CONTINUED) 
APPENDIX 0.4

Radiological Analytes, CY 1996

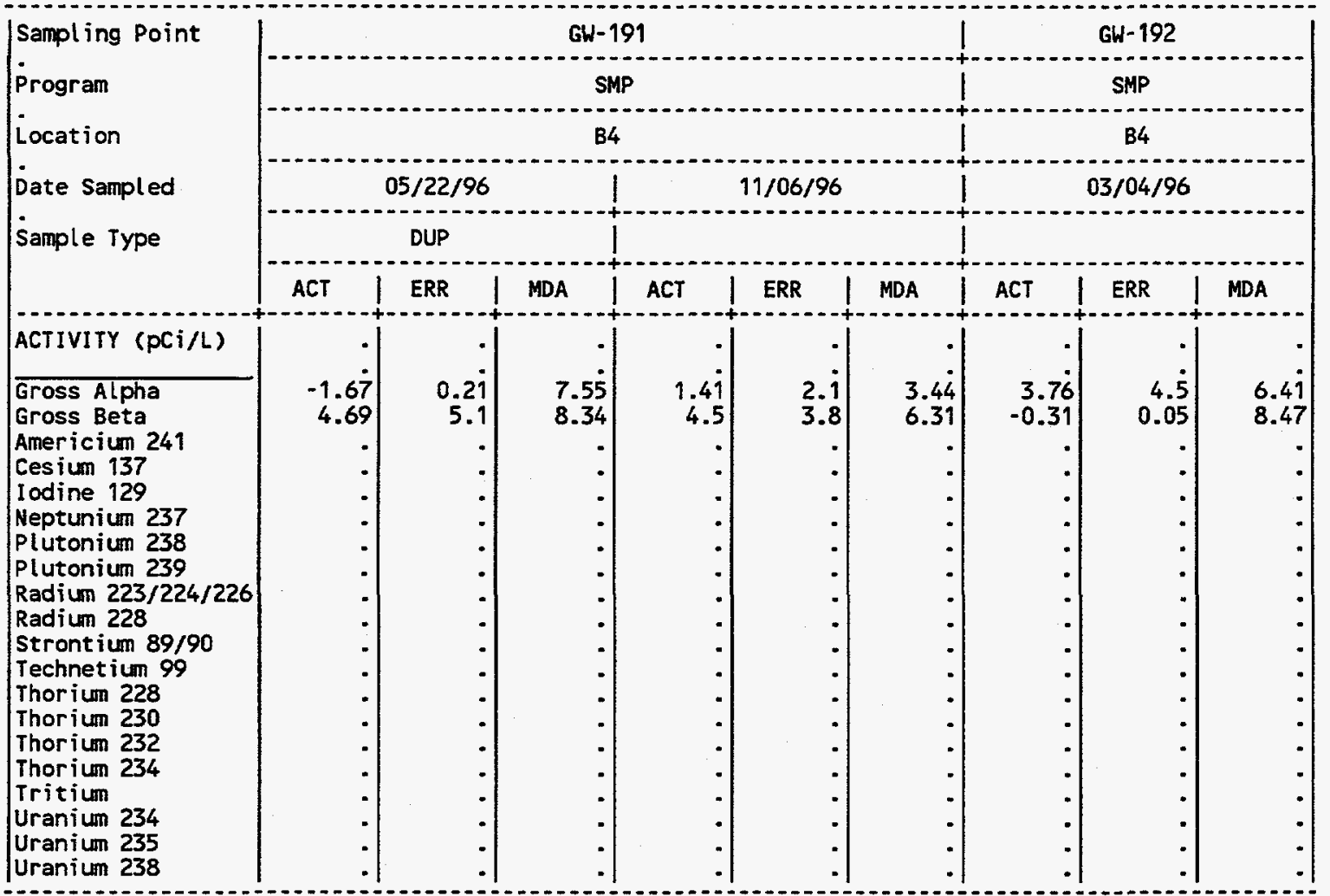

\section{(CONTINUED)}

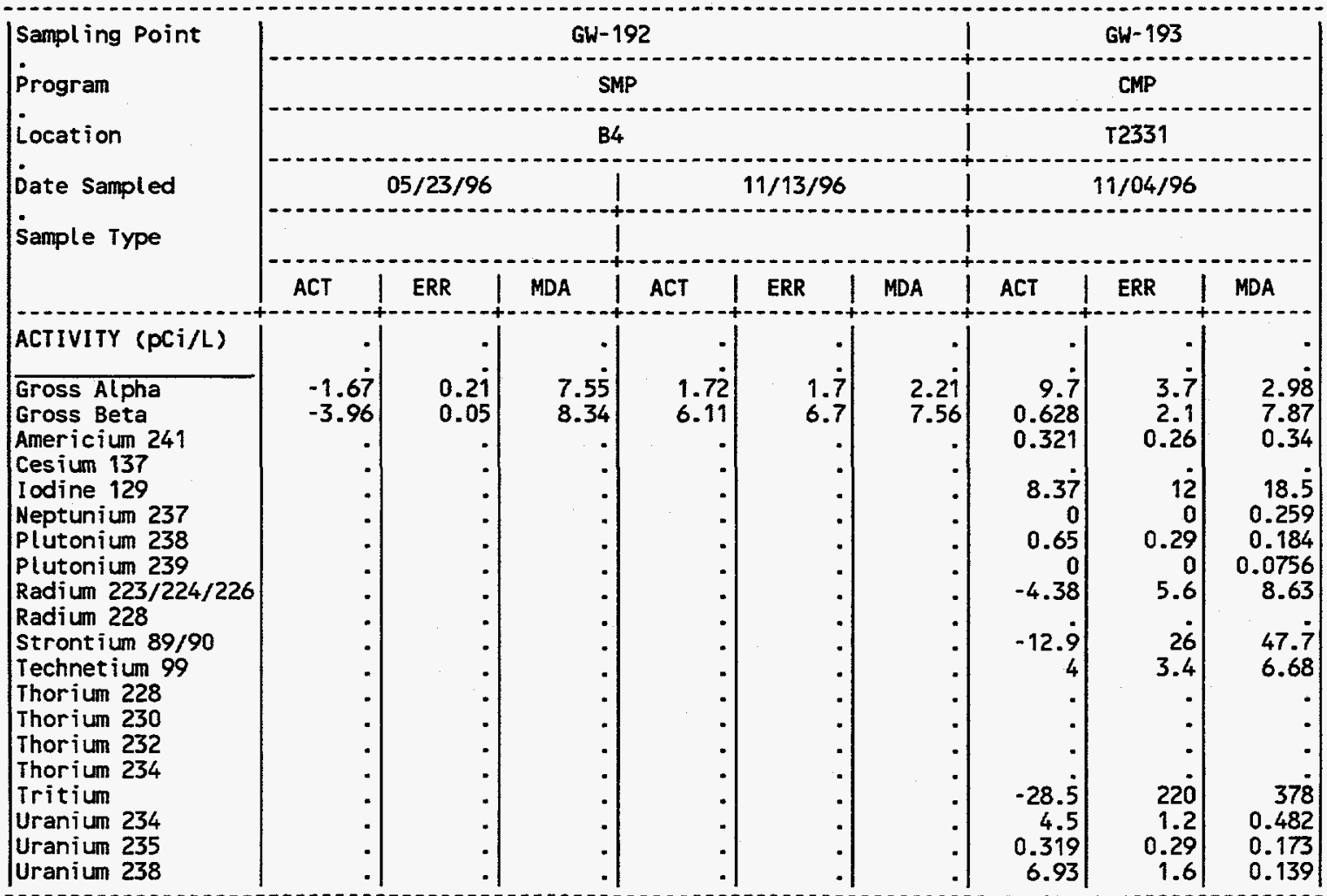


Radiological Analytes, CY 1996

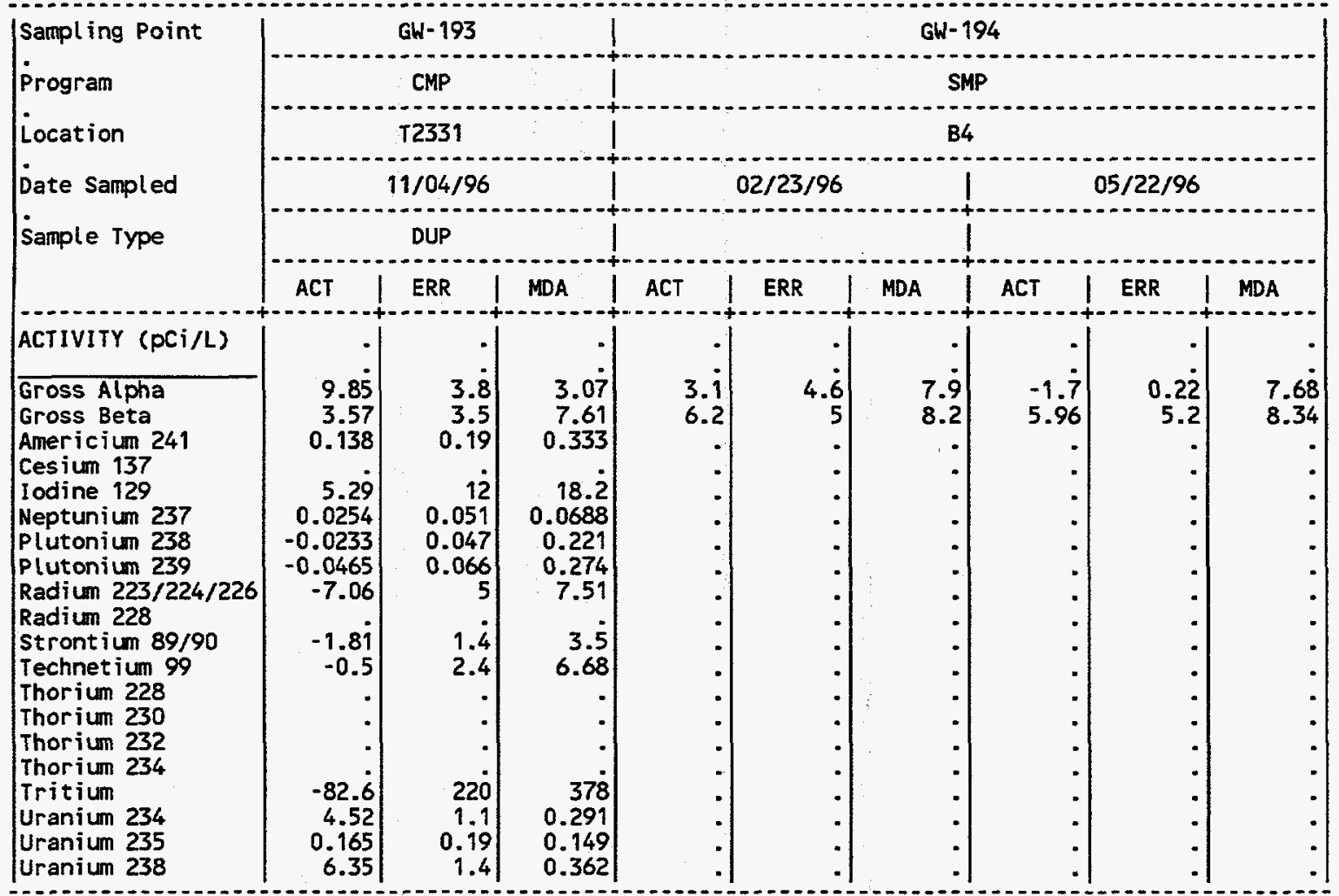

(CONTINUED)

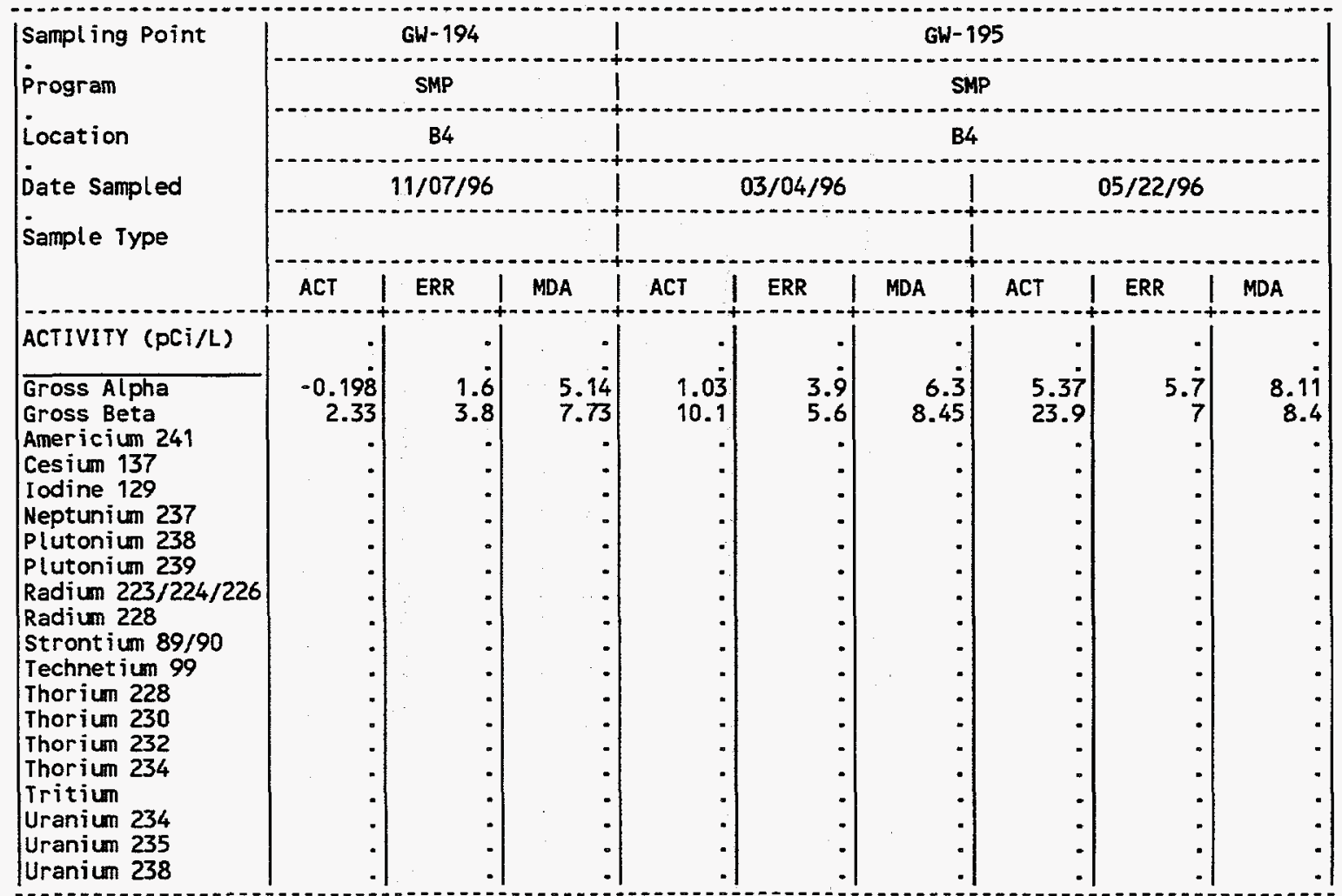

(CONT INUED) 
APPENDIX 0.4

Radiological Analytes, CY 1996

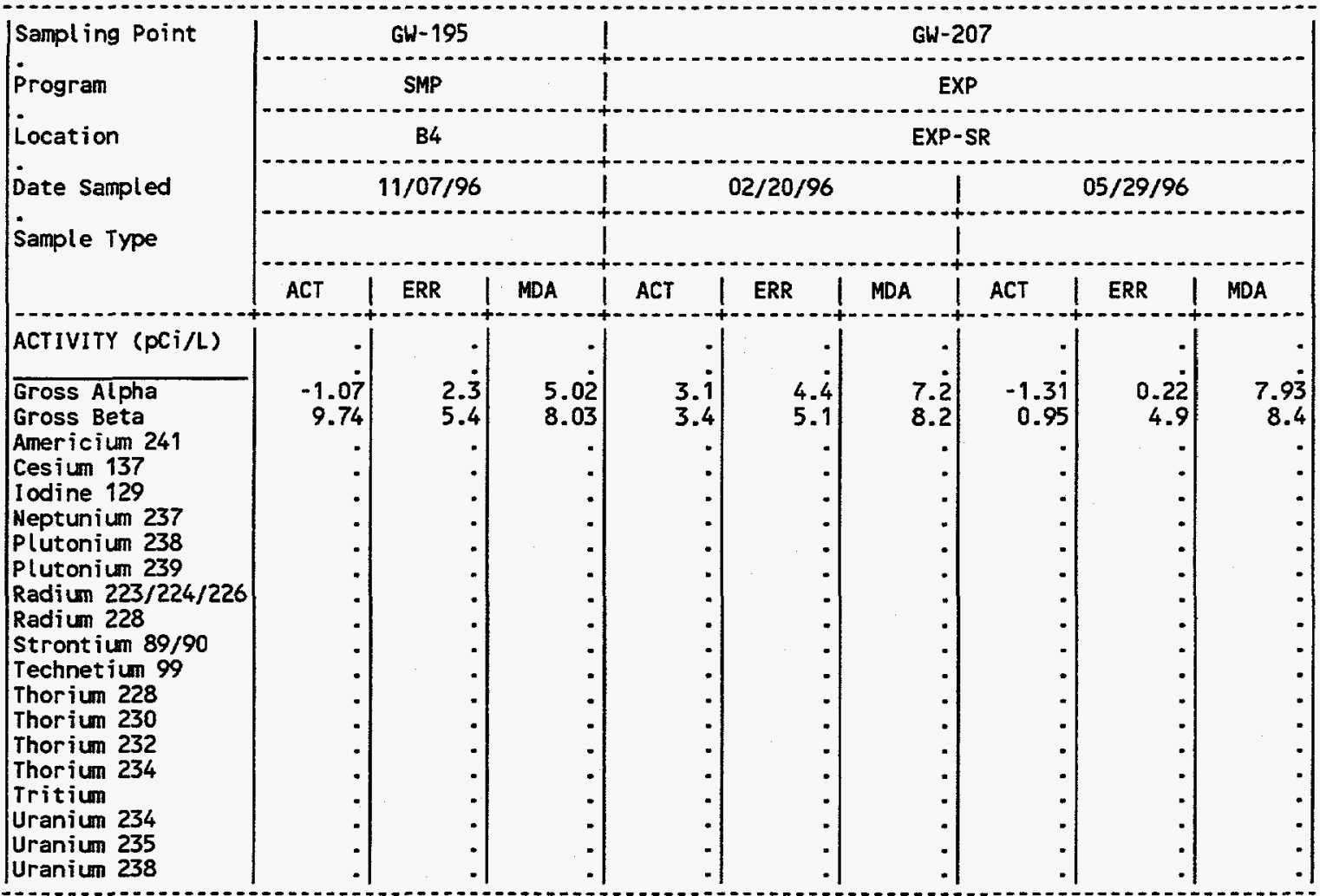

(CONTINUED)

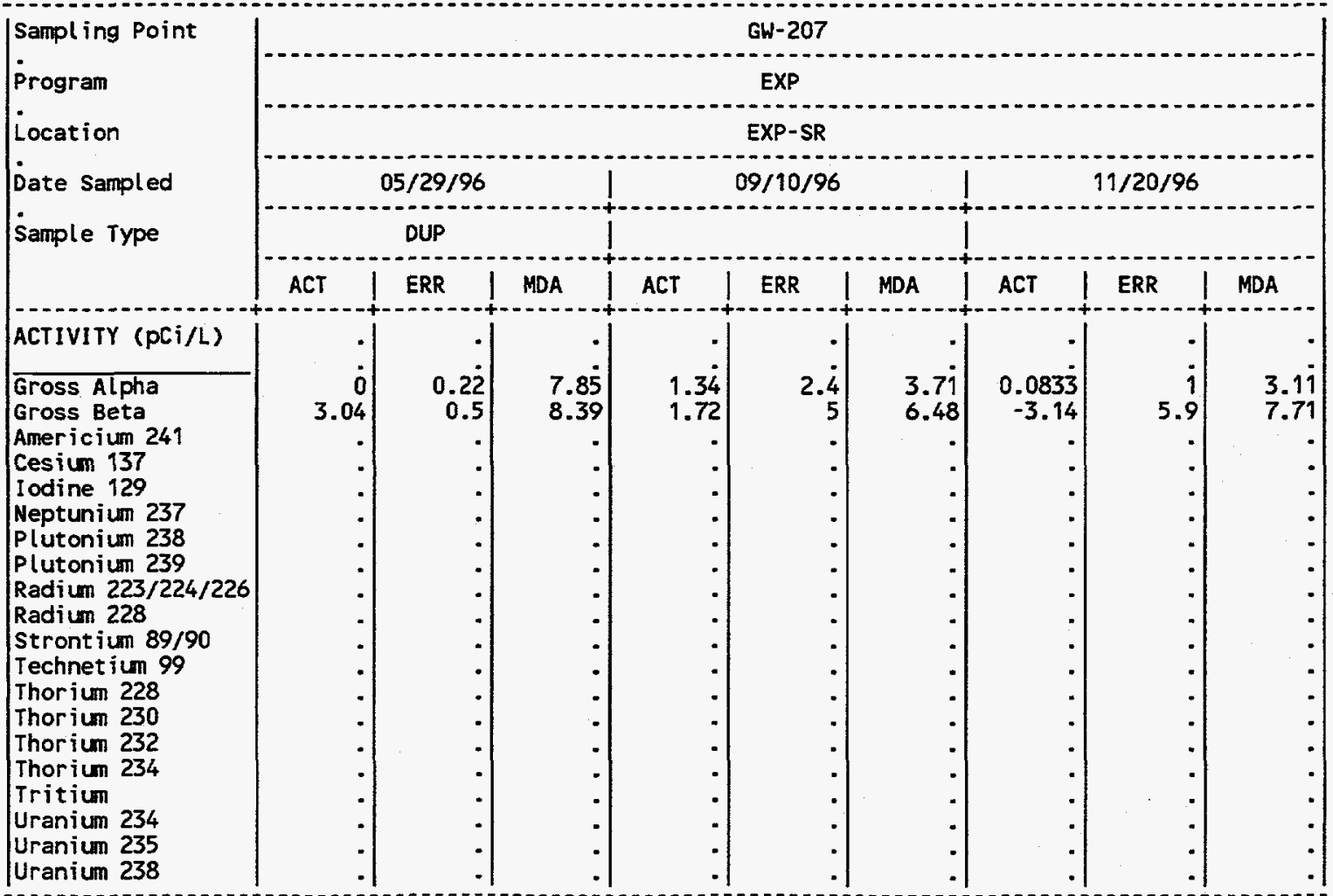


APPEND IX 0.4

Radiological Analytes, CY 1996

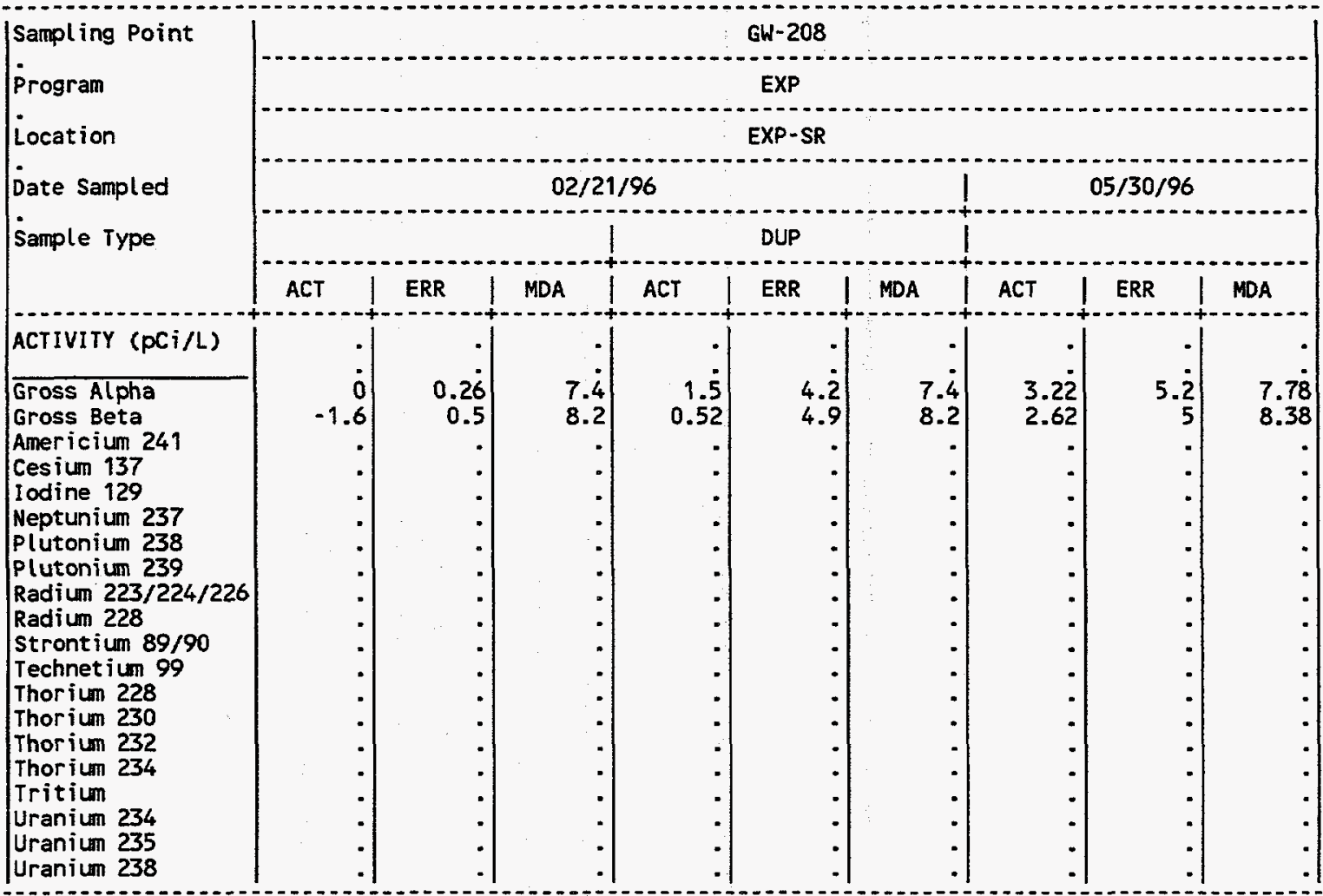

(CONT INUED)

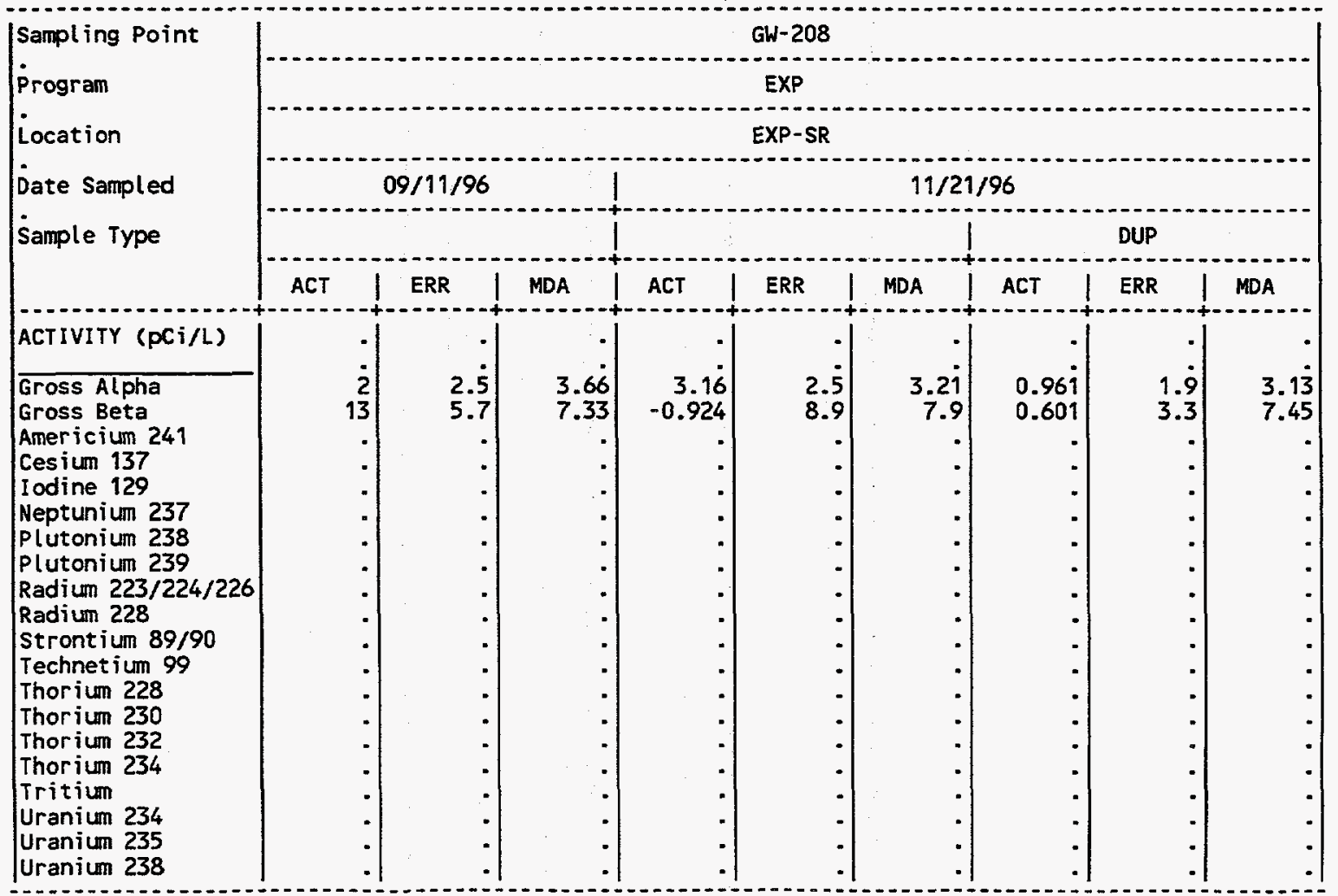

(CONT INUED) 
APPENDIX 0.4

Radiological Analytes, CY 1996

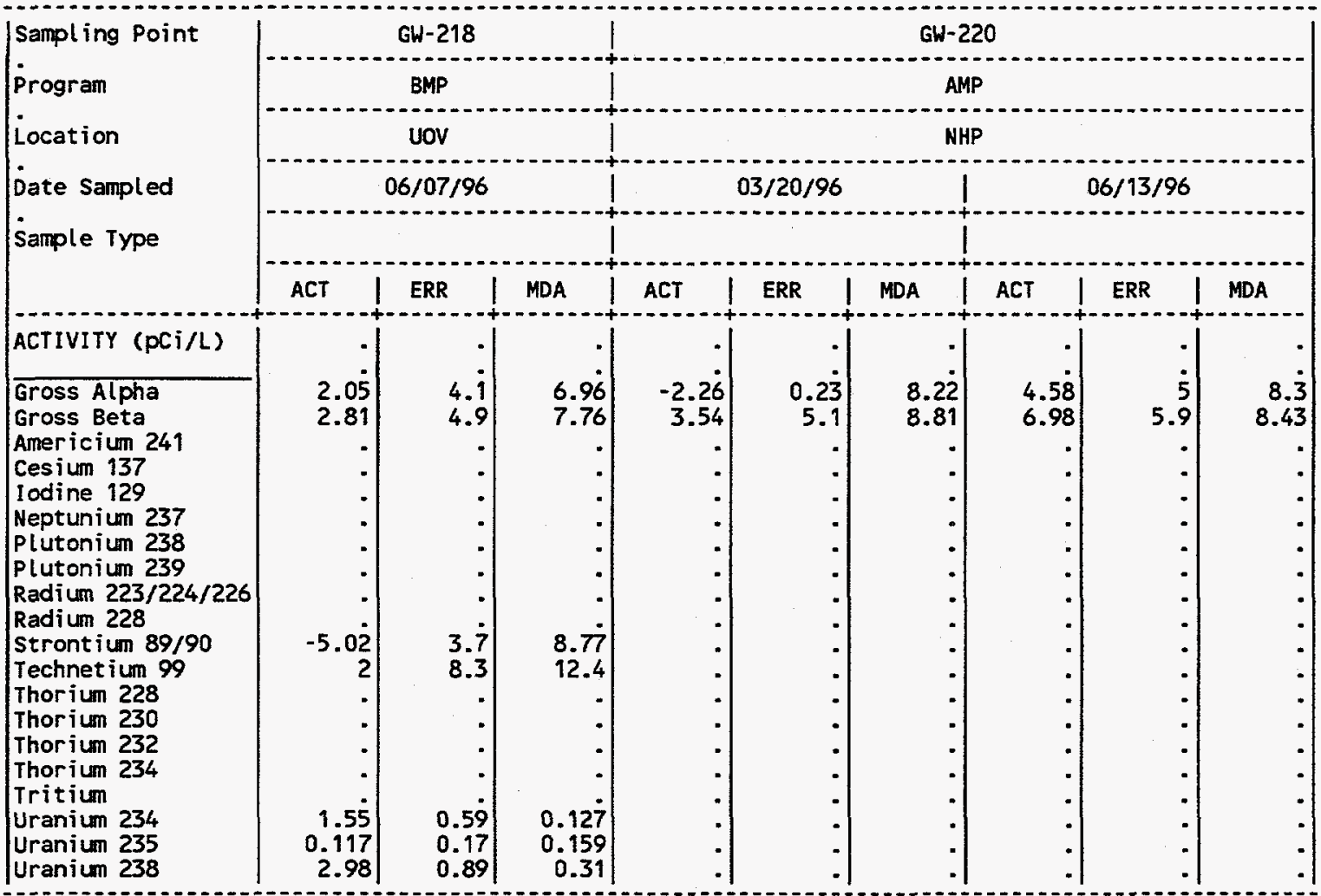

(CONT INUED)

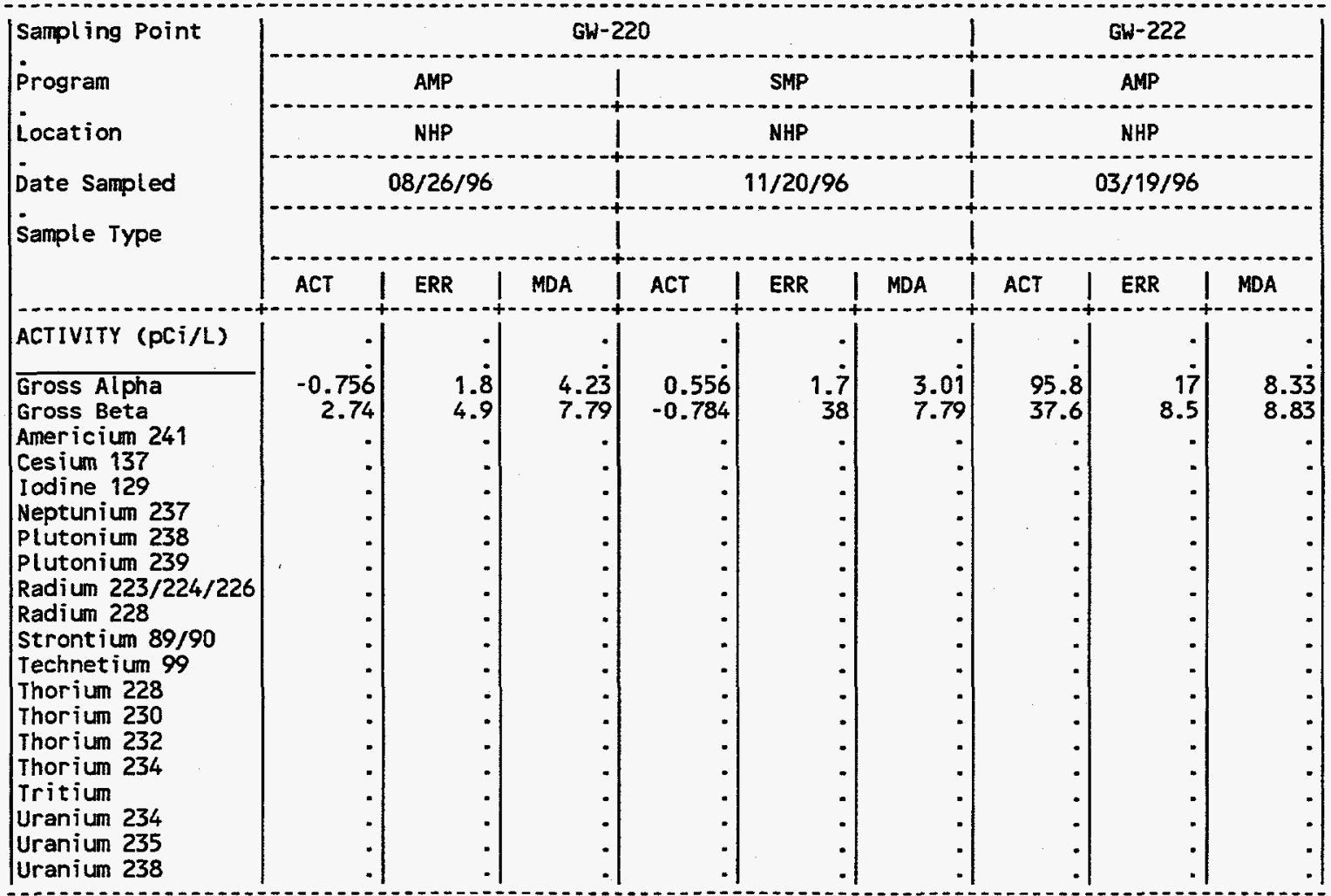

(CONT INUED) 
APPENDIX 0.4

Radiological Analytes, CY 1996

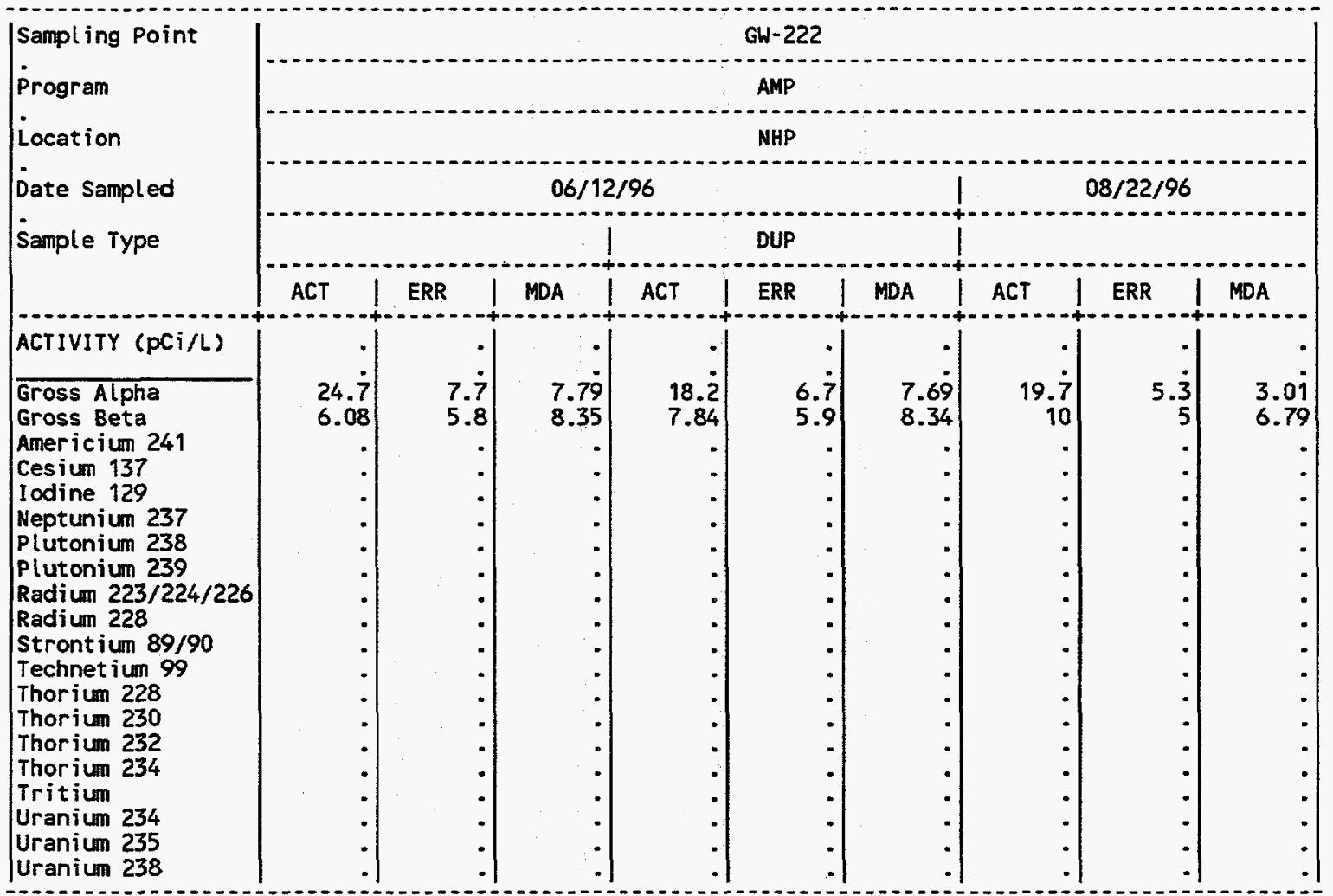

(CONTINUED)

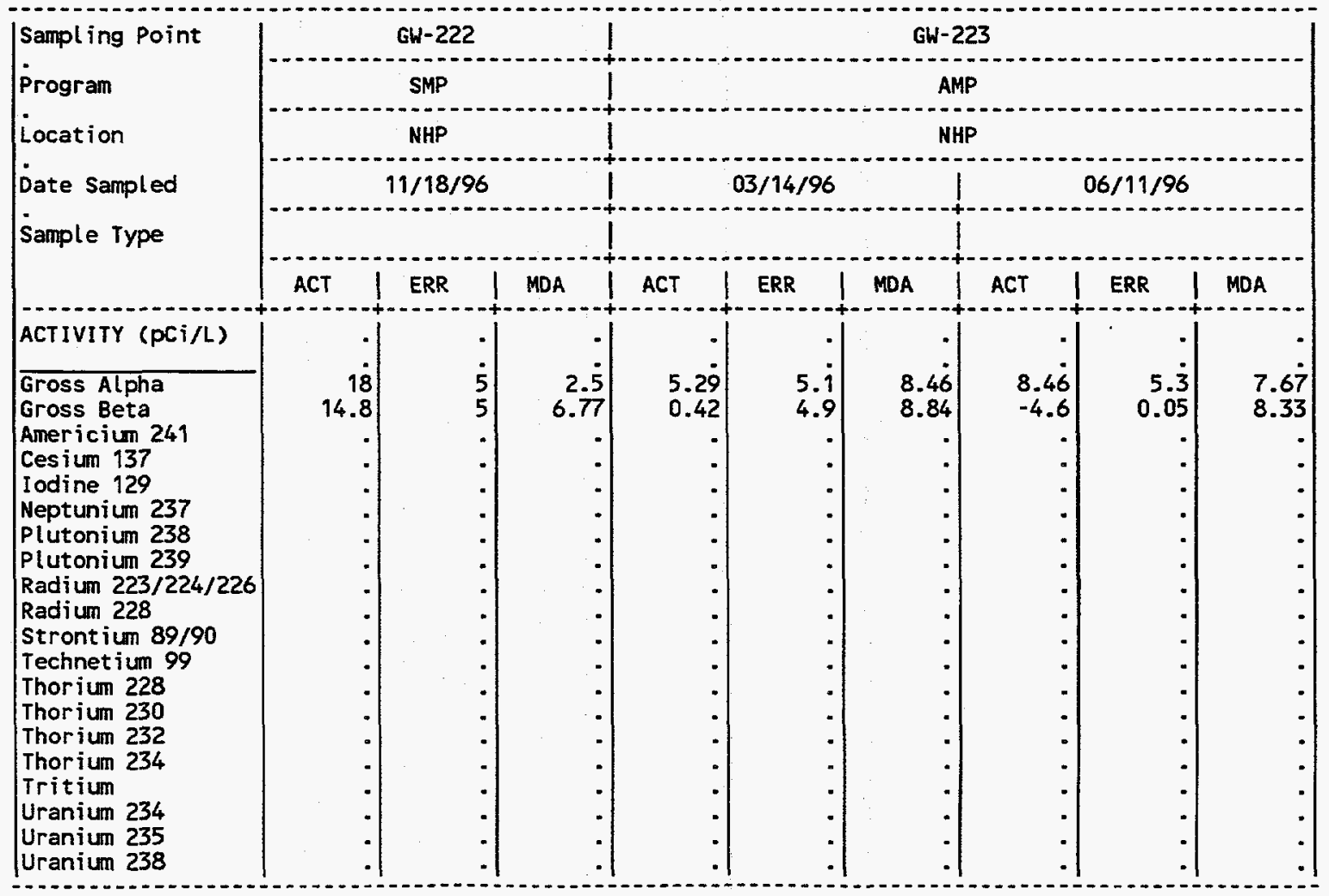

(CONTINUED) 
APPENDIX 0.4

Radiological Analytes, CY 1996

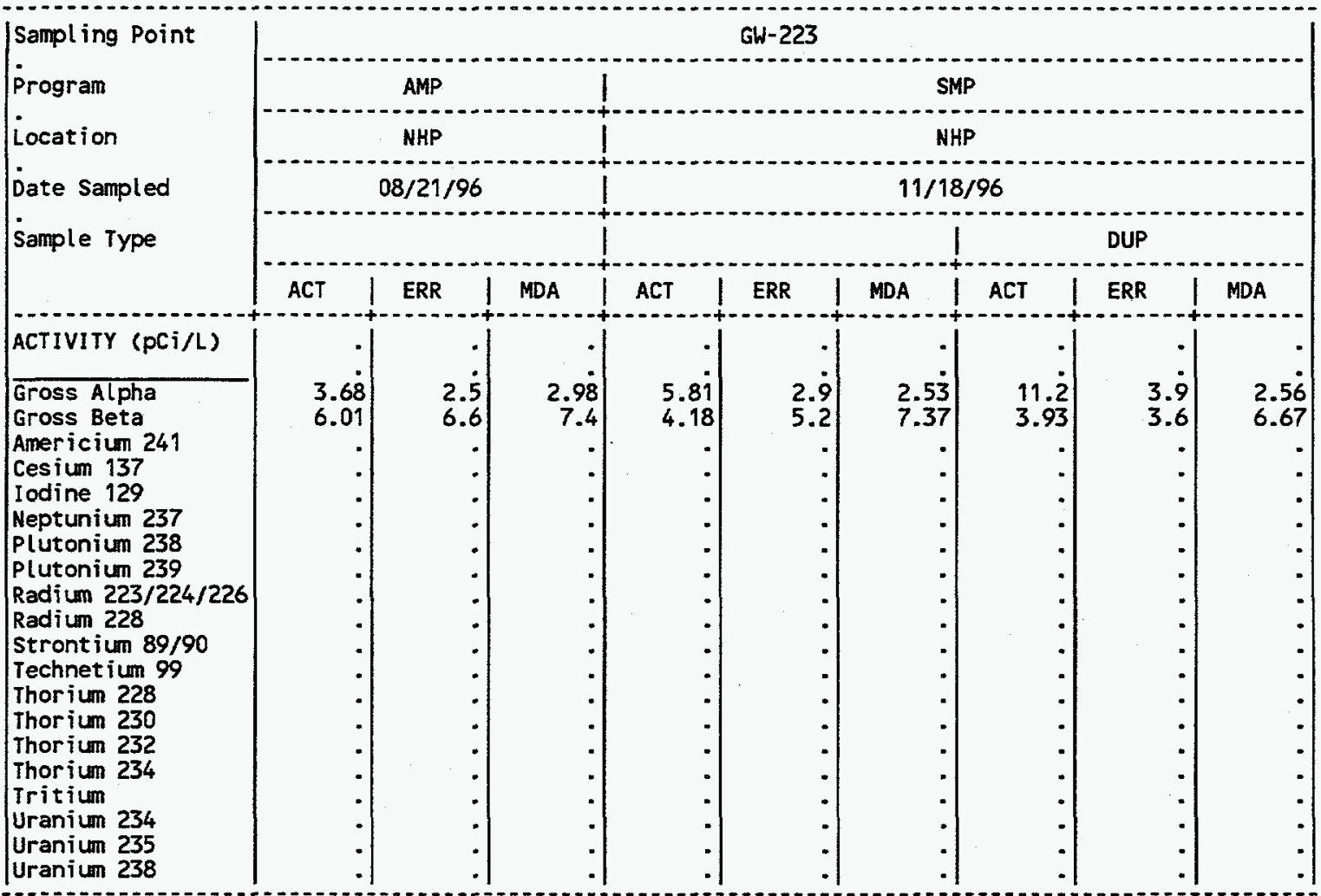

(CONT I NUED)

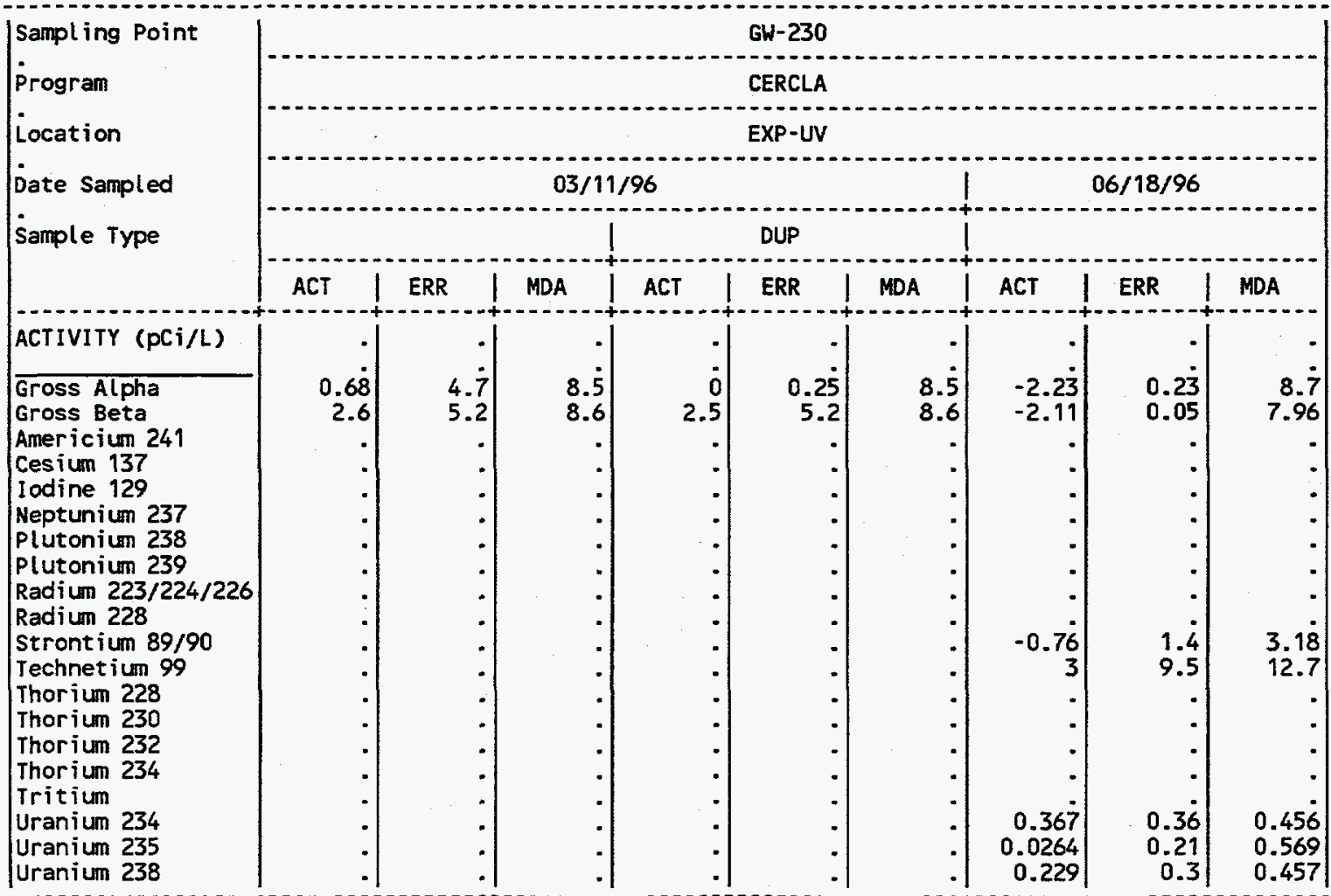


Radiological Analytes, CY 1996

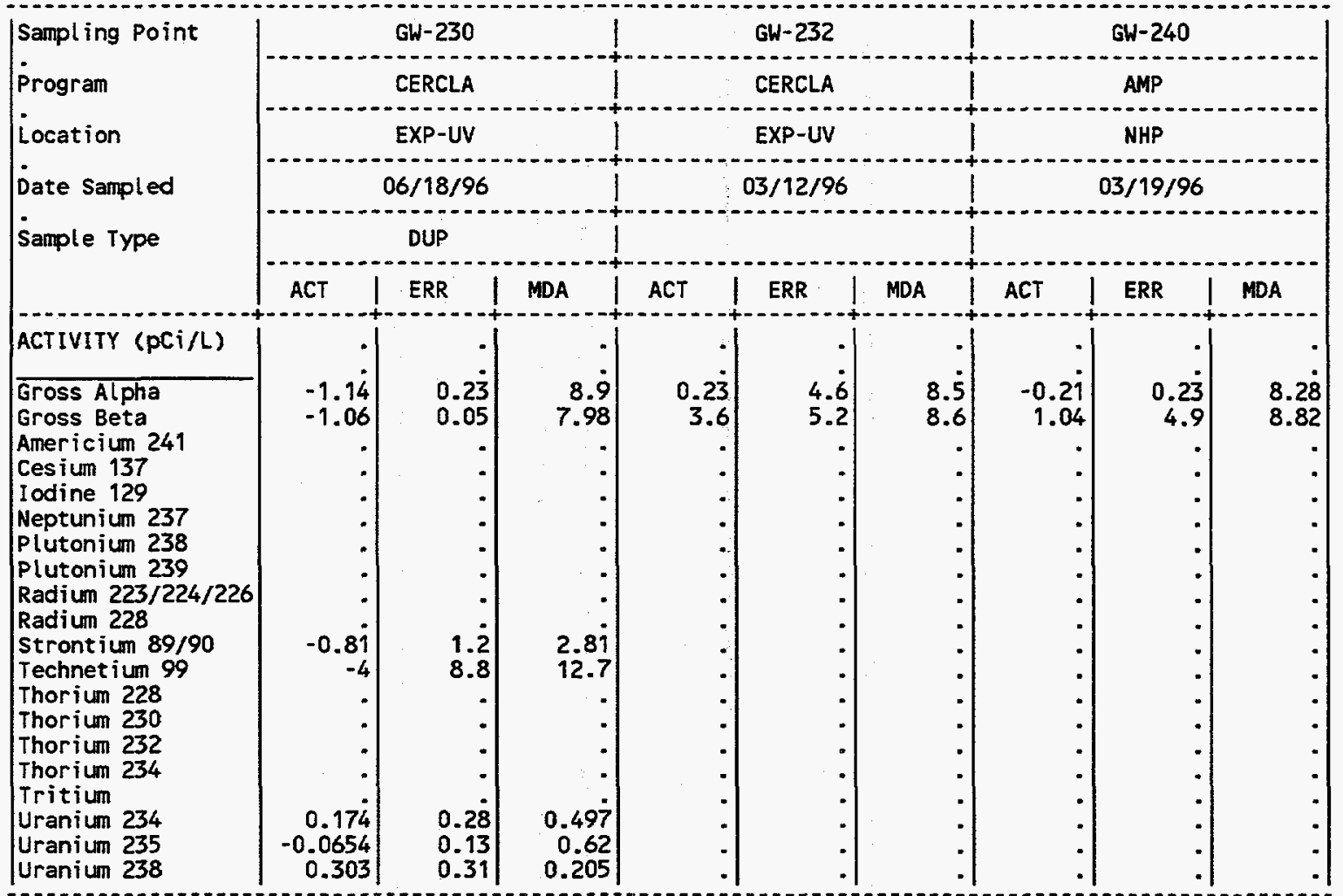

(CONT INUED)

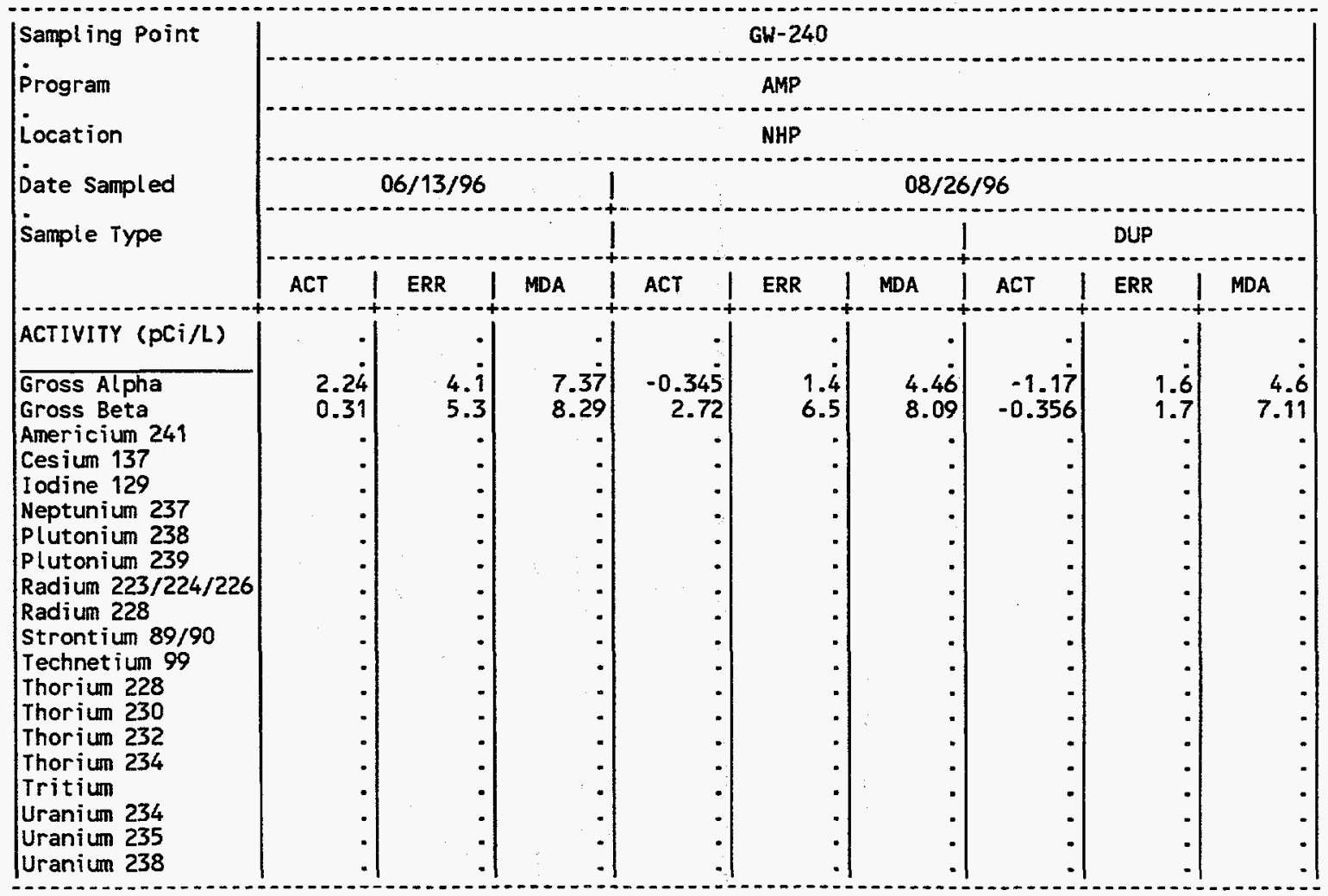


APPENDIX 0.4

Radiological Analytes, CY 1996

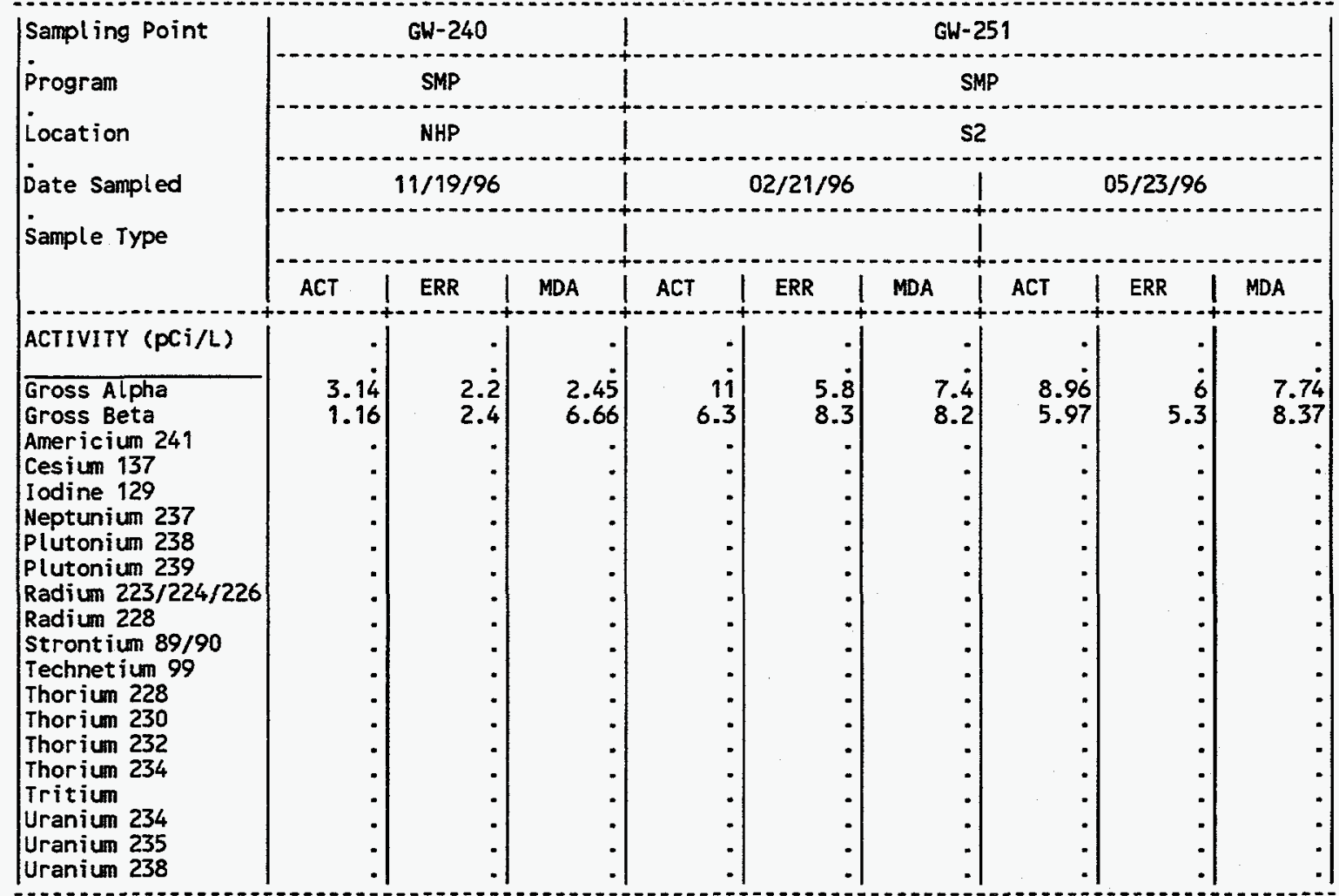

(CONTINUED)

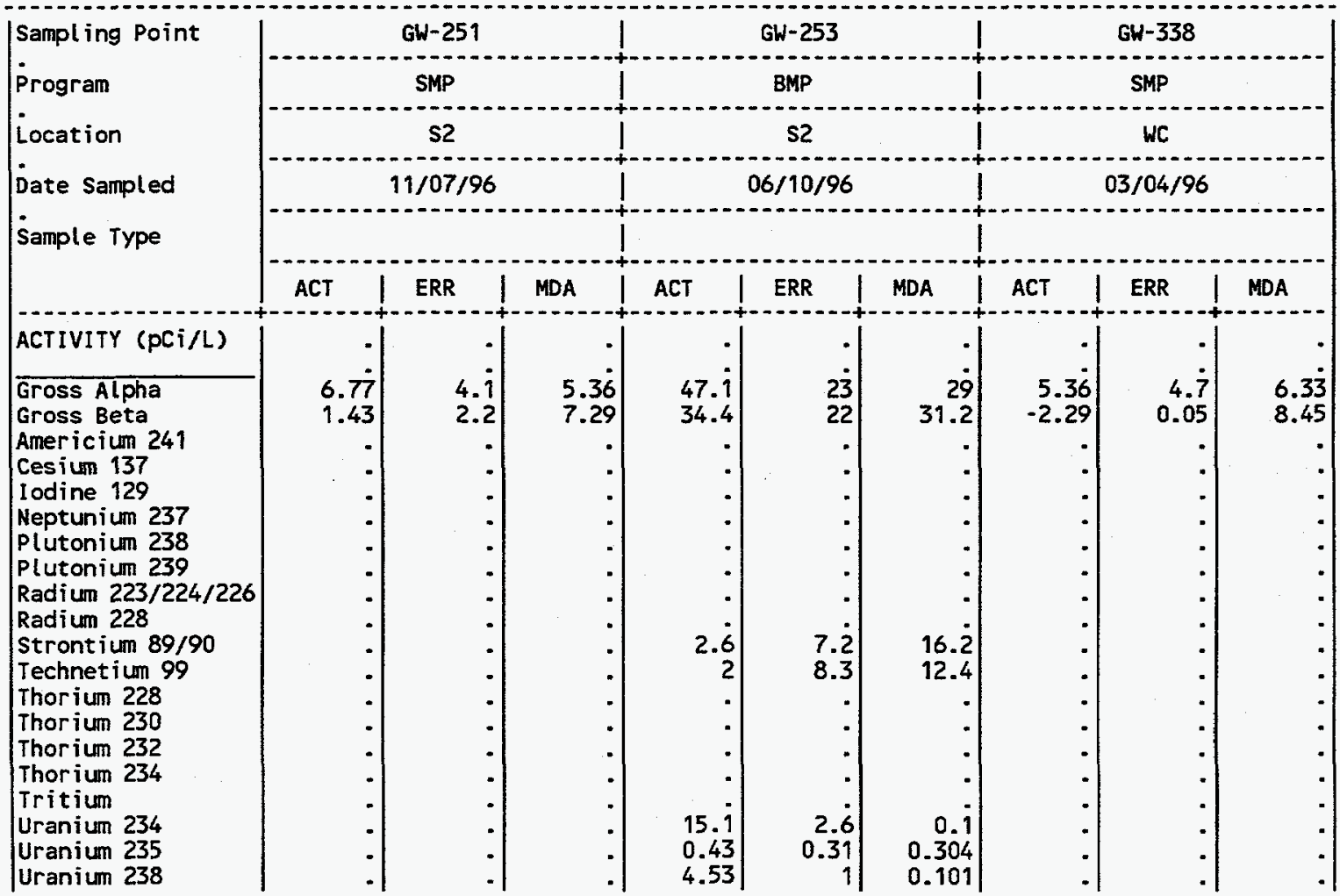


APPENDIX 0.4

Radiological Analytes, CY 1996

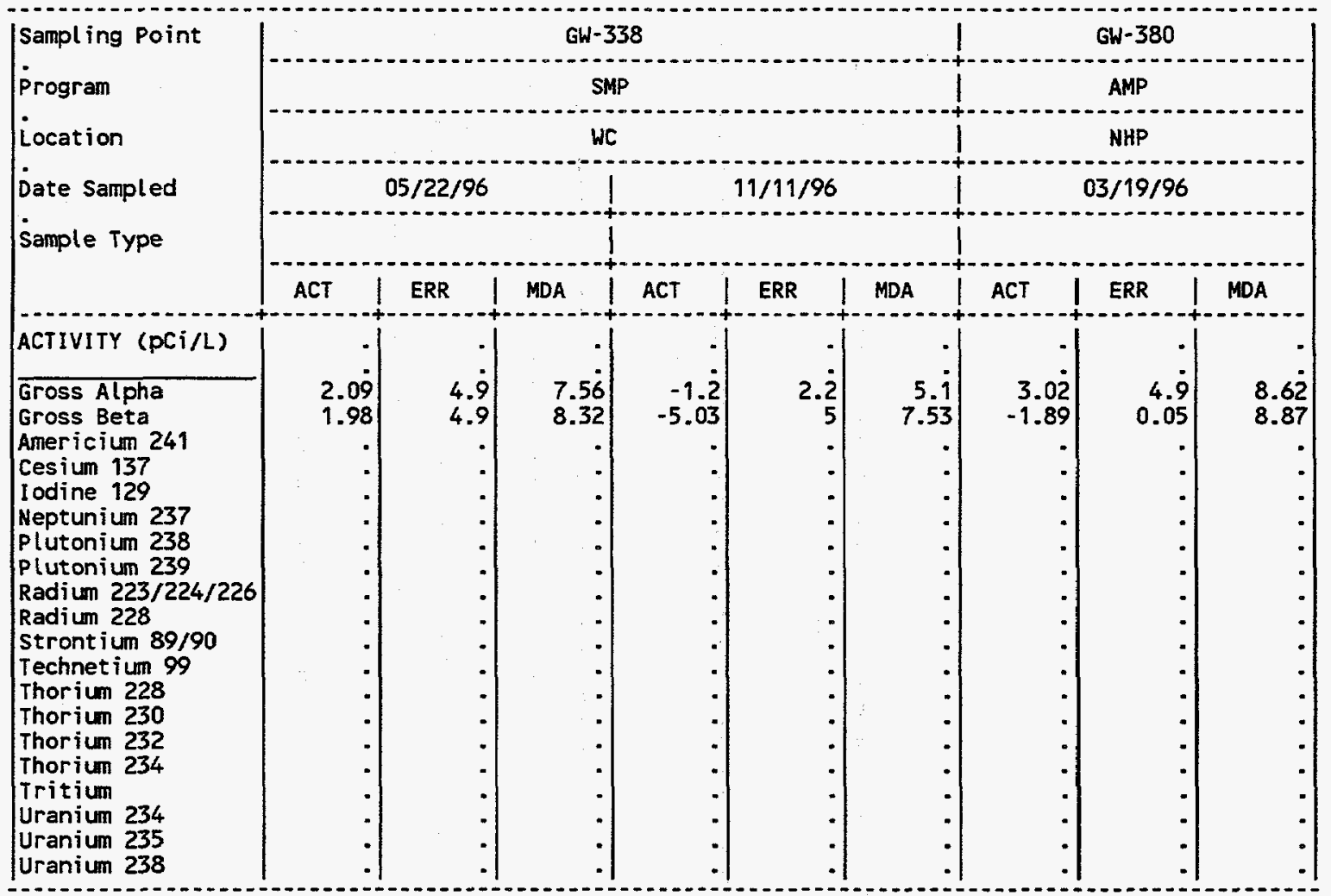

\section{(CONT INUED)}

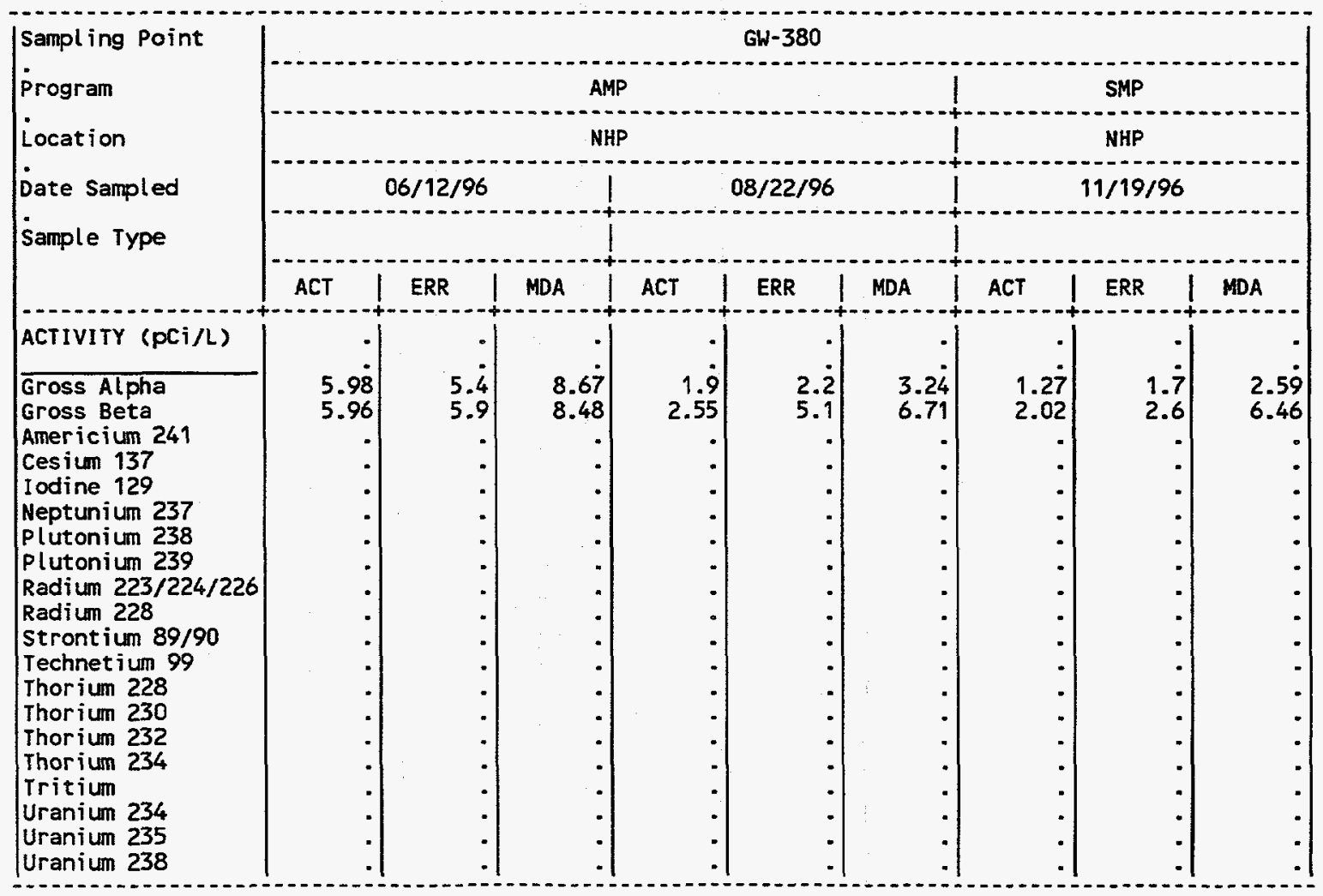


APPENDIX 0.4

Radiological Analytes, CY 1996

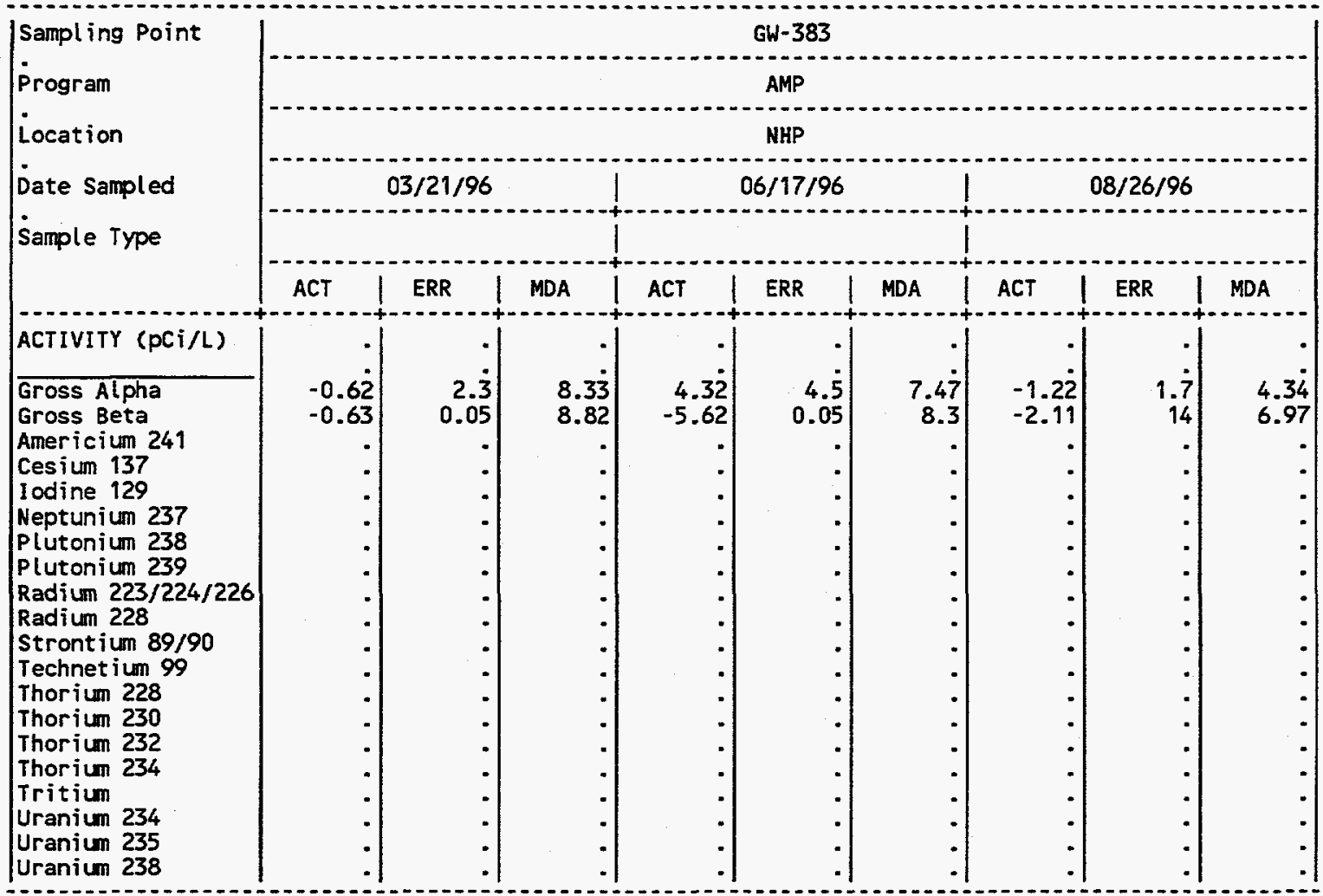

(CONTINUED)

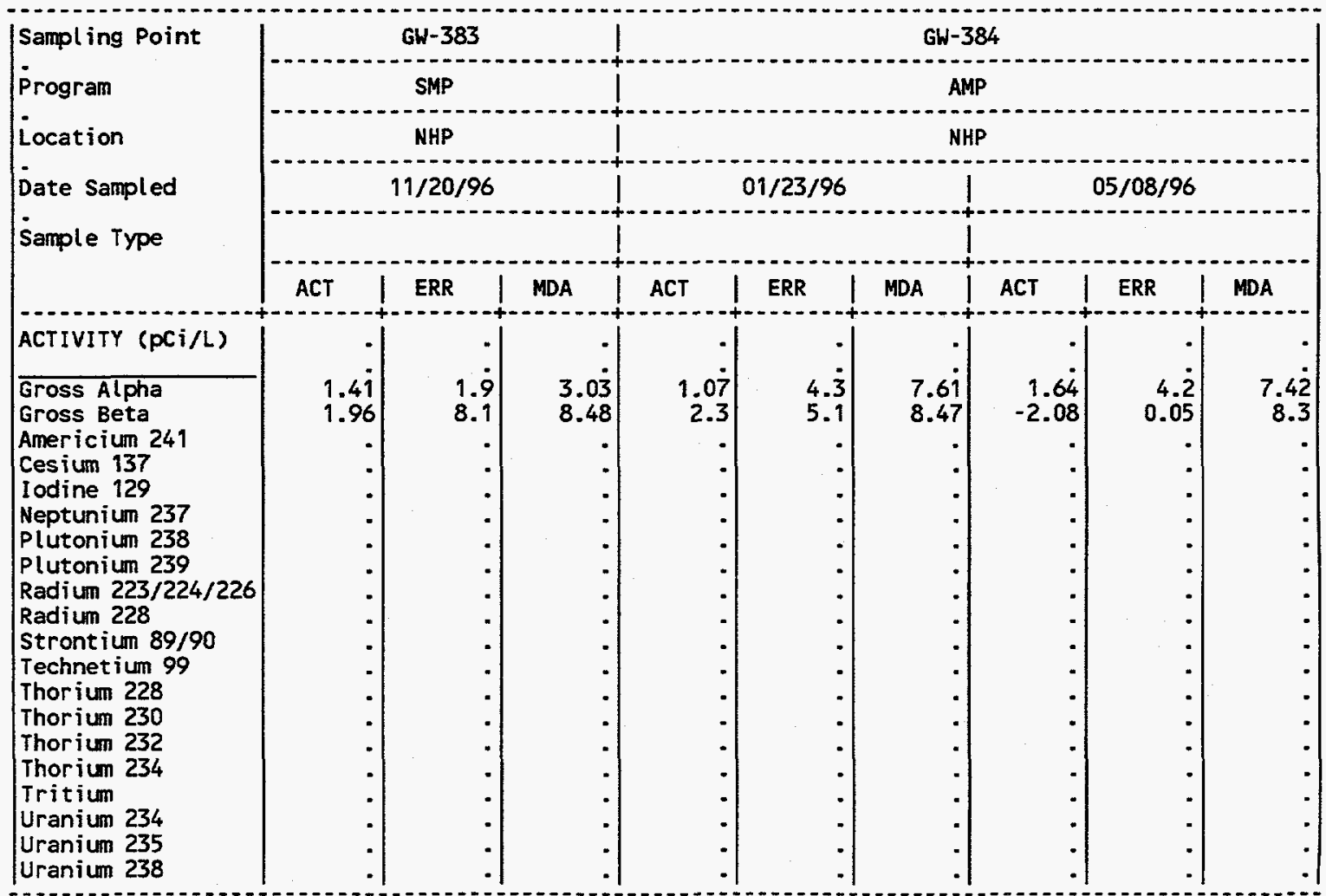


APPENDIX 0.4

Radiological Analytes, Cr 1996

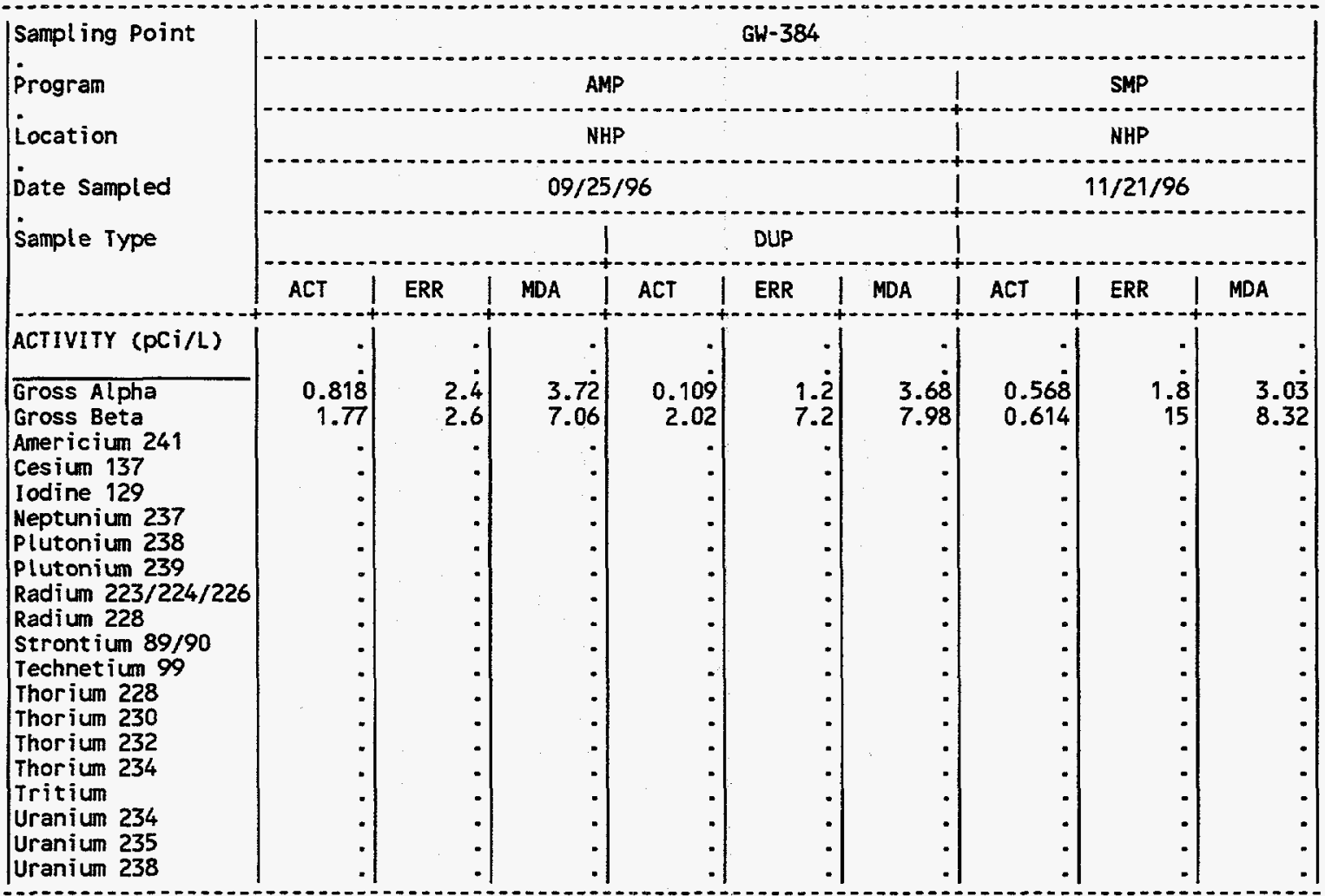

(CONTINUED)

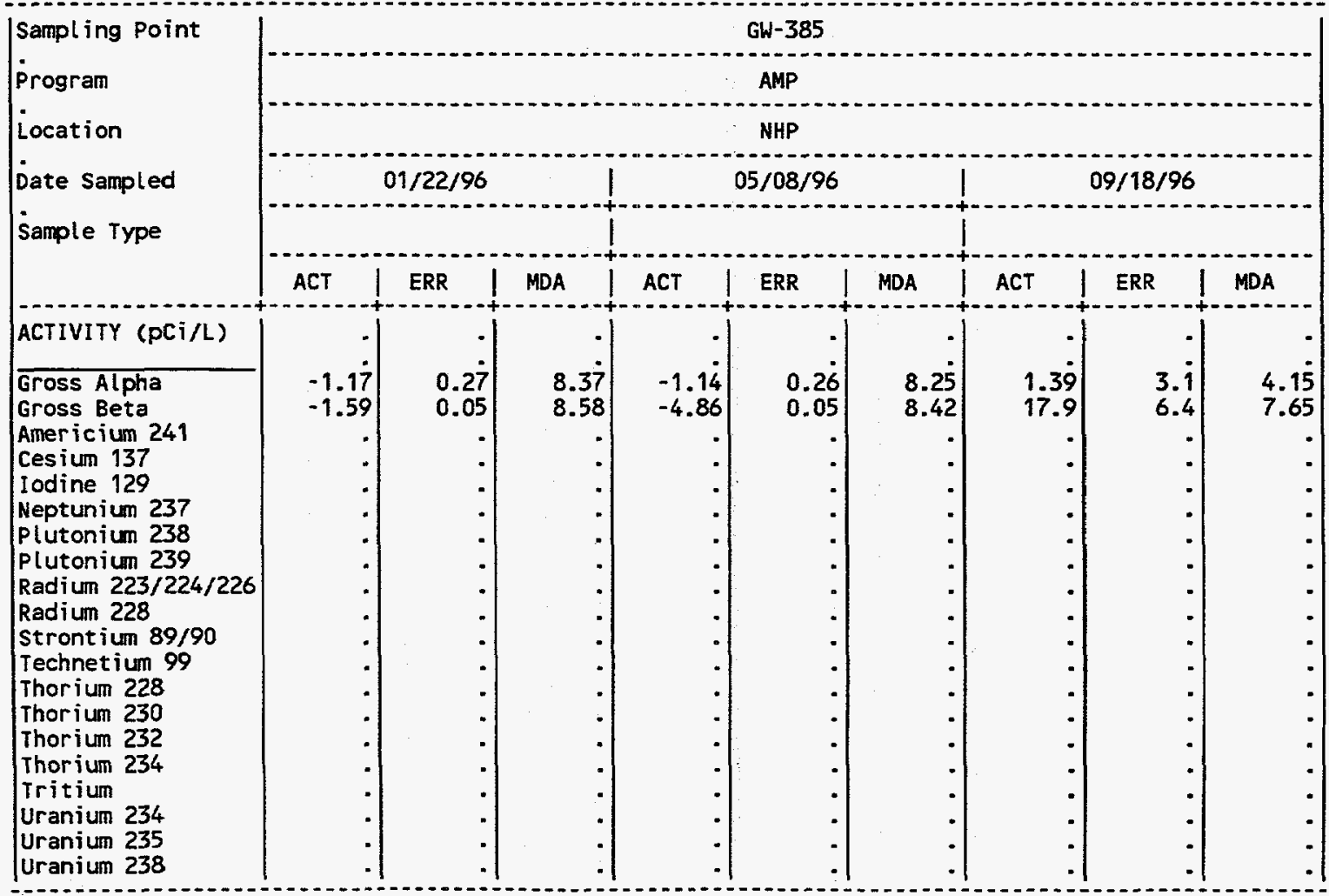

(CONT INUED) 
APPENDIX 0.4

Radiological Analytes, CY 1996

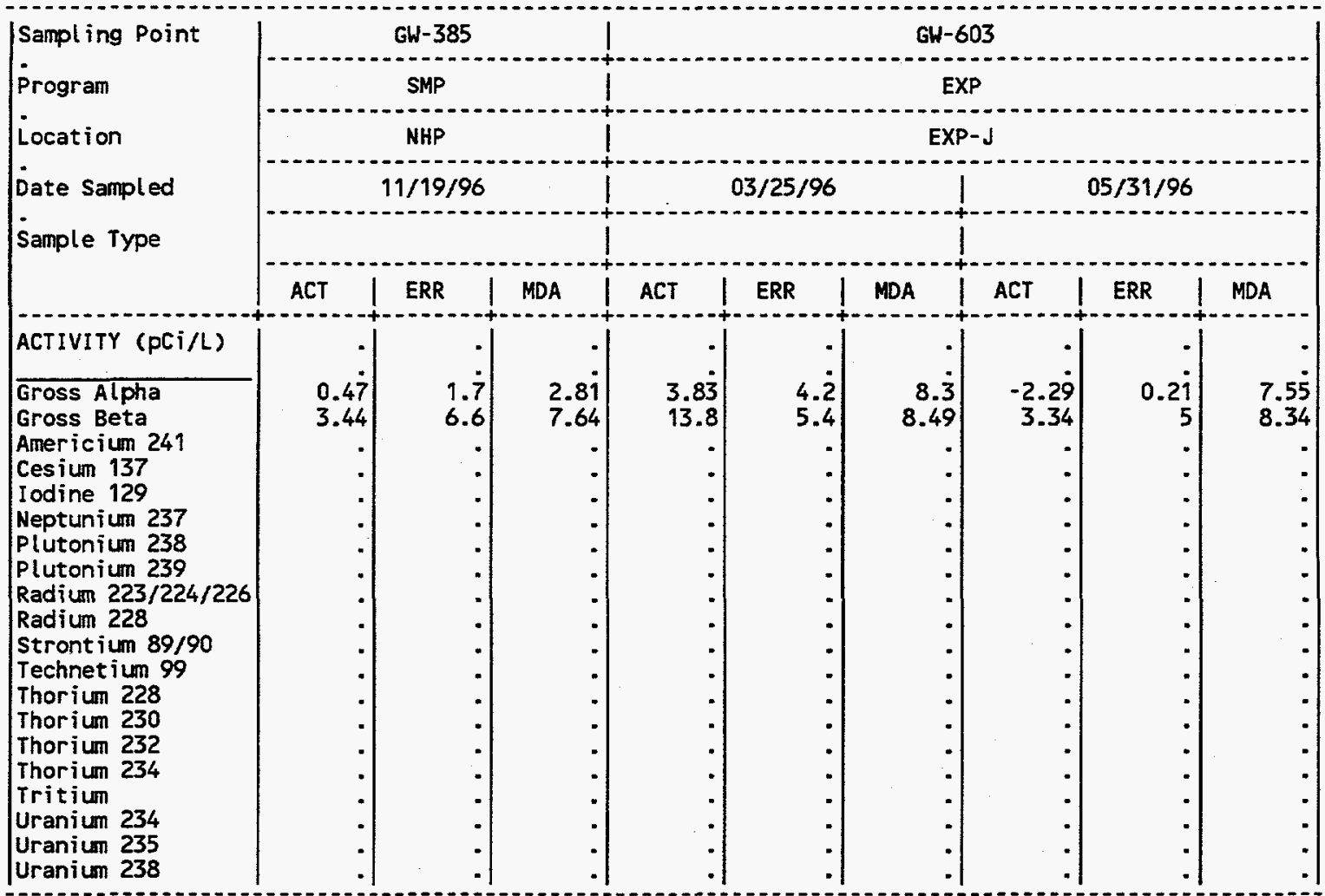

(CONTINUED)

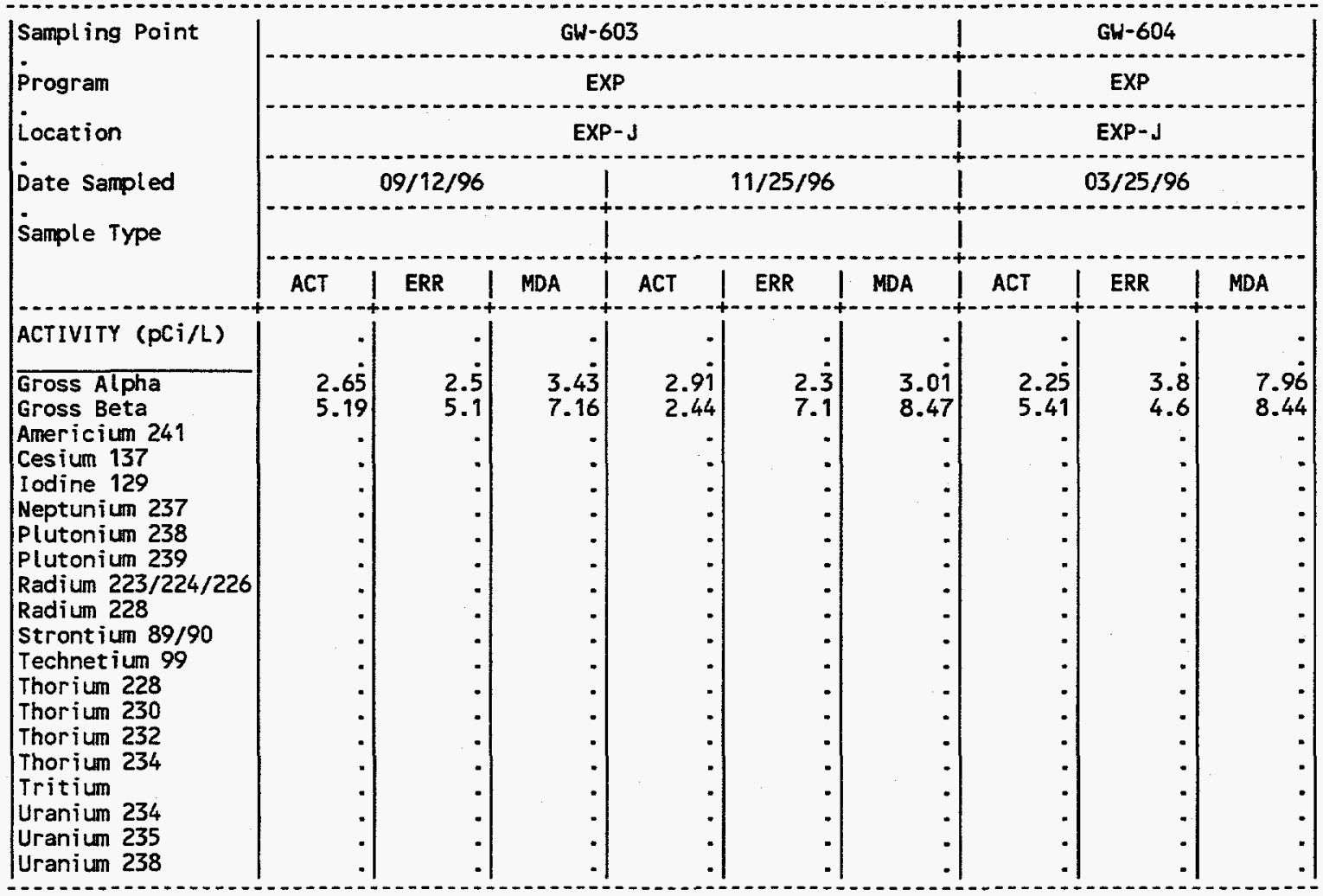

(CONTINUED) 
APPENDIX 0.4

Radiological Analytes, CY 1996

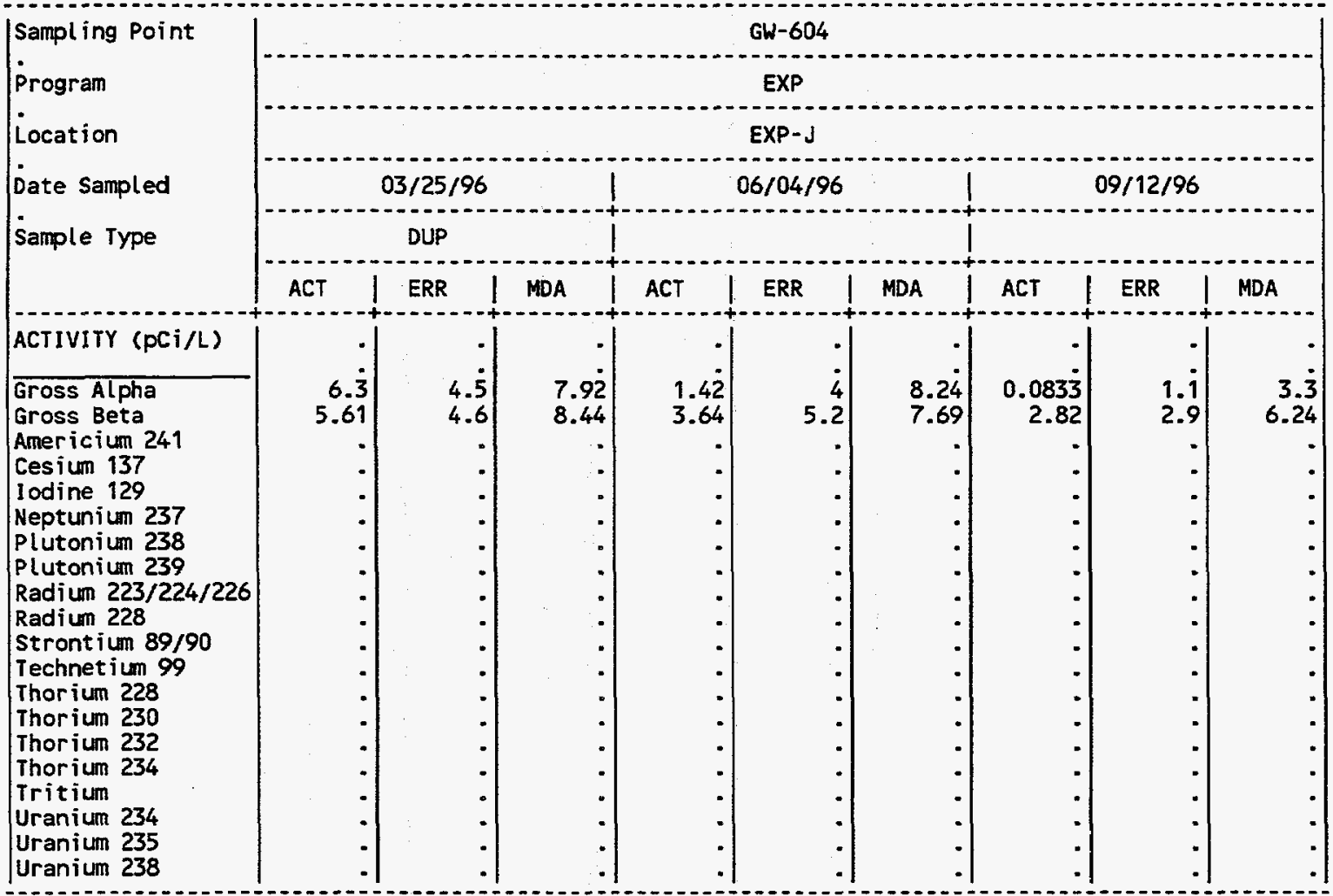

(CONT INUED)

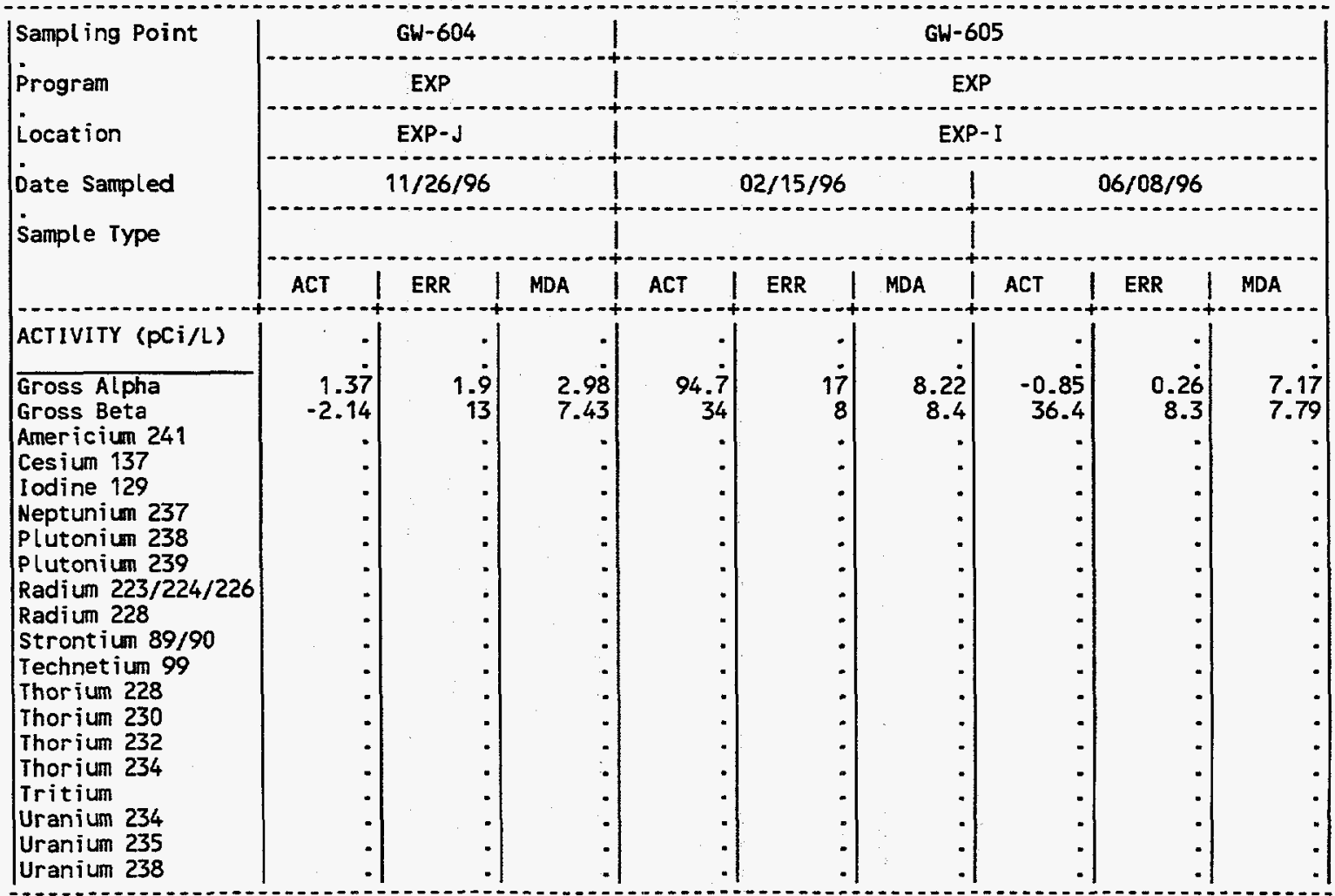

(CONTINUED) 
APPENDIX 0.4

Radiological Analytes, CY 1996

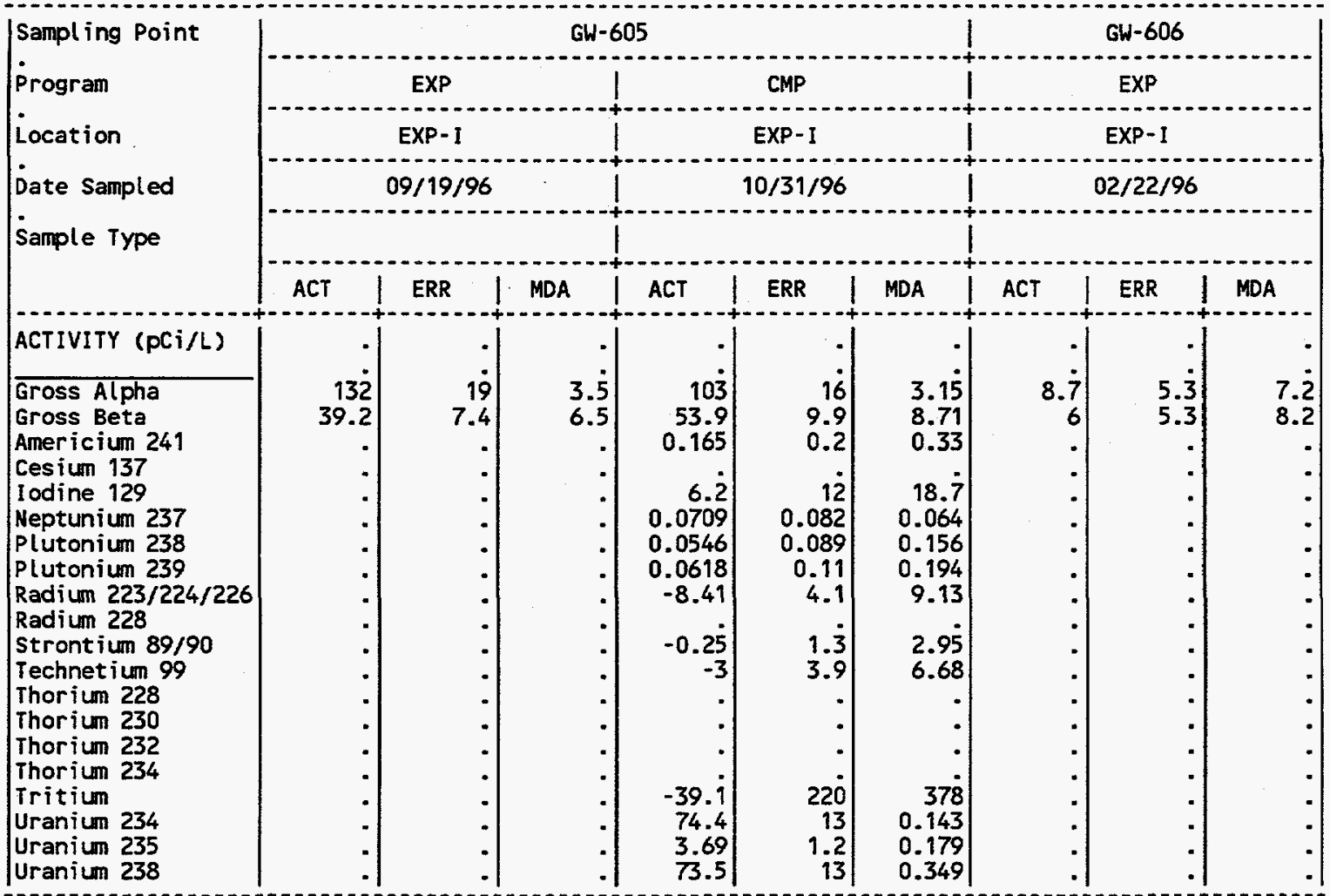

(CONT INUED)

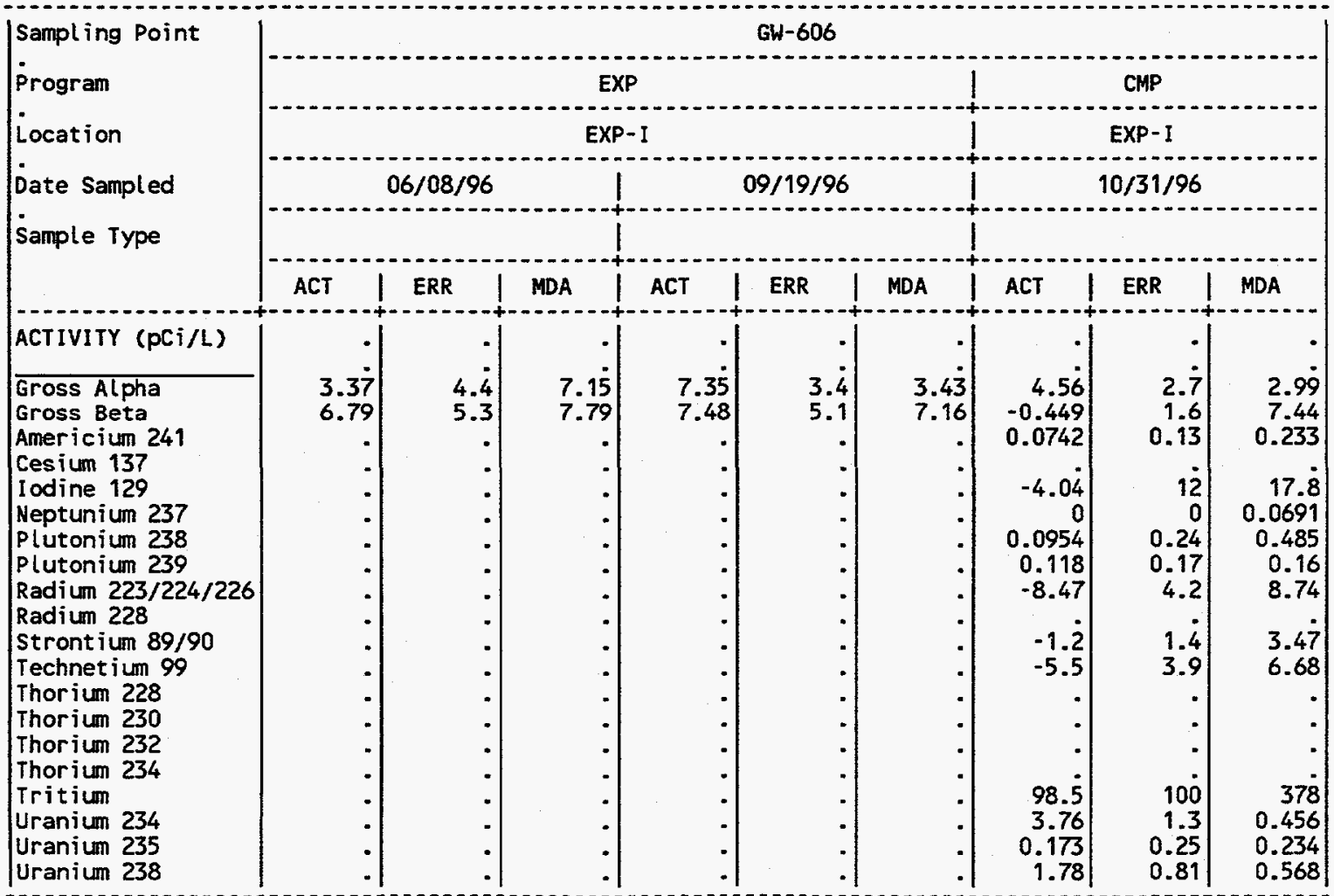


APPENDIX D.4

Radiological Analytes, CY 1996

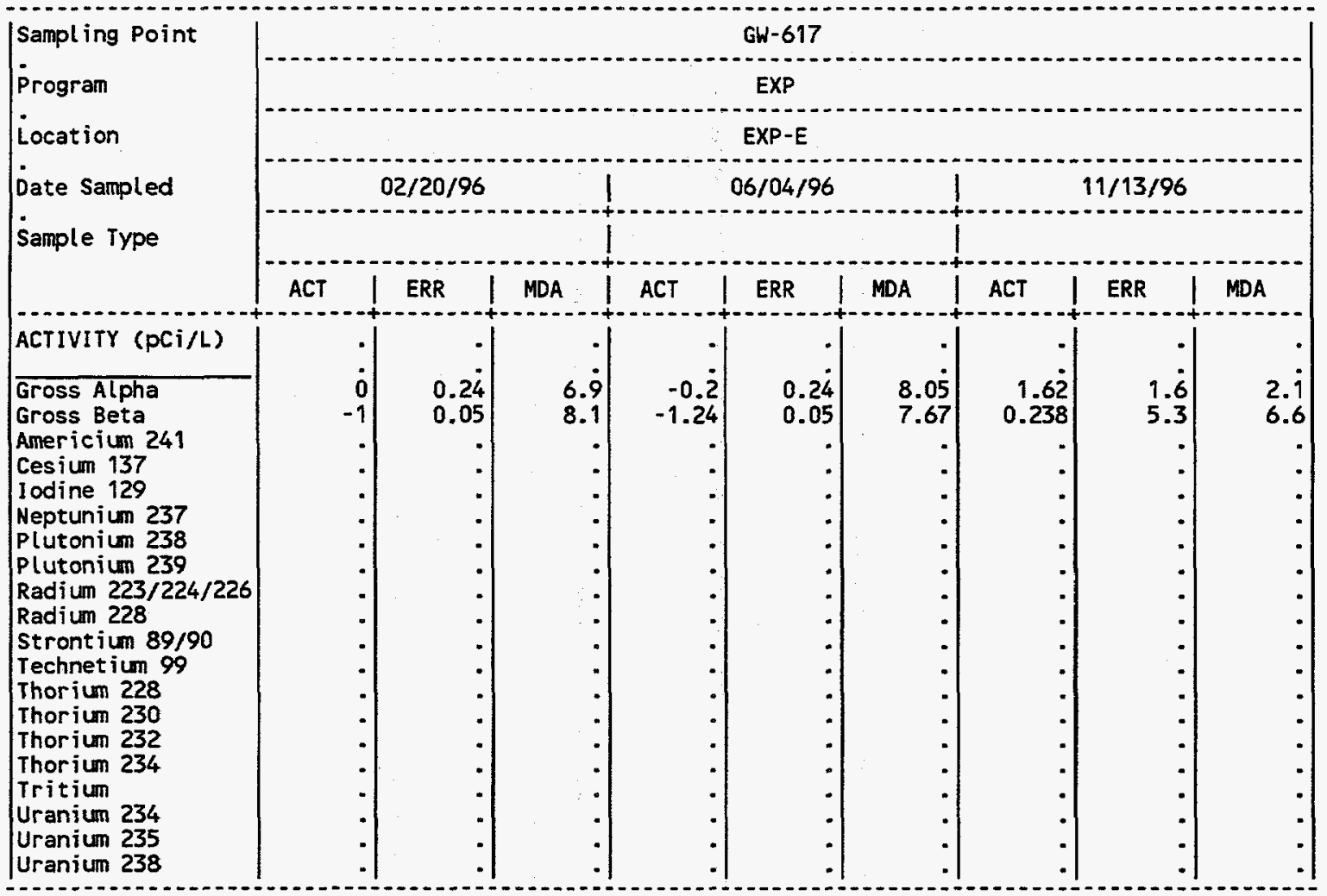

(CONTINUED)

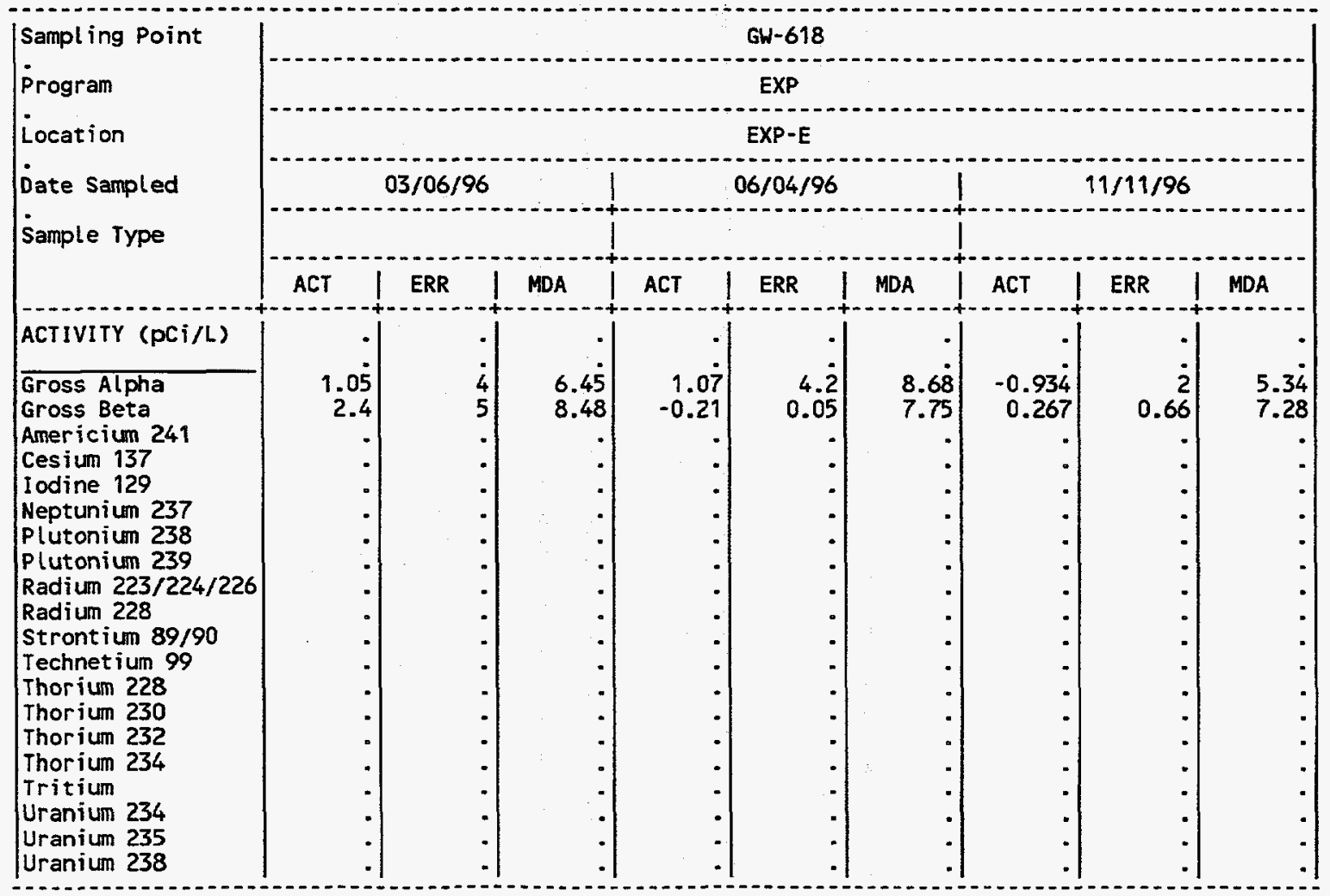

(CONTINUED) 


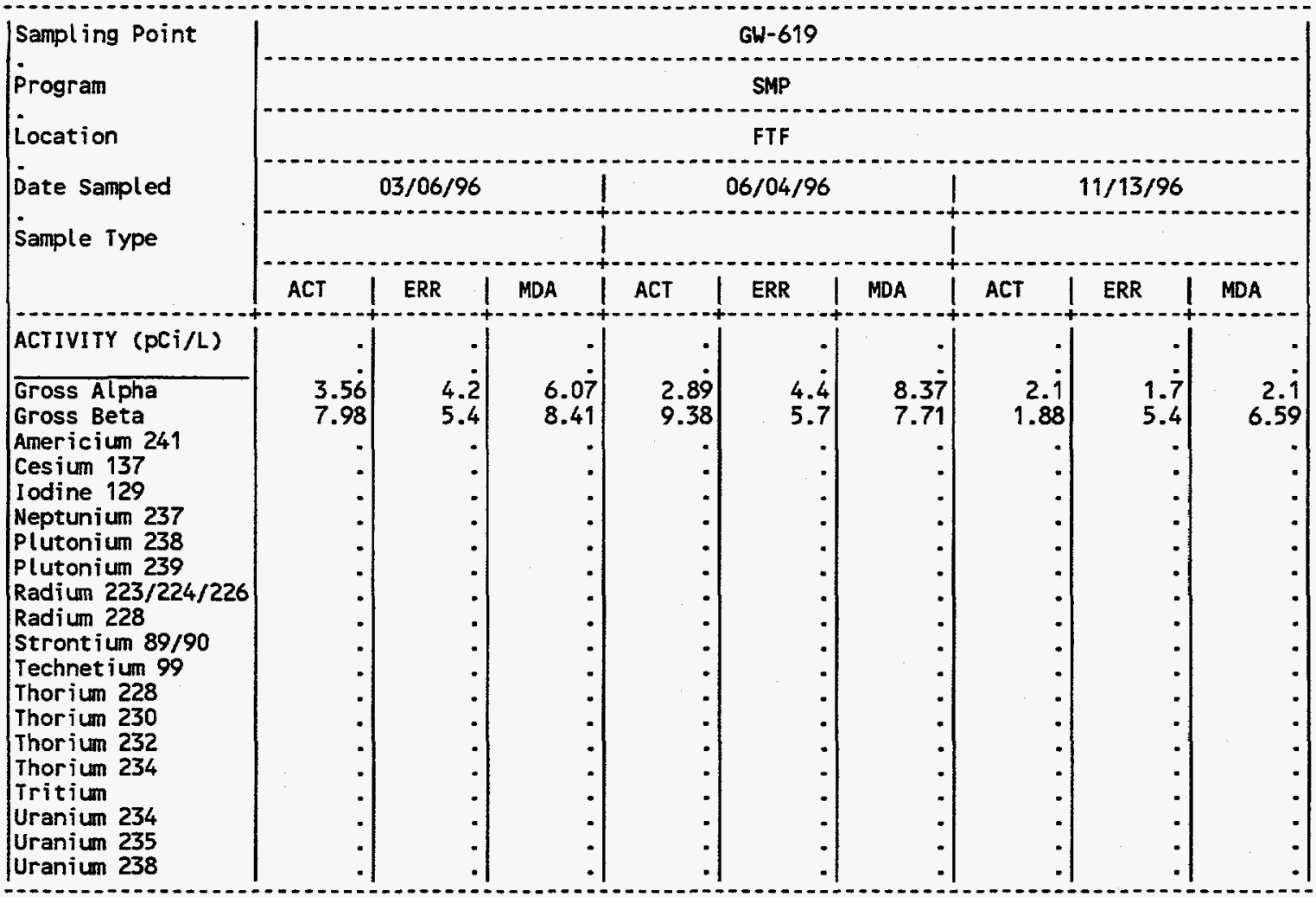

(CONT INUED)

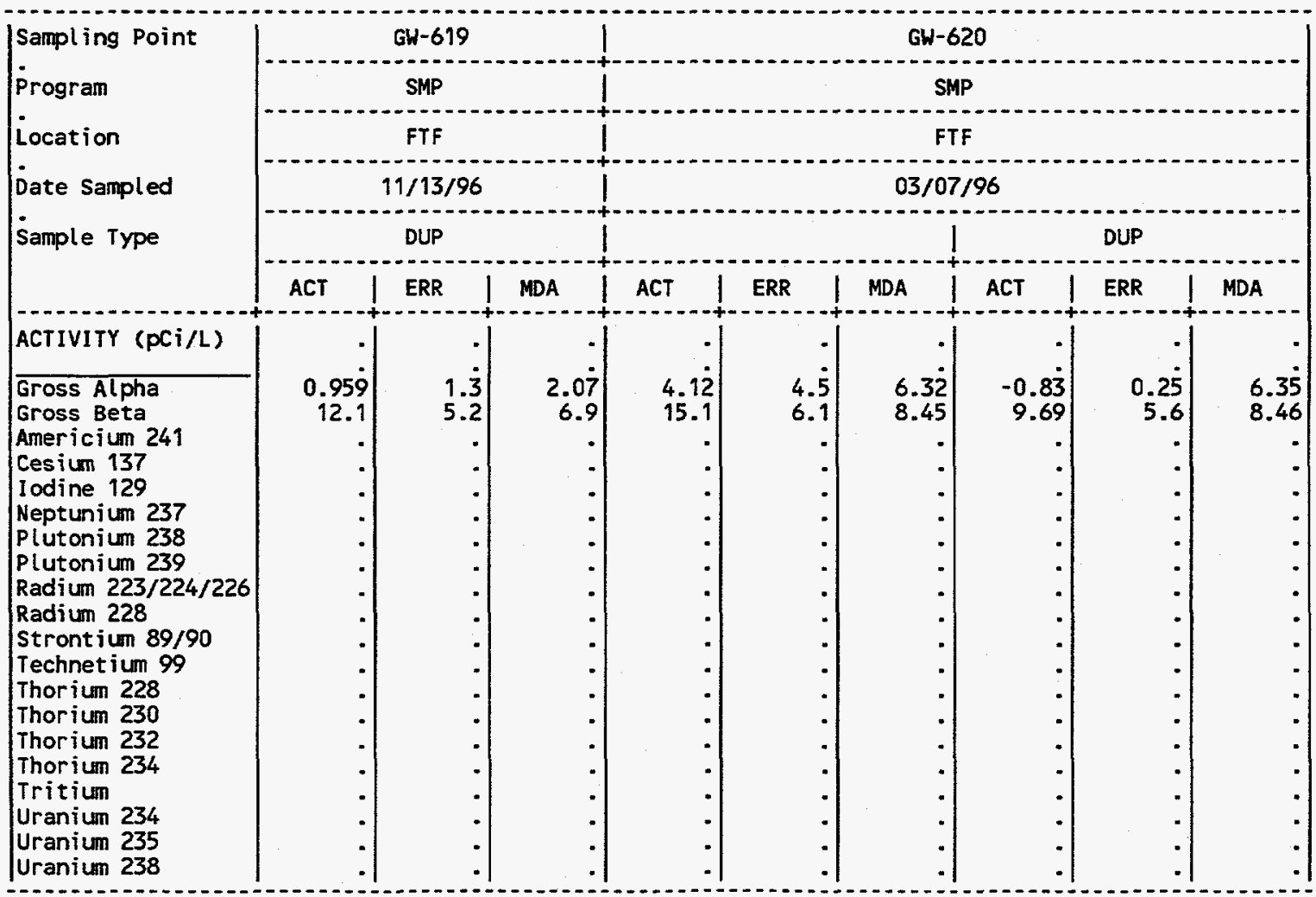

(CONTINUED) 
APPEND IX 0.4

Radiological Analytes, CY 1996

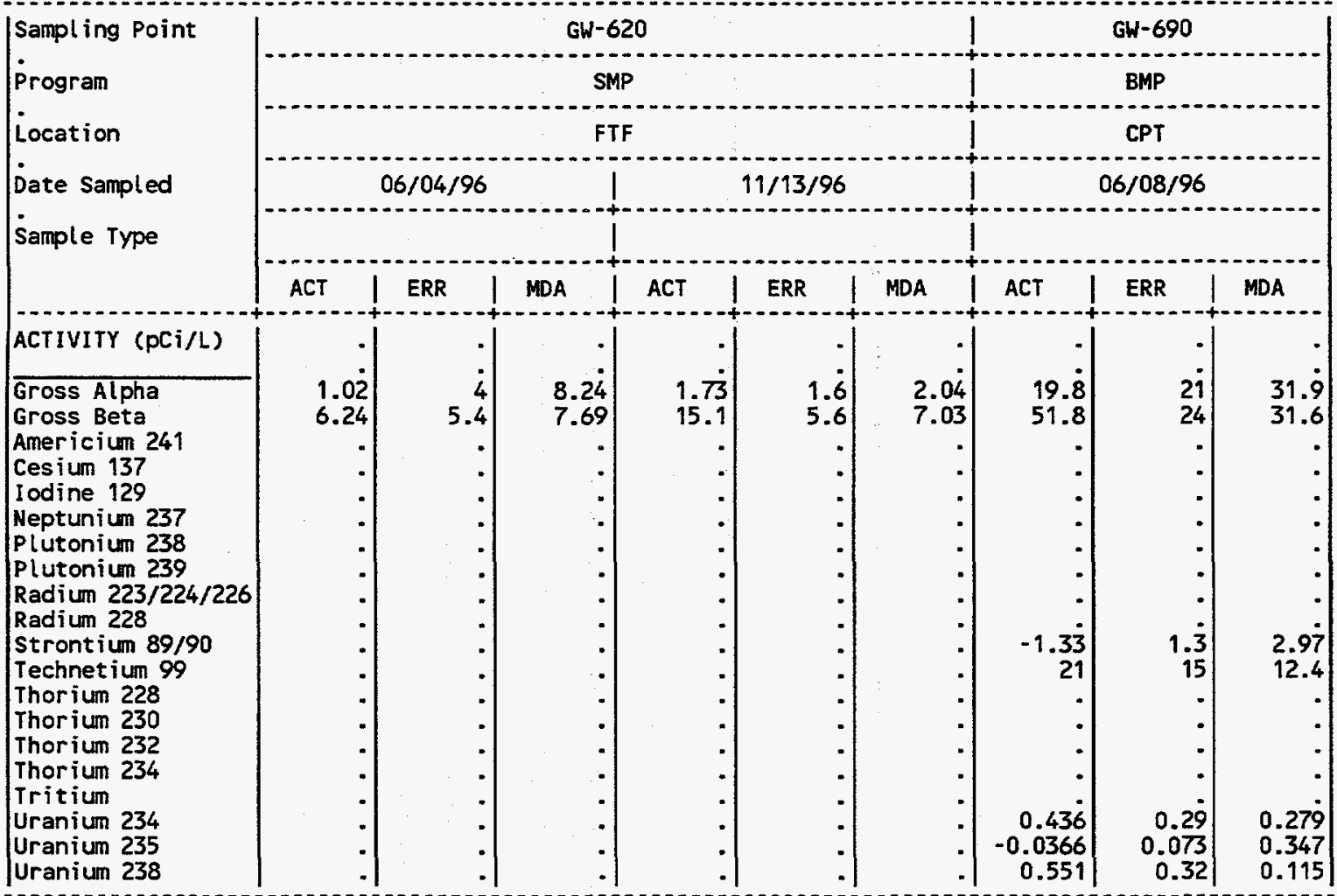

(CONT INUED)

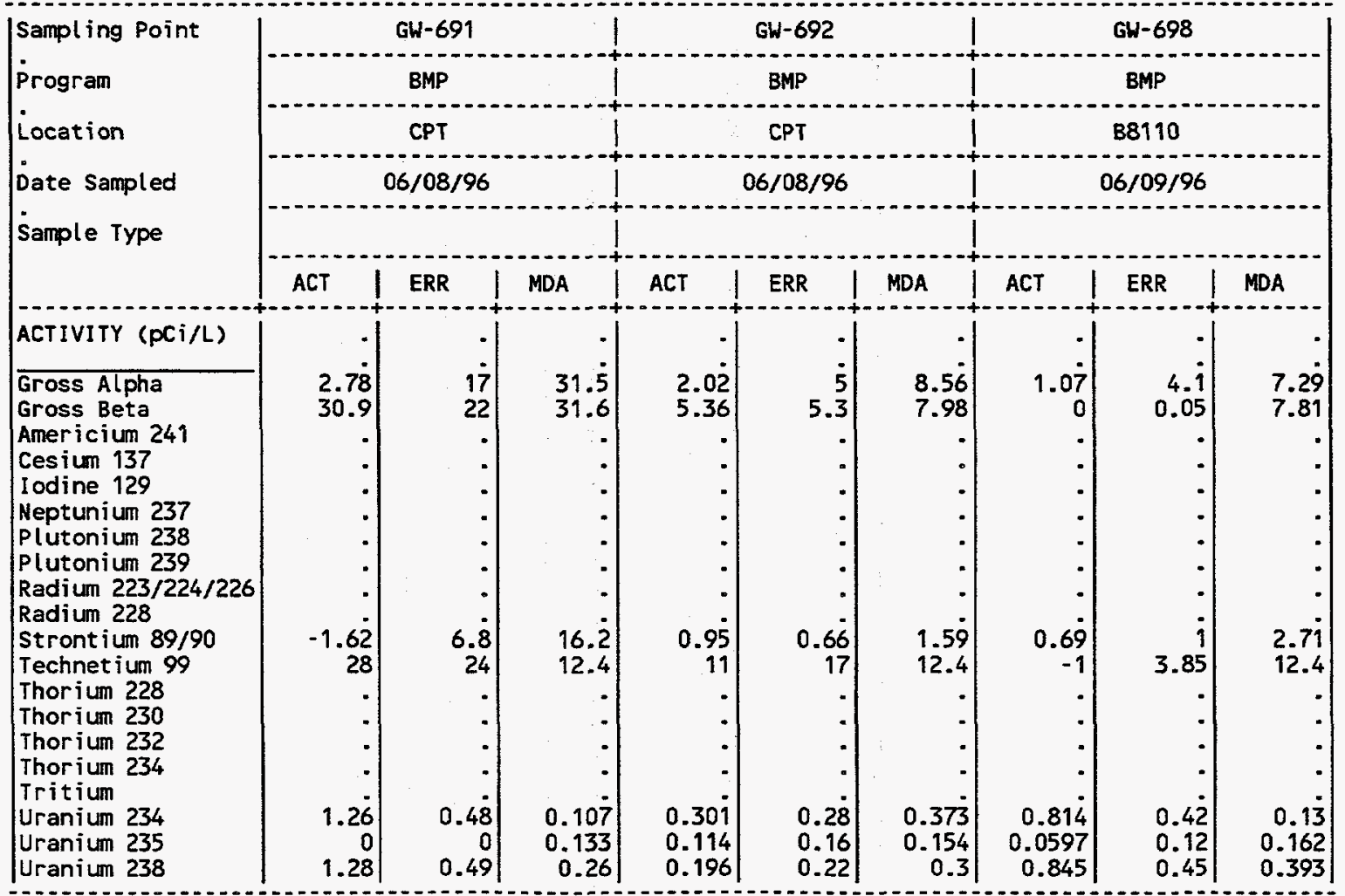


APPENDIX 0.4

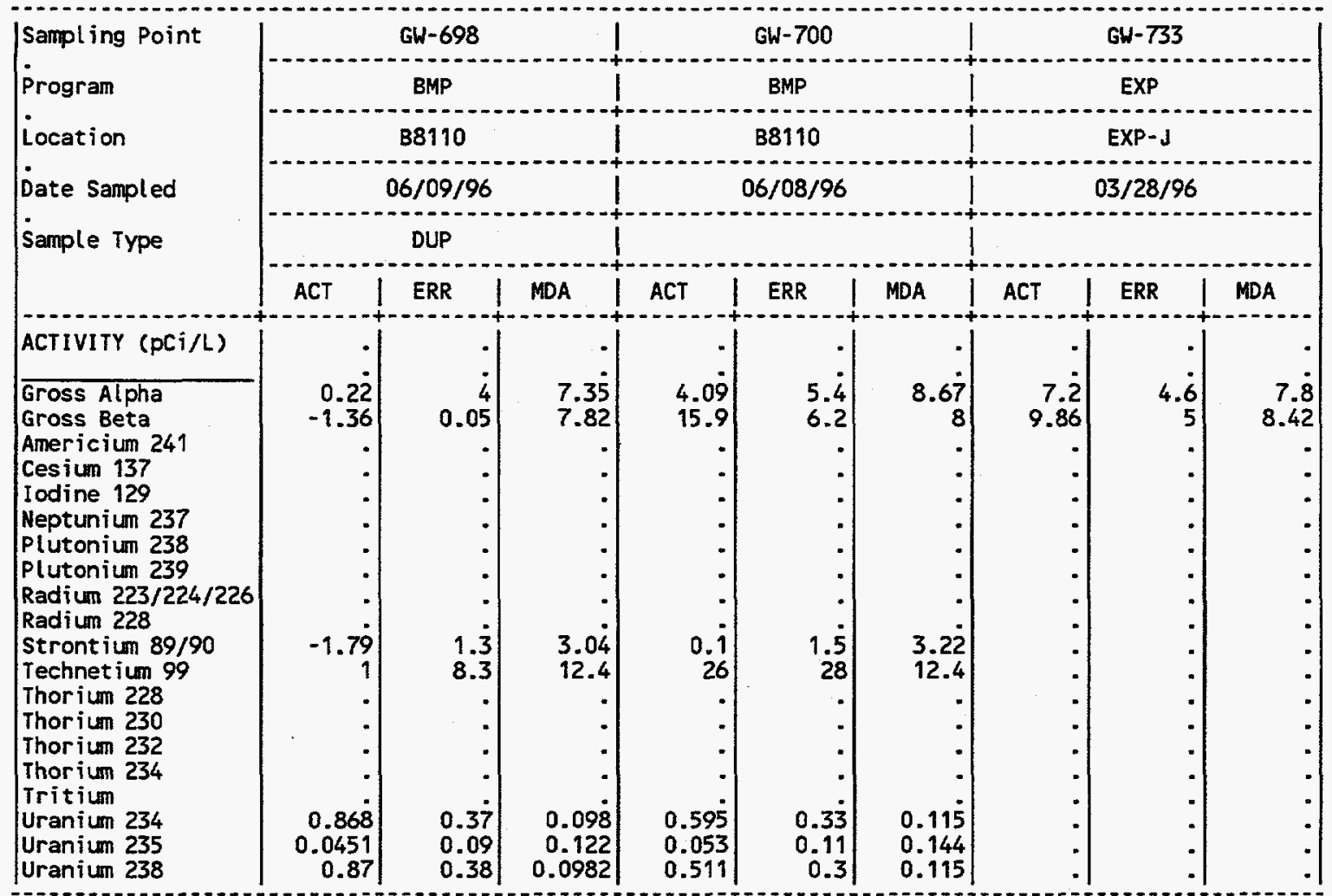

(CONT INUED)

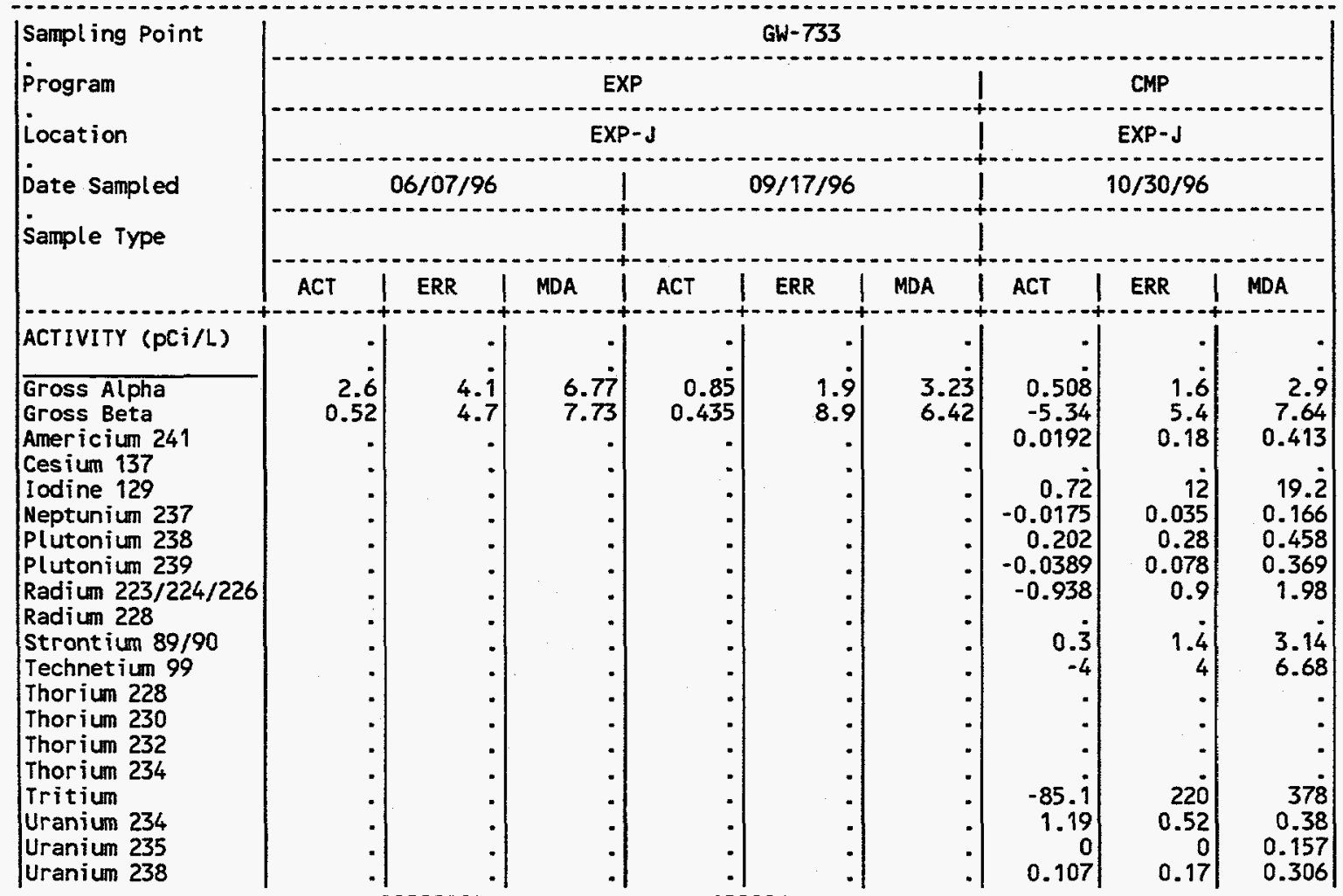


APPENDIX 0.4

Radiological Analytes, CY 1996

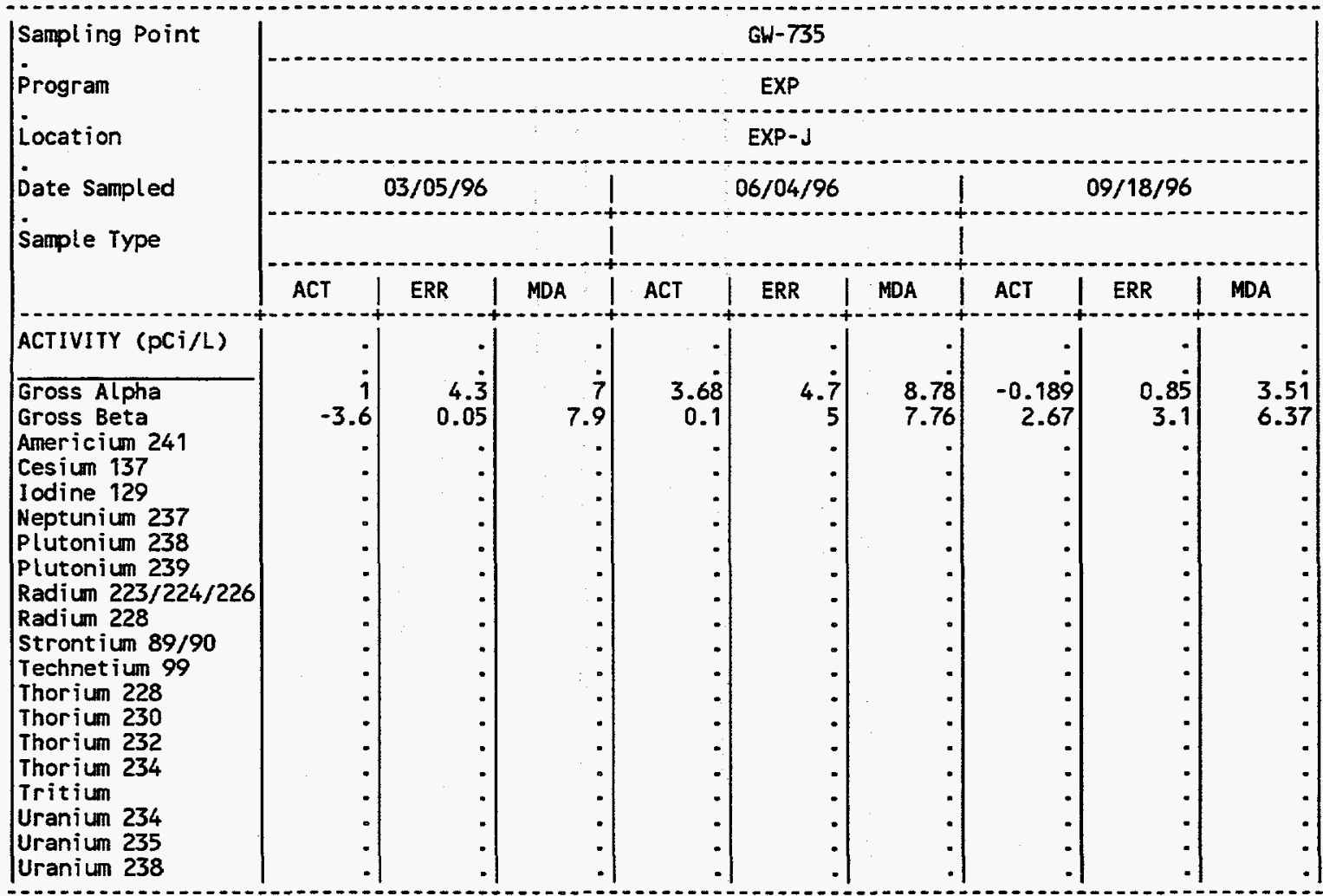

(CONTINUED)

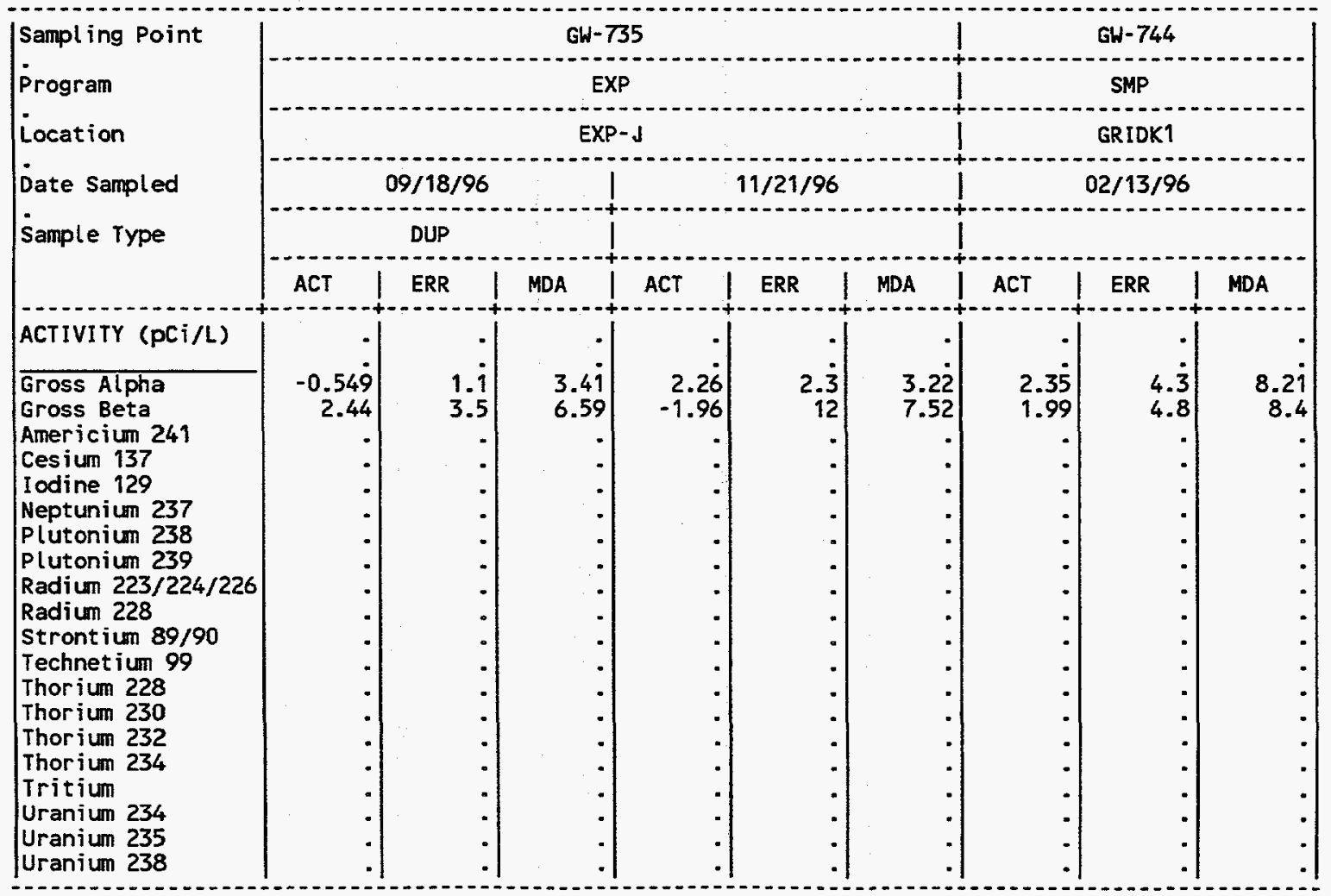


APPEND IX 0.4

Radiological Analytes, CY 1996

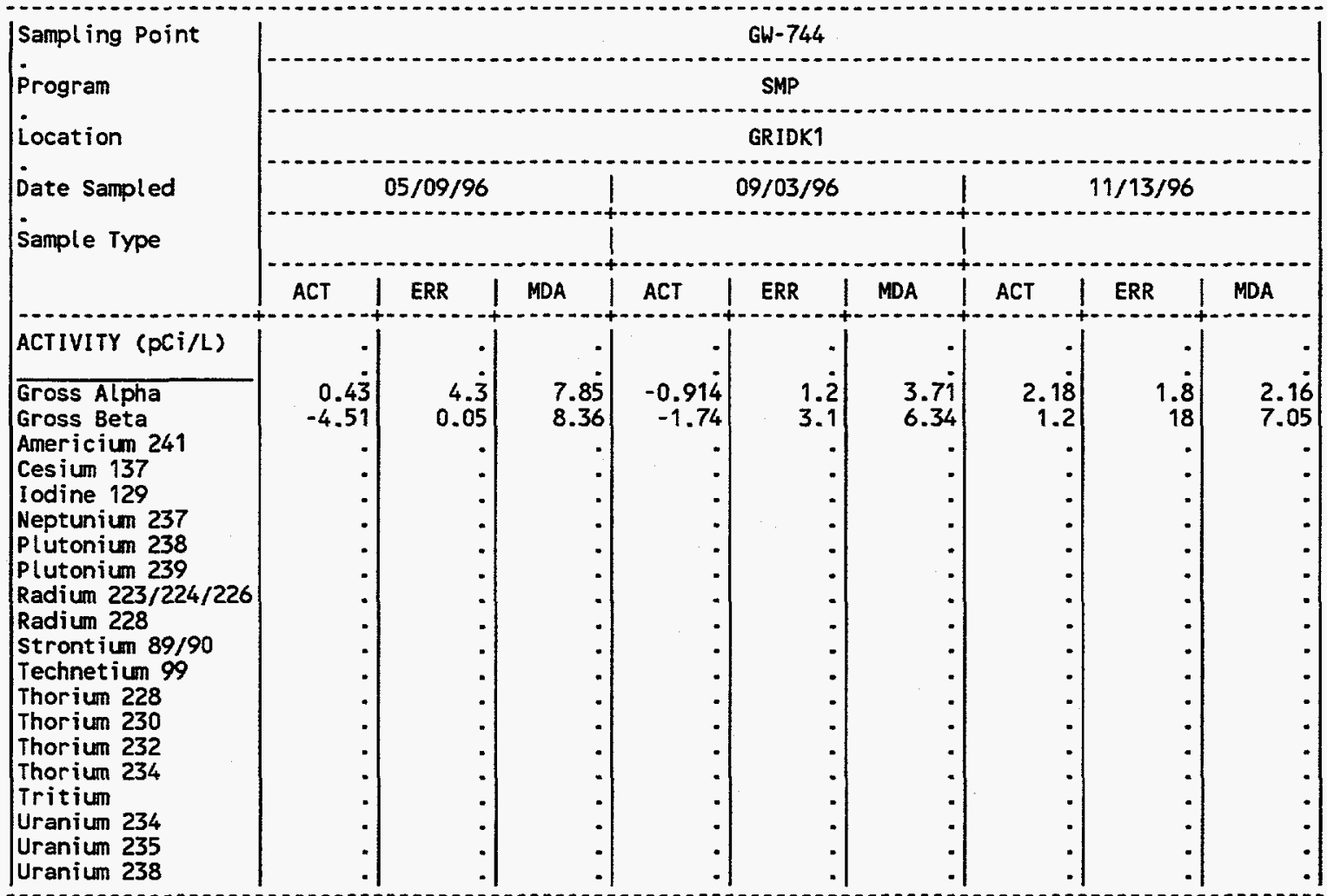

(CONT INUED)

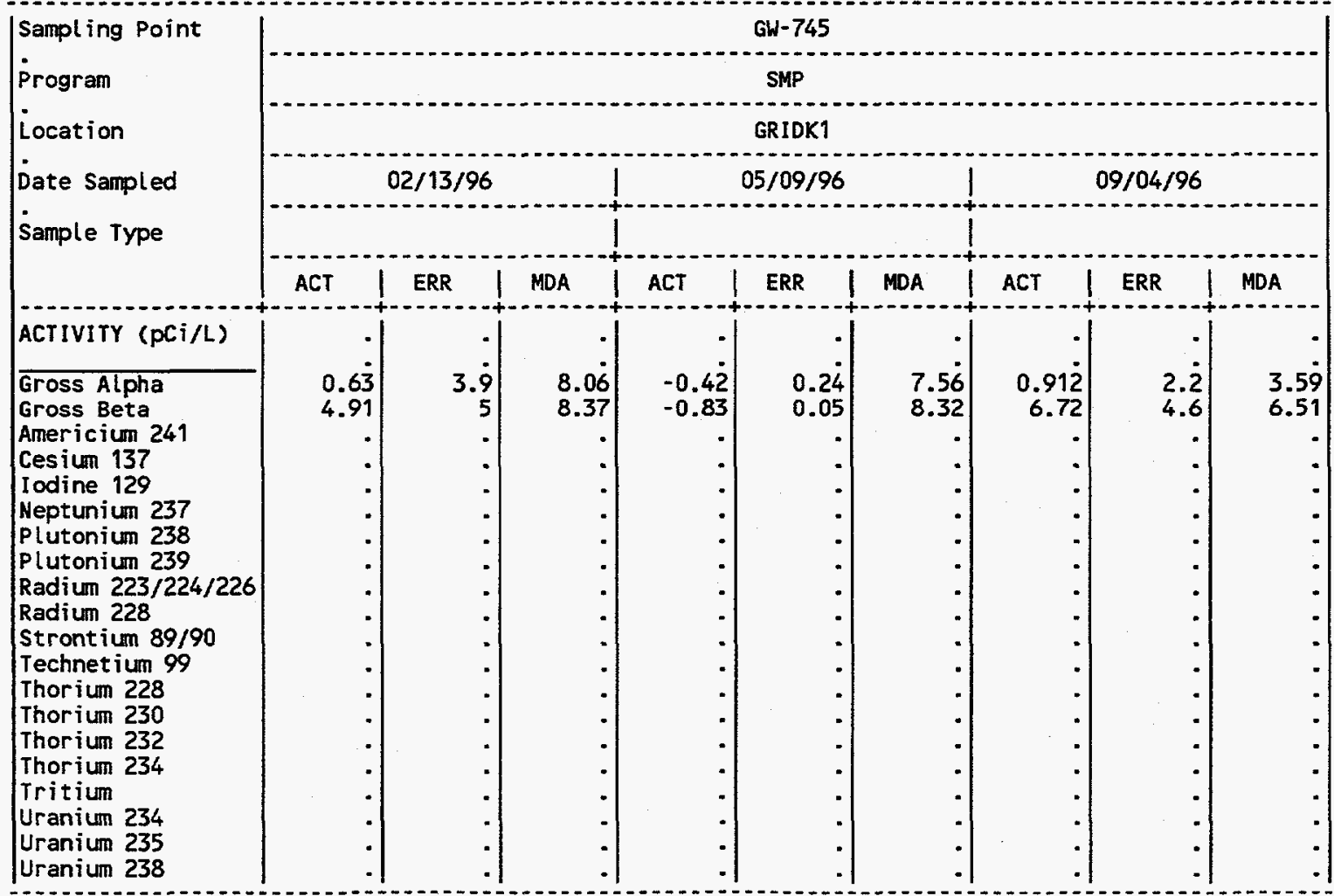

(CONT INUED) 
APPENDIX 0.4

Radiological Analytes, CY 1996

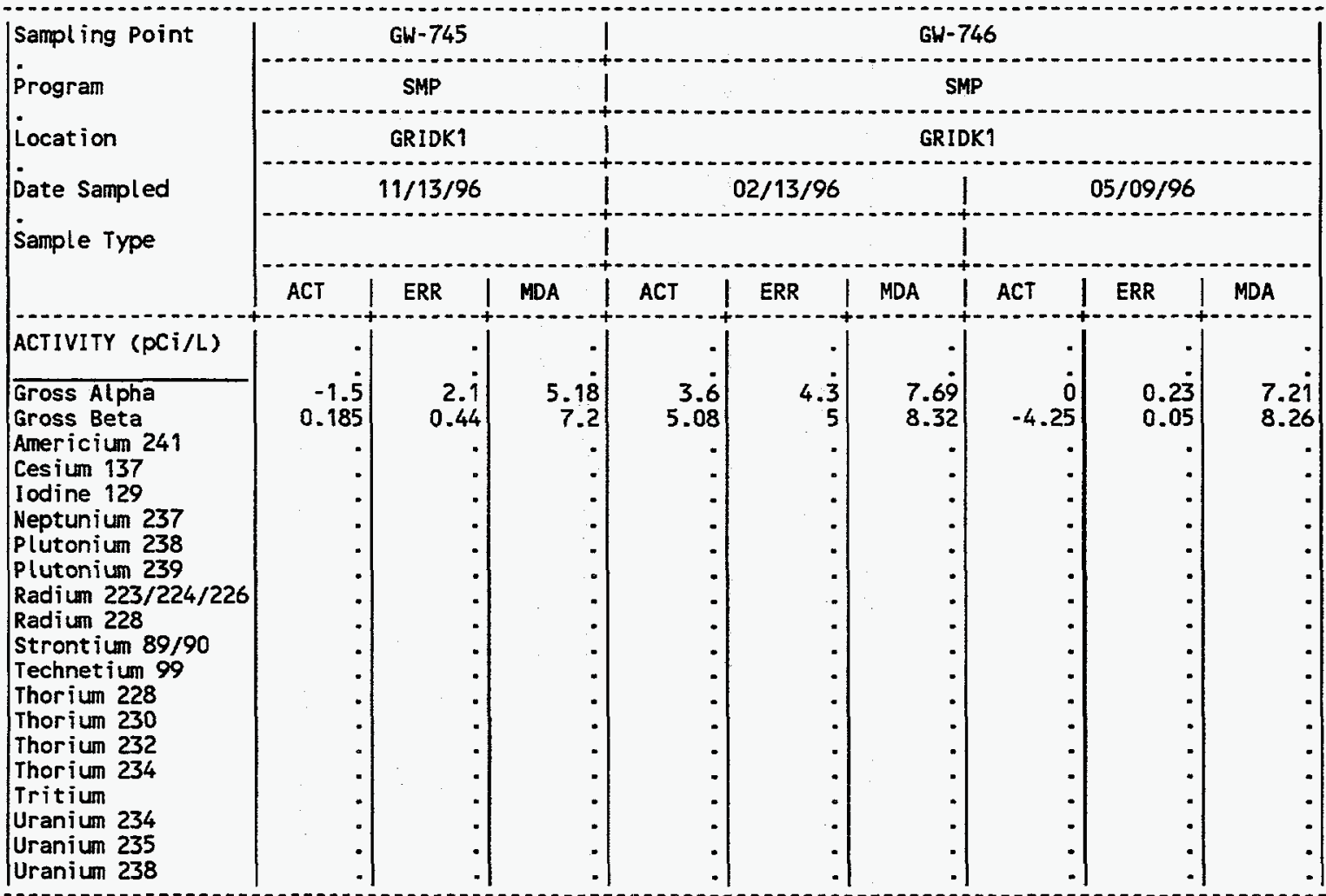

(CONT INUED)

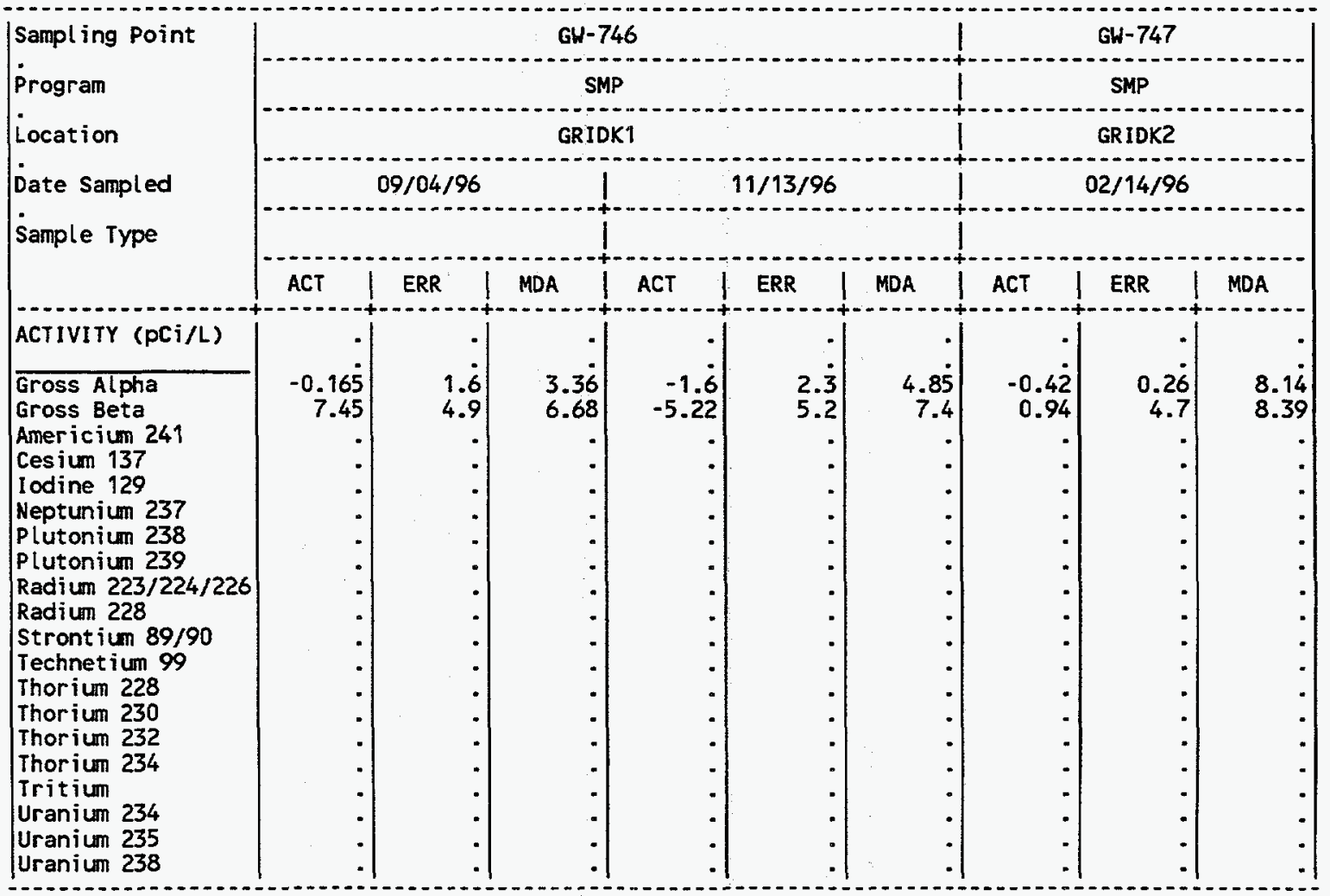

(CONT INUED) 
APPENDIX 0.4

Radiological Analytes, CY 1996

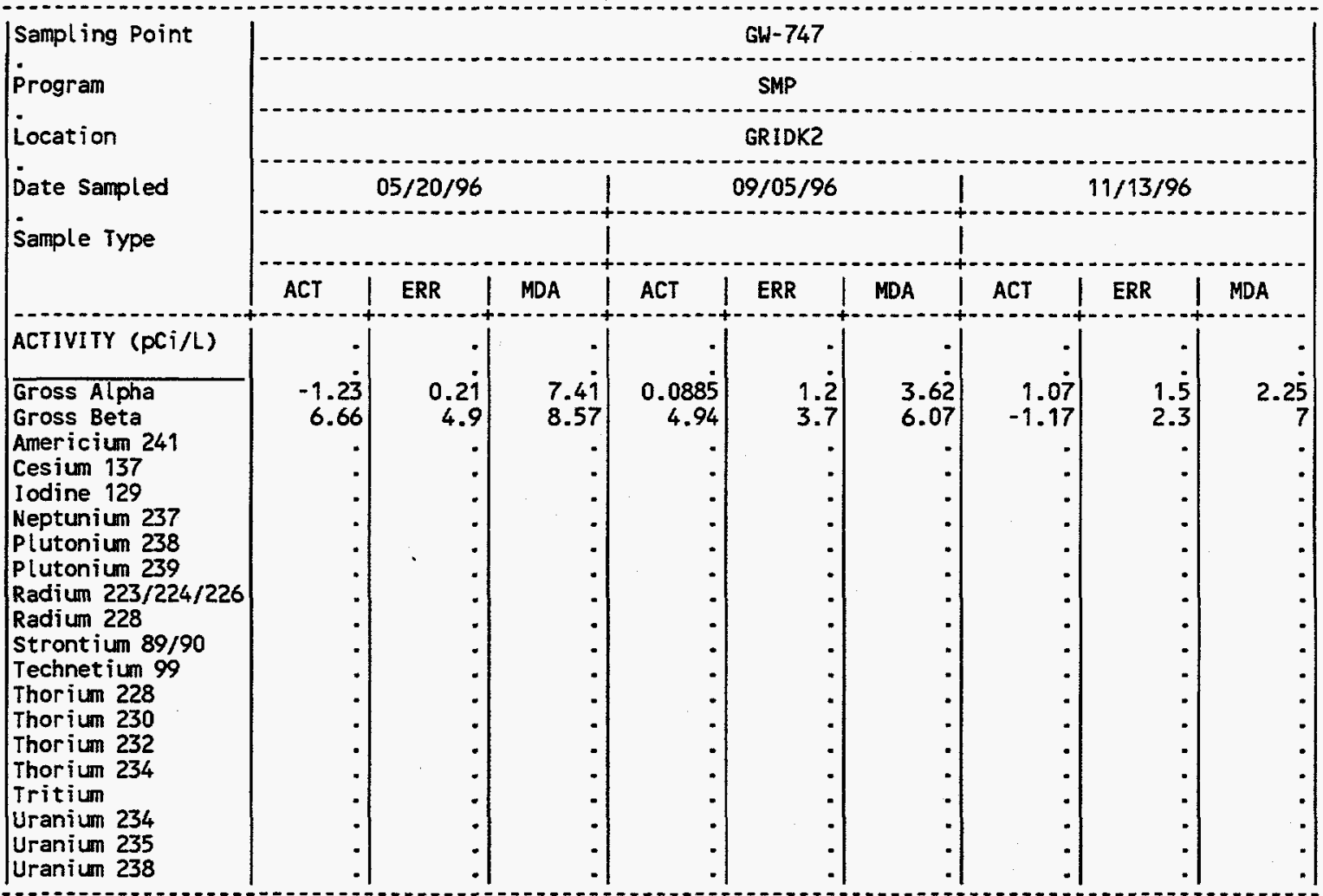

(CONTINUED)

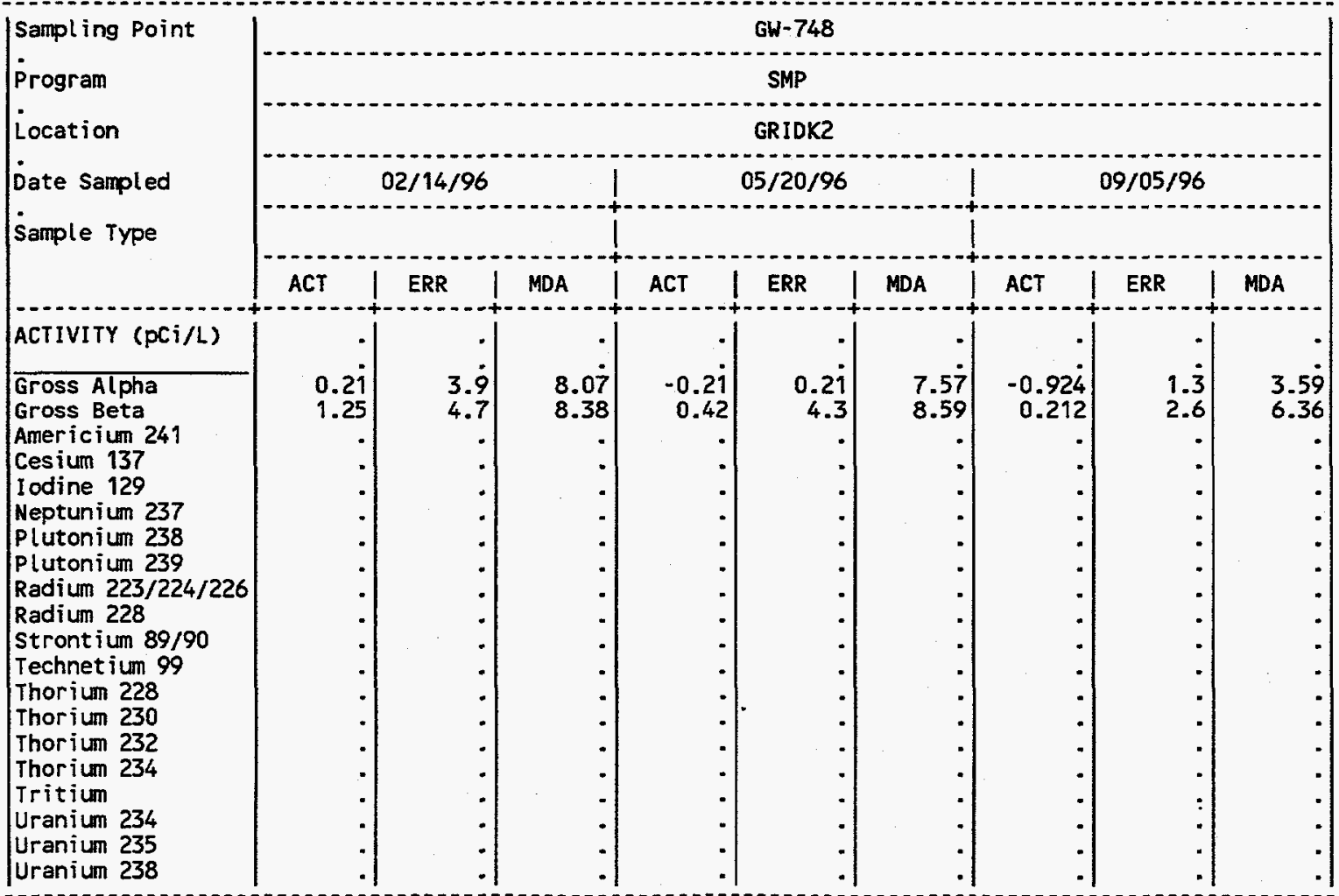


APPENDIX 0.4

Radiological Analytes, CY 1996

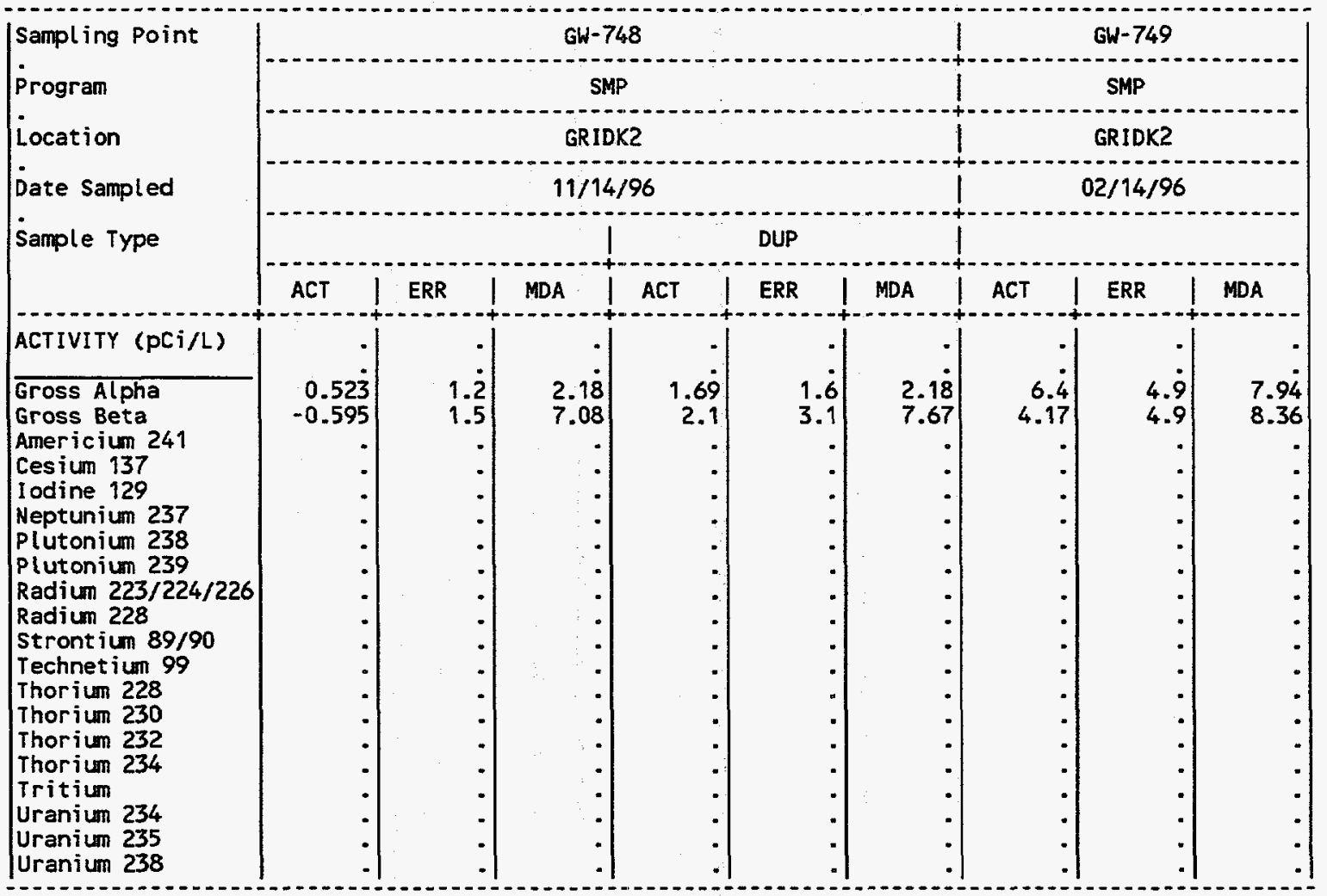

\section{(CONTINUED)}

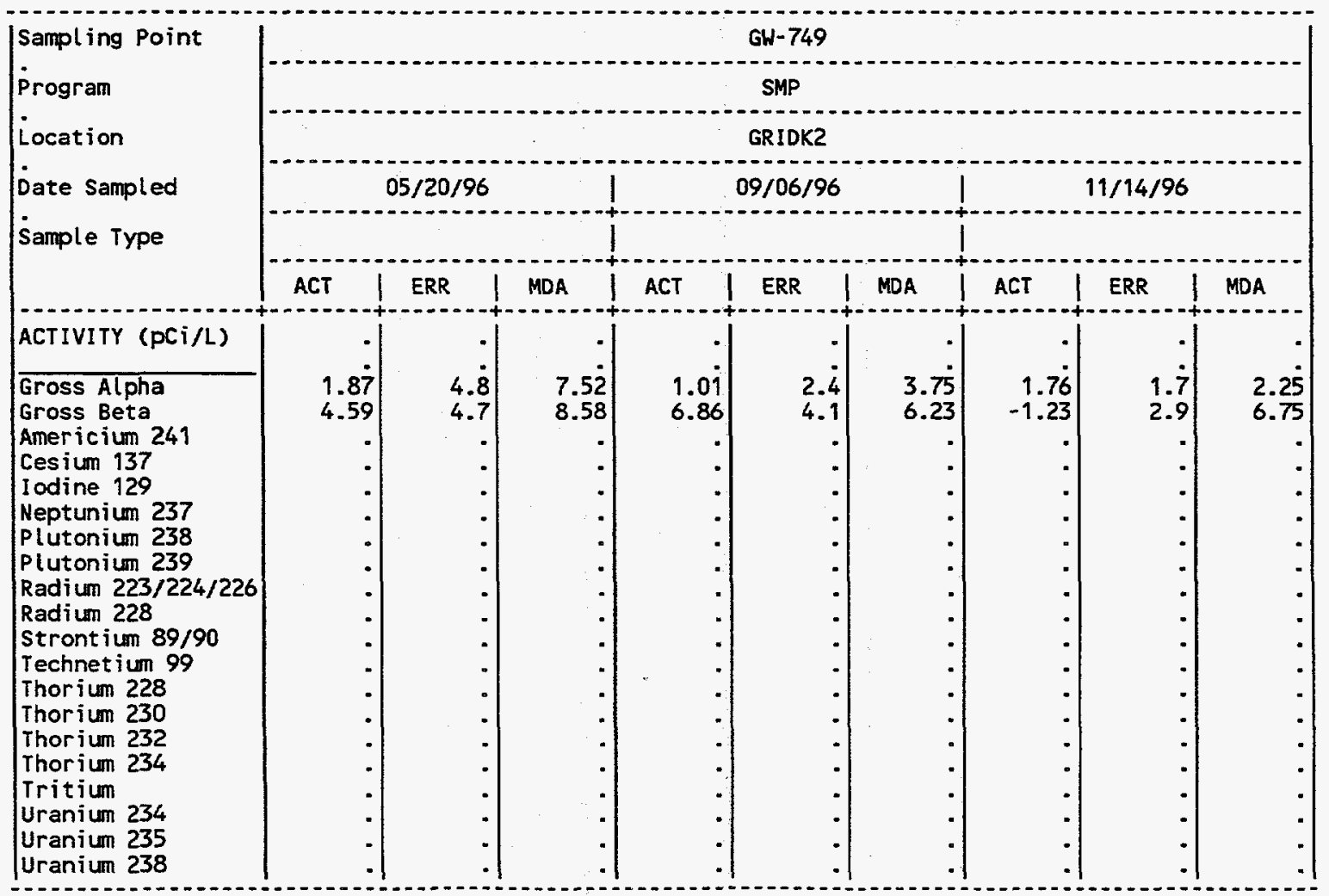


Radiological Analytes, CY 1996

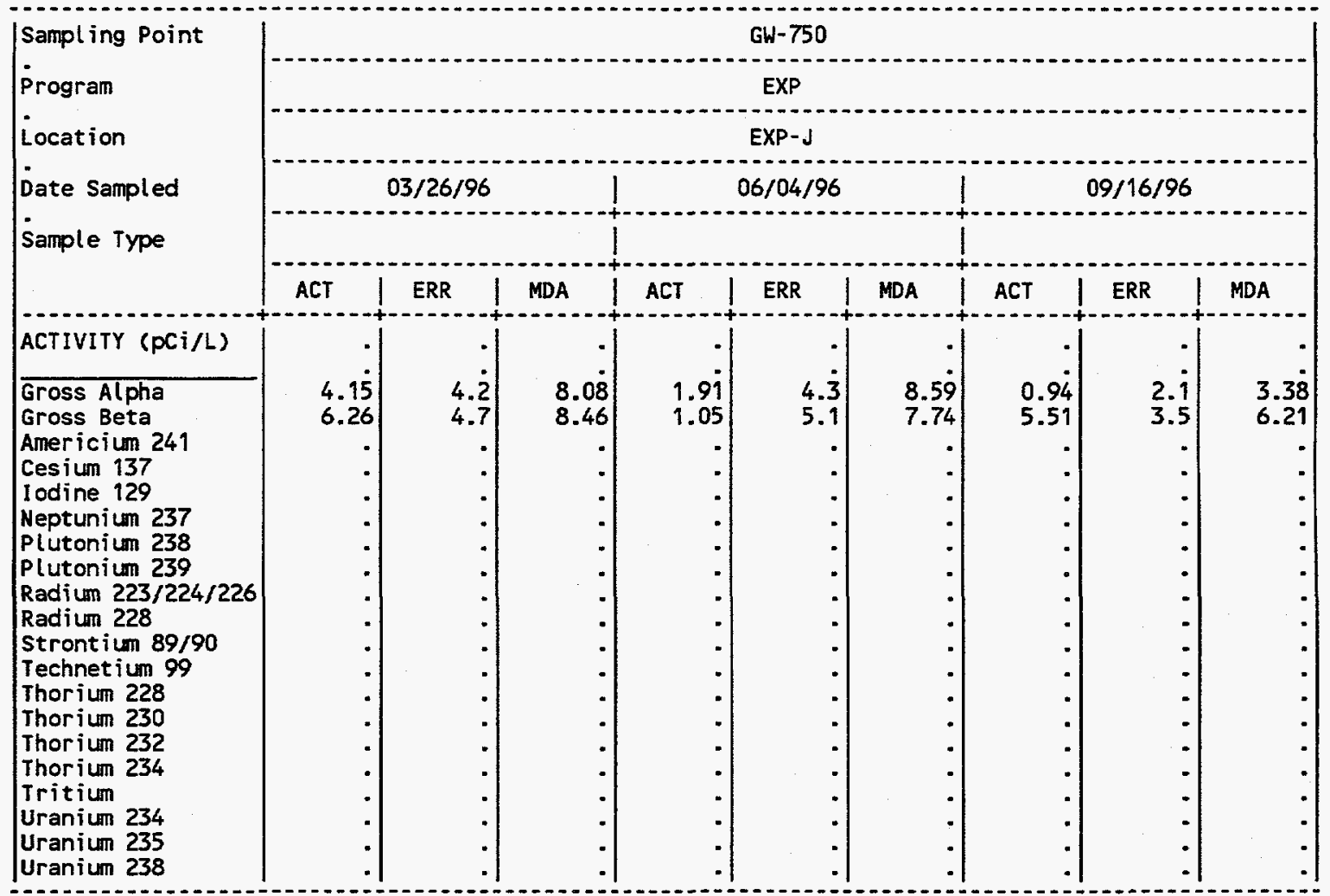

(CONT INUED)

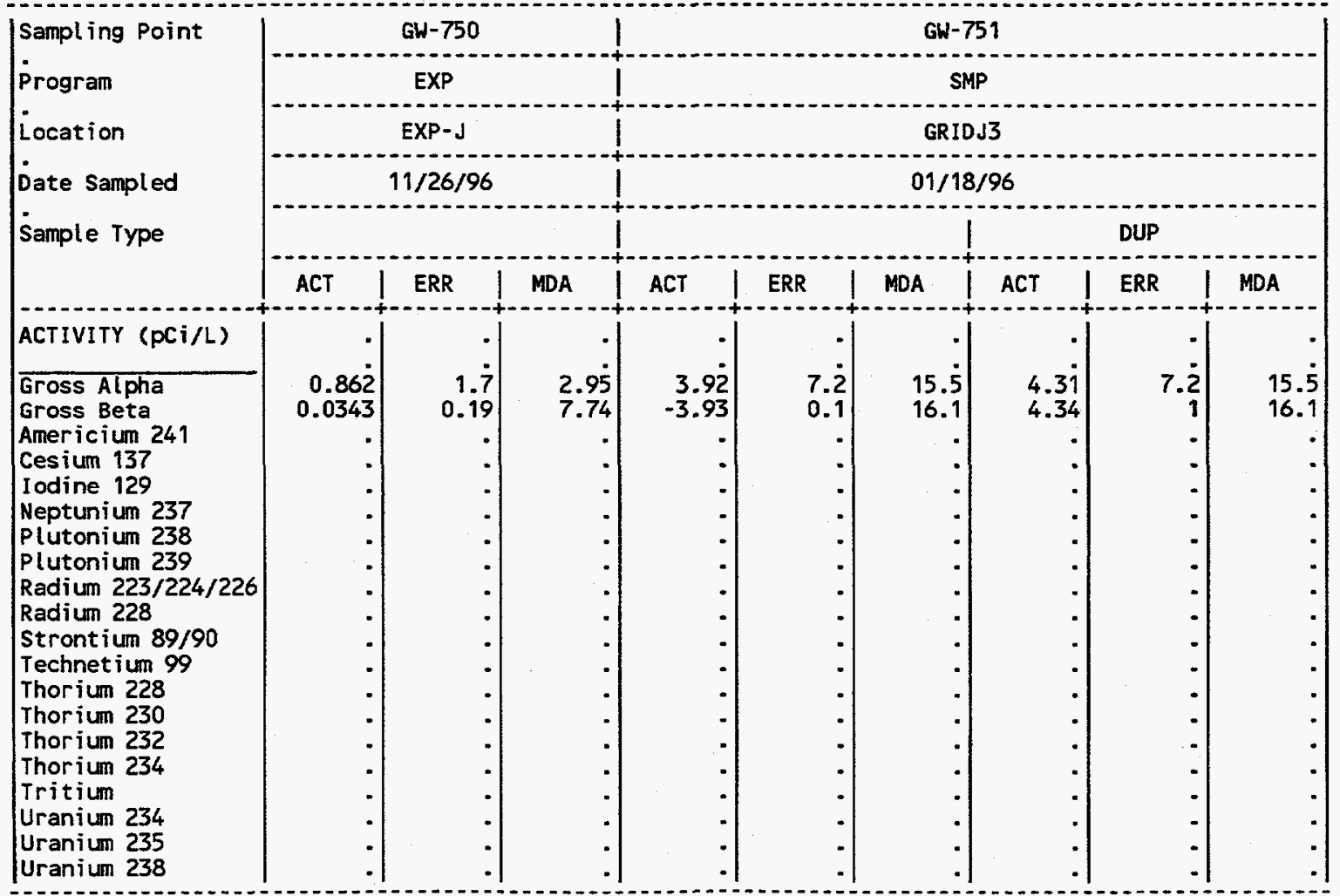

(CONTINUED) 
APPENDIX D.4

Radiological Analytes, CY 1996

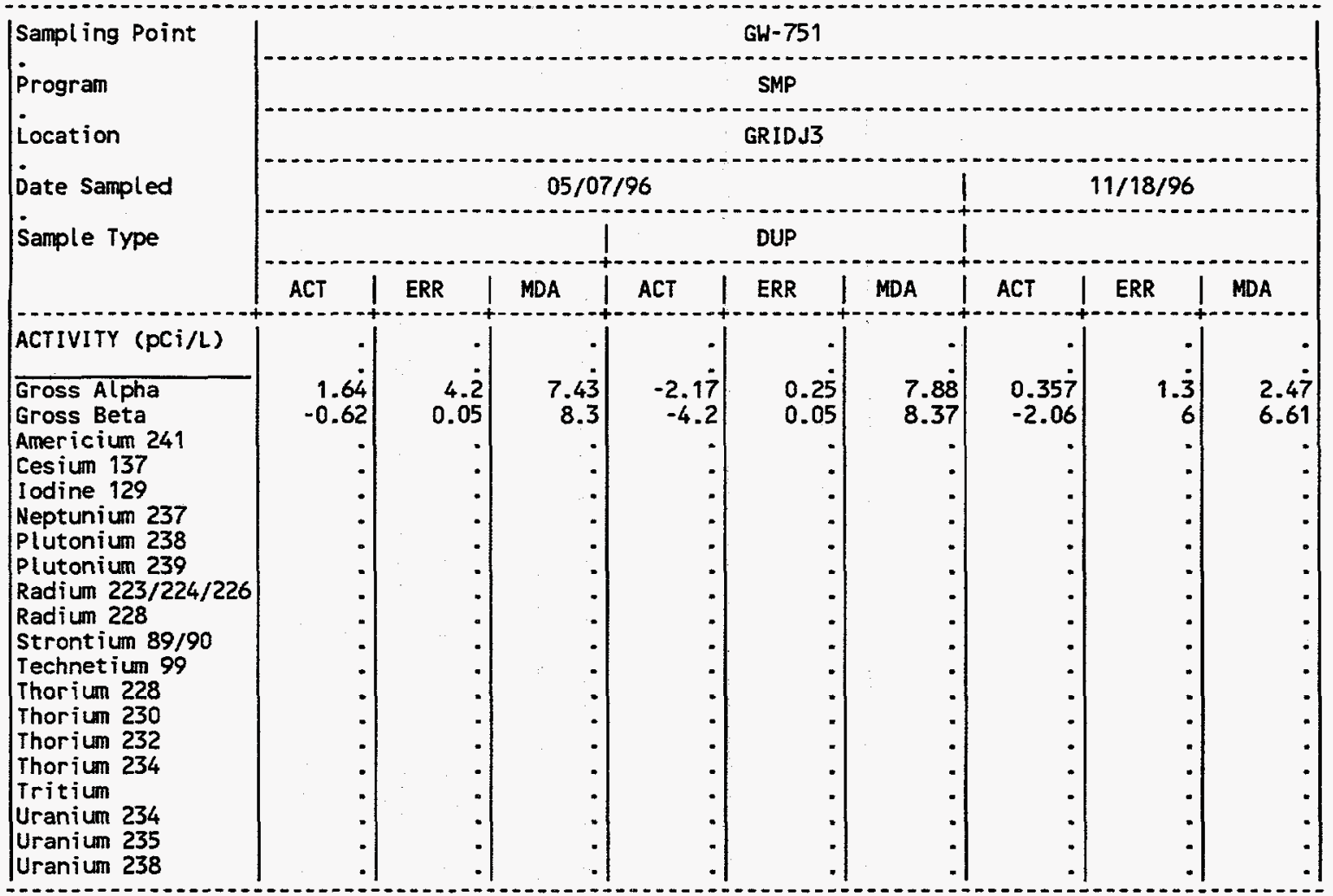

(CONTINUED)

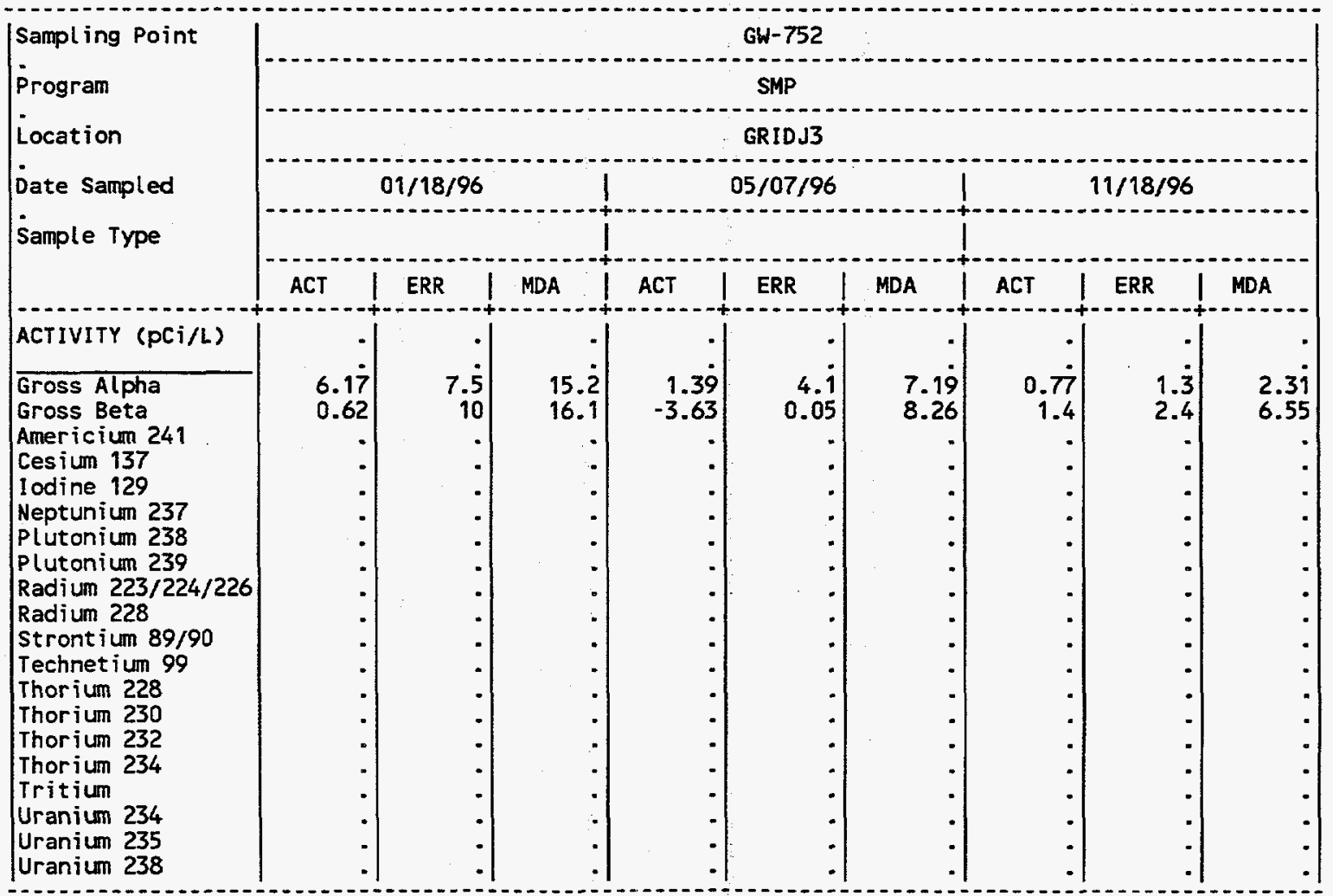

(CONT INUED) 
Radiological Analytes, CY 1996

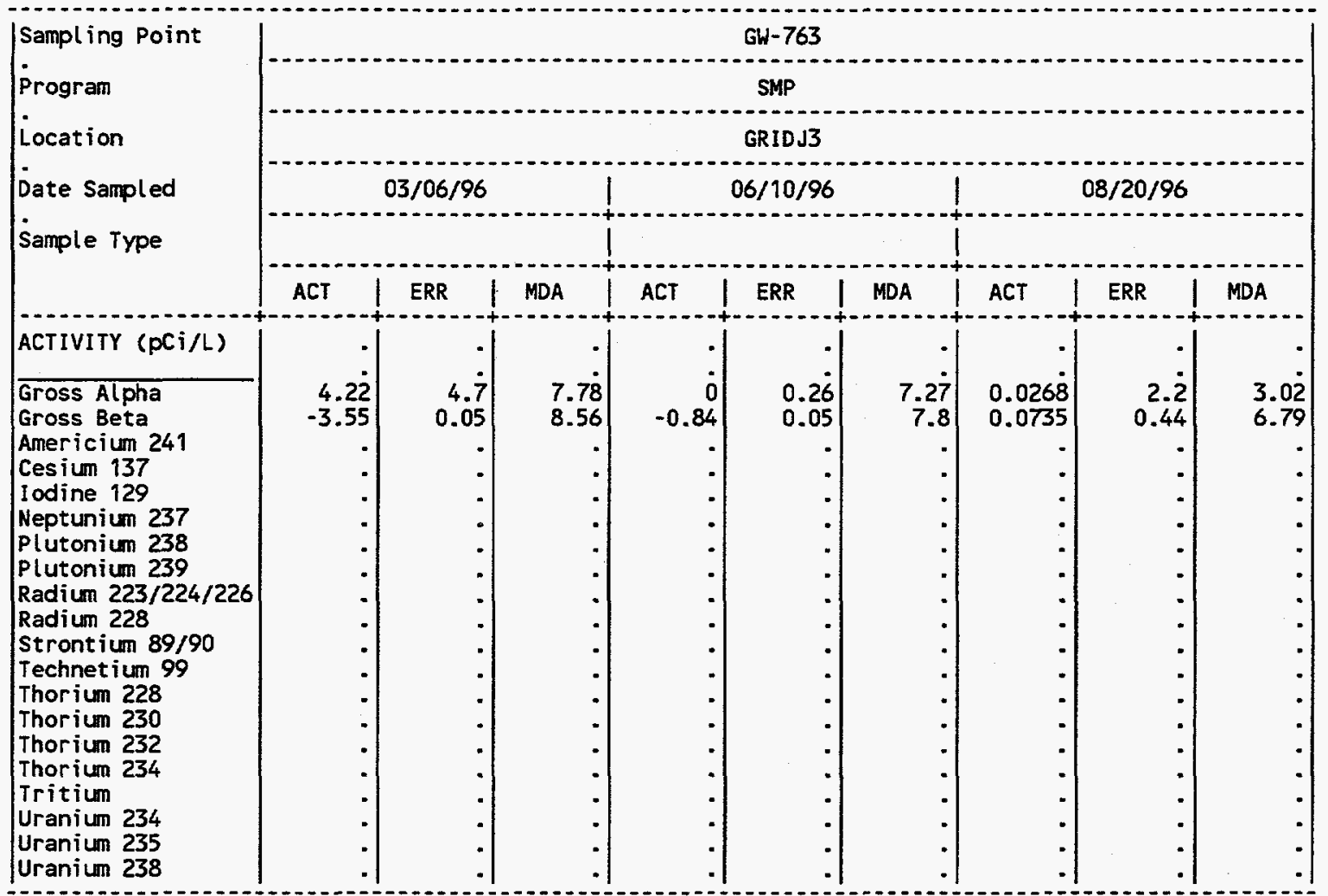

(CONTINUED)

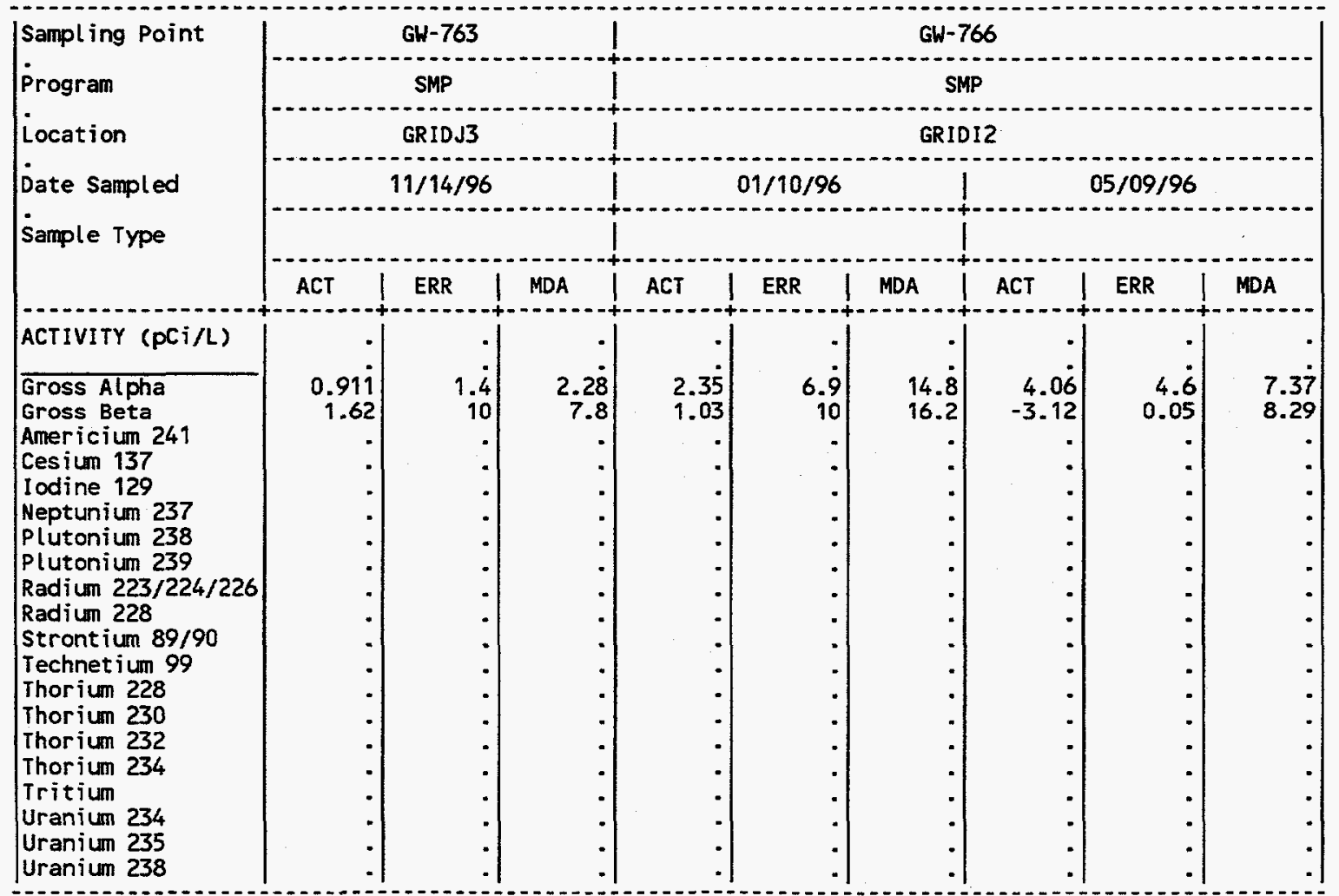


APPEND IX 0.4

Radiological Analytes, CY 1996

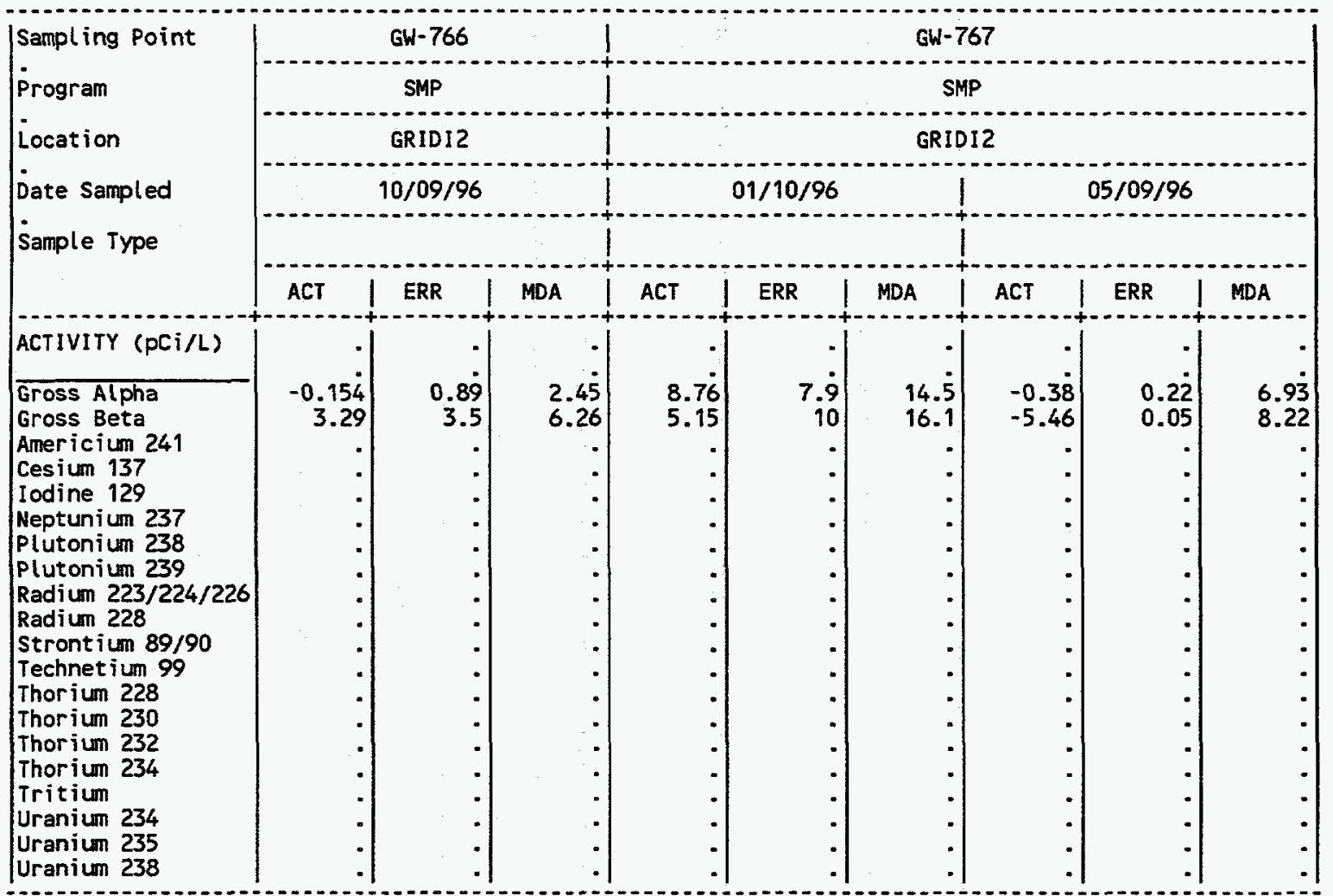

(CONT INUED)

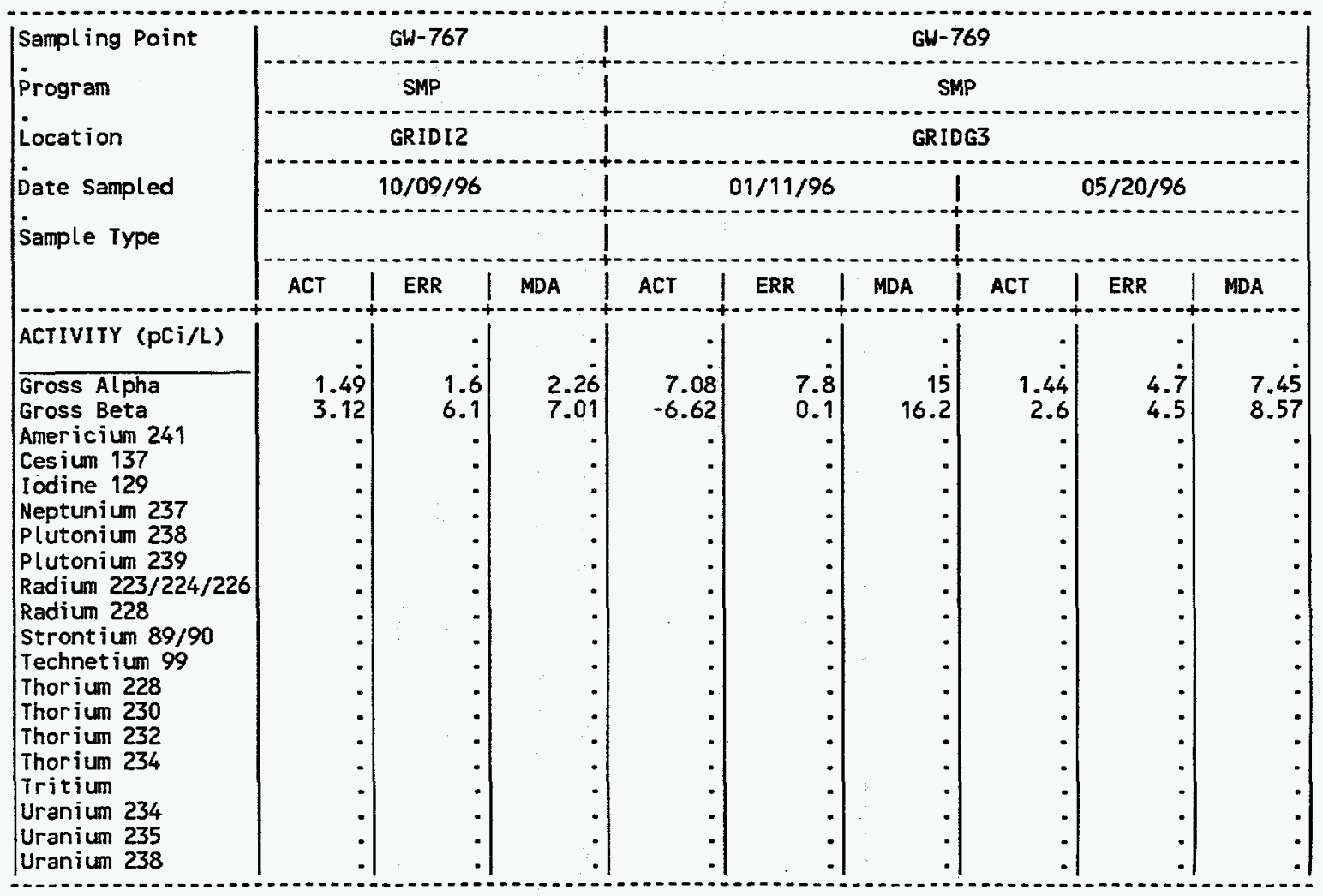

(CONT INUED) 
APPENDIX 0.4

Radiological Analytes, CY 1996

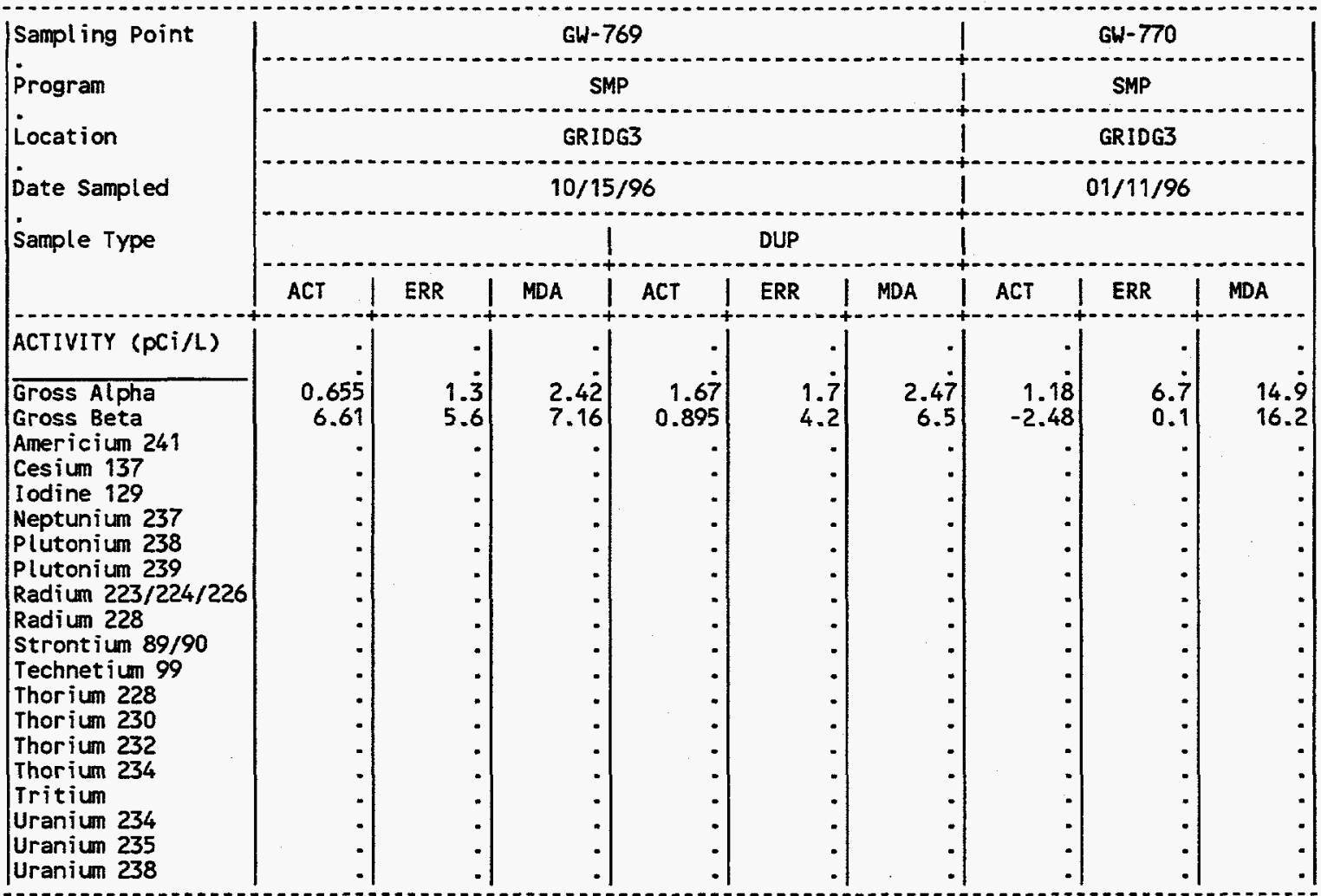

(CONTINUEO)

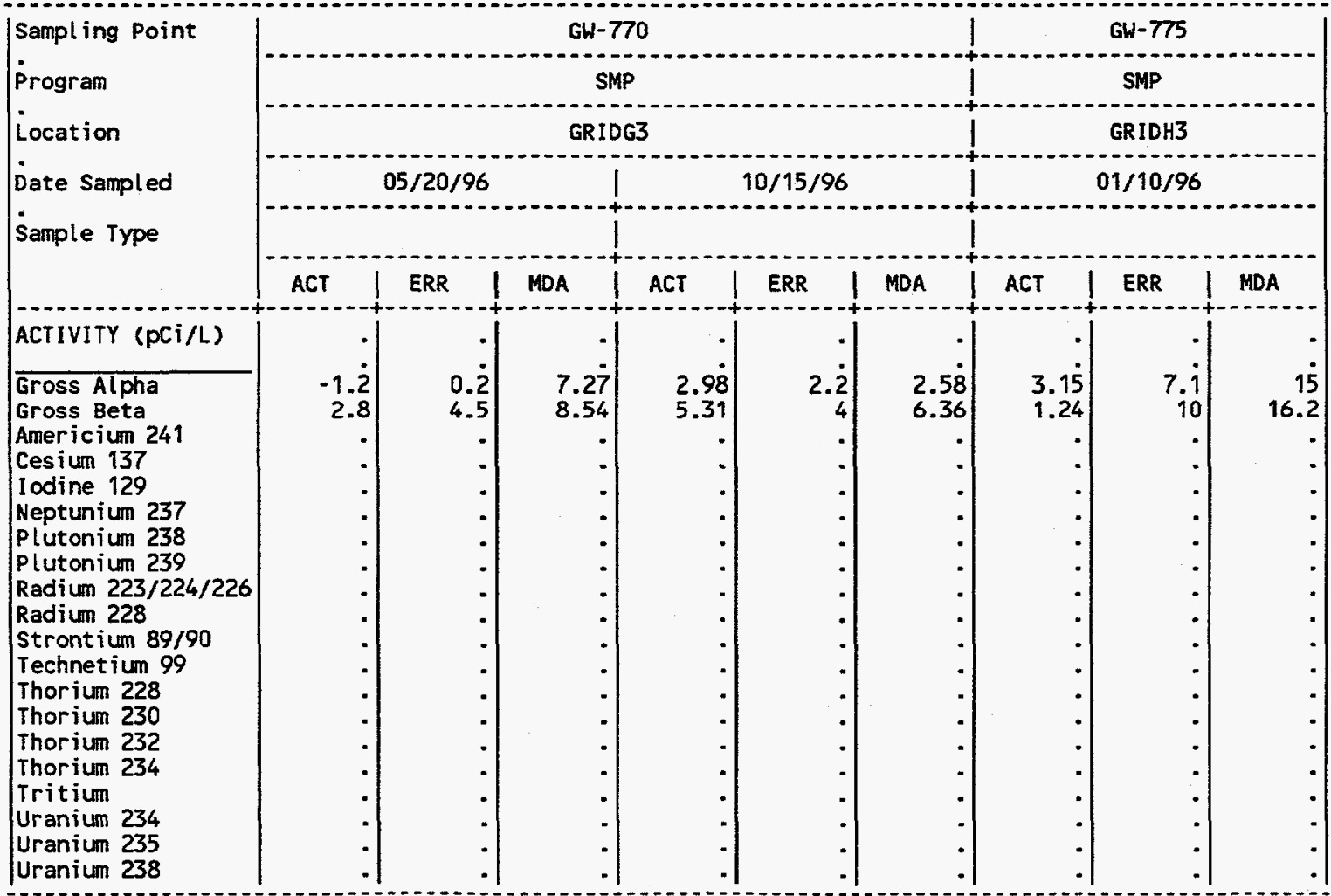

(CONT INUED) 
APPENDIX D.4

Radiological Analytes, CY 1996

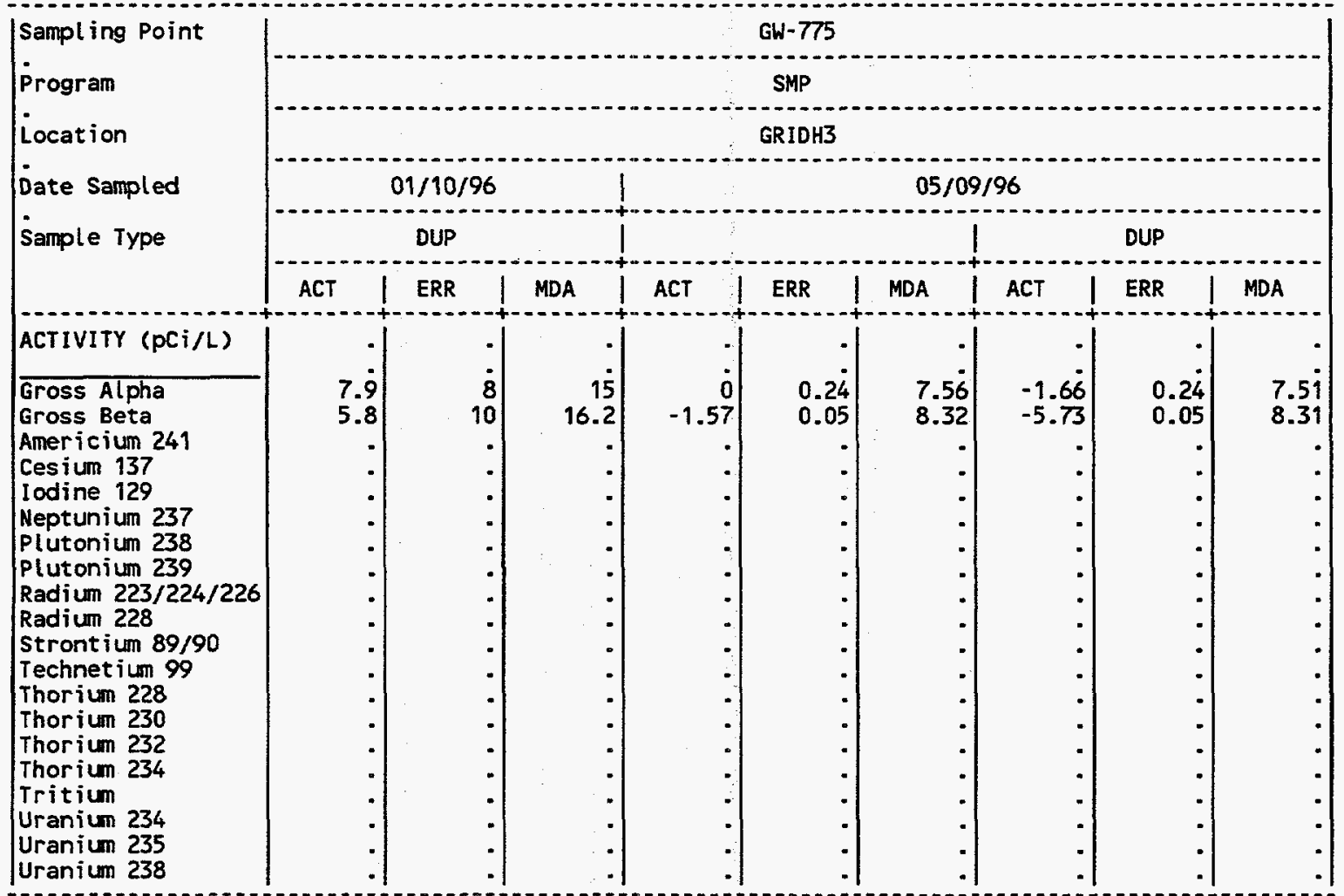

(CONTI INUED)

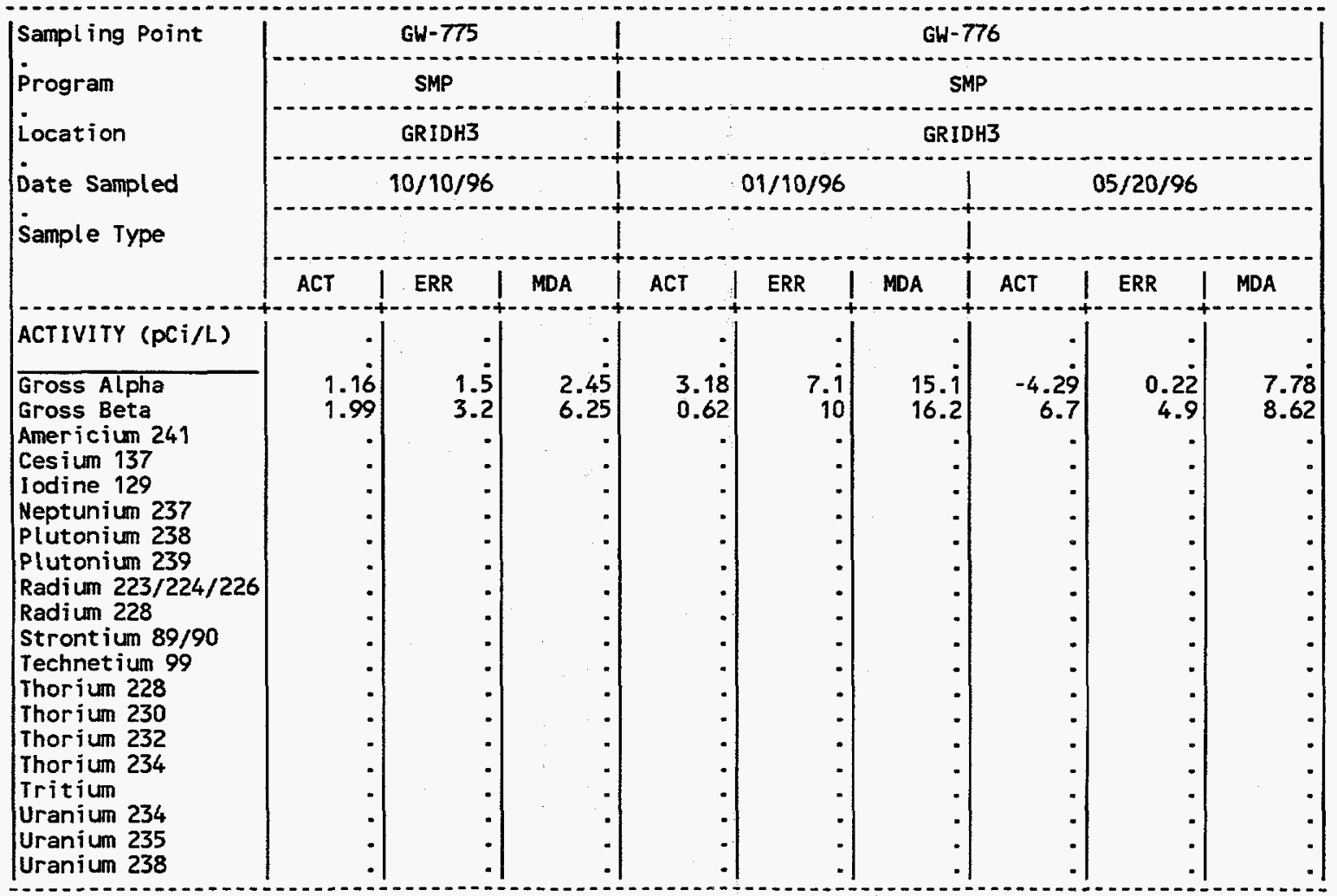

(CONT I NUED) 
APPENDIX 0.4

Radiological Analytes, CY 1996

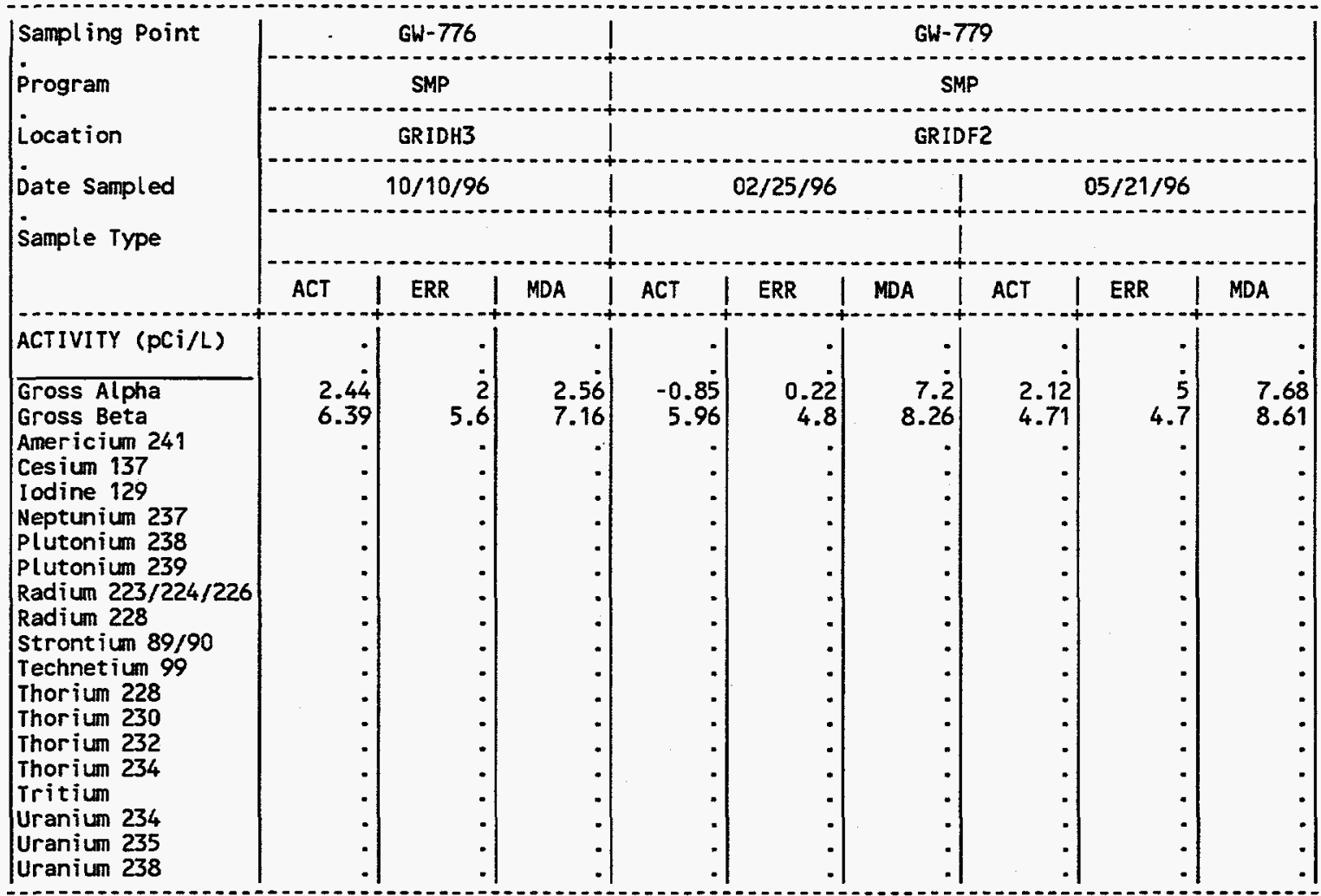

(CONTINUED)

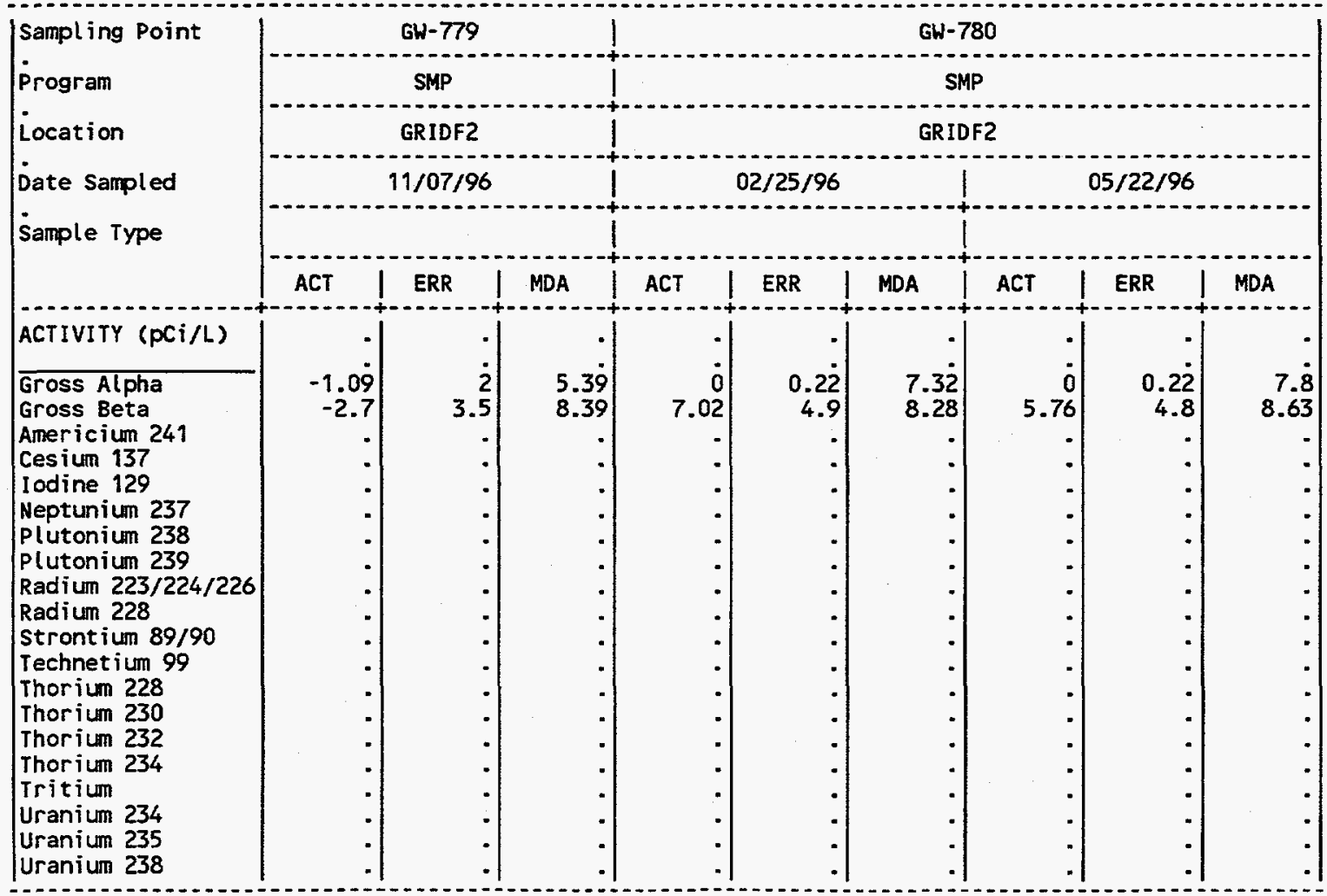

(CONTINUED) 
APPEND IX 0.4

Radiological Analytes, CY 1996

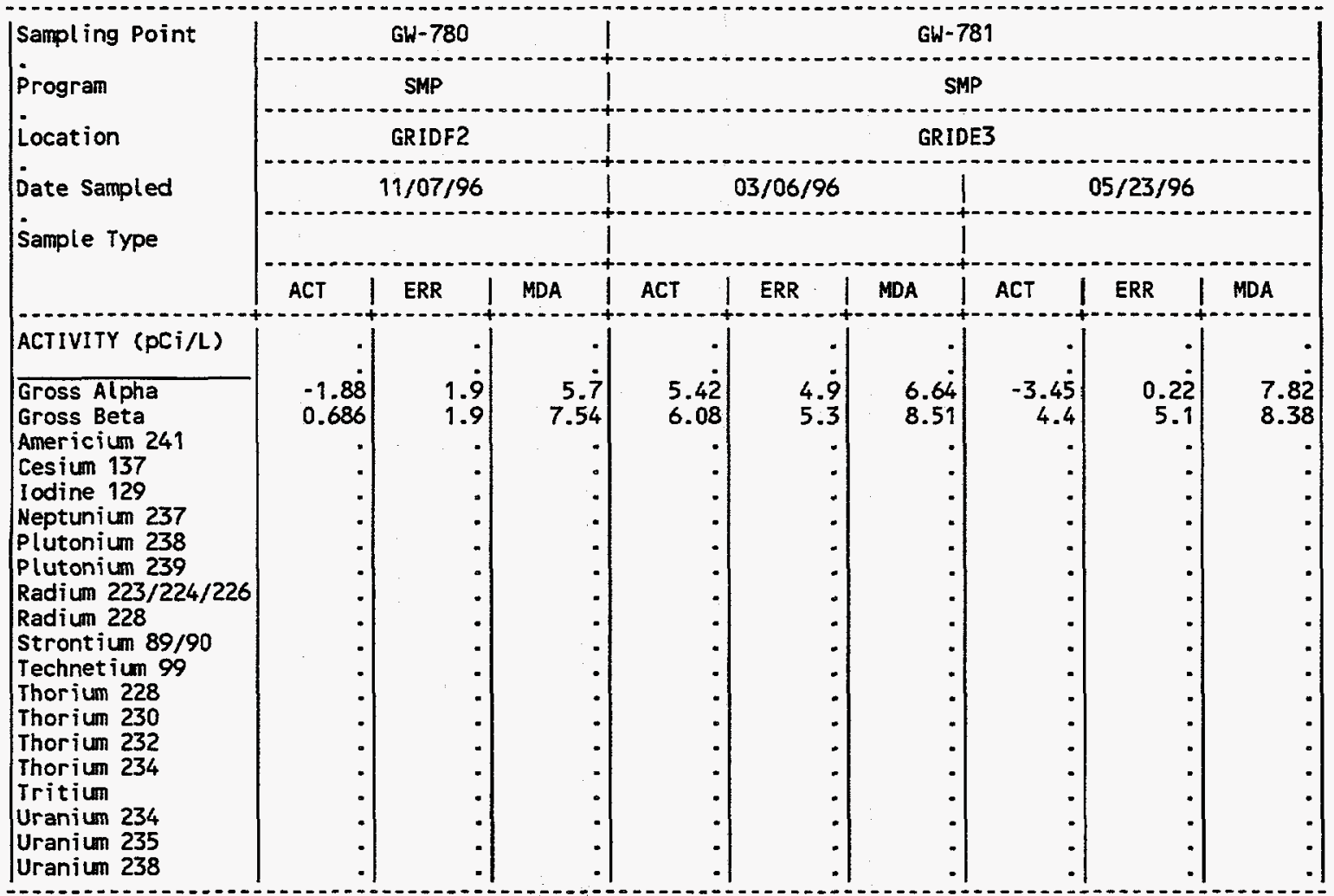

(CONTINUED)

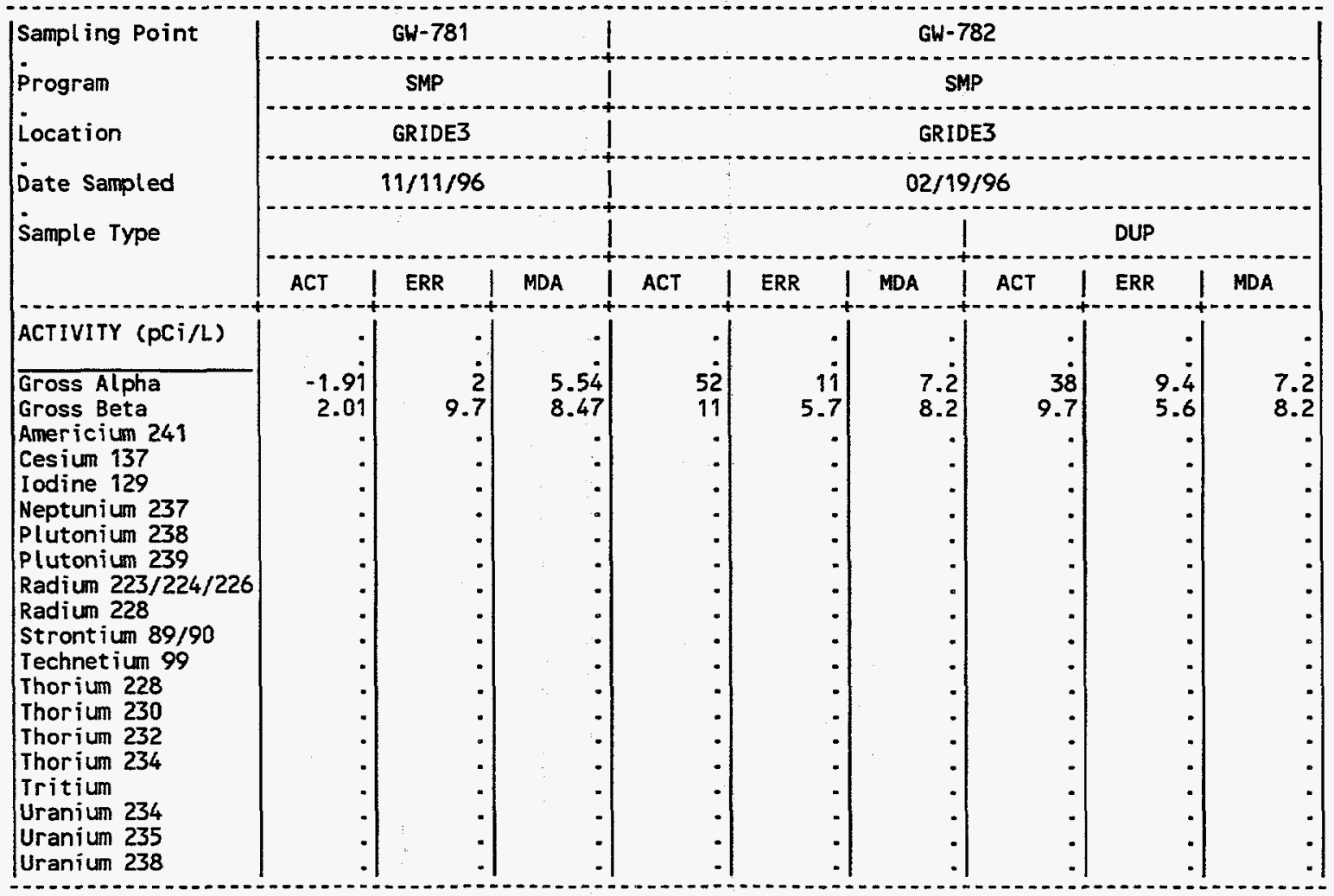

(CONT INUED) 
APPEND IX 0.4

Radiological Analytes, CY 1996

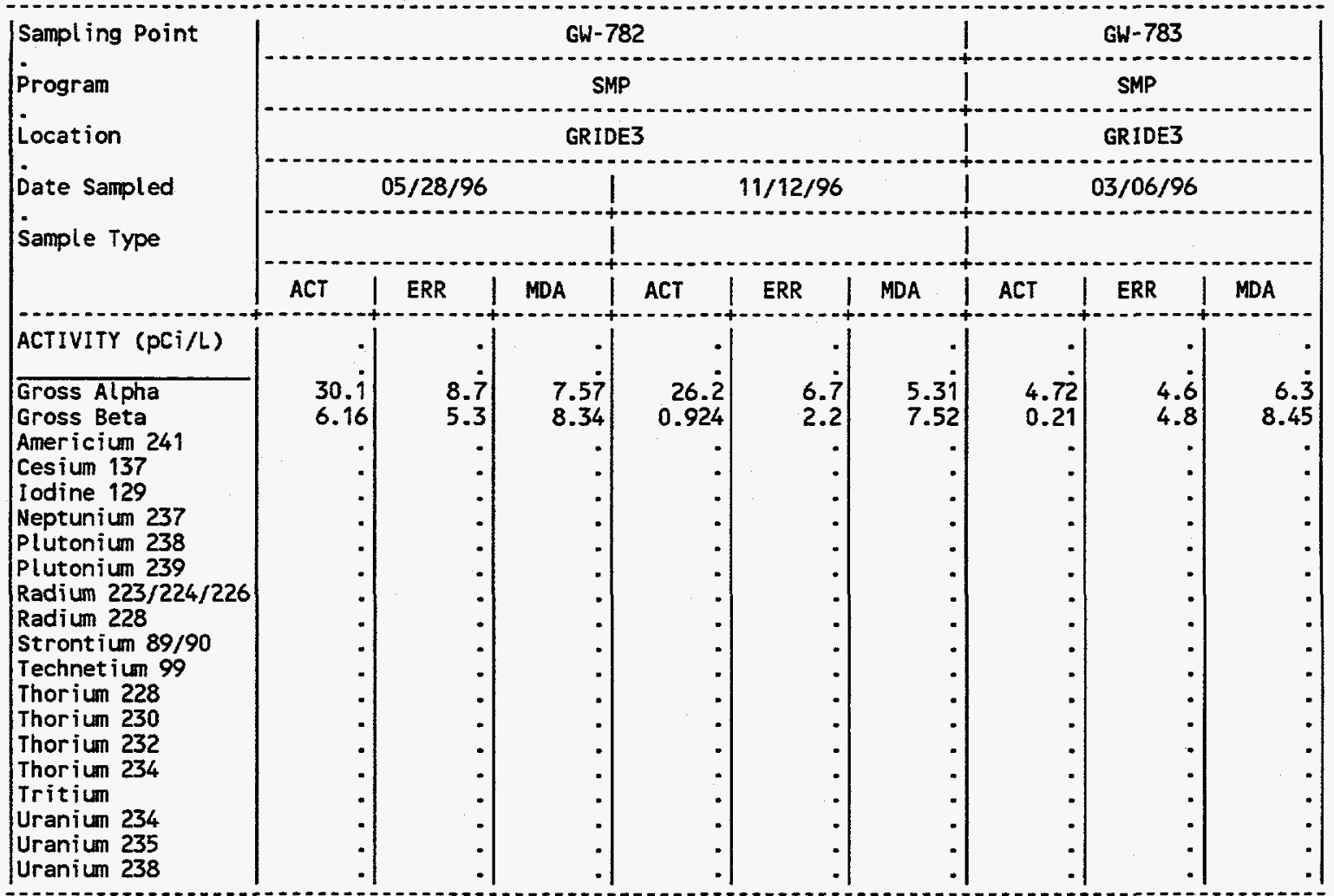

\section{(CONTINUED)}

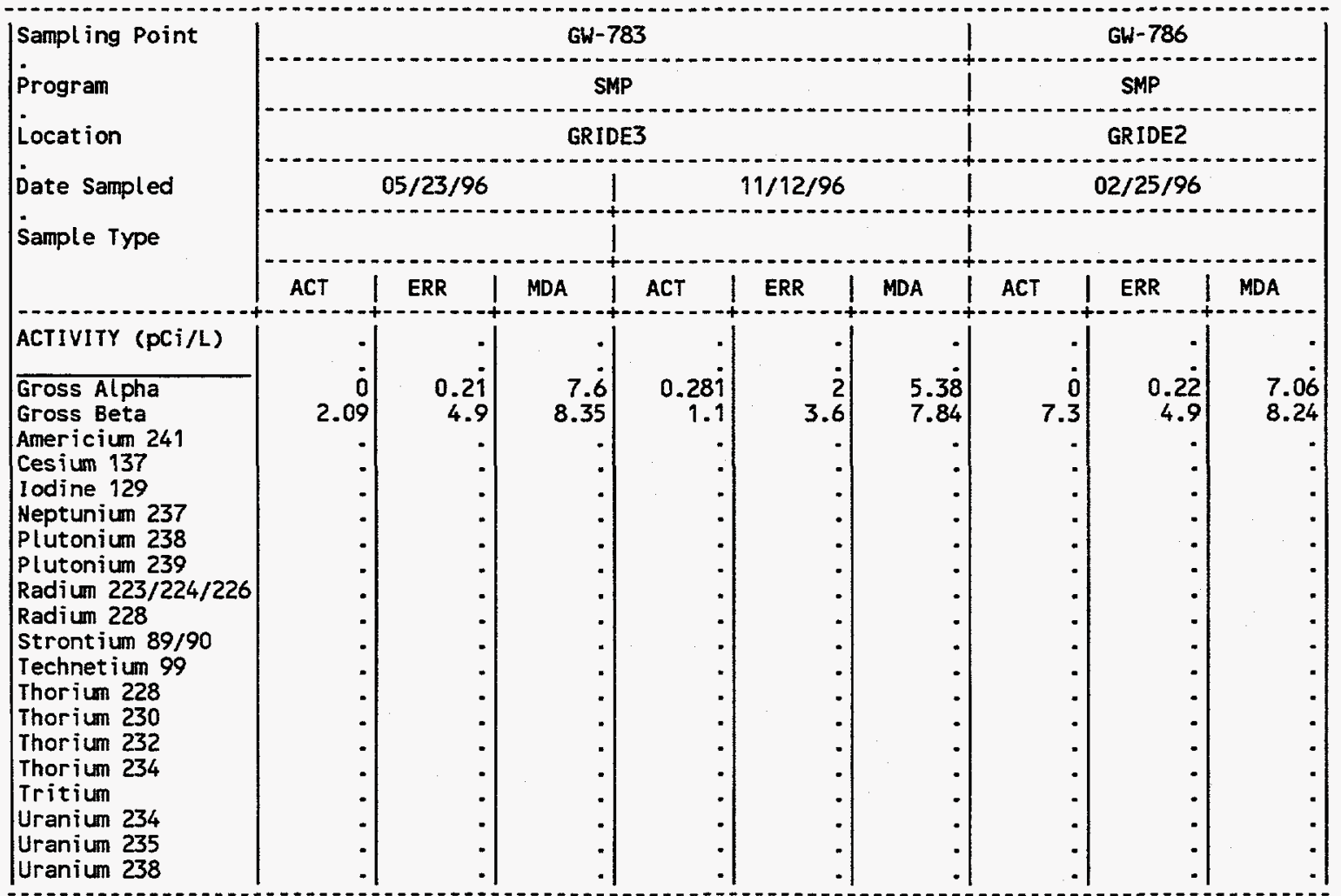


APPENDIX $D .4$

Radiological Analytes, CY 1996

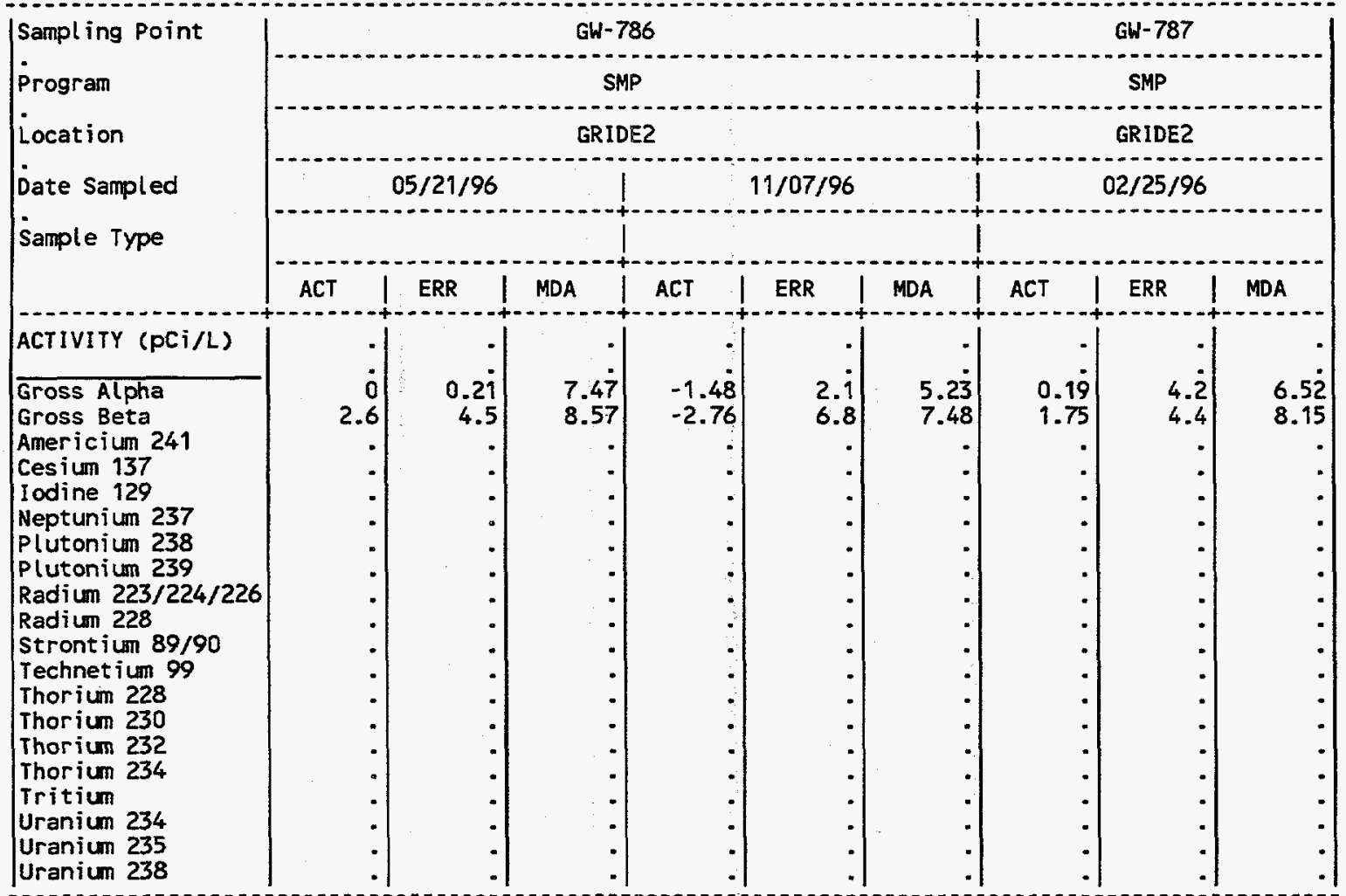

(CONT INUED)

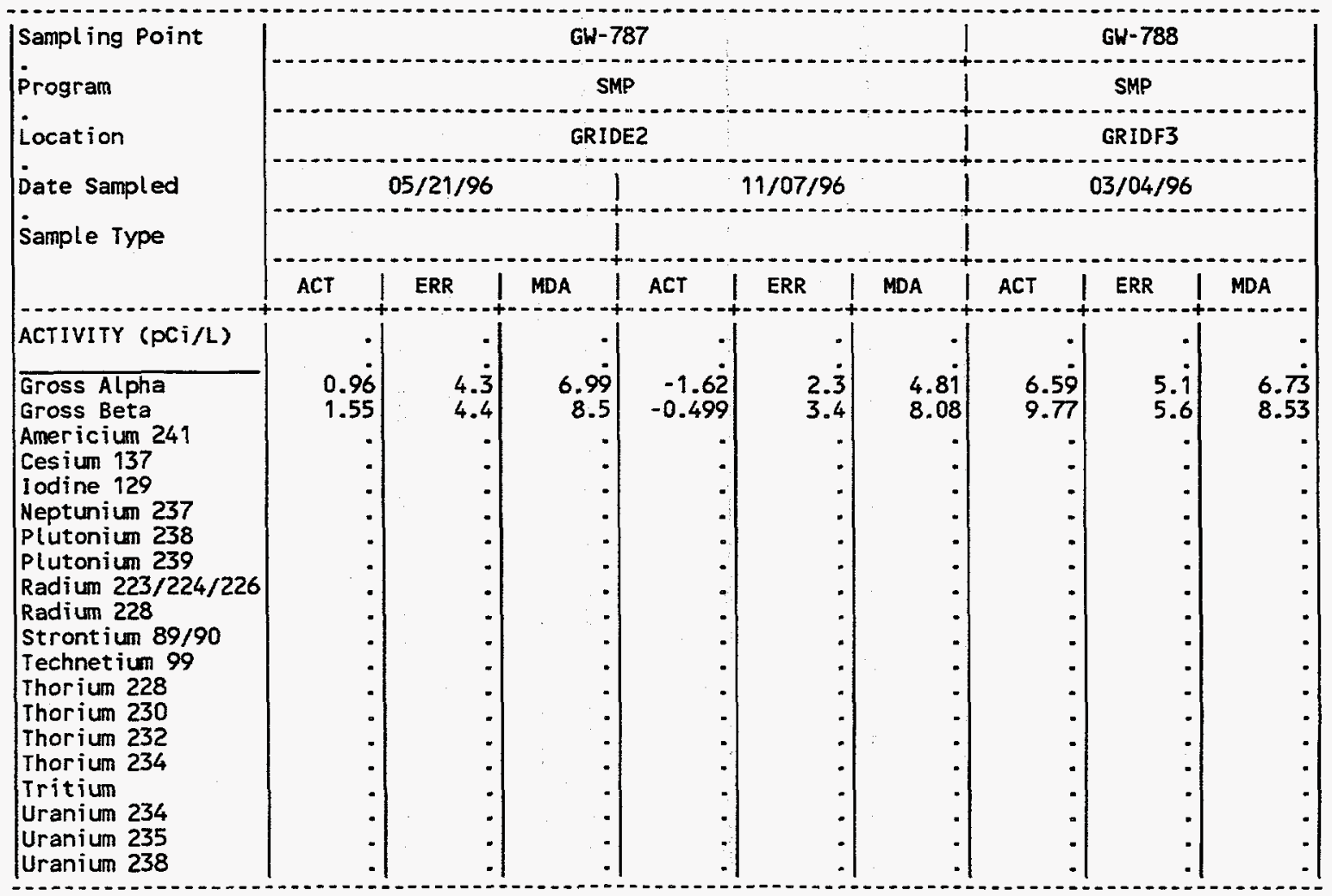




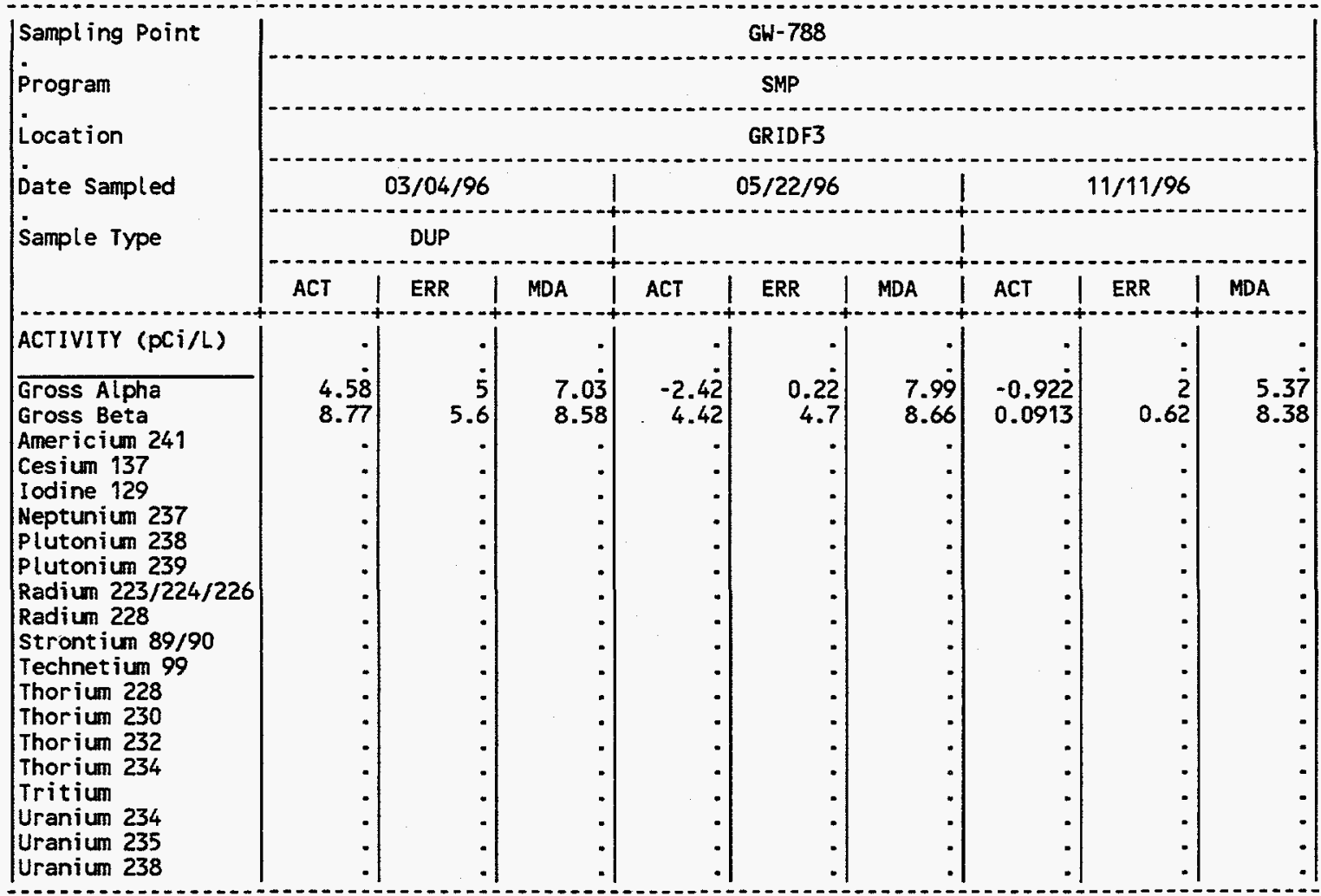

(CONT INUED)

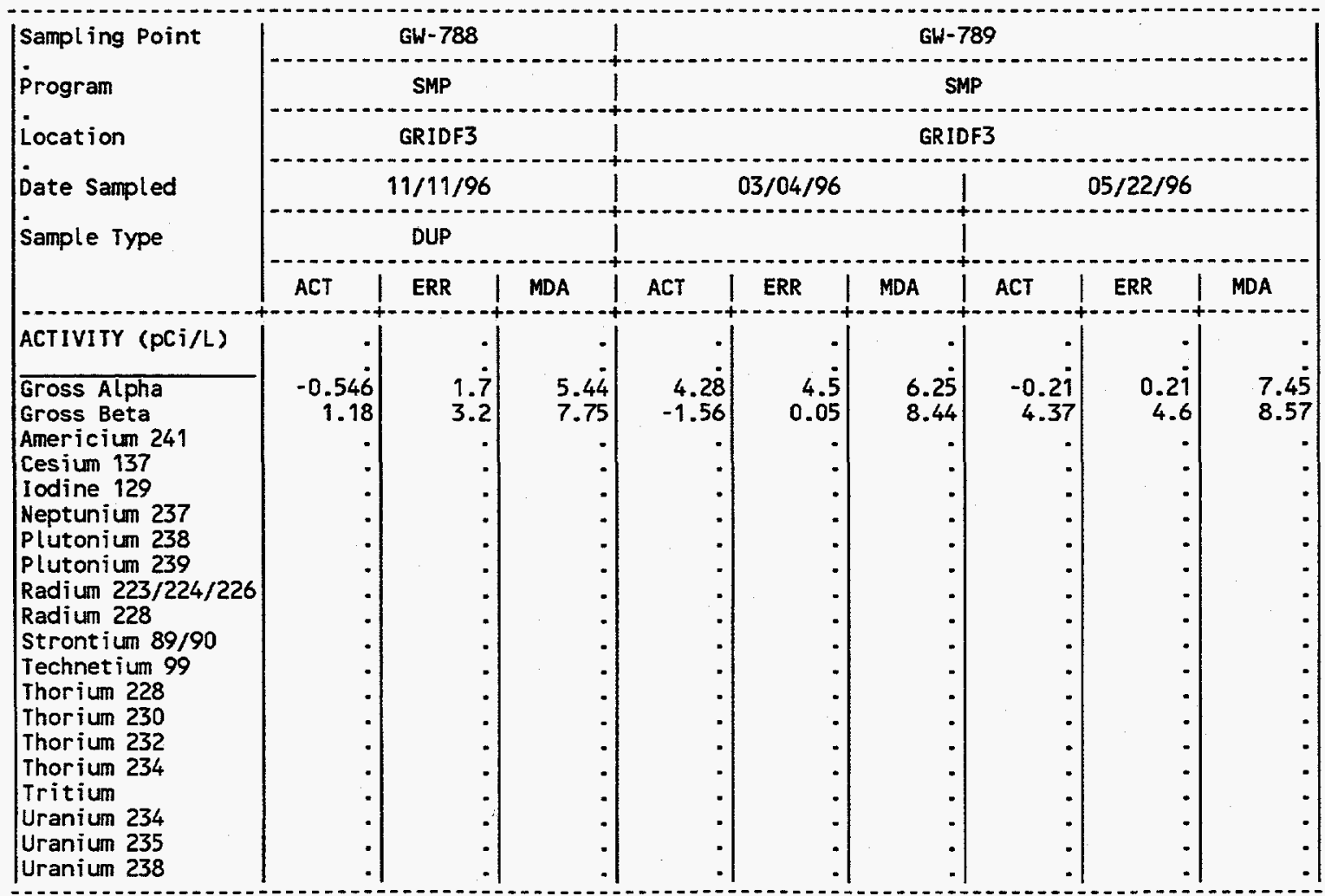

(CONTINUED) 
APPENDIX 0.4

Radiological Analytes, CY 1996

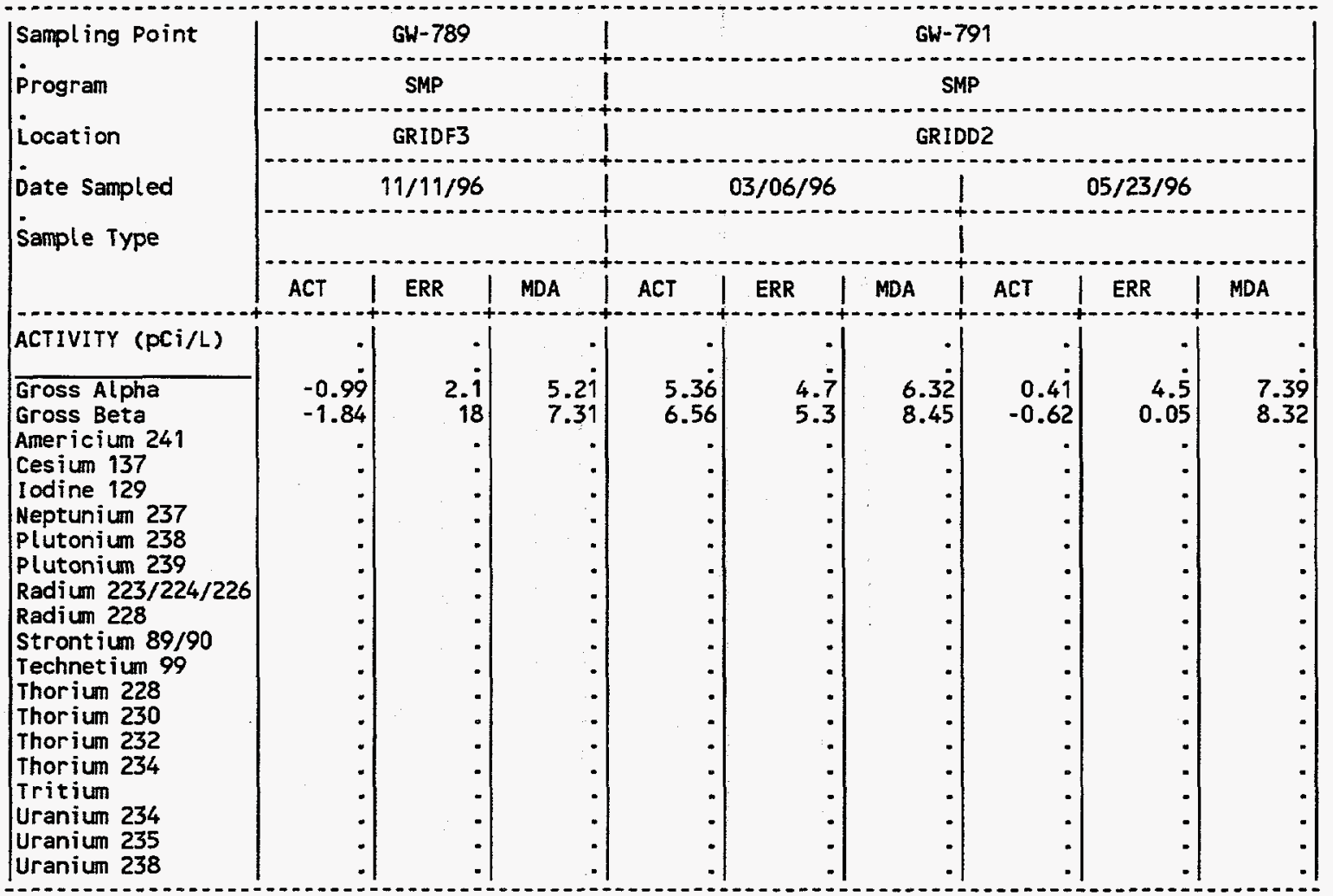

(CONTINUED)

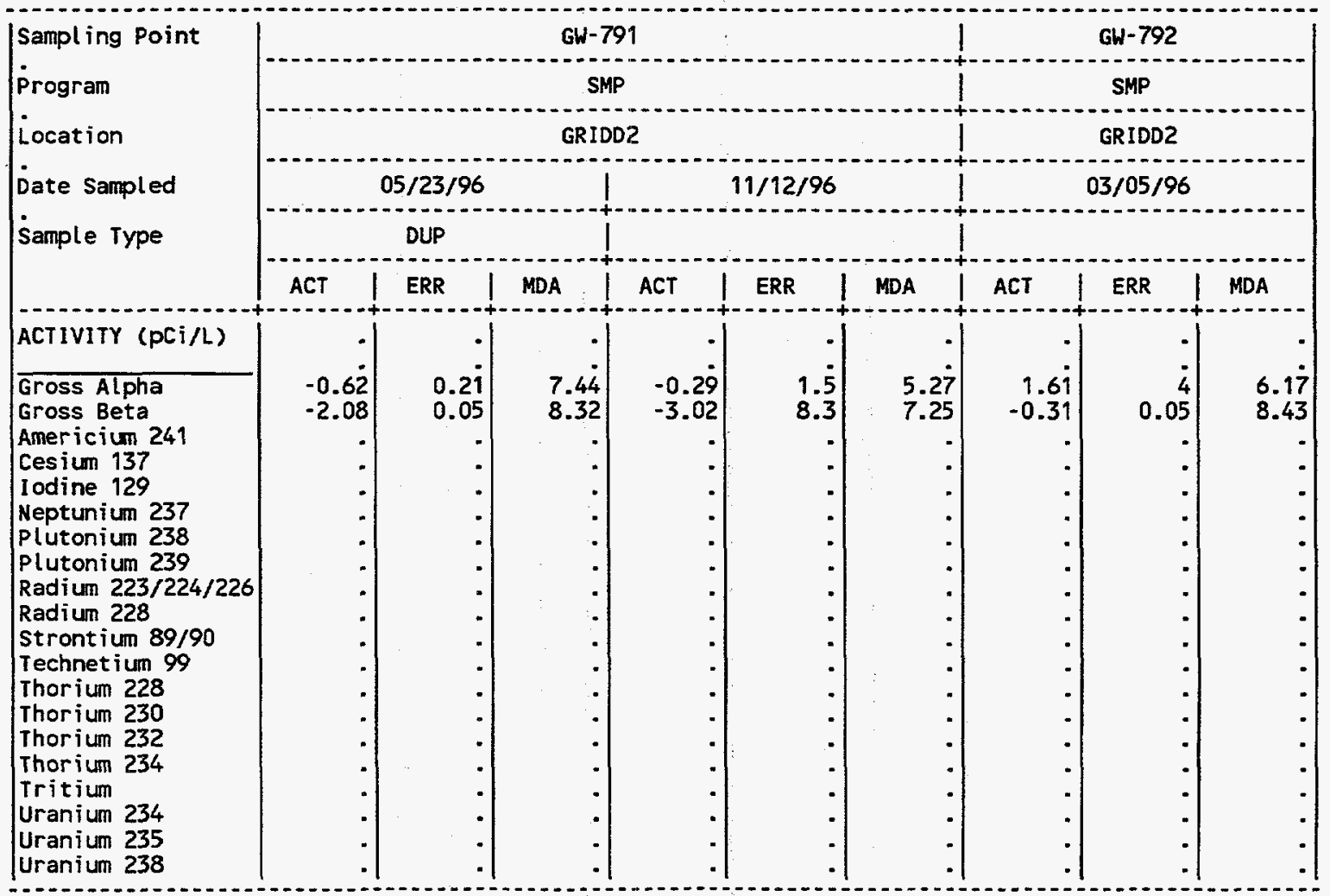


APPEND IX 0.4

Radiological Analytes, CY 1996

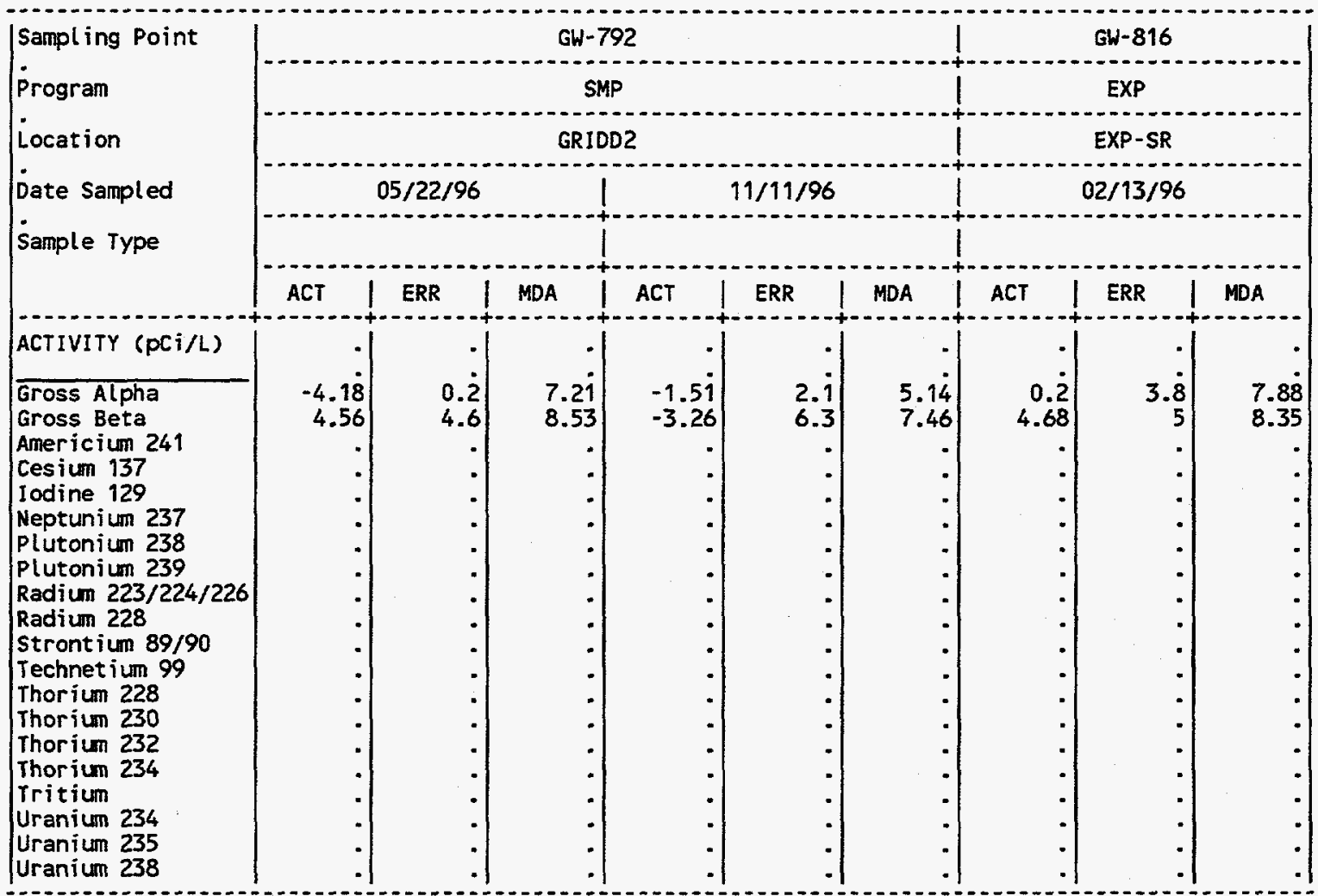

(CONT INUED)

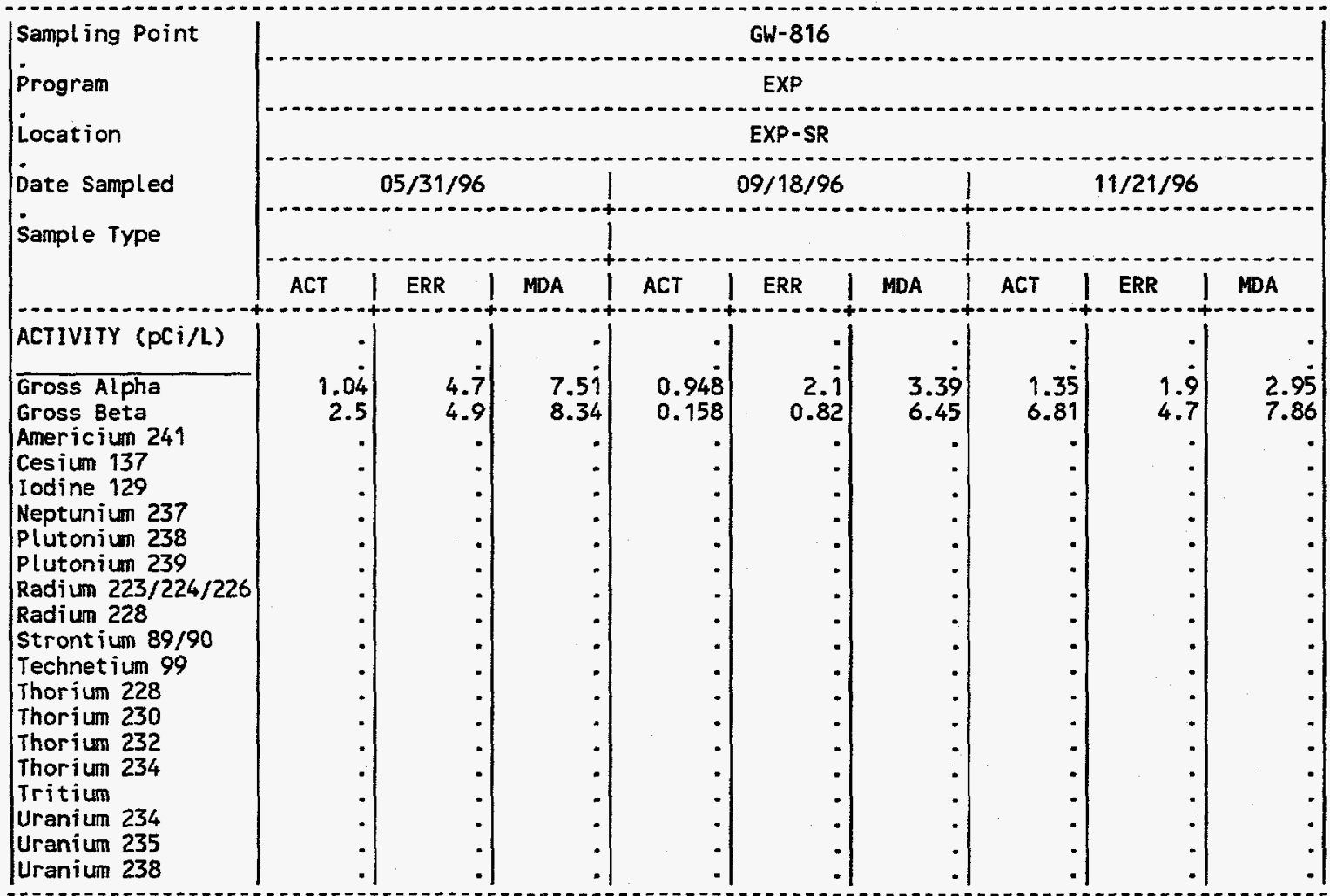


APPENDIX 0.4

Radiological Analytes, CY 1996

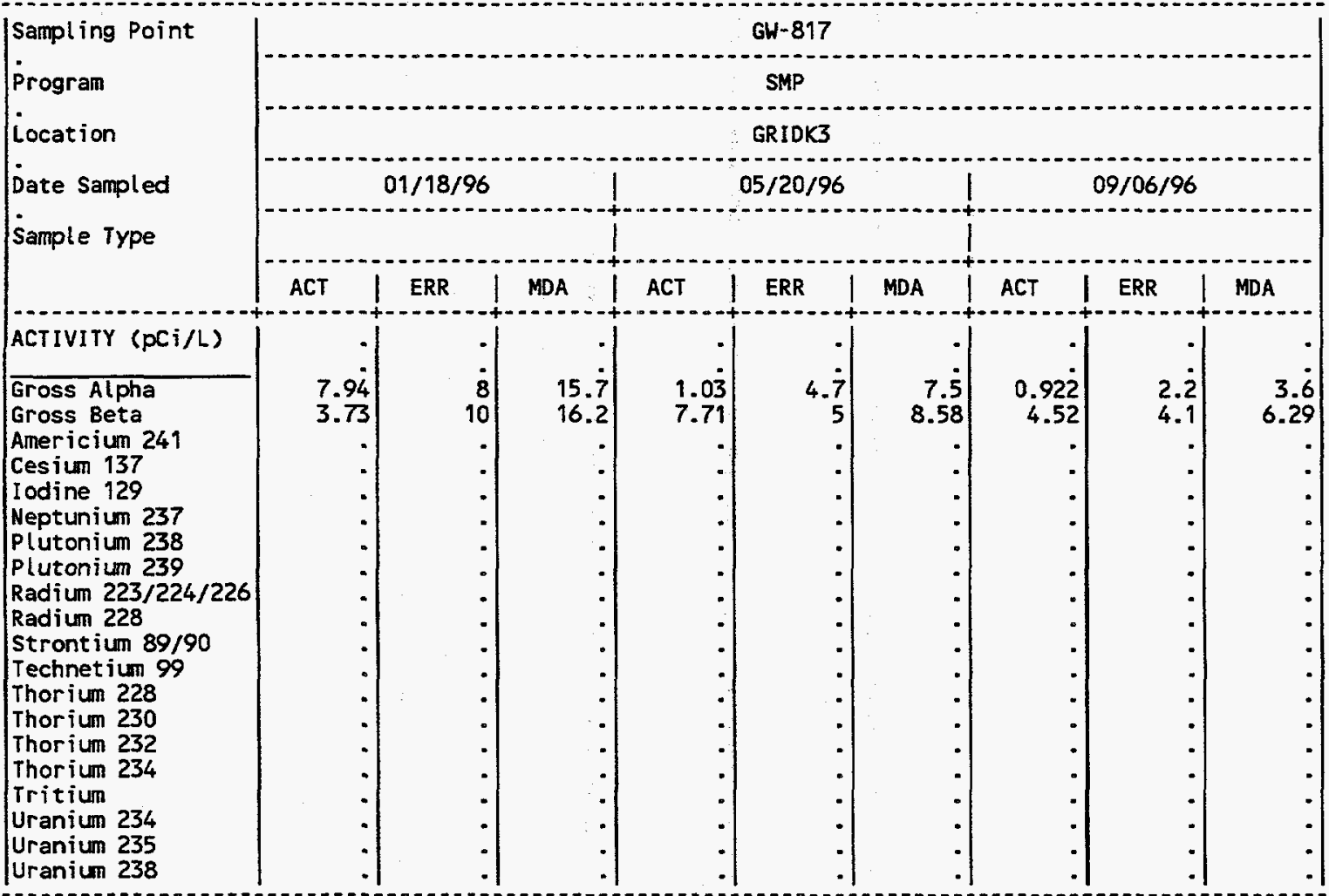

(CONT INUED)

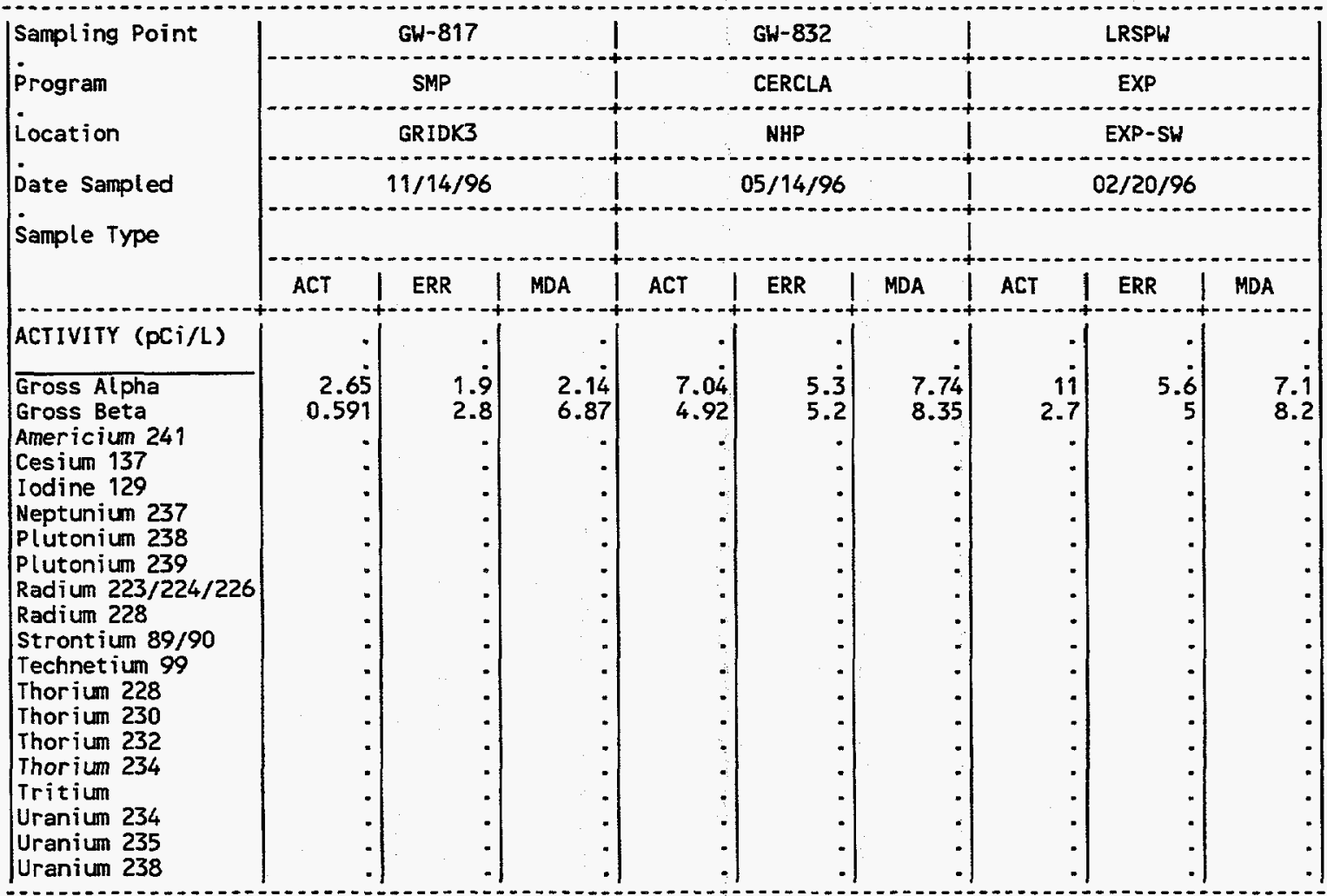


APPENDIX 0.4

Radiological Analytes, CY 1996

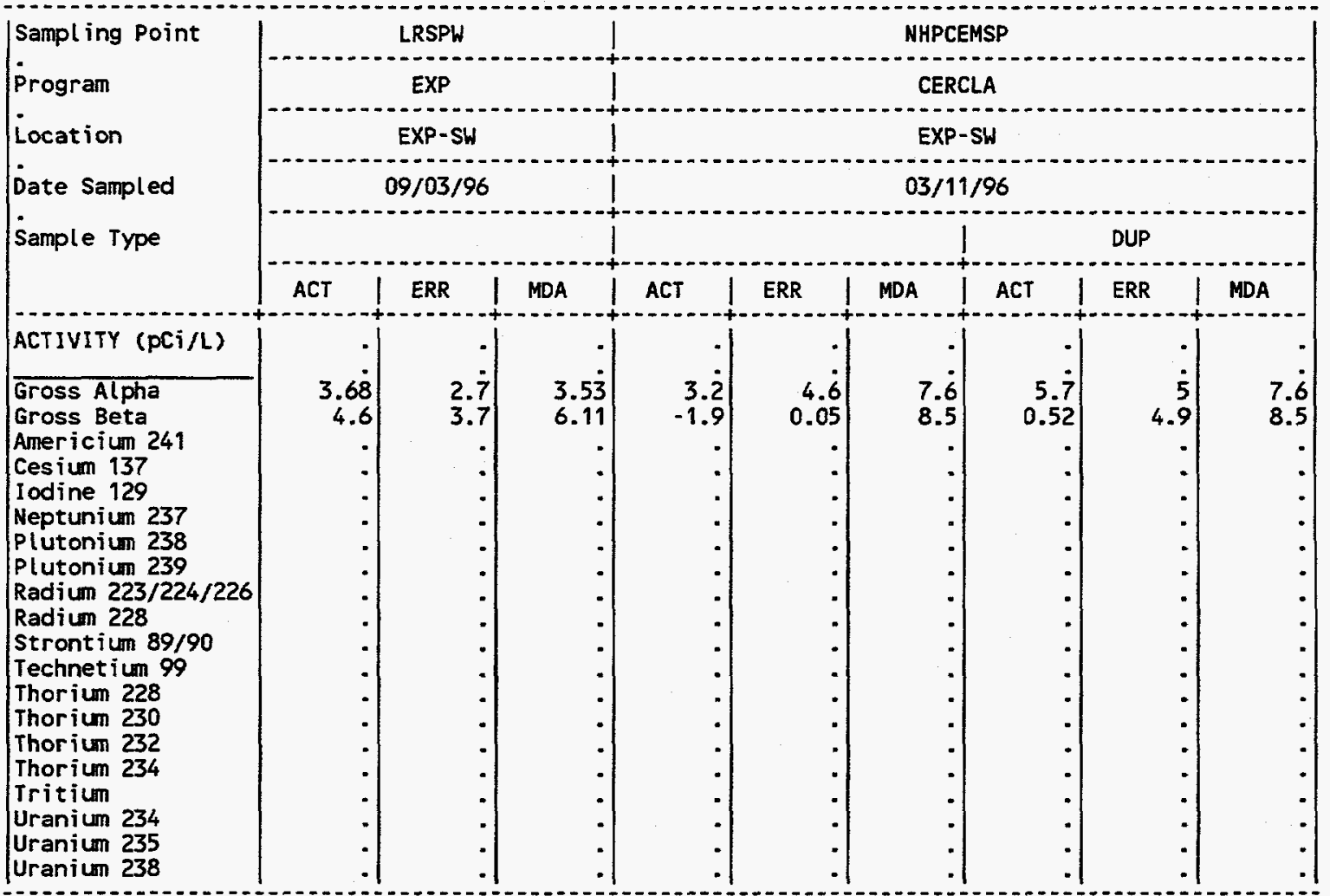

(CONT INUED)

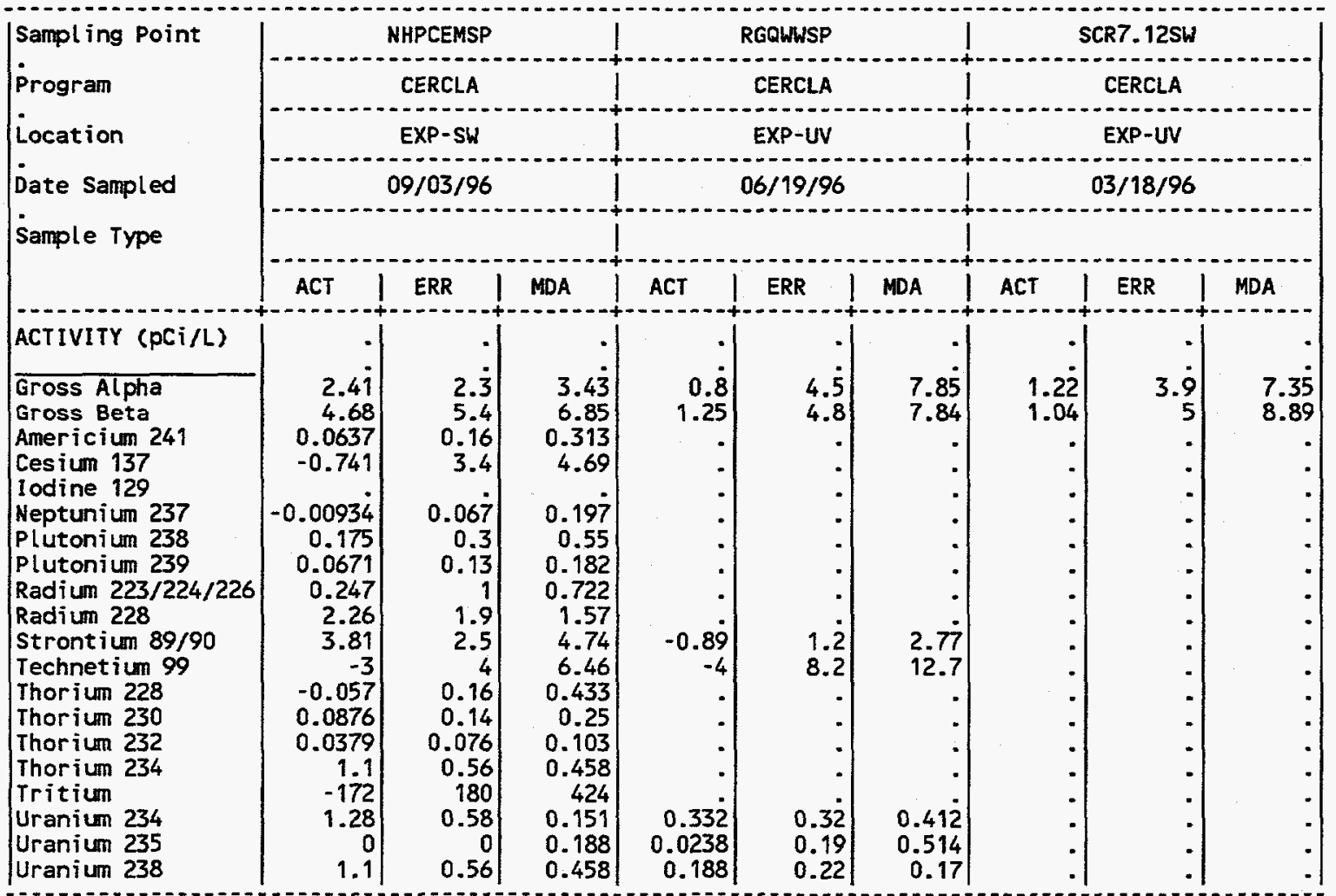

(CONT INUED) 
APPEND IX 0.4

Radiological Analytes, CY 1996

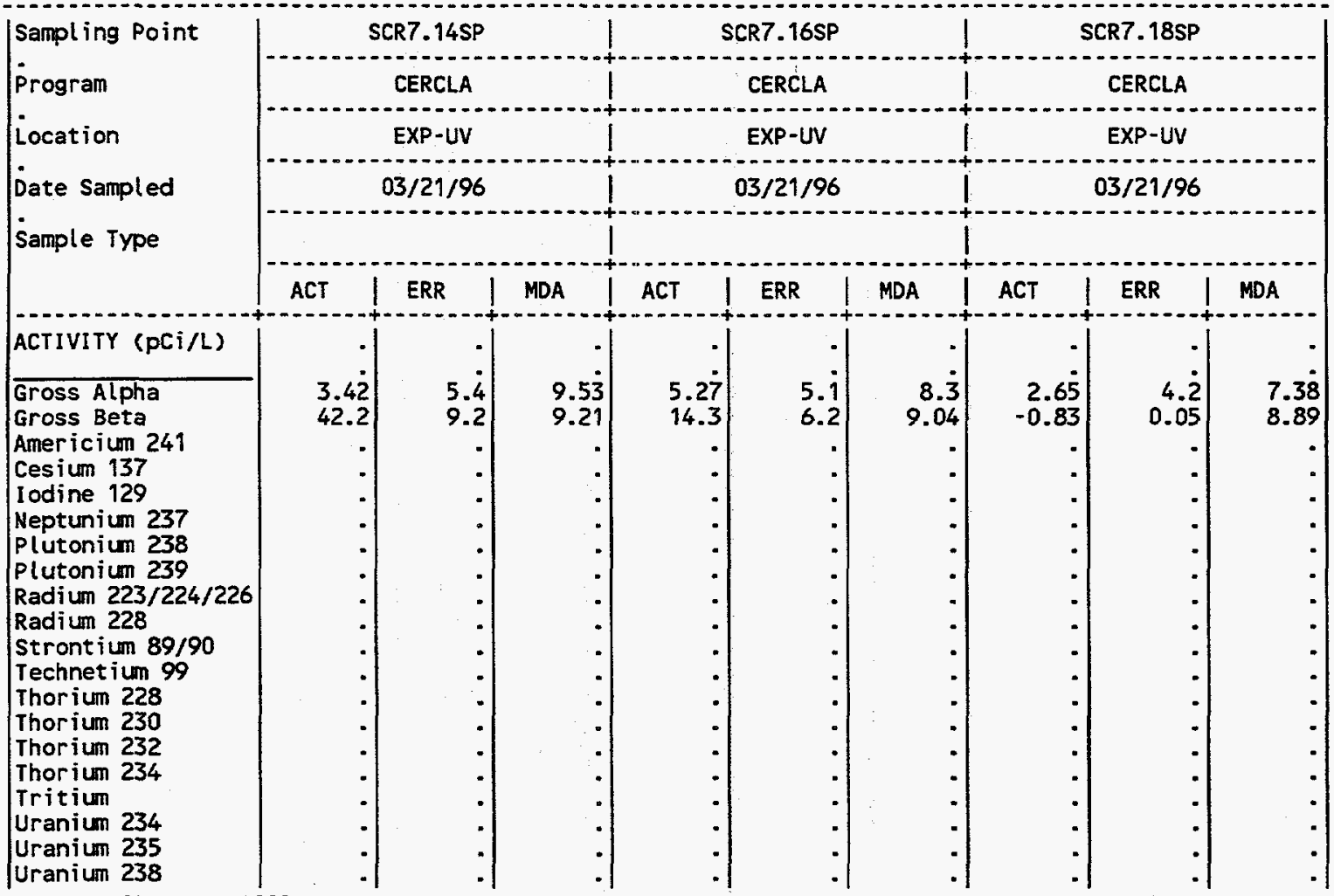

(CONTINUED)

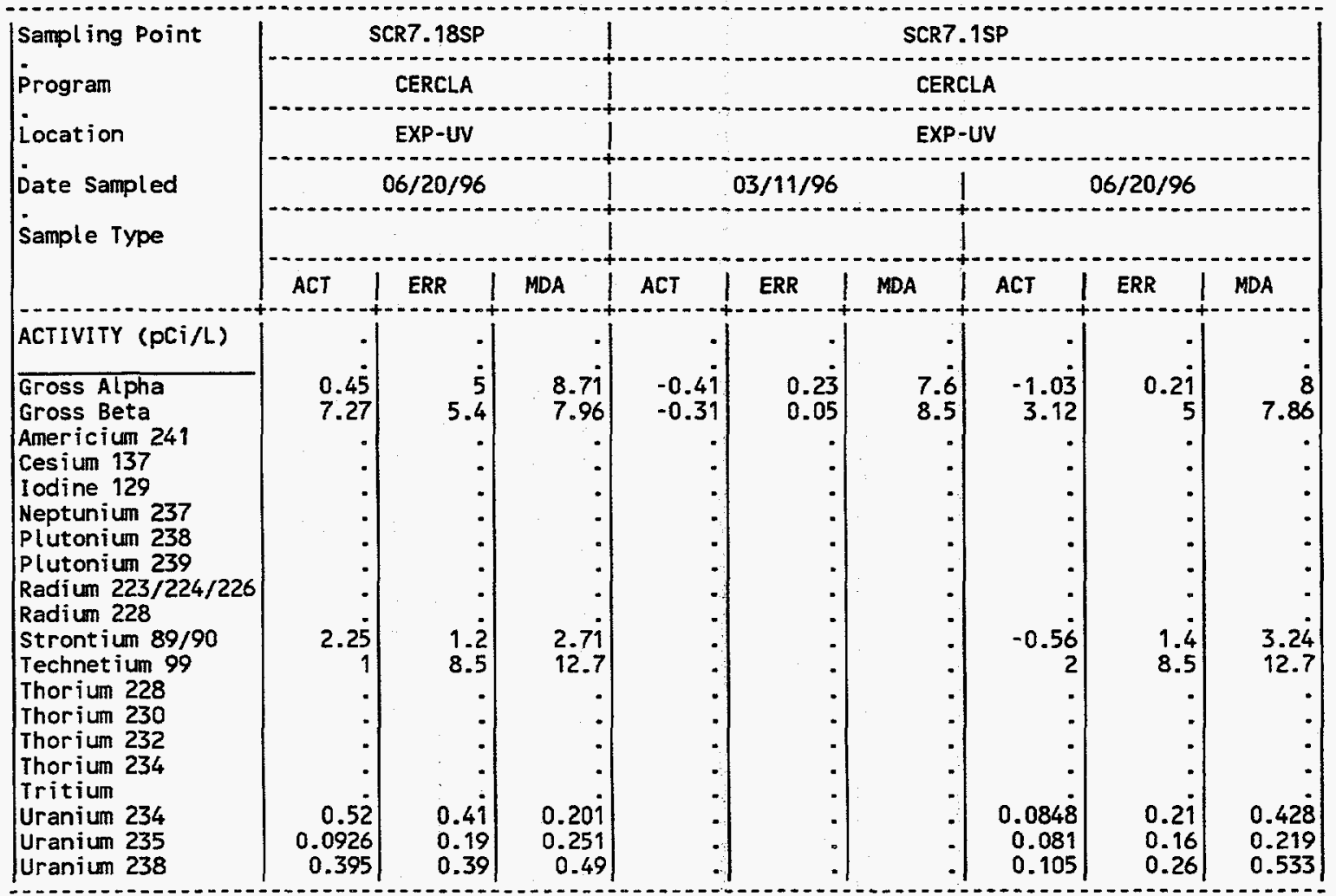


APPENDIX 0.4

Radiological Analytes, CY 1996

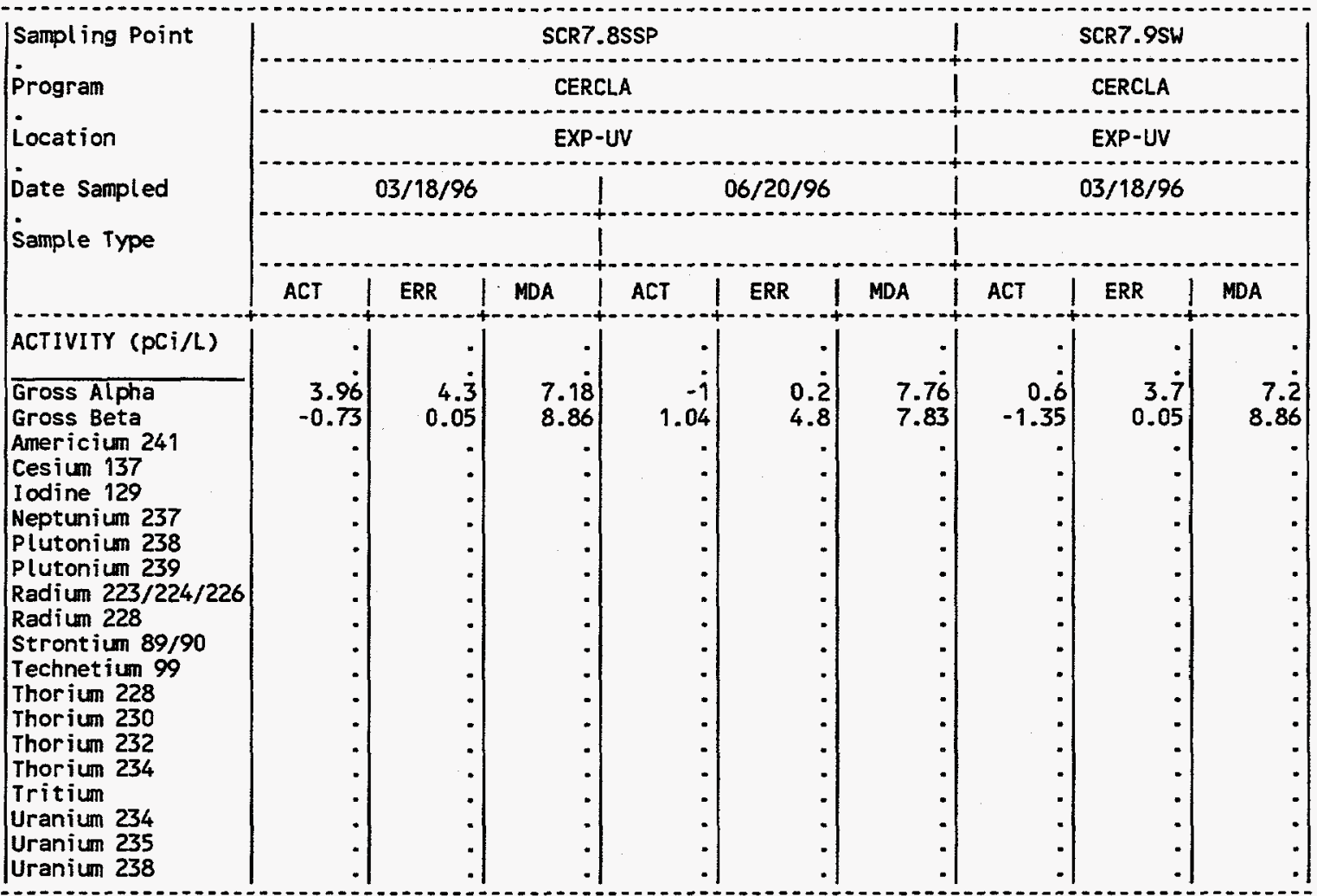

(CONT INUED)

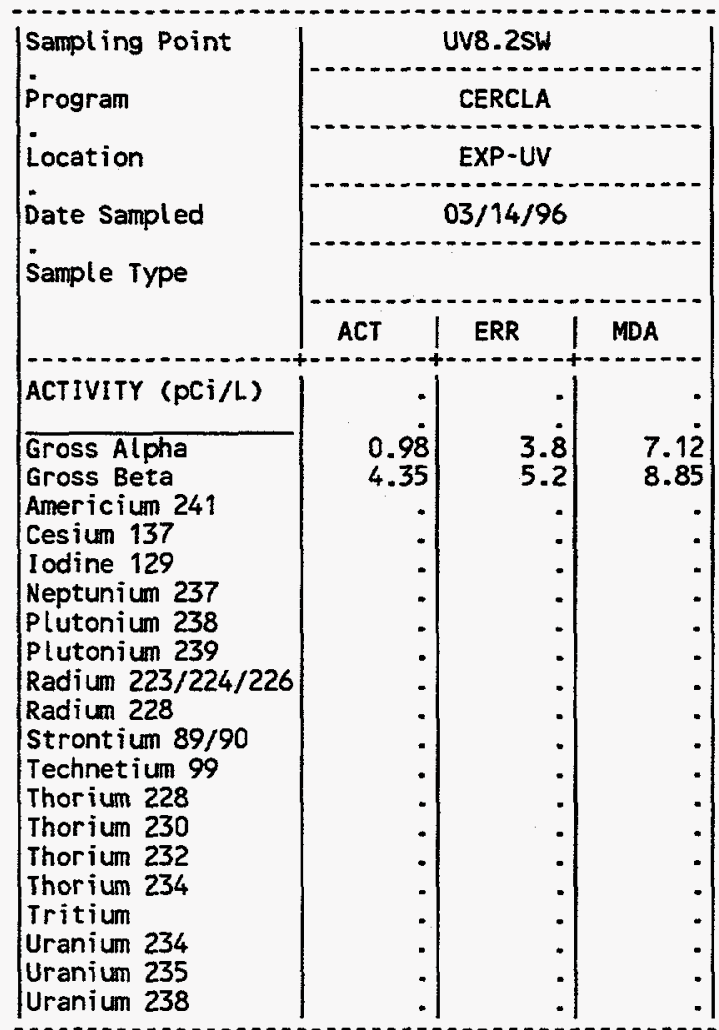


APPENDIX E

CY 1996 DATA FOR

QUALITY ASSURANCE/QUALITY CONTROL SAMPLES 


\section{EXPLANATION}

\section{SAMPLING POINT:}

55- - Monitoring Well (installed for the Mercury Study, 1984)

GW - Monitoring Well

LRSPW - Lake Reality Emergency Spillway, seep

NHPCEMSP - Spring at the New Hope Pond Cemetery

RQWWSP - Offsite spring in the west wall of Rogers Quarry in Union Valley

SCR - Offsite spring and surface water sampling locations:

Scarboro Creek along South Illinois Avenue

UV - Offsite spring in Union Valley east of South Illinois Avenue

D - Field Duplicate Sample

LOCATION:

B4 - Beta-4 Security Pits

B8110 - Building 8110

CPT - Coal Pile Trench

EXP - Exit Pathway Monitoring Location:

Maynardville Limestone Picket (-E, -I, -J)

In the gap through Pine Ridge along Scarboro Road (-SR)

Offsite in Union Valley (-UV)

FTF - Fire Training Facility

GRID - Comprehensive Groundwater Monitoring Plan Grid Location

NHP - New Hope Pond

S2 - S-2 Site

S3 - S-3 Site

SY - Y-12 Salvage Yard

T2331 - Underground Storage Tank T2331-U

UOV - Uranium Oxide Vault

WC - Waste Coolant Processing Area

Y12 - Y-12 Plant Site

\section{UNITS:}

ug/L - micrograms per liter (organic analytes)

$\mathrm{mg} / \mathrm{L}$ - milligrams per liter (inorganic analytes)

$\mathrm{pCi} / \mathrm{L}$ - picoCuries per liter (radiological analytes) 


\section{EXPLANATION (cont'd)}

SAMPLE TYPE (Radiological):
ACT - Activity
ERR - Counting Error (two standard deviations)
MDA - Minimum Detectable Activity

NOTES:
- Not analyzed
$\mathrm{U}$ - Organic compound not detected at the reported minimum attainable detection limit.


Organic Compounds Detected in QA/QC Samples, CY 1996

\begin{tabular}{|c|c|c|c|c|c|}
\hline \multirow[t]{2}{*}{ Trip Blank Samples } & \multicolumn{4}{|c|}{ Quarter of CY 1996} & \multirow{2}{*}{$\begin{array}{c}\text { Annual } \\
\text { Total } \\
\end{array}$} \\
\hline & First & Second & Third & Fourth & \\
\hline Total Number of Samples & 47 & 35 & 19 & 28 & 129 \\
\hline Samples With VOCs & 13 & 22 & 17 & 17 & 69 \\
\hline Percent Contaminated & 28 & 63 & 89 & 61 & 53 \\
\hline Acetone & 2 & 0 & 1 & 10 & 13 \\
\hline 2-Butanone & 8 & 0 & 0 & 9 & 17 \\
\hline Carbon disulfide & 0 & 1 & 0 & 0 & 1 \\
\hline Chloroform & 2 & 13 & 9 & 8 & 32 \\
\hline 1,2-Dichloroethane & 0 & 0 & 0 & 1 & 1 \\
\hline Cis-1,2-Dichloroethene & 1 & 0 & 0 & 0 & 1 \\
\hline 1,2-Dichloropropane & 3 & 14 & 12 & 1 & 30 \\
\hline Tetrachloroethene & 1 & 0 & 0 & 0 & 1 \\
\hline Toluene & 2 & 0 & 0 & 1 & 3 \\
\hline 1,1,1-Trichloroethane & 1 & 0 & 0 & 0 & 1 \\
\hline
\end{tabular}

\begin{tabular}{|c|c|c|c|c|c|}
\hline \multirow[t]{2}{*}{ Laboratory Blank Samples } & \multicolumn{4}{|c|}{ Quarter of CY 1996} & \multirow{2}{*}{$\begin{array}{c}\text { Annual } \\
\text { Total } \\
\end{array}$} \\
\hline & First & Second & Third & Fourth & \\
\hline Total Number of Samples & 32 & 25 & 18 & 16 & 91 \\
\hline Samples With VOCs & 10 & 0 & 0 & 5 & 15 \\
\hline Percent Contaminated & 31 & 0 & 0 & 31 & 16 \\
\hline Acetone & 8 & 0 & 0 & 5 & 13 \\
\hline 2-Butanone & 10 & 0 & 0 & 5 & 15 \\
\hline Tetrachloroethene & 0 & 0 & 0 & 1 & 1 \\
\hline 1,1,1-Trichloroethane & 0 & 0 & 0 & 2 & 2 \\
\hline
\end{tabular}

\begin{tabular}{|c|c|c|c|c|c|}
\hline \multirow{2}{*}{ Equipment Rinsate Samples } & \multicolumn{4}{|c|}{ Quarter of CY 1996} & \multirow{2}{*}{$\begin{array}{c}\text { Annual } \\
\text { Total } \\
\end{array}$} \\
\hline & First & Second & Third & Fourth & \\
\hline Total Number of Samples & 8 & 7 & 5 & 7 & 27 \\
\hline Samples With VOCs & 4 & 7 & 5 & 6 & 22 \\
\hline Percent Contaminated & 50 & 100 & 100 & 86 & 81 \\
\hline Acetone & 3 & 4 & 5 & 3 & 15 \\
\hline 2-Butanone & 1 & 1 & 0 & 3 & 5 \\
\hline Chloroform & 0 & 7 & 5 & 6 & 18 \\
\hline 1,2-Dichloropropane & 1 & 1 & 1 & 0 & 3 \\
\hline Toluene & 0 & 0 & 0 & 1 & 1 \\
\hline
\end{tabular}

\begin{tabular}{|c|c|c|c|c|c|}
\hline \multirow[t]{2}{*}{ Field Blank Samples } & \multicolumn{4}{|c|}{ Quarter of CY 1996} & \multirow{2}{*}{$\begin{array}{c}\text { Annual } \\
\text { Total } \\
\end{array}$} \\
\hline & First & Second & Third & Fourth & \\
\hline Total Number of Samples & 1 & 1 & 1 & 1 & 4 \\
\hline Samples With VOCs & 1 & 1 & 1 & 1 & 4 \\
\hline Percent Contaminated & 100 & 100 & 100 & 100 & 100 \\
\hline Acetone & 0 & 1 & 1 & 0 & 2 \\
\hline 2-Butanone & 1 & 0 & 0 & 0 & 1 \\
\hline Chloroform & 0 & 1 & 1 & 1 & 3 \\
\hline 1,2-Dichloropropane & 0 & 0 & 1 & 0 & 1 \\
\hline
\end{tabular}



APPENDIX E.1

CORRELATION OF GROUNDWATER AND SURFACE WATER

SAMPLES TO ASSOCIATED BLANKS 
APPENDIX B.I

Correlation of Samples to Associated Blanks

First Quarter 1996

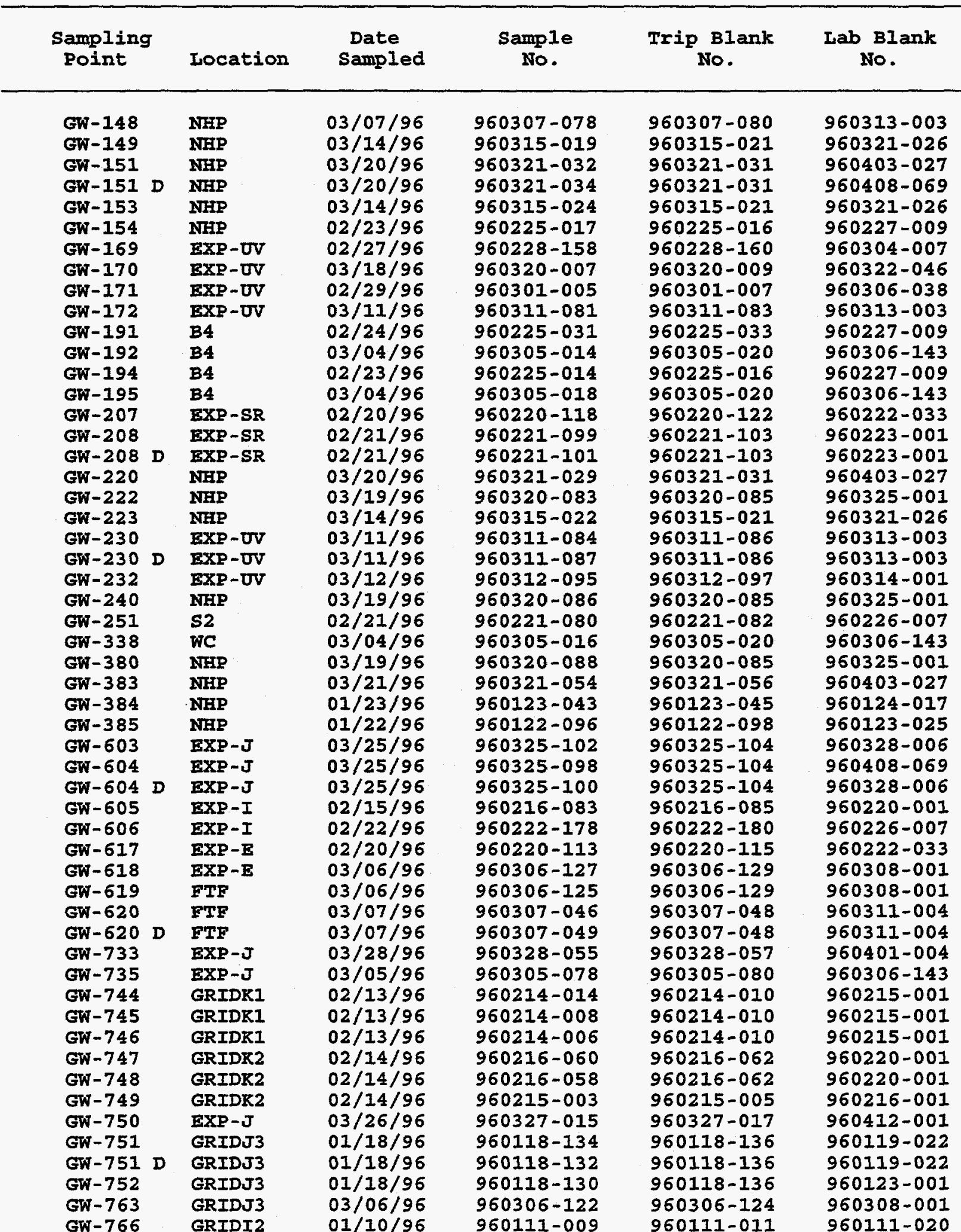


APPENDIX E. 1

Correlation of Samples to Associated Blanks

First Quarter 1996

\begin{tabular}{|c|c|c|c|c|c|}
\hline $\begin{array}{l}\text { Sampling } \\
\text { Point }\end{array}$ & Iocation & $\begin{array}{l}\text { Date } \\
\text { Sampled }\end{array}$ & $\begin{array}{c}\text { Sample } \\
\text { No. }\end{array}$ & $\begin{array}{c}\text { Trip Blank } \\
\text { No. }\end{array}$ & $\begin{array}{c}\text { Lab Blank } \\
\text { No. }\end{array}$ \\
\hline $\begin{array}{r}\text { GW-767 } \\
\text { GW-769 } \\
\text { GW-770 } \\
\text { GW-775 } \\
\text { GW-775 D } \\
\text { GW-776 } \\
\text { GW-779 } \\
\text { GW-780 } \\
\text { GW-781 } \\
\text { GW-782 } \\
\text { GW-782 D } \\
\text { GW-783 } \\
\text { GW-786 } \\
\text { GW-787 } \\
\text { GW-788 } \\
\text { GW-788 D } \\
\text { GW-789 } \\
\text { GW-791 } \\
\text { GW-792 } \\
\text { GW-816 } \\
\text { GW-817 } \\
\text { LRSPW } \\
\text { NHPCEMSP } \\
\text { NHPCEMSP D } \\
\text { SCR7.12SW } \\
\text { SCR7.14SP } \\
\text { SCR7.16SP } \\
\text { SCR7.18SP } \\
\text { SCR7.1SP } \\
\text { SCR7.8SSP } \\
\text { SCR7.9SW } \\
\text { UV8.2SW }\end{array}$ & $\begin{array}{l}\text { GRIDI2 } \\
\text { GRIDG3 } \\
\text { GRIDG3 } \\
\text { GRIDH3 } \\
\text { GRIDH3 } \\
\text { GRIDH3 } \\
\text { GRIDF2 } \\
\text { GRIDF2 } \\
\text { GRIDE3 } \\
\text { GRIDE3 } \\
\text { GRIDE3 } \\
\text { GRIDE3 } \\
\text { GRIDE2 } \\
\text { GRIDE2 } \\
\text { GRIDF3 } \\
\text { GRIDF3 } \\
\text { GRIDF3 } \\
\text { GRIDD2 } \\
\text { GRIDD2 } \\
\text { EXP-SR } \\
\text { GRIDK3 } \\
\text { EXP-SW } \\
\text { EXP-SW } \\
\text { EXP-SW } \\
\text { EXP-UV } \\
\text { EXP-UV } \\
\text { EXP-UV } \\
\text { EXP-UV } \\
\text { EXP-UV } \\
\text { EXP - UV } \\
\text { EXP-UV } \\
\text { EXP -UV }\end{array}$ & $\begin{array}{l}01 / 10 / 96 \\
01 / 11 / 96 \\
01 / 11 / 96 \\
01 / 10 / 96 \\
01 / 10 / 96 \\
01 / 10 / 96 \\
02 / 25 / 96 \\
02 / 25 / 96 \\
03 / 06 / 96 \\
02 / 19 / 96 \\
02 / 19 / 96 \\
03 / 06 / 96 \\
02 / 25 / 96 \\
02 / 25 / 96 \\
03 / 04 / 96 \\
03 / 04 / 96 \\
03 / 04 / 96 \\
03 / 06 / 96 \\
03 / 05 / 96 \\
02 / 13 / 96 \\
01 / 18 / 96 \\
02 / 20 / 96 \\
03 / 11 / 96 \\
03 / 11 / 96 \\
03 / 18 / 96 \\
03 / 21 / 96 \\
03 / 21 / 96 \\
03 / 21 / 96 \\
03 / 11 / 96 \\
03 / 18 / 96 \\
03 / 18 / 96 \\
03 / 14 / 96\end{array}$ & $\begin{array}{l}960111-007 \\
960111-075 \\
960111-077 \\
960111-001 \\
960111-003 \\
960111-005 \\
960226-025 \\
960226-023 \\
960307-037 \\
960219-110 \\
960219-113 \\
960307-035 \\
960226-020 \\
960226-027 \\
960304-092 \\
960304-095 \\
960304-097 \\
960307-032 \\
960305-098 \\
960214-016 \\
960118-128 \\
960220-120 \\
960311-128 \\
960311-131 \\
960320-001 \\
960322-016 \\
960322-019 \\
960322-007 \\
960311-138 \\
960320-005 \\
960320-003 \\
960315-016\end{array}$ & $\begin{array}{l}960111-011 \\
960111-079 \\
960111-079 \\
960111-011 \\
960111-011 \\
960111-011 \\
960226-022 \\
960226-022 \\
960307-039 \\
960219-112 \\
960219-112 \\
960307-039 \\
960226-022 \\
960226-022 \\
960304-094 \\
960304-094 \\
960304-094 \\
960307-039 \\
960305-100 \\
960214-010 \\
960118-136 \\
960220-122 \\
960311-130 \\
960311-133 \\
960320-009 \\
960322-018 \\
960322-018 \\
960322-009 \\
960311-140 \\
960320-009 \\
960320-009 \\
960315-018\end{array}$ & $\begin{array}{l}960111-024 \\
960112-001 \\
960112-001 \\
960111-024 \\
960111-024 \\
960111-024 \\
960228-147 \\
960228-147 \\
960311-004 \\
960222-033 \\
960222-033 \\
960311-004 \\
960227-066 \\
960228-147 \\
960306-038 \\
960306-038 \\
960306-143 \\
960308-001 \\
960308-001 \\
960215-001 \\
960123-001 \\
960222-033 \\
960313-003 \\
960313-003 \\
960322-046 \\
960408-069 \\
960408-069 \\
960408-069 \\
960314-001 \\
960322-046 \\
960322-046 \\
960321-026\end{array}$ \\
\hline
\end{tabular}


APPENDIX E.1

Correlation of Samples to Associated Blanks Second Quarter 1996

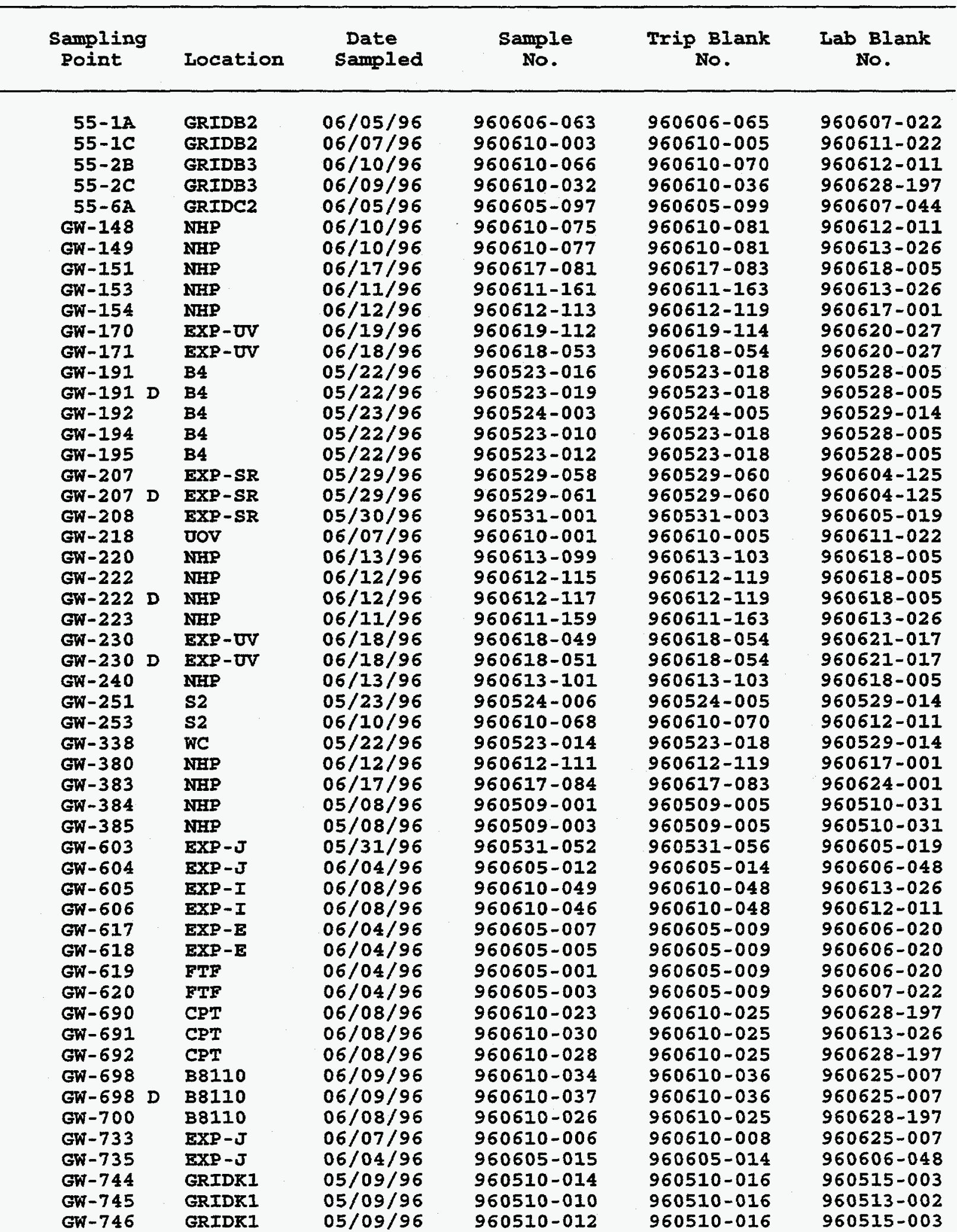


APPENDIX E.1

Correlation of Samples to Associated Blanks Second Quarter 1996

\begin{tabular}{|c|c|c|c|c|c|}
\hline $\begin{array}{l}\text { Sampling } \\
\text { Point }\end{array}$ & Location & $\begin{array}{l}\text { Date } \\
\text { Sampled }\end{array}$ & $\begin{array}{c}\text { Sample } \\
\text { No. }\end{array}$ & $\begin{array}{c}\text { Trip Blank } \\
\text { No. }\end{array}$ & $\begin{array}{c}\text { Lab Blank } \\
\text { No. }\end{array}$ \\
\hline $\begin{array}{r}\text { GW-747 } \\
\text { GW-748 } \\
\text { GW-749 } \\
\text { GW-750 } \\
\text { GW-751 } \\
\text { GW-751 } \\
\text { GW-752 } \\
\text { GW-763 } \\
\text { GW-766 } \\
\text { GW-767 } \\
\text { GW-769 } \\
\text { GW-770 } \\
\text { GW-775 } \\
\text { GW-775 } \\
\text { GW-776 } \\
\text { GW-779 } \\
\text { GW-780 } \\
\text { GW-781 } \\
\text { GW-782 } \\
\text { GW-783 } \\
\text { GW-786 } \\
\text { GW-787 } \\
\text { GW-788 } \\
\text { GW-789 } \\
\text { GW-791 } \\
\text { GW-791 } \\
\text { GW-792 } \\
\text { GW-816 } \\
\text { GW-817 } \\
\text { GW-832 } \\
\text { RGQWWP } \\
\text { SCR7 }-185 P \\
\text { SCR7.1SP } \\
\text { SCR7.8SSP } \\
\text { UV8.5SP }\end{array}$ & $\begin{array}{l}\text { GRIDK2 } \\
\text { GRIDK2 } \\
\text { GRIDK2 } \\
\text { EXP-J } \\
\text { GRIDJ3 } \\
\text { GRIDJ3 } \\
\text { GRIDJ3 } \\
\text { GRIDJ3 } \\
\text { GRIDI2 } \\
\text { GRIDI2 } \\
\text { GRIDG3 } \\
\text { GRIDG3 } \\
\text { GRIDH3 } \\
\text { GRIDH3 } \\
\text { GRIDH3 } \\
\text { GRIDF2 } \\
\text { GRIDF2 } \\
\text { GRIDE3 } \\
\text { GRIDE3 } \\
\text { GRIDE3 } \\
\text { GRIDE2 } \\
\text { GRIDE2 } \\
\text { GRIDF3 } \\
\text { GRIDF3 } \\
\text { GRIDD2 } \\
\text { GRIDD2 } \\
\text { GRIDD2 } \\
\text { EXP-SR } \\
\text { GRIDK3 } \\
\text { NHP } \\
\text { EXP-UV } \\
\text { EXP-UV } \\
\text { EXP-UV } \\
\text { EXP-UV } \\
\text { EXP-UV }\end{array}$ & $\begin{array}{l}05 / 20 / 96 \\
05 / 20 / 96 \\
05 / 20 / 96 \\
06 / 04 / 96 \\
05 / 07 / 96 \\
05 / 07 / 96 \\
05 / 07 / 96 \\
06 / 10 / 96 \\
05 / 09 / 96 \\
05 / 09 / 96 \\
05 / 20 / 96 \\
05 / 20 / 96 \\
05 / 09 / 96 \\
05 / 09 / 96 \\
05 / 20 / 96 \\
05 / 21 / 96 \\
05 / 22 / 96 \\
05 / 23 / 96 \\
05 / 28 / 96 \\
05 / 23 / 96 \\
05 / 21 / 96 \\
05 / 21 / 96 \\
05 / 22 / 96 \\
05 / 22 / 96 \\
05 / 23 / 96 \\
05 / 23 / 96 \\
05 / 22 / 96 \\
05 / 31 / 96 \\
05 / 20 / 96 \\
05 / 14 / 96 \\
06 / 19 / 96 \\
06 / 20 / 96 \\
06 / 20 / 96 \\
06 / 20 / 96 \\
06 / 19 / 96\end{array}$ & $\begin{array}{l}960521-024 \\
960521-022 \\
960521-020 \\
960605-017 \\
960507-163 \\
960507-165 \\
960507-161 \\
960610-079 \\
960510-007 \\
960510-005 \\
960521-004 \\
960521-002 \\
960510-001 \\
960510-003 \\
960521-006 \\
960521-105 \\
960523-007 \\
960524-015 \\
960528-061 \\
960524-008 \\
960521-109 \\
960521-107 \\
960523-001 \\
960523-005 \\
960524-010 \\
960524-012 \\
960523-003 \\
960531-054 \\
960521-018 \\
960514-050 \\
960619-119 \\
960621-002 \\
960621-004 \\
960621-006 \\
960619-118\end{array}$ & $\begin{array}{l}960521-026 \\
960521-026 \\
960521-026 \\
960605-014 \\
960507-167 \\
960507-167 \\
960507-167 \\
960610-081 \\
960510-009 \\
960510-009 \\
960521-008 \\
960521-008 \\
960510-009 \\
960510-009 \\
960521-008 \\
960521-111 \\
960523-009 \\
960524-017 \\
960528-063 \\
960524-017 \\
960521-111 \\
960521-111 \\
960523-009 \\
960523-009 \\
960524-017 \\
960524-017 \\
960523-009 \\
960531-056 \\
960521-026 \\
960514-052 \\
960619-121 \\
960621-008 \\
960621-008 \\
960621-008 \\
960619-121\end{array}$ & $\begin{array}{l}960522-008 \\
960522-008 \\
960522-008 \\
960607-044 \\
960509-015 \\
960509-015 \\
960509-015 \\
960613-026 \\
960513-002 \\
960513-002 \\
960522-008 \\
960522-008 \\
960513-002 \\
960513-002 \\
960522-008 \\
960523-021 \\
960528-005 \\
960529-063 \\
960529-063 \\
960529-014 \\
960523-021 \\
960523-021 \\
960528-005 \\
960528-005 \\
960529-014 \\
960529-014 \\
960528-005 \\
960604-125 \\
960522-008 \\
960515-003 \\
960621-017 \\
960624-001 \\
960624-001 \\
960624-001 \\
960621-017\end{array}$ \\
\hline
\end{tabular}


APPENDIX $\mathrm{E} .1$

Correlation of Samples to Associated Blanks Third Quarter 1996

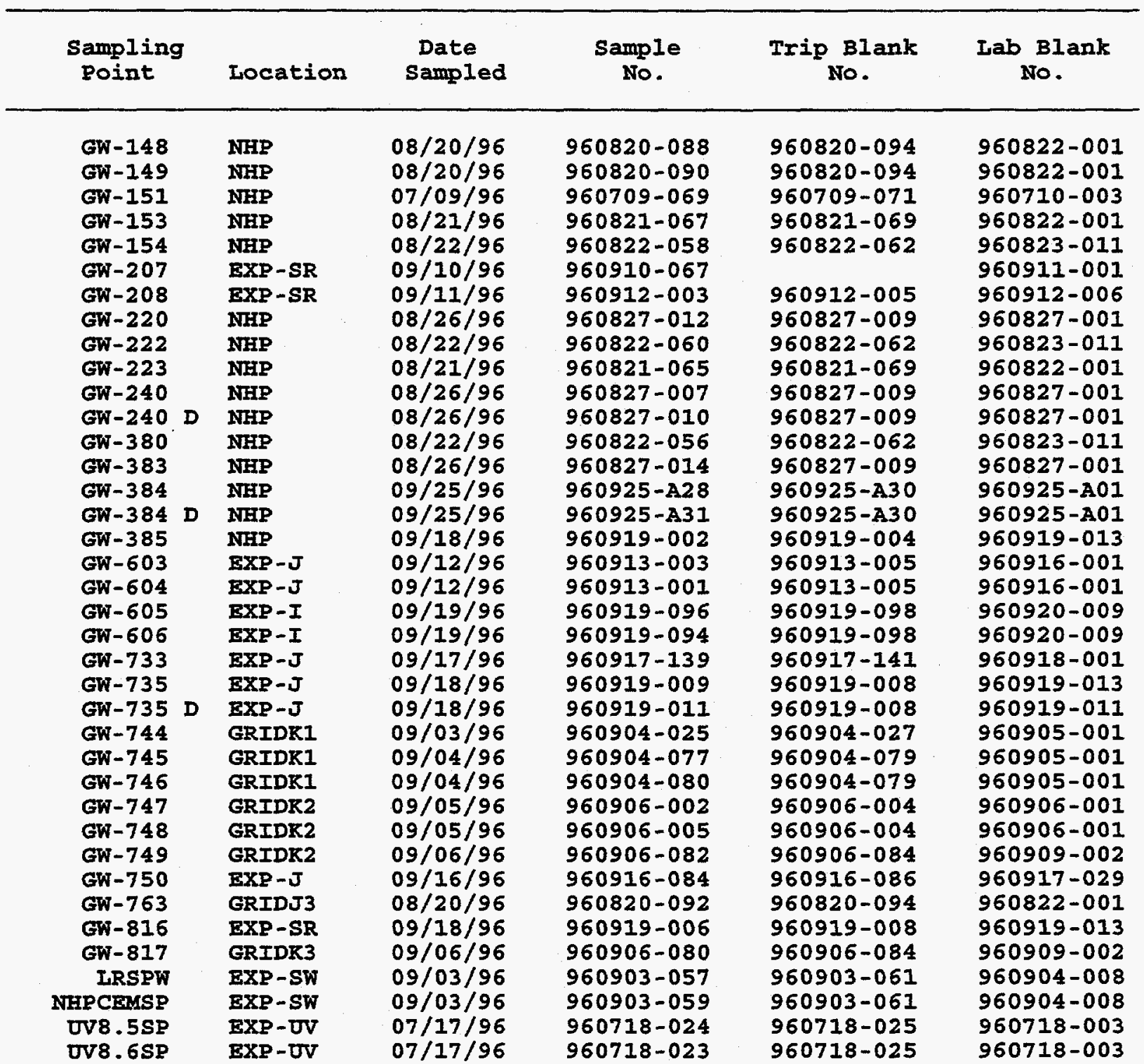


APPENDIX E.1

Correlation of Samples to Associated Blanks

Fourth Quarter 1996

\begin{tabular}{|c|c|c|c|c|c|}
\hline $\begin{array}{l}\text { Sampling } \\
\text { Point }\end{array}$ & Location & $\begin{array}{l}\text { Date } \\
\text { Sampled }\end{array}$ & $\begin{array}{c}\text { Sample } \\
\text { No. }\end{array}$ & $\begin{array}{c}\text { Trip Blank } \\
\text { No. }\end{array}$ & $\begin{array}{c}\text { Lab Blank } \\
\text { No. }\end{array}$ \\
\hline GW-108 & s3 & $11 / 04 / 96$ & $961105-\mathrm{A} 01$ & $961105-A 07$ & $961112-B 10$ \\
\hline GW-115 & s3 & $10 / 29 / 96$ & $961030-A 11$ & $961030-A 13$ & $961107-159$ \\
\hline$G W-148$ & MHP & $11 / 14 / 96$ & 961115-A06 & $961115-\mathrm{A03}$ & $961122-\mathrm{A} 38$ \\
\hline GW-149 & NHP & $11 / 14 / 96$ & 961115-AO4 & $961115-\mathrm{A03}$ & $961122-A 38$ \\
\hline$G W-151$ & NHP & $11 / 20 / 96$ & $961120-\mathrm{A2} 7$ & $961120-A 34$ & $961203-A 13$ \\
\hline$G W-153$ & NHP & $11 / 18 / 96$ & $961118-A 80$ & $961118-A 82$ & $961123-\mathrm{AO} 01$ \\
\hline$G W-154$ & NHP & $11 / 19 / 96$ & $961119-A 77$ & $961119-A 79$ & $961203-A 13$ \\
\hline GW-191 & B4 & $11 / 06 / 96$ & 961107-A09 & $961107-$ A11 & $961113-\mathrm{A} 29$ \\
\hline GW-192 & B4 & $11 / 13 / 96$ & $961114-A 05$ & $961114-\mathrm{A09}$ & $961122-A 35$ \\
\hline GW-193 & $\mathrm{Y} 12$ & $11 / 04 / 96$ & 961105-A05 & $961105-A 07$ & $961112-\mathrm{B} 10$ \\
\hline GW-193 D & $\mathrm{Y} 12$ & $11 / 04 / 96$ & 961105-A03 & $961105-A 07$ & $961112-\mathrm{B} 10$ \\
\hline$G W-194$ & B4 & $11 / 07 / 96$ & $961108-A 13$ & 961108-A12 & $961113-229$ \\
\hline GW-195 & B4 & $11 / 07 / 96$ & $961108-A 15$ & $961108-\mathrm{A} 12$ & $961113-\mathrm{A2} 9$ \\
\hline GW-207 & EXP-SR & $11 / 20 / 96$ & $961120-A 47$ & $961120-A 49$ & $961203-213$ \\
\hline$G W-208$ & EXP-SR & $11 / 21 / 96$ & $961122-\mathrm{A} 03$ & $961122-A 05$ & $961206-A 75$ \\
\hline GW-208D & EXP-SR & $11 / 21 / 96$ & $961122-A 01$ & 961122-A05 & $961206-A 75$ \\
\hline$G W-220$ & NHP & $11 / 20 / 96$ & $961120-\mathrm{A} 32$ & $961120-A 34$ & $961203-\mathrm{A} 13$ \\
\hline$G W-222$ & NHP & $11 / 18 / 96$ & $961118-A 74$ & $961118-A 82$ & 961123-A01 \\
\hline$G W-223$ & NHP & $11 / 18 / 96$ & $961118-A 76$ & $961118-A 82$ & $961123-\mathrm{A01}$ \\
\hline$G W-223 D$ & NHPP & $11 / 18 / 96$ & 961118-A78 & 961118-A82 & $961123-A 01$ \\
\hline$G W-240$ & NEP & $11 / 19 / 96$ & $961119-\mathrm{A} 82$ & 961119-A79 & $961203-A 13$ \\
\hline$G W-251$ & s2 & $11 / 07 / 96$ & $961108-A 10$ & $961108-\mathrm{A} 12$ & $961113-\mathrm{A} 29$ \\
\hline$G W-338$ & wC & $11 / 11 / 96$ & 961111-A49 & $961111-A 51$ & $961118-\mathrm{A} 61$ \\
\hline$G W-380$ & NHP & $11 / 19 / 96$ & $961119-A 80$ & 961119-A79 & $961202-\mathrm{A25}$ \\
\hline GW-383 & NHP & $11 / 20 / 96$ & $961120-A 29$ & $961120-A 34$ & $961202-\mathrm{A25}$ \\
\hline$G W-384$ & NHP & $11 / 21 / 96$ & $961121-\mathrm{A} 40$ & 961121-A42 & $961206-\mathrm{A75}$ \\
\hline$G W-385$ & NHP & $11 / 19 / 96$ & $961119-A 84$ & $961119-\mathrm{A} 86$ & $961203-\mathrm{A} 13$ \\
\hline GW-603 & EXP-J & $11 / 25 / 96$ & $961125-A 21$ & $961125-A 23$ & $961204-\mathrm{A} 17$ \\
\hline $\mathrm{GW}-604$ & EXP-J & $11 / 26 / 96$ & $961126-A 40$ & $961126-A 42$ & $961204-\mathrm{A} 17$ \\
\hline GW-605 & EXP-I & $10 / 31 / 96$ & 961101-A04 & 961101-A06 & $961112-B 10$ \\
\hline GW-606 & EXP -I & $10 / 31 / 96$ & $961101-\mathrm{A} 01$ & 961101-A06 & $961112-B 10$ \\
\hline$G W-617$ & EXP $-\mathbf{E}$ & $11 / 13 / 96$ & $961114-\mathrm{A} 01$ & 961114-A09 & $961122-A 35$ \\
\hline GW-618 & EXP $-\mathbf{E}$ & $11 / 11 / 96$ & 961111-A47 & $961111-A 51$ & $961118-\mathrm{A} 61$ \\
\hline $\mathrm{GW}-619$ & FTF & $11 / 13 / 96$ & 961114-A07 & $961114-A 09$ & $961122-A 35$ \\
\hline GW-619 D & FTF & $11 / 13 / 96$ & $961114-\mathrm{A} 10$ & 961114-A09 & $961122-\mathrm{A} 35$ \\
\hline GW-620 & FTF & $11 / 13 / 96$ & $961114-A 03$ & $961114-A 09$ & $961122-A 35$ \\
\hline GW-733 & EXP-J & $10 / 30 / 96$ & 961031-A07 & 961031-A09 & $961118-A 42$ \\
\hline GW-735 & EXP-J & $11 / 21 / 96$ & 961121-A35 & 961121-A39 & $961206-\mathrm{A75}$ \\
\hline $\mathrm{GW}-744$ & GRIDK1 & $11 / 13 / 96$ & 961113-A49 & $961113-A 51$ & $961122-A 35$ \\
\hline$G W-745$ & GRIDKI & $11 / 13 / 96$ & $961113-243$ & $961113-\mathrm{A5} 1$ & $961122-154$ \\
\hline$G W-746$ & GRIDK1 & $11 / 13 / 96$ & $961113-A 45$ & $961113-A 51$ & $961122-A 54$ \\
\hline GW-747 & GRIDK2 & $11 / 13 / 96$ & $961113-A 47$ & 961113-A51 & $961122-A 35$ \\
\hline $\mathrm{GW}-748$ & GRIDK2 & $11 / 14 / 96$ & $961115-A 08$ & $961115-A 10$ & $961122-A 38$ \\
\hline GW-748 D & GRIDK2 & $11 / 14 / 96$ & 961115-A11 & 961115-A10 & $961122-A 38$ \\
\hline GW-749 & GRIDK2 & $11 / 14 / 96$ & 961115-A15 & $961115-A 10$ & $961123-\mathrm{A} 01$ \\
\hline$G W-750$ & EXP-J & $11 / 26 / 96$ & $961126-\mathrm{A} 43$ & $961126-A 42$ & $961211-\mathrm{A} 03$ \\
\hline$G W-751$ & GRIDJ3 & $11 / 18 / 96$ & 961118-A49 & 961118-A51 & $961123-A .01$ \\
\hline GW-752 & GRIDJ3 & $11 / 18 / 96$ & $961118-A 47$ & $961118-A 51$ & $961123-\mathrm{AO} 1$ \\
\hline GW-763 & GRIDJ3 & $11 / 14 / 96$ & 961115-A01 & $961115-\mathrm{A} 03$ & $961122-A 38$ \\
\hline GW-766 & GRIDI2 & $10 / 09 / 96$ & $961009-B 09$ & $961009-B 11$ & $961011-A 35$ \\
\hline GW-767 & GRIDI2 & $10 / 09 / 96$ & 961009-B07 & $961009-B 11$ & $961011-A 35$ \\
\hline GW-769 & GRIDG3 & $10 / 15 / 96$ & $961015-B 09$ & $961015-B 16$ & $961029-\mathrm{AO} 2$ \\
\hline GW-769D & GRIDG3 & $10 / 15 / 96$ & $961015-B 11$ & $961015-B 16$ & $961029-\mathrm{AO} 2$ \\
\hline GW-770 & GRIDG3 & $10 / 15 / 96$ & $961015-B 14$ & $961015-B 16$ & $961029-\mathrm{A} 02$ \\
\hline
\end{tabular}


APPENDIX E.1

Correlation of Samples to Associated Blanks Fourth Quarter 1996

\begin{tabular}{|c|c|c|c|c|c|}
\hline $\begin{array}{l}\text { Sampling } \\
\text { Point }\end{array}$ & Location & $\begin{array}{l}\text { Date } \\
\text { Sampled }\end{array}$ & $\begin{array}{c}\text { Sample } \\
\text { No. }\end{array}$ & $\begin{array}{c}\text { Trip Blank } \\
\text { No. }\end{array}$ & $\begin{array}{c}\text { Lab Blank } \\
\text { No. }\end{array}$ \\
\hline $\begin{array}{l}G W-775 \\
G W-776 \\
G W-779 \\
G W-780 \\
G W-781 \\
G W-782 \\
G W-783 \\
G W-786 \\
G W-787 \\
G W-788 \\
G W-788 \\
G W-789 \\
G W-791 \\
G W-792 \\
G W-816 \\
G W-817\end{array}$ & $\begin{array}{l}\text { GRIDH3 } \\
\text { GRIDH3 } \\
\text { GRIDF2 } \\
\text { GRIDF2 } \\
\text { GRIDE3 } \\
\text { GRIDE3 } \\
\text { GRIDE3 } \\
\text { GRIDE2 } \\
\text { GRIDE2 } \\
\text { GRIDE3 } \\
\text { GRIDE3 } \\
\text { GRIDF3 } \\
\text { GRIDD2 } \\
\text { GRIDD2 } \\
\text { EXP-SR } \\
\text { GRIDK3 }\end{array}$ & $\begin{array}{l}10 / 10 / 96 \\
10 / 10 / 96 \\
11 / 07 / 96 \\
11 / 07 / 96 \\
11 / 11 / 96 \\
11 / 12 / 96 \\
11 / 12 / 96 \\
11 / 07 / 96 \\
11 / 07 / 96 \\
11 / 11 / 96 \\
11 / 11 / 96 \\
11 / 11 / 96 \\
11 / 12 / 96 \\
11 / 11 / 96 \\
11 / 21 / 96 \\
11 / 14 / 96\end{array}$ & $\begin{array}{l}961010-\mathrm{A} 71 \\
961010-\mathrm{A} 69 \\
961108-\mathrm{AO} 1 \\
961108-\mathrm{A} 03 \\
961112-\mathrm{A} 34 \\
961112-\mathrm{B} 02 \\
961112-\mathrm{B} 06 \\
961108-\mathrm{A} 07 \\
961108-\mathrm{A} 05 \\
961112-\mathrm{A} 42 \\
961112-\mathrm{A} 40 \\
961112-\mathrm{A} 38 \\
961112-\mathrm{B} 04 \\
961112-\mathrm{A} 36 \\
961121-\mathrm{A} 37 \\
961115-\mathrm{A} 13\end{array}$ & $\begin{array}{l}961010-\mathrm{A} 73 \\
961010-\mathrm{A} 73 \\
961108-\mathrm{A} 09 \\
961108-\mathrm{A} 09 \\
961112-\mathrm{A} 44 \\
961112-\mathrm{B} 08 \\
961112-\mathrm{B} 08 \\
961108-\mathrm{A} 09 \\
961108-\mathrm{A} 09 \\
961112-\mathrm{A} 44 \\
961112-\mathrm{A} 44 \\
961112-\mathrm{A} 44 \\
961112-\mathrm{B} 08 \\
961112-\mathrm{A} 44 \\
961121-\mathrm{A} 39 \\
961115-\mathrm{A} 10\end{array}$ & $\begin{array}{l}961011-\mathrm{A} 35 \\
961011-\mathrm{A} 35 \\
961113-\mathrm{A} 29 \\
961113-\mathrm{A} 29 \\
961118-\mathrm{A} 61 \\
961122-\mathrm{A} 54 \\
961122-\mathrm{A} 54 \\
961118-\mathrm{A} 61 \\
961113-\mathrm{A} 29 \\
961118-\mathrm{A} 61 \\
961118-\mathrm{A} 61 \\
961118-\mathrm{A} 61 \\
961122-\mathrm{A} 54 \\
961118-\mathrm{A} 61 \\
961206-\mathrm{A} 75 \\
961123-\mathrm{A} 01\end{array}$ \\
\hline
\end{tabular}


APPENDLX E.2

TRIP BLANK DATA SUMMARY 


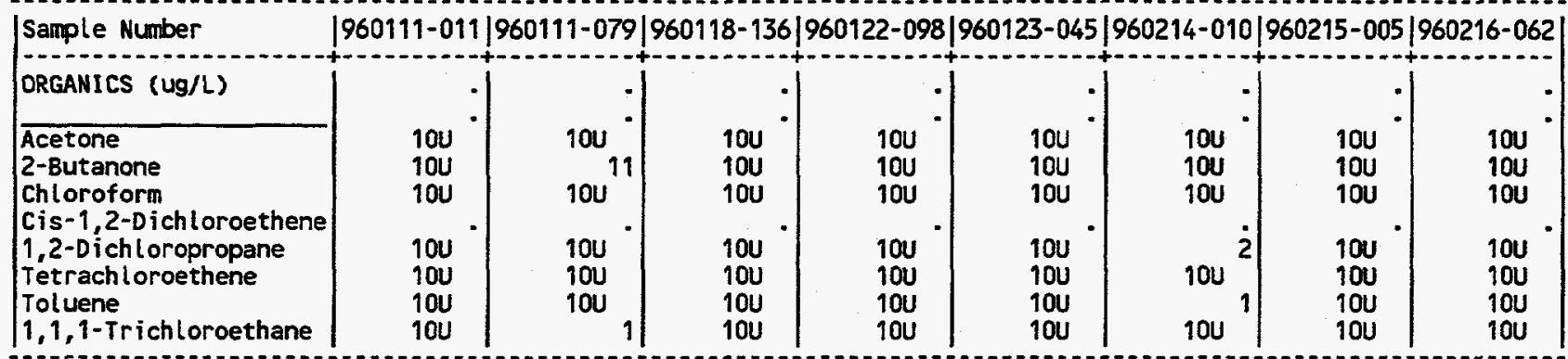

(CONT INUED)

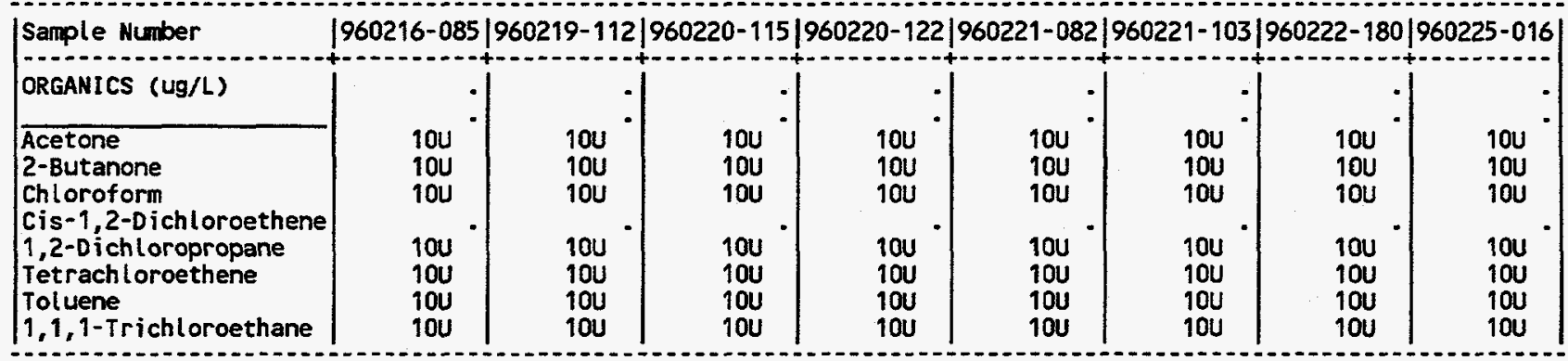

(CONTINUED)

\begin{tabular}{|c|c|c|c|c|c|c|c|c|}
\hline Sample Number & $|960225-033|$ & |960226-022 & $|960228-160|$ & |960301-007 & |960304-094 & $|960305-020|$ & |960305-080| & $60305-100$ \\
\hline ORGANICS (ug/L) & & & & & - & & & \\
\hline $\begin{array}{l}\text { Acetone } \\
\text { 2-Butanone } \\
\text { Chloroform } \\
\text { Cis-1,2-D ichloroethene } \\
1,2-D \text { ichloropropane } \\
\text { Tetrachloroethene } \\
\text { Toluene } \\
1,1,1-\text { Trichloroethane }\end{array}$ & $\begin{array}{l}100 \\
100 \\
100 \\
100 \\
100 \\
100 \\
100\end{array}$ & $\begin{array}{l}100 \\
100 \\
100 \\
100 \\
100 \\
100 \\
100\end{array}$ & $\begin{array}{l}100 \\
100 \\
100 \\
100 \\
100 \\
100 \\
100 \\
10 u\end{array}$ & $\begin{array}{l}100 \\
100 \\
100 \\
100 \\
100 \\
100 \\
100 \\
100\end{array}$ & $\begin{array}{l}100 \\
100 \\
100 \\
100 \\
100 \\
100\end{array}$ & $\begin{array}{l}100 \\
100 \\
100 \\
100 \\
100 \\
100 \\
100\end{array}$ & $\begin{array}{l}100 \\
100 \\
100 \\
100 \\
100 \\
100 \\
10 u\end{array}$ & $\begin{array}{l}10 U^{13} \\
10 U^{-} \\
10 U^{100} \\
10 U^{-}\end{array}$ \\
\hline
\end{tabular}

\section{(CONT INUED)}

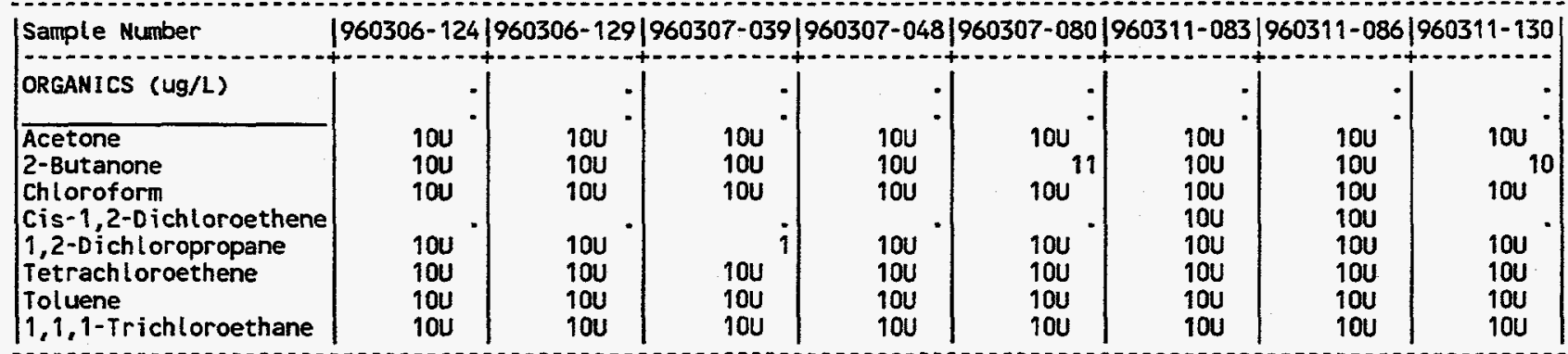

(CONT INUED) 
APPENDIX E.?

Organics Detected in Trip Blank Samples, First Quarter 1996

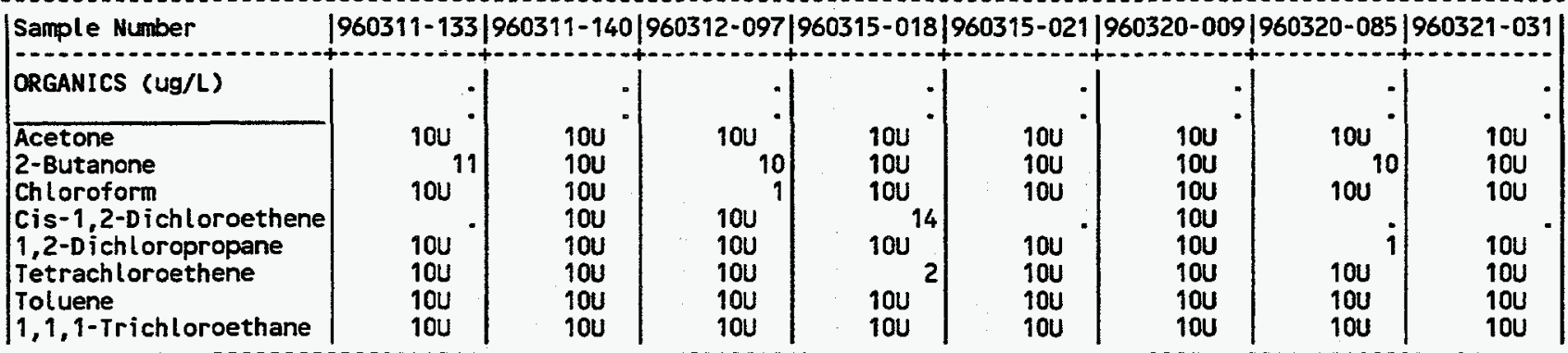

(CONT INUED)

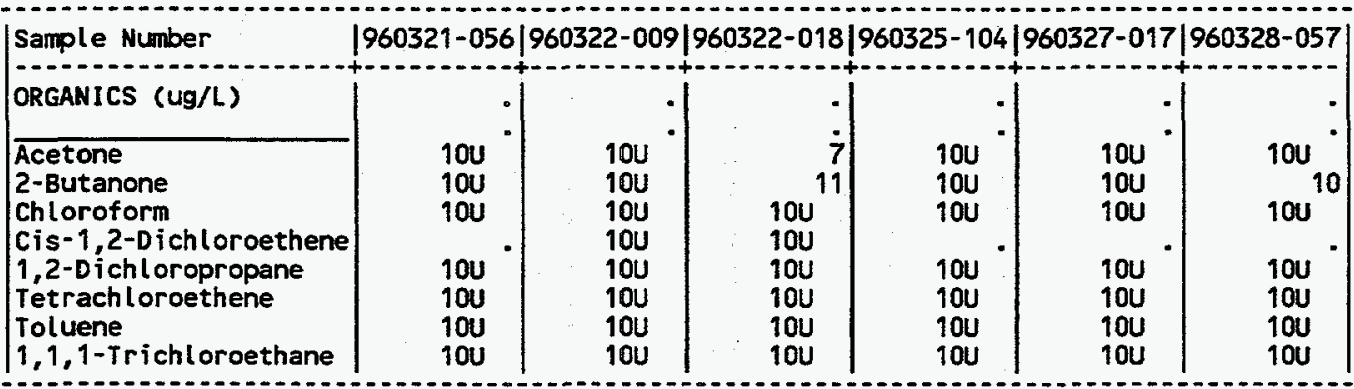


APPENDIX E.2

Organics Detected in Trip Blank Samples, Second Quarter 1996

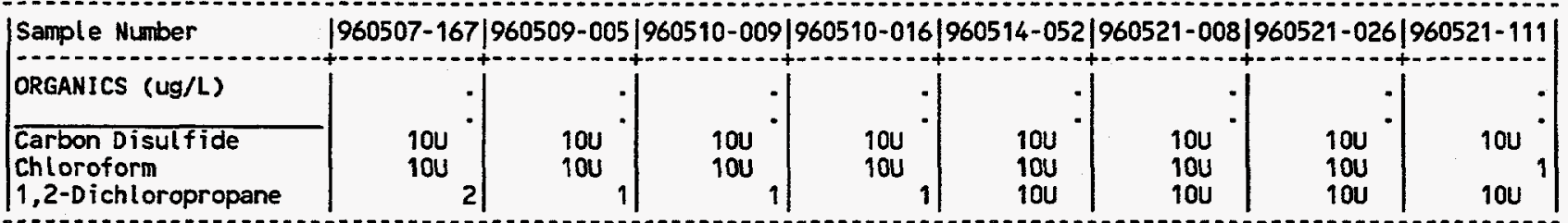

(CONT INUED)

\begin{tabular}{|c|c|c|c|c|c|c|c|c|}
\hline Sample Number & $|960523-009|$ & $|960523-018|$ & |960524-005| & |960524-017| & $|960528-063|$ & |960529-060 & $|960531-003|$ & $|960531-056|$ \\
\hline ORGANICS (Ug/L) & & & & & & &.$j$ & \\
\hline $\begin{array}{l}\text { Carbon Disulfide } \\
\text { Chloroform } \\
\text { 1,2-Dichloropropane }\end{array}$ & $100^{\circ}$ & $\begin{array}{r}100 \\
2 \\
2\end{array}$ & $\begin{array}{l}100 \\
100\end{array}$ & $\begin{array}{l}100 \\
100 \\
100\end{array}$ & $\begin{array}{l}100 \\
100 \\
100\end{array}$ & $\begin{array}{l}100 \\
100 \\
100\end{array}$ & $\begin{array}{l}100 \\
100 \\
100\end{array}$ & ${ }_{2}^{100^{\circ}}$ \\
\hline
\end{tabular}

(CONT INUED)

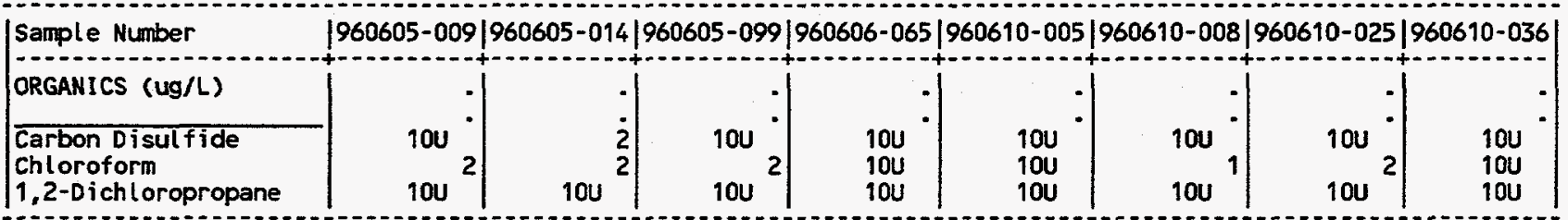

(CONTINUED)

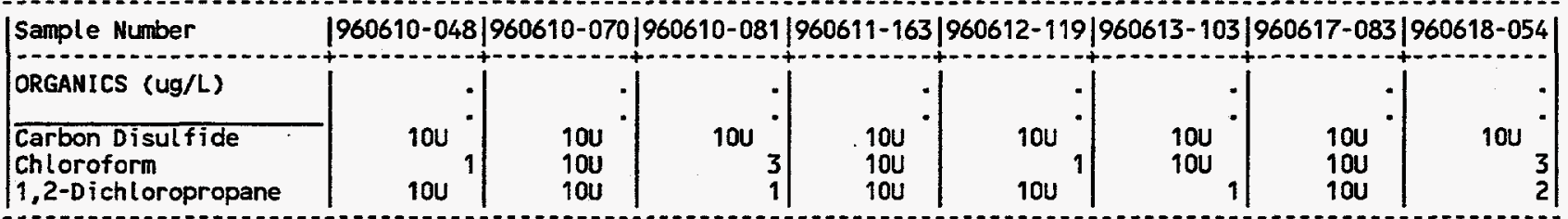

(CONTINUED)

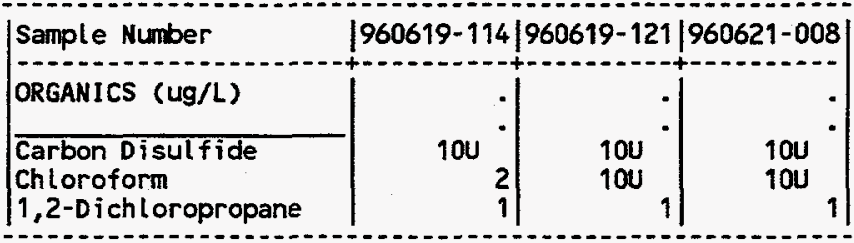


APPENDIX E.2

Organics Detected in Trip Blank Samples, Third Quarter 1996

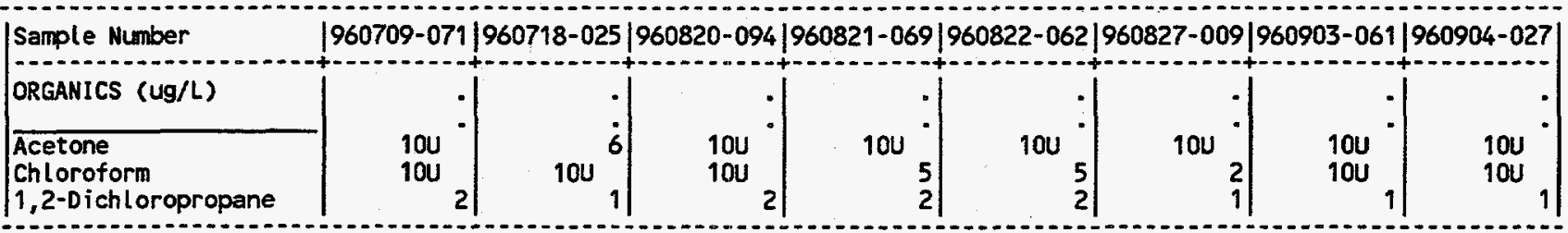

(CONT INUED)

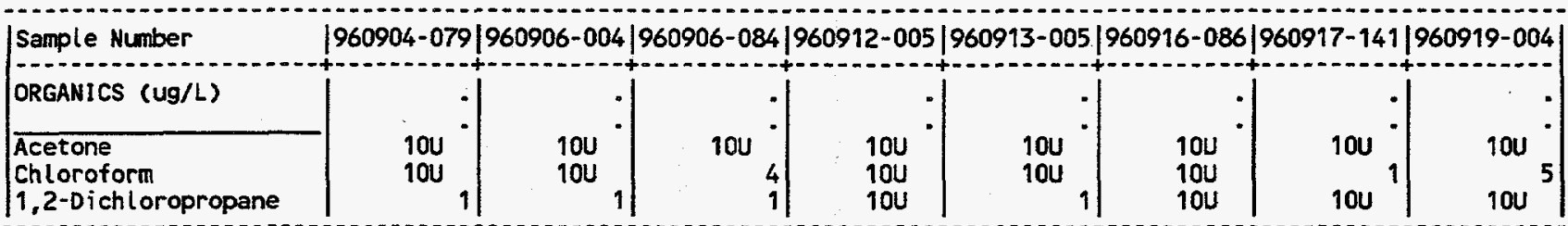

(CONTINUED)

\begin{tabular}{|c|c|c|c|}
\hline Sample Number & |960919-008 & |960919-098 & 1960925-A30 \\
\hline ORGANICS (ug/L) & & & \\
\hline $\begin{array}{l}\text { Acetone } \\
\text { Chloroform } \\
\text { 1,2-Dichloropropane }\end{array}$ & ${ }_{100^{10}}^{6}$ & ${ }_{100}^{100} 2$ & ${ }_{100}^{100} 7$ \\
\hline
\end{tabular}


APPENDIX E.2

Organics Detected in Trip Blank Samples, Fourth Quarter 1996

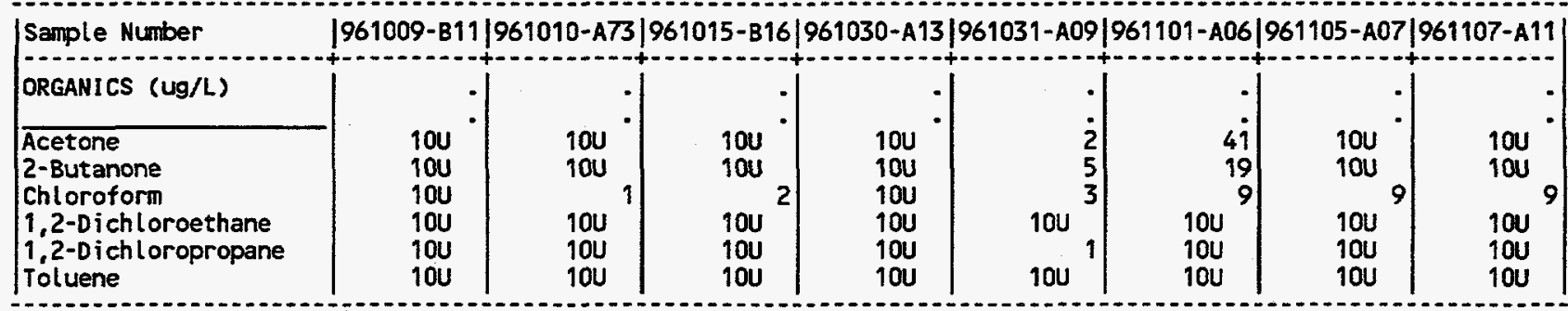

\section{(CONT INUED)}

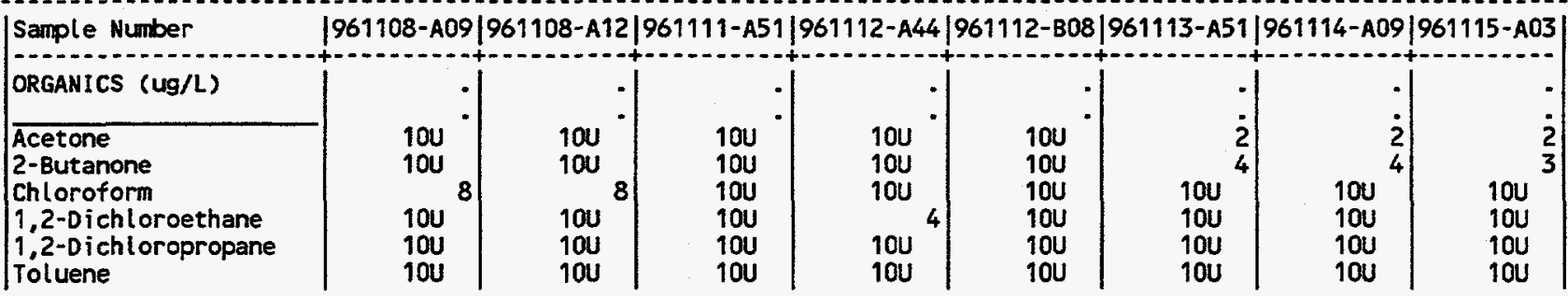

(CONT INUED)

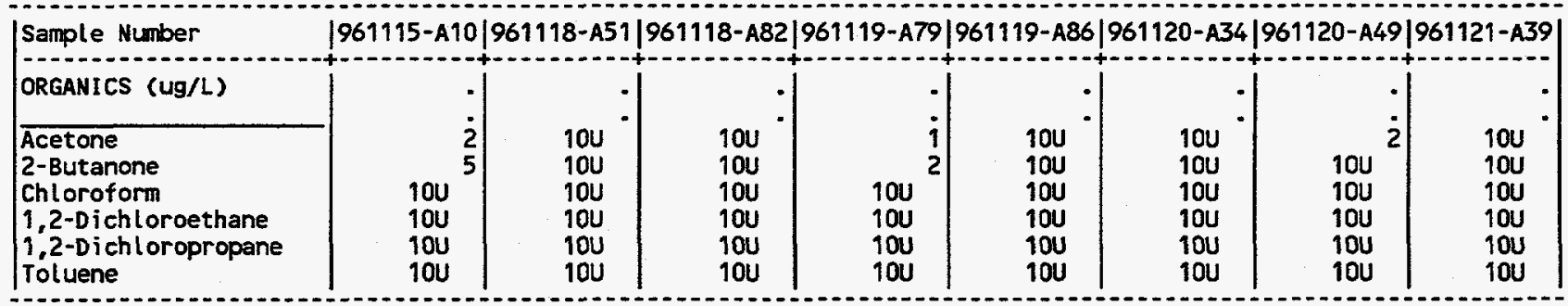

(CONT INUED)

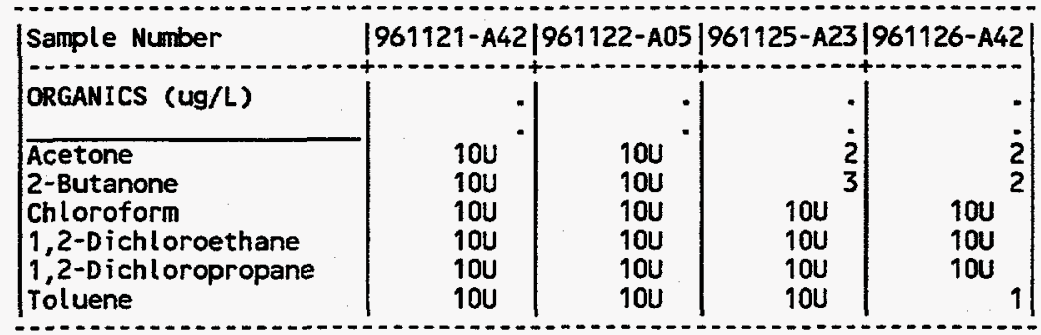


APPENDIX E.3

LABORATORY BLANK DAT A SUMMARY 


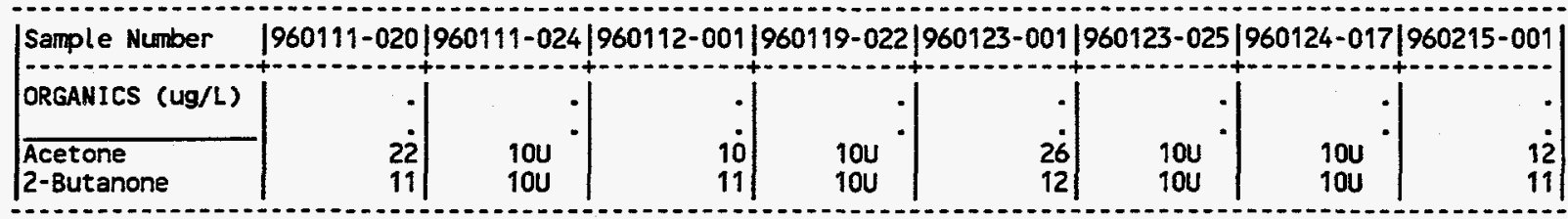

(CONT INUED)

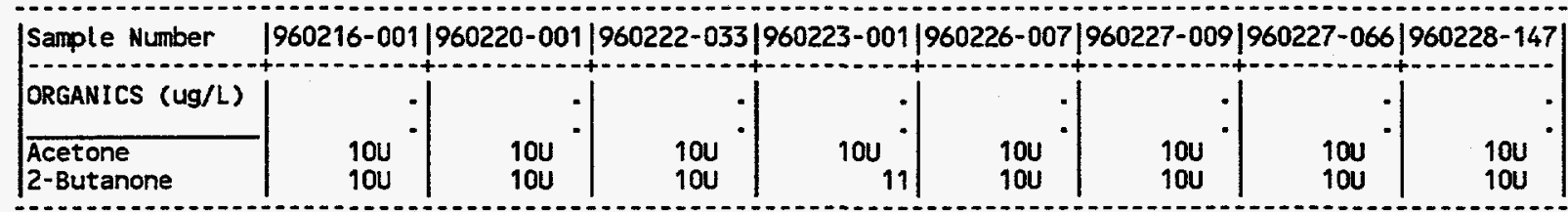

(CONT INUED)

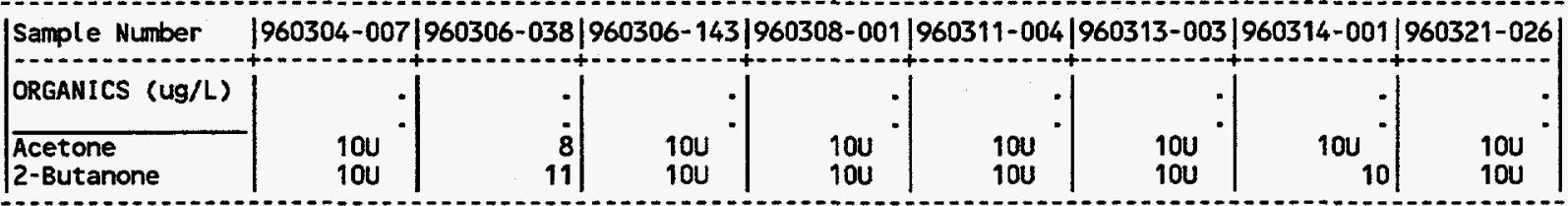

(CONTINUED)

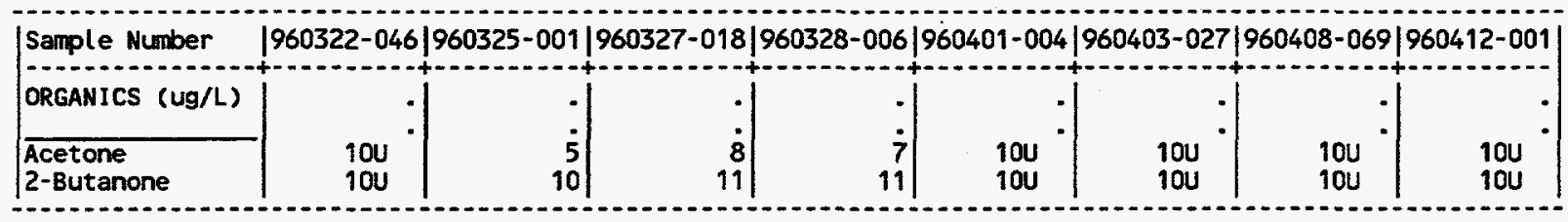




$\mid$\begin{tabular}{l} 
Sample Number \\
\hline ORGANICS (ug/L)
\end{tabular}

(CONTINUED)

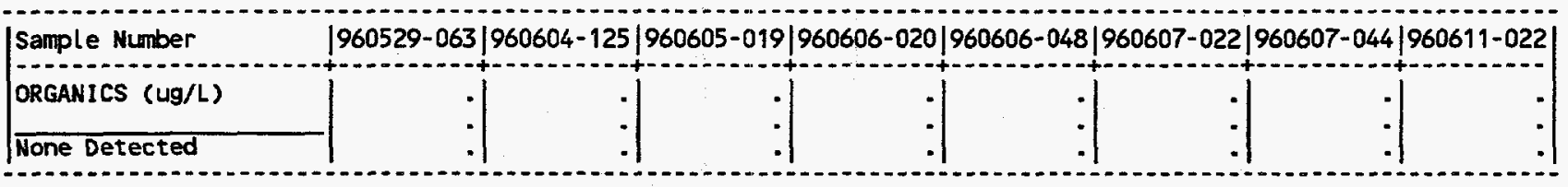

\section{(CONT INUED)}

$\mid$\begin{tabular}{l} 
Sample Number \\
\hline ORGANICS (ug/L)
\end{tabular}

\section{(CONT INUED)}

$\mid$\begin{tabular}{|r} 
Sample Number \\
\hline ORGANICS (ug/L) \\
\hline None Detected
\end{tabular}


Organics Detected in Laboratory Blank Samples, Third Quarter 1996

Sample Number $|960710-003| 960718-003|960822-001| 960823-011|960827-001| 960904-008|960905-001| 960906-001 \mid$ ORGANICS (Ug/L)

None Detected

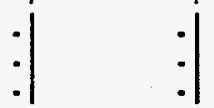

.
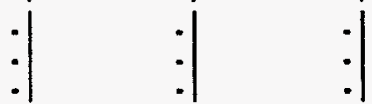

(CONTINUED)

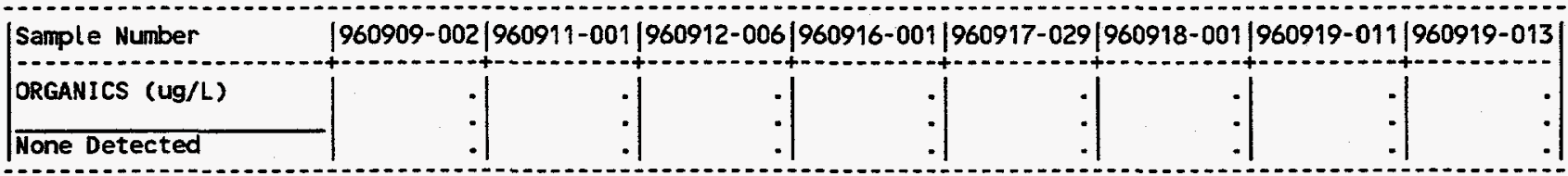

(CONTINUED)

$\left|\begin{array}{l}\text { Sample Number } \\ \hline \text { ORGANICS (ug/L) }\end{array}\right|$


APPENDIX E.3

Organics Detected in Laboratory Blank Samples, Fourth Quarter 1996

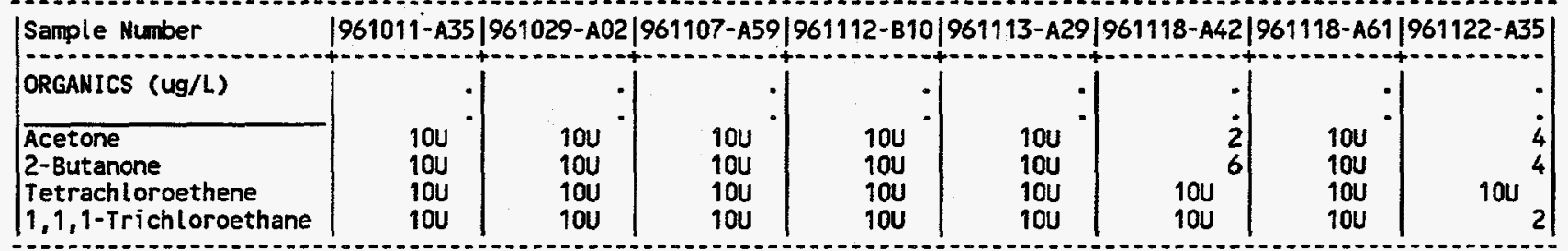

(CONTINUED)

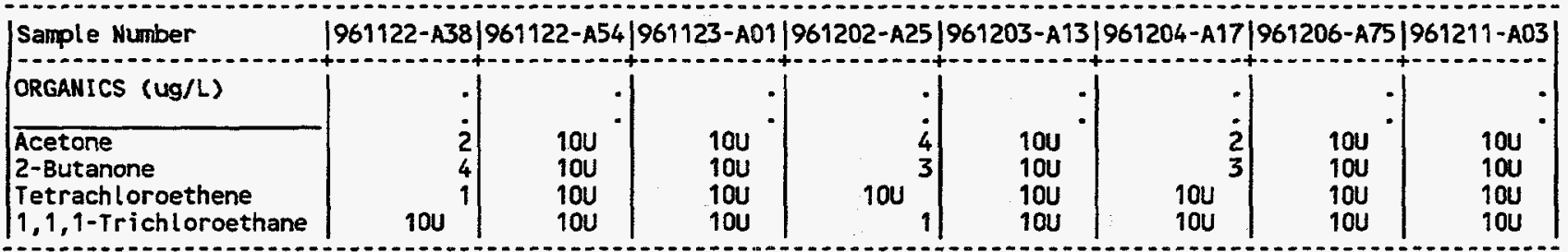


APPENDIX E.4

EQUIPMENT RINSATE DATA SUMMARY 
APPENDIX E.4

Organic and Inorganic Analytes Detected in Equipment Rinsate Samples, CY 1996

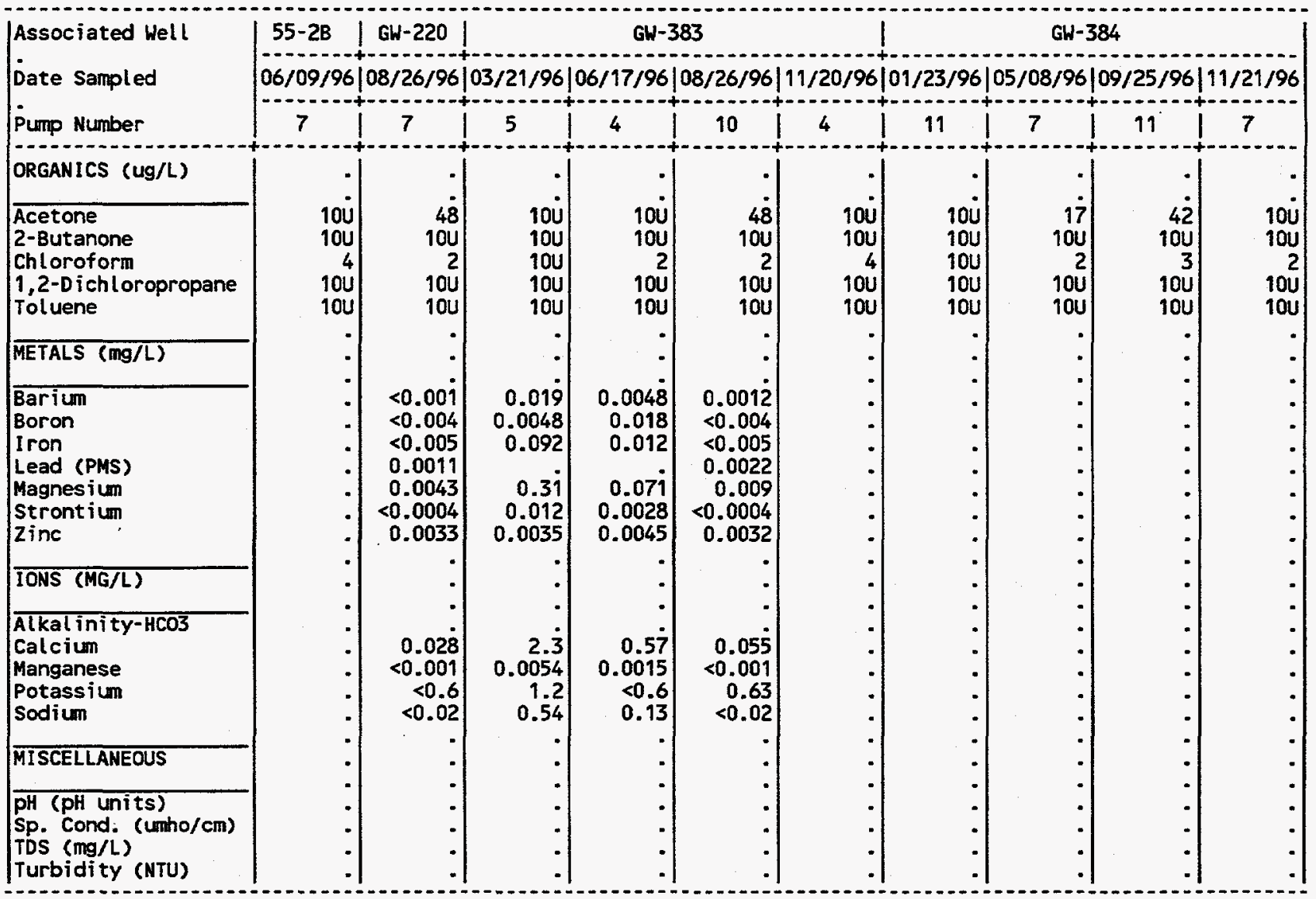

(CONTINUED) 
APPENDIX E.4

Organic and Inorganic Analytes Detected in Equipment Rinsate Samples, CY 1996

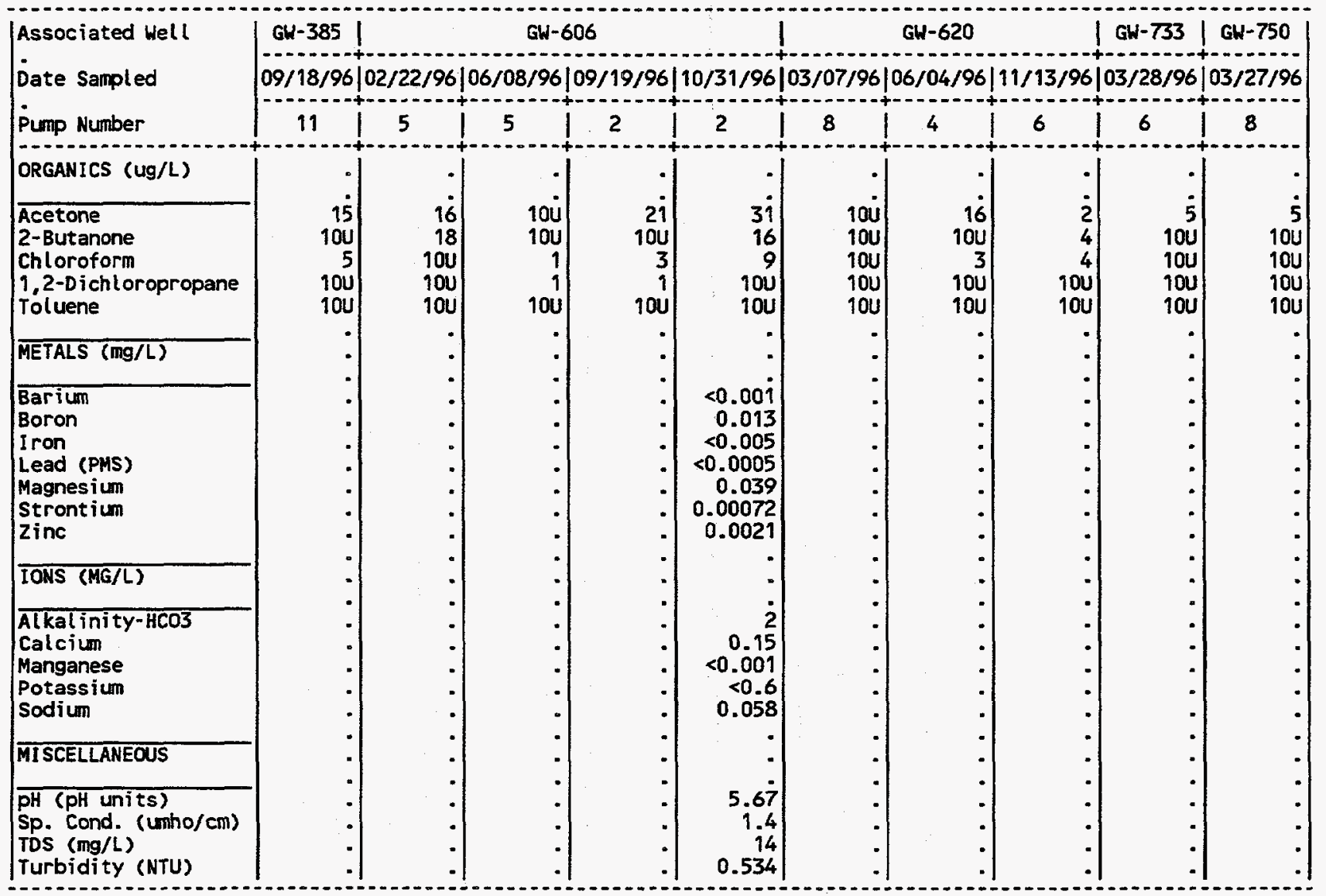

(CONTINUED) 
APPENDIX E.4

Organic and Inorganic Analytes Detected in Equipment Rinsate Samples, CY 1996

\begin{tabular}{|c|c|c|c|c|c|c|c|}
\hline $\begin{array}{l}\text { Associated Well } \\
\text { Date Sampled } \\
\text { Pump Number }\end{array}$ & \begin{tabular}{|c|} 
GW-750 \\
$11 / 26 / 96$ \\
5
\end{tabular} & $11 / 96$ & $\begin{array}{c}\text { GW-769 } \\
05 / 20 / 96\end{array}$ & $|10 / 15 / 96|$ & $03 / 06 / 96$ & $\begin{array}{c}\text { GW-791 } \\
05 / 23 / 96 \mid\end{array}$ & $1 / 12 / 96$ \\
\hline ORGANICS (ug/L) & & & & & & - & \\
\hline $\begin{array}{l}\text { Acetone } \\
\text { 2-Butanone } \\
\text { Chloroform } \\
\text { 1,2-Dichloropropane } \\
\text { Toluene }\end{array}$ & $\begin{array}{l}10 u \\
100 \\
100 \\
100 \\
100\end{array}$ & $\begin{array}{l}100 \\
100 \\
100 \\
100 \\
100\end{array}$ & $\begin{array}{r}16 \\
100 \\
2 \\
100 \\
100\end{array}$ & $\begin{array}{r}100 \\
100 \\
2 \\
100 \\
1\end{array}$ & $\begin{array}{r}100 \\
100 \\
10 U \\
1 \\
10 U\end{array}$ & $\begin{array}{r}10 \\
12 \\
3 \\
100 \\
100\end{array}$ & $\begin{array}{r}22 \\
13 \\
9 \\
10 u \\
10 u\end{array}$ \\
\hline METALS (mg/L) & 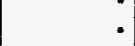 & & - & . & - & . & $\theta$ \\
\hline $\begin{array}{l}\text { Barium } \\
\text { Boron } \\
\text { Iron } \\
\text { Lead (PMS) } \\
\text { Magnesium } \\
\text { Strontium } \\
\text { Zine }\end{array}$ & $\begin{array}{l}: \\
: \\
:\end{array}$ & - & : & $\begin{array}{l}: \\
: \\
: \\
:\end{array}$ & : & $\begin{array}{l}: \\
- \\
:\end{array}$ & 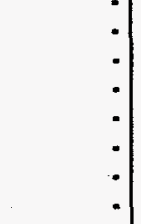 \\
\hline IONS (MG/L) & & $\bullet$ & - & - & : & . & - \\
\hline $\begin{array}{l}\text { Alkalinity-HCO3 } \\
\text { Calcium } \\
\text { Manganese } \\
\text { Potassium } \\
\text { Sodium }\end{array}$ & $\begin{array}{l}: \\
: \\
-\end{array}$ & - & $:$ & $\dot{:}:$ & - & : & \\
\hline MISCELLANEOUS & & & - & . & $\bullet$ & : & 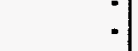 \\
\hline $\begin{array}{l}\text { PH (pH units) } \\
\text { Sp. Cond. (umho/cm) } \\
\text { TDS (mg/L) } \\
\text { Turbidity (NTU) }\end{array}$ & ${ }^{-}$ & & : & $:$ & - & : & • \\
\hline
\end{tabular}


APPENDIX E.4

Radiological Analytes in Equipment Rinsate Samples, CY 1996

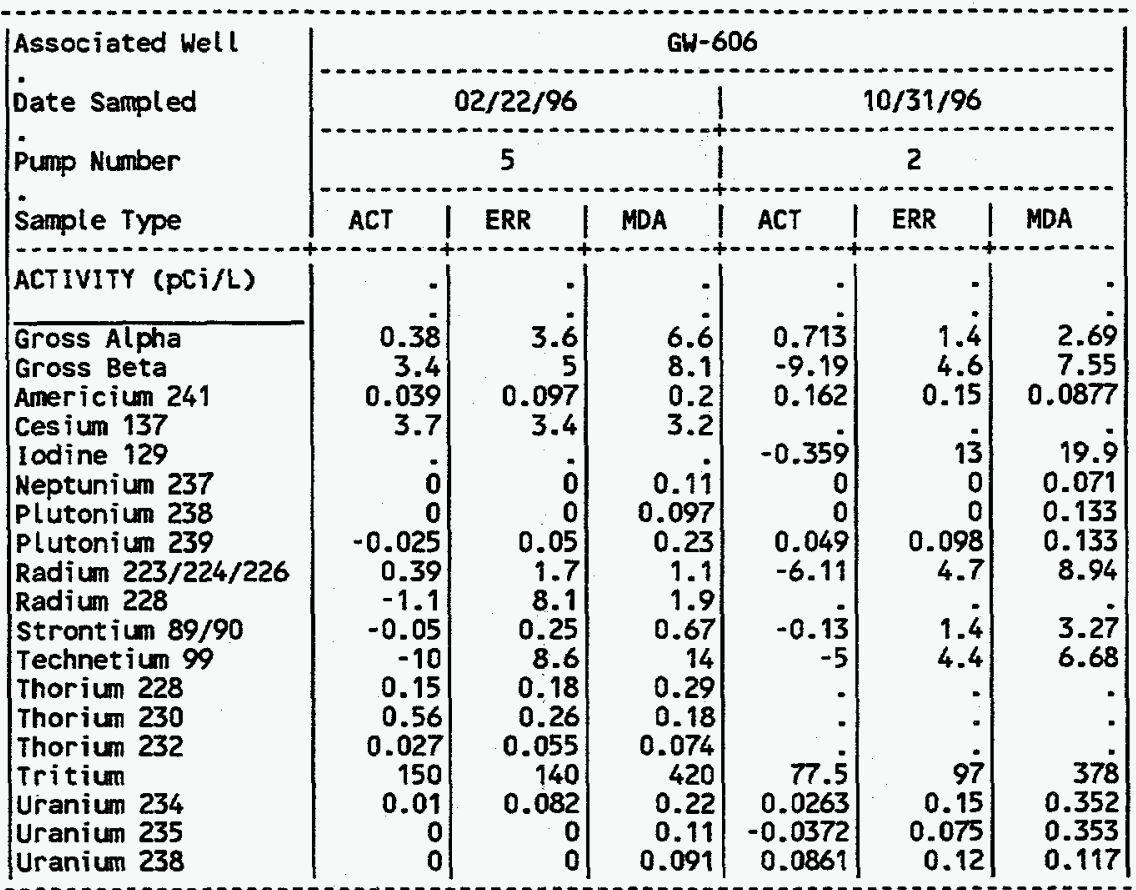


APPENDIX E.5

FIELD BLANK DATA SUMMARY 
APPENDIX E.5

Organic and Inorganic Analytes Detected in Field Blanks, CY 1996

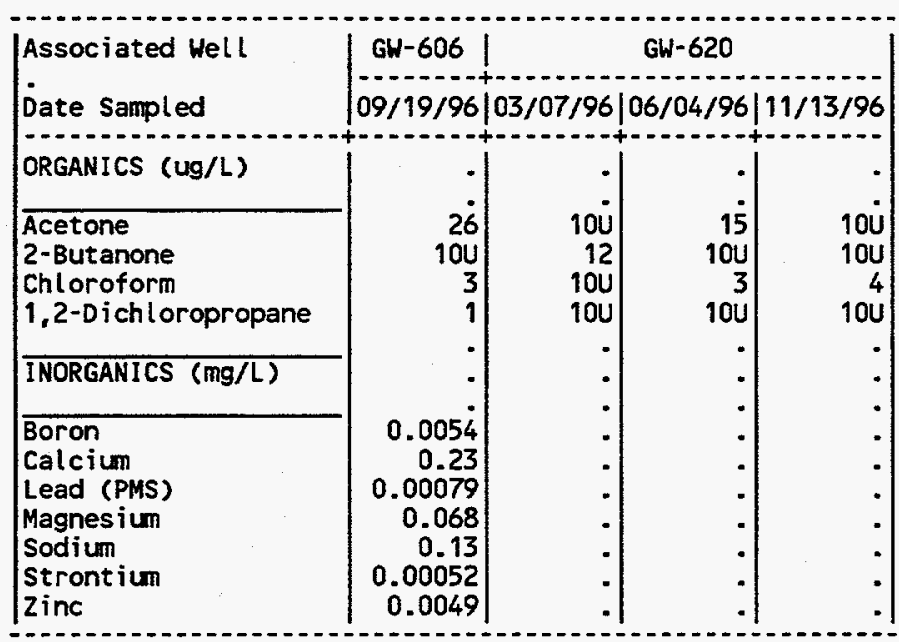




\section{APPENDIX F}

DATA SCREENING PROCESS AND DQO CRITERIA 


\section{CONTENTS}

$\underline{\text { Section }}$

Page

List of Tables F-2

List of Acronyms and Abbreviations F-3

F.1 INTRODUCTION F-4

F.2 SCREENED RESULTS FOR DUPLICATE SAMPLES F-5

F.3 SCREENED RESULTS FOR FILTERED/UNFILTERED SAMPLES F-6

F.4 SCREENED RESULTS FOR PRINCIPAL IONS $\ldots \ldots \ldots \ldots \ldots \ldots \ldots \ldots \ldots$ F-7

F.5 SCREENED RESULTS FOR VOLATILE ORGANIC COMPOUNDS F-9

F.6 SCREENED RESULTS FOR RADIOANALYTES F-12

F.7 SUMMARY AND CONCLUSIONS F-13 


\section{List of Tables}

$\underline{\text { Table }}$ Page

F-1 DQO Criteria for Groundwater and Surface Water Quality Data . . . . . . . . . F-4

F-2 Duplicate Sampling Locations and Dates $\ldots \ldots \ldots \ldots \ldots \ldots \ldots \ldots \ldots \ldots$

F-3 Screened Results for Duplicate Samples $\ldots \ldots \ldots \ldots \ldots \ldots \ldots \ldots \ldots \ldots \ldots$ F-6

F-4 Screened Results for Filtered/Unfiltered Samples $\ldots \ldots \ldots \ldots \ldots \ldots \ldots \ldots \ldots$ F-7

F-5 Samples with Unacceptable Charge Balance Errors $\ldots \ldots \ldots \ldots \ldots \ldots \ldots \ldots \ldots$ F-8

F-6 False Positive Results for VOCs $\ldots \ldots \ldots \ldots \ldots \ldots \ldots \ldots \ldots \ldots \ldots \ldots$

F-7 Screened Results for Radioanalytes $\ldots \ldots \ldots \ldots \ldots \ldots \ldots \ldots \ldots \ldots \ldots \ldots \ldots \ldots$ 


\section{List of Acronyms and Abbreviations}

$\mathrm{BQR}$

CERCLA

\section{CY}

DOE

DQO

GWPP

GWPS

MDA

$\mu \mathrm{g} / \mathrm{L}$

$\mathrm{mg} / \mathrm{L}$

$\mathrm{pCi} / \mathrm{L}$

RCRA

RI

VOC blank qualification result

Comprehensive Environmental Response, Compensation and Liability Act

calendar year

Department of Energy

data quality objective

Groundwater Protection Program

(RCRA) Groundwater Protection Standard

minimum detectable activity

micrograms per liter

milligrams per liter

picoCuries per liter

Resource Conservation and Recovery Act

Remedial Investigation

volatile organic compound 


\section{F.1 INTRODUCTION}

The following sections describe the data screening process used to identify calendar year (CY) 1996 groundwater and surface water quality data that did not meet data quality objectives (DQOs) of the Y-12 Plant Groundwater Protection Program (GWPP). The data screening process applied to groundwater and surface water quality data obtained for: (1) Resource Conservation and Recovery Act (RCRA) interim status assessment monitoring; (2) RCRA post-closure corrective action monitoring; (3) Department of Energy (DOE) Order 5400.1 surveillance monitoring and exit pathway/perimeter monitoring (DOE Order 5400.1 Monitoring); (4) Comprehensive Environmental Response, Compensation and Liability Act (CERCLA) monitoring performed in support of the remedial investigation (RI) for the Upper East Fork Poplar Creek characterization area (CERCLA Monitoring); and (5) monitoring performed as a best management practice of the Y-12 Plant GWPP.

Table F-1 shows the DQO criteria applicable to analytical results for principal ions, trace metals, volatile organic compounds (VOCs), radiological analytes, and miscellaneous laboratory analytes (see Table 5 in Appendix B)

Table F-1. DQO Criteria for Groundwater and Surface Water Quality Data

\begin{tabular}{|c|c|c|c|c|c|c|}
\hline \multirow{2}{*}{$\begin{array}{l}\text { DOO } \\
\text { Criteria }\end{array}$} & \multicolumn{2}{|c|}{ Principal rons } & \multirow{2}{*}{ Mrace } & \multirow[t]{2}{*}{ Vors } & \multirow[t]{2}{*}{ Gadioanalytes } & \multirow{2}{*}{ trisc. } \\
\hline & Anions: & Cations & & & & \\
\hline Duplicate Sample Results & 9 & - & 8 & 9 & 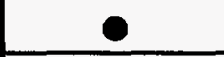 & 0 \\
\hline Filtered/Unfiltered Sample & . & - & - & . & . & . \\
\hline Ion Charge Balance Errors & 9 & - & . & . & . & $\dot{.}$ \\
\hline False Positive Results & . & . & . & - & . & . \\
\hline Counting Errors & & & & & 0 & \\
\hline
\end{tabular}

As described in the following sections, results that did not meet applicable $D Q O$ criteria were replaced with an appropriate surrogate value (e.g., zero) or considered qualitative (principal ions). Each section is particularly focused on results for the RCRA Groundwater Protection Standard (GWPS) constituents specified for the Eastern S-3 Ponds plume in the RCRA Post-Closure Permit for the Upper East Fork Poplar Creek Hydrogeologic Regime (East Fork Regime). 


\section{F.2 SCREENED RESULTS FOR DUPLICATE SAMPLES}

As shown in Table F-2, a total of 29 duplicate groundwater samples were collected from one spring and 23 monitoring wells, including two wells (GW-115 and GW-193) used for RCRA postclosure corrective action monitoring in the fourth quarter of 1996.

Table F-2. Duplicate Sampling Locations and Dates

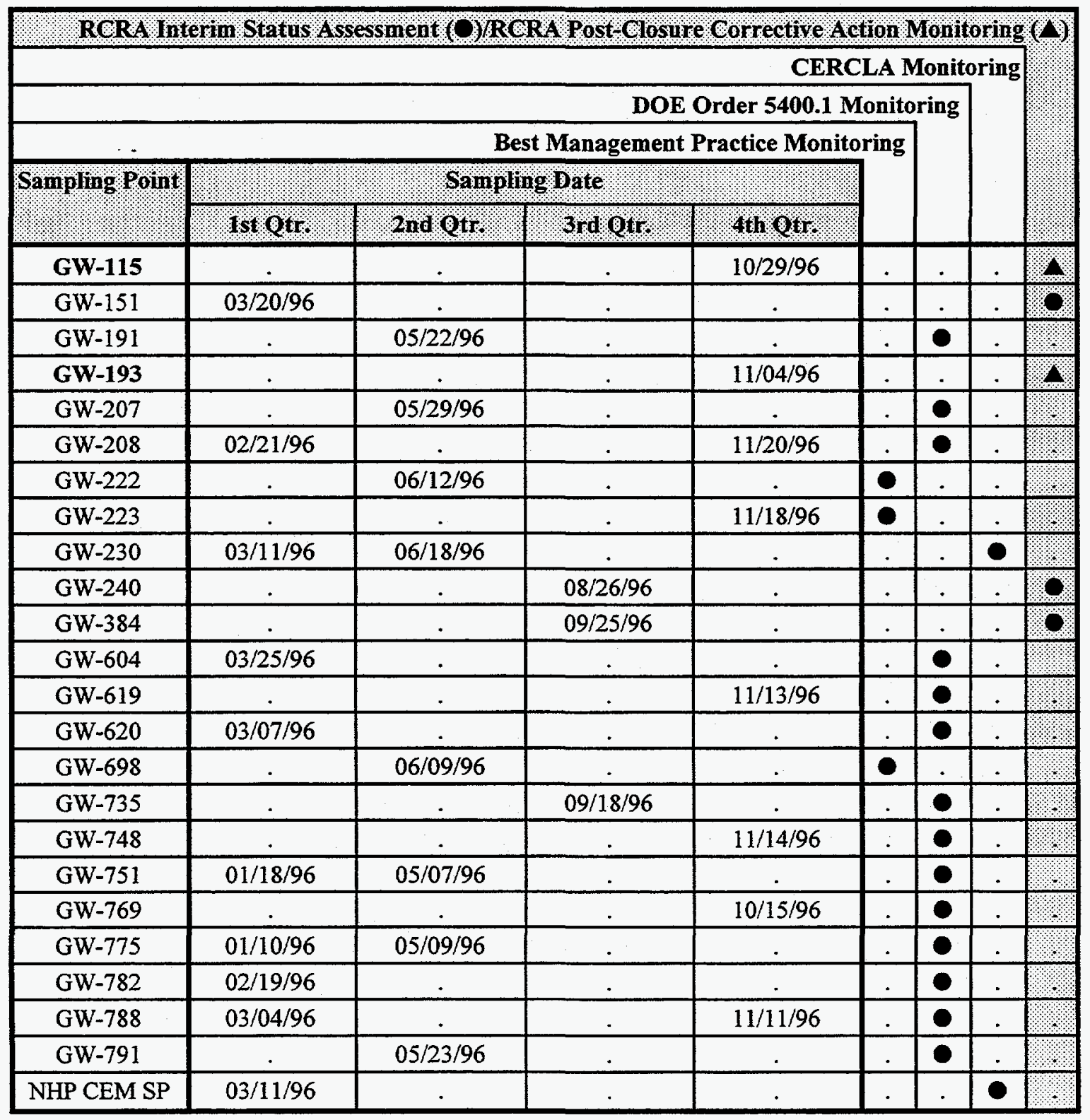


Duplicate samples were analyzed for the same suite of laboratory analytes required by the applicable monitoring program. Corresponding results for duplicate samples that differed by an order-ofmagnitude or more were screened; each screened result was replaced with a missing value (i.e., no analytical result). Such differences occur between the original sample and duplicate sample results shown in Table F-3.

Table F-3. Screened Results for Duplicate Samples

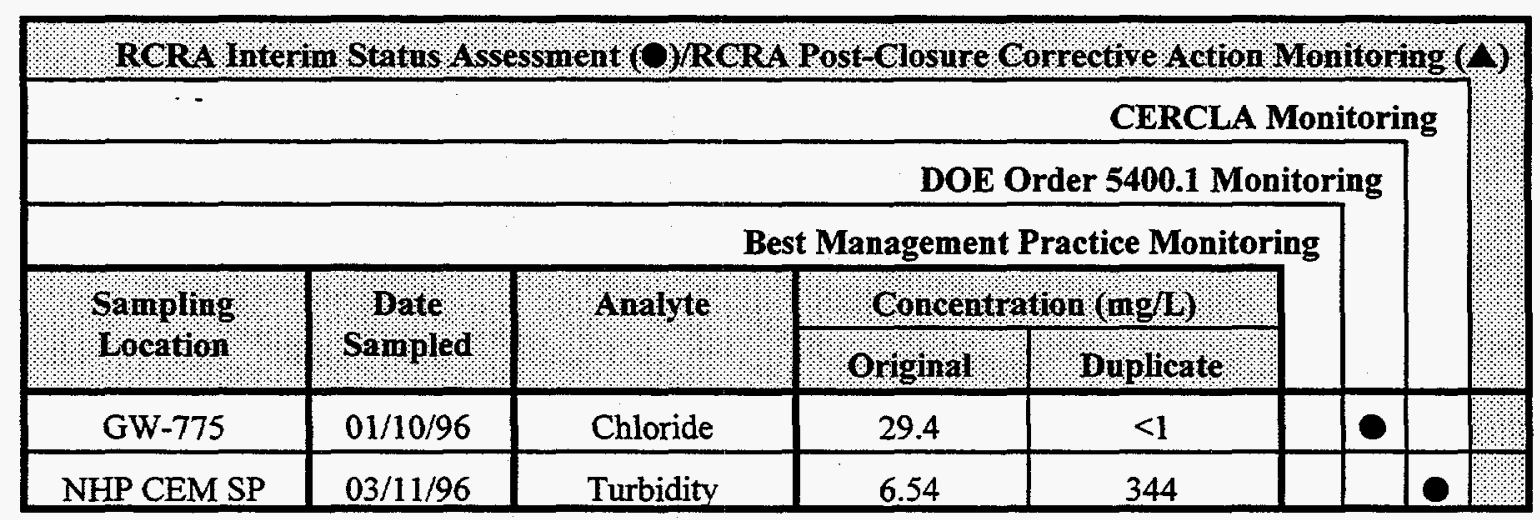

These results are probably analytical or data transcription/reporting errors (chloride), or reflect nonrepresentative sampling (turbidity).

\section{F.3 SCREENED RESULTS FOR FILTERED/UNFILTERED SAMPLES}

Filtered and unfiltered groundwater samples were analyzed for the principal cations and trace metals (see Table 5 in Appendix B). Results were screened (replaced with missing values) if the dissolved (filtered) concentration exceeded the corresponding total (unfiltered) concentration by an order-of-magnitude or more. As shown in Table F-4, such differences occur between the total/dissolved concentrations of six trace metals reported for filtered and unfiltered samples from seven monitoring wells and one spring. 
Table F-4. Screened Results for Filtered/Unfiltered Samples.

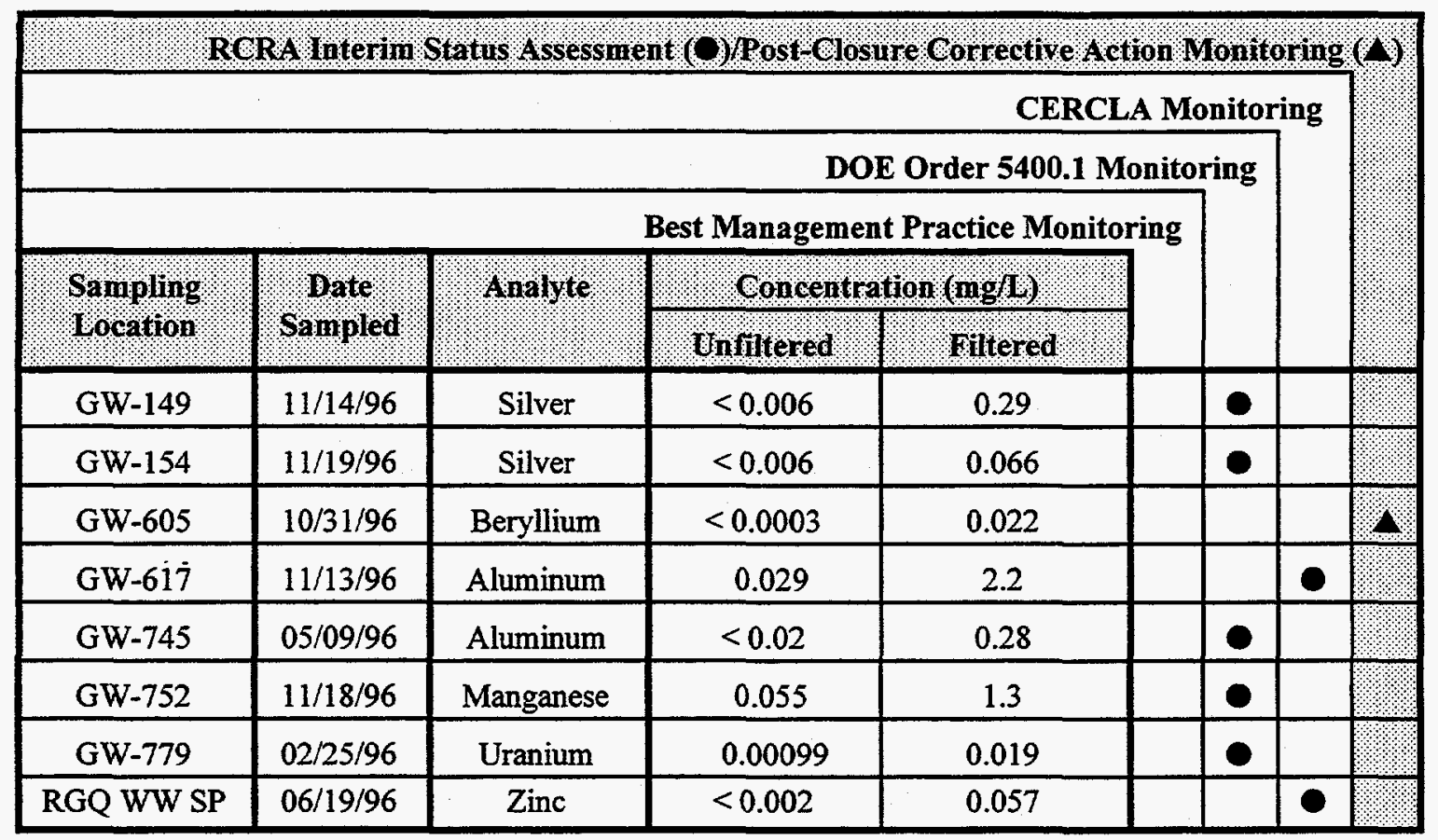

Differences between the total and dissolved concentrations of these metals are probably analytical or data transcription/reporting errors. Screening these results had no impact on the evaluation of RCRA post-closure corrective action monitoring data.

\section{F.4 SCREENED RESULTS FOR PRINCIPAL IONS}

Data for the principal anions (bicarbonate alkalinity, carbonate alkalinity, chloride, fluoride, nitrate, and sulfate) and cations (calcium, magnesium, potassium, and sodium) were screened based on the ion charge balance. Results for all the principal ions were considered qualitative if the charge balance error, expressed as the relative percent difference between respective summed milliequivalent concentrations (i.e., molecular weight of the ion divided by the net ionic charge) of the dissolved cations (which exclude digested cations) and the total anions, exceeded $10 \%$. As summarized below in Table F-5, such charge balance errors were calculated from the principal ion data reported for a total of 21 groundwater samples collected from one spring and 13 monitoring wells, none of which were used for RCRA post-closure corrective action monitoring. 
Table F-5. Groundwater Samples with Unacceptable Charge Balance Errors

\begin{tabular}{|c|c|c|c|c|c|c|c|}
\hline & \multicolumn{7}{|c|}{ RCRA lnterim Status Assessment (O)Post Closure Conrective Action Monitoring ( $)$} \\
\hline & & & \multicolumn{5}{|c|}{ CERCLA Monitoring } \\
\hline & & & \multicolumn{5}{|c|}{ DOE Order 5400.1 Monitoring } \\
\hline & & & \multicolumn{3}{|l|}{ Best Management Practice Monitoring } & & \\
\hline $\begin{array}{l}\text { Sampling } \\
\text { Location }\end{array}$ & Sampled & Balance Error & Suspected Source of Grror & & & & \\
\hline GW-251 & $02 / 21 / 96$ & $-12 \%$ & High nitrate (as $N$ ): $79.2 \mathrm{mg} / \mathrm{L}$ & & - & & \\
\hline GW-253 & $06 / 10 / 96$ & $-21 \%$ & High sodium: $98 \mathrm{mg} / \mathrm{L}$ & - & & & \\
\hline GW-338 & $11 / 11 / 96$ & $21 \%$ & Low bicarbonate: $137 \mathrm{mg} / \mathrm{L}$ & & - & & \\
\hline GW-618 & $11 / 11 / 96$ & $19 \%$ & Low bicarbonate: $148 \mathrm{mg} / \mathrm{L}$ & & & - & \\
\hline GW-619 & 03/06/96 & $28 \%$ & High $\mathrm{pH}: 9.47$; high potassium: $16 \mathrm{mg} / \mathrm{L}$ & & 오 & & \\
\hline GW-619 & $06 / 04 / 96$ & $38 \%$ & High pH: 9.9 ; high potassium: $20 \mathrm{mg} / \mathrm{L}$ & & 오․ & & \\
\hline GW-619 & $11 / 13 / 96$ & $20 \%$ & High pH: 8.61 ; high potassium: $17 \mathrm{mg} / \mathrm{L}$ & & 은 & & \\
\hline GW-619 D & $11 / 13 / 96$ & $26 \%$ & High pH: 8.69 ; high potassium: $18 \mathrm{mg} / \mathrm{L}$ & & - & & \\
\hline GW-620 & $03 / 07 / 96$ & $-29 \%$ & High pH: 11.8 ; bicarbonate $<1 \mathrm{mg} / \mathrm{L}$ & & - & & \\
\hline GW-620 D & $03 / 07 / 96$ & $-23 \%$ & High pH: 11.8 ; bicarbonate $<1 \mathrm{mg} / \mathrm{L}$ & & e & & \\
\hline GW-620 & 06/04/96 & $27 \%$ & High pH: 9.9 ; bicarbonate: $7 \mathrm{mg} / \mathrm{L}$ & & O & & \\
\hline GW-620 & $11 / 13 / 96$ & $28 \%$ & High pH: 9.32 ; bicarbonate: $20 \mathrm{mg} / \mathrm{L}$ & & 으 & & \\
\hline GW-700 & $06 / 08 / 96$ & $-15 \%$ & High sulfate: $98.1 \mathrm{mg} / \mathrm{L}$ & - & & & \\
\hline GW-749 & $11 / 14 / 96$ & $-12 \%$ & High sulfate: $46.4 \mathrm{mg} / \mathrm{L}$ & & 온 & & \\
\hline GW-751 & $11 / 18 / 96$ & $-13 \%$ & High chloride: $23.5 \mathrm{mg} / \mathrm{L}$ & & 은 & & \\
\hline GW-786 & $11 / 07 / 96$ & $24 \%$ & Low bicarbonate: $124 \mathrm{mg} / \mathrm{L}$ & & 운 & & \\
\hline GW-787 & $02 / 25 / 96$ & $-20 \%$ & Low pH: 5.84 ; low calcium: $1.8 \mathrm{mg} / \mathrm{L}$ & & - & & \\
\hline GW-787 & $05 / 21 / 96$ & $-12 \%$ & Low pH: 5.48 ; low calcium: $1.5 \mathrm{mg} / \mathrm{L}$ & & 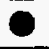 & & \\
\hline GW-787 & $11 / 07 / 96$ & $-28 \%$ & Low pH: 5.35 ; low calcium: $4.3 \mathrm{mg} / \mathrm{L}$ & & e & & \\
\hline GW-792 & $03 / 05 / 96$ & $-13 \%$ & Low calcium: $30 \mathrm{mg} / \mathrm{L}$ & & 운 & & \\
\hline SCR 7.14 SP & $03 / 21 / 96$ & $-12 \%$ & High chloride: $138 \mathrm{mg} / \mathrm{L}$ & & & O & \\
\hline
\end{tabular}

The charge balance errors for these samples potentially reflect: analytical and/or data transcription/reporting errors (GW-338, GW-618, GW-786, and GW-792); the geochemical influence of groundwater contaminants (GW-251, GW-253, GW-700, GW-748, GW-749, GW-751, GW-787, and SCR 7.1 SP); or localized grout contamination (GW-619 and GW-620). 


\section{F.5 SCREENED RESULTS FOR VOLATILE ORGANIC COMPOUNDS}

Results for the associated laboratory blank and trip blank samples were used to screen false positive results (i.e., sampling and/or analytical artifacts) for VOCs detected in the groundwater and surface water samples (including estimated results below analytical reporting limits). If the reported VOC concentration was less than the blank qualification result ( $B Q R)$ for the compound, the result was screened (replaced with zero as a surrogate value). The $B Q R s$ for acetone, methylene chloride, toluene, and 2-butanone (common laboratory reagents) represented the highest concentration in either associated laboratory or trip blank multiplied by a factor of 10; a factor of 5 was used to determine BQRs for all other VOCs (U.S. Environmental Protection Agency 1988).

A total of 61 VOC results reported for 41 groundwater samples from one spring and 30 monitoring wells, including four wells used for RCRA post-closure corrective action monitoring (GW-108, GW-605, GW-606, and GW-733), were screened as false positives. As shown in

Table F-6, most (49) of the false positive results were for acetone and 2-butanone (i.e., common laboratory reagents), and more than half (38) were 5 micrograms per liter ( $\mu \mathrm{g} / \mathrm{L})$ or less.

Table F-6. False Positive Results for VOCs

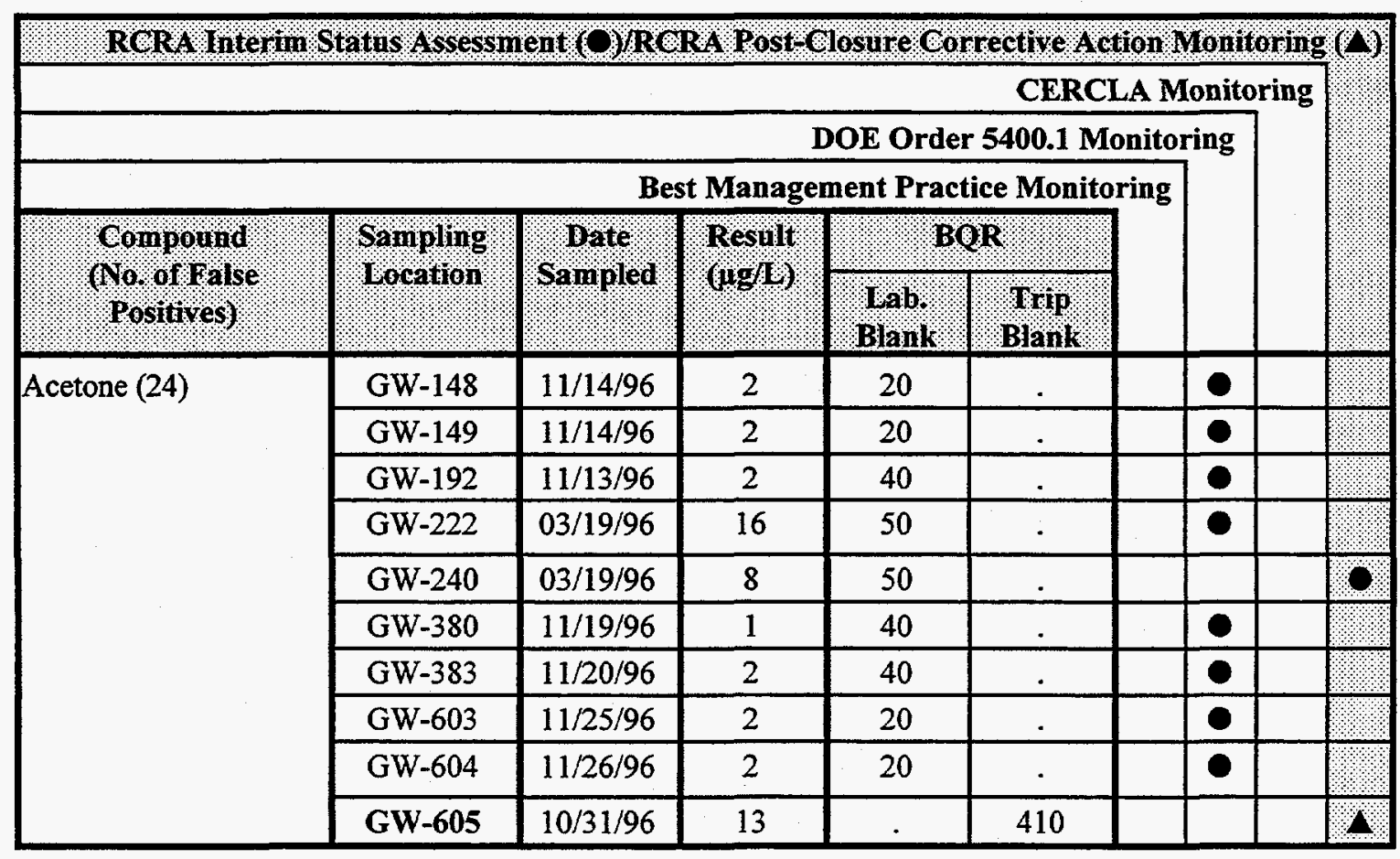


Table F-6. (cont'd)

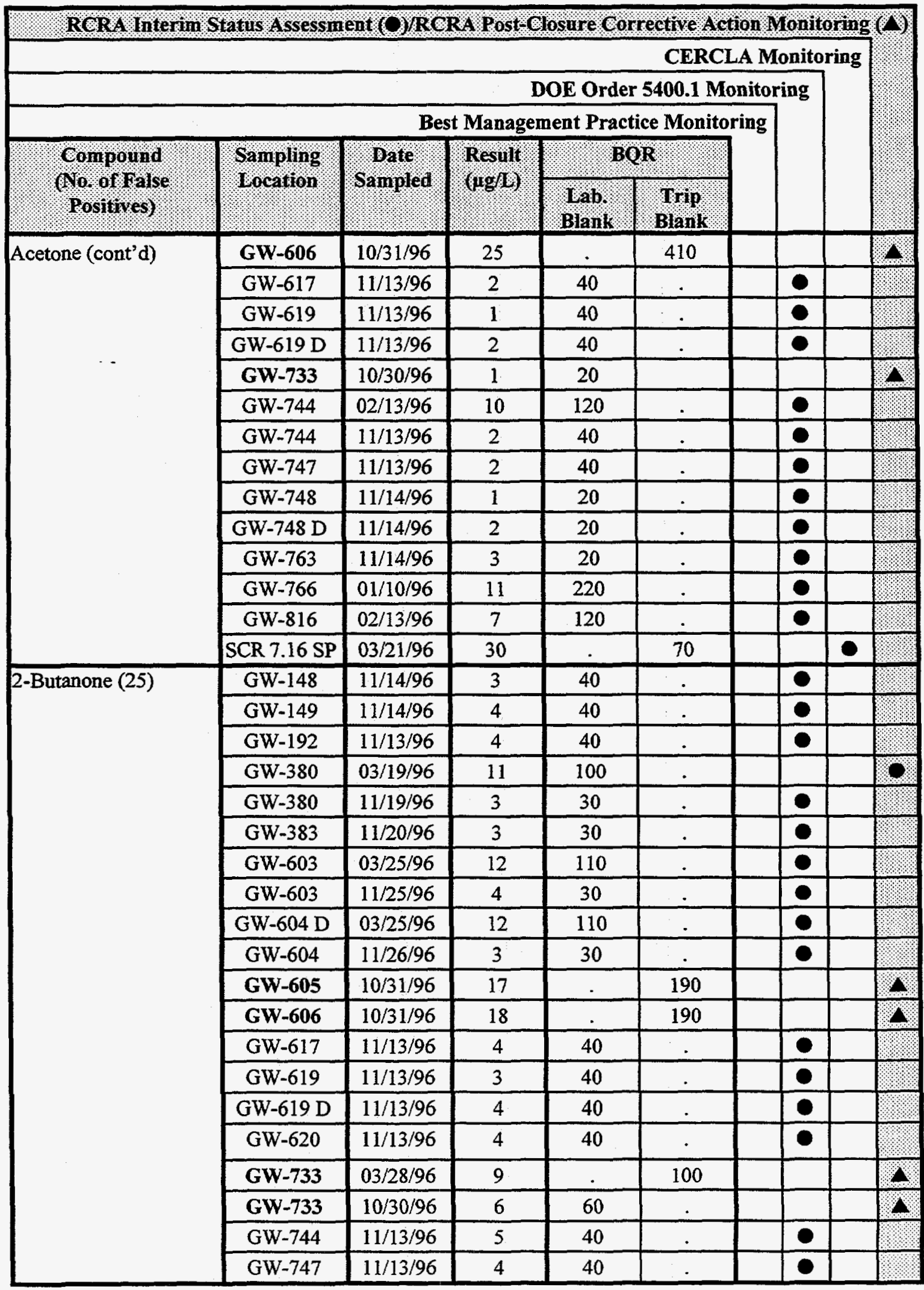


Table F-6. (cont'd)

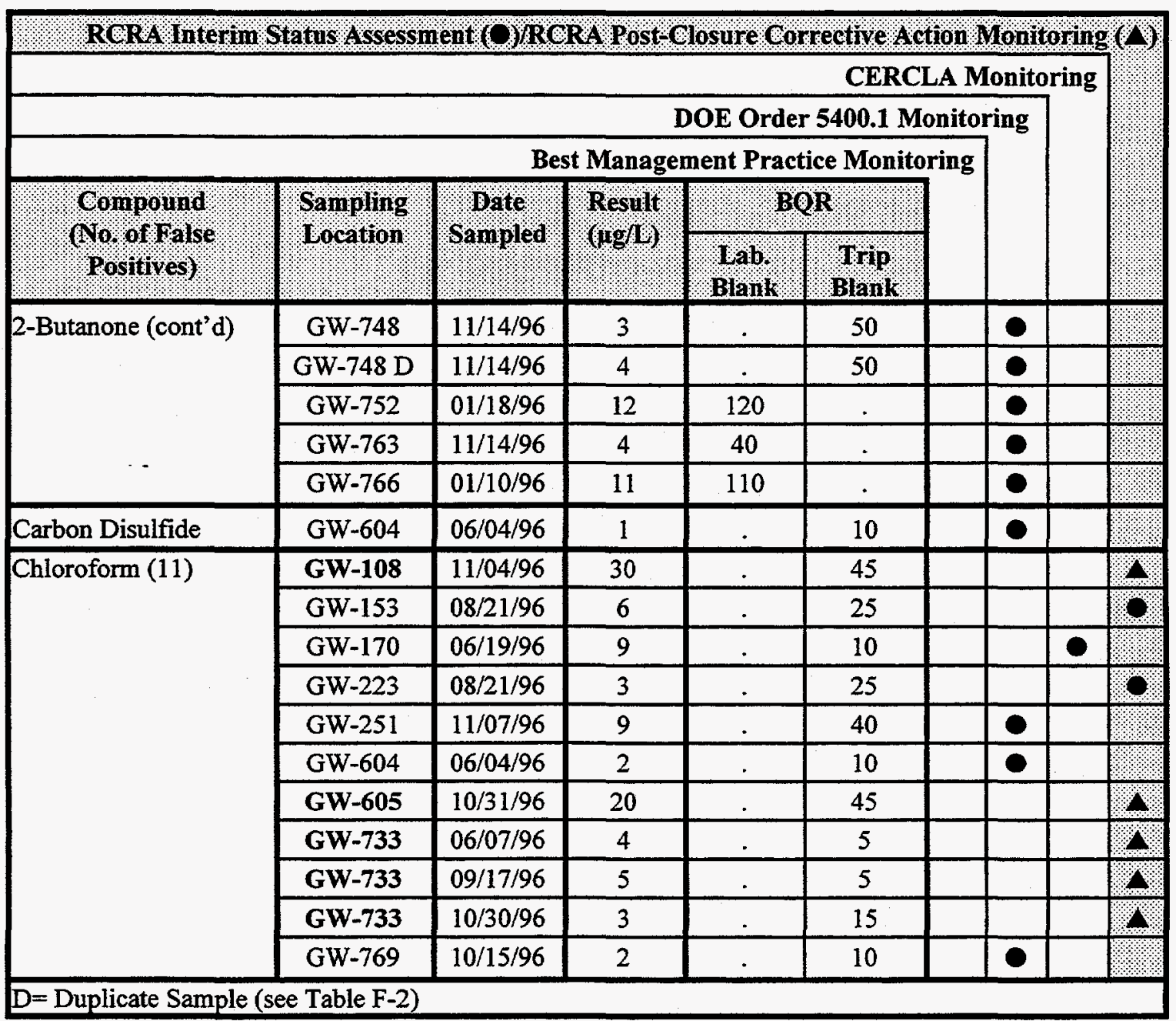

All but eight of the 49 false positive results for acetone and 2-butanone were screened by laboratory $\mathrm{BQRs}$, including 23 screened by $\mathrm{BQRs}$ associated with five laboratory blanks analyzed on November 12,18 , and 22,1996 . Indeed, the bulk (about $70 \%$ ) of all false positive VOC results were associated with blank samples analyzed during the fourth quarter of 1996 . Similar patterns have been evident during the last several years as indicated by increased proportions of false positive VOC results during the final quarter.

False positive results for carbon disulfide and chloroform were screened by BQRs associated with 11 trip blanks. The lack of either compound in the associated laboratory blanks discounts the analytical environment as a source of the contamination in these trip blanks. All of the false positive results for chloroform occurred in wells that consistently yield groundwater samples containing this 
compound, including three wells used for RCRA post-closure corrective action monitoring (GW-108, GW-605, and GW-733). Contamination of the deionized water used to prepare the trip blanks most likely has occurred. Similar "source water" chloroform contamination occurred during CYs 1991 and 1992, and was determined by the K-25 Analytical Service Organization to have resulted from problems with system handling and maintenance (Buckley 1992). Although a water filtration system was installed and source water quality monitoring was initiated in CY 1996, chloroform is still the most-detected compound in trip blank samples (see Appendix E) .

False positive VOC results included a total of ten results for acetone, 2-butanone, and chloroform reported for groundwater samples collected from the RCRA post-closure corrective action monitoring well network: point-of-compliance well GW-108, and plume boundary wells GW-605 and GW-733. False positive results for chloroform are problematic because it is a RCRA GWPS constituent for the Eastern S-3 Ponds plume, and historical data indicate chloroform in the groundwater at each of these monitoring wells. Despite the loss of data quality, screening these chloroform results did not significantly impact the data evaluation required for RCRA post-closure corrective action monitoring.

\section{F.6 SCREENED RESULTS FOR RADIOANALYTES}

Results for radioanalytes (gross alpha, gross beta, and radioisotopes) were screened based on comparison of the reported activity to the associated counting errors. The counting error, reported in picoCuries per liter $(\mathrm{pCi} / \mathrm{L})$, expresses the degree of analytical uncertainty for each radioanalyte result, and is defined as twice the sample standard deviation. If the reported activity for each radioanalyte exceeded the specified minimum detectable activity (MDA), but was less than the reported counting error, the result was replaced with a missing value. These screened results are summarized in Table F-7. 
Table F-7. Screened Results for Radioanalytes

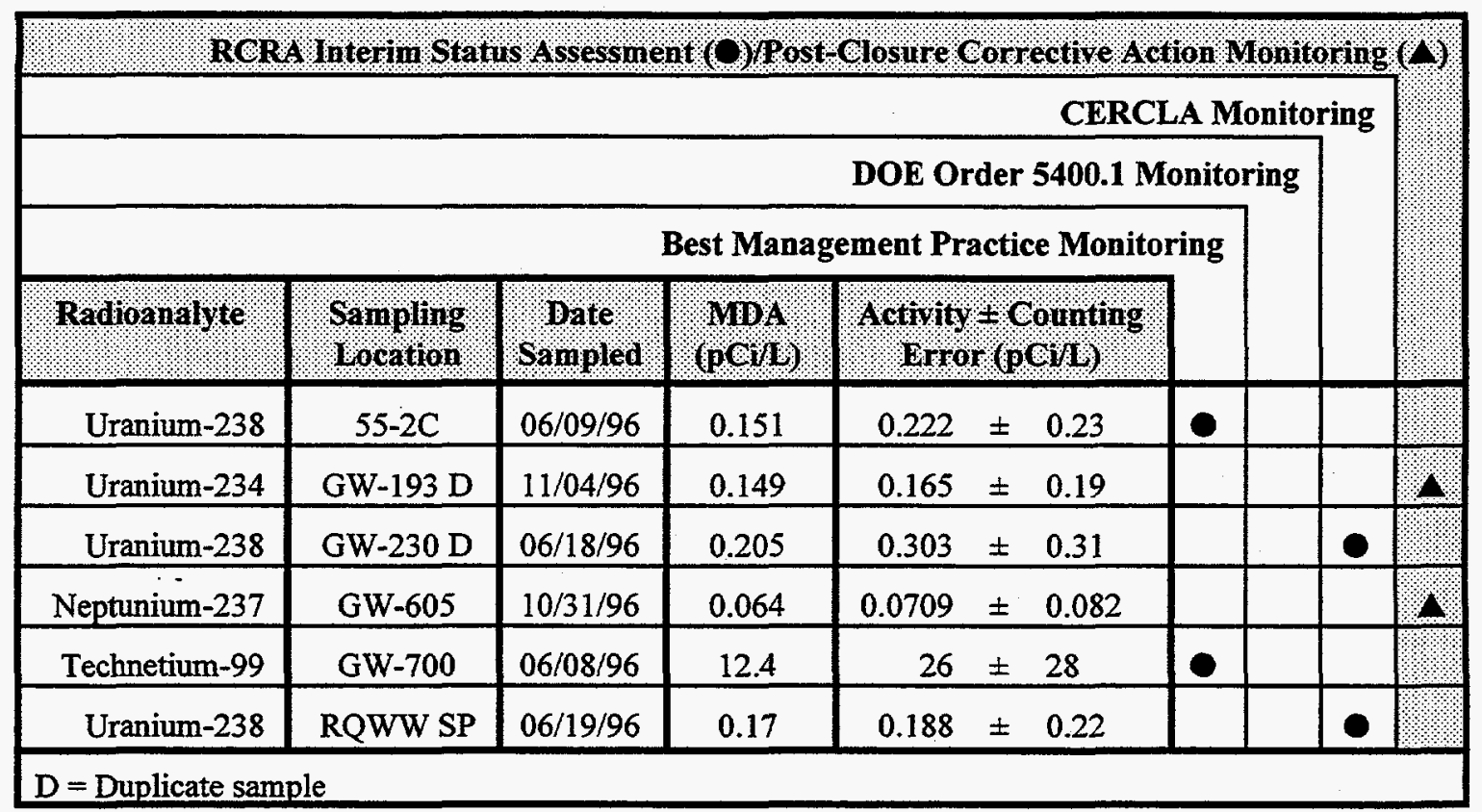

Although the screened results were reported for samples collected from plume boundary wells GW-193 (duplicate sample) and GW-605 after the effective date of the post-closure permit, neither uranium-234 nor neptunium-237 are GWPS constituents for the Eastern S-3 Ponds.

\section{F.7 SUMMARY AND CONCLUSIONS}

The overwhelming majority of analytical results reported for the CY 1996 groundwater and surface water samples met applicable DQOs of the Y-12 Plant GWPP. Screened data included two duplicate sample results and eight total/dissolved trace metal concentrations that differed by an order-of-magnitude or more; 61 false positive results for VOCs, most of which probably reflect contamination from the laboratory environment; and six radioisotope results that exceeded MDAs but were less than the associated counting errors. Additionally, principal ion data for 22 groundwater samples are not suitable for qualitative evaluation because of charge balance errors. However, the outcome of the data screening process resulted in minimal loss of data quality with respect to RCRA post-closure corrective action monitoring in the East Fork Regime. 


\section{DISTRIBUTION}

DEPARTMENT OF ENERGY

J.P. Donnelly

P.J. Gross

P.A. Hoffman

L.L. Radcliffe

W.B. Mansel

\section{ENVIRONMENTAL COMPLIANCE} ORGANIZATION

C.C. Hill

W.K. Jago

S.B. Jones

J.E. Powell

E.B. Rundle

L.O. Vaughan

GWPP-File-RC (4)

ENVIRONMENTAL RESTORATION

PROGRAM

H.L. King

File-ERDMC-RC

UNIVERSITY OF TENNESSEE

B.W. McMaster

TENNESSEE DEPARTMENT OF

ENVIRONMENT AND CONSERVATION -

DOE OVERSIGHT DIVISION

D. Gilmore (3)
ENVIRONMENTAL SCIENCES DIVISION

C.T. Rightmire

D.B. Watson

ORNL - LIFE SCIENCES DIVISION

B.D. Nourse

K-25 ANALYTICAL SERVICES

ORGANIZATION

P. Buckley

SCIENCE APPLICATIONS

INTERNATIONAL CORPORATION

W.P. Kegley / P.D. Moss

\section{CDM FEDERAL PROGRAMS}

C. Lutz
Y-12 Central Files

Y-12 Plant Records Services (2) 9711-5, MS-8169

[ 2 copies for OSTI] 
y/2 Pantreerds Services

$-971-5$ ms 8169

(2copu for OSTI) 